IDEOLOGÍA y PRAXIS COMO CRÍTICA A LA ESCUELA INMEDIATA UNA FILOSOFÍA MARXIANA DE LA EDUCACIÓN

\title{
ESTUDIANTE
}

CLAUDIO RAMÍREZ ANGARITA

DOCENTE TUTOR

DIEGO GERMÁN PÉREZ VILLAMARÍN

DOCTORADO EN FILOSOFÍA

UNIVERSIDAD SANTO TOMÁS

BOGOTÁ

2018 


\section{IDEOLOGÍA y PRAXIS COMO CRÍTICA A LA ESCUELA INMEDIATA UNA FILOSOFÍA MARXIANA DE LA EDUCACIÓN}

\section{MOMENTO CERO KARL HEINRICH y SU REALIDAD}

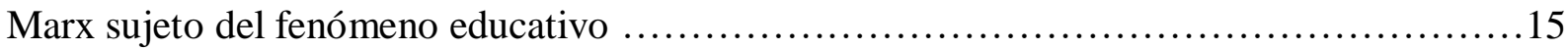

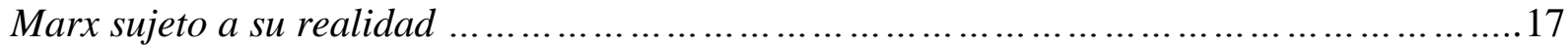

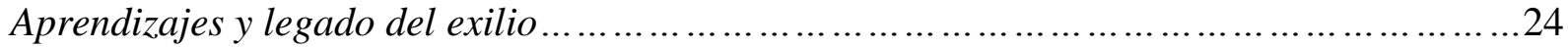

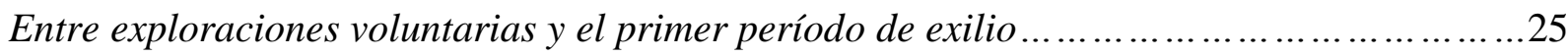

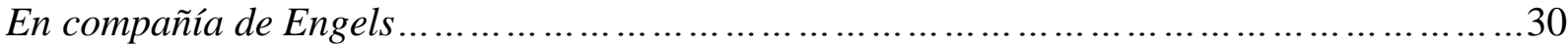

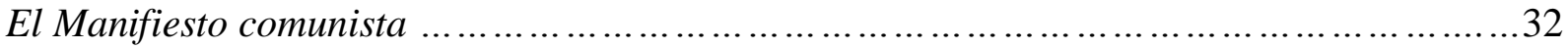

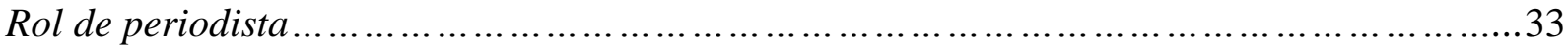

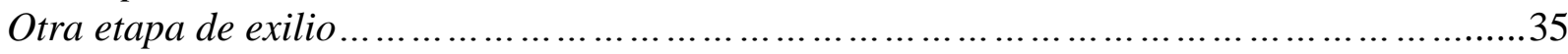

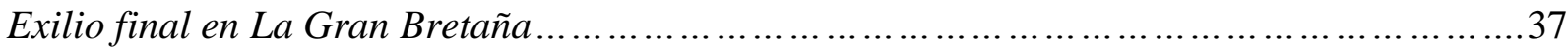

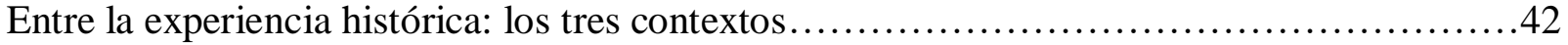

Extensión material e impacto de lo marxista sobre lo marxiano..............................................46

\section{PRIMER MOMENTO INTERÉS MARXIANO POR LA FORMACIÓN HUMANA: LA REVOLUCIÓN EDUCATIVA CON MARX}

1.1.Interés por la educación y la posibilidad de una filosofía de la educación en Karl Marx .....50

1.1.1. La conexión de la preocupación............................................................55

1.2 Una episteme marxiana para una filosofía de la educación .............................63

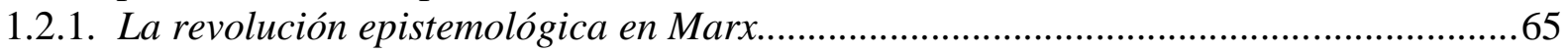

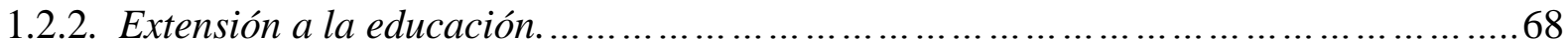

1.3. La filosofía como "cerebro" de la filosofía de la educación ..................................71

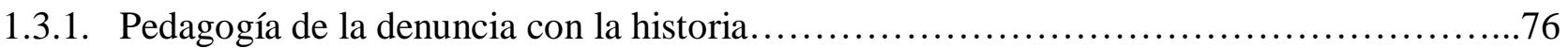

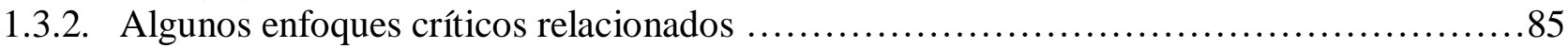

1.3.2.1. La educación como reproducción social ...........................................86

1.3.2.2. Las reflexiones del constructivismo social ..........................................99

1.3.2.3. Manifestaciones de la educación liberadora: algunos atisbos en Latinoamérica .........92

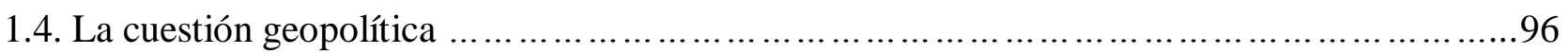




\section{SEGUNDO MOMENTO \\ LA IDEOLOGÍA DESDE LO MARXIANO PARA UNA FILOSOFÍA DE LA EDUCACIÓN}

2.1. La ideología como interés filosófico en educación .102

2.2. La ideología desde una mirada marxiana y sus implicaciones para la filosofía de la educación ...107

2.3. El asunto de la ideología 109

2.4. La denuncia contra la alienación 117

2.4.1. El caso de la religión

2.5. Filosofía de la educación y alienación .125

2.6. Estado y poder: crítica desde la filosofía de la educación liberadora

2.7. Crítica de la filosofía de la educación contra la ideologización de la ciencia 138

2.8. Filosofía de la educación y currículo: entre ideología y conciencia

2.9. El caso más universal: la cuestión del imaginario infundado y polemizado sobre Marx .151

\section{TERCER MOMENTO}

\section{LA PRAXIS DESDE LO MARXIANO PARA UNA FILOSOFÍA DE LA EDUCACIÓN}

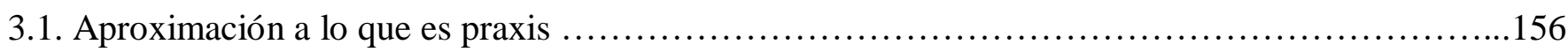

3.2. La formación praxiada, menester de una filosofía marxiana de la educación.......................163

3.2.1. La praxis frente a la ideología ................................................... 165

3.3. La filosofía de la educación y el planteamiento de la educación como acontecimiento político......170

3.4. La educación como ejercicio político................................................. 175

3.5. El tema del trabajo praxiado 180

\section{CUARTO MOMENTO \\ LA ESCUELA INMEDIATA COMO MATERIALIDAD DE LO IDEOLÓGICO y DE LA PRAXIS}

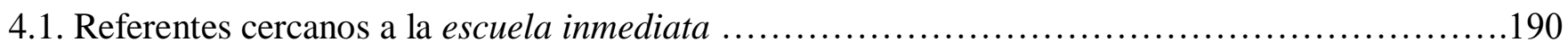

4.1.1. autores-actores ................................................................ 190

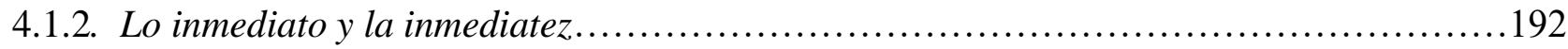

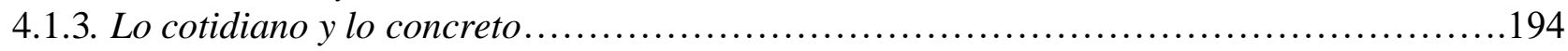

4.1.4. La superación de la inmediatez................................................196

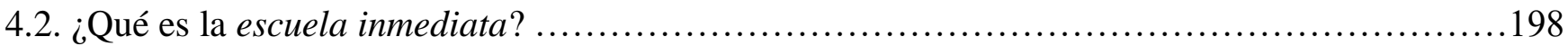

4.2.1. Su presencia dialéctica........................................................201

4.2.1.1. La escuela inmediata como materialidad de lo ideológico............................203

4.2.1.2. La escuela inmediata como manifestación material de la praxis............................205

4.3. Dos materialidades: el actor docente y el factor currículo...................................209

4.3.1. El docente entre lo inmediato y lo práxico..........................................210

4.3.2. Las manifestaciones ideológicas del currículo: entre lo evidente y lo oculto..................216

4.3.3. El currículum praxiado como oportunidad emancipadora ..................................2219

4.4. El doble movimiento de la oportunidad sociopolítica .............................................223

4.5. La escuela inmediata como acontecimiento para una filosofía de la educación marxiana..........228 
CONCLUSIONES.

.232

BIBLIOGRAFÍA .238 COLOFÓN

Más que la injusticia contra Marx: reacción lógica.............................................271 
Transformemos nuestra escuela, colega, que no es un sueño ni un discurso, sino algo más: compromiso socio-histórico...

...para Adrianchus Camilín y Cayo Alejo que la praxis no les esté ausente; y la ideología les sea repelente... recuerden: pensar en cambiar al mundo no es locura ni simple utopía, es justicia,... asi se lo dijeron al Principito, ahora les digo a Ustedes...me siento cono un Jeddy...

Bogotá-Caracas 


\section{DEDICATORIA y AGREDECIMIENTOS ${ }^{1}$}

La moratlidad está llena de injusticias. De modo pues, dedico este trabajo a aquellas almas que han partido y que no puedieron liberarse materialmente en su mundo injusto, y también para aquellas que aun están en la terrenalidad y siguen encadenadas o padeciendo injusticias, sean o no conscientes de su situación.

Especialmente les dedico a dos almas materialmente presentes, cercanas a mí, quienes son dos luces, dos motivos materiales y espirituales, estas son: Cayo Alejo y Adrianchus Camilín, dos almas que crecen y de los quienes espero sean sujetos comprometidos con la trasnformación sociohistórica positiva donde les corresponda vivir. Así también, a Luz Dary; quien con su paciencia y comprensión ha colaborado brindándome sosiego y apoyo desinteresado en mis proyectos desde hace un poco más diez años. A mi madre Eleticia Angarita "Lety", quién está pasando por difíciles quebrantos de salud.

No puedo dejar de decir: dedico este esfuerzo a todos aquellos que, a través de mi camino por esta mortalidad, por este mundo historial, directa o indirectamente, han hecho que forje mi carácter y mi forma de ver a las cosas, la realidad, quiénes de una u otra manera, hicieron que e inquietara por el mundo y por la necesidad de seguir insistiendo en su tranformación.

Agradecimiento fraterno al "Master" Edgar Riveros Leal, rector del Colegio Enrique Olaya Herrera IED por su incondicional apoyo durante los arduos años de estudio de doctorado. Las metas logradas y muchas propuestas han sido irrestrictamente apoyadas desde sus facultades como rector y amigo.

Extiendo mi agradecieminto a la Secretaria de Educación del Distrio de Bogotá DC, en cabeza de quienes fueran los impulsadores, en ese entonces y hasta finalizar mi proceso de formación, por patrocinar este logro el cual, se verá reflejado en las dinámicas y en proyectos en pro de la educación de carácter social.

Al maestro y amigo venezolano Gregorio Valera-Villegas cuya desinteresada ayuda me dio luces para culminar esta reividnicativa tesis; cual hospitalario en la "ciudad de los techos rojos", no dudó en extender su ilustre mano amiga. Más que académico, agradezco al maestro Diego Pérez Villamrín por sus orientaciones y gran amistad; persona que también contribuyó y se acercó a los fenómenos sociales de la mano de lo marxiano.

Finalmente, a la Universidad La Gran Colombia, en los respectivos decanos de la Facultad de Ciencias de la Educación: Rosalba Osorio Cardona (2012-2017) y Daniel Cardona (2017- ND), por apoyar mis estudios, por permitir desempeñarme como docente grancolombiano. Esto demuestra el grado de apertura que tiene esta alma mater, comprometida con sus educadores y la universalidad del diálogo académico.

Claudinovic RA-018

\footnotetext{
${ }^{1}$ Claudio Ramírez Angarita. Colombiano. Licenciado en Ciencias Económicas y Sociales de la Universidad de Pamplona (NS). Es Magister en Filosofía. Es candidato a doctor en filosofía. Latinoamericana. Se desempeña como docente investigador de la Universidad La Gran Colombia. Es docente de planta en educación media del Distrito en Bogotá DC, en el Colegio Enrique Olaya Herrera IED. Lidera el Proyecto Editorial medio pan y un libro del EOH-IED desde 2010. Correo electrónico: claudinovic@olayista.com; claudinovic@gmail.com
} 


\section{INTRODUCCIÓN}

"Wir überließen das Manuskript der nagenden Kritik der Mäuse um so williger,
als wir unsern Hauptzweck erreicht hatten - Selbstverständigung."
London, im Januar 1859. In Vorwort von Zur Kritik der Politischen Ökonomie. ${ }^{2}$

\section{La pregunta y el porqué general}

La educación es el acontecer social concreto de más alto impacto, así como el más susceptible, el que define y es definido por las fuerzas materiales. Escribir sobre Marx es tocar la mortalidad humana y con ella su mundo historial, definitivamente marcada por la formación e influencia que un sujeto recibe en esa mortalidad, cuyas pautas pueden convertirse en dictamenes opresores o liberadores, esto hace volver a sus esfuerzos teóricos para replantear no únicamente interpretaciones sino propuestas de praxis auténticas.

Teniendo en cuenta el sentido general de una filosofía de la educación en los contornos materiales actuales, en compañía del ingrediente marxiano, es pertiennte preguntarse si ¿puede ser la escuela inmediata, una oportunidad a pesar de ser una manifestación de las contradicciones del sistema de cosas imperante a nivel micro? Para esto, deberá revisarse lo que significa Marx y lo marxiano; a su vez, la caracterización de ideología con sus consecuencias definidas que son alienación y enajenación.

Por ser sujeto histórico consciente de mi rol como docente, al ser observador de lo que pasa en mi entorno inmediato -en este caso la escuela-, me preocupo por las fuerzas materiales que siguen influyendo en la educación, fuerzas que parecen invisibles pero que están ahí, unas haciendo daño, otras buscando abrirse paso en medio de las dificultades. De todos modos, estas fuerzas no son abstractas ni generadas por leyes inmutables, son consecuencias directas del sistema económico, son hechas por personas de carne y hueso, y solo otro tipo de personas, también de carne y hueso pero con energías transformadoras, podrán dar la vuelta a la situación, devolver la posibilidad a la educación libertaria.

\section{¿Por qué con Marx?}

A doscientos años del natalicio de Karl Heinrich Marx, su proyección sigue estando en las mentes de quienes buscamos transformar nuestros entornos de la manera más comprometida y social. Hace cien años, el 4 de mayo de 1918, Gramsci rememoraba con el escrito: Nuestro Marx, una suerte de epifania, el año inmediatamente anterior, en el oriente de Europa llegan los soviets al poder con su idea local de marxismo. Vuelvo, a cien años de la Revolución de octubre y a doscientos del natalicio de Karl Marx, la mirada a las contradicciones existentes en el cotidiano. Tratar a Marx es tratar al hombre de carne y hueso sufriente.

No cabe duda, Marx tuvo presente la fuerza que tiene la formación humana. Leerle con esa perspectiva es encontrarse a un "sociopedagogo" enfatizador del redescubrimiento de dinámicas sociales para repensar y, sobre todo, dar vuelco a la labor filosófica de transformar, meta de la que no escapa dicha perspectiva. La filosofía como factor de transformación es su lema. Una apuesta consciente en la idea de que "la educación

\footnotetext{
2 “Abandonamos el manuscrito a la crítica roedora de los ratones con tanto mayor gusto por cuanto habíamos alcanzado nuestra meta principal: dilucidar nuestras propias ideas.” (Marx, 1989, p. 8, Contribución a la crítica de la economía política)
} 
más allá del capital aspira a un orden social cualitativamente diferente" tal cual apuntala Mészáros (2008, p. 66), es una apuesta por rescatar a la educación de las garras del sistema económico de cosas imperante.

Existe hoy una necesidad histórica para tocar el tema de la educación, pero esta necesidad es más que histórica, se sustenta filosóficamente por ser asunto esencial para la humanidad si segumos los criterios marxianos de Marx. Tratar filosóficamente a la educación, es también convertirlo a él en orientador teórico, en guía metodológico, en acompañante de una propuesta socioeducativa que asuma compromiso crítico. Ello redunda en la consolidación del compromiso político de la educación en pro de la emancipación humana, la cual puede alcanzarse en el proceso educativo donde prime la conciencia sociohistórica que comience a liberarse de la modélica concepción mercantilista del mundo que ha primado y se ha mimetizado.

Cabe mencionar que, si bien Marx no se ocupó de manera sistemática o directa a la educación, ni elaboró una filosofía de la educación (de hecho, se le señala de no haber creado un sistema filosófico como tal, pero eso es otra cosa, tampoco era de su interés ser reconocido por eso), los sustentos teóricos por él elaborados serán insumo para generar debates y hasta corrientes alternativas para pensar el fenómeno educativo. Demostrado está: Gramsci realizó trabajos en su momento, posteriormente Manacorda (1979) ya en los años sesenta intentaba retomar una lectura sobre el valor pedagógico en Marx, y así muchos ejemplos. Las lecturas de un Marx crítico de los sistemas educacionales capitalistas ya existían, incluso con él en vida.

En cambio, lo que se constata fácilmente en Marx es, precisamente, el estudio y los efectos dramáticos de las relaciones sociales y económicas en los diferentes ámbitos de la vida humana, entre ellos los que tenían que ver con la formación del hombre desde la institucionalidad escolar y el aparato productivo basado en la ganancia, así como en la necesidad de adormecer al ser humano con apariencias por parte de las clases dminantes. Cosa que no ha cambiado.

Hablar de educación en clave filosófica-marxiana, es hablar de emancipación material y hasta espiritual. En efecto, Glasser (1941) afirmaba que, "toda la actividad de Marx estaba impregnada de un amor inmenso a la humanidad oprimida, no deteniéndose ante ningún sacrificio personal en la lucha por su emancipación" (P.23); en ese orden el mismo Russel dirá: "el estímulo de su obra fue siempre la esperanza de la revolución social, si no en su vida, por lo menos en un futuro no muy distante" (2009, p. 838). Evidentemente, la perspectiva educacional de Marx traspasa cualquier banalidad discursiva disfrazada de cambio que no lleva la denuncia radical de los males del sistema o que no toma en cuenta el sufrimiento y la injusticia.

Pero, ¿qué tiene que decir Karl Marx en materia de educación? Basta con observar su obra y su vida. Hay que invitar a ese Marx distinto a dialogar sobre el acontecimiento educativo cotidiano en este incio de siglo XXI, especialmente a los contextos de las sociedades dependientes del sistema desigual imperante. Hay que echar mano de sus aportes para proponer teoría y prácticas transformadoras de esperanzas concretas buscando otorgar a todos los actores su rol histórico, especialmente al docente.

Ahora bien, al entrar en contacto con mi realidad social, material y concreta, a través de la profesión docente, encontré en lo filosófico una perspectiva que me ha ayudado a reconocer la importancia de valorar al pensamiento crítico-propositivo que se preocupa por brindar herramientas más allá de intereses intelectuales, en procura reivindicar la toma de conciencia socioeducativa y, con ella, la posterior liberación de las influencias ideológicas que acorralan al libre pensar y, que le dan al mismo tiempo matices errados. 
Para sustentar teóricamente la vuelta a la visión que puede brindarnos lo marxiano en el campo de la educación, es menester tener en cuenta dos elementos tangibles en las vivencias educativas del cotidiano. Estas dos grandes sociocategorias son: la ideología y la praxis. Presentes en el qué hacer educativo cotidiano; se identifican, allí se presentan. La una, como amenaza, manifestándose en alienación y en la enajenación. La otra, como algo más allá de la práctica, como oportunidad consciente de transformación no como poiesis. Las dos, de manera dialéctica confluyen, caracterizando sociopolíticamente al acontecer educativo actual con sus consecuencias en los actores escolares. Asi también, la inmediatez y lo inmediato, en tanto fenómenos más que categorías constitutivas que han emergido de la visión capitalista del mundo, podrán ser leídas dialécticamente.

Aquí es donde aparece la escuela inmediata. A partir de la manifestación de los anteriores factores, aparecerá su definición dialéctica como espacio tangible producto de las relaciones sociales y las fuerzas desatadas por el sistema de cosas imperante cuya base es la manera capitalista dependiente de (sub)desarrollo. Identificarla y explorarla con las herramientas marxianas para una filosofía de la educación, ayudará a establecer una lectura crítica y formas de proponer transformaciones tangibles no inmediatistas.

La lectura filosófica de Marx, de lo marxiano, desde una perspectiva de la filosofia de la educación resulta ser de las mejores construcciones para hacer de la formación humana todavía un halo de esperanza material. Con la experiencia viva en la docencia de base, se identifican los fenómenos que produce el sistema de cosas cuyo origen está en la visión capitalista del mundo, sobre todo aquella existente en los países en estado de dependencia, dictadora de estilos de vida e idearios negativos aparentadores.

\section{Lo marxiano y lo marxista}

A lo largo del siglo XX, se presentaron tres grandes conjuntos: uno oficial que lideraba la visión soviética; otro que era aún europea e intelectualista, la cual alimentaría las visiones críticas independiente de Moscú; y otra más abierta, integradora, diversa, inclusiva y ajustada a los problemas reales que encontraron en lo marxiano herramientas para apostar por la transformación. La primera fue, entre otras, sustento de la salida armada al sistema capitalista; la segunda se desenvolvió en la academia; la tercera, caracterizó las propuestas alternativas en América Latina.

Kohan (Sf.), comenta: "existen muchas lecturas posibles de Marx. Han existido y existirán diversos marxismos. Pero no todas esas lecturas resultan equivalentes o intercambiables" (P. 59). Por su parte W. Roces (1982a), denunció que los dogmáticos desconocieron el "proceso dialéctico vivo y real, profundamente educador para nosotros" (P. X) que tenía Marx, le deformaban. Hubo un apresuramiento irresponsable en culpar a Marx por los hechos acaecidos en el siglo XX; la satanización mediática de Marx cumplió su cometido, la vinculación con el término comunismo y marxismo era total como lo es hoy todavía. Por aquello se insiste en la demarcación si se quiere ser radical desde Marx, máxime en materia de educación. Lo marxiano puede reivindicar la propuesta que denuncia al sistema de cosas imperante.

Para identificar a "la escuela inmediata" es menester establecer dos grandes diferencias mas que conceptuales. Esto es, lo marxista y lo marxiano, más allá de un interés lingüístico, son dos concepciones ligadas a lo histórico, cuyo reflejo se sienta en los idearios de las sociedades de las últimas décadas. Entonces, lo marxista estará unido al contenido ideológico, lo que se entiende por las ideas emanadas de Marx y, que en su mayoría han sido interpretadas y aplicadas de varios modos. 
Mientras, lo marxiano que hace parte de una visión que busca enfatizar en la conciencia más que en la ideología tal como lo sugiere Silva (2009), es un constructo dinámico de aportes sobre la emancipación humana sin olvidar la base económica del sistema que el determina. Esto último es, una conciencia social e histórica, la cual avance a la propuesta para enfrentar fenómenos y problemas de la mano de las opciones políticas materiales de alto entendimiento circunstancial. Lo marxiano es bien definido por el venezolano L. Silva (2009), quien se preocupa por la distinción entre ideología y conciencia revolucionaria. El énfasis en el rescate de la praxis también le caracteriza, Adolfo Sánchez V. (2003) ya lo apunta. Esto es importante para hablar de filosofía "marxiana" y no netamente marxista. La escuela inmediata tendrá en cuenta lo marxiano sin dejar de acudir a los aportes marxistas alternativos elaborados, muy conocidos en el ámbito intelectual.

El mismo Marx recalcó en varias intervenciones su: “Je ne suis pas marxiste"3, pues no le agradaba quedar en el imaginario como fundador de una corriente ideológica. Él alegaría contra el uso del "ismo" a su pensamiento cuando estuvo en Francia, en 1882. Inclusive, escribiría luego de un texto sobre economía, que no propendía por el establecimiento de un "sistema socialista" (Heinrich, 2016), de ahí lo flaco que resultan los comentarios infundados al pretender convertirlo fanáticamente en fundador.

\section{El modo de proceder y las fuentes}

Platón escribió en su momento que, cuando una labor se inicia, se tiene la mitad de esa labor; yo agrego que la metodología es la otra mitad. Esta exploración ha acudido a las generalidades del método dialéctico al servicio de un fenómeno concreto, pero se ha basado también en la definición abstracta de manifestaciones materiales, las cuales a su tiempo han sido efecto de situaciones concretas, de encubrimientos. Entonces, se parte de fenómenos específicos, para verlos en su totalidad y traerlos de nuevo al campo de la realidad y desde allí, proponer su transformación necesaria mediante la criticidad para conllevar el despertar de la accion política.

Engels (1974), ya advertía en misiva de 1895 que en Marx no hay doctrina sino método. Marx tomará elementos vistosos de Hegel, pero les dará un vuelco metodológico. La aplicación dialéctica es siempre válida para la connotación de los cambios en los fenómenos, así lo recuerda Vigotsky (2003), pues para este referente del pensamiento pedagógico, "un eje central de este método consistía en que todos los fenómenos debían ser estudiados como procesos en constante cambio" (en Introducción, p. 25).

La dialéctica como pauta metódica, se erige en oportunidad para el enriquecimiento de esta investigación en filosofía de la educación. Más que un método, es una aplicación vital, vigente para los temas sociales como el de la educación por ser un espacio donde se mueven fuerzas sociales y fenómenos de todo tipo. Esto lo respaldan, esfuerzos de comprensión como los que elaboró Ludovica Silva, quien a su vez reconoció la aportación althusseriana de que no se dejó una teoría dialéctica sino una práctica teórica (Silva, 2011, b). Marx y Engels desarrollaron el método dialéctico como un sendero para observar los asuntos sociales, a la manera científica y así comprender el desarrollo de la sociedad humana comentaba Woods \& Sewell (2016). Con razón, "el método dialéctico, pues, se ha convertido por naturaleza propia en un método histórico"

\footnotetext{
${ }^{3}$ En artículo de la DW, aparece reseña periodística a propósito del tema. Ver en, http://www.dw.de/marx-no-se-cans\%C3\%B3de-repetir-que-no-era-marxista/a-3313328
} 
afirmaba Marcuse (1993, p. 308). Incluso desde Marx, nunca se completa del todo, así lo acotó Russell (2009).

El acontecimiento educativo vista bajo la lente de la criticidad, exige una resignificación epistemológica de

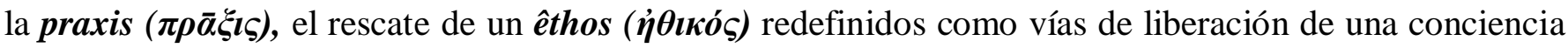
colectiva e integradora, no sin antes evolucionar en la individualidad. Para este caso, el enfoque crítico ha sido elaborado a partir de la experiencia propia, de mi cercanía con lo que denomino la escuela inmediata.

Marx insistía en que el teatro de la historia era dialéctico; era histórico y allí, en los espacios, se desataban las luchas de clases, la puja entre conciencia reivindicadora e ideología, de sectores como manifestación de antagonismos siempre con un fin material para generar ganancia, para consolidar todo un sistema de cosas que ocultara a su vez sus contradicciones.

El aprecio o descuido de las obras de Marx, lo mismo que al análisis coyuntural, pueden dar sustento a la importancia de tocar este tipo de especificaciones concpetuales o metodologicas. Los primeros escritos en generalizarse fueron lo de su llamada etapa de "madurez", en su mayoría girando en torno a la teorización y a las reflexiones combinadas con la economía y la sociedad. Dichas obras fueron redactadas entre 1847 e incluso después de su muerte. Luego, llegaría la clasificación de sus obras de juventud, de corte idealistahumanista; dichos trabajos fueron compilados y difundidos a partir de 1932, lo que se extendería hasta la década de los 80s, entre ellos Manuscritos según Sánchez Vásquez (2003).

\section{Discriminación de fuentes}

Sobre las fuentes y su tratamiento se procedió en la revisión de tres grandes clasificaciones de textos. Teniendo presente que, como dice Martínez (Sf.): "el estudio de los textos marxistas ha presentado problemas epistemológicos en su abordaje metodológico", ello se debe en gran parte, al presupuesto de "división" del pensamiento de Marx elaborado para intentar defender dos extremos: el que promueve la importancia de los trabajos de juventud frente a los que esgrimen la preponderancia de los escritos de madurez. En esta exploración, el objetivo es mostrar a un Marx interesado por el tema de la formación, de la escuela, del individuo-comunidad y, para esto, es central entender la obra marxiana como un todo, un todo teórico-práctico de carácter social, conscientemente revolucionario, de interés político, más no de imposición ideológica alguna -cosa difícil por la naturaleza del asunto-.

En primer lugar, está la vertiente de aquellas alusiones procedentes de las obras de Marx y Engels traducidas en su mayoría al castellano ${ }^{4}$. Se destacan las obras llamadas de juventud junto a aquellos clásicos de la economía y la política. En esta clasificación se constatan claras temáticas que pueden diferenciar un Marx juvenil de otro llamado maduro en temas específicos de filosofía, economía o política. Puede hablarse de una homogeneidad cuando buscando un sentido educativo se tratan a las obras marxianas. Entre los trabajos tempranos están su tesis doctoral sobre Demócrito y Epicuro; la variada correspondencia, entre la que se destaca la carta de un hijo a su padre a la hora de escoger una profesión. Obras que pueden leerse en su sentido pedagógico para entender varias categorías marxianas de carácter filosófico. Claves son: Crítica a la filosofía del derecho de Hegel, Crítica del derecho del Estado de Hegel, La ideología alemana y la

\footnotetext{
${ }^{4}$ Para profundizar sobre los trabajos recopilados en el siglo XX, y traducidos al español, Ediciones de Marx y Engels en español desde Moscú, véase en: http://www.filosofia.org/cla/ome/moscu.htm
} 
Sagrada familia en conjunto con Engels, La miseria de la filosofía y El Manifiesto del Partido comunista. Los manuscritos económico-filosóficos mostrarán la teoría extendida al cambio social. Por su parte, La lucha de clases en Francia de 1848 a 1850 es una muestra de la aplicación del materialismo histórico a un caso particular. Al tiempo, las Tesis sobre Feuerbach darán la más sencilla intencionalidad praxiológica marxiana. El conjunto de obras teóricas es indispensable a la hora de fundamentarse. Entre Trabajo asalariado y capital de 1847 y Salario, precio y ganancia de 1865, aparecerán los llamados, a futuro, Grundrisse (1857) o borradores. El Dieciocho Brumario de Luis Bonaparte (1852) y la Introducción a la Crítica de la economía política en 1859; todos con el inicio del análisis económico y sus relaciones dentro del sistema. Teoría sobre la plusvalía (1862), será un trabajo que si bien se centra en lo económico no deja de estar cargado de un fuerte halo de filosofía política y económica. En 1875, su Crítica al programa de Gotha, destacará un punto especial y lleno de propuesta para la construcción colectiva de idea de educación. Das Kapital de 1867, y los volúmenes 2 y 3 en compañía también de Engels, serán textos para comprender la denuncia marxiana contra las del sistema que se estaba consolidando en Inglaterra; será copiado según los requeriemientos de las clases dominantes. Allí madurarán categorías aun validas que vienen desde sus primeros escritos, las cuales develarán el carácter mercantil que se daba ya a la educación en pro de un sistema de cosas. A pesar de secciones densas y aritméticamente simbólicas. El capital es en sí una obra sociopedagógica, que no deja de preocuparse por el sufrimiento humano llena de observaciones. Entre los textos clave para encontrar algunos rastros de los pensamientos de Marx en educación está Textos sobre educación y enseñanza editado en 1977, en el cual se encuentran alusiones en variados pasajes, declaraciones y algunas correspondencias. Las Cartas sobre las ciencias de la naturaleza y las matemáticas (1973a) es otra interesante conjunción de fragmentos alusivos a posturas que tuvo Marx sobre estos campos.

La segunda vertiente, está subdividida entre aquellas que tratan los temas abordados desde el marxismo sobre todo en el bagaje de las categorías que en Marx dejaron abiertas las posibilidades teóricas a futuro, las cuales se conectan con el tema de la formación educativa. En esta vertiente de textos y posturas, aparecerán desde pensadores marxistas teóricos y prácticos alternativos, hasta fragmentos de oficialidades de la ortodoxia marxista-leninista. Caben mencionar los aportes de Gramsci, Marcuse, Althusser, Adorno, Lenin, entre otros no menos importantes; o de comentarios sobre marxismo de M. Sacristán. Y otra vertiente donde se cuentan los aportes de los mediadores en temas que buscan sostener el puente entre educación y filosofía, representada principalmente en Suchodolski, Mészáros y Broccoli que logran definir una actitud marxiana de la educación. También están algunas biografías y comentarios actualizados. En general, estas fuentes provienen de la tradición europea.

La tercera vertiente agrupa fuentes que tratan a Marx desde la carecterización dada en América Latina, aunque se encuentran otras que analizan el tema de la educación de manera generalizada y que van desde la citación de algunos autores clásicos en filosofía de la educación (Vigotsky, Freinet). Entre otros seconsultarán a J.C. Mariátegui, E. Dussel, A. Sánchez, A. Ponce (1981), P. Freire (Fernández Fernández, 2007) y algunos de S. Rodríguez. Todos brindan reflexiones alrededor de las corrientes alternativas en educación, sociedad y política, lo cual es de importancia para el itinerario investigativo ya que pueden encontrarse relaciones con la visión marxiana. Para los temas de praxis e ideología, serán tratados, entre otros, algunos apuntes de González, Bermudo y A. Sánchez V., y sobre todo de L. Silva, respectivamente.

Los escritos de Engels serán tomados en cuenta al momento de relacionar varios temas que fueron desarrollados con Marx; obras como La situación de la clase obrera en Inglaterra (1845); El origen de la 
familia, la propiedad privada y el Estado; el Anti-Düring; Dialéctica de la naturaleza; Del socialismo utópico al socialismo científico o Ludwig Feuerbach y el final de la filosofía clásica alemana, serán relacionadas en la medida en que aparezcan elementos básicos para seguir construyendo una filosofía de la educación con Marx.

Se citarán las traducciones de versiones marxianas y marxistas más aproximadas a los originales, destacándose la que sobre El capital existe de Pedro Scaron, editadas para las personas hispanoparlantes por Siglo XXI editores, se dividen, en sus diferentes ediciones en volumen 1 al 3 Libro primero: El proceso de producción de capital; volumen 4-5 del Libro segundo: El proceso de circulación del capital; y volúmenes 6, 7 y 8 como Libro tercero: El proceso global de la producción capitalista. En Scaron se encuentran las traducciones de otras obras marxianas; todas ellas sin dejar de lado los apuntes propios que destaco de la lengua alemana, francesa e inglesa.

También están los trabajos de Wenceslao Roces (1976 a,b,c); entre ellos El Capital del FCE, criticado por P. Scaron (2013), pero muy idóneos para acercarse a las lecturas que se dieron por ser la más difundida. Los documentos seleccionados en Los escritos de juventud 1835-1844 de Roces, compilan algunos escritos claves para entender el pensamiento marxiano, que parte, entre otras, por unos intereses filosóficos estrictamente en los campos de lo antropológico, lo epistemológico y hasta ético con el sello característico de la punzante pluma del pensador líder del socialismo científico.

Las versiones de escritos marxistas editados en la URSS y otras zonas la óribita socialista de antaño también hacen aparición. De la internet se consultaron los archivos digitales en The Marxists Internet Archives, los cuales contienen textos de Marx-Engels y marxistas posteriores en sus lenguas originales y principales traducciones al castellano (MEW, MEGA). Estas compilaciones dirigidas desde Moscú o Berlín ${ }^{5}$, son materiales pertinentes para la comprensión de lo marxiano y lo marxista.

\section{La propuesta expositiva}

El momento cero, está designado para mostrar los aspectos más destacados del trasegar mortal de Marx en el mundo que le correspondió vivir. La relación de sus obras y su evolución filosófica extendida a otros campos de la realidad social humana (economía, política) tendrán una estrecha relación con el interés por la formación humana conocida como educación. Karl Heinrich formado en y por su realidad, es más que una simple semblanza biográfica, pues ofrece una contextualización del devenir que afectó al propio Marx y su contacto con los procesos educacionales de su época. Se relacionarán brevemente las obras más destacadas, en las que aborda su particular interés por la formación de los sujetos; entre otros aspectos de interés para entender el carácter personal e intelectual del Marx de carne y hueso.

Enseguida viene el momento uno. Así, Interés marxiano por la formación humana: la revolución educativa con Marx destacará el interés que tendrá Marx en el tema de la educación contrario de los presupuestos esgrimidos por los modelos regidos de la visión del capitalismo. Poniendo a Marx como un sociopedagogo vigente, en ésta sección habrá un encuentro con otros aspectos del interés primario marxiano que ayudarán

\footnotetext{
${ }^{5}$ Junto a las ediciones provenientes de Moscú y Berlín que llaman la MEW, está también las de Karl Dietz Verlag Berlin y las demás que enuncia Scaron en su introducción a El capital plasmado en ocho tomos editados por Siglo XXI.
} 
a entender el porqué de tocar al acontecimiento educativo sin descuidar lo epistémico. También, algunas posturas críticas que se conectan directamente con lo marxiano, harán presencia.

En bloque, presento el segundo y el tercer momento. Acá se engloban dos grandes "socioconceptos". Por un lado, la ideología y, por el otro la praxis, explayados para dar un sentido teórico a una filosofía de la educación marxiana a nivel general del cotidiano. En ese orden, el segundo momento denominado: $L a$ ideología desde lo marxiano para una filosofía de la educación, tratará sobre la caracterización de la ideología con autores sin perderse de su última relación con el acontecer educativo; enajenación, alienación e imaginarios serán fenómenos denunciados por su negación y efectos negativos. El tercer momento: $L a$ praxis desde lo marxiano para una filosofía de la educación, esta será vista como oportunidad en la transformación escolar inmediata, centro fundamental de la visión marxiana para rescatar la meta del reconocimiento material de la emancipación humana.

Centralizándose todo, la propuesta se presenta en el cuarto momento. Allí se pondrá a la escuela inmediata como acontecimiento social donde se desatan las fuerzas que determinan los fines reales, ideologizados u ocultos del acontecimiento escolar. Estará la pauta de su negatividad en la inmediatez y la relación con lo inmediato, que corresponden al sistema de cosas imperante. La lectura dialéctica de este lugaracontecimiento expresará sus condiciones más allá de las apariencias con las que quiere ser teorizada hoy la educación. Haciendo énfasis en la formación de sujetos políticos, transformadores, y orientados por la conciencia y la actuación pertinente frente a los retos que el cotidiano les plantea, se construirá la propuesta en reconocimiento de la acción de las contradicciones del sistema sobre el espacio escolar. La escuela inmediata será expuesta como amenaza ideológica pero también como oportunidad de praxis.

\section{MARX Y LO MARXIANO \\ teórico}

IDEOLOGÍA y PRAXIS metodológico

ESCUELA INMEDIATA sociocontexto

Gráfico No. 1. Generalidad dinámica de la exploración para llegar a la comprensión de un Marx aun vigente. El susutento teorcio pasa a ser método al abordar a la ideología y la praxis, luego serán herramientas dielactica de comprensión de espacios como la educación en lo que se llama escuela inmediata. 


\title{
MOMENTO CERO \\ KARL HEINRICH y SU REALIDAD
}

\begin{abstract}
Por eso, Marx era el hombre más odiado y más calumniado de su tiempo. Los gobiernos, lo mismo los absolutistas que los republicanos, le expulsaban. Los burgueses, lo mismo los conservadores que los ultrademócratas, competían a lanzar difamaciones contra él.

Marx apartaba todo esto a un lado como si fueran telas de araña, no hacía caso de ello; sólo contestaba cuando la necesidad imperiosa lo exigía. (...)

Su nombre vivirá a través de los siglos, y con él su obra. ${ }^{6}$

Engels, 1883
\end{abstract}

\section{Marx sujeto del fenómeno educativo}

Decir Karl Heinrich, es decir persona de carne y hueso. Primero como hijo, luego como estudiante, después como activista y teórico, como padre orientador y hasta como maestro sin aula. Su vida se desarrolló "en" un contexto, acontecimientos, vivencias que influyeron hasta sus últimos días. Ahora, decir "por", está atado a esa actitud transformadora propia que se extenderá desde sus aportes siempre seductores para ser dinamizados en espacios concretos, en este caso, el de la educación pensada con su pensamiento el cual también es resultado de las coyunturas históricas, de las vivencias.

Se estudia el pensamiento marxista como una fase más de la historia del pensamiento, sin profundizar en el Marx humano, las condiciones históricas, económicas, políticas y sociales en las que vivió, las pasiones que posibilitaron los descubrimientos científicos de un hombre extraordinario. Este es un problema político. (Martínez, Sf., p. 3)

Comenzar un asunto que toque la forma de pensar de un individuo como Marx y no presentar su contexto, es traicionar su propia forma de ver al mundo. Todo hombre es sujeto de un contexto, producto de una realidad, y Marx no fue la excepción. En ese orden, a Marx hay que aplicarle su propio método dice Riazánov (1962). Marx se apersona de los infaustos contextos. Es por eso que:

Las investigaciones de Marx muestran concretamente la situación de los hombres trabajadores y explotados, y no sólo la situación en el mercado de mercancías. Muestran las causas reales del dominio de las cosas sobre los hombres, y no sólo el proceso de la acumulación del capital. (Suchodolsky, 1977, p. 43)

El siglo XIX será un siglo de cambios y convulsiones en todos los ámbitos que se extenderán hasta el siglo XX. Él mismo será sujeto de la trama consuetudinaria y educacional de su época, que se debatía entre lo formal y la informalidad familiar, prefiriendo seguir un camino de autoformación libre de cualquier requerimiento del sistema de cosas de su época. Esta fue una realidad, fue su realidad inmediata.

En el estilo marxiano destaca el estilo irónico y mordaz. No es capricho o simple perfil de personalidad. Supo combinar esa forma literaria para denunciar, evidentemente para hacerse notar, más allá había un sentimiento de indignación el cual habría de conducir a una reacción revolucionaria, por ello su estilo literario como apuntala Silva (2013) no escatimará a la hora de incomodar a las clases dominantes de su época, como todavía lo logra hoy.

Es importante, cuando se desee hablar de un Marx sociopedagogo, conocer y entender su contexto, pues los problemas pedagógicos, son tratados desde Marx en la medida en que se refieren a la relación de la

\footnotetext{
${ }^{6}$ Discurso pronunciado en inglés por F. Engels en el cementerio de Highgate en Londres, el 17 de marzo de 1883
} 
filosofía con la vida, los problemas y en general, su situación en la sociedad burguesa (Suchodolski, 1977), en esa sociedad que vivió.

En el Manifiesto, Marx (2008) reprocha enérgicamente la objeción burguesa de querer acabar con la educación doméstica al intentar, desde el programa comunista, suplantarla por un tipo de educación social. No es que Marx quiera en el sentido estricto abolir esta forma, de lo que se trata es precisamente de abrir las posibilidades a una formación en sociedad, conociéndola. Su postura sobre la educación familiar puede verse en su rol como padre y tutor.

Ahora, podría pensarse que Marx estaba al lado de la masificación de la educación; la respuesta es: no. Difícílmente se puede pensar en un Marx que quisiera hacinar a las personas, sobre esto es enfático cuando reclama condiciones dignas, hasta de espacio y calidad social, en su obra cumbre Das Kapital, no solamente lo hace con la industria sino con casos específicos de la escuela. Como científico predictivo, en palabras de Silva (2011) sabia los daños irreparables de esa forma mezquina de arrumar seres humanos.

Lo que preocupa a Marx es el sentido y los mensajes que da la instrucción familiar, sobre manera de corte aburguesado al interior de las familias a sus niños. Conoce ese mundo, sabe de la indolencia lógica que las clases dominantes tienen por los otros sectores, especialmente, hacia los desprovistos de riqueza. A su vez, se percibe el interés por una formación básica para los sectores populares en los distintos campos del conocimiento que ha de complementarse con la formación de conciencia de clase. Es difícil pensar que Marx, el Marx llamado humanista, pudiera utilizar el resentimiento, como se ha dicho desde sus tiempos, en combustible para que se formarán las personas solo con la meta de venganza o sometimiento barbárico de otros seres humanos.

En Marx, influenciarán tres grandes realidades materiales inmediatas, a saber: la Revolución francesa que tendrá un carácter muy político; la revolución industrial la cual desatará cambios económicos tangibles, y la filosofía alemana compilada, leída en clave dialéctica, darán aportes teóricos y prácticos para su trabajo terrenal, aquí lo que significó Hegel fue fundamental. Lenin (1909) dará su recomendación sobre el menester de leerle para entender al otro; tampoco puede olvidarse sus lecturas sobre Spinoza (Marx, 2012) y la literatura universal.

Estos hitos darán elementos para que pueda entenderse la obra de Marx como una obra que resalta las consecuencias de los hechos sobre el hombre y su comunidad, y por supuesto en temas hasta epistémicos que de alguna manera impactarán en la forma en que lo marxiano verá la formación humana en estos tres hechos que pueden leerse, al tiempo, en tres campos: política, economía y filosofía.

Lo especial del "espíritu de la época" en la que Marx vivió sus años de infancia y de juventud, es la aguda contradicción del sisitema. El antagonismo entre formas antiguas de ver y dominar la realidad, se movían entre la reacción estática y la adaptación para contrarrestar las ideas que ya venían imponiéndose desde el siglo XVIII. La visión de un hombre en crisis era la posibilidad que aún tenía el Antiguo Régimen para repeler la idea de hombre que se había retomado en el Renacimiento. El antagonismo empezará a manifestarse aún más en las nuevas clases protagónicas (burguesía-proletariado), fiel reflejo de la influencia del medio y de las ideas. Los intentos de restauración, a pesar del triunfo de Waterloo en junio de 1815 , chocarán contra nuevas fuerzas aparecidas en el plano material. 


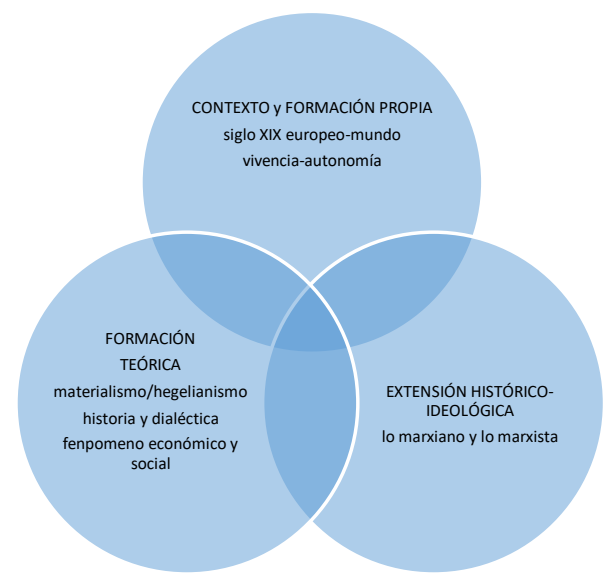

Gráfico No. 2. Para entender el significado de Marx desde su propia vivencia: conjunción entre lo teórico recibido, lo contextual vivido y la extensión de sus aportes junto a a las interpretaciones y aplicaciones de su pensamiento (lo marxiano y lo marxista).

\section{Marx sujeto a su realidad}

El 5 de mayo de 1818, en el seno de una familia acomodada prusiana de origen judío, en Trier región de Rheinland-Pfalz limítrofe con Francia, nace a quien bautizarán en el protestantismo con el nombre de Karl Heinrich Marx tercero entre nueve hijos. La razón de cambio a una oficialidad cristiana, fue evitar la segregación típica de la época.

Su madre lo llamaba Glückskind, hijo de la fortuna, bajo cuyas manos todo salía bien. Su padre hablaba de los maravillosos dones naturales de su hijo, y acariciaba el deseo de que Carlos siguiese sus huellas, llegara a ser lo que él anheló ser en su juventud: un gran jurista y erudito en leyes, un defensor, ampliamente respetado, de la razón y la humanidad. (Gemkow, 2010, p. 12)

El contexto en el que nació Karl era el propio de un inicio de siglo convulsionado por cambios de toda índole, todavía estaba vivo el recuerdo del corso Bonaparte y la revolución industrial ya rampaba con madurez. El sistema global ya acariciaba los últimos rezagos de feudalismo. Mientras, en Prusia nos comenta Gemkow (2010) se oscilaba entre el absolutismo y las medidas liberales

Pero el rey prusiano tenía las manos atadas frente a las nuevas relaciones sociales y económicas que el capitalismo llevó al primer plano en la provincia del Rin. Mientras reforzaba el dominio del knut, la censura y el espíritu de subyugación en las zonas situadas al este del Elba y en la Alemania central, al comienzo se vio obligado a seguir una política en apariencia liberal con su provincia occidental recién adquirida. El gobierno de Berlín envió a Renania a funcionarios administrativos y judiciales tan educados y expertos como pudo encontrar. (P. 10)

Marx "nació en ese período de la más negra reacción" (P. 11). Renania era la provincia económica y políticamente más progresista de toda Prusia. Marx se educa informal y formalmente con la visión propia de un núcleo familiar imbuido por la ilustración y el humanismo burgués.

Su medio cercano, según Riazánov (1962), caló en su estructuración de mundo: "Tréveris conservó hasta cierto punto las costumbres de una ciudad medieval. Interesado entonces Marx por la situación de los campesinos, realizaba excursiones a las ciudades de los alrededores y se documentaba prolijamente sobre su vida" (Pp. 8-9). 
$\mathrm{Su}$ madre era de origen judeo-holandesa, se dice que era poco proclive a los ejercicios intelectuales. Su padre, hijo de un rabino; Herschel se convirtió al luteranismo para así no sufrir señalamientos discriminatorios tan propios de la época. Adoptó el nombre de Heinrich, así mismo lo hizo con sus hijos. El padre de Karl recibió una educación laica, era cercano a las discusiones intelectuales, gustaba leer, en sus lenguas originales, a los grandes clásicos y por supuesto, los textos provenientes de la Francia revolucionaria. "Henrich Marx poseía un carácter tímido y bonachón, siendo un ferviente lector de Leibniz, Voltaire, Rousseau y Kant. Precisamente, este gusto por la lectura se lo transmitió a su hijo Karl” (Cardona Castro, 2002, pp. 12-13).

A sus doce años (en 1830) fue enviado por su padre a estudiar. Karl estudió entre jesuitas por cinco años; se dice que era un infante dominante, "incluso un tanto tirano con sus compañeros de juego" (P. 13). Se dice que la relación con su padre era una constante enseñanza, hasta el día que aquel murió. Pero,

¿Y a la escuela, qué debe a la escuela, a sus primeros años de estudio, Carlos Marx? Esta aportación es mucho menos fácil de deslindar. Marx no habla nunca de sus compañeros de escuela, ni sabemos tampoco de ninguno que registrase sus recuerdos de él. (Mehring, 1965, p. 15)

Karl tuvo el privilegio de educarse de la mejor manera. Recuérdese que perteneció a una familia acomodada, por lo tanto, su padre se asegurará de que reciba una educación correspondiente a la visión liberal que defendía. Las instituciones influyen de una u otra manera en los individuos que se forman en ellas. En esta línea, Gemkow rescata que:

En 1815 el Gimnasio de Tréveris se encontraba bajo la jurisdicción del ministerio de Cultura prusiano, pero el gobierno de Berlín no consiguió cambiar el espíritu de la escuela para convertirlo en el de los Junkers del este del Elba. Ello lo debía la escuela, ante todo a su director, de orientación liberal, Johann Hugo Wyttenbach, quien sabía cómo cultivar la Ilustración y el Humanismo en su instituto. Por lo demás, las normas técnicas de la escuela eran elevadas, y muchos de sus maestros respetados hombres de ciencia. (2012, p. 12)

Mehring (1965), uno de los más clásicos biógrafos de Marx, llegó a acusar de que tenía un rendimiento bueno en diversas ramas del estudio más no le iba muy bien ni en religión ni en historia; al parecer tampoco en composición alemana. No obstante, recitaba pasajes de odas y textos clásicos de memoria, esto lo traspasará a sus hijas. Sin embrago, no existen, hasta el momento desde Mehring, registros de la vida escolar básica de Marx. Aun así, "en su juventud y a lo largo de toda su vida, Marx fue, como su obra revela un profundo conocedor de la literatura y la poesía y él mismo escribió, en sus años mozos, poemas, ensayos y relatos literarios" (Roces en Marx, 1982, p. VIII).

En su época de bachillerato escribirá una reflexión que aún se conserva, ésta deja sentir el sabor de la libre elección a la hora de definir un futuro relacionado con algo que puede marcar a una persona al desenvolverse dentro de una sociedad, y es la búsqueda de la satisfacción propia; por ello en Reflexiones de un joven al elegir su profesión de 1835, Marx (1982) comparte: “cuando el hombre sólo se preocupa de sí mismo, puede llegar a ser, sin duda, un famoso erudito, un gran sabio, un excelente poeta, pero nunca llegará a ser un hombre perfecto, un hombre verdaderamente grande" (P. 4). Ya esto avizoraba el carácter social, el sentido comunitario que profesaría en sus obras. Redundando, esa preocupación por los demás, pues se podía tener satisfacción personal por los logros individuales, más de nada valdría si no se le da una aplicación social.

Como en cualquier sujeto, las edades tempranas son claves. No hay duda en que, durante la infancia y la primera adolescencia, está la época de desarrollo personal; desarrollo que puede ayudar a definir los perfiles 
futuros, para el caso de Marx, de ver al mundo. Criado en el seno de una familia algo acomodada, su compromiso filosófico no dejó de ser el mismo durante toda su mortalidad.

En la casa de los aristócratas Westphalen, Karl departirá mucho con sus cercanos; será una forma distinta de aprender para él, cosa que apreció mucho, costumbre que no abandonará en sus tertulias. El intercambio de ideas y los encuentros informales alrededor de obras y situaciones del momento, serán aliciente para encontrar en Marx un aprecio por el sentido común y las formas alternativas de socializar. De hecho, como anécdota importante, recordará en su madurez que con los Westphalen se encontró los presupuestos de Saint-Simon (Gemkow, 2010). Hablando de la casa de los Wesftfalia: “...pudo recoger Carlos Marx muchas sugestiones que no le brindaban la suya propia ni las aulas” (Mehring, 1965, p. 18). Para Cardona Castro (2002):

Karl Marx debe a su suegro el primer conocimiento sólido de bienes que durante toda su vida le serán disfrute y apoyo connaturales: Homero y los trágicos griegos leídos (y muy sabidos) en el original, Dante en italiano, Shakespeare en inglés, Cervantes en castellano. (P. 22)

El joven Marx tenía la preocupación por alcanzar los objetivos que le planteaba el centro de estudios básicos. La educación formal no fue descuidada en sus primeros años. Cabe notar que en su entorno era lógico predisponer a los niños y jóvenes a seguir con el oficio de sus padres o con el negocio de sus familias (ni Marx ni Engels escaparon a este dictamen). Sus personalidades encararon la situación y siguieron sus propios criterios, sus caminos, sus intereses; no acpetaron la imposición de un destino planeado por terceros.

En septiembre de 1837 alcanzó su grado ${ }^{7}$. Según observaciones de las autoridades de ese centro educativo (Gimnasio Federico Guillermo de Tréveris, escuela de primeras letras), el joven Karl aprendía muy rápido y lograba sortear las dificultades que se le presentaban (Gemkow, 2010).

Entre 1830 y 1840 la situación en los territorios alemanes era de persecución, represión y censura. La fugaz revolución parisense de Julio no pudo sostener su ímpetu y pronto fue sofocada lo mismo que las esperanzas de cambio en los territorios alemanes como lo señala Gemkow (2010).

Prusia se propuso especialmente, aunque evitando la violencia extrema y brutal, "purificar" y germanizar a Trier. El llamado "lado izquierdo", del Rin, la región renana, era el territorio subversivo par excellence, la una más afrancesada, peligrosa, revolucionaria. (González Varela en prólogo de Marx, 2012, p. 17)

La represión soportada por los sectores menos favorecidos y el papel de los funcionarios del Estado en pro de los privilegios de las clases altas, llamará mucho la atención en Marx, ya por si mismo veía la realidad, ese antagonismo de clases.

Un Marx estudiante, asiduo observador, que no mostró haber sido permeado por la ideología ni por las opiniones apresuradas sobre un fenómeno, se verá en toda su obra futura (Bloch, 1983). A sus cortos 17 años ya definía sus observaciones y decisiones sobre las imposiciones ideológicas como la supuesta predestinación poiética sobre los oficios-profesiones. Reconoció que el primer filtro aplicado no era otro que el impacto material reflejado en cada ser humano y su sociedad inmediata, es decir, en su propia prole.

\footnotetext{
7 "Tiene dotes, y muestra una muy elogiable contracción al trabajo en idiomas antiguos, en alemán e historia, una elogiable capacidad para las matemáticas, y una muy escasa aplicación para el francés". La comisión le otorgaba el título de graduación "en la esperanza de que satisfaga las favorables expectativas que sus dotes justifican". Reifezeugnis von Marx (Informe de fin de curso), Tréveris, 24 de setiembre de 1835. MEGA, vol. 1, págs. 183-184. citado por Gemkow, 2010 , p. 14.
} 
En octubre de 1835 Karl sale por río a la ciudad de Bonn. Está dispuesto a seguir con sus estudios superiores en derecho como lo recomendaba su padre. Aprovecha y observa con lupa crítica la situación de zozobra que atraviesa la ciudad. Ya en sus estudios fue nombrado líder estudiantil.

Marx no tropezó con dificultades. Pero pronto advirtió que la mayor parte de las cátedras no lo satisfacían. Redujo el número de aquellas a las cuales concurría, y comenzó a estudiar por su cuenta, en consonancia con un plan personal que más tarde, en Berlín, se convirtió en su método básico de estudio. (P. 17)

Siguió su vida de estudiante y hasta de bohemio con camaradería. Cabe resaltar que su apasionamiento por el conocimiento fue constante, sobre todo por las tramas que podía existir detrás de este. En su círculo de estudiantes se departía, se hacía poesía -en lo que era muy prolijo- y se debatía. "El joven Marx se contaba entre quienes reaccionaban de esa manera. No sólo se unió a una asociación de jóvenes poetas, detrás de cuyos intereses literarios, no cabe duda, también se ocultaban objetivos políticos (Gemkow, 2010, p. 18).

En 1836 Karl se va a Berlín a continuar sus estudios apoyado por su padre. Se retira de la Universidad de Bonn. Berlín ofrece un horizonte distinto a la pequeña Bonn, era una metrópoli, un lugar de concentración de la actividad intelectual y cultural, estaba actualizada. Él llega con entusiasmo de dedicar mucho tiempo al estudio. En Carta al padre escribe: "Al llegar a Berlín, rompí todas las relaciones que hasta entonces había cultivado y me dediqué con desgano a visitar lugares raros, tratando de hundirme en la ciencia y en el arte" (Marx, 1982, p. 5).

El joven Karl, quizás sintió la frustración y el desengaño de un sistema educacional -para sus tiempos instruccional-, que no delineaba un camino de real emancipación, de conciencia social, de abono para la crítica. Un ambiente frívolo, además de agitado era bien percibido por el joven estudiante en su estadía capitalina. Es sorprendente que Marx desarrollara esta facultad sin una clara orientación específica de alguien -por lo menos no se registra-; esto le da más crédito a una lectura de su mundo, sin intervención directa alguna de un tutor o intérprete inmediato, él mismo deducía y objetaba.

¿De qué le sirvieron sus estudios de latín y de griego, su jurisprudencia, su mitología? Le sirvieron para burlarse de esa tradición. Supo, desde muy joven, que los representantes de esa tradición eran los burgueses, grandes revolucionarios primero y, luego, grandes impostores. Los estudios le sirvieron, como a todo buen estudiante, para detestar todo cuanto había estudiado. (Silva, 2009, pp. 42-43)

Berlín era todavía epicentro de lucha de la visión feudal contra la visión propuesta por el progresismo capitalista burgués. La pugna no era abstracta, eso que en Marx se llamará antagonismo, demostrará las contradicciones del sistema aún imperante pero moribundo frente a las del sistema que se impondría.

La situación de la sociedad alemana será particular. Fue una realidad histórica entendida y no entendida al tiempo, los mismos estudiosos de la época especulaban más no deducían lo oculto. Gracias a Hegel y su extensión marxiana, la comprensión dio un giro epistémico y metodológico. Además, parecía que la revolución moderna en los diferentes ámbitos, tardaría mucho en llegar a todos los territorios alemanes; una de las grandes preocupaciones era consolidar un Estado central al tiempo que reemplazar las viejas prácticas manufactureras por el tecnicismo. Acá se ve una difícil jerarquización entre ideas y materializaciones a la hora de definir los inicios del desarrollo en la patria marxiana.

Pero, aunque la burguesía alemana no fue lo bastante madura y fuerte, hasta la década del 30, para derrotar y destruir al feudalismo en el plano político, en el plano ideológico preparó el terreno para la revolución burguesa. Ello se logró por medio de la literatura clásica alemana, y ante todo gracias a la filosofía clásica de finales del siglo XVIII y comienzos del XIX. Los representantes de esa literatura y 
filosofía apuntaban el arma de la crítica, en particular en el terreno de la religión, hacia los mismos enemigos contra quienes luchaba la burguesía en el campo político: la fanática clase feudal. (Gemkow, 2010, p. 21)

El joven Karl, al retomar sus estudios de derecho- siendo fiel a las indicaciones de su padre-, aplica una forma autodidacta que le servirá luego para investigar, como apuntará Glasser (1941), para construir su visión del mundo. Pero, tras la muerte de su padre el 10 de mayo de 1838, Karl abandona la jurisprudencia (González Varela en Marx, 2012). Afirmará en el prólogo, de su Contribución: "aunque el objeto de mis estudios especializados fue la jurisprudencia, la consideraba sólo como una disciplina subordinada al lado de la filosofía y la historia "(1989, p. 7).

Todos los conocimientos en el campo de la jurisprudencia le serán armas para arremeter con conocimiento, contra las imposiciones que buscaban dar un carácter legítimo a las ordenanzas jurídicas en las que se sustentaban Estados y procederes desfavorables a la clase obrera (Silva, 2011).

Ya tristemente "libre", Karl puede dedicarse a lo que le gusta, es decir a la reflexión totalmente filosófica, ahora en términos formales. Las preguntas filosóficas empezaron a asaltarle, pero la tradición no lo sació. Aquí se puede encontrar los primeros rastros concretos, documentados de su despertar filosófico dentro de la misma filosofía, o sea una crítica de ésta. Consintió en la filosofía, una alternativa de comprensión pero que debía ser tratada de manera distinta, con objetivos prácticos más allá del utilitarismo.

Muy pronto sus estudios técnicos de derecho dejaron paso, cada vez más, a una preocupación por la filosofía. "Tenía que estudiar jurisprudencia, pero ante todo sentía ansias por dedicarme a la filosofía", ${ }^{9}$ escribió más tarde en punto de ese período. En rigor, el estudiante empezó a buscar entonces, con apasionamiento, una Weltanschauung, una visión del mundo que pudiese darle una base para su labor científica y para sus concepciones políticas. (Gemkow, 2010, p. 22)

Se enrumbó entonces, por otros intereses distintos a la jurisprudencia. Sintió interés profundo por la historia y la filosofía, a las cuales llegó por los caminos de la literatura desde niño. El universo de ideas del centro de estudios berlinés, le dio ánimo para transitar por el sendero del pensamiento humano que le brindara herramientas críticas para entender la realidad. La socialización con las personas de allí, le permitió conocer las distintas formas de pensar, le dio instrumentos teóricos también. El espacio influyó:

La influencia intelectual que primaba en la Universidad de Berlín en aquella época era la filosofía de Hegel. A Marx, lógicamente, le llegó también la influencia. Así, el problema de la libertad social y las causas que le impiden alcanzarla fue básicamente el tema de los primeros escritos de Marx. Enfocó el problema y le dio solución según un espíritu básicamente hegeliano. (Cardona Castro, 2012, pp. 16-17)

Cabe retocar lo anterior con "lo que planteaba Marx: la filosofía por sí sola no va a resolver el problema del ser del hombre, de su práctica cotidiana, de su existencia real" (Núñez Tenorio, 1998, p. 73). Las fuerzas humanas materiales serán el motor de las transformaciones.

El estudiante Karl defiende su tesis en Jena en el año de 1841 (aunque otras veriones destacan su no presentación). Termina los estudios en 1842 graduándose al final, también en filosofía (Abbagnano, 1994, b.). Demócrito y Epicuro ${ }^{10}$ como sujetos de estudio del joven Marx, mostrarán el sendero inicial del materialismo (Mc Lellan, 1982).

\footnotetext{
${ }^{8}$ Karl amaba a su padre más de lo que puede esperarse de un hijo entre retraído y rebelde para con su padre.

${ }^{9}$ Marx a Heinrich Marx, 10 de noviembre de 1837. En MEW, Suplemento I, pág. 4 (nota del autor).

${ }^{10}$ Der Unterschied zwischen der Naturphilosophie von Demokrit und Epikur (Diferencia entre la filosofía de la naturaleza de Demócrito y la de Epicuro).
} 
En su tesis doctoral, Marx (1982), ofrece una pedagógica comparación entre dos legendarios pensadores influyentes. "Mientras que Demócrito trataba de aprender de los sacerdotes egipcios, de los caldeos persas y de los gimnosofistas indios, Epicuro se ufana de no haber tenido ningún maestro, de ser autodidacta" (P. 26). En este escrito interesante, fugitivo de la versión tradicional de la estática de su ambiente intelectual, sigue el pensador de Tréveris destacando que, "mientras que Demócrito, insatisfecho con la filosofía, se echa en brazos del saber empírico, Epicuro desprecia las ciencias positivas, que en nada contribuyen a la verdadera perfección" (P. 26). Ya se encuentra en su escrito un evidente interés por discriminar la acción de la contemplación realizándola con maestría.

Por consiguiente, propuso dedicarse a la filosofía y también a la ciencia. Al ser destituido su amigo Bruno Bauer quien era crítico de la teología, Karl no tuvo oportunidad de ejercer en la universidad como docente. Él "renunció a la docencia, al "examen prusiano para el profesorado" (Mehring, 1965, p. 33). La docencia le fue negada, acaso por su tendencia peligrosa que podría afectar negativamente el stau quo.

Sobre el anterior asunto, Riazánov (1962) hace énfasis en lo que Engels escribió en 1842 contra las posturas del "adversario" de Hegel: Schelling. Este último, auspiciado por el oficialismo de Prusia, debía reconciliar Evangelio y ciencia; ponerlo a él y truncar al "Doctor Rojo", era iniciar la retoma de la universidad para la causa del Estado. No había espacio para la crítica, menos para los asomos de un tipo de socialismo beligerante. Esta coyuntura más que administrativa, pues fue netamente ideológica, marcará a Marx, confirmando con su experiencia personal, que las relaciones de poder permean la academia.

Marx, el Marx terrenal, muy humano, siente la necesidad de organizar una sociedad marital de derecho. Es por lo anterior que, en 1843 contrajo matrimonio con su amada de antaño. Jenny von Westphalen, con la cual tendrá seis hijos, le dará el sí, muy a pesar de sus marcadas diferencias socioeconómicas, mas no de perspectivas del mundo, de intereses comunes. Debido a situaciones materiales, perderán tres hijos de muy temprana edad. La muerte prematura de sus pequeños hijos marcará a Marx, pero en su trabajo no desfallecerá.

De hecho, gracias a su compañera, con la que pasó vicisitudes, pudo sentir un apoyo moral y material en la continuación de su propuesta de pensamiento. De ahí también que el socialismo propuesto por Marx pusiera a la mujer como pilar complementario de su pensamiento. Ninguna postura en la historia de la filosofia había tenido tanto esto en cuenta. La mujer debería liberarse de las cadenas del ahora sistema de esclavismo asalariado.

Marx tenía tanto respeto por la inteligencia y el sentido crítico de su mujer que le mostraba todos sus manuscritos y daba gran importancia a su opinión, según él mismo me dijo en 1866. La señora Marx copiaba los manuscritos de su marido antes de enviarlos a la imprenta. La señora Marx tuvo varios hijos. Tres de ellos murieron a una tierna edad, durante el periodo de dificultades que atravesó la familia después de la Revolución de 1848. Por entonces vivían como emigrantes en Londres, en dos pequeñas habitaciones en Dean Street, Soho Square. (Lafargue 1890-1891, en Fromm, 2012, p. 247)

No escatimaba líneas para describir las inclemencias del trabajo al que eran sometidas las mujeres y el mismo abandono que debía hacer de sus hijos cuando ellas mismas querían estar al lado de su núcleo, al lado de sus seres queridos tal como lo inmortalizó en el libro I de El capital (Marx, 1975). El capistalismo ofrecía libertad, pero para pasar del hogar como ama de casa sumisa, a trabajadora en fábricas sometidas a los efectos del mercado.

El encubrimiento ideológico, esa apariencia de armonía impuesta y justificada, fue resaltado en su momento como lo escribe Silva (2009): 
Ahora bien, en innumerables ocasiones - particularmente en El Capital— insistió Marx en que tanto el Estado como su soporte jurídico son formas ideológicas encargadas de justificar y darle lustre legal a la explotación. El contrato jurídico entre obrero y capitalista es una forma ideológica encargada de presentar como igualitaria y justa una relación en la cual una parte es explotada y la otra es explotadora: es la ideología jurídica que esconde a la plusvalía. (P. 107)

Las denuncias sobre el maltrato también se extendían en la medida en que rechazaba la interpretación bíblica de la responsabilidad femenina del "pecado original", con la que había cargado por muchos siglos este género. La formación no debía ser vedada a la mujer; pues ella misma es por naturaleza educadora, esto le facilitaría formar en consciencia ${ }^{11}$.

Karl sacrificó su vida, su salud y su familia por su trabajo práctico (Dognin, 1975), en esto coinciden todos sus biógrafos. A pesar de las circunstancias y los problemas de todo tipo, la familia ubicaba un lugar importante en su vida. Paul Lafargue su yerno franco-cubano, escribió a propósito:

Marx se pasaba horas jugando con sus hijas. Éstas recuerdan todavía las batallas marítimas en una gran tina de agua y el incendio de las flotas de barcos de papel que les hacía y a los que prendían fuego después para su gran entusiasmo. Los domingos sus hijas no lo dejaban trabajar; les pertenecía por todo el día. (Lafargue 1890-1891, en Fromm, 2012, p. 245)

Y sigue: "era un padre amoroso, bondadoso e indulgente. "Los hijos deben educar a sus padres" — decía. Nunca hubo la menor señal del padre autoritario en sus relaciones con sus hijas, cuyo amor hacia él era extraordinario" (P. 245). El padre "Mohr" luego haría lo mismo con sus nietos denotando, como aparece implícitamente en relatos de sus hijas, la importancia que daba al desarrollo infantil a través del juego, las lecturas (los cuentos de los hermanos Grimm les compartía a sus niñas) y del tiempo que debían pasar los hijos con sus padres (Marx E., 2014). Su hija Eleanor nos comparte:

Pero era en su relación con los niños donde Marx era quizás más encantador. No ha habido compañero de juegos más agradable para los niños. El recuerdo más antiguo que tengo de él data de mis tres años de edad, y "Mohr" (tengo que usar el viejo apodo familiar) me llevaba cargada sobre sus hombros alrededor de nuestro pequeño jardín en Grafton Terrace poniéndome flores en mis cabellos castaños. (Marx E., 2014, párr.6)

La importancia del tiempo compartido en familia fue tratada en varias de sus obras. Tocaba el factor tiempo como ese espacio que era entregado a otros por parte del trabajador, esto no le daba ningún beneficio sino todo lo contrario, afectando así las relaciones de familia y fraternidad que tanto se señalaban de ser despreciadas por parte de los comunistas según las posiciones antagónicas a lo marxiano. Los beneficiados eran los propietarios, los compradores de la fuerza de trabajo, del trabajo viviente.

En Razón y revolución, Marcuse (1993) conecta os primeros intereses denunciativos marxianos:

Los primeros escritos de Marx son la primera declaración explícita del proceso de la reificación (Verdinglichung), a través de la cual la sociedad capitalista transforma todas las relaciones personales entre los hombres en relaciones objetivas entre cosas. Marx expone este proceso, en El Capital, como el «fetichismo de la mercancía». El sistema capitalista relaciona a los hombres entre sí a través de las mercancías que se intercambian. El status social de los individuos, su nivel de vida, la satisfacción de sus necesidades, su libertad y su poder están determinados por el valor de sus mercancías. (P. 274)

${ }^{11}$ Después, entre otras, Rosa de Luxemburg dará constancia de lo acotado por Marx; en América Latina también aparecerán célebres personalidades como María Cano. 
En textos como El capital $^{12}$, Contribución a la crítica de la economía política (Marx, 1989) y hasta en sus textos de la década de los cuarenta, se encuentran alusiones a aquella situación de vida enajenada (Marx, 1989). Situación usurpadora de ese límite material que tiene todo ser historial, el cual puede y debe ser invertido en la misma persona, en su crecimiento y disfrute de la vida, dedicación a sus allegados o todo aquello que le individuo considere pertinente en uso de su libertad, de su tiempo. En el Manifest der Kommunistischen Partei (Marx, 2008) se cuestionaba la contraparte que expresaban los burgueses contra el comunismo al culparlo de abolicionista de las relaciones familiares y su estilo de formación, Marx evacúa dialécticamente a través de la pregunta el supuesto argumento burgués.

\section{Aprendizajes y legado del exilio}

La obra marxiana directa de Marx es un conjunto de experiencias y no solo de abstracciones o suposiciones. El gruso de sus aportes reflejan el contexto vivido, gan parte de este contexto soportado en su exilio por Europa occidental. Es sorpredente como, a pesar de los trajines de una vida en persecusion, haya podido dedicar su intelecto a pensar filosófica y cientficamente, él es ejemplo de dedicación a una causa. Fue fruto de su entorno, con su espíritu inquieto no dejó nada que veía en su cotidiano por fuera. Puedo decir con Kuhn que:

Un hombre puede ser atraído hacia la ciencia por toda clase de razones. Entre ellas se encuentra el deseo de ser útil, la emoción de explorar un territorio nuevo, la esperanza de encontrar orden y el impulso de poner a prueba los conocimientos establecidos. Esos motivos y otros muchos ayudan también a determinar a qué problema particulares dedicará más tarde su tiempo el científico. (1996, p.72)

Para el carácter científico y el sentido común como maneras complementarias de comprensión de lo cotidiano, contribuirán sus amargas experiencias. Su vida intelectual y de autodidacta, en tanto conocedor de varios campos de estudio, les permitió poner eso al servicio de su labor teórica y de base. Su entrelazamiento de derecho con filosofía (Glasser, 1941) le permitió entrar en las lides de la política entendida al servicio de los derechos inalienables.

Caso sonado fue la defensa en la Dieta de Renana acaecido en 1842, donde daba otra razón más profunda sobre el robo de leña, que en sí era una apariencia ideologizada que ocultaba la verdadera razón, o sea la acumulación por desposesión en detrimento de la comprensión de los bienes comunes a los cuales toda la población debía acceder; arguyó que el "hurto" solo era pretexto para usurpar e imponer reglas que favorecieran a los poderosos. Descubrir y difundir que la cosificación de todo ponía al hombre por debajo de la mercancía ya era un hecho reprochable para las esferas de poder. Esto le acarreará una fama de alborotador en su propia tierra.

Entre las acusaciones contra Marx estaban la de agitador y comunista férreo. Sin embargo, Riazánov nos dice que: "cuando abandonó la Gaceta Renana, Marx no era aún comunista, pero sí el hombre a quien interesaba, el comunismo como tendencia, como filosofía concreta (1962, p.11). Más adelante, su labor estará al servicio del movimiento comunista obrero internacional. Lo poco que tenía ya estaba listo para ser empacado, buscando otros horizontes presionado por los poderes que tanto criticaría.

${ }^{12}$ El capital es un tratado en tres volúmenes. El primero se publicó en Hamburgo en 1867; el segundo y el tercero fueron publicados por Engels después de la muerte del autor, respectivamente en 1885 y en 1894. 
Naturalmente, existían razones para ser objetivo de los poderes de la feudal y la nueva Europa. En la primera, aun moribunda pero no derrotada, estaban vigentes las cosmovisiones del Ancien régime, por ello era inaudito pensar en que una clase de harapientos pretnedieran decidir por si mismos, mucho menos llegar al poder; debía enterrarsele de tajo pues eral a extensión del oscurantismo, de resignación y del derecho divino medieval. En la segunda Europa, la de la nurguesía, que proponía libertades pero sin radicalismo no se debía confiar más era preferible por ahora ya que está podía garantizar el cumplimiento dialéctico del "destino" para la clase trabajadora. Lo interesante de Marx, es que a la hora de estar como errante y sin patria, no abandonó sus intereses, todo lo contrario, dicha experiencia le sirvió para consolidar su visión de mundo, enfrentadose a las dos mencionadas perspectivas.

\section{Entre exploraciones voluntarias y el primer período de exilio}

Hadot (1998) recuerda en su texto sobre los primeros filósofos que, estos eran al principio viajeros, querían conocer las cosas por sí mismos, exploraban, observaban y especulaban; eso los hizo especiales, eso los hizo filósofos. Muchos de la antigüedad no se quedaban quietos en un lugar; unos a voluntad otros muchos por presiones, se dedicaban a escribir sus impresiones. Hasta Descartes, reconcía la importancia de conocer al mundo. Si para el maestro Séneca su patria era el mundo, para Marx no había patria solo la patria de los trabajadores de todo el mundo. Claro, marx no salió de Europa occidental, gran cosa que habría que reclamarle, pero no podemos restarle su interés por recorrer el cotidiano de su entorno inmediato.

Paradójicamente, su exilio fue una enseñanza, un afianzamiento de sus convicciones frente al mundo enajenado que debía desenmascararse. Fue en sus etapas de huidas, desprecios y desesperanzas donde pudo conocer otras realidades, escribir sus aportes, integrarse a los obreros directamente, consolidar su amistad con Engels, discrepar con idealistas, soportar las inclemencias del cotidiano, pero sobre todo apreciar todo como un gran campo social para establecer que al teorizar se podía pensar en una superación.

En 1844 Marx propone que la única clase determinada a liderar la revolución es el proletariado. Esta nueva clase podía y debía asumir la emancipación del pueblo alemán (Riazánov, 1962). Comenzaría a interesarse por el estudio de los elementos propios del sistema para construir la propuesta pedagógica hacia la construcción de una conciencia de clase sin fronteras; así llegaría a reconocerse esta clase, en que "sólo le falta la conciencia de su misión, la ciencia, la filosofía; y constituirá el eje de todo movimiento emancipador si llegara a penetrarse de esta conciencia, de esta filosofía, si comprende el gran papel que le corresponde" (P. 18). Es peligroso ser teórico de unas masas desposeídas, mucho más incentivar a que se formen.

Erige a la ciencia con una perspectiva crítica, desmontada de la etiqueta de elite y de objetividad; las observaciones parten de la aplicación del método crítico, de una intención de mostrar las evidencias del fenómeno productivo y sus atroces consecuencias. "En las divergencias con sus enemigos, Marx y Engels repitieron que los principios de la enseñanza científica constituyen un arma para la clase obrera en su lucha contra la burguesía" (Suchodolski, 1977, p 53).

En su estadía y posterior exilio inglés ${ }^{13}$, no escatimó en tiempo para hacer de la actitud científica un arma social. Así lo hizo con la economía cuyo fundamento se encontraba ligado al capitalismo mismo. Leyó filosóficamente al hecho económico, vio lo que ganancia degeneraba y le dio la vuelta a sus fines.

${ }^{13}$ En 1845 viaja con Engels para estudiar fenómenos sociales y económicos. En 1849 se exiliará con su familia hasta su muerte. 
Marx reanuda sus estudios de economía política en 1850 en Londres, en donde decide "volver a empezar desde el principio", pero mejor armado teóricamente, lo que le ayudará a alcanzar importantes resultados en la tarea de aislar o abstraer conceptos simples, para analizarlos a profundidad y regresar a reconstruir totalidades mayores, cada vez más reveladoras y explicativas de la anatomía de la sociedad burguesa. (Osorio, 2004, p. 25)

Los temas de las ciencias naturales y las ciencias históricas estuvieron en la agenda de Marx. Su vida se movió en una época de grandes cambios en esta dimensión. Mucha fue la correspondencia que puede dar fe del interés por temas concretos, incluso con personalidades destacadas en algunas disciplinas de la ciencia natural. "En los años 1850-60 es sobre todo Marx quien se ocupa de las ciencias de la naturaleza: la física, la cosmología, la geología, la físiología” (Lefebvre en Marx, Engels, 1975, p. 9).

Hace seguimiento de Darwin para relacionarlo con su modo de ver la sociedad capitalista. Mientras, "durante este periodo, Engels se dedica preferentemente a las matemáticas, y es con relación a ellas que lee las obras físicas publicadas en los años 60” (P. 10). Amplios conocimientos de Engels en la medicina lo destacan como un pensador que relacionó esto con las problemáticas de salud de las hacinadas comunidades obreras que también sufrían las consecuencias mortales de la exposición a material y desechos tóxicos.

Marx será perseguido y expulsado de su terruño, buscará las tierras occidentales de Francia y Bélgica. Ésta será la gran consecuencia, el precio que debía tributar a la historia por su intento de despertar con su acción el desafío al sistema imperante. En su nueva situación, redactará obras de alta influencia y reflexión filosófica extendida a las dimensiones sociológica, política, histórica y económica; todas con el firme compromiso de formación en la crítica.

Cuando llegó a París, consecuencia del exilio, Marx se dio cuenta de que era un buen momento para regresar a su filosofía y confrontar sus escritos con los de un filósofo de gran influencia en esa coyuntura Ludwig Feuerbach, quien había publicado, en 1841, La esencia del cristianismo. (Cardona Castro, 2002, p. 31)

Procurará llegar a las audiencias y, como crítico de los estilos encopetados de los ideólogos filosóficos, se apartará en gran medida con su estilo de esa postura no comprometida con la transformación material del mundo. Por ello si era necesario denunciar las acciones de cualquier persona o institución no ahorraba letras. He aquí que parecen los ataques a la religión por ser una de las manifestaciones más inlfuyentes de la época. Esto le acabó de incluir más enemigos y una incomprensión que se respira aun en poelna siglo XXI. La Iglesia - pesar de las divisiones de doctrinas cristianas- por fin tenía un enemigo común que no fuera Satanás en persona.

Para contrarrestar, primero la influencia de la doctrina eclesial y, luego, los señalamientos de aquella, utilizará su particular forma de expresión no sin acudir al sustento histórico y filosófico. Será ilustrativo y echará mano de la metáfora. Las metáforas están presentes en toda la obra de Marx. "Son las metáforas con que ilustra su concepción de la historia, y al mismo tiempo las que le sirven a menudo para formular sus implacables críticas contra los ideólogos y economistas burgueses” (Silva, 2011, p. 64) ${ }^{14}$.

En el texto, Zur Kritik der Hegel' schen Bechts - Philosophie von Karl Marx en Deutschefranzosische Jahrbücher herausgegeben von Arnold Ruge und Karl Marx (Crítica a la filosofía del derecho de Hegel), que aparecerá en París, y la cual verá la luz en 1843, estará una de las más polémicas formulas marxianas. En aquella, Marx dio sus incomodas apreciaciones sobre la religión, desmontando el mito de la religión como salvadora y, con la deducción, de la educación alienante que se promueve desde los religiosos selló

${ }^{14}$ Entre las que están tres grandes, a saber: la metáfora de la superestructura, la del reflejo y la de la religión. 
su rotulo de ateo. Tiempo después, será un sustento para optar por la educación secular por parte de las visiones marxianas.

La miseria religiosa es, por una parte, la expresión de la miseria real y, por otra, la protesta contra la miseria real. La religión es el suspiro de la criatura agobiada, el estado alma de un mundo desalmado, porque es el espíritu de los estados de alma carentes de espíritu. La religión es el opio del pueblo. (Marx, 1982a, p. 491)

Cabe decir, Marx como judío difilmente se desprendió de sus ideas, pues son influencia de siglos en su familia. Ello quiere decir que, de todas maneras sus observaciones mordaces no eran del todo ateas como quiso adjudicárseles dicho apelativo -muy ofensivo y excluyente para la época-; eran simplemente opiniones, consecuencia del binomio Estado-Iglesia, la cual precisamente, se destacaba por comportamientos no muy caritativos. Parece que Marx no diferenciaba entre católicos y protestantes u otros credos, para él el germen de la religión era el mismo, sus fines al servicio de la idea de sumisión que no solo fué característico del mundo feudal sino que se había sofisticado con la nueva sociedad burguesa. La religión ahora tenía un nuevo protector y aliado: la burguesía moderna, la que en principio también atacó a la religión establecida, pero sin vehemencia. El poder alienador de la Iglesia era monumental, su ideario e influencia seguían establecidas cómodamente, sus formas de reproducción contibuaban siendo muy efectivas.

De todas maneras, podría decirse que el Marx de carne y hueso y sosicopedagogo no quería compalcer a ninguan institución, por ello elevó acérrimas críticas a la Iglesia, sobre todo a las cúpulas a quienes despreciaba por su utilización del discurso teológico para someter mentes, para justificar crímenes o la explotación. Como el opio, la doctrina es potencialmente adictiva; pero ellas son adictivas precisamente porque es la sociedad de consumo las que las hacen adictivas, las que las promociona y se normaliza así mismo.

Además, obedecen a un estilo artificial que busca alejarnos de la realidad tangible. La religión se convertía cada vez más en mercancía. Marx no desconoce la espiritualidad; él mismo aprecia el tema de la conciencia y si esta no es espiritual no será verdadera sino falsa conciencia. Esa frase será interpretada de diversas maneras; apreciada, dialécticamente leída por la teología de la liberación, tildada de atea y vetada. La demostración de la fetichización de la religión ahora en mercancía y productora de comerciantes, se hace presente al relatar sobre el fenómeno en las colonias norteamericanas decía Marx (1982 a).

También la publicación de los Anales franco-alemanes se dará en la capital francesa. En estos "formula por primera vez los puntos fundamentales de su futura filosofía en los cuales de demócrata se transforma en comunista" (Riazánov, 1962, p. 11). La comparación entre los regímenes republicano y despótico moderno, y luego del monárquico constitucional, darían en Marx la misma conclusión: el poder en manos de quienes no reprsentaban sino a sus propios sectores; el pueblo llano estaba rezagado, y este pueblo llano era el que producía la riqueza de los países. Ni sus Estados les garantizaban formación seria e inclusiva. El derecho a al educación universal se limitaba a algunas ordenanzas famélicas que no tenían en cuenta las realidades sociales. Los recursos a educación eran ínfimos, la infraestructura y la cobertura un ridículo, las promesas ni siquiera se hacían ecos, pues era más importante el tema del pan que las exigencias educativas por parte de los obreros y campesinos. El Estado burgués no era garantía de nada, las formas variaban, la esencia no.

A propósito, la Francia postrevolucionaria que le fuera cercana desde sus primeros años en su terruño, era vista con aprecio porque a pesar de todo el papel de la burguesía, ya se veía un tipo de apersonamiento de la clase trabajadora, de ese pueblo que se había levantado en 1789, pero que había sido traicionado por la 
burguesía; esto no volvería a pasar. Marx estaba atento de lo que sucediera en ese país. Prefirió no pensar más en posibilidades en la Alemania fragmentada, donde la población no tenía la madurez de tomar las riendas de su propio destino. Así,

Marx recorrió los centros insurreccionales en Karlsruhe y Kaiserslaurtern, y tuvo ocasión de convencerse de que su puesto no estaba en medio de aquellos burgueses, sino más bien en el centro de la revolución, en París, donde se estaba preparando una crisis político social. (Mesa, en Marx, 1999, p. 30)

En el joven Marx se da una ruptura política también. El abandono a la idea de un Estado burgués por una versión de Estado racional (universal) que incluya al sector obrero, será el inicio de su etapa de autocrítica. De un aprecio a la clase revolucionaria burguesa, se pasará a la antipatía. La burguesía no será más revolucionaria, de hecho en la msma visión de educación promoverá la perspectiva conservadora. Es mejor una población ignorante que un pueblo minimamente letrado o menos aun: pensante. La nueva clase no iba a hacer nada por cambiar de fondo las cosas, ni a mediar por el bienestar de los más desamparados, pero si seguir acrecentando sus ganacias y hasta su plusvalía ideológica. Por esto:

La ruptura política de Marx con la burguesía condiciona la intensa revisión a que va a someter el joven Marx sus posiciones teóricas y políticas anteriores. El carácter político de la ruptura determinará que, en todo este primer período de autocrítica que se realiza en la Crítica a la Filosofía del Estado de Hegel y en los Anales franco-alemanes, el elemento ideológico dominante sea la alternativa al Estado burgués. Marx busca una alternativa al Estado liberal: no una alternativa al Estado. De momento el joven Marx conservará la alternativa del Estado racional: se trata de concretar esta alternativa políticamente, puesto que ya no coincide con el Estado burgués. (Bermudo, 1975, p. 103)

Siguiendo a la Cuestión judía (Zur Judenfrage), "replicaba que no era suficiente investigar quién había de ser emancipador y quien el emancipado, sino que la crítica debía indagar de qué clase de emancipación se trataba, si de la emancipación política meramente o de la emancipación humana" (Mehring, 1965, p. 66). De acá, puede tomarse a la educación crítica en camino para concretar y educar en la emancipación humana, solidaria e irrenunciable en la medida en que hay que reconocer las circunstancias materiales en torno a los fenómenos para comprenderlos mejor y no caer en simples opiniones carentes de análisis.

En el recorrido voluntario y obligado, el Marx reflexivo pudo desarrollar trabajos importantes. La experiencia en el exilio fue una experiencia precoz, juvenil. "Este primer período de Marx resulta relevante para la pedagogía” afrimará Suchodolski (1977, p. 4) por cuanto está el afán de tocar el tema de la liberación humana de las materialidades y de las apariencias que no son tan materiales, pero parten de la materialidad del sistema alienante y, a su vez, al ser aprehendidas por el sujeto y su colectivo, reproducen ese resabio. Del Noce y Riestra (1975) concluyen refiriéndose al papel de los escritos llamados juveniles, y que estuvieron fuera del alcance durante los últimos años del siglo XIX y primeras décadas del XX, que:

A lo largo de todos estos textos se observa una crítica al ideal de la filosofía - la comprensión de lo real - , en nombre de la revolución. La supresión-conservación recuerda el método dialéctico hegeliano, que adoptará decididamente a partir de 1844. La síntesis, en este caso es la praxis marxista que supera la contradicción existente entre filosofía y realidad. La filosofía quedará aquí reducida a la actividad práctico-sensible, al igual que el hombre quedó reducido a lo sensible, al negar toda posibilidad de participar de la trascendencia. (Del Noce - Riestra, 1975, p. 46).

Defintivamente, salir de un territorio abre la mente. Marx (1845) sintetizará la postura sobre la práctica en tanto praxis, separándola sustancialmente del criterio desprendido de la práctica y el instrumentalismo 
simple. En la undécima indicación de lo que se conocerá como sus Thesen uber Feuerbach ${ }^{15}$ (Tesis sobre Feuerbach), estará la "mina" de la cual deberá sostenerse gran parte de los sustentos que quieran justificar una reividnicacion de la dignidad humana y del reconocimiento a su fuerza transfomadora e histórica.

Con estos apuntes, rescatados por Engels, se dará inicio, evidencia positiva, al naciente materialismo aplicado a la historia. En ellas, tratará de no disociar teoría y práctica, será la praxis tema inscrito, su más destacado aporte filosófico (Silva, 1974).

¿Cuál es el momento en el cual el hombre aparece como forjador del momento histórico? Esto lo vamos a ver mucho en Marx. Está claro que si Marx en la XI tesis sobre Feuerbach dice que no sólo se trata de interpretar al mundo, sino sobre todo de transformarlo, para transformar el mundo necesitamos a los hombres. (Feinmann, 2006, p. 99)

La tercera tesis recordará y recomendará apersonarse del papel de formador sin dejar de reconocer la incidencia del factor humano, y su basamento material en la creación de su propio entorno (Marx, 1845). Allí se exhorta a la conciencia de docente, como sujeto no terminado, sino que está en constante formación. Es una necesidad formarse, dinamizarse sabiendo que hay unas situaciones materiales que afectan los procesos y las estructuras de pensamiento. El profesor, también debe ser educado, no ideologizado. La profesión docente en Marx, muy apreciada por éste como constata en sus cartas, es y debe ser orientadora, no cercenadora, comprometida políticamente con las causas sociales. Esto puede rescatarse, concretamente de sus tesis. He ahí la evidencia crítica del Marx pensante en la formación del hombre que no cambiaría con el tiempo. "Las Tesis sobre Feuerbach expresan la ruptura del joven Marx con la filosofía burguesa" (Bermudo Ávila, 1975, p. 111). Estas alusiones harán parte del compendio escrito tras las fronteras de la Alemania post feudal pero aun rezagada en muchos aspectos si se le comparaba con Inglaterra en lo económico o con Francia en lo político.

El matrimonio Marx-Westphalen que ya llevaba dos años de haberse contraído, saldrá de Prusia en noviembre de aquel mismo año de 1845, si bien la capital francesa ofrecía rasgos de tolerancia y exuberancia, lo único que preocupaba a Karl era la "comodidad" para producir con libertad su pensamiento.

Ante la imposibilidad de publicar los Anales Alemanes en Alemania, Ruge y Marx decidieron crear los Anales Franco-Alemanes, revista editada en Francia de la que se tiró un solo número. Marx publicó allí: «Introducción a una crítica de la filosofía del derecho de Hegel», en la que no rompe con sus convicciones antiguas, pero comienza a buscar en el cauce de la historia la interpretación de la sociedad. Engels publica en la revista «Bosquejos para una crítica de la economía nacional», primer aldabonazo económico de uno de los fundadores. (Guevara, 2006, párr. 14)

Un nuevo exilio se dará en 1845 cuando la monarquía de Luis Felipe se encargó de expulsarle de territorio galo. Todo a consecuencia de su pluma que seguía molestando al régimen prusiano de Federico Guillermo IV de Prusia. De Francia pasa a Bruselas, allí escribirá sus once tesis.

En 1847 contestando a Proudhon y dando término a ciertos acercamientos en temas sociales, Marx escribe en francés su Misére de la philosohpie (Miseria de la filosofía), corría el año de 1847. Para Mesa, en Marx

${ }^{15}$ Carlos Marx escribió las Tesis sobre Feuerbach en Bruselas, en la primavera de 1845, cuando había terminado ya el desarrollo, de los rasgos principales de su teoría materialista de la historia y había extendido el materialismo a la explicación de la sociedad humana. Según definición de Engels, es «...el primer documento en que se contiene el germen inicial de la nueva concepción del mundo». [Véase, pág. 613.] (En, versión soviética publicado en Marxits Archive) 
(1999), en sus líneas se expresa la defensa del comunismo y el combate contra los errores de las escuelas económicas y de los pensadores que se decían ser socialistas y alardeaban de revolucionarios cuando no lo eran, ello se rastrea desde 1843 cuando criticó a Proudhon y su visión romántica de los hechos. Aquí habló Marx de una escuela de tipo humanista enfrentada a la visión del socialismo utópico. Toca a la historia como experiencia a tener en cuenta, e ilustra con lo acaecido en la Inglaterra del siglo XVIII. Por ejemplo:

El taller automático señaló su principio con actos que no tenían nada de filantrópicos. Los niños fueron forzados a trabajar a latigazos; se traficaba con ellos y se hacían contratos en las casas de huérfanos. Aboliéronse todas las leyes sobre el aprendizaje de los obreros, porque, para servirnos de las frases de Proudhon, no se necesitaban obreros sintéticos. (Marx, 1999, p. 155)

La pauta marxiana de la ciencia - no el cientificismo que pretenden achacarle a Marx-, se iniciará al confrontar al utopismo. En la arena de la educación, no cabe duda del rechazo a la visión paradisiaca de los utopistas cuando no se esfuerzan por superar idealismos románticos para dar razón, para construir un discurso convincente desde la ciencia, comenzando por la historia, y así crear horizontes de comprensión sobre las relaciones mundanas que inundan el contexto.

Hoy puede verse, desde la lectura dialéctica, ese esfuerzo de los utopistas; pareciera que lo marxiano no intenta doblegar inmisericordemente al utopismo, sino más bien mostrar el camino de la praxis con teoría, invitar a redireccionarse mediante la ciencia para no malgastar esfuerzos en una posible causa común: la emancipación humana. Marx sabe que ha de tener posición frente a las especulaciones del socialismo utópico. En este punto Engels (1976c-4), después, dará a conocer su postura en su texto intitulado: Del socialismo utópico al socialismo científico.

\section{En compañía de Engels}

El trasegar seguía en la vida del joven pero ya definido Karl Heinrich. La amistad tendrá difícilmente una manifestación en la historia de la filosofía como la que tuvo en la relación Marx-Engels. No hay registro hasta hoy, incluso, de los fuertes lazos establecidos entre dos pensadores. "Fue en París, por último, donde Marx selló su alianza fraternal con Engels, cimentada sobre una identificación sustancial de sus ideas y de la lucha revolucionaria" (Roces, en Marx, 1982, p. XXXIV). Se dice que, en los tiempos difíciles es cuando se conoce a las personas; en este caso, el proverbio mencionado aplicó.

Difícilmente puede hablarse de una filosofía de la educación desde lo marxiano excluyendo a Engels. Él hizo parte de la vida intelectual y colaborativa. En temas de otro tipo, en otras materias, se discute la postura de Engels un poco distanciada de Marx; el caso de los tomos y las ediciones póstumas, de El capital comprueban esto; también algunas interpretaciones marxistas. En materias desdeñadas desde las lecturas que puedan hacerse en una filosofía de la educación, no existe variación, ya que, desde el inicio Marx se plantea una necesidad emancipatoria del hombre y Engels no renuncia a esto; ya hay un compromiso difusor y pedagógico con la obra primigenia de Marx. Al respecto, Lenin en general repunta: “supo cómo éste acumular conocimientos, enriquecer su memoria con el "conocimiento de todos los valores creados por la humanidad" [cf. Lenin, ob. Comp. T. XXV, pág. 407] (Lenin citado por Glasser, 1941, p. 26).

Friedrich Engels fue educado como comerciante, pero no siguió tal sendero, otro ejemplo de resistencia frente a las imposiciones familiares, pero estuvo pendiente de los negocios industriales en Inglaterra. Engels tuvo un sentimiento militar el cual será dilucidado en algunos apartes de sus obras. 
El encuentro entre Marx y Engels en 1842, daría un rumbo complementario al trasegar del compendio socialista erigido por Marx. Fue la oportunidad para conocer las condiciones socioeconómicas inglesas (Russell, 2009). Ahora de aquí en adelante, no estaría solo en la dispendiosa empresa de generar una ruptura con la realidad dominante. Su amigo se convertirá también en mecenas, permitiéndole dedicar más tiempo a su monumental proyecto; las condiciones para filosofar estaban dadas, aunque no sin pasar por algunas penurias. Guevara (2006), afirma que:

Más o menos hacia octubre de 1842, se conocieron Marx y Engels en circunstancias en que el primero había roto con los jóvenes hegelianos y el segundo aún no, por lo que el primer encuentro fue más bien frío y no hacía sospechar la identificación que alcanzarían con el correr de los años. (Párr. 13)

Ambos prepararán su primera obra en sociedad: Die heilige Familie (La Sagrada familia) en 1844, en la cual se encuentra la relación de dependencia del hombre con su ambiente, la necesidad de transformarlo, mostrando una preocupación por esta relación traducida en problema de la formación frente a la adaptación como lo expresa también Suchodolski (1977). También escribirán Die deutsche Ideologie (La Ideología alemana) después de un periplo, en Bruselas entre los años de 1845 y 1846; de este libro Broccoli (1980) abre una interrogante a la hora de pensar la educación desde lo marxiano, en la cual, dice: ¿por qué no pensar a esta obra como una negación a quienes buscan establecer una ideología en la educación recordando precisamente la actitud de los jóvenes hegelianos al respecto? O sea, en una postura marxiana sobre el desmonte ideológico de la educación, pues esto desviaría todo objetivo serio de negación de un sistema de cosas impostor, pues la ideología suplirá a la conciencia, pero esa conciencia que pretenderá ponerse como tal, solo será una ilusión pues obedecerá a un modo particular.

Todo se resumirá en la máxima de: "la conciencia, por tanto, es ya de antemano un producto social, y lo seguirá siendo mientras existan seres humanos" (Marx-Engels, 2012b, en Fromm, p. 211). La Ideología alemana no sería publicada en vida de los autores, solo hasta 1932, de ahí tantos desaciertos según lo consuetudinario, aunque no puede culparse al desconocimiento de esta obra, toda la negativa situación generada en vivencias políticas e intelectuales del siglo XX.

La conciencia es producto de la historicidad de los hombres, no la que se determina en sí, no sale por arte de magia; no viceversa. Clave es entender este texto cuando afirma que la filosofía alemana ponía la relación vertical hacia abajo, desde el cielo a la tierra, pero precisamente de lo que se trata es de poner la dirección a la inversa (Marx-Engels, 2012b). La crítica a la forma de pensar extremadamente idealista se hace de manera ilustrativa, de todas maneras, la intención es la invitación a dirigir la mirada a la materialidad inmediata, sin despreciar del todo la intencionalidad teórica que debe existir en la vida cuya extensión se da en el trabajo y sus relaciones económicas.

Las circunstancias y el contacto con otras perspectivas le dieron luces a Marx en su trasegar por el mundo de la teoría, elementos clave en la búsqueda de complementos a su propuesta materialista recorrido con su amigo "El General"16. La correspondencia era clave entre los dos, sus percepciones de cotidiano no pasaron desapercibidas para realizar sus teorías de la sociedad. En este orden complementario de su amistad, Lenin (2000) nos comenta que:

Después de esclarecer, ya en los años 1844-1845, uno de los defectos fundamentales del antiguo materialismo, que consiste en no comprender las condiciones de la actividad revolucionaria práctica, ni apreciar su importancia, Marx consagra, a lo largo de su vida, una intensa atención, a la vez que a los trabajos teóricos, a los problemas tácticos de la lucha de clase del proletariado. Todas las obras de Marx,

${ }^{16}$ Así le llamaban las hijas de Karl Marx a Federico Engels. 
y en particular los cuatro volúmenes de su correspondencia con Engels, publicados en 1913, nos ofrecen a este respecto una documentación copiosísima. (Párr., 36)

Su relación fraternalmente empática será una gran lección, a la par de ser un compartir de conocimiento. Engels describe a Marx la situación en Manchester. Como conocedor de la realidad inmediata de su entorno empresarial, Engels ilustrará a Marx. Entre julio y agosto de 1845, emprenderán un breve viaje voluntario a esa ciudad inglesa. Allí convivió con las contradicciones del sistema. Ya el propio Engels había descrito gran parte de la situación generalizada, especialmente de la situación obrera (Engels, 2002).

El siglo XIX le permitieron tanto a Marx como a Engels en la ciudad de Manchester comprender que era necesario normar el sentido de la historia. Las soluciones para las masas de desposeídos estaban en la tierra, no en el más allá. (Guzmán, 2017, p. 168)

Observaron como las mujeres daban opio a sus hijos pequeños mientras ellas cumplían su labor industrial casi como esclavas, entre otras problemáticas, Lenin (2000) no perdió tiempo para rescatar estas dramáticas observaciones. Podemos pensar en la impresión de Marx frente a esa escena, tuvo que ser impactante para una persona de quien sostenía su hija Eleonor, tenía -él- un grado alto de afecto hacia la niñez (Eleanor Marx-Aveung, en Fromm, 2002).

Cuando entre 1844 y 1845 Engels redactó y publicó la Die Lage der arbeitnden Klasse in England (La situación de la clase obrera en Inglaterra), se daba un debate en el seno de la sociedad inglesa. Entre otros temas, estaba el de la pertinencia del acceso a la formación escolar e instrumental. El texto, considerado una investigación descriptiva, es una clara denuncia sobre la esclavización moderna y lo fútil del sistema, también destacó la importancia por despreciar las causas que desataban el sufrimiento de aquellos que invertían su tiempo y su salud en producir para aquellos que se servían del capital; el estado de ignorancia y la ausencia de verdaderas políticas educativas garantizó la prolomgacion de ese modelo de desigualdad.

En aquella obra, se comprende la paupérrima condición de niños y mujeres gracias a Engels (Marx, 1975). Tomó en cuenta los procesos en los que la materia prima, era resultado del doble saqueo: el interno de mano de obra, y el de expoliacion de las colonias, todo en función de la nueva economía imperialista. Con Engels se ocupará marx de estudiar el fenómeno a nivel global, será una etapa de apertura en la medida en que observan los fenómenos en el mundo. Desde allí, puede decirse se incicia la postura anti imperialista y geopolítica que caracterizará al legado marxiano a futuro.

Finalmente, Engels será más que un mecenas, es un complemento. En su discurso para Karl el día de su entierro, expresará con sinceridad su afecto, pero sobre todo el papel protagonico que vendría a tener Marx en las luchas de los excluidos que no se limitaría a Europa. Es incomprensible a una teoría marxiana sin los aportes de Engels.

\section{El Manifiesto comunista}

Siguiendo el asunto de la conjunción Marx y Engels, ellos seguirán con su proyecto de amistad sociocomprometida. Entre 1847 a 1848 redactan, una de las obras más sencillas, y podemos decir pedagógico-denunciativas realizada: Manifest der Kommunistischen Partei (Manifiesto del partido comunista). Esta misión fue encargada por la Liga de los comunistas, cuya publicación oficial sería en Londres el 21 de febrero de 1848. 
El Manifiesto es un texto de pauta, en muchos sectores. Siguiendo a Cardona Castro (2002), las reivindicaciones del partido Comunista Alemán tenían, entre otras: el sufragio universal, la creación de un ejército popular, separación iglesia-Estado, abolición de cargas feudales, educación gratuita, esto iba junto al Manifiesto.

"El Manifest der Kommunistischen Partei mantiene la tesis de que la educación constituye un fenómeno de carácter clasista" (Suchodolski, 1977, p. 38). Lo marxiano manifiesta textualmente, para reconocer la propuesta de formación, que:

Und ist nicht auch Eure Erziehung durch die Gesellschaft bestimmt? Durch die gesellschaftlichen Verhältnisse, innerhalb derer Ihr erzieht, durch die direktere oder indirektere Einmischung der Gesellschaft vermittelst der Schule u. s. w.? Die Kommunisten erfinden nicht die Einwirkung der Gesellschaft auf die Erziehung; sie verändern nur ihren Charakter, sie entreißen die Erziehung dem Einfluß einer herrschenden Klasse ${ }^{17}$. (Marx-Engels, 2008, p. 55)

En la educación se hacen aclaraciones, donde se emite la importancia de la formación no solo como clase sino también de manera general. La educación universal es una obligación, pero la misma debía ser desmontada del ingrediente injerencista del Estado en la formación de conciencia.

Del primer capítulo del Manifiesto comunista, Feinmann (2006) dice que el pensador alemán parece "enamorarse" de la burguesía; precisamente la ortodoxia marxista ha ocultado esto; afirma que aquel sostiene esto porque hace una lectura dialéctica; se enamora del padre porque ésta, -como aquel- dará a su hijo: el proletariado oprimido, las razones para rebelarse.

Aunque De Soussa (2011) tiene algunas reservas lógicas sobre aquel texto, se reconoce que, "no obstante los males sociales denunciados por el Manifiesto son hoy día tan graves como entonces (P. 258), de ahí su valor. Dicho texto debe verse como todo, menos como un manual rígido y doctrinario, ha de leerse, se insiste con la lupa dialéctica. "El lugar en el cual la dialéctica en Marx funciona de modo más evidente es en el Manifiesto comunista, más aún que en El capital" (Feinmann, 2006, p. 114). El primero invita a la lucha, es un manifiesto, el segundo expone un modo de producción, el capitalista con sus contradicciones.

Marx en 1872 hace una crítica al propio Manifiesto comunista del 48 y Engels en 1896 formula un rechazo a la política que ellos sostuvieron en el 48 y propone otra táctica completamente distinta, porque las condiciones políticas habían cambiado. (Núñez Tenorio, 1998, p. 154)

El texto será por excelencia un hito. Sufrirá distintas interpretaciones y señalamientos. Con el tiempo la exigencia coyuntural hará que sea leído a través de distintas salvedades contextuales, pero en esencia su contenido será, en una considerable parte, válido.

\section{Rol de periodista}

Faceta importante para entender a Marx, fue su participación en la prensa de la época. Su estilo sarcástico, y demoledor con los poderes de la época, le convirtieron en una de las plumas más temidas por los gobiernos

\footnotetext{
17 ¿Acaso vuestra propia educación no está también influida por la sociedad, por las condiciones sociales en que se desarrolla, por la intromisión más o menos directa en ella de la sociedad a través de la escuela, etc.? No son precisamente los comunistas los que inventan esa intromisión de la sociedad en la educación; lo que ellos hacen es modificar el carácter que hoy tiene y sustraer la educación a la influencia de la clase dominante.
} 
y hasta pensadores. De hecho, el rol de periodista crítico le valió muchos inconvenientes. Fue cofundador de varios espacios denunciativos, pero sin abandonar su tinte filosófico, su compromiso social y el carácter pedagógico de sus estimaciones. En sus períodos de exilio es donde más se mostrará como perisodista prolífico.

Periodista empírico dirá Russell (2009), Marx tenía las dotes que la actitud crítica da para una persona que quiera ejercer esta profesión. A través de la redacción de artículos se hizo conocer, al tiempo que denunciar las infamias del sistema de cosas imperantes y de sus ejecutores. La Rheinische Zeitung (Gaceta Renana) fue la primera artillería pública para el nuevo campo de batalla; lanzaron la primera edición en enero de 1842 hasta marzo de 1843 año en el que sería clausurado por el gobierno prusiano bajo presión de Rusia debido a las “ofensas” contra Nicolás I. Roces en Prólogo a los Escritos de juventud, confirma:

La cátedra universitaria a la que el despotismo le cerrara el paso, se convertía así para él, ventajosamente, en la tribuna del periódico, en la que por las ideas circula la savia vitalizadora de la realidad de cada día, en una lección que es a la vez enseñanza y lucha. (Roces en Marx, 1982, p. XI)

Como dato curioso, al llegar del viaje de recién casados, un amigo de su padre le ofreció un puesto en la burocracia al parecer para sujetarlo al silencio, pero el joven Karl aseveró que cómo era posible que el gobierno que le había negado dar cátedra en una universidad, que le había cerrado su diario ahora le ofreciera un cargo burocrático, "la negación de Marx fue rotunda" (Cardona Castro, 2002, p. 30). Partirá a Francia a estudiar al socialismo (Russell, 2009). Su talento denunciativo le abrirá el camino en el periodismo.

Marx se marcha a París, allí en el periódico Worwärts el joven Marx empezó a colaborar conformando "La Liga de los Justos”. Después estaría en Bélgica e Inglaterra por casi cinco años (Mc Lellan, 1982). De Francia será expulsado por su mordacidad periodística y por agitador, esto constataba la solidaridad entre las despóticas monarquías europeas.

"Marx pasaba mucho tiempo en compañía del poeta Heine y de su futuro contrincante, el anarquista Bakunin" (Mc Lellan, 1982, p. 23). Los archivos, esas notas de unos cuadernos, que serían compilados en Los Manuscritos económico-filosóficos (o Cuadernos de París) de 1844 vieron la vida en su estancia parisina, los mismos fueron publicados por vez primera en 1932 (Mc Lellan, 1982). Con los Manuscritos, se dará inicio al interés por la economía y su crítica desde la visión de clases (Bermudo, 1975). En esos apuntes, realizaría juicioso "análisis sobre la función del dinero, dónde trató de fundamentar la teoría de que los valores del mundo están invertidos, ya que el propietario de las cosas no es el hombre, sino el dinero" (Cardona Castro, 2002, p. 36).

Karl Marx, tuvo que abandonar sus estudios voluntarios. La afectación económica a sus ingresos por el trajín empezaba a agudizarse. Los problemas y cosas a cubrir en su núcleo familiar demandaban algo de dinero. Sus profundizaciones categoriales, se retomaron posteriormente. Esto lo vivió antes de su exilio definitivo en Gran Bretaña y, luego en la misma Inglaterra.

Años después, al reiniciar su investigación económica — interrumpida, irónicamente, por tener que vender su fuerza de trabajo intelectual en el mercado del periodismo: esa fuerza era, en efecto, su única mercancía, su único medio de vida, salvo las ayudas de Engels - vuelve Marx a su vieja teoría de la alienación, en diversos y muy ricos textos. (Silva, 2009, p. 75) 
A pesar de adscribirse a la misión de periodista, no dejó de tomar partido en la causa en la que creía. Entre los diferentes periódicos, fue corresponsal del New York Daily Tribune entre 1852 al 1861 desde Inglaterra. Este oficio le proporcionaba buenos ingresos, permitiendo también identificar toda la serie de sucesos que acaecían sobre todo en Europa y algunas partes del mundo, siempre ligándolos al nuevo orden mundial que se estaba posicionando. Ahora debía escribir en el idioma hablado más influyente del globo.

An American newspaper published from 1841 to 1924. Until the middle eighteen fifties it was the organ of the Left wing of the American Whigs, and thereafter the organ of the Republican Party. Karl Marx contributed to the paper from August 1851 to March 1862, and at his request Frederick Engels wrote numerous articles for it. During the period of reaction that set in Europe, Karl Marx and Frederick Engels used this widely circulated, and at that time progressive, newspaper to publish concrete material exposing the failings of capitalist society. (Marxists Internet Archive Encyclopedia, Sf.)

Marx procuraba leer los idiomas europeos más difundidos, escribía en tres de ellos: en alemán, en francés e inglés, para admiración de los expertos lingüistas de su época. Gustaba de repetir: "una lengua extranjera es un arma en la lucha por la vida" (Lafargue 1890-1891, en Fromm, 2012, p. 237).

Se dedicó a estudiar el ruso cuando ya tenía 50 años y, aunque ese idioma no tenía mucha afinidad con ninguna lengua occidental moderna, él solo quería leer los acontecimientos de esa "potencia atrasada" la cual tenía algo que le hacia ruido, que al mismo tiempo lo animaba a seguir hechos de esa lejana tierra, haciendo revisar sus propias posturas anteriores, por ejemplo el caso de las aldeas atrasadas de Rusia (Dognin, 1975) a las cuales catalogaba sin ninguna esperanza, ahora eran vistas con otra mirada; ahora se contemplaba la opción de la aparición del socialismo en una sociedad agrícola y no neceariamente industrializada. Cabe decir que, las críticas de Marx sobre Rusia no eran contra su pueblo, pues él reconoció su lucha contra la autocracia y el modelo feudal ${ }^{18}$. En 1917 los hechos darían la razón a la nueva revisión de Marx, aunque quizás nunca pensó en la sovietización como versión roja del zarismo.

En su papel de periodista no siempre fue tan riguroso, esto se evidenció en su muy desacertado escrito sobre Bolívar. En su papel de columnista, Marx escribió el polémico artículo sobre Bolívar, en $1858^{19}$. Esta singularidad ha sido tratada por la academia latinoamericana de distintas formas. Algunas posturas lo condenan enérgicamente (Kohan, Sf.), otras lo tocan con sutileza y desde la coyuntura (Aricó, 2010).

\section{Otra etapa de exilio}

Tras el exilio de 1845, llega a la capital belga en febrero del mismo año. Allí funda la Gaceta alemana de Bruselas, defendiendo la causa de los tejedores a los cuales el mismo Heine dedicará poemas contestatarios. En Bélgica pasará gran parte del tiempo con su camarada Engels, será "una época de estudio y acción política” según Cardona Castro (2002, p. 39).

Es expulsado de nuevo de Bruselas, pues la condición de exiliado exigía no hacer parte de ningún tipo de rol con ingredientes agitadores; Marx no pudo cumplir ni con su pluma ni con su actitud ante tal exigencia limitante (cabe recordar que fue allí donde redactaron el Manifiesto). Es así que otra vez el régimen prusiano

\footnotetext{
${ }^{18}$ Véase, Introducción de José Raed Espalla, Marx, Carlos (1985), en Historia de la vida de lord Palmerston. Palmerston y Rusia. Buenos Aires: Rescate.

${ }^{19}$ Lástima que no pudo leer Marx, lo que fue más que una anécdota en Bolívar, cuando este opinó sobre el estado de sumisión parecido más a la alienación-enajenación, fenoemno negativo que ya venían tomando forma entre los ciudadanos de la Colombia recién liberada del poder peninsular, esto lo notó y criticó el mismo Libertador, quedando plasmado en el Diario de Bucaramanga De Lacroix (2007).
} 
exige la expulsión, y eso que Karl ya había renunciado a la nacionalidad prusiana. Hasta su esposa Jenny es retenida. Les dan 24 horas para abandonar el reino (Cardona Castro, 2002).

Sale con su familia hacia París de nuevo gracias a una invitación (25 de marzo de 1848); se queda poco allí, decidiendo regresar a Renania el 5 de abril, sin hacer pocos reparos al estatus al que fue sometido desde su tierra natal. Según Mc Lellan (1982), los Marx no eran realmente pobres, sus ingresos eran promedio, la dificultad estaba en algunas apariencias que buscaban sostener en el seno de su núcleo familiar, parece ser, paradójicamente que la microeconomía no era su fuerte. La subsiguiente situación de exiliados no dirá lo mismo. Solo al final de la década de los setenta tendrá algo de estabilidad.

En 1848, año de especial interés histórico y político, Karl regresa a Colonia y refunda la ahora llamada Neue Rheinische Zeitung: Organ der Demokratie, más radical e incendiaria. "Desde Colonia y Elberfeld, respectivamente, Marx y Engels, al frente de la Nueva Gaceta Renana en 1848, siguieron a través de su actividad periodística, el desarrollo de la revolución" (Cue en Marx \& Engels, 2006, p. 40). Esta durará hasta el 19 de mayo de 1849. Trabajo asalariado y capital donde expone posturas de economía política, sobre lucha de clases y carácter beligerante que debe tener la clase obrera, serán una serie de artículos editados por este espacio.

Bermudo Ávila (1975), comenta que la época de la Gaceta, es la época en que se puede hablar de un "Marx burgués". Allí hace defensa política del modelo burgués de Estado, el cual desechará luego a través de la vivencia de la práctica. Marx ve un tipo de burguesía progresista que puede ofrecer libertad en los diferentes campos, incluyendo la liberalización de la educación del yugo feudal.

En 1849 es desterrado y su gaceta cerrada. "En mayo de 1849 le fue cursada la orden de expulsión” (Mc Lellan, 1982, p. 33); no obstante, su genial defensa ante la acusación de conspiración; "su alegato en defensa propia fue una auténtica lección sobre la concepción materialista de la historia" (P. 32). El sistema "democrático" de justicia liberal no contemplo conmutación, era un conspirador, solo eso y como tal sería tratado.

Marx regresa a París, pero solo puede pedir una licencia para Jenny quien esperaba su cuarto hijo. La situación en Europa se torna caótica, el sistema capitalista comienza a percibir la crisis; los economistas de la época, defensores de la abstracción de las supuestas leyes invisibles, advierten sobre la aplicación de medidas que van desde la austeridad hasta la negociación con la clase obrera ofreciendo medidas impensables, con una doble intención. La agitación política recorre todo el continente; el socialismo se convierte en la bandera de muchos movimientos, la formación sindicalista eclosiona. Pero, la fundamentación teórica parece ser famélica, no existe una formación al interior del movimiento obrero, carece la condición de conciencia de clase, por ello y por otras razones se convierten en presa fácil de la represión estatal.

En 1850 Marx y Engels dirigen la Neue Rheinische Zeitung. Politisch-ökonomische Revue editada en Hamburgo. A la par, serán elaboradas: Die Klassenkämpfe in Frankreich 1848 bis 1850 (La Lucha de clases en Francia de 1848 a 1850); Der 18te. Brumaire des Louis Napoleon ${ }^{20}$ (El 18 Brumario de Luis Bonaparte) escrito entre1851 y 1852, ambas de Marx. Así mismo Engels elaborará: Der dutsche Bauernkrieg (La guerra campesina en Alemania) (Engels, 1976b-1); Reich Kampagne (La campaña del Reich); Revolution und Konterrevolution in Deutschland (Revolución y Contrarrevolución en Alemania), durará esta empresa

${ }^{20}$ Según portada de la época 
un año. Después aparecerá: Die Bauernfrage in Frankreich und Deutschland (El problema campesino en Francia y Alemania) (Engels, en Marx-Engels, 1963) de su misma autoría.

En ese tipo de obras busca desmontar las versiones de la historia de los acontecimientos, las cuales pretenden, consciente o por ignorancia y estudio profundo, poner a un hombre la responsabilidad histórica. Es decir, la apología que conlleva al peligroso defecto de poner en la cúspide de un proceso al individuo desconociendo la fuerza que puede representar el accionar popular como factor de transformación. El desmantelamiento de los mitos personalizados es necesario para la educación crítica, precisamente esto no sucedió con el ejemplo stalinista. El desmantelamiento de los mitos personalizados es necesario para la educación crítica, precisamente esto no sucedió con el ejemplo stalinista que bien nos ilustró George Orwell $^{21}$.

Marx como teórico y especie de difusor pedagógico de la clase obrera, la cual era sometida -a veces sin saberlo-, aprendía de las masas; puede decirse que él confiaba en la fuerza y conciencia popular. En el Brumario, publicado en la revista newyorkina Die Revolution, relata la traición a la que fueron expuestos los proletariados, la medida en que fueron utilizados por intereses ajenos a los suyos. Reconoce la importancia de esta experiencia, recordando que los objetivos de las clases siempre serán antagónicos, por tanto, la clase obrera debe formarse en historia y política para no caer en trampas. Con su epígrafe asevera, complementando a Hegel, que los personajes de la historia aparecen dos veces, lo mismo los sucesos, pueden ocurrir dos veces, más a Hegel, dice, se le olvidó resaltar a la primera como tragedia y la segunda como farsa (Marx, 2000).

Marx y Engels en sus años de juventud, escuchaban sobre organizaciones obreras de educación (Riazánov, 1962). Sus participaciones en las revueltas de 1848 en Francia y Alemania le significaron el inicio de lo que a la postre sería la denominación de "el doctor terrorista rojo" como algunos llamarán a Marx después de los sucesos de la Commune. Por lógica, consecuencia de lo anterior fue la repulsión que se ganó en varios gobiernos de la Europa de mediados del siglo (Russell, 2009) y que le llevaría a su "dialéctico" confinamiento en la Inglaterra victoriana.

\section{Exilio final en La Gran Bretaña}

“A finales de agosto de 1849 Marx se embarcó con rumbo a Inglaterra; iba a ser su última emigración” (Mc Lellan, 1984, p. 23). Inglaterra y su sociedad no les eran ajena a su interés desde muy joven. La cuna de la revolución industrial y de la teoría económica era un lugar propicio para consolidar saberes y seguir en la causa de los trabajadores. Sus obras maestras serán escritas desde allí, lo mismo que muchas proclamas, intercambio de correspondencia y artículos feroces.

Volviendo a su vivencia, los recursos escaseaban. De nuevo las penurias se hicieron sentir. Jenny Marx ${ }^{22}$, en una situación de desespero escribe a los amigos de Karl para que le brinden una mano, entre otras, como afectados directos de la contradicción del sistema. Denuncia sus cuitas..“(...) vinieron los alguaciles y me embargaron los pocos objetos que poseía -ropa, camas-, todo, hasta la cuna de mi pobre hijito y los mejores juguetes de mis hijas, que se pusieron a llorar amargamente" (Marx, J., 1850, en Fromm, 2012, p. 255).

${ }^{21}$ Célebre novela Animal farm (1945)

${ }^{22}$ Carta De Jenny Marx A Joseph Weydemeyer* Londres, 20 de mayo de 1850. Publicada en Die neue Zeit, vol.2, 1906-1907. Comprobado con una fotocopia del manuscrito. [T.L] 11 Neue, Rheinische Zeitung. Politisch-ökonomische Revue. [nota E.] 
Las condiciones de vida en la emigración eran en extremo duras, como lo revela con toda claridad la correspondencia entre Marx y Engels (editada en 1913). La miseria asfixiaba realmente a Marx y a su familia; de no haber sido por la constante y abnegada ayuda económica de Engels, Marx no sólo no hubiera podido acabar El Capital, sino que habría sucumbido inevitablemente bajo el peso de la miseria. Además, las doctrinas y tendencias del socialismo pequeñoburgués, no proletario en general, que predominaban en aquella época, obligaban a Marx a librar constantemente una lucha implacable, y a veces a repeler, como hace en su obra Herr Vogt, los ataques personales más rabiosos y salvajes. (Lenin, 2000, párr. 6)

Pero la situación económica de la familia Marx no parecía muy confortable. Además, se suma la perdida de algunos de sus miembros. Pese a sus cuitas, Karl disfrutaba leyendo e ilustrándose en diferentes sitios de la capital inglesa.

Fue precisamente durante ese período tan desgraciado cuando Marx hizo su contribución más importante al desarrollo teórico del comunismo científico, redactando su monumental obra Das Kapital, la revolución teórica más importante experimentada por la cultura moderna y la denuncia más implacable de la "esclavitud" moderna. (Castro Cardona, 2002, p. 71)

En los años de la crisis mundial de mediados del siglo XIX y en medio de su propia situación económica, 1857-1858, redacta segmentariamente, los que pueden llamarse borradores de su principal obra Das Kapital. Los Grundrisse o Lineamientos fundamentales para una crítica de la economía política tendrán su aparición pública en 1939 gracias al Instituto Marx-Engels-Lenin de Moscú. Para Martín Nicolaus (2007), "los Grundrisse son el eslabón perdido entre el Marx maduro y el Marx joven” (P. XXXVIII). Esta introducción fue el inicio de la visión económica-científica marxiana. No hay una división de dos Marx para esta lectura holística de la educación con Marx.

Entre 1858 y 1859 escribe Marx su Contribución a la crítica de la Economía política en la que plasma estudios científicos exponiendo los pilares de su teoría de la historia. Esta obra será leída y releída, tendrá implicaciones futuras en círculos de estudiosos de la historia de sus respectivas naciones y regiones junto a la búsqueda de aplicación del materialismo dialéctico a la vida inmediata de sus realidades político-sociales. Con ella, se demuestra la capacidad que tuvo Marx mediante su prosa científica para hacer que una persona medianamente instruida pudiera aprender a razonar económicamente como lo corrobora Silva (2011).

La Contribución presenta un particular interés, por ser ahí donde Marx expuso por primera vez su noción de proletariado y su concepción de la superación de la filosofía por la praxis revolucionaria, y también por contener buena parte de su crítica a la religión. Todos estos temas los continuará y radicalizará más en 1845, en las Tesis sobre Feuerbach. (Del Noce - Riestra, 1975, p.18)

Marx gustaba enclaustrase para trabajar en su pensar al mundo, pero también disfrutaba de un tipo de peripato. Lafargue recuerda que, "durante muchos años lo acompañé en sus caminatas nocturnas por Hampstead Heath y fue caminando por los prados como adquirí mi formación económica. Sin advertirlo, me fue exponiendo todo el contenido del primer libro de El capital mientras lo escribía" (Lafargue 18901891, en Fromm, 2012, p. 240). Las reflexiones sobre los problemas socioeconómicos asaltaban, según versiones, cada instante de su mortalidad, cada operación mental de su existencia material e inmaterial.

En 1862 se recrudece su precaria situación. Escribe a Engels con desespero; deseando hasta la muerte (Dussel, 1988). Buscó trabajo en la empresa de ferrocarril de Londres, pero fue rechazado por su caligrafía. Más, “entre agosto de 1861 y julio de 1863, Marx escribió veintitrés Cuadernos de apuntes que fueron publicados por primera vez de 1976 a 1982. Este material fue consultado por Engels y Kautsky para publicar los tomos II, III y IV de El capital” (P. 13). Dichos manuscritos fueron desconocidos por los marxistas inmediatamente posteriores. 
Sobre los contenidos de alienación, de la transformación de dinero - dinero, Silva (2009), comenta:

El mismo punto encuentra un magnífico desarrollo en Teorías sobre la plusvalía, ese ingente manuscrito de los años 1861-1863, destinado, según es opinión aceptada, a formar el Libro IV de El Capital. Siendo este Libro IV uno de los lugares más ricos de la obra marxista en lo que se refiere al problema de la alienación, y estando publicado en su mayor parte desde 1905-1910 (edición de Karl Kautsky). (P. 80)

Su sitio favorito era el British Musseum, donde se dedicaba a escudriñar desde las viejas lecturas de clásicos, matemáticas, a la par de las nuevas tendencias científicas (Marx, Engels, 2003). Al contrario de muchas ciudades del continente, el ambiente social de Londres no era caldo de cultivo para la revolución, pero si para entrar en contacto con la técnica de punta y los avances en diferentes ramos de la ciencia. El espíritu conservador predominaba y de todos modos la Inglaterra industrial sabia sostenerse en las crisis gracias a la buena administración para sí de sus colonias. Gracias a la dedicación, pudo Karl Marx -al estilo ateniense clásico-, dedicarse a sus estudios.

"Als erste Frucht seiner langjährigen ökonomischen Studien erschien 1859: "Zur Kritik der Politischen Oekonomie", erstes Heft (Berlin, Duncker). Diese Schrift enthält die erste zusammenhängende Darstellung der Marxschen Werttheorie einschließlich der Lehre vom Gelde"23 (Engels, 1999, párr. 11).

1864 será el año de fundación de la Asociación Internacional de trabajadores de la que el mismo Marx participaría como fundador, bajo el papel de miembro activo hasta su disolución en 1876. Este espacio fue de provecho y lucha; allí pudo evidenciar las pretensiones de los diferentes sectores como los de Bakunin, Proudhon y Lasalle, principalmente.

En 1865 termina de redactar el primer volumen de Das Kapital (los otros dos serán terminados por Engels tras la muerte de Marx). Será publicado al cabo de dos años. En esta obra de suma importancia para entender la madurez marxiana, la exploración de datos oficiales y su comprobación fáctica, expondrá no solo su visión científica sino toda una denuncia del sistema imperante, incluyendo las contradicciones evidentes del capitalismo en la propia cuna de la industrialización: Inglaterra. Así como las relaciones de poder locales que impactarían a las internacionales. Entre los grandes aportes están las teorías de la mercancía, la plusvalía y el fetichismo, la madurez de su postura sobre enajenación, el devenir histórico-económico, etc. Hay una advertencia que nos comparte Silva (2009) -quien tiene una postura antimanualesca-, para prestar la mayor atención:

Los que piensan que El Capital es una descripción minuciosa de la sociedad capitalista se equivocan: el capital a que se refiere Marx es un capital teórico, el capital de un modelo teórico. Y el punto modélico de este modelo es la mercancía. (P. 176)

La nueva visión de la mercancía es más que denunciante, es más que revelador; es pedagógica. Utilizar todo un análisis que parte de lo económico, que ingenuamente se trataba desde la teoría económica capitalista para explicar modelos y leyes supuestamente abstractas; con lo marxiano este concepto pasará de la abstracción a la materialidad para entender lo perjudicial del sistema de cosas que tiende a ocultar la realidad como la fuerza de trabajo y la enajenación tras las cosas que se compran y venden.

23 "Como primer fruto de sus largos años de estudios económicos apareció en 1859 la "Contribución a la crítica de la Economía política. Primer cuaderno" (Berlín, Duncker.) Esta obra contiene la primera exposición sistemática de la teoría del valor de Marx, incluyendo la teoría del dinero". Versión castellana de, https://www.marxists.org/espanol/m-e/1870s/cmarx.htm (Marxist Archive) 
Su interés por los acontecimientos continentales se expresaba en la mayoría de sus artículos periodísticos. Estaba al pendiente del movimiento obrero. Es por eso que apoya desde el exilio a la Comuna de París en 1871. Decide escribir The Civil war in France (La guerra civil en Francia) tomando partido después de cerciorarse de la real participación de los trabajadores y menos favorecidos en dicha experiencia. De esto, cabe aclarar que previamente:

En 1870, cuando la guerra franco-prusiana, Marx tomó primero posición más bien en favor de Prusia, eso sí que recomendando a la clase obrera alemana que no permitiera que "la guerra perdiese su carácter estrictamente defensivo y degenerase en una guerra contra el pueblo francés". (Dognin, 1975, p. 28)

Allí establece las líneas más científicas de sus teorías sobre economía como aliciente de conflicto, madura la relación evidente pero disfrazada entre los diferentes poderes que se desarrollan en una sociedad humana, los cuales desatan toda su influencia en las mentes, instituciones y en la propia versión de la historia. "La Comuna de París fue un paso importantísimo y un ejemplo histórico para el socialismo científico. Ella enseñó al movimiento revolucionario de la clase obrera la forma en que se asume la dirección del Estado derrocando el poder político del capital" (Casas, 1989, p. 62).

La represión contra los comuneros confirma su teoría sobre la coerción inmisericorde de las clases poderosas sobre todo intento de subversión popular. En este tipo de exposiciones Marx destaca su postura, su subjetividad frente a las posibilidades de los hechos, no se vuelve un historiador más muy a pesar de reconocer el valor de describir los hechos tal como se presentan. No cabe duda en la candidez con la Marx y millones de sus contemporáneos cayeron bajo las falacias y estratagemas del régimen prusiano fiel representante de la Realpolitik, del doble discurso, de la doctrina propia del imperialismo contemporáneo. Ya en Marx la suerte está echada pues no queda más opción que la confrontación.

Durante los dos meses de su existencia, Marx apenas quitó la vista de la Comuna. Le fascinaba. Sus críticas y denuncias a la segunda república de Louis Napoleón eran feroces; pero confiaba en que faltaba poco para que ocurriera una nueva revolución francesa (...)

En marzo de 1871, nació un nuevo tipo de poder. En su análisis inspirador de la Comuna de París, Marx da una visión del poder obrero, de sus límites y posibilidades, de los problemas que tendría que enfrentar y la creatividad que sería capaz de expresar al construir un orden nuevo y diferente. A pesar de sus dudas Marx era un apasionado; hasta mandó a su yerno, Paúl Lafargue, a París a trabajar con la Comuna.

Pero ¿qué tenía de nuevo la Comuna? En La Guerra civil en Francia, donde examina los acontecimientos de París, Marx contesta la pregunta a su generación y a las venideras: "La Comuna era, esencialmente, un gobierno de la clase obrera, fruto de la lucha de la clase productora contra la clase apropiadora, la forma política al fin descubierta que permitía realizar la emancipación económica del trabajo." (González, 2012, párr. 4-6)

En esta coyuntura, tras tantos aciertos, disputas, vacilaciones y radicalismos de uno y otro lado; Marx fue señalado siendo acorralado llagando hasta las amenazas de su vida por apoyar a la Comuna que tuvo no pocos excesos propios de los procesos revolucionarios llenos de resentimientos históricos. Así empezaba el declive de la Internacional y la desesperanza del ahora llamado "rojo doctor terrorista" (Cardona Castro, 2002).

Las obras terminales de Marx llegaron a ser un poco programáticas. Por ejemplo, Kritik des Gothaer Programms (Critica al Programa de Gotha) de 1875, muestra contenidos ya concretos de recomendaciones estructurales como la misma educación. 
Respecto a sus producciones, vistos en totalidad y al tiempo en sus particularidades temático-temporales, Cardona Castro en 2002, dice: “de sus escritos podemos concluir que no lo consideró un sistema filosófico, sino como un método práctico de análisis social e histórico y una nueva base para la estrategia política" (P. 99).

Pero mientras tanto lo que pudiéramos llamar su "filosofía" está constituida sustancialmente por una antropología, por una teoría de la historia y por una teoría de la sociedad: esta última, partiendo de la reducción de la sociedad misma a su estructura económica, no es más que una teoría de la economía. (Abbagnano b., 1994, p. 178)

A finales de la década de los setenta, Marx comienza a complicarse en su salud; el ánimo decae. Las fuerzas de la naturaleza le acosan lentamente. No puede olvidarse que Marx era un fumador empedernido. En 1881 le invadió una bronquitis que le obligó retirarse a sus aposentos. "El 2 de diciembre de 1881, la esposa de Marx murió como había vivido, como comunista y materialista" (Lafargue 1890-1891, en Fromm, 2012, p. 252). La desaparición física de Jenny le agobió en extremo, para un hombre con visión materialista, con espíritu idealista y en realidad romántico, esto era insoportable. Solía sostener breves encuentros con todo tipo de personas interesadas en abordarlo.

La fragilidad biológica le tocó; la acumulación de trabajos y necesidades pasaron su cuenta. En 1882 por recomendación de su galeno, se retiró al norte de África. Argel fue el destino de su corta instancia pues el clima no le favoreció. Pasó a París por un breve lapso a visitar a su amada hija Jenny. Al reinstalarse en Londres le llegó la aciaga noticia del deceso repentino de su hija Jenny; esto terminó por desmoralizarlo y enfermarlo aún más. Desde que llegó a la metrópoli inglesa en 1849, hasta su muerte, Marx se fue aislando cada vez más de una actuación directa en las agitaciones que sacudieron a Europa (Cardona Castro, 2002), más sus estudios no cesaron. A pesar de una mejora en la situación económica en sus últimos años, la familia Marx pagó con creces las consecuencias de años de sufrimientos, de irreparables secuelas físicas y morales.

Aunque hay que decir que gracias a sus encuentros con trabajadores que se reunían en la capital inglesa, con los cuales compartía y procuraba exponer sus apuntes de manera sencilla (Silva, 2009), vendría a enterarse de un sinnúmero de situaciones, sirviéndole para generar en sí mismo un espíritu de aprecio hacia los demás y todo aquello que pudiera alimentarlo en teoría y práctica. Siempre hubo un compromiso formacional para con la clase obrera.

Deja la materialidad inmediata una tarde del 14 de marzo de 1883, en su sillón, en su escritorio rodeado de sus amados testigos, los libros, y sus papeles. La descripción que da la mayoría de biógrafos del día de su huida de la materialidad, concuerda con la de su yerno: "murió en su mesa de trabajo, el 14 de marzo de 1883, a la edad de sesenta y cuatro años (Lafargue 1890-1891, en Fromm, 2012, p. 252), frente a la foto de su padre, la cual nunca dejó y que le acompañó en su ataúd.

En su sepelio, junto a la tumba de su compañera, su amigo y camarada Engels pronunció unas palabras sintéticas $^{24}$, muy profundas, que culminaban con esta reflexión:

And, consequently, Marx was the best hated and most calumniated man of his time. Governments, both absolutist and republican, deported him from their territories. Bourgeois, whether conservative or ultrademocratic, vied with one another in heaping slanders upon him. All this he brushed aside as though it

${ }^{24}$ Discurso pronunciado en inglés por F. Engels en el cementerio de Highgate en Londres, el 17 de marzo de 1883. Primera publicación En alemán en el Sozialdemokrat del 22 de marzo de 1883. 
were a cobweb, ignoring it, answering only when extreme necessity compelled him. And he died beloved, revered and mourned by millions of revolutionary fellow workers -- from the mines of Siberia to California, in all parts of Europe and America -- and I make bold to say that, though he may have had many opponents, he had hardly one personal enemy.

His name will endure through the ages, and so also will his work. (Engels, 1993, párr. 8-9) ${ }^{25}$

La muerte sería su fin al exilio, ya no sería más, sería lo que fue: un mortal más que transitó por una vida llena de contradicciones de la cual aprendería y aseguraría entregar a nuevas generaciones independiente de la interpretación y posibles adjudicaciones, advocaciones, en fin. "Marx no era un economista, ni un sociólogo, ni un filósofo, ni un jurisconsulto, ni un historiador, ni un literato: era todas las cosas al mismo tiempo" (Silva, 2009, p. 196).

En el siglo venidero, su obra sería centro de polémicas internas y señalamientos presionantes externos, la mayoría de estas injustas contra su persona o pensamiento. El ejemplo de los manuales doctrinarios (Silva, 2009), enredos teóricos, revisionismos sin orientaciones, división en épocas con base política, la burocracia, la postura armamentista, la exegesis, y la aplicación de persecuciones en contra de la crítica misma, determinaron un desvío en el socialismo real del sentido marxiano de la vida, el mundo y la acción humana.

\section{Entre la experiencia histórica: los tres contextos}

La experiencia vivida es, en cualquier caso, una dimensión de suma atención al momento de recrear una forma novedosa de hacer filosofía de los fenómenos, para esta exploración, desde la filosofía de la educación con lo marxiano. Marx no se quedo en lo inmediato, en lo que se le presentaba, iba más allá del simplismo historicista; sabía que todo era originado a la final, por los intereses humanos.

Las vivencias de y en la historia, han de ser espacios dignos de estudio. Cuando se apunta en la dirección de señalar a la experiencia de contenedora de una doble enseñanza, es porque precisamente hay una doble situación: por un lado, en tanto acontecimiento, un hecho genera un impacto por ser creación humana, o sea como tal puede observarse. Por otro lado, la situación puede contribuir al establecimiento de una metodología que puede sufrir variaciones, edificarse y perfilarse como propuesta. En el caso de Marx, hubo una doble enseñanza, una teórica y otra práctica de los hechos en desarrollo. Para Gemkow, "la actividad de Marx fue tan universal e internacional como sus enseñanzas” (2010, p. 7).

Para el caso de un avistamiento del interés marxiano por la educación, así como históricamente se ha dicho, existen elementos clave en los tres contextos (alemán, francés e inglés) internos europeos. Indispensable es tomar las observaciones generales de cada espacio desde los ámbitos más tratados desde la teoría marxiana. Estos contextos deben verse, desde la óptica marxiana, como una obra pedagógica ya que en todas se atraviesa el interés denunciante y crítico.

\footnotetext{
${ }^{25}$ Por eso, Marx era el hombre más odiado y más calumniado de su tiempo. Los gobiernos, lo mismo los absolutistas que los republicanos, le expulsaban. Los burgueses, lo mismo los conservadores que los ultrademócratas, competían a lanzar difamaciones contra él. Marx apartaba todo esto a un lado como si fueran telas de araña, no hacía caso de ello; sólo contestaba cuando la necesidad imperiosa lo exigía. Y ha muerto venerado, querido, llorado por millones de obreros de la causa revolucionaria, como él, diseminados por toda Europa y América, desde las minas de Siberia hasta California. Y puedo atreverme a decir que si pudo tener muchos adversarios, apenas tuvo un solo enemigo personal. Su nombre vivirá a través de los siglos, y con él su obra. (Engels, 1999, párr. 6)
} 
Guzmán (2017), indica: "para Marx lo más importante fue entender que el concepto de revolución significaba liquidar su anterior modo de pensar, de sentir. Marx tomaría como modelo fundamental para este desarrollo la concepción hegeliana de furia de destrucción” (P. 169). En los tres contextosnacioanles, lo referente a la formación es tocado con sus particularidades, muy ligado a las relaciones concretas presentadas en las realidades que el mismo Marx aclara.

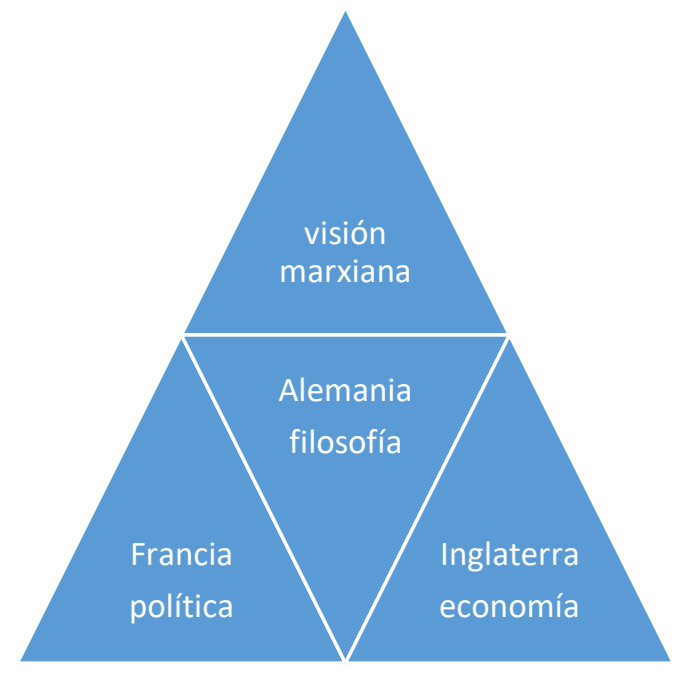

Gráfico No. 3. Las tres experiencias que alimentaron histórica y teóricamente a Marx.

Ahora bien, de Francia puede notarse el interés político e ideológico; se denota la puja por rescatar la participación popular, el pueblo como actor directo, esto también significa el derecho universal a recibir instrucción; en otras palabras, Revolución francesa y socialismo utópico como hitos (Guzmán, 2017).

Francia, su sitio de interés donde se empapó de socialismo era el centro de operaciones teórico del socialismo ahora científico. En definitiva, será con este trabajo que se dará una ruptura con el hegelianismo al relacionar al hombre, aún de modo incipiente, con las relaciones sociales de producción (Guzmán, Sf.)

Es en los Manuscritos del 44, donde según Silva (2009), se dan las expresiones de alienación, aunque ya están los rasgos en La sagrada familia. Sobre ella, tomará "giros en escritos anteriores" (P. 70). Después, se hará más científica, abandonando la vestimenta filosófica (Silva, 2009) para definirse aún mejor en el campo de lo histórico-económico; esto será un acontecimiento de autocrítica como puede constatarse en las alusiones del Manifiesto.

París será de especial impacto en la formación político-económica para el establecimiento de la teoría marxiana. Sus ideas y categorías irán encontrando receptores, críticas y aceptación. Su interés se profundiza al intentar dar papel protagónico a la clase trabajadora y a la denuncia de la propiedad privada que ya venía de tiempo de la Gaceta. Una pauta a tomar en cuenta es:

De la economía política va a tomar el joven Marx el concepto del trabajo como fuente de todo valor. De Hegel el trabajo como autorrealización del hombre. Pero, sobre todo, va a ser su posición de clase la que determine el contenido del trabajo en los Manuscritos. En esta época Marx vive en París, con algún contacto con el movimiento obrero. De cualquier forma, París conoce en esta época la expansión de las ideas comunistas, realizada sobre el auge de las luchas obreras. Los intelectuales con que Marx se relaciona en París no son "teóricos", sino hombres políticos, comprometidos en la lucha política, en la lucha obrera. En París se da el predominio de la práctica: la lucha revolucionaria concreta predomina sobre la "crítica". (Bermudo, 1975, p.106) 
El tema de la praxis no aparecerá en los Manuscritos, tampoco el de autoemancipación del proletariado. Empero, en estos materiales:

Aparecen formulaciones que se acercan a ambas. Por ejemplo, en los Manuscritos ya presenta el joven Marx la conciencia, las ideas, como producto de la práctica; los sentidos como producto social, histórico, de la práctica. Al mismo tiempo se señala el comunismo no como una alternativa ideal, sino como una etapa necesaria del desarrollo de la producción. (P. 107)

De Inglaterra, contando con sus peculiaridades y énfasis marxiano en economía, aparece una investigación sobre datos que arrojan las penurias del sistema educativo, la exclusión y otras situaciones; en yuxtaposición, el ingrediente empírico-pragmático es expuesto en varios apartes de la obra marxiana, la automatización completa esa enajenación sofisticada al servicio del mercado; la realidad inglesa demostrará que la economía depende de situaciones de explotación dramáticas y de un interés nulo por la emancipación educativa y laboral del ser hombre, la mujer y los niños.

La forma alemana de pensar estará en Marx hasta el final de sus días, obviamente con las adaptaciones propias; el espíritu germano estará presente a la hora de la rigurosidad y de la densidad en asuntos reales, los cuales, poca evidencia da de sus relaciones, no sin rechazar cualquier forma aburguesada y justificadora que intente borrar cualquier crítica al sistema; de la denuncia de Marx a la filosofía no escapa el espíritu filosófico alemán. El esfuerzo marxiano por aterrizar a la mundanidad temas y procedimientos abstractos, contiene siempre un sentido social.

En complemento, la tradición filosófica describe una perspectiva; Lenin (1980) en su texto sobre las Tres fuentes y tres partes integrantes del marxismo del año 1913, teoriza sobre tres grandes orígenes del pensamiento ahora llamado marxista; a saber: el materialismo desde Alemania, la teoría económica capitalista de origne inglés y el socialismo francés. Paradójicamente dichas fuentes no proponían lo que Marx pensaba, más fueron leídas y utilizadas dialécticamente.

Las influencias de la fuerza de la historia junto a su componente epistémico, se denotan en los tres espacios de desarrollo. No hay que olvidar, que precisamente de esta interpretación sobre las tres fuentes, surge la postura leninista, la cual permeará a lo marxiano y permitirá una partida distinta al pensamiento de Marx sobre todo en el campo de la praxis. No obstante, con el análisis de los hechos como fuentes de aprendizaje y aluviones de teoría, se logra desmontar el grado de dogmatismo que vendría a reemplazar el real aporte de Marx al pensamiento crítico, y con éste a la visión de que los contextos son fuentes de enseñanza material que, en sentido doble, pueden facilitar la transformación.

En lo marxiano no hay elementos fuera de contexto. El principal aporte es la visión crítica de la historia retomada como ciencia, más allá de las discusiones sobre la teorización de ésta, o los señalamientos de forzarla a leyes universales. No caben dudas, la interpretación marxiana de los hechos va ligada a los cambios estructurales que se presentan en las determinadas épocas, y estos cambios son generados por el devenir de intereses meramente humanos. Es así que el sendero hacia la comprensión real, debe tener como meta una revolución social más que metodológica.

Entonces, epistemológicamente hablando, no hay una teoría del conocimiento al estilo tradicional; la única visión válida para descubrir la intencionalidad del conocimiento es la lupa de la crítica, esa crítica que precisamente escudriñe las relaciones sociales al interior, una praxis distinta de los presupuestos hasta la época considerados consistentes, válidos en tanto los fenómenos eran independientes de cualquier 
intencionalidad humana. Así lo fueron las tres vertientes que son más epistémicas que históricas desde esta perspectiva.

La filosofía nace en la antigüedad griega con la apertura del continente de la matemática, transformada en la modernidad cartesiana por la apertura de la dimensión de la física; ahora, desde Marx, según Althusser \& Balibar (1974), la filosofía es revolucionada gracias a la apertura del continente historia, realizada por Marx. Por esto, la historia es un eje principal para el análisis de los intereses encubiertos en las intencionalidades que a la final se aplican a las instituciones.

El contexto marcó la propuesta marxiana de abordar las situaciones y de darles un sentido distinto al pragmático al que venía acostumbrada la ciencia social. Se pasa de una visión meramente descriptiva a una visión que toma postura, que subjetiviza intencionalmente para entrar en la dialéctica de los procesos como ejemplificación material, como materia de estudio y sobre todo como centro de interés para generar una propuesta.

Es así como en Marx cala la situación histórica como expresión humana, de felicidad y desdicha, de cubrimiento de necesidades y generación de pobreza. Su labor pedagógica se devela cuando, con magistral fluidez y actitud crítica, denuncia los males que ocasiona el sistema imperante a la población menos favorecida en el transcurrir de los sucesos. Los elementos teóricos se convierten en "arma" de la revolución, de una revolución que debe impactar en las conciencias; una invitación a conscientizarse de la situación y emprender medidas que intenten transformar la situación.

Acá reluce la concepción humanista de Marx, ya no, -como pasó con la visión epistémica del mundo-, desde los criterios del sistema de mercado sino desde la materialidad humana como centro de interés sin menoscabar los objetivos sociales, de la colectividad. Althusser (1974), destaca lo siguiente en los dos lapsos del Marx humanista:

Para ver claro, recordaré brevemente la experiencia de Marx, que no llegó a la teoría científica de la historia sino pagando el precio de una crítica radical a la filosofía del hombre, que le sirvió de fundamento teórico durante los años de juventud (1840-45). Empleo el término "fundamento teórico" en su sentido estricto. Para el joven Marx, el "Hombre" no era solamente una exclamación que denunciaba la miseria y la servidumbre. Era el principio teórico de su concepción del mundo y de su actitud práctica. La "esencia del Hombre" (fuera de esta libertad-razón o comunidad) fundaba a la vez una teoría rigurosa de la historia y una práctica política coherente. (P. 184)

El llamado fundador del materialismo científico, estudia y participa de las tres grandes situaciones presentadas en tres países emblemáticos del mundo contemporáneo, las vive, las registra de manera distinta y hasta toma partido. Las ve, las vive, extrayendo de las mismas aquello que pueda servir a la causa de la emancipación del hombre. Con maestría elaboró sus obras temáticas para que quedaran a la posteridad como enseñanzas mismas.

Dichas fuentes no se quedan en simple hechos histórico-sociales, trascienden hacia una propuesta, incluso epistémica que puede verse desde lo marxiano; esas que Sacristán (1978) distinguió y que enfatiza Martínez en 2002. La visión de ciencia y de proyecto político, se deja ver en estas tres grandes situaciones. Acá encontramos un aporte del compañero de Marx, quien complementó dicha reflexión. Dice Comninel (2012), “en 1843 Engels ya distinguía a Inglaterra como el país donde se daba prioridad a lo económico; a Francia como el que priorizaba lo político, y a Alemania como el que hacia prevalecer lo filosófico” (P. 47). 
La Francia políticamente convulsionada y aportante de pensamiento ahora socialista; la Inglaterra potencialmente industrial y pionera del sistema económico; junto a las oleadas del pensamiento alemán, logran afectar la lectura de la realidad que hace Marx, de la cual traduce a su peculiar actitud crítica para levantar los cimientos de la praxis filosófica con sus aportaciones a las diferentes áreas que se preocupan por el bienestar de la humanidad y su entorno.

Más que las situaciones históricas o político-ideológicas, es lo que representan cada una de estas conjunciones materiales. Curiosamente, se puede denotar una relación entre elementos idealistas, empiristas y materialistas al abordar una interpretación de estos focos-fenómenos a la hora de intentar la teorización. Luego de casi doscientos años, lograr una comprensión de estas tres emergencias referentes de la contemporaneidad, es dar su peso histórico y filosófico a la positiva extensión del pensamiento marxiano.

Debe recordarse que si bien Marx puede ser juzgado por sólo tratar temas de su entorno inmediato es, salvo pocas excepciones ${ }^{26}$, porque de hecho estas circunstancias calarían en el devenir futuro y eran a su vez, producto de esas circunstancias materiales precedidas. No era un capricho de ese denotado eurocentrismo de la época decimonónica el que embargaba al Marx inconforme con las interpretaciones de la realidad, era la búsqueda de la verdad en las concreciones de las relaciones inmediatas.

A propósito, el biógrafo F. Mehring (1965) comentó que "Marx se compenetró con las luchas y sus aspiraciones de la época a la luz de la Revolución Francesa; Engels estudiando la revolución industrial" (P. 85). Sin embargo, los aportes de Engels, Marx dedica gran parte de sus reflexiones de madurez a la realidad inglesa para, precisamente, demostrar las contradicciones irreconciliables del sistema imperante. Broccoli en 1980, relacionando el tema de sus obras de madurez, de su experiencia, con la educación, comenta: "en última instancia, en la sociedad dividida en clases la relación educativa es el modo de ser de la ideología: esta es la lección que nos deja toda la obra de madurez de Marx" (P. 29). A su vez, los escritos juveniles se levantan como crítica al comunismo utópico; las Tesis sobre Feuerbach son el culmen, Marx impugna a la doctrina materialista de ese tiempo, de la educación, en su tercera tesis; muy a pesar de los contenidos en La Sagrada familia. Marx relaciona teoría y práctica, sentido y razón, pero todo esto con una perspectiva humana mas no de trascendencia a la humanidad (Broccoli, 1980).

Puede decirse que las tres fuentes marcaron el desarrollo del pensamiento de Marx que también vendría a extenderse a la interpretación desde la filosofía de la educación. No fueron únicamente materialidades históricas, fueron situaciones reales, con seres humanos y relaciones sociales reales, las cuales llegaron a marcar las dos etapas "tradicionales" en lo que ha sido dividido el aporte marxiano, y del cual se ha vertido sobre los asuntos educativos desde el marxismo y otras vertientes.

\section{Extensión material e impacto de lo marxista sobre lo marxiano}

El pensamiento de K. Marx encuentra distintos matices con el transcurrir del tiempo y la relatividad de los contextos. A esto se suman, precisamente, las particularidades de las traducciones y comentadores a las distintas lenguas; entre el elenco de clásicos intermediarios pueden contarse a Bernstein, Plejanov, Kautsky y Bebel (Suárez, 2010). No existen excusas de peso para evadir los aportes de tan descomunal compendio de ideas e impacto en el mundo desde hace más de 150 años de historia contemporánea. Los ejemplos

${ }^{26}$ El caso de las reseñas periodísticas, ejemplo es el artículo Bolívar y Ponte. 
materiales van desde la ordenación geopolítica adjudicada, hasta los asuntos de conciencia subjetiva. Por estas razones, si bien el ámbito contextual en el que vivió el filósofo de Tréveris es importante, lo es también en un terreno praxiológico, todo el ambiente vivido con la apertura y desenvolvimiento del siglo XX con proyección al XXI.

Si el mismo Marx recomendó la transformación del mundo en su onceava tesis, entonces, se ha cumplido desde su legado, más que la paradoja marxiana, un desconocimiento o desacato de su visión. O sea, muchos se dedicaron a interpretar a las obras de Marx, a implantar formas, pero se olvidaron de transformar. Esto no quiere decir que lo marxiano expresado en algunas experiencias marxistas, fueran obtusas como pudo ilustrarlo Hobsbawm (2003), porque pueden rescatarse ejemplificaciones donde precisamente hubo una evolución, una dinámica, una adaptación de las ideas y no una adaptación de sus realidades propias a las ideas.

En términos de la filosofía de la educación, el trabajo marxiano abrirá los caminos a las formas marxistas de pensar y actuar frente a esta categoría. Por un lado, la educación se venía pensando desde corrientes tradicionales que pasaban desde la versión cristiana hasta la rousseuniana pasando por el empirismo o el pragmatismo. Los contenidos no superaban algunos matices idealistas. Por otro lado, con la aparición de la instrucción pública como derecho universal (aún limitado por el veto a mujeres o baja incidencia en los sectores deprimidos) las instituciones direccionan sus políticas. En el fondo se empezaba a discutir la objetividad en la que debía nadar la educación, sus fines y papel en la sociedad, entre otras pautas.

La actitud crítica desde la educación solo fue pensada en ciertas etapas históricas. En la Francia prerrevolucionaria está la concreción del germen de la criticidad, pero solo dedicada al interés del sector que podía reemplazar a la vieja estructura feudal. Este tipo de formación se dará, se infiltrará incluso en los futuros líderes de los procesos de independencia de América. Sin embargo, la formación solo empezó a verse como una necesidad material, de crítica, de extensión popular, no alienante y transformadora con la aparición de la teoría marxiana.

Ahora bien, la historia misma será una guía para comprender conceptualmente la temática de la propuesta que busca madurar una postura desde lo más rescatable de Marx para seguir pensando en sus aportes en este siglo XXI. Elemental es tratar -más que definir, concienciar- los apelativos de marxiano y de marxista de manera discriminada, por lo menos al tratar este recorrido. Dentro de lo marxiano puede verse que pocos elementos fueron tomados en cuenta, hubo teóricos posteriores que reflexionaron sobre sus temas sin romper el hilo conductor de los fines de Marx. De este campo salieron grandes aportes a la educación como camino de cambio sustancial y emancipación sobre todo en la periferia.

Mientras las corrientes marxistas, más encaminadas a la doctrina política o económica radicalmente hablando, se preocuparon afanadamente por constituir entes institucionalizados en partidos, subversión armada o Estados; se dieron cismas ideológicos y combinaciones, el marxismo-leninismo, el marxismomaoísmo, y así otras acepciones eclosionarán alrededor del mundo, algunas exitosas, otras menos que eso.

Lo principal no es la división de concepciones. Entonces, es menester comenzar por la definición para evitar confusiones y tener claro, que más que un apunte de significado, es una aclaración metodológica para no apartarse del objetivo pedagógico que busca establecer las diferencias y relaciones. La idea central consiste en reivindicar lo definitivamente marxiano para cernirlo del imaginario marxista. 
Aunque Roces (en prólogo de Marx, 1982), aseveraba: "se dice que hay muchos "marxismos". A mí me parece que hay solamente uno, que es el que descansa sobre los fundamentos establecidos por Marx" (P. $\mathrm{XXI}$ ), es justo señalar los puntos que separan lo uno de lo otro máxime en la extensión para comprender la inmediatez y lo inmediato en un campo especifico como lo es el acontecer educativo.

Si se quiere hablar de filosofía de la educación con Marx, ha de puntualizarse en lo marxiano con sus categorías aún válidas, pues aún los problemas de la humanidad no han cambiado, es más han degenerado cada vez más con nocivos resultados. Elementos marxianos pueden ser una opción para repensar y revolucionar la actividad educativa en diferentes esferas de la vida individual y comunitaria.

Volviendo a Marx, este llegó a afirmar que no era marxista ${ }^{27}$. De hecho, en las entrevistas concedidas por él a los curiosos de su época, insistía en su desconocimiento y desapego a grupos que afirmaban afiliación a su pletórica teoría. En la epístola de Engels a E. Bernstein, el propio camarada de Karl Marx, exponía su disentir sobre la supuesta anuencia ideológica e incluso personal de Karl sobre las manifestaciones de un tipo de marxismo de su época. Toma el ejemplo de Francia, y así pudo aplicar para otros tantos. En aquel papel en francés de 1882, se exhorta lo siguiente:

Quand vous ne cessez de répéter que le « marxisme » est en grand discrédit en France, vous n'avez en somme vous-même d'autre source que celle-là - du Malon de seconde main. Ce que l'on appelle « marxisme » en France est certes un article tout spécial, au point que Marx a dit à Lafargue: « Ce qu'il y a de certain, c'est que moi je ne suis pas marxiste ». Mais si Le Citoyen a tiré l'été dernier à 25000 exemplaires et acquis une position telle que Lissagaray a mis en jeu sa réputation pour la conquérir, cela semble tout de même contredire quelque peu ce prétendu discrédit. Mais ce qui le contredit davantage encore, c'est que ce discrédit n'empêche pas ces gens d'avoir assez de crédit pour que, chassés du Citoyen, ils fondent le jour même un nouveau grand quotidien et, en dépit des chicanes du propriétaire de l'ancien Citoyen, le maintiennent en vie pendant quinze jours, grâce au seul appui de travailleurs et de petits-bourgeois (ouvriers et petits industriels, écrit Lafargue), et trouvent un capitaliste avec lequel ils vont traiter demain sur le sort définitif du journal : oui ou non *. Lorsque les faits parlent si haut, Malon ferait bien de garder pour lui son « discrédit ». ${ }^{28}$ (Engels, 1882, p.1)

Para el siguiente horizonte, se hace la recomendación de tener en cuenta que se tratará de marxismo, de ese marxismo "al estilo siglo $X X$ ". Salva aclarar, en la medida en que se hable de marxiano se entenderá, sin prejuicios cronológicos, los aportes más cercanos a la propuesta escrita por Marx. Los intentos de interpretación marxista vendrán a darse luego de la Primera Guerra Mundial (Abbagnano, 1964).

Nunca un pensamiento ha sido tan polémico, ni ha generado un impacto de orden mundial inmediato como el que desató la influencia directa o indirecta del pensamiento de Karl Marx. De hecho, Engels en 1883

\footnotetext{
${ }^{27}$ En artículo de la DW, aparece reseña periodística a propósito del tema. Ver en, http://www.dw.de/marx-no-se-cans\%C3\%B3de-repetir-que-no-era-marxista/a-3313328

${ }^{28}$ Al seguir repitiendo que "el marxismo" es en gran descrédito en Francia, tiene que sumar a sí mismo otra fuente que esto la. Segunda mano Malon esto se le llama "el marxismo "Francia es sin duda en una sección especial hasta el punto de que Marx dice Lafargue:" lo cierto es que yo no soy marxista ". Pero si Le Citoyen disparó el verano pasado en 25.000 copias y ganó un puesto como Lissagaray ha apostado su reputación para ganar, todavía parece un poco en contradicción con la supuesta descrédito. Pero lo que aún más contradice es que este estigma no impide que la gente tenga suficiente crédito para que, expulsados de Ciudadanos, que se basan en el mismo día un nuevo gran día y, a pesar de los deflectores propietario la ex ciudadano, mantenerlo vivo durante quince días, con el único apoyo de los trabajadores y los pequeños burgueses (y los pequeños trabajadores industriales, Lafargue escribió), y se encontró un inversor de capital con la que van a tratar mañana sobre el destino final de periódico: sí o no. Cuando los hechos hablan tan fuerte, Malon haría bien en mantener su "desacreditada". (Trad. en, https://www.marxists.org/francais/engels/works/1882/11/fe18821102.htm)
} 
exclamaba en Highgate: "Marx era el hombre más odiado y más calumniado de su tiempo" (Engels, 1976c5, p. 172), y lo sigue siendo a doscientos años de su nacimiento, llegando a adjudicársele de manera visceral, eufemísticamente reconocida como algo falaz, la muerte de millones de personas desde la Revolución rusa de 1917 hasta, incluso, nuestros días. Por lo anterior, cualquier relación de un tema con Marx genera sospechas de contener subversión y rebelión, de contener comunismo, del más puro ateísmo y sello de atentar contra la libertad y la democracia entendida desde la postura liberal tradicionalista y fetichista.

A pesar de algunas apreciaciones epocales, Marx sigue siendo indivisible. La preocupación constante fue la generación de conciencia para superar la etapa de sometimiento al sistema imperante. El pensamiento de tendencia filosófico no ideologizado, siguiendo al propio Marx (1845), es también praxis, es transformación (Broccoli, 1980). También, la comprensión de eso que se llama conciencia -Bewusstsein- (Marx, 2102a) que, busca siempre ser materializada y, que a la vez las materializaciones sean convertidas en conciencia, cosa importante para transformar la escuela y la educación en general. 


\title{
PRIMER MOMENTO
}

\section{INTERÉS MARXIANO POR LA FORMACIÓN HUMANA: LA REVOLUCIÓN EDUCATIVA CON MARX}

\author{
Quiero que sea mi vida una sola cometida, \\ emplear mi energía y mi poder en escalar las cimas del saber ${ }^{29}$. \\ K. Marx (Marx-Engels, et al. 1973, p. 18) \\ El ciudadano Marx afirma que una dificultad de índole peculiar está ligada a esta cuestión. \\ Por una parte, es necesario cambiar las condiciones sociales para crear \\ un nuevo sistema de enseñanza; por otra, hace falta un sistema de enseñanza nuevo \\ para poder cambiar las condiciones sociales. \\ Karl Marx, en la Exposición ante el Consejo General de la AIT, 1869
}

Karl Marx no fue alguien excepcional en el sentido planteado por los extremos sobre este pensador, mucho menos un personaje digno de religiosidad -nada más antimarxiano- o de apología. Antes que nada, fue un sujeto de su tiempo. Su vida y obra y su extensión tocan muchas facetas de la vida cotidiana. Al formarse en su tiempo, haciendo resistencia al sistema de cosas inmediato, Marx es referente obligatorio sobresaliente para hacer de la educación un asunto de suma importancia. El Marx que tiene mucho para dar en el campo de la educación, desplaza fácilmente esa versión ideologizada que le intenta siempre desdibujar.

Todo su compendio servirá para atender los asuntos problémicos como la educación, he ahí la importancia de las denuncias que levanta contra el sistema capitalista, las cuales no dejan de ser más que pedagógicas. Sus obras se centran en la búsqueda de las condiciones materiales adecuadas para la humanidad.

Marx se forma en su realidad, la critica y propone materializaciones; llama la atención sobre la necesidad imperiosa de combatir el sistema socioeconómico que atenta contra la dignidad humana. Es sujeto tocado por lo interno y lo externo; su concepción es una construcción histórica y epistémica al servicio de la causa de los trabajadores, de los humildes, cosa que se extenderá hasta nuestros días.

\subsection{Interés por la educación y la posibilidad de una filosofía de la educación con Marx}

Si en la filosofía Marx generó una revolución, una resistencia contra la forma tradicional de desligar la realidad de lo material, del encubrimiento de todas las relaciones detrás de la vida, en el ámbito de la educación las cosas no serán distintas. Lo marxiano toma la totalidad humana, dentro de la cual está la educación como acontecimiento social e histórico. El campo de la educación es el campo de batalla donde mejor se pueden notar las pujas y sometimientos característicos de los intereses de clase.

Con Marx, se puede pensar una filosofía de la educación que desmonte el carácter mercantilista y alienante, una revolución educativa rescatadora de los aportes marxianos para interpretar realidades, y con ello presupuestar transformaciones, empezando por el de la escuela inmediata que propongo desde mi

${ }^{29}$ Sentimientos de los versos juveniles de Marx. 
experiencia. Repensar a un Marx sin dogmatismos que aporte elementos sustanciales para afrontar la llamada crisis de la educación, de la formación humana, estará presente, no caduca.

Cuando un pensador expone sus ideas, cuando las exterioriza ya está en el campo de la educación, es más, está en el terreno de la pedagogía misma, en ocasiones sin darse cuenta así sea por medio de terceros. A esto se expone todo pensador, y no puede quejarse, ya que, al hacerse llegar a través de los sentidos (obras, discursos, etc.), al ser públicas sus ideas, estas harán parte del mundo humano. En este orden, cuando algo se exterioriza, ya se hace social; el mismo pensador es producto material y espiritual de su contexto, más con él, de su devenir. Si bien puede suceder que un autor no tiene en mente ser estudiado -lo cual, difícilmente pasa por la mente de un individuo que quiere entregar algo a su sociedad-, cuando otras personas se acercan a sus obras, ya se convierte en objeto de procesos de enseñanza así sea para reprobarlas

En Marx hay un interés por los actores, fuerzas y fines que se presentan en el acontecimiento educativo. Incluye en este intrínseco interés, a los actores educacionales. Entre ellos el maestro, puede encontrarse algo interesante para reivindicar filosóficamente la labor docente en lo marxiano como sujeto político.

El rol del educador como orientador de procesos, desde Marx se rescata. Se rescata su protagonismo como agente que puede brindar su humanidad para despertar conciencia. La profesión docente como una real forma de vivir y aportar, como un campo abierto y de construcción democrática y solidaria del conocimiento de la realidad y de lo científico. Él mismo denuncia la situación material del maestro de escuela, él mismo sufrió persecución en la academia, él mismo fue vetado para ejercer la profesión educadora formal. La profesión docente no puede ser un camino para seguirle el juego al sistema, no puede ser una simple forma de ganarse la vida, debe ser vivida, disfrutada y muy conciente de su papel transformador.

He aquí un sueño y una verdadera revolución. No se trata de comer mejor, sino de ser más. Ser en todas las posibilidades y vocaciones de uno mismo, sin tener que esclavizarse a una profesión que implica el sacrificio o la mutilación de otras posibilidades del ser. (Barylko, 2005, p. 196)

Encontrar lo anterior en la perspectiva marxiana, en lo referente a actores tan segregados como los docentes, responde a la particularidad de seguir la idea de considerar al docente como sujeto activo en los procesos, lo cual puede llevar a tener conclusiones sobre las cargas ideológicas que han de presentarse al interior de la escuela lo mismo que la aparición de la praxis y su grado de impacto.

Al iniciar la expedición por la obra marxiana, se siente que es un largo camino, que hay muchas cosas por analizar, por leer críticamente; al trasegar se puede "reposar" para tomarse una pausa. En todo el recorrido existen variantes, más en todas ellas se encuentran "alcabalas" donde se exige como mínimo tener en cuenta lo recorrido anteriormente, pero sobre todo las preguntas que inviten a reflexionar sobre el impacto que puede generar la voluntad del hombre sobre su "destino".

Si los estudios de Marx produjeron un revolucón en las diferentes ciencias del hombre y la sociedad; si según Althusser (1974) en Marx hay una "revolución teórica", puede afirmarse con toda seguridad que, desde este último, también hay una "revolución educativa", tomada de dos maneras: una, de su propia forma para llegar a los demás; la otra, es la proyección de sus presupuestos al estudio y a las recomendaciones praxiológicas que pueden desprenderse de esa forma de comprensión filosófica para la formación social y humana. Pensamiento y educación confluyen en la perspectiva marxiana de manera dialéctica. Por un lado, se critica y denuncia. Por otro, se reconoce como medio para establecer más que la negación de la negación, una confrontación propositiva a la negación impuesta por un sistema de cosas. 
La filosofía con Marx, es un pensamiento interesado por el otro. Es una filosofía de la vivencia, por lo tanto, es una filosofía viviente; ella misma puede dar razón de su propio desarrollo histórico. Ella misma es formación, se declara en formación y brinda posibilidades a la estancia del hombre y la mujer en su mundo material sin descuidar lo espiritual.

Por tanto, existe entre la filosofía y la pedagogía una conexión estrechísima, y a primera vista parecerá
como que la diferencia que pudiera existir entre ellas es sólo cuestión de acento. Toda filosofía vital es
siempre, necesaria e íntimamente, una filosofía de la educación, porque tiende a promover modalidades
y formas de cultura de cierto tipo y porque contempla un cierto ideal de formación humana, aunque no
lo considera definitivo ni perfecto. (Abbagnano, 1964, p.15)

Precisamente el aporte de Marx, y hasta la consecuente extensión de sus allegados conceptuales posteriores, han marcado historia en los diferentes campos del saber, otros en la práctica material mediante liderazgos ideologico-políticos. En el campo educativo, lo aportes más significativos han partido de la visión de mundo emanada de la propuesta marxiana, sobre todo en los que tienen que ver con el descubrimiento de las relaciones dentro del fenómeno de la educación; así también la denuncia de la mercantilización de la formación humana y el tema de emancipación sobre todo en la periferia. Difícilmente alguna categoría trabajada por Marx no es compatible directamente con el campo de la educación. Como forma de pensamiento, lo marxiano es de los más citados cuando se habla de sistemas educativos.

$\mathrm{Al}$ acercarse a lo marxiano puede encontrarse, con toda una revolución educativa-formativa donde el centro es el sujeto impactado por el sistema de cosas, el cual debe ser consciente de la situación negativa para llegar a convertirse en un sujeto emancipado, libre para realizarse con un objetivo primordial: ser consciente que puede ser factor de cambio dentro de su propio entorno; emanciparse no es el fin, el fin es colaborar en la emancipación general. Pero para ser consciente de ese tipo de cosas que le rodea, de esos poderes influyentes, debe proyectarse sobre él una estela que colabore con la lectura distinta de su entorno, desmontando apariencias y reconociendo la materialidad de la situación vivida; llevarlo al descubrimiento de esas relaciones que hay detrás de los fenómenos sociales es parte de la labor de una formación crítica.

En definitiva, por mucho que se tilde de anacrónico o exegético el rescate el legado de Marx, precisamente ese tipo de contra argumentos son los que fortalecen teórica y prácticamente la importancia de dinamizar al pensamiento marxiano; ello permite ver en lo marxiano una oportunidad para repensar la educación en una era crítica donde la desesperanza se ha apoderado de la educación.

Se resalta, no es forzar a un pensador fruto de su tiempo, en temas que nunca tocó; este no es el caso de Marx. Él sí tocó directamente algunas situaciones relacionadas con la formación ya sea de la necesidad en la clase obrera o la educación escolar con el trabajo (Engels, 1847). Ahora, se tratará de abordar el pensamiento de Marx, despojado de esa tendencia ideologizada extremista, ortodoxa que en poco o nada contribuyó a establecer un real debate sobre los beneficios de analizar críticamente desde lo marxiano a la realidad.

Es simple y llanamente caminar con Marx, o sea con lo marxiano sin desconocer algún apoyo de lo desarrollado por los compendios marxistas, por los senderos de la reflexión pedagógica para, de alguna manera tangible, contribuir a la transformación positiva del mundo que acontece, y qué mejor ámbito que el basamento de nuestra sociedad global actual: la educación de las actuales y futuras generaciones. 
El interés por Marx no es únicamente interés por él, en tanto materialidad e ideas, es un interés por desmontar toda la interpretación alienada de la realidad. Cualquier tema que se asalte con la visión marxiana, ofrecerá una postura irrenunciable hacia la crítica, también hacia la propuesta transformadora, en este aspecto tiene mucho de deuda la educación desviada hacia el tradicionalismo conservador. Sacristán nos ratifica el interés y nos comparte:

A mí me parece que cuando nos ponemos frente a la obra de Marx hoy, hay unas cuantas cosas claras. La primera es que en el plano científico Marx es un clásico de las ciencias sociales, lo que quiere decir un autor por un lado irrenunciable y, por otro, no actual en todos sus detalles. Y otra cosa clara es que Marx es mucho más que eso: es un clásico también en la secular o milenaria aspiración de la humanidad a emanciparse de las servidumbres que ella misma se ha impuesto. Esto que dicho así suena demasiado hegeliano, en la versión de Marx se concreta suficientemente por medio de los análisis sociales de clase. En los dos campos: como científico y como filósofo de la sociedad Marx es un gran clásico que, en mi opinión, no caducará nunca. (Sacristán, 1983, p. 49-50)

Manuel Sacristán hablando sobre Marx, lo cataloga como filósofo de la sociedad; acá lo catalogaremos como el socio-educador que aún tiene vigencia precisamente por encontrarse en su compendio el interés por la formación humana emancipadora, que libere a través del estudio de la realidad. La escuela, en sus diferentes niveles, brinda una representación de la sociedad, por esto es competente, como también lo creyó Marx, tocarla con las pinzas marxianas. Se trata paralelamente de ver como se ha pensado el fenómeno educativo, con qué intenciones y resultados.

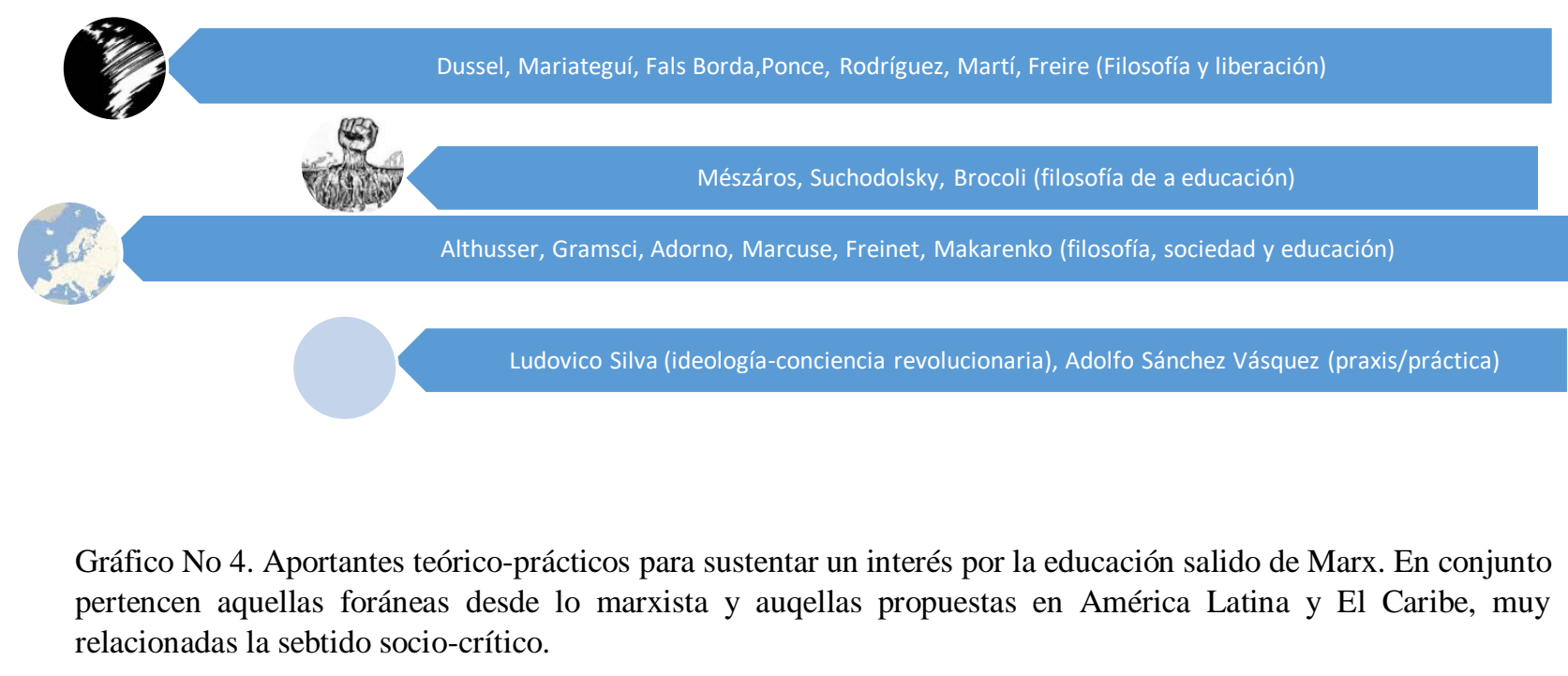

La educación y todos los procesos que la rodean, los materiales y hasta los que puedan denominarse "metafísicos", son procesos sociales, no independientes del mundo humano. Muchos afirman desde diferentes flancos, que hay que volver a Marx, hasta Piketti (2014) lo reconoce. Si Marx regresó y amenaza con quedarse como afirmó Suárez (2010), es en el campo de la educación donde mucho puede aportar pues las posibilidades que brinda lo marxiano para una filosofía de la educación se concentran en propuestas sociales tangibles, cosa que incomoda a las posturas tradiconalistas que se resguardan en lo ideológico.

Consuetudinariamente se ha tomado como punto de referencia la opinión de Marx (1974) en su conocida tercera tesis -de las once que componen el corto texto editado por Engels póstumamente- cuando se hace referencia a la idea de educación. Pero, las obras marxianas arrojan más claves para detectar alusiones claras al tema de la formación y la escuela. 
Ningún trabajo de Marx está desligado de la realidad material vivida por el ser humano. Desde sus cartas hasta su obra cumbre: Das Kapital, el sentido por lo humano tiene el suficiente calado sin dejar de lado su preocupación teórica-reflexiva alrededor de lo que parece centralizar muchos asuntos: el sufrimiento y el sometimiento disfrazado de libertad plena.

Pero Marx y su amigo-colaborador Engels no se quedan ahí. La propuesta emanada del socialismo científico, despojado de ciertas pautas de romanticismos o utopías aburguesadas de carácter contradictoriamente pesimistas, se abre paso, en tanto idea que supera la visión hegeliana o kantiana de la realidad material. La revolución de Marx es una revolución del pensamiento que se revisa así mismo. Marx se aferra a la necesidad de cambios, no de reformas. Preocupado por la difusión de su descubrimiento dialéctico de la realidad, más allá del criticismo o de la lógica, de la superación de la interpretación tácita del idealismo rampante en la Alemania de su tiempo; Marx el filósofo, dará la batalla de las ideas, en pro de la materialización de esas ideas.

Acá, el desafío es develar a un Marx que se interesa por la educación como se puede encontrar en Broccoli (1980) o Suchodolski (1977). A un Marx y un marxismo no limitados, aportantes de elementos valiosos en la interpretación, comprensión, y transformación, más allá de los rótulos subversivos que se les han impuesto con interés maquiavélico, reduciéndolo todo a lo político-ideológico.

En otras palabras, que el interés de Marx no se pierde con sus intérpretes o defensores en materia de educación sino que en esencia el planteamiento de Marx es en sí educativo como se expone en Suchodolski (1977), sociopedagógico toda vez que por ejemplo, reconoce el papel libertario del trabajo y del ser humano, sus condiciones, sus necesidades sin dejar de lado el planteamiento de herramientas para la compresión de la realidad avanzando a la recomendación de formas de lucha contra la opresión del sistema que aliena, explota y representa una nueva forma de sometimiento más sofisticada pero no menos represivo.

Kant (1985) decía que el hombre es producto de su educación. En Marx, paradójicamente, parece que aplica y no aplica al mismo tiempo. Por decir, el pensador de Trévéris, quien perteneció a una familia "algo" acomodada, se supone recibió una educación acorde al modelo imperante, más luego tendrá un cambio de actitud. Marx y Engels levantarían sus beligerantes argumentos sobre este papel de la educación en los procesos de explotación activa y consecuente. La educación burguesa es amañada y desesperanzadora dice Mészáros (2008). A la vez, su desarrollo intelectual no se verá muy permeado por las costumbres educacionales de su época. No obstante, para el caso de Marx, su juicio intelectual le permitió conocer el mundo ilustrado, mundo que no dudó en poner bajo la lente de la crítica con sello propio.

Marx no cree en la doble intención del sistema burgués (liberalismo y desarrollo-progreso), una intención contradictoria pero lógica, para pocos, conscientemente lógica; de esto dará fe, luego de su frustración al ser perseguido por dar sus puntos de vista sobre los atropellos donde la misma propiedad estaba por encima de las necesidades materiales como el hambre tal como lo expuso en el debate llevado a cabo en la ya mencionada VI Dieta Renania y que consignará en su Gaceta (Marx, 1982). Mucho menos en las proclamas que esgrime el sistema sobre la formación adecuada para el hombre y el sostenimiento de las restricciones a las mujeres.

Ayer como hoy, caben los señalamientos que enuncian que la educación no hace libre al hombre, no hace libre y creativo al niño (Cohan, 1996), no incluye al anciano, limita a la mujer, unívocamente es instrumento de sometimiento, de resignación, de aceptación del régimen del capital. Pero es precisamente ese modelo de educación sostenido en una Europa -y luego exportado al resto del mundo-, el que se debatía entre el 
moribundo régimen post feudal y el sistema liberal burgués del siglo XIX. Marx no consentirá ninguno de los dos.

En Marx y lo marxiano existe la posibilidad de retomar una filosofía de la educación que siga llevando las banderas de la equidad más que de la igualdad aburguesada. Puede decirse que es una de las posturas más completas, francas, rigurosas, y esperanzadoras que puedan planificarse, pues ella misma integrará todo aquello que pueda defender la dignidad humana contariando al capital y su idea de ganancia económica e ideológica que se ha amañado en la educación.

\subsubsection{La conexión de la preocupación}

La máxima preocupación es la creciente aceptación del sistema económico y la sumisión del ser humano a dicho sistema, or parte de Marx. Hay una necesidad más que teórica en el Marx socioeducador a partir de aquello. Sus preocupaciones son sensibles, parte de las sensibilidades, del sufrimiento humano. La degradación de las personas y la contradicción del sistema permisivo de cosas que a la vez les impide ser libre, le molesta. Por ello, intenta constuir los puentes para llegar a los sujetos. El sistema de cosas fundamentado en la mercantilización no es inocuo. Por ello le recrimina con toda su artillería intelectual. Entre esos puentes está la educación sociointegral cuyas bases pueden ser los de la filosofía como praxis.

La preocupación marxiana es concretar las condiciones materiales para que la humanidad esté libre de prejuicios y pueda dedicar su existencia a las cosas que, a través de la historia, le han sido ajenas por condiciones producidas por el mismo hombre a través de los poderes e influencias que, él mismo se adjudicó en principio, por derecho divino, luego por medio de representatividad donde estas abstracciones fueron objetivizadas y aplicadas. Entre esas cosas está la formación en conciencia que debe ser la idea de educación.

Entonces, desde esta perspectiva la preocupación es revisar el sistema educacional para corregir el camino y generar las condiciones necesarias para así llegar a la emancipación. Pero esto último sonaba utópico, no obstante, para Marx su visión era científica y así debía ser teorizada.

Marx comparte que es en los griegos donde tiende a desarrollarse esa forma dialéctica de comunicación cultural impregnada en el ambiente social (Marx, 1982), los cuales van más allá de los criterios morales ligados a las creencias. En esta cultura, existe una separación, si se quiere, entre lo natural y lo humano, entre $\lambda \boldsymbol{o} \boldsymbol{o} \boldsymbol{\gamma} \boldsymbol{o} \varsigma(\log o s)$ y $\boldsymbol{\mu} \tilde{\boldsymbol{v}} \boldsymbol{\theta} \boldsymbol{o} \varsigma$ (mythos), entre el vivir en sociedad y hacerse parte de ella. Pero a la vez, un reconocimiento del hombre en su integridad, en su formación, en la importancia de la misma. La $\boldsymbol{\pi} \boldsymbol{\alpha} \boldsymbol{\iota} \boldsymbol{\delta} \boldsymbol{\varepsilon} \boldsymbol{\imath} \boldsymbol{\alpha}$ (paideia) emerge como identidad entre los ciudadanos de la $\boldsymbol{\pi}$ ó $\mathbf{\imath} \varsigma$ (polis).

Ningún filósofo de la antigüedad excluyó de sus reflexiones los temas relacionados con la formación humana; ni que decir de las controversias que en la historia del pensamiento se dieron entre filósofos y sofistas (Calvo, 1992). Quizás Marx con el ejemplo griego observaba los fines de la educación-instrucción en sus polis que, a diferencia de otros pueblos de la época, tenían presentes los criterios de educación; esto se hizo presente en los modelos ateniense y espartano que muy bien distinguió Marx a través de los textos clásicos leídos.

Por ejemplo, en su tesis Differenz der demokritischen und epikureischen Naturphilosophie (Diferencia entre la filosofía de la naturaleza de Demócrito y la de Epicuro), en Marx (2004) se denota el tipo de lógica 
dialéctica al modo hegeliano para mostrar las posturas de dos importantes pensadores de la antigüedad. Este escrito es un referente que intenta desmontar algunas tradiciones que se había dado por terminado ad baculum, entonces Marx desarrolla un modo de exposición que desentraña elementos que a simple análisis no se perciben. Él desarma para armar el rompecabezas de la realidad.

Un punto clave es la relación educación - Estado. Esto ha tenido vital atención marxiana sobre todo por la presencia de la ideología (Marx, 2012bc). Marx Supo que, entre romanos la educación, o mejor los procesos de enseñanza-instrucción (Abaggnano, 1994) no fueron ajenos a los intereses del Estado; de facto se individualizaban, se centraban en la relación tutor-aprendiz. De hecho, por su cercana lectura de los clásicos romanos, Marx pudo identificar las particularidades del modelo romano; en Roma se educaba en la instrucción de la ciudadanía. Podrá notarse en su propia familia: cuando prefiere la formación familiar y fuera de la agrupación aglutinadora, máxime cuando el curriculum obedecía a la visión burguesa que de todos modos formaba a sus niños en círculos cerrados, en cambio lo poco que se ofrecía al resto de población debía ser masificado, los fines serían otros menos académicos y para nada libertarios. Con la actitud, Marx parecía no estar de acuerdo con la masificación del sistema educacional, las críticas al hacinamiento y la incomodidad que describió de los docentes, dan razones de peso.

Con el medioevo, la educación será supeditada, como institución, a los presagios de la cristiandad oficial, al tiempo que, la ciencia y la erudición serían confinadas a monasterios, abadías y conventos. Con la limitación a temas señalados como profanos, lo teocéntrico ocupaba por antonomasia la preponderancia; solo el dogma religioso era el que importaba pues este salvaría el alma y lo terrenal no importaría. Lo escolástico y la disputatio tomarán el puesto teórico y práctico respectivamente. A aquello Marx responderá con contundencia cuando cuestiona el papel alienante de la religión que ocultaba los verdaderos intereses económicos y hasta poco se interesaba por una espiritualidad consciente del sujeto (Marx, 2012c).

No así la modernidad, en la cual comienza una nueva visión de los asuntos humanos y, entre estos, los relacionados con la educación. La educación -tal como se puede concebir hoy día- no llega a retomarse con especial interés sino hasta bien entrado el siglo XVIII con los ilustrados de la Europa Occidental: franceses enciclopedistas; alemanes idealistas, ingleses pragmáticos, acuñando para el momento el sentido de Bildung (Hoyos, 2008). Sin embargo, lo marxiano seguía viendo con sospecha las aplicaciones del sistema burgués a la escuela, pues ahora lo que se iba a instalar era esa educación acrítica, los trabajos científicos sobre el sistema capitalista a Marx le darán la razón.

La instrucción era ahora servilista al capital teniendo dos funciones: una para ser pilar ideológico de una hegemonía sistémica; otra, con un sentido mercantilista que vería a la educación como negocio, en tanto mercancía idea que se mantendrá como crítica Mészaros (2008) y otros.

Lo marxiano escudriña. En Marx existe un motivo más para estudiar las culturas antiguas, esto es: su propio establecimiento como cultura y esto se denota en los modelos de formación adoptados por dichas sociedades; por decir, el modo de producción asiático (Godelier, et. Al. 972) es reflejo de las formas de vida y en relación dialéctica, sostienen esas formas. El estudio de las culturas permite identificar los rasgos de su ideal de hombre que, desde el ciudadano helénico hasta el sujeto de derechos romano y su escola individualizada plantean al sujeto como miembro de una comunidad junto a su estatus. Pero más aún las formas de hacer pensamiento, sostenedoras de sistemas. 
Reconocer que los filósofos griegos, pro ejemplo, pertenecían a una coyuntura esclavista y, por ende, determinados de alguna manera u otra por dicha práctica, era constatar que en el devenir histórico las fuerzas de la historia irrumpían en las subjetividades. Su interés por lo clásico le sirvió para ahondar en los estudios de los regímenes económicos y políticos sobre todo en la influencia de éstos en las vidas humanas.

A semejanza del propio Hegel y de los Jóvenes Hegelianos, Marx había decidido volcarse al estudio de la filosofía de la antigüedad tardía porque encontraba en ella correspondencia con el clima intelectual de la Alemania de su época. Después de Platón y Aristóteles, la filosofía griega se había desplazado de la teoría a la práctica -de la metafísica a la ética- . (Vedda en Marx-Engels, 2003, p. 19)

Aunque Marx no cita extensas observaciones sobre las formas de educación en sus reseñas sobre las sociedades antiguas, a través de ellas hay un radio de acción históricamente material que no puede producirse sin algún tipo de difusión organizada que fuera más allá de la transmisión inmediata de conocimientos.

En el campo aparentemente unívoco de lo económico que se hace en la Contribución, con la operatividad de la moneda del Imperio Romano, y la referencia del Perú (Marx, 1989), logra sentirse un aroma a disciplina a partir de un adiestramiento que debía reconocer la identidad en las relaciones de intercambio para poner al modo de organización política como un todo. En las alusiones al derecho si se puede notar el análisis sobre la importancia que estos dedicaban a la pedagogía en el campo de la ius (Marx, 1982b-1). Cuando, reconoce que, “con el molino hidráulico, el Imperio Romano nos había legado la forma elemental de toda maquinaria" (Marx, 1984, p. 424), lo hace comprendiendo que hay legados que, no obstante, se van transformando según las necesidades de su tiempo, generando toda una cadena de relaciones.

Él sabía que el siglo XVIII generó los cambios estructurales en diferentes aspectos de la vida social. La Revolución Francesa y la consolidación del liberalismo abrirán las puertas a las nuevas relaciones sociales que se darán en el siglo XIX, así también el significado de la Revolución industrial y los presupuestos de la filosofía alemana en la reconfiguración de una sociedad que ya no será la misma; todo aquello será obra del hombre, de su acumulación material, y a la vez generarán dinámicas históricas significativas. Marx será un lector de su contexto y se fijará en las vivencias de su época, con estos antecedentes elaborará su pensamiento filosófico, así mismo al ver las contradicciones del nuevo sistema imperante, se declarará enemigo del mismo, estableciendo categorías para objetarlo.

Dentro de los aspectos más destacados de la llamada cultura humana, está la transmisión de conocimientos, tradiciones, técnicas, etc. que hoy podemos llamar educación. Ningún pueblo, ninguna sociedad ha escapado a esta necesidad, ya sea como vehículo para comprender su entorno, transmitir costumbres saberes o conocimientos, hacerse participe, identificarse dentro de un grupo o simplemente formarse como ilustra Jaeger (1994 a) en su célebre tratado. Siendo que la educación y la transformación del medio, se desarrollan en tiempo y espacio, son de vital interés para cualquier postura filosófica. Como asunto humano es digno de ser estudiado bajo la lupa de la filosofía teniendo una estrecha relación.

La preocupación entre teoría y práctica en Marx se dará en el campo de la filosofía. Ese asunto que no abandonará durante sus obras y durante su vida concreta. A partir de esa situación, puede leerse la obra de Marx como una preocupación por la contradicción sobre todo en sus efectos negativos, consecuencia del 
abandono de la práctica en las entrañas del sistema imperante, por un lado. Por el otro, del olvido de la práctica por parte de las posturas que buscaban reivindicación como las del socialismo utópico que carecían también de teoría y solo se quedaban en un tipo de reformismo conformista.

Eso sí, la práctica entendida por él. En esto hacía falta enfatizar, por eso la labor no era tanto de propaganda sino de educación, de formación para afrontar el reto de la realidad material llena de tanta dificultad. Supo que la filosofía podía tener la palabra para invitar a rechazar el sistema de cosas que humillaba al ser humano y lo rebajaba a su desindentificación como persona al grado de degenerarlo en simple instrumento o mercancía en potencia mientras su fuerza vital no le abandonara.

La filosofía de la educación abre las puertas a una toma de posición que vaya más allá de los meros requerimientos conceptuales para abordar un asunto relacionado. La filosofía de la educación desde lo marxiano, debe comprometerse con los cambios tangibles al interior de una comunidad sin abandonar al sujeto que hace parte de esa comunidad. La argucia sobre el abandono del individuo en lo marxista, niega la misma esencia de lo que se propone praxiológicamente lo marxiano. La reflexión y la acción filosófica han de materializarse en un contexto, en unas necesidades determinadas.

Pensar nuevas filosofías de la educación nos abre la posibilidad de una ética y una pedagogía en la que los contextos, las situaciones, y las relaciones con los otros resulten determinantes a la hora de educar. De ahí, la importancia de una filosofía de la educación, donde se conciba el acto de educar como una respuesta al otro, como una acción de compromiso con el otro. (Ríos Beltrán, 2014, p. 193)

La educación en tanto acontecimiento humano, por ser construcción histórico-cultural, ha de tratarse con especial cuidado porque de ella depende la forma de ver el mundo en las sociedades, sus esperanzas y su desarrollo. Una estructura educativa consciente de su papel protagónico para aportar positivamente a su sociedad, como fruto de la integración colectiva, puede garantizar el bienestar individual y común. Modelo que no se ajuste a las realidades inmediatas carecerá de confianza; la educación debe interesarse por las situaciones de su contexto, retroalimentarse, actualizarse, autocriticarse para mejorar.

Cerrutti (1993), ofrece una analogía pertinente para ambientar este discurrir dialéctico en su vivir, en el contexto latinoamericano. Rescata el valor filosófico de tratar a la educación con esta óptica:

Ocurre con la filosofía de la educación lo que con la filosofía latinoamericana en general. Parece que no existe y en cierto sentido hay razones para afirmar esta inexistencia: no hay un corpus de ideas sistematizado y orgánico que pueda presentarse como aportación original a la reflexión filosófica mundial. Sin embargo, esta consideración es muy insuficiente si prestamos atención al ejercicio del filosofar desarrollando entre nosotros las ideas filosóficas operantes históricamente; entre aquellas ideas que han acompañado, guiado, dado sentido, justificando a posteriori los movimientos socio culturales del subcontinente. (Cerutti, 1993, p. 30).

Se sabe que, tratar aspectos que giran en torno a la filosofía de la educación, es tratar del hombre, es tratar de la naturaleza, es tratar de la historia, es tocar la materialidad del ser humano junto a sus relaciones sociales. Y es acá donde las ideas de Marx pueden no únicamente dar un punto de vista más; avanza cuando dan una serie de herramientas para analizar con otros ojos los fenómenos que a simple vista parecen sencillos de entender, cuyas explicaciones aparecen en un simplismo mediado por la ausencia de crítica. 
Marx no desconoció el papel de la educación formativa en la transformación social y material de los seres humanos según lo define Suchodolski (1977). Si bien su postura sobre la escuela y los sistemas de educación los consideraba inquisidores, en gran parte de sus trabajos termina proponiendo una forma distinta de pensar y de actuar, creía en la formación de los obreros, y hasta en la ciencia como factor de cambio siempre y cuando se divorcie de los intereses del capital tal cual lo expresó en varios escritos, en misivas compartidas con sus allegados (Marx, Engels, 1975).

Educar, para lo marxiano, significa no quedarse en los criterios tradicionales en los que se ha teorizado en educación; educación desde lo marxiano es formarse como ser político, consciente de su rol transformador. No para repetir lo que el sistema antagónico desata. Educar con criterio marxiano exige abandono de ortodoxia, rechaza lo estático, pero también rechaza las posturas defensoras del modelo económico, social y político.

Los planteamientos marxianos y marxistas, desde sus categorías reconocen la relación ser-pensar-praxis desde la misión de la filosofía transformadora. "En la praxis, efectivamente, el hombre debe demostrar la verdad, el poder y lo efectivo de su pensamiento" (Riestra y Del Noce, 1975, p. 53). El resurgimiento epistemológico y pedagógico que propenda por poner en el centro al ser humano del siglo XXI, reconocido así mismo, no ha perdido validez.

Tener en cuenta el aporte de Marx, desde sus posturas originales y auténticas, es poner en diálogo dos grandes lugares de orientación. El primero, la teoría marxista general de la educación como herramienta para la comprensión (Broccoli, 1980), al tiempo que la denuncia contra la visión mercantilista de la educación. Segundo, la criticidad para generar cambios sociales al interior de los procesos educativos tangibles, cambios de conciencia y actuación. Ya Russell (2009) denuncia que Marx es demasiado práctico, “está demasiado atado a los problemas de su tiempo" (P. 844); aquello hace que la obra e interés marxiano tuvo validez en su tiempo, así como algunas situaciones no han cambiado, así también la validez marxiana actual.

Marx está preocupado por la formación integral del ser humano dentro de un sistema de cosas que conjuga contradicciones sensibles, lo cual le acrecienta su validez filosófica; la sensibilidad hace parte del contenido marxiano. A la vez, reconocer que el marxismo no es sólo un movimiento contestatario carente de propuestas aterrizadas en la construcción de alternativas viables, pues hubo y siguen sobreviviendo perspectivas marxistas desligadas del dogmatismo promulgado por la oficialidad de la URSS o los abultados y en ocasiones escuálidos manuales dogmáticos del marxismo-leninismo recriminados en su momento por autores como Silva (2009). Marx es mucho más que eso.

Al ingresar en algunas de las categorías marxianas, pueden encontrarse cosas que superan la conceptualización, son categorías vivificadas, arrancadas de la materialidad sensible del hombre de su tiempo cuyos problemas no varía en la actualidad, sino que parece se han profundizado. Estas características develan la necesidad de mirar la filosofía de la educación como procesos no desligados de las transformaciones históricas o los intereses clasistas en antagonismo constante. Fromm (1989) ayuda a develar, pues

Parte del discurso revolucionario de Karl Marx consistió en señalar que el hombre se ha alienado en el curso de su proceso de realización personal. Ahora, cuando ha transcurrido más de un siglo desde 
que Marx expuso este principio, la alienación no ha perdido nada de su candente actualidad; en realidad se ha convertido en un fenómeno global. Después de los primeros tanteos conceptuales y analíticos que se remontan a Rousseau, Fichte, Schelling y Hegel, fue principal, y paradójicamente, la versión marxista del socialismo -y no del pensamiento reflexivo del humanismo clásico ni el testimonio práctico de la cristiandad, llamado amor - la que continuó analizando concretamente las dimensiones modernas del problema de la alienación humana, y también propuso una solución para el mismo. (P.343)

No mirar el fenómeno educativo con la visión de la filosofía, con matiz crítico, es traicionar los mismos principios de Marx y de otros destacados estudiosos afines al proyecto de emancipación material del hombre (Broccoli, 1987). El universo del pensamiento de Marx no se limita al llamado y amañado "fin de la historia", mucho menos al colapso de experiencias estatales e insurgentes que descuidaron las recomendaciones filosóficas fundadas por Marx-Engels.

Las tesis del propio K. Marx y compartidas al tiempo que, aquellas comentadas por F. Engels, han servido para todo tipo de interpretaciones a través de las décadas en diferentes asuntos lo mismo que en educación. La mayoría de las posiciones sobre Marx han sido de carácter descriptivo en el ámbito de la economía y de la historia del pensamiento, independientemente de las posiciones a favor, apelativas o simplemente "neutrales". Excelentes, pero en verdad, pocos trabajos que se actualicen, se han desprendido sobre el pensamiento de este pensador decimonónico en campos como la educación.

A pesar de ser una postura eurocéntrica, cosa que es superada por el alto contenido reivindicativo, en el fondo abierta, no sorprende -como ocurrirá con los presupuestos teóricos de otros ámbitos- la difusión de las propuestas marxianas y marxistas. Estas encontraron eco allende Europa, paradójicamente, lugares "carentes" de historia como afirmaría Hegel siguiendo las tradiciones modernas eurocéntricas de pensar al mundo (Abbagnano, 1994 b). Así también, permearon el ámbito de formación, claro, no con tanta fuerza y presencia como sí ocurrió con los contenidos ideológicos de tinte político. Sin embargo, comenzó a pensarse en la educación como camino de lucha y reivindicación. Se entendió que no mirar la formación educacional desde un contexto y circunstancias materiales o de influencia espirituales, es seguir la felonía contra los aportes de los iniciadores del socialismo científico cosa está última que ocurrió con las perspectivas implantadas desde el partidismo monolítico.

Así como surgió un horizonte de comprensión en materia política y económica sobre el legado de Marx, distinto al de las directrices soviéticas; así también en el campo de la educación surgirán corrientes que sin duda se alimentaron en gran medida de lo marxiano. Ese fue el caso de las pedagogías críticas, sugiriendo una pedagogía de la liberación que entraría en el escenario denunciando los males del sistema de mercado para las sociedades de la periferia.

Una parte de esa gran conexión entre pensamiento filosófico marxiano y educación, es el interés por el hombre y la mujer, pero mejorando sus condiciones más allá de los discursos de competitividad y tecnocratismo que defendió el sistema de mercado. Si en lo marxiano la praxis es relevante, la transformación filosófica en las dos vías: la del análisis y la de la propuesta, hacen antesala a la gran relación que puede establecerse entre educación y pensamiento filosófico con ingrediente categórico marxiano. La formación humana, como se insiste, es foco producido por los hombres mismos tal como se puede encontrar en la propuesta holística marxiana. 
Cualquier intento por negar esta conexión como preocupación marxiana, es en vano pues aun contando con las evidencias conceptuales y literales, el espíritu liberador está presente en la propuesta. Así las cosas, una filosofía de la educación sin la referencia a Marx quedaría incompleta. Entonces,

Ni Marx ni su fiel colaborador Friedrich Engels (1820-1895), a quien sobre todo se deben los intentos de elaboración filosófica sistemática extendida incluso al mundo de la naturaleza (materialismo dialéctico), se enfrentaron específicamente al problema pedagógico. Sin embargo, es evidente que el marxismo (vocablo con el que se designa la doctrina formulada por ambos pensadores) tiene justamente como núcleo central una teoría de la formación humana. Según esta teoría, la personalidad humana se constituye y se expresa en lo concreto de las relaciones productivas y sociales, en plena continuidad con el ambiente natural. Para Marx, la sociedad es "la verdadera resurrección de la naturaleza, el naturalismo perfecto del hombre, el humanismo perfecto de la naturaleza”. (Abbagnano, 1964, p. 505)

Al ser Marx, sin discrepancia, uno de los pensadores más influyentes de los últimos dos siglos en términos del impacto material, sigue siendo centro de atención para propios y extraños (Mc Lellan, 1984). La capacidad de comprensión holística de la realidad, la cual se extiende a las relaciones que giran alrededor del hombre y su propio entorno, se convierte en elementos de análisis más allá del mundo abstracto y al mundo social al que estaba acostumbrada la labor filosófica tradicionalista.

Su comprensión materialista junto a la aplicación dialéctica que da, demuestra una interdisciplinariedad cuyos objetivos, sin dejar otros asuntos de lado que parecían de poca importancia, como el tema de la cotidianidad. Fue la defensa de una postura filosófica dentro de la crítica a la misma filosofía la que buscó y llegó sostener para la transformación radical. El pensamiento de Marx trastocó puntos sensibles en la interioridad y exterioridad del ser humano, de la sociedad de ayer y todavía la de hoy (Mehring, 1965). Esto será evidenciado en la invitación a reconocer todas las condiciones que esclavizan, pero también que son la oportunidad para tomar el sendero de la liberación individual y colectiva.

Ahora bien, se trata de una comprensión materialista de la realidad que no se remite exclusivamente a la materia como se afirmaba en los viejos manuales de la ortodoxia. Tampoco se trata de sobreponer la materia sobre otros aspectos esenciales del hombre. Se trata pues, de mostrar el grado de influencia de las acciones humanas en el devenir histórico de esa materialidad a la cual el hombre como ser viviente está supeditado.

El factor vida como está en Engels (1979), es lo último, y no la economía -tal como lo presentaba la dogmática economicista soviética-; aunque la sostenibilidad para mantener esa vida está, dentro de una sociedad postindustrial, ligada a la producción de elementos que faciliten el tránsito por la vida historial. Pero es donde el trabajo hace lo suyo; esto es transformar la naturaleza para así cubrir las necesidades materiales del individuo. La naturaleza se convierte en un campo intervenido por la cultura humana a través del trabajo. Las formas de intervenir llamadas trabajo, se han desarrollado a través de la historia y se han transmitido de generación en generación con los avances propios de cada época y sociedad; entre esas formas de transmisión está la formación del ser humano comprendido en su materialidad vital, es aquí donde la educación empieza a tomar una importancia sobresaliente en tanto espacio social en potencia de captación y adaptación a un sistema, a un ambiente de relaciones. "Marx hace problema de la relación educación y ambiente" (Fernández Enguita, 1985, p. 11).

Lo marxiano descubre aquello. La filosofía es un camino, más un camino que primero hay que odenar. Esa vía se establece en la cabeza del muy joven Marx antes de iniciar sus estudios autodidácticos formales 
puesto que tenía contacto con los clásicos grecorromanos y con autores franceses. Ya veía en su época de estudiante formal la necesidad de escudriñar vías de comprensión que no debían quedarse en esa etapa primaria (Gemkow, 2010). Su propuesta de materialismo al que luego llamarán histórico y dialéctico, será fruto de sus observaciones e investigaciones a la vez que servirán para dar lectura a distintos fenómenos, entre ellos la educación. Los problemas que debe afrontar el hombre están a la orden del día, y la formación dictada por un sistema de cosas exige una actitud filosófica para develar la realidad. Aunque los presupuestos teóricos de los dos materialismos son básicos para una lectura marxista, hay que tener cuidado cuando se aborden las realidades, estableciendo las salvedades de estas dos grandes categorías.

Durante la segunda mitad del siglo XX, el aspecto teorizante de legitimidad de discursos predominó entre marxistas en puja ideológica. El tema de la educación estaba sometido a las directrices de los bandos intelectuales y los politizados. Quizás, dejó de pensarse con Marx el tema de la educación. Entre extremos academicismos y duras posturas partidistas se descuidó el tema educativo. Apenas se creía que, hablando de educación gratuita en todos los niveles, las campañas de alfabetismo y la erradicación de la visión burguesa de la historia era más que suficiente, claro siempre y cuando se llegara a los espacios de poder. Solo algunas voces aisladas sabían que el tema de la formación humana con un enfoque marxiano iba más, pero muchos más allá que los validos formalismos.

Lo anterior, rememora tres grandes etapas presentadas. La primera, la irrupción de las interpretaciones llevadas a cabo e impuestas en la Europa oriental, en otras palabras, el marxismo soviético, cuyos fundamentalismos no superaron las versiones dogmáticas que generaron una aversión a las lecturas distintas que pudieran hacerse de Marx, de esto no escapó la categorización que pudiera habérsele dado a una posible postura pedagógica del "sistema no sistema" marxiano. Un segundo ciclo, ese propuesto en la Europa occidental, que renunciaba a las visiones testarudas y burocratizadas de Moscú; en esta se "suavizan" las cuestiones relacionadas con el marxismo, una retoma del marxismo como alternativa (Althusser, 1971).

Ya no existía la univoca versión como lo comprendió también Althusser (1974) en Para leer El capital. Pero también, para el asunto que nos asalta en esta investigación, puede encontrarse un tercer escenario: la llegada al mundo afroasiático y latinoamericano de las ideas directas de Marx y aquellas de talante netamente marxista. En la periferia, el efecto fue distinto a pesar de la eclosión de grupos armados que levantaban las banderas del marxismo-leninismo en su mayoría aunado al concepto de liberación nacional. El marxismo apareció como un tipo de "esperanza" contra la eclosión intencional de la miseria y la coerción en el Tercer Mundo.

Los muros cayeron, los de las realizaciones políticas que se decían afiliadas al marxismo. Pero el marxismo sigue siendo una metodología, un modo de pensamiento y una forma de enfocar intelectualmente la realidad. Quitándole errores de percepción que el tiempo descubrió como tales hace ciento cincuenta años, Marx no podía prever el desarrollo técnico-informático y la aldea globalizada en que vivimos hoy), la estructura de pensamiento marxista, como la estructura de pensamiento platónico, como la del aristotélico o la del tomista, tiene validez. Porque es pensamiento crítico; es filosofía. (Barylko, 2005, p. 200)

La preocupación marxiana por la formación de la clase trabajadora es vital. Científicamente sabía que libre de cualquier atadura alienante, reconociéndose como sujeto activo y pensando en sus semejantes, podría ser libre este sector oprimido. Una clase que sabiendo que si se cambiaba el sistema de cosas por antonomasia debía cambiarse el sistema educacional, ahora adaptado a sus necesidades. Si bien el 
pensamiento de Marx no establece oficialmente un sistema educativo, acude de todos modos una forma de pensar crítica y sociocientíficamente, que se extienda al actuar para garantizar una constante dinámica liberadora. Así los actores educativos serán de igual forma autónomos, libres y solidarios, responsables de su propia formación y no sencillos objetos recipientes de cúmulos o instrucciones.

La teoría educativa marxiana encuentra un punto de apoyo y validez actual en varios conceptos, entre ellos los de praxis e ideología. También está como interés el reinterpretar lo ideológico, para a su vez desmantelarlo y darle otro sentido más cercano a la conciencia consciente de tipo crítico.

El otro interés es la preocupación por levantar un puente. El puente entre filosofía y educación es la praxis, la praxis garantiza un paso del mundo filosófico al campo de la formación. Esa idea de praxis parte de la influencia de August Cieszkowski quien toca a Marx, lo mismo que la postura filosófica de B. Spinoza como lo consigna González (2102). A lo anterior, se ajusta según Broccoli, que "hay un pasaje en los Manuscritos filosóficos juveniles que se remite claramente a una constancia de estimación expresada por Hegel en relación a Kant, y siempre a propósito del mismo argumento: el concepto de praxis" (1980, p. 152). Este gran interés va a ser la realización primigenia de una formación digna para el ser humano donde descubra los reales problemas y empiece a generar soluciones individuales y en colectivo.

La conexión significativa es la relación existente entre filosofía desde la perspectiva marxiana y la educación crítico-liberadora. Desmontar el mito de la educación como superación personal egoísta, desligada de los coail y de lo colectivo, y verla solo como camino económico es la meta inicial de una postura praxica. Pero para ello hay que buscar las razones científicas coayudantes de las posibilidades marxianas para una filosofía de la educación.

\subsection{Una episteme marxiana para una filosofía de la educación}

Marx no escribió textos directos sobre teoría de la ciencia o del conocimiento científico, concretamente hablando, pero este conjunto de cosas no le eran ajenas al interés; su monumental obra es, toda una compilación que delinea su manera peculiar de ver a la ciencia, sus intereses, intenciones y más que otra cosa, su relación con el sistema imperante.

La visión epistemológica que colabora con una propuesta praxiológica en educación, no es otra que aquella procedente de la postura marxiana. Si tomamos en cuenta que, la misma crítica significa examen y construcción continua, es así que puede verse a la ciencia como espacio crítico y no solo instrumental. Dar el lugar a una lectura epistémica para este tipo de exploraciones, significa buscar el punto de equilibrio para que sea solo tomado en cuenta y no similar a intentos de imposición. Miremos la recomendación hecha por Hegel, cuando acota que,

En general se distingue un sistema filosófico con sus ciencias particulares y el filosofar mismo. Según la obsesión moderna, especialmente de la pedagogía, no se ha de instruir tanto en el contenido de la filosofía, cuanto se ha de procurar aprender a filosofar sin contenido; esto significa más o menos; se debe viajar y siempre viajar, sin llegar a conocer las ciudades, los ríos, los países, los hombres, etc. (Hegel, 1991, p. 139) 
La relación entre lo epistemológico y la praxis, desde la propuesta marxiana, ajusta la visión del hombre sobre el ejercicio de su acción sobre el medio para convertirse tras la conciencia como fuerza transformadora que no puede ni debe enajenarse. En principio, podría argumentarse la relación entre el conocimiento y la aprehensión de los conocimientos para desenvolverse en el mundo natural y luego, en el mundo social. Para el caso de la educación como acontecimiento socio-histórico, la visión epistemológica ha de centrarse más que en los problemas del conocimiento, en las tramas sociales como lo dice Azócar (2015).

Una teoría científica del trabajo como la realizada por Marx, será la punta de lanza para la comprensión de un rescate de la educación basada en la dignidad de esta fuerza productiva y creativa. El sostenimiento de la versión antropológica-social del trabajo ha de reemplazar la incompleta e inhumana sujeción economicista, la cual pretende utilizar toda la teoría económica para justificar la explotación, justificar los también incompletos sistemas educacionales que buscan obviar una conciencia de clase.

A simple vista puede pensarse en el tema del trabajo, de esa intervención humana, del hombre quien, con su capacidad -consecuencia de su evolución-, interviene el medio, tecnifica prácticas y busca surtir sus necesidades materiales y, hasta en su extensión, para evacuar las espirituales. Si bien en Hegel existen elementos suficientes para pensar en su interés por el fenómeno del trabajo, al referirse a esto, revisando a Hegel, Marx en su tercer manuscrito, le objeta su grado de abstracción, de visión de ciencia aplicada a este fenómeno material, de la siguiente manera:

De momento, anticiparemos sólo esto: Hegel se coloca en el punto de vista de la Economía Política moderna. Concibe el trabajo como la esencia del hombre, que se prueba a si misma; él sólo ve el aspecto positivo del trabajo, no su aspecto negativo. El trabajo es el devenir para sí del hombre dentro de la enajenación o como hombre enajenado. El único trabajo que Hegel conoce y reconoce es el abstracto espiritual. Lo que, en general, constituye la esencia de la Filosofía, la enajenación del hombre que se conoce, o la ciencia enajenada que se piensa, lo capta Hegel como esencia del trabajo y por eso puede, frente a la filosofía precedente, reunir sus diversos momentos, presentar su Filosofía como la Filosofía. Lo que los otros filósofos hicieron (captar momentos aislados de la naturaleza y de la vida humana con momentos de la autoconciencia o, para ser precisos, de la autoconciencia abstracta) lo sabe Hegel como el hacer de la Filosofía, por eso su ciencia es absoluta. (Marx, Pp. 1912001, 192)

Si bien desde Sánchez Vásquez (1977) hay un rechazo de la versión del marxismo como interpretación, reducido a una nueva práctica teórica; a ésta se suma la interpretación ontologizante y aquella que obedece estrictamente a lo antropológico. Y es que "a diferencia de estas interpretaciones, la filosofía de la praxis considera en unidad indisoluble el proyecto de emancipación, la crítica de lo existente y el conocimiento de la realidad a transformar" (Párr. 15).

Con Marx, se inicia una socio-epistemología aplicada, aunque quizás no era su primera intención, logra convertirse, desde su visión holística, en una manera de acercarse al cotidiano. "Marx examinó el mundo material del mismo modo que un sacerdote examina el mundo ideal, con la esperanza de encontrar en él sus propias aspiraciones creadoras y, en caso contrario, para ver de qué modo podía trasplantarlas en él" (Mariátegui, 1959, p. 109). Martínez (2002) destacando con la epistemología marxista, insiste:

Pero, el conocimiento para Marx no es un elemento puramente cognoscitivo o contemplativo, sino que tiene siempre una dimensión práctica y pragmática dirigida a la transformación de la realidad. Este es 
un punto importante. La realidad es conocimiento aplicado, la ciencia es para Marx conocimiento ligado al interés revolucionario y transformador. Que teoría y práctica estén unidas es otro elemento propio del marxismo que lo distingue del resto de teorías. Nuestro conocimiento es pragmático, tiene el objetivo de transformar. (P. 1)

Otro de los temas polémicos es aquel que busca superponer lo ideológico en contraste a lo científico. Es decir, el sentido ideológico al que se está expuesto en el sistema hegemónico, puede develarse con la ciencia. Lo epistemológico repele a lo ideológico, si no lo hace será llanamente otra manifestación cómplice de la ideología. Por esto, Marx reconoce a su esfuerzo como ciencia, pero no en los términos tradicionales de la línea enciclopedista, empírica o positivista, sino de conciencia, energía real de la actitud científica para combatir el dogma. Ya sabemos el acercamiento de Marx- Engels (1972a) a los avances científicos de la ciencia natural y a las teorías de punta, lo que le da argumentos para emitir opiniones.

También, los apuntes sobre la necesidad de eticidad y de sociabilidad en la ciencia, en toda su dimensión y efectos, servirán para iniciar la batalla de las ideas en pro de una práctica adecuada que rescate al ser humano integral como centro de interés sin acudir a la discriminación de clase, sectores o cualquier otra tipificación que quiera establecerse.

La reflexión científica conduce a un enjuiciamiento ético del sistema, y, ambos aspectos, exigen una actuación práctico-revolucionaria que incida efectivamente en la superación estructural del orden establecido. Ética y ciencia se articulan, para Marx, en una unidad indisoluble: la expresión de esta unidad es la noción de praxis. (González, 2015, p. 196)

En la escuela y para la escuela como acontecimientos sociales e históricos, el marco epistemológico ha de fundarse en los aportes marxianos y en las generalidades de la filosofía de la educación por ser ámbito del que hacer filosófico. La historia, la economía, la sociología y la política, cooperarán en la construcción de los pilares teórico-metodológicos para darle cientificidad al fenómeno educacional.

\subsubsection{La revolución epistemológica en Marx}

Ha de tomarse en aprecio la vital y acusiosa labor de Marx al buscar en la actitud científica toda la posibilidad de tomarla para los fines de sus estudios sobre el sistema capitalista. No dudó en echar mano de todo lo que pudiera concederle conocimiento sobre los fenomenso relacionados de una u otra manera. Así, la ciencia más que un campo, es actitud para ser herramienta de comprensión y de lucha. Al incluir el sufrimiento humano y su mortalidad como interés científico-social, Marx logra que su legado pueda extenderse a otras dimensiones.

La visión educativa con Marx, demanda una comprensión del asunto epistémico. La epistemología entendida con Marx combina los preceptos de un materialismo cuyo objetivo es relevar un tipo de humanismo desligado de las concepciones tradicionales. Va más allá de las dos posturas materialistas conocidas, no se empantana en la simple crítica, ni aún en la propuesta metodológica; se hace denuncia de un sistema de cosas imperantes que ya vislumbra todas las nefastas consecuencias para el mundo material, e incluso, para la dimensión inmaterial. No puede pensarse en la mera escisión entre idealismomaterialismo, aunque importante, como único tema para abordar el pensamiento en los tiempos de Marx.

Con su antítesis abstracta respecto al idealismo Feuerbach da a Marx el fundamento para una nueva disposición de pensamiento no idealista, hasta el punto de que en ocasiones incluso Marx echa por la borda importantes motivos dialécticos que más tarde retomó. En algunos pasajes de La sagrada familia, por ejemplo, parece que Marx, siguiendo a Feuerbach, identifica directamente la dialéctica 
con el idealismo. En La ideología alemana, en las Tesis y en todas sus obras posteriores Marx retorna, sin embargo -a través de la crítica realizada por Feuerbach contra Hegel- a posiciones hegelianas. (Schmidt, 1977, p. 18)

W. Roces en su prólogo de Escritos de juventud comenta: "Bajo la influencia de Feuerbach y partiendo de sus firmes posiciones revolucionario democráticas, Marx comienza a desprenderse del idealismo hegeliano y a orientarse hacia el materialismo" (Marx, 1982, p. XXIX). Marx desarrolla un materialismo propositivo, un materialismo dedicado a buscar los factores "culpables" de tanta inequidad social. Su finalidad no era finalidad como tal; su interés no puede ser leído como la presunción de movimientos entre sujeto - objeto, o validas especulaciones. No. Él descubre que el conocimiento aplicado tiene otras consecuencias no tan idílicas, el sufrimiento -que él mismo vivió- será parte de la medicación para comprender los patrones de las relaciones sociales y de poder del sistema de cosas dictado por el capital y la mercancía.

En misiva de Marx a Ludwig Kugelman, el de 6 marzo del año 1868, el primero confirma de su puño y letra:

Düring sabe perfectamente que mi método de exposición no es el mismo de Hegel, pues yo soy materialista y Hegel es idealista. La dialéctica de Hegel es la forma fundamental de cualquier dialéctica, pero sólo cuando conseguimos desnudarla de su ropaje místico, y esto es precisamente lo que distingue mi método... (Marx \& Engels, 1975, p. 62)

La dicotomía idealismo-materialismo planteaba un universo de asuntos dignos de ser mirados con una novedosa lupa, la de la dialéctica; así también lo apuntalaba Rosental (Sf.) en su tratado. Para referenciar un poco esto, en relación directa con los compendios de Hegel frente a la nueva filosofía no filosófica, puede decirse.

Un cambio epistemológico, significa por efecto, un cambio en los paradigmas pedagógicos, del fenómeno educacional. Tradicionalmente se ha denominado a Marx junto a su amigo Engels, como los "fundadores" del socialismo científico. Podría decirse que son, a todas luces, los impulsores de la cientificidad del sufrimiento humano para que sea conocido, denunciado y reemplazado por otra forma más digna.

En el siglo XX saldrán voces a refutar la ciencia elaborada por Marx. Claro, obedeció a acciones ideológicas en su mayoría. Una ejemplificación está en la refutación a Popper (1971) por su incongruencia con las posturas de Marx. Existen unos desfases en su obra La sociedad abierta y sus enemigos, así lo expone Slavin (2008) con centralidad, las no razones para discrepar lo afirmado en Popper (1957), de parte de otras visiones más que contradictoras, en ocasiones viscerales, no se establecen pruebas sufcientes para objetar la maginfica integración que hace lo marxiano sobre el uso de la ciencia como campo limitado a los poderosos, lo que la hace fenómeno de críticas validas cuando se aleja del sentido social. Más otros saldrán a contrarrestar las demandas elaboradas de manera ideológica en vez que científicas, Althusser se pondrá en escena.

Siguiendo una pregunta consecuente, “¿no nos compromete Marx a dejar de filosofar, es decir, de desarrollar sueños ideológicos, para pasar a estudiar la realidad misma?” (Althusser, 1974, p. 21), esto ya plantea un cambio, quien se acerca a este tipo de concepción netamente marxiana puede comprender mejor la dialéctica aplicada por Marx, extensión pertinente para el caso particular de la educación. Claro, dejar de "filosofar" desde la perspectiva denunciante de Marx sobre la filosofía de su época. Hoy difícilmente podemos hablar de "filosofía burguesa", pero no es secreto que esta misma es tributaria de gran cantidad de posturas filosóficas contemporáneas muchas de las cuales contraponen asuntos de la realidad dando 
prioridad a academicismos apartados del papel protagónico que socialmente debe dar la filosofía para los desafíos de este siglo XXI.

Total, cabría reconocer, además, que ese mosaico teórico derivado de Marx -sin deseo de excluir a Engelsha impactado en las prácticas educacionales, sobre todo de aquellos países que alguna vez giraron en la órbita autodenominada socialista. Eso sí, con todas las complicaciones praxiológicas y de resultados que ya se conocen por medio de la historia. Y sí, hubo una incomprensión del carácter marxiano de la educación. Si bien hubo una incomprensión y una nefasta aplicación de un cierto "modelo" marxista en distintas dimensiones a nivel macro, por efecto directo también sucedió lo mismo con los aspectos educacionalespedagógicos. En fin, el desconocimiento de los aportes que en materia de formación pueden encontrarse en Marx, fue y ha sido una constante, esto por desconocimiento directo de su obra y sobre todo por la carencia de adaptación epistemológica en algunos contextos, en algunas conciencias.

Ahora, abordando este basto tema desde el ámbito de la epistemología, se tiene dos asuntos: ver los aspectos epistemológicos generales en Marx y algunas tendencias marxistas y, en segundo aspecto, leer en clave epistemológica para construir con una propuesta de comprensión que debe darse al pensar la filosofía de la educación con lo marxiano.

Cuando a mediados del siglo XX, L. Althusser en su obra intitulada Pour Marx de 1965 (La revolución teórica de Marx), expone una cantidad de elementos para repensar las posturas marxistas que se desprendían de la obra de Marx, da su guiño al concepto de ruptura epistemológica al comentar los elementos que en el ámbito epistémico se pudieran extraer o defender de la obra de Marx, con la intención de un rescate cientificista.

El presupuesto de la división entre las obras de Marx, es un problema que tiene dimensiones epistemológicas. Por un lado, la teoría de las fuentes, donde solo se dice que el tema, por ejemplo, de la alienación debe preponderar -o puede ser también subvalorado- sobre el resto de aportes; por el otro lado, la teoría de la anticipación cuya pauta es poner las obras llamadas de "madurez", como únicas validas por su ocupación a asuntos concretos dentro de un sistema (Martínez, Sf.).

No hay dos, ni tres, ni cuatro Marx; solo hay uno. Por lo menos, en lo que interesa a esta exploración del tema de la filosofía de la educación, esto no significa un atrevimiento a desconocer posiciones, todo lo contrario, hace parte de la dialéctica del espacio académico.

Gran parte de la discusión sobre la división a la que se ha sometido a Marx, ha nadado en la idea planteada por Althusser con su concepción de ruptura. Veámos que decía este último al respecto:

Esta ruptura epistemológica, divide el pensamiento de Marx en dos grandes periodos esenciales: el periodo todavía "ideológico", anterior a la ruptura de 1845. Este segundo periodo puede dividirse en dos momentos, el momento de maduración teórica y el momento de la madurez teórica de Marx. (Althusser, 1974, p. 25)

Lo anterior da fe de la idea divisoria antes que unificadora, la cual caló en los círculos de estudio sobre Marx; cosa que no puede obviarse al abordar a Marx desde la perspectiva de una comprensión filosófica desde la educación, pues, como se ha ratificado, esta postura puede desmontarse bajo la lente de una filosofia de la educación. Desde Latinoamérica, como ejercicio ilustrativo, Kohan (Sf.) se manifiesta de manera contraria: la postura de Althusser debe restársele en lo tocante a la llamada ruptura de Marx. A su vez, Sánchez Vásquez tendrá sus reservas, lo mismo que Ludovico Silva. No obstante, los aportes 
althuserianos y los reproches de otras posturas, al parecer, enriquecen el diálogo entrando al conjunto abierto del debate en temas de interés para lo marxiano, máxime en educación.

Y es que se toma en cuenta la "división" de un Marx pensado en retrospectiva, precisamente para no compartir dicha visión, pues para recrear una filosofía de la educación con lo marxiano, esta disensión no aporta elementos clave ya que la obra de Marx es mirada como un todo, socio pedagógicamente hablando. Se ve que parte de unas especulaciones simples, para avanzar al rastreo científico, y luego a la sistematización de los estudios realizados.

\subsubsection{Extensión a la educación}

El esfuerzo teórico que establece la diferencia existente entre las diversas interpretaciones marxistas y aquella que emanan directamente de los textos del propio Marx, en cuanto al conocimiento, ayudan a solventar la propuesta que apueste no solo por el rescate de una lectura marxiana de la educación sino de su propia praxis. Aunque tampoco realizó escrito específico sobre lo epistemológico, esto no escapa de sus reflexiones que parten desde la naturaleza y su relación con el trabajo hasta las relaciones detrás del conocimiento y de la misma ciencia, de los modos de interpretar al mundo que de todas maneras llegarán siempre a tratarse en los procesos de formación de los individuos.

"La concepción hegeliana de la enseñanza subraya la dialéctica interna del sujeto y el objeto, pero de un modo "intelectual y especulativo" y no sensible y práctico" (Suchodolski, 1977, p. 180). La clásica relación entre dos extremos (sujeto-objeto), es abordada por lo marxiano de una manera que no descuida esto, pero que pone en entredicho todas las posturas que se quedan en la teoría saltándose toda la trama social que puede existir tras estas bambalinas teoréticas. La propuesta epistemológica marxiana no centra su interés en el problema del conocimiento de manera contemplativa, sino como producto de las mismas relaciones sociales, a la vez lo devela como intencionalidad ideológica. Para la época de Marx esto fue destacable, aun hoy en pleno inicio del siglo XXI las cosas no han cambiado ni en esencia ni en formas.

En los Manuscritos económico-filosóficos, Marx describe la relación entre conciencia y los supuestos de sujeto-objeto. Es a partir del fragmento de Una crítica de la dialéctica y de la filosofía de Hegel, donde se afirma la idea materializada de enajenación de esa misma relación que afectará los discursos posteriores sobre el conocimiento. Marx va más allá de la apariencia; por ello afirma al respecto:

El modo en que la conciencia es, y en el que algo es para ella, es el conocimiento. El conocimiento es su único acto. Así, algo cobra existencia para la conciencia en tanto que conoce este algo. Conocerlo es su única relación objetiva. Conoce, pues, la nulidad del objeto (es decir, conoce la no-existencia de la distinción entre ella misma y el objeto, la no-existencia del objeto para ella), porque conoce al objeto como su autoenajenación. Es decir, se conoce a sí misma (conoce al saber como objeto) porque el objeto es sólo la apariencia de un objeto, un engaño, que no es intrínsecamente nada más que el conocimiento mismo que se ha confrontado con él mismo y ha establecido frente a sí una nulidad, un "algo" que no tiene existencia objetiva fuera del conocerse mismo. El conocer sabe que al relacionarse con el objeto está sólo fuera de sí mismo, se enajena y que sólo aparece a sí mismo como objeto; o, en otras palabras, que lo que le aparece como objeto es sólo él mismo. (Marx, 2012, pp. 190-191)

Desde lo marxiano la relación sujeto-objeto, tan clásico para el pensamiento epistemológico, no ocupa sino el lugar que le corresponde: otra manera de persuadir la verdadera realidad de los fenómenos que tienen vigencia en la materialidad concreta. Así el vuelco se da, sobre todo en el enfoque hegeliano que no será descuidado por Marx; en Hegel se parte de lo abstracto para llegar a lo concreto; Marx hace lo contrario (Sacristán, 1978). 
Asimismo, es necesario recordar que la filosofía de Hegel se basa en una interpretación específica de la relación sujeto-objeto. Hegel convierte el antagonismo epistemológico tradicional entre sujeto (conciencia) y objeto, en la reflexión de un antagonismo histórico definido. El objeto aparece primero corno objeto de deseo, algo que ha de ser confirmado y apropiado con el fin de satisfacer una necesidad humana. (Marcuse, 1993, pp. 255-256)

Aparece la "necesidad" como categoría de orden primario. No puede quedarse por fuera el espléndido aporte de Hegel, por decir, que ayudó a delinear un rumbo teórico aportando de manera dialéctica a los asuntos del conocimiento, además, el sentido común apunta a que "el hombre desprovisto de formación permanece estancado en la intuición inmediata" (Hegel, 1991, p.184). No obstante, Marcuse (1993) destaca sobre estas relaciones algo importante, al decir que

El gran error de Hegel fue el de aferrarse al idealismo en una época en que la solución materialista del problema estaba al alcance de la mano. La nueva filosofía es, entonces, una realización de la filosofía hegeliana, pero sólo como su negación. (P. 264)

En definitiva, comenzará el camino de comprensión, de propuesta -incluso- de las posibilidades de comprensión en el asunto que entabla la relación entre los sustentos desde Marx en materia epistémica que van a colaborar con la observación de la educación. Althusser en 1974, nos comparte especifiamente esto:

Que el marxismo pueda y deba ser objeto de la cuestión epistemológica; que esta cuestión epistemológica no pueda ser planteada sino en función de la problemática teórica marxista, proviene de la necesidad misma de una teoría que se define dialécticamente, no solamente como ciencia de la historia (materialismo histórico) sino también y al mismo tiempo como filosofía, capaz de dar cuenta de la naturaleza de las formaciones teóricas, y de su historia, por lo tanto capaz de dar cuenta de sí, tomándose a sí misma como objeto. El marxismo es la única filosofía que afronta teóricamente esta prueba. (P. 29)

Los asuntos tratados en esta sección han sido abordados de manera particular, pues se ha enfocado el tema del conocimiento desde una perspectiva que antes de poner las relaciones entre sujeto y objeto, se interesa por las situaciones reales, materiales del sujeto en su construcción teórica de objetos también ligados a las realidades sociales construidas, hasta aparentadas por el hombre. Los problemas epistemológicos no son el centro, el centro es: a que obedecen esos problemas y como se han tratado en la historia del pensamiento, a qué orden social obedecen y cuales sus impactos sociales; esto es lo importante para una visión marxiana, así mismo lo será al momento de tener en cuenta la lectura del acontecimiento educativo. Es más, esto mismo está ligado al tema formacional y del trabajo, con ello el de la misma ciencia. No existe inconsistencia entre ciencia, filosofía transformadora y la educación. En definitiva, no hay, como alude Broccoli, "antítesis entre filosofía y ciencias, tan sugestivas como improductivas" (1980, p. 97).

La educación, delineada por aquella lógica social, es importante para lo marxiano pues, en ella se puede revelar las relaciones humanas de alto calado, sobre todo aquellas que a simple vista parecen bizantinas. La cognoscibilidad del mundo significa una propuesta educacional, permeada por formas ideológicas. Este es el aporte marxiano que denuncia las manipulaciones ideológicas que pueden darse para justificar órdenes o sistemas de dominación del conocimiento y de la ciencia.

Aunque "la revolución teórica de Marx consiste justamente en fundar sobre un nuevo elemento su pensamiento teórico liberado del antiguo elemento: el de la filosofía hegeliana y feuerbachiana" (Althusser, 1974, p. 37), esto mismo es un ingrediente a tomarse en cuenta ya sea como un "giro" elaborado por la inconformidad filosófica de Marx, ya sea como muestra de ruptura con un sistema imperante no sin reconocerse los pilares a tenerse en cuenta en la misma elaboración de esa propuesta nueva. 
En Marx, el conocimiento no es una cosa simplemente cognoscitiva, no puramente contemplativa, además, sobre todo contiene el conocimiento, una fuerte presencia de elementos cuyo objetivo será la transformación de la realidad (Martínez, 2002). El conocimiento no es el fin, es el medio para la transformación. No hay duda en la defensa que hace Marx de la ciencia para acabar de retirar lo que el mismo llama "escoria", toda la superstición y los sometimientos epistémicos heredados de otros contextos; por decir, el desmantelamiento de las banderas dogmáticas de la religión y las creencias ideológicas ortodoxas, son objetivos de todo el compendio que podríamos decir epistemológico de Marx, una epistemología crítica, revolucionaria que vendría a tocar los diferentes espacios de desenvolvimiento del ser humano.

El marxismo se sostiene tanto en una teoría de la ciencia, como en una interpretación dialéctica y critica de los procesos sociales y filosóficos. En torno a estos presupuestos epistemológicos han levantado su voz muchas escuelas y tradiciones marxistas. El afán medular de esta teoría es conquistar la justicia social del hombre en la tierra. (Guzmán, 2017, p. 167)

En Marx puede leerse el gran aprecio que tenía por la explicación de los fenómenos científicos, sobre todo, su curiosidad por la relación entre estos y el hombre; su relación práctica con los fenómenos científicos materializados en los grandes avances de su mundo. Fenómenos científicos que, a su vez, daban razón de la comprensión de los fenómenos externos al hombre y que estaba ahí manifestándose a través de la naturaleza real. "La práctica refuta la teoría kantiana del conocimiento, ya que el dominio del hombre sobre la naturaleza y sobre sus relaciones sociales es la demostración más contundente de la cognoscibilidad del mundo" (Rhózin et. al, 1966, p. 248). El aporte marxiano consiste teóricamente, desde Bauman, en "la comprensión objetiva no es alcanzable a menos que la crítica científica y el sentido común se desenvuelvan dentro de la crítica de la realidad social, que tanto la ciencia como el sentido común reflejan verdaderamente" (Bauman, 2002, p. 53).

Gramsci en fragmento: La ciencia y las ideologías "científicas" guardado en Filosofía de la praxis, rescata y genera una versión marxiana de la ciencia con relación al contexto social. De hecho, los aportes intelectuales de este pensador italiano -otro ejemplo de praxis viviente-, a la cultura, los intelectuales y la escuela cuando los relaciona con el campo político de acción, le hacen referente adecuado al momento de tocar también la ciencia. Así nos aporta:

La labor científica tiene dos aspectos principales: uno que rectifica incesantemente el modo del conocimiento, rectifica y refuerza los órganos de las sensaciones, elabora principios nuevos y complejos de inducción y deducción, esto es, afina los instrumentos de la experiencia y de su control; otro que aplica este complejo instrumental (de instrumentos materiales y mentales) al establecimiento de lo que hay en las sensaciones de necesario o de arbitrario, individual, transitorio. Es decir, se establece lo que es común a todos los hombres, lo que todos pueden controlar del mismo modo, independientemente unos de otros, siempre y cuando observen igualmente las condiciones técnicas de verificación. «Objetivo» significa únicamente que se afirma que es objetiva, realidad objetiva, la realidad verificada por todos los hombres, independiente de cada punto de vista meramente particular o de grupo.

Pero, en el fondo, también se trata de una concepción particular del mundo, de una ideología. Ahora bien, la filosofía de la praxis puede aceptar esta concepción, globalmente y por la orientación que marca; en cambio debe rechazar la del sentido común aunque lleve materialmente a la misma conclusión. El sentido común afirma la objetividad de lo real porque la realidad, el mundo, ha sido creado por Dios independientemente del hombre, antes del hombre; es, por consiguiente, la expresión de la concepción mitológica del mundo; por otro lado, al describir esta objetividad, el sentido común 
cae en los errores más groseros; en gran parte, se ha quedado en la fase de la astronomía ptolemaica, no sabe establecer los nexos reales de causa y efecto, etc., es decir, afirma como «objetiva» una cierta «subjetividad» anacrónica porque ni siquiera concibe que pueda existir una concepción subjetiva del mundo ni sabe lo que esto puede significar. (Gramsci, 1970, p. 46)

La postura marxiana no se agota en sus esenciales caracterizaciones económicas, sociales o políticas. Se extiende, sobre todo junto a éstas, a la cotidianidad sin perder su seriedad teórica, su aporte crítico en el análisis de las diferentes situaciones concretas; esto servirá de aliciente para dilucidar las relaciones intrínsecas del fenómeno educativo y todo lo que alrededor de él gira. El simple hecho de establecer las relaciones del hombre con la naturaleza, la mediación del trabajo y las herramientas materiales de la ciencia y la técnica, dan razón de su importancia cuando de formación humana se trata, en los campos individual y social. Marx afirmó en el siglo XIX lo siguiente:

Hoy día, todo parece llevar en su seno su propia contradicción. Vemos que las máquinas, dotadas de la propiedad maravillosa de acortar y hacer más fructífero el trabajo humano provocan el hambre y el agotamiento del trabajador. Las fuentes de riqueza recién descubiertas se convierten, por arte de un extraño maleficio, en fuentes de privaciones. Los triunfos del arte parecen adquiridos al precio de cualidades morales. El dominio del hombre sobre la naturaleza es cada vez mayor; pero, al mismo tiempo, el hombre se convierte en esclavo de otros hombres o de su propia infamia. Hasta la pura luz de la ciencia parece no poder brillar más que sobre el fondo tenebroso de la ignorancia. Todos nuestros inventos y progresos parecen dotar de vida intelectual a las fuerzas materiales, mientras que reducen a la vida humana al nivel de una fuerza material bruta. Este antagonismo entre la industria moderna y la ciencia, por un lado, y la miseria y la decadencia, por otro; este antagonismo entre las fuerzas productivas y las relaciones sociales de nuestra época es un hecho palpable, abrumador e incontrovertible. Unos partidos pueden lamentar este hecho; otros pueden querer deshacerse de los progresos modernos de la técnica con tal de verse libres de los conflictos actuales; otros más pueden imaginar que este notable progreso industrial debe complementarse con una regresión política igualmente notable. Por lo que a nosotros se refiere, no nos engañamos respecto a la naturaleza de ese espíritu maligno que se manifiesta constantemente en todas las contradicciones que acabamos de señalar. Sabemos que para hacer trabajar bien a las nuevas fuerzas de la sociedad se necesita únicamente que éstas pasen a manos de hombres nuevos, y que tales hombres nuevos son los obreros. (Marx, 1976 a1, p. 514)

Está claro, el impacto de la ideologización del conocimiento por parte del sistema del capital, supera la afección a un grupo de seres humanos determinado, es decir, ya no solo al obrero-proletario, sino a todo individuo inmerso en una sociedad regida por relaciones de explotación en diferentes ámbitos incluyendo el del conocimiento, y su respectivo acceso.

Así las cosas, la importancia en reconocer un enfoque epistemológico marxiano extendido en la educación reside en la identificación de los objetos de estudio propios de lo marxiano por un lado, y de la naturaleza misma de lo marxiano en cuanto, teoría crítica de los fenómenos sociales. La actitud científica con la lente de la subjetividad que tiene la ciencia al hacerse material, afecta de una u otroa manera y legitima cualquier accion que se tome frente a la educación.

\subsection{La filosofía como "cerebro" de la filosofía de la educación}

Si existe la versión de la filosofía como "arma de la revolución” según Althusser (1971); esa arma intelectual a la que los obreros, para el ideal de Marx, debían tomar. Con lo marxiano se descubre una argumentación filosófica cuyo centro es la praxis, desde la cual se exige la transformación del sistema de cosas. 
Lo marxiano toma en cuenta que la filosofía no es solo interpretación -que es parte integra-, es ante todo transformació. La educación, desde lo marxiano debe tomarse, planificarse a la par de este principio

Como el hombre tiene una condición finita se dedica a reflexionar, a buscar respuestas a las necesidades, en el caso de lo marxiano se complementa con las necesidades materiales. Por ser finita la sociedad y el sistema de cosas, no cabe la absolutización de las mismas. La sociedad ha de transformarse si quiere dejar atrás las contradicciones, y en esto el sistema de mercantilización no hace apuestas a pesar de que aparentemente genera cambios según sus aparatos ideológicos. Los únicos que se ofrecen son cambios cuyo fin es, precisamente, los que siguen consolidando la individualidad en detrimento de la colectividad.

Entonces la filosofía es arma de la educación. Pero no esa arma violenta tomado literalmente del concepto de "arma" como puede pensarse precisamente por los idearios creados alrededor de todo lo que suene a Marx; así también entendió Marx a la filosofía, como esa herramienta para lograr un cambio de cosas. Una verdadera arma que debe mejorarse, evolucionar y ser utilizada para resistir los abatimientos del sistema de cosas. La filosofía debe ser autónoma pero no alejada de las problemáticas, esto lo supo teorizar muy bien desde joven Marx, si no lo es pasaría como un sistema más, pasaría a ser ideología en el sentido más negativo, sería negación.

Si generar pensamiento filosófico se basa en buscar la verdad, la esencia de las cosas, si es investigación de fenómenos que afectan a los seres humanos y a su entorno inclusive; si es preguntar; lo marxiano cumple con estas expectativas sin necesidad de encartonarlo. Aun así, lo marxiano no pretende ser sistema, no así quizás algunas vertientes marxistas rotuladas. Lo marxiano se erige como antisistema pero leído en clave dialéctica. Es decir, lo marxiano es un no sistema que estudia un sistema, y que a la vez propone una sistematización para mostrar las desventajas de un sistema de cosas basado en la explotación de la vida.

En 1843, siguiendo su contexto inmediato sobre la situación alemana, escribe en la Introducción a la Crítica de la filosofía del derecho de Hegel: (...) "la cabeza ${ }^{30}$ de esta emancipación es la filosofía; su corazón, el proletariado. La filosofía solo llegará a realizarse mediante la abolición del proletariado, el cual no podrá abolirse sin la realización de la filosofía" (Marx, 1982b-4, p. 502) ${ }^{31}$. Si bien aquello parte de su contexto, en su obra futura, esto se vislumbrará para el resto de lugares donde esté el sector de los trabajadores o los sectores que estén llamados a liderar procesos revolucionarios.

Marx no inventó ni quiso inventar ningún sistema; aunque "de modo, pues, que entenderemos por «sistema» de Marx su teoría de la historia y, en especial, su teoría del capitalismo” así lo dice Silva (2009, p. 174).

Otra concepción marxiana para desmontar los dogmas sobre la realidad humana terrenal es, el apunte sobre la religión como "opio del pueblo" en su Kritik des hegelschen Staatsrechts de 1843, [Crítica del derecho del Estado de Hegel] (Marx, 1982). Texto publicado en 1844, en Deutsch-Französischen Jahrbücher ${ }^{32}$.

\footnotetext{
${ }^{30}$ En otras traducciones al castellano se da como cerebro.

${ }^{31}$ Der Kopf dieser Emanzipation ist die Philosophie, ihr Herz das Proletariat. Die Philosophie kann sich nich verwirklichen ohne die Aufhebung des Proletariats, das Proletariat kann sich nicht aufheben ohne die Verwirklichung der Philosophie.

${ }^{32}$ Das religiöse Elend ist in einem der Ausdruck des wirklichen Elendes und in einem die Protestation gegen das wirkliche Elend. Die Religion ist der Seufzer der bedrängten Kreatur, das Gemüth einer herzlosen Welt, wie sie der Geist geistloser Zustände ist. Sie ist das Opium des Volks. Die Aufhebung der Religion als des illusorischen Glücks des Volkes ist die Forderung seines wirklichen Glücks. Die Forderung, die Illusionen über seinen Zustand aufzugeben, ist die Forderung, einen Zustand aufzugeben, der der Illusionen bedarf. Die Kritik der Religion ist also im Keim die Kritik des Jammertales, dessen Heiligenschein die Religion ist. [Karl Marx, Einleitung zuZur Kritik der Hegelschen Rechtsphilosophie; in:Deutsch-Französische Jahrbücher 1844, S. 71f, zitiert nach MEW, Bd. 1, S. 378-379]. Marxists Archive.
} 
Este apunte tan abierto y mal interpretado solo busca exponer la necesidad de ocuparse de las cosas terrenales, pues en la tierra es donde se sufre y donde deben darse los cambios. La idea religiosa del más allá solo sirve como dogma y tiene un doble sentido, una funcionalidad en las clases dominantes. Lo que con Guzmán podemos llamar, "la toma del cielo por asalto" (2017, p. 170).

Antes de Marx, varios pensadores se encargaron del caso desde la Grecia clásica hasta Voltaire y Feuerbach. La lucha contra el sufrimiento debe darse en la tierra. Superar este estado debe ser uno de los frentes del pensamiento filosófico, es decir criticar este tipo de aseveraciones preñadas de ilusionismo pero que tiene un fuerte contenido de supeditación; no es un simple asunto de creencias religiosas.

Hacer una revolución filosófica es hacer una revolución educativa. Al tiempo, hacer una revolución educativa es hacer una revolución filosófica. Es precisamente aquel grado de exigencia praxiológica lo que puede incomodar los tradicionalismos "filoso-cráticos". De hecho, la reacción de incomodar es precisamente lo que puede producir una dialéctica para que puedan darse los procesos materiales que conlleven a una aproximación al empoderamiento de la filosofía como herramienta crítica, cuidando en no llegar a los extremismos pues pasaría de ser filosofía a convertirse, como ya se dijo, en ideología.

Una filosofía no alienante, que no sea un producto más del mercado, de las necesidades banales; ha de ser una filosofía de la praxis. Empero, no se trata de elevar una lectura donde se asuma al marxismo, ni siquiera a lo marxiano como una filosofía en el sentido tradicional de los gentilicios. Solo saber que la filosofía es una como uno es el pensamiento marxiano, simplemente que ha de echarse mano de las observaciones marxianas para establecer puntos de análisis al caso educativo.

Sus luchas conceptuales y encarnizadas contra defensores del sistema capitalista, contra los de la vieja guardia feudal, contra los sectores religiosos, y contra los mismos socialistas utópicos, eran luchas contra concepciones del mundo y de la ciencia, contra la anticiencia que había que abolir si se quería progresar en el colectivo e individual sentido de la palabra.

Reconocer en todas las cosas materiales e inmateriales productos de la sociedad humana, para su beneficio sin que nadie reclame por ellas como propiedad, libres de ideologías alienantes o pretensiones de adquisición, será algo sin precedentes en la historia de la filosofía. La producción humana es para toda la humanidad. La naturaleza ha de ser transformada por el hombre, sus beneficios distribuidos con equidad y sin lucro.

El contexto de pensamiento teutón calará fijamente en Marx como se afirmó líenas muy atrás; las priemras experiencias de las inclemencias del sistema capitalista los vió y los vivió en su tierra natal. ¿Cómo pensar a la filosofía de vertiente alemana con carácter revolucionario? Bueno, la vertiente de la izquierda hegeliana logró que un Marx inquieto por lo social se definiera. La filosofía alemana es la que dará muchos elementos conceptuales, precisamente por los trabajos allí realizados. Las observaciones que señalan al Marx de eurocéntrico extremo ${ }^{33}$, puede revisarse, sin llegar a negar las particularidades sobre esto; en su momento

\footnotetext{
${ }^{33}$ No hay registro fehaciente que demuestre un rechazo contundente de Marx a otras etnias; reclamaba más las formas de ver al mundo por parte de algunos pueblos, que por su origen histórico ${ }^{33}$ pues sabía que la lógica de la dominación ocasionaba atraso en los pueblos sometidos. A los reclamos se suman sus posiciones sobre la necesidad de pasar por etapas dolorosas para tomar conciencia, cabe la posibilidad de que no las anhelara como tal, sino científicamente hablando, aseguraba que eran necesarias para la posibilidad material de cambios como los casos de México (Marx-Engels, 1972), o la rebelión necesaria de la expoliada India en Futuros resultados de la dominación británica en la India (Marx, 1976 a3) o en China; dio una lectura que precisa cuidado a la hora de tratarse los casos.
} 
escribe refiriéndose al papel de la filosofía como camino revolucionario que: "la emancipación del alemán es la emancipación del hombre" (Marx, 1982b-4, p. 502); aunque esta cita puede tomarse de varias maneras fíjese que se habla de emancipación de la humanidad. Silva (2009), hablando del tema y su relación con lo ideológico en términos de civilización, la colonización y el mercado, nos aclara que:

Puede observarse en ambos planteamientos la reafirmación de la visión eurocentrista que los fundadores del marxismo habían ido superando en sus últimos escritos, así como la falta de conocimiento de la diversidad de culturas y de situaciones que se presentaban en las distintas colonias. (P. 248)

Se comprobará que lo marxiano no será aplicable a esas sociedades, las cuales, gracias al desarrollo sofisticado, se pensaba serían a la vanguardia. No. La teoría directa de Marx fallará en la predicción. Serán otros contornos los que prestarán oído a sus obras.

Volviendo al asunto central del pensamiento filosófico como "arma" (Waffe) del cambio, la denuncia marxiana tocará el que hacer filosófico. La filosofía entendida como producción de la clase burguesa, ha de ser repelida. Ahora la filosofía debía llegar a las clases protagonistas. Esto último será algo desafiante para el academicismo de la época.

Había que dar el vuelco. Solo baste con ver los casos de Hobbes, Locke o Descartes en sus abordajes de la realidad política o de los temas sociales; claro, ellos también estaban en función de su tiempo que es el determinado por el sistema imperante. Engels decía:

Ahora bien, durante este largo período, desde Descartes hasta Hegel y desde Hobbes hasta Feuerbach, los filósofos no avanzaban impulsados solamente, como ellos creían, por la fuerza del pensamiento puro. Al contrario. Lo que en la realidad les impulsaba eran, precisamente, los progresos formidables y cada vez más raudos de las Ciencias Naturales y de la industria. (Engels, 1986, p. 19)

Gran aporte fue la versión hegeliana de la realidad y la dialéctica aplicada al trabajo; sin embargo, todavía estaba limitada a una extrema idealización y una obediencia al statu quo. Gran misión fue utilizar los aportes del idealismo para emprender el compromiso político de la nueva forma de hacer filosofía. Poner pies abajo a Hegel ${ }^{34}$ no es solo una manera metafórica o anecdótica, pues partirá de la necesidad de "terrenalizar" al pensamiento filosófico; la dialéctica hegeliana se invierte, esto se verá en la teoría de la historia. Marx defendía su propuesta contra las versiones tradicionalistas al decir que, "totalmente al contrario de lo que ocurre en la filosofía alemana, que desciende del cielo sobre la tierra, aquí se asciende de la tierra al cielo" (Marx, 2012b, p. 205).

No es que Marx sea un "antifilósofo" en el sentido estricto, solo es un contradictor de aquella forma que pretende hacer filosofía sin abordar las realidades materiales. Esto hace parte de lo que desde Dussel (1998) se plantea como un desconocimiento que se ha elaborado de Marx, pero sobre todo de su enfoque en materia de filosofía. Infortunadamente, efecto de la reacción de los sectores conservadores y capitalistas del siglo $\mathrm{XX}$, por un lado, y con el descuido y la ortodoxia del otro, la recuperación del legado filosófico de Marx se presentó en pocos escenarios.

\footnotetext{
${ }^{34}$ En carta a Engels de 1858, Marx expresó: «epígonos mediocres que ponen cátedra en la Alemania culta» dieron en arremeter contra Hegel, tratándolo como «perro muerto», lo que le decidió a declararse abiertamente discípulo de aquel gran pensador: sólo sería necesario «volverlo del revés». En, http://www.marxistsfr.org/espanol/m-e/cartas/index.htm
} 
Si la filosofía ha servido para interpretar, ahora debe transformar ${ }^{35}$. Esto recuerda la onceava tesis sobre Feuerbach. Así el verdadero papel de la filosofía ya libre del ingrediente hegemónico podría alimentar los ímpetus de la clase obrera. Había que comenzar por la dimensión física, es decir comprender que el ser humano es materialidad y como tal es agotable. Lo único que tiene para enfrentarse a la naturaleza es su capacidad racional para intervenirla, transformarla; pero con el nuevo sistema no hay sino el camino de la venta de su fuerza de trabajo que le es arrebatada a través de la transacción desalmada en pro de la producción de cosas y servicios para que éstas, a su vez, sean consumidas por ellos mismos dando su porte grandioso a la generación de riqueza la cual se acumulará en pocas manos.

El camino a seguir propuesto en lo marxiano es la dialéctica en su versión materialista, no pensada antes para el conocimiento (Mao Tse Tung ,1968). Esta sugerencia metódica establecerá la ruta de comprensión de los fenómenos a la vez que relacionar las propuestas materiales de cambio de una manera conjunta. Es esa dialéctica que recuerda Engels (1976c-6) cuando haciendo parangón con la industria empujada por la burguesía, lo cual llevaría al derrumbe del régimen feudal, decía: "esta filosofía dialéctica acababa con todas las ideas de una verdad absoluta y definitiva y de estados absolutos" (P. 359); es decir la misma búsqueda de la raíz de las cosas que afectaban a la clase obrera, vulnerable teniendo en cuenta la no estática que pretendía argumentarse desde el horizonte burgués.

De Hegel tomó de éste la negación de la historia. Su adhesión a la izquierda hegeliana le traería situaciones problemáticas con las autoridades académicas y las visiones de filosofía de su contexto. Marx toma la negación y la encarna en la clase trabajadora; para él la burguesía será negada por el proletariado. Esta nueva clase tendrá la responsabilidad de derrocar al sistema burgués, negándolo al abolir la explotación del hombre por el hombre. La praxis ha de ser el medio por el cual se llegue a esa conciliación final, o sea la tercera etapa de la dialéctica hegeliana, donde se establezca la nueva sociedad sin clases; en fin, esta es la propuesta hipotética de Marx. Si bien esto no se cumplió, la comprensión del tema y su carácter de actualización no se agota en esta instancia.

La dialéctica del amo y el esclavo hegeliana, va a ejercer una influencia en la teoría de Marx. El proletariado será quien revolucione la historia humana a su favor, ella dará el carácter social. Pero para alcanzar esto, han de darse las condiciones necesarias.

La filosofía marxiana es llamada para algunos, materialismo histórico. Es tal, por encargarse de las cosas concretas de la historia como consecuencia de eventos materiales producidos por seres humanos y no por conciencias abstractas. Se acude al estudio de la historia para concientizar a los trabajadores. Una filosofía de la historia convocará a la toma de posición para asumir los cambios; una filosofía de la historia, por ejemplo, de la escuela, del conocimiento y de la ciencia conllevará a concluir que estos ámbitos han estado a la orden de las clases dominantes que han ostentado el poder público dentro de los países. Pensar la materialidad de la escuela y del conocimiento desde la perspectiva marxiana es pensarla con criticidad para asumir los cambios que han de generarse. Es por eso que el estudio de la historia de la educación es un deber de todos los actores de la escuela en sus diferentes niveles, pero el reto es sobre todo de los sectores menos favorecidos.

\footnotetext{
${ }^{35}$ De esta célebre frase se desprenden críticas y apoyos. Al parecer todo se desprende de la edición de Engels y la transcripción a otros idiomas. Lo real es que Marx no desconoce el papel de la interpretación, sino que el centro de interés pareciera que fuera solo eso.
} 
Entre los escritos se encontraban posturas sustentadas en hechos, así como en formas de tratar la realidad. Para la muestra un apunte: "Los Manuscritos Parisinos presentan un lenguaje esencialmente radical, hay que devolverle a los hombres lo que les ha sido expropiados, esto es su fuerza de trabajo y su propiedad" (Guzmán, 2017, p. 176). Podríamos decir, es ahora devolverle a los actores de base de la educación, su papel histórico, el protagonismo.

La retoma de las categorías alienación y enajenación, las cuales parten de una reflexión muy abstracta, pero con la manifestación material, hará parte de ese arsenal que puede lo marxiano ofrecer para desmontar y reconstruir las impresiones reales del mundo exterior. Hacerse consciente de esas etapas, superándolas se convierte en reto filosófico, en reto mental con la esperanza de ser forma de vida dentro de una sociedad emancipada.

Con Marx, la denuncia filosófica toca primeramente a la misma filosofía. Lo marxiano exige de la filosofía una atención especial a los problemas de la humanidad; exige de ella una teoría válida, que sea histórica, que sea constructo para superar la etapa de la abstracción desembocando en el mar de las posibilidades para repensar la realidad e iniciar la propuesta de cambio. El cerebro sigue siendo la alegoría al pensamiento para afrontar las exigencias sociohistóricas, sin este, no puede hablarse de transformación.

\subsubsection{Una pedagogía de la denuncia con la historia}

Una filosofía de la educación que no apunte teórica y praxiológicamente al ámbito de la historia, es un modo más que no supera los discursos reciclables. Un ámbito tan importante para ser olvidado, tan concreto para ser soslayado, ha de otorgársele todo el crédito cuando de transformación social se trata. El compromiso de la educación, es un deber histórico, por ende, las formas de hacer pensamiento alternativo encuentran en este ámbito una fortaleza. La pedagogía desde el socialismo comprendió y fue radical frente a la denuncia, sobre todo para los países de la periferia donde las condiciones materiales eran negativas (Dietrich, 1976).

El acto de conocer es una actividad del sujeto que logra objetivarse y prolongarse dando al proceso educativo una historicidad que lo constituye como tal. El hombre se lo constituye como tal. El hombre se realiza en la construcción de la realidad, es decir, en la construcción histórica. (Gutiérrez, 2002, p. 156)

Otra vez, se trata de tomar dos perfiles sobre un elemento. En esta ocasión, la historia como el suceso ubicado en un espacio de tiempo, tiempo medido y conceptualizado positivamente por el hombre y sus ciencias, para tratar de "facilitar" la comprensión. El otro perfil está constituido en el reconocimiento de la historia en tanto ciencia, como crítica desde lo marxiano.

Los acontecimientos se convierten en historia por quedar plasmados en un espacio temporal, de manera objetiva, y si hay extensión, su tratamiento demanda especialidad. Más solo se les da importancia a los acontecimientos, llegando utilizarlos como legado cuando se imprimen en la memoria colectiva o mediante la intelectualidad orgánica como también lo reseñó Gramsci (1970).

El método dialéctico crea la posibilidad en la constitución de su paradigma de interpretar tanto las sociedades presentes como las pasadas. Así dirá Marx para comprender el pasado basta ver la historia del hombre de hoy, allí está la síntesis dialéctica del pasado. Este método opera de lo abstracto a lo 
concreto y busca dar cuenta analíticamente de un universo determinado. El método marxista de estudio rompe con el materialismo vulgar y con el empirismo clásico. (Guzmán, 2017, p. 167)

Recuérdese la inversión marxiana de la historia que plantea al sistema de Hegel. A éste las ideas eran las que producían la historia. Con lo marxiano, se invierte la relación. La historia, la material, como conjunción de acontecimientos generan a las ideas y no al revés cosa que involucrará a la ideología según Silva (2009).

Si se toca la praxis, se toca la alienación, la cual desde Marx está conectada históricamente con la misma historia, con su materialidad. Musto (2015, citando a Marx, 1965), hace eco al decir que anterior a los Manuscritos, ya había aparecido el concepto alienación de la pluma de Marx. Con certeza, Marx ya había usado el concepto de alienación antes de haber escrito dichos Manuscritos. Sigue acotando de manera literal: "En un texto de Marx publicado en el Deutsch-Französische Jahrbücher (febrero de 1844) escribió" (P. 174) al respecto ${ }^{36}$.

No obstante, la subjetividad hace presencia cuando se decide cuales hechos son válidos para ser rescatados, interpretados y actualizados con la revisión y la crítica. No un tipo de subjetividad científica, sino aquella vigilada por los poderes dominantes. Con esta última apreciación, se puede deducir la manipulación de la historia, la misma historia nos conduce a comprobar -más allá del criterio de científico- que efectivamente es susceptible de manipulación; la ideologización de la historia se ha normalizado, el punto reprochable es la utilización del discurso histórico o el olvido de hacer historia.

La escuela es un campo "históricamente" afectado por los dos extremos: la ideologización o el olvido. De todas maneras, el olvido puede ser intencional del sistema de cosas y no por conciencia u olvido de los individuos pertenecientes a una sociedad, las cuales tiene las riendas del poder y creen que les pertenece.

Reconocendo en Silva (2009), hay que ser cuidadosos a la hora de tocar las categorías de materialismo en su relación con el apelativo de dialéctica.

La noción clave para entender el sistema de Marx es la noción de historia; si teoría es una teoría de la historia, de la evolución de los seres humanos en el curso de su acción para producir su vida. Y esta teoría de la historia fue desarrollada según un método dialéctico, método que jamás fue usado por Marx para explicar «las leyes generales del universo», sino para explicar concretos fenómenos históricos, muy en especial el modo de producción capitalista. (P. 172)

El interés marxiano es un interés por la historia sin este aspecto no sería lo que es, esto le hace especial para una filosofía de la educación de alto impacto. La historia será uno de los elementos que han de fortalecerse para el análisis de la ideología dentro del acontecimiento educativo.

Las observaciones científicas del capitalismo, y de su cotidianidad, logran establecerse en la cabeza de Marx como manifestación real pero que puede ser susceptible de visualizaciones dependiendo del lado ideológico donde se ubique la conciencia y los intereses ideológicos. Las relaciones prácticas se relacionan con el significado de historia desde su novedosa perspectiva materialista; acá la praxis será clave. Entonces puede leerse:

\footnotetext{
36 "Una vez desenmascarada la forma sagrada que representaba la autoalienación del hombre, la primera tarea de la filosofía que se ponga al servicio de la historia, es desenmascarar esa autoalienación bajo sus formas profanas. La crítica del cielo se transforma así en crítica de la tierra, la crítica de la religión en crítica del derecho, la crítica de la teología en crítica de la política." En Karl Marx, Crítica de la filosofía del derecho de Hegel, Buenos Aires: Ediciones Nuevas, 1965, p. 11.
} 
De esta forma, el concepto que unifica y da sentido a la labor teórica y política de Marx es justamente el concepto de praxis. Este concepto es el que permite fundar la concepción materialista de la historia. Y esto es así porque, para Marx, la praxis, es una actividad humana fundamental, en virtud de la cual el hombre produce la realidad histórica y se produce así mismo. (González, 2005, p, 195)

El pathos marxiano se encuentra en la indignación (Feinmann, 2008). Marx pone a la indignación como forma de concientización por más trágica que sea la realidad. Precisamente, el desatamiento de injusticias ha de conducir a la acción para reversar la situación. La historia será el ámbito teórico-práctico para entablar la batalla contra la opresión. La historia da sus veredictos sobre el sufrimiento humano, por esto el ser individual no puede soslayar la trágica e histórica lucha contra el sufrimiento que se desata gracias, entre otras, a la indignación que hace presencia como acontecimiento interno que obedece a factores externos materiales. Entonces, la internalidad se hace material cuando en el colectivo aparece el sentimiento de indignación y lleva a que revolucionen en procura de embatir las estructuras establecidas que parecen perennes pero que no lo son.

Aquí tiene cabida esa interpretación de la historia como lucha de sectores, de clases para utilizar el léxico marxista-marxiano, que han de sobrepasar lo anecdótico, lo historiográfico para dar paso al papel de las fuerzas que ocasionan la historia, a las que debe darse el protagonismo, a ese protagonismo de los colectivos, los cuales al final del caso, son suma de individualidades, de inconformidades frente a situaciones contradictorias. Esto no quiere decir que la historia debe limitarse a esa visión.

El antagonismo de clases fue ocultado de manera tácita por la mayoría de los pensadores modernos. El factor ideológico de apariencia hará compañía a las versiones manipuladas de la historia. Marx va establecer, entre líneas, su caracterización metodológica.

Marx empleaba un método dialéctico. Este consistía en ver la historia humana como lo que efectivamente ha sido: como un Theatrum mundi de la dialéctica, no es ese teatro sospechoso que nos inventan los ideólogos, es el teatro real, sangriento y monstruoso (...). (Silva, 1974, p. 25)

Hay una intención de hacer de la ideología el motor de la historia; precisamente al querer mostrarse únicamente a la historia como resultados abandonando los asuntos materiales (Silva, 2011). Entonces, el grueso del pensamiento marxiano es una explícita denuncia al sistema de cosas establecidas, y que quiere, además, hacerse pasar por algo invariable, inmune a los cambios sobre todo aquellos que puedan desplazar ese mismo sistema de cosas. Ese sistema de cosas promueve la prevalencia de las ocultas relaciones político-económicas sobre el factor humano, tendiendo a mostrar al trabajo forzado como algo ahistórico, inmodificable, únicamente amarrado al "destino".

El trabajo - en tanto fuerza transformadora - ha sido negado ya que es peligroso reconocerlo como elemento fundamental de la historia. La división del trabajo es denunciada en la medida en que discrimina la situación del ser humano, profundiza la enajenación. La división del trabajo es presentada como una normalización histórica, llegándola a poner en exigencia divina; la visión aburguesada no prescinde de esta falacia. $\mathrm{He}$ aquí un ejemplo ilustrativo que puede llegar a ofender a las mentes del común tal como fue en su momento: "Así como el pueblo elegido lleva escrito en la frente que es propiedad de Jehová, la división del trabajo marca con hierro candente al obrero manufacturero, dejándole impresa la señal que lo distingue como propiedad del capital" (Marx, 1984, p. 439) o la analogía entre Dios Padre y Dios Hijo, tal como sucede con el dinero-mercancía, las formas natural y transmutada (Marx, 2013) ${ }^{37}$.

${ }^{37}$ El capital, Tomo I, Vol. 1. Libro primero: el proceso de producción del capital. Trad. de Pedro Scaron. 
La prevalencia de las negatividades de la historia como algo inevitable, han de asumirse estoicamente, ya que no se sabe cuáles pueden ser las consecuencias de un cambio. Solo pueden darse unas ligeras variaciones a través de reformas siempre y cuando no afecten a los sectores que "sabiamente" dirigen las riendas de una comunidad; cambiar un sistema de cosas sería un desafío a la providencia o la misma naturaleza humana. Por lo menos, aquello puede identificarse en las versiones sobre la historia como algo incambiable, y menos si es para asumirla como transformación.

La idea de vivir el presente aprendiendo del pasado, pero insistiendo en fortalecer el presente para prever el futuro, es inadmisible si no tiene la visión de progresividad sistémica que propone el capitalismo. Evitar la relegación de una historia crítica y propositiva en una misión de una filosofía de la educación; las prácticas dentro de la educación y sus extensiones inmediatas han de retomar a la historia como oportunidad y no como un simple campo de estudio que tiende a la repetición o a lo acrítico.

La denuncia no puede quedarse en simple reclamo. Desde lo marxiano es fundamental avanzar hacia la propuesta. Por ejemplo, la denuncia de la situación material de la escuela, es una denuncia que debe ser revisada para descubrir la real situación, construyendo una criticidad se ayudará a transformar la situación negativa; no puede y mucho menos debe quedarse en la simple observación. Hay que actuar. No puede quedarse en la necesaria, pero simple denuncia. Tampoco se trata de desechar los mínimos académicos, la rigurosidad con que debe tratarse a la historia; hay que rescatarla como ciencia aportante y vivencia del cotidiano, como aquello que puede ayudar a identificarnos como sujetos de transformación.

Para Marx su realidad es una constante enseñanza y un aliciente para seguir en la búsqueda de generar herramientas de comprensión para la clase menos favorecida que a su vez estaba alienada en sus imaginarios, enajenada en su trabajo material. En Marx (1975): “el desarrollo de las contradicciones de una forma histórica de producción, no obstante, es el único camino histórico que lleva a la disolución y transformación de la misma” (P. 594).

Puede decirse que en y con Marx existe una denuncia teórica contra el sistema de cosas. Pero no solo una denuncia teórica sino una pedagogía de la denuncia social que a su vez servirá como sendero para avizorar el resto de situaciones otorgando elementos para dirigir las otras denuncias futuras, esas situaciones que no han cambiado mucho en doscientos años solo que se acentuado más en la periferia de la comunidad planetaria.

Ahora bien, existe un doble sentido de la denuncia marxiana: el primero, su obra es una denuncia, sin lugar a dudas una denuncia basada en la reflexión y la actitud científica, en la observación y vivencia de los seres humanos, en su sufrimiento, no solo especulación o abstracción o en simples deducciones. El segundo, hay una oportunidad dentro de las mismas contradicciones, las cuales no pueden desperdiciarse.

La pedagogía de la denuncia establece la influencia de aquellas fuerzas creadas por los humanos de carne y hueso sobre su alrededor, en el caso primario del contexto histórico de Marx, en la economía por solo citar un ejemplo, se denotan la supremacía de los intereses de clase para aumentar la ganancia a expensas del tiempo de los trabajadores, de su irrecuperable mortalidad.

Conforme a lo anterior, se tratará de mostrar la denuncia marxiana en algunos aspectos y/o espacios que de alguna manera u otra afectarán un análisis que quiera hacerse de la educación como acontecimiento histórico y campo de acción de la aplicación de las mismas versiones de historia. 
La filosofía marxiana -permítaseme decirlo así- es un medio que escudriña y difunde las contradicciones del sistema de mercado y su influencia en procesos como la educación. Además, impacta de manera cuestionable la cotidianidad del sujeto. En los tiempos de Marx la situación social permitía sustentar todo el andamio crítico, en los tiempos del siglo XXI las condiciones son similares donde hasta el tecnócrata economicista Piketty (2014) con su postura controversial lo reconoce.

Con Marx se nota la dialéctica de la historia en diversidad de puntos para analizar. Cuando se mira a la historia como construcción humana frente al idealismo, se puede encontrar también que las ideas salidas de la materialidad influyen en el devenir. La postura que pone al hombre como centro y no a la Providencia, se redondea con un antropocentrismo marxiano.

La denuncia de la supuesta objetividad de la historia junto a la observación que hace sobre quienes hacen historia, así de cómo tomar postura frente a las exigencias de la historia; todo hace que la crítica a la historia sea uno de los desarrollos más destacados de lo marxiano.

La historia es esa dimensión que en lo marxiano justifica la praxis revolucionaria. En términos de la filosofía de la educación, es un ámbito extenso el cual merece ser explorado a profundidad para establecer relaciones. La materialidad que aplica la visión marxiana a todos los procesos de la mortalidad humana y sus instituciones, contiene la trama de relaciones sociales.

Hablar de historia es hablar de mortalidad, de un momento dentro de una línea de tiempo. Es decir, de esa estadía en el mundo que conocemos a través de los cinco sentidos y que percibimos con la mente también. En carta de Engels a Eduard Bernstein (1883), comunica aquel: "de igual manera que Darwin descubrió la ley de la evolución de la naturaleza orgánica, Marx descubrió la ley de la evolución de la historia humana (P. 115); aunque esta postura ha despertado valiosas polémicas, puede decirse que la abstracción de la materialidad, de la finitud toma relevancia, por ello es necesario dar paso a la transformación de las condiciones para aprovechar positivamente la estadía en el mundo sensible.

La propuesta marxiana de repensar, de pensarse desde la materialidad, arrojará una serie de preguntas relacionadas con la historia. La historia venía concentrándose en los hechos narrados por sujetos con sentimiento y pasiones propias de los seres humanos. Sujetos inmersos en una realidad y con una forma de pensar definida por su propio contexto, por la influencia ideológica. Marx desata un punto de opinión frente a la clásica forma de ver y contar la historia en su materialidad aplicada.

Abbagnano en 1964, ya señalaba que, "al idealismo de Hegel que, a partir de la idea tiende a justificar post factum toda la realidad Marx opone una filosofía que, a partir del hombre, tiende a transformar activamente la realidad misma" (P. 501). Su trabajo dedicará análisis a los hechos, a sus reales orígenes, muchas veces económicos, pero sobre todo a develar el carácter no tan objetivo que tiene la historia. El hegelianismo será revisado, sus aportes serán grandes, pero la retoma de Marx de la subjetividad será la pauta esencial.

En términos epistémicos, lo marxiano hace un encaramiento del dilema del conocimiento y la llamada comprensión objetiva; Bauman (2002) aporta una perspectiva de comprensión como actividad de la historia en Marx:

El rechazo de toda manera contemplativa de objetivar el conocimiento, al considerar el camino conducente al conocimiento objetivo como algo que implica la transformación en historia tanto del sujeto cognitivo como del mundo, o que conduce a la anulación de la oposición misma de sujeto y objeto (oposición que no está en la naturaleza de la existencia, sino que es atributo de una existencia alienada). (P. 49) 
Pensar al hombre y para el hombre, su papel en el devenir y en protagonista de los hechos en tanto causante u oprimido, dará pie a generar debate para establecer no solo crítica sino propuesta que se enfocará en el marco social, político y por supuesto, económico. Por esto, en su extensión, "la teoría de Marx realizó en la historia de la pedagogía una transformación radical y entre otros motivos porque opuso a la concepción metafísica del hombre la concepción histórica" (Suchodolski, 1977, p. 320)

Desde esta perspectiva se fortalece el tratamiento teórico de los problemas con su manifestación y desarrollo histórico y el cómo se imbrican en el análisis. No hay en Marx, por tanto, una preeminencia de un método lógico (cualquier cosa que esto signifique) por sobre un método histórico, problema que ha propiciado un intenso y extenso debate entre los marxólogos. (Osorio, 2004, p. 68)

Su concepción sobre la historia es renovadora del materialismo aplicado, conectándolo con el apelativo humanidad; tanto él como Hegel son creyentes de una fórmula racional que puede sintetizar la evolución de la humanidad (Russell, 2009); pero también para Russell, la filosofía de la historia en Marx, es una mezcla de Hegel y economía inglesa. En lo marxiano existe una clara relación entre su visión de materialismo y el materialismo dado en la historia del pensamiento. Esto es clave para explorar el terreno de la propuesta marxiana.

Para comprender la vinculación existente entre materialismo de Marx y el materialismo filosófico en general es esencial también el problema tradicional referente al sentido de la historia y del mundo. La dialéctica materialista es no teleológica. Por más extraño que esto pueda sonar de entrada. Para ella la historia no es un conjunto caótico de hechos como para Shopenhauer, ni una estructura de sentido espiritual y unitaria como para Hegel. Marx no hipostasía panteísticamente la historia. (Schmidt, 1977, p. 31)

La aparente simpleza de la lucha de clases como motor presente en la historia, se complejiza al encontrar vestigios en las etapas históricas que son contadas o registradas independiente de autores, posturas o hechos. El materialismo histórico, como posteriormente ha de llamarse (Cardona Castro, 2002) desde la postura de Plejanov (1946) con todo y sus polémicas, sobrepasa la interpretación marxista de la lucha de clases o del hombre como protagonista de su devenir, como autor de su historicidad. Las concepciones que parten de una visión histórica marxiana son, por lo tanto, también posturas críticas y propositivas. De hecho, tienen que verse como alternativa pedagógica y hasta didáctica.

La lectura dialéctica de los hechos de esos fenómenos sociales que llamaremos historia, es una opción que puede aportar a la construcción de un conocimiento abierto, no hegemónico. El ejemplo en Marx y Engels, es muestra de aquella visión que, recordando los clásicos criterios, ponen en duda, pidiendo una exhaustiva revisión de los hechos, de sus causas materiales y claro, de una interpretación adecuada que conlleve a una toma de posición la cual conduzca a la reflexión pero sobre todo a la acción concreta para transformar la realidad indiciada. He aquí una alusión competente relacionante sobre la particularidad del marxismo al separarse de uno de sus supuestos fundamentos histórico-filosóficos:

Si pasamos de la naturaleza a la sociedad, advertimos una variación igualmente amplia en las perspectivas históricas, las concepciones sociales y los códigos morales de las escuelas materialistas. Aunque las escuelas antiguas y modernas se apoyan en una concepción materialista del mundo y del lugar que el hombre ocupa en éste, la orientación social de los epicúreos, por ejemplo, era totalmente opuesta al marxismo. Los epicúreos predicaban la sumisión a la naturaleza, el desapego de los problemas del mundo y de la lucha política, la práctica de la contemplación. Predominaba en ellos lo pasivo, lo restrictivo, lo pesimista. Contrario a esta filosofía de la resignación, el materialismo dialectico adopta una posición agresiva frente a la naturaleza, y exige su alteración progresiva en función del bienestar humano; es revolucionario en su intervención en las cuestiones sociales y 
políticas; coloca la actividad práctica por encima de la contemplación teórica. Su actitud es enérgica, expansiva, optimista y siempre constructiva. (Novack, 1977, p. 24)

Marx parte la historia de la filosofía por su carácter histórico. Si la filosofía aparece en la antigüedad griega, como tradicionalmente se afirma, con la apertura del continente de la matemática; transformada en la modernidad cartesiana por la apertura de la dimensión de la física; así pues, desde Marx la filosofía es revolucionada con la apertura del continente historia tal cual afirman Althusser \& Balibar (1974), entonces todo ello concatena con la aspiración histórica de llegar a una instancia de comprensión de la historia, prescindiendo de la visión historicista vertical, provocando el inicio de una toma de conciencia transformadora, dinámica y consecuente. Aunque, para Mondolfo, referenciando los antecedentes de pensamiento, expone que: "la transición de Feuerbach a Marx es, en opinión del propio Marx y de Engels, transición del naturalismo al historicismo" (Mondolfo, 1936, p. 85).

La filosofía es producto de la misma historia, de la mano de ella están los cambios y es producto de cambio, más solo se extiende a su importancia y urgencia, al momento en que empieza a reconocerse que es otro instrumento histórico de ideologización de sectores dominantes y pasa a establecerse como herramienta crítica, como instrumento propositivo, como está en Marcuse (1993) y sobre todo en Althusser (1971), como arma de la revolución, revolución que tiene varios sentidos, pero en términos de la educación, en una revolución profunda que haga temblar las bases de la postura tradicional burguesa y oligárquica sobre todo en su mimetismo social.

Proponer una lectura nueva de la realidad, ahora desde una lectura distinta de los hechos con sus relaciones, es un acto político y pedagógico en la medida en que se muestran las herramientas para hacerlo de la manera más acertada. “Así, cuando Marx reemplaza, en la teoría de la historia, la vieja pareja individuo-esencia humana por nuevos conceptos (fuerzas de producción, relaciones de producción, etc.), propone, de hecho, al mismo tiempo, una nueva concepción de la "filosofía" (Althusser \& Balibar, 1974, p. 189), y con ella la apertura para formas de pensar el mundo real, de ese que es percibido, sufrido por los sentidos.

A partir de lo marxiano, la historia no será mirada de la misma forma. El desmonte de los romanticismos y las versiones oficiales serán blanco de todo tipo de observaciones, sobre todo las críticas que a posteriori se hacen del supuesto establecimiento de leyes inmóviles sobre la historia que se le adjudican a Marx, llegándolo a catalogar de manera eufemística como profeta. Si bien existen puntos clave para entender y teorizar sobre la historia, como lo es la relación de producción - sociedad, no puede decirse que en definitiva lo marxiano llega al punto teleológico que precisamente denunció por ser una perspectiva maleable, ideologizada por los sectores dominantes y fácil de manipular.

La impostura marxiana toma muy en cuenta la idea un cambio sustancial. Aquí otra vez, pueden recibirse observaciones debido a la forma marxiana de ver al mundo. Marx no acepta dicha perspectiva, su interés, su afán es mostrar el carácter científico de todo su campo de pensamiento. Se evidencia la ruptura epistemológica con la forma tradicional de entender la historia como un absoluto, como una dimensión inmóvil e inmodificable.

Esta "ruptura epistemológica" concierne, al mismo tiempo, a dos disciplinas teóricas diferentes. Fundando la teoría de la historia (materialismo histórico), Marx, en un solo y mismo movimiento, rompió con su conciencia filosófica ideológica anterior y fundó una nueva filosofía (materialismo dialéctico). (Althusser, 1974, p. 24)

La historia tiene una conciencia, pero no una conciencia abstracta, sino material. Conciencia generada y que ha de generarse en el propio ser humano y su entorno social. Engels, constata que: 
Los hombres hacen su historia, cualesquiera que sean los rumbos de ésta, al perseguir cada cual sus fines propios con la conciencia y la voluntad de lo que hacen; y la resultante de estas numerosas voluntades, proyectadas en diversas direcciones, y de su múltiple influencia sobre el mundo exterior, es precisamente la historia. (1986, p. 47)

Entonces, no se prescinde de la conciencia. Acostumbra a creerse en la idea equivoca de lo contrario. Aunque la concepción de conciencia desde lo marxiano, permite repensar el papel de la conciencia como producto de la materialidad. Así también, la materialidad produciendo conciencia. Pero una conciencia tangible que debe hacerse evidente en las transformaciones que procuren reconocer la necesidad de cambios estructurales. Es por ello que la conciencia histórica va ligada al grado de responsabilidad de los sujetos que hacen parte del colectivo. Si bien es cierto que la misma categoría de conciencia ha de relacionase con una dimensión, quizás metafísica, precisamente el aporte extendido de lo marxiano es reconocer a esta conciencia en tanto protagonista de los cambios o por lo menos de la reflexión crítica; podría decirse que la historia también es la historia de las conciencias, de las conciencias en sus efectos.

La crítica a la conciencia o mejor, a su manipulación, es histórica como también lo aprueba Silva (1979). Historia y conciencia no se desconocen; su relación está presente en la propuesta marxiana. Descartar dicha argumentación implica, o bien desconocer la obra marxiana que es constructo social de un nuevo ambiente de pensamiento u ocultar intencionalmente las herramientas metodológicas presentes que puedan contrarrestar la predominancia de un sistema univoco. Esto recuerda la conocida disparidad entre la conciencia filosófica entablada en Hegel y la vertiente sobre este concepto recibida por Marx, la cual fuera modificada por este último al despojarla de su manto extremadamente abstracto e idealista. La "ruptura" en Marx se presenta en la medida en que avanza de una postura sobre la conciencia filosófica hacia una teórica; en otras palabras, del abandono de una conciencia ideológica (Althusser, 1974) para encontrar caminos científicos que coadyuven a su explicación.

Al tratar sobre conciencia de clase, por decir, tiende esto a la búsqueda de un papel en la historia. Solo y solo si hay un apersonamiento individual y colectivo de conciencia de clase, de aceptación por desarrollar un papel transformador, se logrará entender lo descrito por Marx. "No es la objetividad misma, sino su forma alienada, el mayor obstáculo en el camino hacia la plena y libre autoconciencia" (Bauman, 2002, p. 49).

Si la historia del hombre -ahora léase también: de la mujer-, ha girado en torno a la lucha de clases; la historia de la escuela y de todos sus fenómenos correlacionados no se sustraen de tal proposición. Solo basta echar un vistazo a la historia de la educación en sus diversas formas, espacios y cronologías para constatar las diversas manifestaciones de conflicto subyacentes, situaciones no ajenas a las generalidades presentadas por la tensión entre poderes de distintas índoles. La pugna por el poder tendrá siempre como objetivo, la imposición de un determinado modelo para ser aplicado en los procesos formales -e incluso informarles- de la educación.

La visión marxiana de la historia, ofrece la posibilidad de establecer puntos de quiebre en la comprensión de los fenómenos adoptando una postura crítica. Wallerstein (2007) recomienda reconocer las partes que hacen parte del todo; "historizar no es lo contrario de sistematizar (...) Todos los sistemas son históricos y toda historia es sistemática" (P. 105); por tal motivo no puede quedarse atrás la contextualización de los hechos, la visión en que se plantean estos, así como la visualización general de la que se puede partir para realizar un análisis pertinente para acercarse a los puntos neurálgicos que son centro de la propuesta crítica. 
En Marx (1979), "las revoluciones son las locomotoras de la historia" (P. 116). Valga aclarar, de esa historia vista con la lupa del materialismo que le caracteriza. Si las revoluciones son las locomotoras, los vagones contienen, en su orden, la conflictividad dialéctica propia de cada época y sociedad. Dichos vagones, están unidos, no estarían en movimiento sin esas locomotoras, indistintamente de sus colores son representación de esas vivencias materiales además interpretadas, es decir que pasan por diversas fronteras, alcabalas o estaciones, para ser abordadas por pasajeros ansiosos de llegar a sus destinos; revisados por autoridades con diferentes credenciales y cánones; o simplemente cargados y descargados con elementos ideológicos. Las locomotoras llevan y cumplen su rol. Este análisis, prevé la concepción sobre la cual reposa el protagonismo de la organización social en la consecución de las metas planteadas o en el mismo fracaso de un programa proclive al cambio.

Lo marxiano permite un estudio crítico del origen del pensamiento más allá de las convenciones tradicionales y las latitudes. Por ejemplo, en Hegel hay un "demiurgo", sí, la idea es un tipo de demiurgo ideal de la realidad, de él parte todo lo exterior o mejor: es su manifestación. En cambio, en Mariátegui (1959), siguiendo a Marx, todo surge del cerebro humano, todo lo material.

La naturaleza no construye máquinas, ni locomotoras, ferrocarriles, electric telegraphs, selfacting muebles, etc.. Son éstos, productos de la industria humana; material natural, transformado en órganos de la voluntad humana sobre la naturaleza o de su actuación en la naturaleza. Son órganos del cerebro humano creados por la mano humana: fuerza objetivada del conocimiento. El desarrollo del capital fixe $^{38}$ revela hasta qué punto el conocimiento o knowledge social general se ha convertido en fuerza productiva inmediata, y, por lo tanto, hasta qué punto las condiciones del proceso de la vida social misma han entrado bajo los controles del general intellect y remodeladas conforme al mismo. Hasta qué punto las fuerzas productivas sociales son producidas no sólo en la forma de conocimiento, sino como órganos inmediatos de la práctica social, del proceso vital social. (Marx, 2006, p. 229)

Parecería existir una dicotomía entre naturaleza en el sentido externo del término frente a la humanidad. Pero mirando bien, no existe la última sin la existencia de la primera, sin sus dictámenes. El asunto es que, debe acondicionarse el humano a la naturaleza, conocerla y después, transformarla. Pero la cuestión es el desvío y objetivos de dicha transformación, de dicho aprovechamiento. Ahora, no hay tal dicotomía, solo es un proceso dialéctico. El conocimiento se erige como la herramienta material para presentarse a la naturaleza. La naturaleza es histórica en la medida en que ella hace parte de los procesos humanos.

Lo marxiano no es profecía, ni simple ánimo de sublevación. No puede entenderse como teorías irrefutables en el campo de la historia, no sería marxiano. De ahí que los intentos dogmáticos, por un lado; y los señalamientos de profético en lo marxiano, por otro; afectarán considerablemente. Con Marx se trata de reflexionar sobre las relaciones detrás de los hechos y la historia como oportunidad de liberación.

Todavía es certera la invitación althusseriana de: "la práctica teórica marxista de la epistemología, de la historia de las ciencias, de la historia de las ideologías, de la historia de la filosofía, de la historia del arte, debe todavía en gran parte constituirse" (Althusser, 1974, p. 139).

La historia determina las formas de apropiación material y espiritual. Así mismo las historias son determinadas por esas mismas fuerzas productivas cuyo liderazgo reposa en las clases dominantes, en aquellas que prevalecen en tanto defensoras y productoras de un determinado sistema de cosas, las cuales suelen crear su historia. Las relaciones políticas, sociales, económicas y hasta religiosas, dependen del grado de filtración de una postura ideológica sistemáticamente apta, o que se autocataloga apta para dirigir

\footnotetext{
${ }^{38}$ Del francés, fijo.
} 
las riendas del poder. En ese orden, el hombre también se enajena, se aliena según los dictámenes de una determinada sociedad.

\subsubsection{Algunos enfoques críticos relacionados ${ }^{39}$}

No puede dejar de abonarse la extensión de lo marxiano a los esfuerzos teóricos posteriores enrumbadas hacia alternativas de pensamiento en educación, en distintas latitudes. A pesar de la indicación crítica de Broccoli (1980) sobre la dificultad de desligarse de una ideología a la hora de establecer una pedagogía, puede decirse que las formas críticas de los últimos años si han logrado superar la etapa ideologizante, y esto es gracias al mismo fundamento marxiano de dinamismo y transformación. El carácter crítico de algunas corrientes precisamente lo que buscan es ser incentivo para reconocer la necesidad de explorar dimensiones del ser humano y de la sociedad sin renunciar al cambio positivo de garantía social y emancipadora (Kohan, 1998) la cual fluye de la obra marxiana y de sus más dedicados intérpretes.

Lo crítico, que es el examen de la realidad material de sujeto, fuerzas productivas y sociedad, hace parte del contenido marxiano. La crítica engloba lo científico social y la praxis; por ser un ejercicio que exige autonomía y elementos teóricos, se convierte en baluarte de una filosofía de la educación propositiva. En términos históricos, decir que fuera de la órbita soviética, de la ortodoxia oficial y los esfuerzos de corrientes alternativas al dogma, ilustrativo es el caso de la Escuela de Frankfurt (Wiggershaus, 2011). América Latina, especialmente, se convirtió en un campo germinal de las propuestas más centradas en la crítica, en diferentes espacios. La reivindicación de sectores históricamente marginados, la lucha anti imperialista, la inclusión de criterios cristianos y las ideas ancestrales pudieron encontrar en algunos elementos teóricos salidos del marxismo, una herramienta para ser acondicionada a las distintas formas de lucha o acción. El impacto tocó a las ideas que no comulgaban con la educación oficial. Así también lo es la pedagogía crítica cuyo basamento tiene tintes fuertes de lo marxiano.

En la pedagogía crítica, los conceptos de currículo, enseñanza y aprendizaje se concretan en las representaciones de la realidad (cómo es y cómo debería ser) y tienen efectos reales. El discurso sobre el currículo crea una idea social y pragmática del sujeto. El papel de la escuela, especialmente el de la escuela pública, no se interpreta sólo como espacio de reproducción ideológica y social, sino como escenario de investigación y de resistencia contrahegemónica. En este contexto, el saber escolar no soslaya las realidades culturales presentes en el aula, es un espacio de intercambio y de cruce cultural que genera competencia cultural e ideológica y, por tanto, capacidad para afrontar problemas diversos y respuestas alternativas. (Ramírez Bravo, 2008, p. 114)

Lo crítico tomado como examen, en este caso, examen de las relaciones que se encuentran detrás de los fenómenos sociales, los cuales son percibidos por sus efectos materiales en las individualidades y en las colectividades, es un espíritu contenido en los anhelos de los cambios políticos profundos de la sociedad. Lefevbre (1981), aclaraba lo que era la crítica en la cotidianidad:

¿Qué significa criticar a la sociedad? Criticar a una sociedad es mostrar una contradicción entre el modo de existir de la misma, cómo funciona en la realidad, y la forma en que se nos presenta, aparece y justifica a sí misma. En otras palabras: hay un contraste, e incluso una contradicción, entre los valores que ella pretende representar y su realidad. Si yo critico a la sociedad de consumo, mostraré que nos habla de la felicidad, mientras que lo que obtiene es malestar e insatisfacción. Uno crítica a la sociedad

\footnotetext{
${ }^{39}$ Algunos a partes de esta sección fueron publicados como producto de esta exploración investigativa en memorias del 3er Congreso Internacional de Filosofía de la Educación en la UNAM, México DF, en 2015. Con el título de Corrientes alternativas para una filosofía de la educación latinoamericana, en coautoría con el sociólogo y magister Alexander Pereira García.
} 
contrastando los síntomas reales de malestar e insatisfacción, con su justificación ideológica, o formuladora de valores, con su proyecto de felicidad. (Sp.)

En la educación las formas críticas de teorizar y hacer praxis, no dejan de estar ligadas a los problemas tratados por Marx en el siglo XIX. Entonces, el asunto no es que contenidos marxistas o marxianos haya, sino las problemáticas para actuar y hacerles frente. El objetivo de la crítica con lo marxiano es denunciativo y propositivo con miras al compromiso político de cambio. Si se denomina a una postura sobre educación como "crítica", difícilmente estará fuera del análisis abordado por las categorías marxianas y sobre todo por su postura sobre fenómenos sociales. Gran parte de los problemas de antaño, son los mismos o consecuencias del pasado.

La educación es un acto político. Por tal aseveración, se debe ser radical en términos de perseguir los ideales para materializar un proceso más liberador desde los escenarios de la academia. "Ser radical es atacar el problema por la raíz. Y la raíz, para el hombre, es el hombre mismo", decía Marx (2012c, p. 230). Lo radical es desmontar el discurso conservador de un extremo y el reformista líquido por el otro y poner en equilibrio el interés por la emancipación a través de la formación, ya no en masa como quizás se proponía alguna vez desde lo marxiano a propósito de sus metas, sino que individualice socialmente, al tiempo que, de manera dialéctica integre al sujeto su contexto-comunidad y viceversa.

Tal cual se ha repujado, la educación desde la postura crítica es radicalmente opuesta a los modelos que orbitan al capital, a la enajenación, a la alineación; opuesta también a la visión que no se plantea el bienestar y la felicidad del hombre individual, en conjunto y con la naturaleza. La educación pensada desde la crítica tampoco se alinea al extremo de los retazos y "experimentos" que desde algunas tribunas que se declaran alternativas, lo que han hecho es dar más elementos para que el sistema de mercado siga adueñándose en la realidad, de los espacios materiales en detrimento del sentido emancipador pero responsable de la formación humana.

En este aparte se ha de presentar brevemente, un panorama de algunas destacadas aportaciones que, desde la perspectiva sociofilosófica de la educación, se han desarrollado como referentes para la comprensión del fenómeno educativo. En tanto son posiciones alternativas que tienen mucho que decir para la construcción de la reflexión educativa en teoría y praxis al momento de tomar en cuenta a la escuela inmediata, la cual se debate entre las posturas extremas de la tradicionalidad enajenadora, la doble intencionalidad oficial.

\subsubsection{La educación como reproducción social}

Vuelve y juega el Marx de la teoría de la lucha de clases, para nada desligada de la comprensión de la educación desde esta perspectiva. Los apuntes sobre este enfoque, aunque parten de Europa, logran tener un punto de vista aportante en la periferia (Dietrich, 1976). No puede olvidarse lo complicado que es el tema de las clases sociales pensadas y presentadas desde el viejo mundo, a las manifestaciones del hemisferio sur. Elementos de juicio importantes se dan desde esta perspectiva que encabeza Bourdieu (2003). La escalada que enrumbe a una posición social que puede degenerar en competitivismo u olvido de lo social-solidario en el sujeto, solo profundiza las diferencias y hasta reprime pues los anhelos, incluso, están supeditados al tema de accesibilidad por el factor monetario adquisitivo al cual los sectores excluidos no pueden acceder. 
Althusser (2003), describió en su propuesta la reproducción necesaria de las situaciones para que un sistema de cosas se sostenga. Toca desde el trabajo hasta los aparatos ideológicos del Estado, cuyos fines no son otros que reproducir, precisamente, las fuerzas de producción. La principal: la educación como sostenedora de la apariencia. Pero, acá de lo que se trata es de mirar esas formas de reproducción social que aunque construidas teóricamente en Europa, no dejan de tener afinidades para el caso latinoamericano.

Ahora, la dialéctica nos permite ver los cambios de formas en los modelos educativos, pero, curiosamente, también las reales esencias que mutan poco en la medida en que se intencionan para ejercer un control alienante, para legitimar un poder dominante. Marx y Engels en el Manifiesto expresaban, objetando las visiones que les achacaban cosas fuera de las exigencias comunes de una sociedad en antagonismos, que:

Und ist nicht auch Eure Erziehung durch die Gesellschaft bestimmt? Durch die gesellschaftlichen Verhältnisse, innerhalb derer Ihr erzieht, durch die direktere oder indirektere Einmischung der Gesellschaft vermittelst der Schule u. s. w.? Die Kommunisten erfinden nicht die Einwirkung der Gesellschaft auf die Erziehung; sie verändern nur ihren Charakter, sie entreißen die Erziehung dem Einfluß einer herrschenden Klasse. ${ }^{40}$ (Marx-Engels, 2008, pp. 54-55)

Y es que precisamente las clases dominantes de la época señalaban las propuestas analíticas y criticas de Marx como instrumentos de influencia negativa, ideologizante que amenazaba la estabilidad y la "neutralidad" del sistema educativo prevaleciente. Esto no dista mucho de los señalamientos que se hacen a nivel macro y micro a las posturas críticas-propositivas en la praxis educativa por parte de los sectores que defienden la visión del capital y del tradicionalismo contradictorio no sin ser consciente de su papel de gendarme.

El referente de Bourdieu (1986) plantea una perspectiva de la educación acudiendo a los elementos reflexivos de carácter sociológico, donde se evidencia el análisis de los mecanismos de reproducción de las jerarquías características del contexto social.

Hay que ligar el asunto desde sus antecedentes como asunto filosófico; en misiva de Marx (1982) a Feuerbach en el año de 1844, reconocerá aquel, el aporte que luego desenvolverá con su teoría social, con su materialismo dialéctico e histórico. El tema de la sociedad es indispensable, eso lo recoge Marx, y destaca en Feuerbach que, además,

El concebir la unidad del hombre con el hombre, basada en las diferencias reales entre ellos, y el bajar el concepto del género humano del cielo de la abstracción para situarlo en la tierra real, ¿qué es todo eso más que el concepto de la sociedad? (P. 679)

En la obra de Bourdieu se encuentran según Brenger, (2004) extensiones filosóficas, de Wittgenstein, Heidegger y Austin, además de los importantes aportes de Marx, Weber y de la teoría foucaultiana. El sociólogo francés hace énfasis en la mediación simbólica y científica en la vida social y en los mismos procesos de conocimiento. Rojas (2010) afirma que, en Bourdieu, todo conocimiento es mediación simbólica-discursiva. Él trata de explicar las estructuras de dominación, así como la distribución asimétrica de posiciones en el campo social que afecta y es afectado a su vez por la escuela, o mejor, por el sistema educativo en general. De tal modo indica:

\footnotetext{
40 ¿Acaso vuestra propia educación no está también influida por la sociedad, por las condiciones sociales en que se desarrolla, por la intromisión más o menos directa en ella de la sociedad a través de la escuela, etc.? No son precisamente los comunistas los que inventan esa intromisión de la sociedad en la educación; lo que ellos hacen es modificar el carácter que hoy tiene y sustraer la educación a la influencia de la clase dominante.
} 
El origen social define las posibilidades de escolarización, determina modos de vida y de trabajo completamente diferentes y es, entre los factores que intervienen en la configuración de la vida escolar, el único cuya influencia se irradia en todas las direcciones y alcanza todos los aspectos de la vida estudiantil, comenzando por el de las condiciones de existencia. (Bourdieu \& Passeron, 1967; en Gil, 1997, p. 208)

Conceptos claves en la comprensión educativa del francés son los de espacios y capitales (Baranger, 2004). En los espacios está como supuesto lo social (donde se llevan a cabo las relaciones de fuerza), el concepto de campo conforma el espacio que determina la posición y el de habitus está relacionado con lo genético y la conformación del hábito. En cuanto a los capitales, está el capital lingüístico, o legado de la lengua, que marca cercanía con lo académico y tiende a ser hegemónico; el capital cultural, en sus formas o estados y el capital simbólico relacionado directamente con lo económico, lo cultural o lo social (Bourdieu, 1979). En la educación uno de los objetivos de gruesas capas de la población es perseguir y adquirir estos capitales, en otros solo es sostenerlos (Bourdieu, 2003). En la relación educación y clases sociales, la primera no es liberadora para nada.

Y es que, en definitiva, se habla de esa educación que parte del modelo capitalista de producción, que por naturaleza es proclive a reproducir la desigualdad y la competencia desmesurada, es aquí donde aún Marx está vigente, su composición por técnica que parezca o económica que se vislumbre, debe surtir el efecto positivo de ser herramienta para la comprensión crítica. Por todo eso no debe olvidarse la siguiente observación hecha en el tercer libro de El Capital traducida por Roces, donde aparece:

La producción capitalista es siempre, pese a su tacañería, una dilapidadora en lo que se refiere al material humano, del mismo modo que en otro terreno, gracias al método de la distribución de sus productos por medio del comercio y a su régimen de concurrencia, derrocha los recursos materiales y pierde de un lado para la sociedad lo que por otro lado gana para el capitalista individual. (Marx, 1976c, p. 99)

Esta es la denuncia de Bourdieu: "el sistema educativo para nada es liberador. En la escuela y la universidad las clases sociales se hallan muy desigualmente representadas" (Rojas, 2010, p. 301). En Marx encontramos una reseña tipo parábola que refuerza lo que luego sostendrían muchos pensadores como Bourdieu:

Todos estos intentos nos recuerdan a aquel profesor de gimnasia inventor de un método de enseñanza del salto consistente en llevar al alumno hasta una ancha zanja, para hacerle ver allí, por medio de una serie de cuerdas, hasta donde tenía derecho a saltar. No podía saltar el primer día la zanja entera y el profesor iba moviendo las cuerdas, a medida que el alumno se entrenaba. Lo malo es que, en la primera lección el alumno caía al fondo de la zanja, de donde ya no le sacaba nadie. El profesor a que nos referimos era alemán y el alumno se llamaba "libertad". (Marx, 1982, p. 216)

Solo se piensa en la escuela como ese espacio que permite el ascenso social mediante una franca o a veces disfrazada aculturación pero que de todos modos se cree la reproductora irreprochable de la herencia cultural. Sin embargo, únicamente la enseñanza humanista puede romper ese paradigma. La visión republicana de corte liberal y la posición populista de la escuela son rechazadas por considerárseles mitos cargados de ideología que se defienden desde sus respectivas posturas. Bourdieu (1986) es crítico en el tema del acceso efectivo de los sectores más vulnerados a la educación y cuando ésta logra "colarse", sus perspectivas, salvo casos aislados, no pasan del límite de adiestramiento o instrucción básica para los oficios y profesiones medias que sirven de forma directa al sistema productivo.

La escuela no motiva la cooperación, pues lo que predomina es la competencia individualista. Lo que se desprende del reconocimiento de que el capital cultural se hereda, "el origen social actúa tanto en una 
vertiente explícita, a través de información, recursos económicos, recomendaciones, como en otra implícita, pero no por ello menos importante" (Gil, 1997, p. 209), a través de esta última es que se reproducen los comportamientos, modos y hábitos culturales, como una especie de determinación social de los individuos. Sin embargo, Bourdieu no se queda en el fatalismo que genera la situación social, en términos de las relaciones sociales del ámbito educativo.

Uno de los factores más destacados es el elemento lenguaje. Dicho elemento se erige como capital cultural y de aceptación, éste es difícil de adquirir de parte de los niños de bajos recursos económicos y quienes lo pueden adquirir llevan la ventaja. Cabe aclarar que estas sensibilidades son observadas en la Francia de su tiempo, no dista mucho de la realidad de otros hemisferios y épocas más recientes. La teoría en la que se denuncia a la escuela como reproductora ya no únicamente del sistema sino de la desigualdad social que éste proyecta, tiene no muy poco eco al comprender la situación real del fenómeno educativo desde el constructivismo estructuralista.

En ese orden de ideas, el constructivismo estructuralista de Bourdieu (2003), da importancia a la dimensión estética y a sus manifestaciones materiales, lo mismo al cambio y en la misma medida a las apreciaciones que se dan desde las clases sociales. La estética con sus conceptos hace fácil la comprensión de lo que es el placer o la relatividad de lo bello y de lo que es arte.

Bourdieu se interesa en mostrar una sociología de la educación desde la cual rescata indicaciones de Marx sobre el fenómeno. Él también considera, como ya lo había mostrado Marx (1982), que es mejor conocer la verdad de lo real, por severa que esta nos parezca, y no confundirla con nuestros piadosos deseos, pues solo sobre la base de una verdad real es posible una acción inteligente y razonable.

Siguiendo el anterior criterio, hizo distinción entre la verdad de lo científico y los requerimientos prácticos de la acción, junto al análisis del lenguaje como elemento que puede destacar discriminación. Afirma Rojas (2010) que "para Bourdieu es imposible no conocer la realidad socio-educativa, por ello hay que interiorizarse en ella en aras de solucionar esa crisis que es particular y general al mismo tiempo en la mayoría de sociedades actuales" (p. 305). Bourdieu es un referente importante para la comprensión del fenómeno educativo, tanto desde la perspectiva de una filosofía de la educación, como desde el abordaje sociológico que da cuenta de las prácticas inherentes a la educación como campo teórico-práctico de transformación.

Para Rovira (2011), el pensamiento de Bourdieu ha logrado influir de manera importante en América Latina. Autores como García Canclini "se apoyan en la arquitectura heurística bourdieuana para explicar la constitución de una sociedad que está cruzada por procesos de hibridación cultural" (P. 220), lo que permite establecer un ejercicio dialéctico entre apropiación de formas culturales foráneas y su adaptación a la realidad local (Rovira, 2011, p. 220). Ya se ha discutido el problema de la hibridación cultural que representa asumir el conocimiento eurocéntrico en un contexto particular como es el de América Latina, situación que se evidencia de manera significativa en las luchas de la educación por convertirse en un escenario pertinente a las realidades locales, problema que los autores latinoamericanos han resaltado de manera recurrente.

Vale mencionar la existencia de vínculos entre la importante obra de Freire (1974) y el pensamiento de Bourdieu, para este último la educación es dominación simbólica por excelencia, 
.. en una sociedad donde la clase dominante ya no puede invocar los derechos de sangre para transmitir su herencia, ni apelar a la virtud ascética como justificación del éxito, la certificación académica se convierte en el vehículo para justificar y transmitir su dominio. (Burawoy \& Von Holdt, 2012)

La reproducción es entonces, por vía de la educación, el mecanismo para mantener escenarios de poder. La Pedagogía del Oprimido de Freire, publicada en el mismo año de 1970 que la obra La Reproducción de Bourdieu, evidencia un reconocimiento de la postura bourdieuana y una alternativa a esa única posibilidad dominante de lo educativo. Dicen Burawoy \& Von Holdt (2012) que, si bien ninguno de los autores hace referencia al otro, existe un paralelismo en su pensamiento, principalmente un criticismo a la pedagogía tradicional y la contribución progresiva de la educación formal para el cambio social.

En estos momentos, a finales de la segunda década del siglo XXI, la escuela inmediata parece remover esa postura sobre la reproducción social -de la cual hace todavía parte-, al mostrarse como moldeadora de una reproducción consumista que hace ver inocente los efectos que la teoría de la reproducción social plantea.

\subsubsection{Las reflexiones del constructivismo social}

Las teorizaciones del constructivismo enmarcan un giro epistemológico para el pensamiento filosófico y social, logrando alcances para la reconfiguración de la sociología, la teoría del conocimiento y la filosofía educativa misma. El problema central enmarcado por el constructivismo corresponde con la determinación de la forma en que se lleva a cabo la adquisición del conocimiento. La filosofía había centrado el asunto en el problema de determinar la existencia de una realidad objetiva, al tiempo que independiente de los sujetos cognoscentes; si eso que conocemos con el nombre de realidad, significa que es producto de la mente, $o$ sea subjetiva. Esto traduce en el cómo el ser humano conoce su entorno, en consecuencia, determinar si acaso es posible un conocimiento verdadero de dicha realidad (Galindo, 2010).

Por eso, de lo que se trata es de refundar, mostrar que "la tarea de la filosofía consiste principalmente en la liberación del hombre de las ilusiones al mostrarle las raíces sociales de las mismas y en estimularle a una acción para cambiar el mundo" (Suchodolski, 1977, p. 5), elemento que no ha perdido vigencia, todo lo contrario.

El problema central relativo a la forma de conocer, no es novedoso, éste aparece como eje de las discusiones filosóficas en su larga tradición, que habían sido centralizadas en las reflexiones kantianas respecto al racionalismo y al empirismo, pero las ideas del constructivismo logran romper la dicotomía entre sujeto/objeto en tanto que entienden los objetos del conocimiento como constructos sociales, además, de que centran su análisis en la explicación del proceso en el que ocurre el conocimiento, ampliando los alcances tradicionales de la filosofía de la educación.

La perspectiva constructivista empieza a ser dominante en el pensamiento educativo, en general, en la teoría social desde el siglo XVIII. Ello marca un punto de quiebre en la comprensión tradicional de la teoría y práctica educativa, un auténtico cambio conceptual, asunto tan relevante en el fondo de muchas controversias filosóficas (Martínez, 2005). Suele asociarse como abanderado del constructivismo a Vygotsky, pero es realmente en el pensamiento de Marx (Suchodolski, 1977) en que puede rastrearse tal dimensión; el primero lo lleva lleva estrictamente al campo de lo pedagógico.

Puede afirmarse que el constructivismo se basa en la importancia de la construcción del conocimiento, es decir, en la comprensión en tanto proceso de conformación constante y colectiva en la cual el contexto 
social es un aspecto determinante. Marx (1980) exponía que no es la conciencia de los hombres lo que determina su ser, sino, por el contrario: es su existencia social lo que determina su conciencia; tal supuesto filosófico le da piso a la comprensión más práctica de Vygotsky respecto a que los procesos de desarrollo cognitivos no ocurren de manera independiente al contexto social en que se producen, esto es que "la característica central de las funciones [psicológicas y cognitivas] elementales es que están directamente y totalmente determinadas por los estímulos precedentes del entorno" (Vygotsky, 1979; en Vila, 2007, p. 213).

En Vygotsky los aportes de la filosofía de la ciencia y de la sociología del conocimiento de la segunda posguerra, han sido claves para la comprensión del proceso de construcción social del conocimiento, replanteando las nociones de la vieja educación que mostraba al aprendiz como una tabula rasa, concepto heredado de Locke (Rice, 1997, p. 130) y a la educación como un proceso acumulativo y de adiestramiento (Bernardini \& Soto, 1984, p. 174) ${ }^{41}$. En todo caso, el bagaje conceptual de otros autores es más cercano a la comprensión filosófica del constructivismo. Desde la perspectiva de Kant y en sus elementos fundamentales como la noción de a priori, lo universal y otras categorías, así como sus aportes al análisis de la moral (Herrera, 2005), o bien, la de Luhmann y su crítica a la objetividad, se evidencian elementos fundamentales para el análisis de la filosofía de la educación desde las bases del constructivismo social (Corsi, et al., 1996).

Para el caso de Luhmann, la crítica a la pretendida "objetividad" deconstruye las nociones citadas de la vieja educación en el replanteamiento de las relaciones entre objeto y sujeto, en beneficio de este último (Ibañez, J., 2013). Como punto en común en el planteamiento de los dos autores mencionados, ni objetividad ni universalidad se oponen a construcción; al contrario de lo "producido" por la Naturaleza, lo del hombre es construcción, una construcción social. Esto significa el transito del arte, del saber hacer al conocimiento; pero aún existen posiciones de debate sobre lo que es construcción y lo que no lo es. Lo que no tiene mucha discusión es que el conocimiento humano es construcción y está directamente relacionado con este concepto. Autores criollos actuales como Maturana y Varela (2003), han acuñado su propia concepción, la deriva natural que, por ejemplo, implica una mayor cercanía a la armonización entre las posturas naturalista y la socio-cultural, que de todas las maneras están relacionadas con las capacidades humanas.

Puede afirmarse, entre tanto, que el constructivismo social es crítico y liberador (Rojas, 2010, p. 271) desde una perspectiva que supone que el ser humano es un ser del mundo y está en el mundo ${ }^{42}$, así, el constructivismo enfoca el influjo social y cultural propio del devenir histórico-social. En el constructivismo, la experiencia individual, y particularmente la social, tienen sus propios objetivos en la apuesta por que cada estudiante construya por sí mismo y aporte a otros a partir de lo que pueda realizar: "el conocimiento, para el constructivismo, es apropiación por parte del sujeto, y no mera representación o información. El sujeto se construye en un proceso social, cultural y educativo, pero también el objeto es construido por la actividad apropiativa del sujeto. Sujeto y objeto se relativizan al mismo tiempo" (Rojas, 2010, p. 282).

En tal sentido, el sujeto construye, deconstruye y reconstruye el conocimiento de las cosas que le rodean; estas cosas, elementos y fenómenos no existen independientes del hombre. He aquí lo significativo del hombre y su capacidad de hacer constructos a partir de su entorno, pese a que para algunas corrientes no se

${ }^{41}$ Para mayor documentación revísese los estudios del campo de la Sociología del Conocimiento y la Sociología de la Ciencia.

${ }^{42}$ Desde lo bio-social y M. Heidegger, respectivamente. 
puede conocer sino parcialmente y para otras ni siquiera es viable el proceso ya que la realidad existe de facto. Vale la pena recordar la muy sucinta y célebre onceava tesis marxiana ${ }^{43}$ (Engels, 1986), y que en todo caso complementa y es complementada en relación recíproca con la tercera de las tesis de Marx sobre Feuerbach:

La teoría materialista de que los hombres son producto de las circunstancias y de la educación, y de que por tanto, los hombres modificados son producto de circunstancias distintas y de una educación modificada, olvida que son los hombres, precisamente, los que hacen que cambien las circunstancias y que el propio educador necesita ser educado. Conduce, pues, forzosamente, a la sociedad en dos partes, una de las cuales está por encima de la sociedad (así, por ej.,, en Roberto Owen). La coincidencia de la modificación de las circunstancias y de la actividad humana sólo puede concebirse y entenderse racionalmente como práctica revolucionaria. (Engels, 1986, p. 55)

No hay duda de la relación que hay entre el constructivismo y las posturas propias de Marx; pero dicho concepto puede ser objeto de señalamientos que recuerdan el macartismo más rancio, o bien, el simple descuido al evitar citar al marxismo en el marco de una corriente de pensamiento tan influyente en la contemporaneidad.

Es posible afirmar que, las discusiones sobre el constructivismo tienen una importancia significativa para el contexto educativo, en este caso el Latinoamericano, lo que se hace evidente en la intención de los pensadores locales, críticos de la forma de comprender los procesos de apropiación de un conocimiento que se produce en otros contextos como un ejercicio pasivo de recepción. El alejamiento de una concepción educativa relacionada con la simple adquisición acumulativa de conocimientos conlleva un argumento político, el de empoderar a los sujetos como productores de conocimiento.

En autores tan importantes como Freire (1994) es posible rastrear las bases del constructivismo como aportes para una interpretación crítica y local del fenómeno educativo desde una perspectiva política, particularmente en su intención de otorgar una naturaleza política y constructiva a la educación, adquiriendo los individuos objeto de educación una importancia significativa en su propio proceso, ya que "Paulo Freire ha aportado a la reflexión pedagógica latinoamericana un esfuerzo sistematizado por pensar el fenómeno educativo desde la perspectiva de los oprimidos y los marginales" (Cerutti, 1993, p. 36). Desde la misma orilla en que Vygotsky hiciera referencia a la importancia de la experiencia y los conocimientos previos de los aprendientes (Gros, 2002, p. 231), de tal suerte, que el conocimiento deja de ser una reproducción de la realidad siendo ahora una construcción que reconoce un carácter ontológicamente relevante para los sujetos de la educación.

\subsubsection{Manifestaciones de la educación liberadora: algunos atisbos en Latinoamérica}

La corriente de la educación liberadora, que se retoman en algunos contextos de América Latina, propone una alternativa crítica y reflexiva que pretende la concienciación sobre la condición social del individuo quien no deberá olvidar su historia, la que ha de ser rastreada; esta perspectiva se adscribe a la línea de reflexión elevada en pensadores como Freire y Hostos u otros insignes clásicos como J. Martí y S. Rodríguez. Aparecen las retomas, no de modas, sino de conciencia pedagógica que como Ledesma Reyes (1997), nos recuerda los criterios de una pedagogía pensada desde acá, desde la disidencia y la liberación

${ }^{43}$ Die Philosophen haben die Welt nur verschieden interpretiert; es kommt aber darauf an, sie zu verändern 
que también propaga Bolívar Echeverría (2011) en su análisis latinoamericano. En el campo del marxismo, podemos encontrar a De Arismendi (1965) con su clásica pero crítica postura sobre pedagogía y maxismo.

Antecedente es, la preocupación mostrada por el mismo Miranda, en su momento, por la formación educativa que, no fue más relevante que su preocupación por la formación de personas mentalmente libres (Ramírez A.-Patiño, 2013). Así, en sus planes podemos ver la propuesta de educación laica y la promoción de talleres nacionales, pero con adaptación a las necesidades de Hispanoamérica. El conocimiento hizo parte de las armas de la independencia, aunque no fuera pensada para la totalidad de la población.

Se tiene como característica relevante, la localidad de la condición latinoamericana al pensar la educación en relación con su realidad particular en factores como la convergencia de este modo de pensamiento con la misión educadora. Existen aspectos generados en la etapa de la teología de la liberación de algunos sectores progresistas de la iglesia, así mismo en el trabajo de autores tan importantes como Fals Borda (2003) y E. Dussel (2006a). Así pues, recogiendo en conjunto, sus raíces calan en la definición de la educación como "práctica de la libertad” (Mendieta, 2008, p. 342).

Un elemento característico de la criticidad aplicada en educación, es además de la inclusión de lo culturalmente negado, es el anti neo colonialismo y en las posturas anti imperialistas. Sin esto difícilmente habría propuesta original desde América Latina. Así mismo, no hay duda en la necesidad de teorizar, y ver a través de la historia, el papel de las clases dominantes con sus intereses que se reflejan en el modo de operar políticamente en el seno del Estado. Se piensa que, alojándose en los requerimientos de forma, se garantiza la finalidad de la formación humana. Dussel cita un ejemplo adecuado por allá en 1982 donde combina crítica con liberación; la realidad no ha cambiado o ha sido poco:

De la misma manera en los modelos de conservadurismo- liberal, cuyo caso típico es Colombia, y de franca dependencia político-económica, el sistema pedagógico no es tan autoritario como en el modelo anterior. Sin embargo, la educación del pueblo no pasa de ser un enseñarle a manejar los canales y signos del lenguaje imperante, mediación entonces para una mejor dominación. La educación crítica poco o nada ha avanzado en estas regiones. (1982, p. 82)

El puertorriqueño Villarini (1988) no renuncia a las oportunidades que ofrece el pensamiento crítico para pensar el ámbito de la educación, por tanto, reúne los elementos del pensamiento crítico occidental que se avoca a la reflexión y los aportes de personajes tan relevantes para el campo, como Piaget y su teoría de lo biopsicosocial y la adaptación. La caracterización de la educación en Villarini presenta tres aspectos, a saber: los sociales, los epistemológicos y los éticos. Estos, además, complementan y ajustan el buen "funcionamiento" del proceso educativo en la región. El enfoque dialéctico se refleja al analizar los aspectos sociales y los aspectos culturales. Los primeros, obedecen al marco histórico-cultural; los segundos, a la aculturación, a la humanización.

En ese mismo orden se distingue el enfoque epistemológico derivado de la perspectiva de lo biopsicosocial y lo cultural. Todo lo anterior se sintetiza en una teleología que lleva a la construcción de conocimiento, así como la humanización franca de cada individuo; es decir, la dimensión humana se convierte en base cimentada para el desarrollo social bien entendido. Todo proceso gira entorno a los principios latos de la humanidad, sobre todo entendida desde un interés común que tampoco obvie la particularidad individual.

La relación dialéctica no es conflictiva, es más bien, una relación en busca de comprensión y soluciones ajenas a la dependencia hegemónica. No hay duda que el constructivismo logra tener un tono distinto en su enfoque latinoamericano el cual no dista mucho del estrictamente foráneo, como indica Rojas (2010), “en 
este proceso de adaptación al mundo el ser humano usa su pensamiento no solo para procesar información, sino también para solucionar problemas y, finalmente, para construir conocimiento" (P. 320).

En estos términos, el fin de la educación termina convertido en un fin ético, donde han de primar los valores básicos, a la sazón, dignidad y solidaridad. El ser humano debe ser proyecto de la finalidad antropológica, ser solidario y digno, difundir y defender estos sumos valores es menester del ethos. Debe haber un interés objetivo y subjetivo que facilite la liberación individual y colectiva. La educación, por tanto, es liberación. Por otro lado, se establecen cuatro supuestos del proceso de aprendizaje. Estos supuestos giran en torno al sentido estricto de conocimiento conceptual; a lo significativo; a la motivación personal y la autoestima y, finalmente, de los objetivos que se proponga cada estudiante para el caso de la educación.

Con Rojas (2010) se reconocen ciertas competencias humanas generales con sus características propias, a saber: pensamiento sistemático, pensamiento creativo y pensamiento crítico; comunicación, entre otras. También, reconoce las destrezas básicas y las destrezas avanzadas o complejas a la par de sus diferencias (P. 153). En definitiva, a partir de estos criterios, el pensamiento crítico es autocognición y autoexamen que están dentro de lo que son las dimensiones del pensamiento crítico (autocontrol, lógica, sustantiva, contextual, dialógica y pragmática) tal como se consigna en Villarini (2001).

Metodológicamente hablando, el pensamiento de Villarini se conecta con lo que se conoce como la ECA (conceptualización, explicación, y aplicación). A su vez, el papel del docente es más de moderación que de emisión. En cuanto a las humanidades, en sus distintas expresiones, se proponen como transformadoras y liberadoras. En síntesis, Villarini (2001) toca dos ámbitos claves: lo ético-moral y la estética dirigida hacia la libertad y la democracia cuyas bases son la solidaridad y la dignidad como dos pilares que deben consolidarse en todos los procesos pedagógicos.

La escuela tiene que ser crítica, denunciante de cualquier situación discriminatoria o que esté en contra de los valores, de los derechos y deberes humanos. El papel de los actores educativos es activo y de lucha en el modelo de educación liberadora y crítica pero siempre coherente y racional. Eso, por un lado. Por otro lado, se plantea cinco estrategias para la enseñanza de los valores morales y cinco grados de desarrollo en la misma línea (Rojas, 2010, p. 154). Segundo, con relación a la estética, da por sentado que el arte, y su comprensión, está estrechamente relacionado con la interpretación de lo real. El arte o puede ser liberador o puede someter. Por ello se pretende una búsqueda de la apertura hacia lo bello a través de una consciencia estética que logre fortalecer la integridad y criticidad en el ser humano que se está formando. La sensibilidad es clave en este ámbito, el cual, no se puede descuidar.

Ordoñez Peñalonzo, otro pensador del fenómeno de la educación en América Latina, se destaca por la insistencia en pensar la pedagogía desde el territorio latinoamericano - caribeño (Ordoñez, 2004). Pensar la pedagogía latinoamericana y lo que ello implica es fundamentarse en: primero, pensar en América Latina; segundo, pensarla desde su remoto pasado y cultura; tercero, integrar los aportes de otras latitudes y experiencias propias o foráneas (Ordoñez, 2010). En una palabra, escudriñar el pasado ancestral nativo, pues, así como se estudia la Paideia, debe y tiene que estudiarse y aplicar las otras formas de enseñanzas que existieron en la tierra Abya Yala, aun las que por fortuna hoy sobreviven en los rincones de las 
comunidades del continente. La construcción teórica de Ordoñez Peñalonzo identifica ocho grandes tendencias pedagógicas que han marcado e influenciado a lo largo y ancho de estos últimos tiempos ${ }^{44}$.

El punto de quiebre del análisis de Ordoñez (2004), reconociendo los aportes de autores principalmente europeos, a la comprensión local del mundo subdesarrollado, es la relación tiempo-sociedad, la cual intenta caracterizar cada época de la historia latinoamericana, en sus dimensiones y dinámicas educativas, es decir, sus actores, sus efectos, sus avances y sus limitaciones. No en vano, establece cuatro significados de la educación que son: la etimológica, la antropológica, la cultural y la social. Todo esto junto para comprender los procesos propios de Latinoamérica, propendiendo por la búsqueda de una identidad y sentido hacia la construcción de una realidad diferente y liberadora.

En definitiva, Villarini y Ordoñez, convergen en la necesidad de un modelo propio no discriminatorio e integrador donde el educar sea estimulación del pensamiento libre e independiente, en el cual, se logre una sociedad libre, de mente libre y corazón solidario más allá de la válida utopía que siempre ha estado presente en el imaginario regional (Rojas, 2010). Las perspectivas de los autores citados son tan relevantes como las ideas de la educación liberadora construidas por Freire (1974) y Dussel (1995), puede afirmarse que para el caso de estos últimos existe una visión de la educación en tanto forma para la liberación de la persona humana, consciente de su lucha contra las determinaciones opresivas, que refleje autonomía, que se concrete en una plena humanización (Severino, 2014).

En este contexto, resalta la postura de Freire (1982) sobre la pedagogía crítica como parte necesaria de la revolución, por tanto, de la liberación. La transformación, el cambio social, posibilita la eliminación de las condiciones de opresión en que se encuentran inmersos los individuos, situación que se hace más evidente en las realidades propias de América Latina, "la educación liberadora propuesta por Freire encamina hacia la formación de seres humanos pensantes, comprometidos con su devenir. El desarrollo de las naciones se alcanza con una educación que haga libre al educando al reafirmar su identidad gracias al pensamiento" (Paiva, 2004, p. 134), de tal modo que la emancipación del individuo (educado) es la emancipación del hombre. "Pero también el proyecto pedagógico puede ser de liberación. La educación dominadora es agresiva, patriarcal, autoritaria; es un filicidio. En cambio, la educación liberadora es <el despliegue de las fuerzas creadoras del niño>, de la juventud, del pueblo" (Dussel, 1982, p. 83).

Los aportes de la perspectiva latinoamericana se han caracterizado por ser incluyentes, históricos e integradores de todo lo cultural, inclusive llegando a pensar no en una educación local sino en un enfoque continental de lo que llaman Patria grande, rescatando los ideales de los primeros lideres independentistas hispanoamericanos y caribeños. Esto choca con la propuesta eurocéntrica que busca replegar cualquier atisbo de autoctonismo. Por lógica, los Estados regionales no se han empeñado en crear y promover políticas que intenten hacer un giro hacia la realidad latinoamericana, precisamente no ocurre porque lógicamente una versión liberadora y latinoamericanista no cae bien entre los gobiernos que por casi dos

\footnotetext{
${ }^{44}$ La visión-tendencia de Marx (critica a la educación liberal burguesa y la alternativa socialista-comunista). La tradicional, donde el centro del proceso es la autoridad desmedida del maestro. La Escuela Nueva o Activa, donde le centro es el estudiante, pero con la idea de educación para el trabajo. La tecnológica, con los contenidos propios del conductismo y orquestados por los tecnócratas. La pedagogía personalizada, que elimina la interacción entre los estudiantes y tiende a ser individualista y más sujeta al mercado educativo. La autogestionaria, que propende por la autonomía. Esta tiene otras vertientes. La personalista, que enfatiza en la dinámica de grupo. La pedagogía cognitiva, que se enmarca en el ámbito de la primacía conceptual. La pedagogía operativa, cuya fuente es la psicología operatoria.
} 
siglos han desconocido lo propio, la riqueza de la cultura y las verdaderas necesidades de justicia social que pueden procurarse desde el acontecimiento educativo basado en una aplicación de la praxis y un desmonte ideológico.

La escuela inmediata en su inmediatez, puede contener un descuido por estudiar, reconocer y difundir aquellas posturas teóricas relacionadas con términos de liberación de la mujer y el hombre construidas en Latinoamérica. La inmediatez relacionada con lo próximo, con su aprovechamiento.

\subsection{La cuestión geopolítica}

La crisis de la educación generada por el sistema de cosas, es un problema mundial. De hecho, gran parte de los problemas de la actualidad, comenzando por la explosión demográfica, el deterioro ambiental, el desprecio por la vida, la brecha socioeconómica, las guerras, la drogadicción, la corrupción, los extremismos religiosos, y todo ese mosaico de azotes generados por la materialidad humana, están relacionados directamente, en su agudeza con la ineficacia de los sistemas educativos y la formación del cotidiano. Por tanto, aquello se convierte en un asunto global, en un tema geopolítico. ¿No es acaso mediante la manipulación de los espacios educativos donde un sistema puede prolongarse?

Hoy el debate mundial esgrimido para los sectores críticos, no es sobre la recomendación del socialismo en tanto forma de gobierno. El centro de atención de los movimientos socialistas son problemas explícitos que, sin duda son denunciados por sus raíces profundas en el sistema capitalista global. La retoma de las ideas socialistas pierden fuerza si dejan de ser sociales; por ser sociales la educación sigue siendo el mayor de los retos en sí misma. La revolución mundial debe y tiene que ser formacional, integral y de conciencia si no, no será. La retoma geopolítica no tiene otro sentido que abrirse paso en el incierto horizonte que ha empezado a transitar la humanidad, horizonte minado de todo tipo de adversidades producidas por su misma acción destructora. Si ayer era el llamado a todos los trabajadores del mundo a unirse contra el enemigo sistémico, hoy el llamado es a la especie humana a combatir mancomunadamente al mismo sistema, pero mejorado a lo que se suman las trágicas consecuencias de ese mismo sistema imperante que aliena y enajena a nivel universal.

Todavía a la hora de escribir estas líneas, se vive un ambiente global parecido al de la época del bipolarismo ideologico, con la diferencia que no existen grandes bloques declarados oficialmente de una ideología política. El riesgo es enorme, pues el poder nuclear de potencias y otras no tan potencias, generan cada día que pasa, más zozobra. Se escucha de una OTAN delineando intervenciones y rodeando a Rusia. A una Corea del Norte comunista con arsenal nuclear, que no quiere seguir ordenanzas del sistema mundial, etc. El desprecio por la conservación y por la vida ha llegado a su culmen. Las religiones han ofrecido sus brazos para, solo garantizar un mundo más feliz, pero en el más allá; por el más acá no hay nada que hacer: la autodestrucción es innata al ser humano. Parece que, en este panorama tan desolador, cuyo futuro no es difícil de predecir si no se hace un alto en el camino, ninguna oportunidad política es viable.

La educación desde la perspectiva marxiana también es una apuesta geopolítica. Lo marxiano tiene que ver con la fraternidad internacional de los pueblos. Apunta Guzmán (2017, p. 172) "El marxismo es una teoría que tiene como aspiración esencial la ruptura con la alienación económica, política y cultural de los pueblos". En ese orden, la retoma de lo formativo replantea la idea de hombre y mujer preparados para 
afrontar los retos más trágicos que ha dejado el sistema al mundo entero que ha sobrepasado los temas tradicionales de la política global. Ahora la unidad de criterios y acciones hasta deben tocar los efectos desatados por el deterioro ambiental y, aun la educación es un espacio competente.

La consecución de una situación de bienestar para el ser humano y el mundo natural, es un desafío para la educación; hasta el momento es la vía más adecuada para operar; esto es algo global lo que hace que lo marxiano tenga mucho que aportar. Si bien la experiencia del siglo XX fue decepcionante en varios aspectos, la transición al sistema de mercado ha generado estragos en los antiguos bastiones del socialismo real. Y ello se debió, en gran medida a la debilidad de las instituciones (Fazio Vengoa, 1994), al alto grado de corrupción prevaleciente que no funcionaba ahora bajo unas indicaciones burocráticas sino bajo las prácticas de clientelismos de carácter económico. La crisis social se sigue presentando desde la década de los noventa y no puede achacársele toda la culpa al contexto anterior.

Ahora bien, mientras existan condiciones contradictorias que se manifiestan en exclusión, desigualdad y expoliación entre otras tragedias humanas de origen humano, también existirán posturas que enfrenten este tipo de ambientes socialmente hostiles. Acá lo marxiano tendrá su lugar por muy independiente que quiera mostrarse una postura, pues tendrá en común la reivindicación de la dignidad humana en los distintos ámbitos de la vida social humana, desde las luchas de género hasta las causas ambientales.

Curiosamente, es en el espectro extraeuropeo donde las ideas de Marx encuentran un nicho significativo cuando se toca el asunto social. Pocas concepciones han sido aceptadas en el ámbito periférico como las que se emanan del marxismo, solo comparables con la influencia de las ideas de la Revolución francesa de 1789.

Varias voces afirman que "Marx debe volver" (Valdez, 2015), pero no ese marxismo leninismo catequésico, manualesco que denuncia Silva (2009), sino "sacando al Marx mismo". La retoma del escenario no es por parte del comunismo, ni siquiera del socialismo estrictamente hablando, aunque la única forma de ver al mundo que se ha enfrentado a la visión al dictamen del capital ha sido el socialismo en sus diferentes manifestaciones, por lo menos de manera franca no sin argumentos. Es la conciencia de la necesidad de una concepción distinta de las relaciones de poder, de sometimiento, del rescate de la dignidad en toda su materialidad.

A pesar de la imposición que se presentó en gran parte de Europa Oriental, por medio de una fuerza ideologizadora acompañada del músculo militar; en regiones como Latinoamérica -muy a pesar de algún tipo de apoyo del bloque del Este- la ideología marxista llegará a establecerse como el arma teórica de la lucha reivindicativa. Por decir, mientras los tanques soviéticos ametrallaban la revuelta democrática en las calles de Budapest, los sindicatos se preocupaban por fortalecer su acervo conceptual con las obras marxianas y marxistas.

A finales de los años ochenta que fueron clave por la implantación del neoliberalismo en las periferias, se cuenta, por ejemplo que, "para el VI Congreso de la Internacional la delegación latinoamericana hace presencia con informes y ponencias que tienen amplio debate ante las posiciones de los europeos" (Casas, 1989, p. 157). Mientras en los círculos intelectuales de la izquierda occidental se discutía sobre las revisiones durante tres décadas (60 a 80); en América Latina se expandía con éxito la teología de la 
liberación (Guadarrama, 2013). La pedagogía del oprimido, de la liberación ya comenzaba a ganar espacios en las visiones pedagógicas de la región.

La afirmación tan conocida de Lenin: "No hay revolución sin teoría revolucionaria" - significa precisamente que no hay revolución con verbalismo y tampoco con activismo, sino con praxis, por tanto, con reflexión y acción que inciden sobre las estructuras que tienen que ser transformadas. (Freire, 1971, p. 148)

El aporte de Marx se miraba como algo esperanzador en muchos sectores de la sociedad, en los campesinos, en los estudiantes, en los movimientos de base de todo tipo. Incluso en la segunda década del siglo XXI todavía se tiene una percepción positiva del socialismo en varios sectores de la vida de los países. La propuesta de cambio de algunos aspectos ortodoxos, confirman que el socialismo debe y puede ser dinámico, propositivo y garantizar el establecimiento de unas condiciones distintas a las presentadas por su sistema antagónico. En fin, hoy se habla de socialismo del siglo XXI, de progresismo humanizado, de ecología (Lowy, 2003) encarnado en el ecosocialismo, entre otros. La mayoría de las alternativas con un fuerte ingrediente teorético desprendido de las interpretaciones de Marx que incluyen elementos propios de cada contexto. Por ejemplo, Lowy (2003) apuesta por un campo de un vital interés global, por lo cual sostiene que

La cuestión ecológica es, en mi opinión, el gran desafío para la renovación del pensamiento marxista en el umbral del siglo XXI. Ella exige de los marxistas una ruptura radical con la ideología del progreso lineal y con el paradigma tecnológico y económico de la civilización industrial moderna. (Lowy, 2003, párr. 41)

Los años ochenta y noventa fueron años difíciles, de crisis profundas para las regiones de la periferia tercermundista. Si bien existieron movimientos verticales en materia de lucha armada autoproclamada marxista, alimentada por las luchas campesinas ancestrales, sobre todo en las peticiones de reformas agrarias y de redistribución de ingresos. También, hubo aquellos que seguían los dogmas extranjeros al pie de la letra olvidando conciliar las realidades propias. Tampoco puede quedar por fuera, para comprender esto, la represión política, militar y paramilitar activada por parte de los Estados afiliados a la visión de Washington, los cuales también representaban a los sectores oligárquicos locales sostenedores del statu quo en los distintos países.

La intención de subvertir el orden establecido, por parte de los intérpretes del marxismo, se presentaron como oportunidad trascendente en el campo de lo político y en la misma economía como modelos alternativos. Aunque puede resumirse una intención de cambio social fuerte en los presupuestos del marxismo, no debe olvidarse que precisamente esta ideología fue fruto, en sus raíces, de un proceso llevado a cabo en la Europa decimonónica. De ahí lo importante del proceso de conciencia o asimilación de estos contenidos programáticos, de distinción de sus adaptaciones. De ejemplo sirve lo escrito por Mc Lellan en 1984: El <hombre nuevo soviético> difícilmente logra imponerse a la mayoría de la población, que estando constituida por campesinos, o por hijos y nietos campesinos, sigue practicando la indolente desorganización y el tosco hedonismo de sus antepasados" (P. 119); he allí una prueba de lo difícil que es interiorizar procesos de formación cuando en primer lugar está la producción material o la adscripción a una forma partidista de organización que intenta dominar todos los aspectos de la vida.

Abbagnano en 1964 recuerda que, "al idealismo de Hegel que, a partir de la idea tiende a justificar post factum toda la realidad Marx opone una filosofía que, a partir del hombre, tiende a 
transformar activamente la realidad misma" (P. 501). El Marx esencial para transformar la realidad del ser humano, más allá de los romanticismos y las válidas utopías, estuvo oculto o simplemente no quiso dejarse al descubierto en muchas experiencias materiales. Esta última característica fue típica en la oficialidad gubernamental, así como en los grupos diseminados por el mundo, los denominados alzados en armas. En muchos casos los actos de estos grupos fueron catalogados de terroristas, unos con toda la razón objetiva; otros por simple posición alineada.

Desde finales de los 90s (Kohan,1998) por rescatar de la historia del siglo XX, las experiencias relacionadas con la aplicación de lo que se denominó marxismo, ya sea en el campo de facto para revisar consecuencias actuales y aspectos negativos o positivos, de un lado; y por el otro un interés por los estudios sobre marxismo. Los movimientos sociales alrededor del mundo, sobre todo en América Latina, no niegan su interés por tomar ideas marxianas y marxistas en sus programas ya que la opresión no ha variado sino más bien se ha profundizado (Hinkelammert, 2001).

La situación no ha variado mucho desde hace dos siglos, si bien los protagonistas han cambiado, y si bien hay que tener en cuenta las cosas marxianas que son de la época de Marx, otros fenómenos no han variado. Hoy, autores como Jonathan Sperber en Karl Marx: A Nineteenth-Century Life (2013), expresa que Marx solo fue vigente para su época, si bien es apreciable para comprender las cosas de su época y quizás las del sistema actual, esto no significa que sea repensado en perspectiva actual, mucho menos que tenga algo que decir en este inicio del siglo XXI. Las situaciones problémicas se agudizan, los efectos de la economía regida por las "leyes" (muy humanas, pero para nada humanizadoras) se demuestran en la situación planetaria.

Por eso, algunas experiencias de socialismo alrededor del mundo, ya sean establecidas en formas de Estado o no, invitan al diálogo urgente, pues el sistema imperante con las contradicciones que ya decían Marx y Engels (Dietrich, Sf.), sigue en marcha con su descuido del ámbito humano, con el detrimento de la naturaleza y con la cacería de brujas que lo ha caracterizado. Siguen existiendo asomos cercanos al enfoque marxiano; Núñez Tenorio (1998) decía: "pienso que sigue teniendo plena vigencia. Ha existido una distorsión, digamos, una <mala digestión> de Marx" (P. 22).

Algunos países se han conformado en bloques para contrarrestar el grado de influencia de las potencias. Desmantelar el sistema hegemónico se encuentra en sus agendas de desarrollo, no sin obvias dificultades que plantea el mismo sistema de cosas imperante. Para esto la educación se ha convertido en uno de los medios más utilizados.

La resistencia persiste en el campo económico, pues si bien existe un sistema capitalista "reformado", las consecuencias negativas ahora son globales. Si hay unas sociedades avanzadas es precisamente porque hay una base que las sostienen, esta base son los países periféricos. Por tal motivo no es raro observar los conflictos desatados en varias regiones estratégicas del mundo cuando estalla una crisis relacionada con el capital. Ramonet en 2002, exhortaba: "pues ha llegado el momento de fundar una nueva economía, más solidaria, basada en el principio del desarrollo sostenible y que tenga al ser humano como preocupación central. Y el primer paso para conseguirlo es desarmar al poder financiero" (P. 182); las evidencias del sistema de mercantilización como generador de infelicidad, son preocupantes más que esclarecedoras.

Los medios de información han tomado el papel de difusores, expulsando de la colectividad, todo rasgo de análisis y crítica; solo pocos espacios mediáticos cumplen con su función social. Esto es problema global 
que ha de ser asaltado por la educación centrada en la integralidad; que esa sociedad del conocimiento se convierta en democrática y pluralista para contrarrestar los nefastos efectos de la globalización de la información manipulada que sirve a los intereses de los emporios.

Las políticas educativas se plantean como soluciones globales, cargarlas de un fuerte discurso y práctica de lo humano es característico de las visiones que piden cambios. Se sabe que la caída de la versión del socialismo real no ha garantizado la propuesta de un mundo tolerante y multipolar.

En el campo geopolítico una de las vertientes de la educación alternativa con fuertes fundamentaciones crítico-sociales, se presentan al mundo para coadyuvar a la formulación de soluciones. Las epistemologías alternas juegan papel determinante ya que éstas intentan llegar, sobre todo, al público interesado por la educación; muchos educadores han encontrado en esta corriente un respaldo teórico interesado por el rescate de la crítica y la propuesta. La epistemología del sur es la más representativa, convirtiéndose en una extensión geopolítica del conocimiento integrador y solidario con un ingrediente que acerca a los principios marxianos.

El proyecto colonial continúa hoy en vigor bajo nuevas formas y puede incluso afirmarse que su articulación con el capitalismo global nunca fue tan intensa como ahora. De este modo, la epistemología del Sur para ser consistentemente anticapitalista ha de ser también anticolonial y viceversa. (De Soussa, 2001, p. 13)

La retoma del escenario geopolítico por parte de corrientes alternas propenden por la unidad de criterios y al respeto por visiones que habían sido invisibilizadas. Por poner un caso, el rescate de lo ancestral, de ese legado que puede dar indicaciones para mejorar la estancia material y espiritual del ser humano en la Tierra. Dussel, sostendrá: "de la cultura revolucionaria liberadora surgirá una nueva cultura pluriversa mundial, alternativa mucho más rica que la actual cultura imperial” (2014, p.154).

Aún existen movimientos políticos con fuertes tintes de concepciones sociales salidas de las dimensiones marxianas. En países como EE.UU e Israel, los temas de Estado generan reacciones de sectores sociales que llegan a invocar las luchas populares como ejes integradores globales (antirracismo, antixenofobia, ecologismo, antiguerrerismo, lucha de género, etc.). En el lejano oriente se ve otra ejemplificación: la popularidad y éxito del partido comunista del Japón en su postura antimilitarista, de rechazo a injerencia (Sputnik, 2016). Parece que la ideología ha dado paso a la conciencia ya no solo de clase sino de género humano, creo que a esta meta quería llegar la máxima de Marx.

Muchos sectores aún ponen sus esperanzas en el cambio, en una actitud global para hacer frente a los problemas delicados de carácter planetario. En esto, el establecimiento y desarrollo de un pensamiento crítico-propositivo tiende a convertirse no en una moda sino en una necesidad de primer orden, por eso los niveles de formación deben centrarse en hacer consciente al hombre como protagonista de su propio destino y el destino de sus semejantes de su entorno social y natural. Se ha planteado el desafío por oxigenar la interpretación marxiana en distintos campos como dice Dussel (2014 a). Puede decirse que, las propuestas de repensar los problemas que nos aquejan desde los proyectos de praxis, son a su vez, apuestas geopolíticas.

En el proyecto de la Ética de la liberación, entendido por unos como una ética preventiva, busca la consolidación de un humanismo universal que bajo sus principios de reconocimiento cultural, descentralización de la razón, una racionalidad abierta a la historia, una práctica liberadora, la ciudadanía y la participación popular, la preservación del medio ambiente, la solidaridad de las naciones como práctica de la justicia y la convivencia, y a su vez, la necesidad de cambio y 
transformación a partir de la concientización de su ser; forja unas relaciones dialécticas o pares categoriales que en el discurso dusseliano ayudará a entender su necesidad hoy. (Santos, 2016, p. 2)

Núñez Tenorio (1998) apuntaba a finales de los años noventa, en pleno inicio de los procesos de gobiernos llamados "progresistas en América Latina que: "hay que desenmascarar la estrategia política del capitalismo imperialista mundial del Desarrollo Humano Sostenible (DHS), como irrealizable dentro de la sociedad capitalista, sin desconocer las reformas sociales menores que puedan conquistarse en algunos países" (P. 210). Esto demuestra una actualización de la confrontación contra la hegemonía del sistema y sus representantes tangibles.

El rescate de la perspectiva marxiana en educación, complementa desde América Latina y El Caribe, las formas de pensamiento gestoras de esperanza en la educación para asomarse a la salida de tantas situaciones fortuitas creadas por el hombre actual. Así, repensar la educación es apuntar a un proyecto político comprometido. Kohan colabora al decir que,

Nuestro proyecto político de alcance mundial es a largo plazo y a nivel estratégico varían de país en país, de acuerdo con las tradiciones culturales, a los debates del movimiento popular, a las polémicas...creo que lo que hay que tener claro es el rumbo estratégico. (Kohan, sf., pp. 12-13)

Esa estrategia puede ser la educación bajo los criterios marxianos para construir un proyecto político de transformación de conciencia que lo que al final propone Marx, hay que intentarlo y no tanto de manera ideologizado tal como pasó con el llamado socialismo real.

La retoma de una educación crítica con elementos marxianos para entender y transformar realidades globales en tanto parte de esa postura alternativa, es una retoma geopolítica, lo cual significa concretar el lugar a esas voces que han sido calladas o no escuchadas y que siempre llevarán una pisca de lo marxiano. Todo esto recuerda la pregunta de Einstein (2009): ¿Por qué el socialismo? ${ }^{45}$, pero ese socialismo pensado para la mujer y el hombre, para ser emancipados y que pueda debatir francamente con otras posturas cercanas a sus metas y también que pueda abrírsele espacio para controvertir con las posturas lejanas.

El acontecimiento educativo al reconocerse como pieza clave del desarrollo equilibrado de los pueblos en sus necesidades, logrará acrecentar la solidaridad en términos de complementariedad, llegando a establecerse una Geopolítica de la liberación que, con Escalona (2016) reconoce en la formación educacional de los pueblos y su conciencia de complementariedad con otras formas de educación, una vía exitosa para llegar a la anhelada realización de una educación pensada con y para los pueblos; ahora no para los proletarios a la manera del Marx decimonónico sino de su actualización en la medida en que ahora hablamos de la liberación del sujeto y de los pueblos. De todas formas, lo marxiano tiene mucho que seguir aportando.

${ }^{45}$ Artículo publicado por primera vez en Monthly Review, Nueva York, mayo de 1949 


\title{
SEGUNDO MOMENTO \\ LA IDEOLOGÍA DESDE LO MARXIANO PARA UNA FILOSOFÍA DE LA EDUCACIÓN
}

\author{
"Es ist nicht das Bewußtsein der Menschen, \\ das ihr Sein, sondern umgekehrt ihr gesellschaftliches Sein, \\ das ihr Bewußtsein bestimmt". \\ Vorwort von Zur Kritik der Politischen Ökonomie. ${ }^{46}$ (1859)
}

La teoría marxista de la ideología es una teoría dinámica, mientras que la teoría del reflejo es estática y, por tanto, es ella misma ideológica y no científica.

Ludovico Silva, 2009, p. 99

La sección anterior presentó una ilustrativa ratificación de la existencia de una revolución educativa no ideológica, entendida con Marx y otras perspectivas cercanas a lo sociocrítico. No obstante, sus observaciones severas contra las formas de hacer filosofía, su propuesta de pensamiento es tan abierta, tan enriquecedora que no descuida los finales materiales para la humanidad así sean tildados de utópicos. Él supo que en la formación estaban las claves para el rescate de la sociedad humana de los efectos del sistema de cosas imperante.

La concepción marxiana de las cosas, enfatizándose en lo referente a la formación humana, lograron impactar, extendiéndose en contextos particulares. Queda claro que Marx es uno de los pocos pensadores polifacéticos, él mismo tuvo resquemores con el atributivo de filósofo no menos que con el de filosofía, esto le procuró no pocos contendores. Sin embargo, su pensamiento es filosófico, destacándose en lo social abordado como totalidad. Independiente de lo que quiera decirse contra sus imposturas. Él mismo al ser releído y traido a nuestra realidad, aporta elementos conceptuales, los cuales mas que eso son vivencias.

Después de reconocer a un Karl Marx al que aquí reconocemos como sociopedagogo, respaldado por su vida, su obra y su extensión, podemos adentrarnos un poco en su labor teórica que nunca dejó de estar cimentada en la práctica; es el caso del tema de la ideología. Esta última, es producto del sistema de cosas que a su vez se sostiene de ella. En el acontecer educativo hace presencia la ideología de diferentes formas, pero con el mismo fin: alienar y enajenar, ocultando la realidad para así desistir de la idea de transformación de las cosas.

\subsection{La ideología como interés filosófico en educación}

Tradicionalmente se ha relacionado al término ideología con una forma de militar en el marco de un compendio de ideas, en su mayoría contenidas en un partido político o movimiento que busca el poder o simplemente supremacía o reconocimiento. Lo ideológico es otra cosa, más profunda y extendida. La ideología es una apariencia que trata de imponerse como conciencia. Puede ser que, sin saberlo, se tenga

46 "No es la conciencia de las personas su ser, pero a la inversa su ser social, eso determina su conciencia " 
una visión ideológica de la ideología. Solo a través de la dialéctica de orientación marxiana puede identificarse y develarse esta manifestación que se debate entre el origen abstracto y el material, cuando esto no es lo importante cuando hay escenarios en los que se ven presentes sus consecuencias como lo es el caso del acontecimiento educativo.

¿Qué otra intención es más fuerte en la ideología que la de tratar de hacer pasar lo inmediato como algo real e inmutable? La inmediatez oculta la realidad material. Se trata de la inmediatez ideológica de la cual el acontecer educativo también es nicho. Si bien la educación, en su extensión escolar debe atender los asuntos inmediatos, no se pueden pensar y sanear a los mismos con únicamente dejarlos en el plano de la solución inmediata ya que las situaciones sociales, que son materiales por antonomasia, difícilmente cambiarán si no se dan cambios estructurales. Por ello, pensar con inmediatez tiene un doble sentido.

Aunque parezca frase de cajón, desde la perspectiva marxiana, es definitivamente establecer las diferencias entre ideología y conciencia, lo fue en el campo de la concepción de clase, lo es en el campo de la caracterización de lo revolucionario. Ideología y conciencia revolucionaria (Revolutionäres Bewusstsein), tienen, sin lugar a dudas, una centralidad al momento de revisar la forma filosófica de tomar a la educación con el ojo crítico pero propositivo.

En Latinoamérica el interés por la educación con una mirada propia será tomado, principalmente, por la sociología, muy a pesar de debatirse entre posiciones externas. Luego, la filosofía con matices latinoamericanos dará la batalla por abordar a la educación sin la instrumentalización a la que se estaba acostumbrado; se va a leer, interpretar y hasta transformar - caso de la visión escolar de la teología de la liberación- los entornos no solo institucionales sino a alborotar las estructuras políticas mismas. Y es que se veía que:

La educación como práctica de la dominación, que viene siendo objeto de esta crítica, al mantener la ingenuidad de los educandos, lo que pretende, en su marco ideológico (no siempre percibido por muchos de los que la realizan) es adoctrinarlos en el sentido de su acomodación al mundo de la opresión. (Freire, 1971, p. 72)

Freire con su vigente pedagogía del oprimido (2005), advierte que el hombre no se libera solo, sino con el otro, de lo contartio estaría incompleta dicha liberación. Vasconi (Sf, Sp.) en sus referidas tesis sobre la contra escuela pensada desde América Latina. Resalta que "Los estudiantes, inmersos en el sistema creado por la Escuela capitalista, expresan -en la sociedad contemporánea- de la manera más viva, las contradicciones del sistema".

La ideología será el centro para las visiones filosóficas auténticamente latinoamericanas. También Dussel hará su aporte con la analéctica pedagógica, señalando un rumbo praxiológico, marcadamente ético-político (Santos Gutiérrez, 2016). "La analéctica pedagógica es el camino para la superación y posterior liberación de la alienación del hijo-discípulo ante la ontología de la dominación moderna. Es la metafísica trascendental que va más allá de su mundo" (P. 49). Avanzamos hacia una ontología social como dirá Gould (1983), desde Marx.

Se evidencian dos formas objetivas de ideología. Uno como espectro que merece ser estudiado por sus implicaciones sociales, sobre todo en el acontecimiento educativo que es donde puede apreciarse su presencia y efectos. Otro, es la ideología en tanto categoría que solo servirá para definir dentro de un 
conjunto de cosas una especificidad, o sea un tipo de exigencia taxonómica. Aquí pueden estar las respuestas a la toma consecuente de lo que es, lo que no es y aquello que puede llegar a ser y/o denominarse ideología.

No es recomendable acelerarse en señalamientos hacia la ideología sin tener en cuenta un camino teórico. Tampoco actuar justamente de la manera en la que se crítica. Lo ideológico es una realidad, una socioconstrucción innegable, presente por ser histórica pues, así como existe una ideología dominante es porque hay una ideología dominada. "Toda persona posee pues, su ideología, su manera de actuar ante la vida, su forma de ver las cosas, el mundo, etc.” (Núñez Tenorio, 2015, p. 30).

La ideología desde la perspectiva marxiana es toda una gama de relaciones, de intencionalidades, las cuales pretenden legitimar un sistema de cosas existente. En Marx existió la contraposición entre ideología y ciencia (Bermudo, 1975); de aquí establecerá su teoría sobre la misma. Esta se aplica, o mejor se impone a través de la ideologización en cada uno de los espacios que esté a disposición. Justamente la escuela, la educación, es uno de estos espacios, ella hace parte del problema, pero también hace parte de la solución. La ideología debe ser reemplazada por la conciencia consciente.

La ideología se convierte en una plataforma para lanzar un análisis propositivo sobre la educación. Pero la ideología como punto de interés puesta en comprensión dialéctica, si bien es un tipo de negatividad también su apreciación hace que esta sea descubierta. Desmantelar la ideología como falsa conciencia es una responsabilidad más que filosófica, es una responsabilidad histórica.

Al tratar a la ideología desde su negación propia, se descubren relaciones intencionales cuyo origen no son otros que los dictámenes de poderes supramateriales. Poderes que se materializan en decisiones, orientaciones, posturas frente a la realidad, las cuales son hechas por hombres y mujeres, y no son simples abstracciones, no totales herencias que perviven, sino que son recalcadas en el presente. La ideología es imposición, aunque no se perciba así. Marx, se vuelve contra las apariencias de su sociedad (Lewis, 1989), se convertirá con esto, en un facineroso para los que no gustaban por obvias razones y quienes eran parte del poder político o económico, pero también de aquellos sectores de la población alienados que no podían concebir un cambio de conciencia y menos una propuesta material de cambio. Silva, en este orden, nos comparte:

Esa ironía que no describe primero las apariencias felices de las relaciones sociales para luego denunciar su estructura real y miserable; esa inmensa requisitoria contra la economía clásica y vulgar, a la que acusa con limitarse a describir las funciones aparentes del capital y, por tanto, a ocultar su relación antagónica con el trabajo; todo ello no es sino la aplicación concreta y especial de la concepción general que Marx tenia de la historia. Si Marx era un materialista ello se debía a que siempre se empeñaba en descubrir, por detrás o por debajo de las apariencias ideológicas (Estado, derecho, religión, moral, metafísica) con que nos suelen presentar los hechos históricos su estructura material. (Silva, 2011, p. 114)

Desde campo crítico se cataloga a lo ideológico como imposición. Ella busca establecer patrones de comprensiones de la realidad, casi siempre estáticas, difíciles de modificar desde su discurso. Contra la situación imperante no puede hacerse mucho. Solo seguir reproduciendo la forma de ver al mundo que predica dicha postura ideológica. Al ideologizarse al individuo se ideologiza al colectivo, luego de esto el proceso de desmonte de la ideología es onerosa pero no imposible. Esto último lo comprende el propio 
Marx quien, con su obra, establece más que una importancia, una necesidad de transformación, de voltear la realidad.

Desde la historia de la filosofía, este concepto ha sido tratado de diferentes maneras. El mismo Platón en su alegoría de la caverna, despejó el camino para el inicio de una reflexión práctica sobre el tema del sometimiento y las apariencias. Hegel, así como Feuerbach, de los que bebe y se reserva Marx (Althusser, 1974), tratarán a sus modos el asunto de la conciencia, la ideología y conexos.

Cuando una influencia de la supremacía de ideas a desmedro de otras realidades desconocidas, se vuelven políticas, las consecuencias llegan a ser nefastas, y lo peor es que se desatan tragedias incluso que llegan a justificarse, este es un buen ejemplo del papel de la ideología en tanto desplaza la conciencia misma y solo actúa en favor de un sector. Para un caso inmediato, ha de tomarse en cuenta que hasta algunas interpretaciones filosóficas sirvieron para el sometimiento de mentes y cuerpos como ocurrió en las cruzadas medievales; ejemplo fue la aplicación de la concepción de esclavitud aristotélica que se extendería a la política de sometimiento llevada a cabo en lo que llamaran América. El nazismo que consumió millones de vidas ( siendo asesinado un ser humano millones de veces como se pregonó desde la literatura), reposaba, justificándose en la ideología de supremacía racial. Otro ejemplo competente es lo que ocurrió con la experiencia del socialismo real del siglo XX, sus aplicaciones e interpretaciones desviadas de lo marxiano; así mismo toda la presión, propaganda y persecución de cualquier asomo de marxismo por parte de poderes de todo tipo (Hobsbawm, 2003). Todos estos son, entre miles, ejemplos destacados en la materialidad histórica del hombre.

Siguiendo lo histórico, solo en la modernidad hubo aproximaciones teóricas sobre la misma gracias al desarrollo de nuevas corrientes de pensamiento, las cuales también harán parte de ese gran aparato ideológico como lo denunciará Marx más adelante; no obstante, los compendios teóricos no pierden validez para su estudio. Consecuentemente, las exigencias históricas están de la mano con los cambios y pretensiones de la ideología.

Hoy la sociología ha avanzado bastante en este campo, llegando desde algunas posturas academicistas extremas, a repeler a la ideología al exclusivo campo sociológico que aún conservan algunas posturas desde hace décadas tal cual logra leerse entre líneas en Fernández Enguita (1986b). Entonces, no puede olvidarse que los temas que atañen al ser humano siempre deben ser temas filosóficos, máxime si quieren verse con la crítica marxiana. De hecho, el estudio de la ideología es común a las dos dimensiones como lo son la filosofía y la sociología; y por supuesto a otras disciplinas en una doble relación: una de la ideología como tema de estudio de éstas y, otra como campos de estudio en la medida en que las mismas disciplinas han sido caracterizadas o influidas por el fenómeno ideológico.

En esto último, también se da en la educación, por su propia naturaleza y contenidos, una ideologización de las áreas de estudio que se desarrollan en los espacios escolares en todos sus niveles. La ausencia de la crítica al interior de la academia es un claro indicador del impacto sustancial que puede tener una visión ideológica.

Para el caso que nos avoca, tratar a la ideología con Marx y llegar a describirla en el ámbito de la educación, varía poco con respecto a los contextos del propio Marx. Aquí es donde la filosofía con sus herramientas y 
recomendaciones, puede intervenir para facilitar la comprensión e importancia de tratar las relaciones intrínsecas en la educación del siglo XXI en la escuela latinoamericana tal cual apoyó Gutiérrez (2005) con miras al futuro. La ideología es más que un compendio de ideas sistémicas que defienden una posición, que surge de individualidades en algunos casos, pero que toma fuerza en lo colectivo.

Para escudriñar desde una propuesta filosófica con ingredientes marxianos las verdaderas relaciones que se dan al interior de la educación, solo basta con mirar la situación de esta última. Las consecuencias que se expresan en la sociedad son en su mayoría, producto del sistema educativo el cual está sobrecargado de la imposición ideológica ya sea de manera oficial o aquella que parte de otros ambientes, ya sea el familiar o de círculos cercanos de tipo fraternal o académico, religioso y político.

La ideología en su revisión dentro del campo de la educación, nos llevará a encontrarnos con los conceptosvivencias de alienación y enajenación. Dícese concepto-vivencia, pues traspasan la alienación-enajenación cualquier explicación teórica, ellas mismas son vivencia que se encuentran en los sujetos y las comunidades, producto de esa fuerte presencia de lo ideológico en muchas esferas de la realidad cotidiana.

Desde lo marxiano, el interés que gira alrededor del conocimiento del mundo para transformarlo, de la misma cognoscibilidad del mundo, tendrá sentido en cuanto sea resultado del factor humano, de su intervención, así lo hace saber Schmidt (1977). Aunque Marx sostiene las sospechas en el papel de la filosofía frente a la realidad, sobre todo esa filosofía que nace de la reflexión realizada a partir de una visión ideologizada del mundo, de esa manera de pensar aburguesada de su tiempo, al cual desdice, en cuanto desconoce los asuntos materiales, que simplifica las mismas necesidades mortales, no puede prescindir de la filosofía, sino que la hace protagonista en la medida en que identificándose ella como enajenada debe reponerse y actuar. Reconoce en la filosofía un marco importante, esto se comprueba cuando la recomienda como parte integral de la formación misma de los obreros (Marx, 2000).

Hablar de ideología, de ese sistema de representaciones, de organización mental de las mentalidades, es hablar también del Estado catalogado como principal aparato ideológico. Con el ascenso de la representatividad en las formas de gobernar, precisamente esas formas de la representación son las que han definido no solamente las riendas decisorias de los países - para el caso latinoamericano- sino también las conciencias. Esto es un hecho práctico.

La filosofía con el acompañamiento de otros campos del conocimiento y la practicidad, debe convocar el proyecto de transformación como se consigna en la onceava tesis marxiana (Marx en Engels, 976c-6). Por lo mismo, destacar el papel de la ideología en clave marxiana para una filosofía de la educación entendida desde y para lo latinoamericano, amerita señalar su caracterización denunciando filosóficamente, sin perder la intencionalidad pedagógica y precisamente de generar conciencia, la alienación encubierta por la falsa conciencia se convierte en uno de los pasos concretos que recoge el aporte de Marx más allá de lo que tradicionalmente se relaciona con él.

El mismo ejercicio de retirar la visión ideologizada, desdibujada, de lo marxiano para tratar el asunto de la ideología plantea un ejercicio filosófico y pedagógico que se verá intrínseco en el desarrollo orientador. En defensa de una visión dialéctica pero antagónica, Marx y Engels, plantean el siguiente razonamiento ante los señalamientos ideologizados cuando se pretendió contraponer un estilo social de la educación que amenazaba la típica versión de las clases dominantes: "Werft Ihr uns vor, daß wir die Ausbeutung der 
Kinder durch ihre Eltern aufheben wollen? Wir gestehen dies Verbrechen ein. Aber sagt Ihr, wir heben die trautesten Verhältnisse auf, indem wir an die Stelle der häuslichen Erziehung die gesellschaftliche setzen" 47 (Marx-Engels, 2008, p. 55). El temor por la educación social era apenas lógico, como lo es hoy, para las oligarquías en América Latina; esto recuerda a Guevara (2007a) y su propuesta de hombre y la mujer (2007b).

También, en el Manifiesto, la historia de las ideas es una prueba palmaria de cómo cambia y se transforma la producción espiritual con lo material; las ideas imperantes en una época han sido siempre las ideas propias de la clase imperante (Marx-Engels, 1999). Es por ello que, si la costumbre es que las relaciones sean verticales desde las altas esferas del Estado y su burocracia ideologizada, dependiente siempre -en los modelos dependientes semi capitalistas- se pueda planificar una estrategia para retomar un espíritu distinto. Entonces, el camino de la llegada al poder ha sido la más contemplada para proponer el cambio, ya sea desde el juego proselitista ya sea -como en otros casos- a través de la beligerancia. Pero, también hay que contemplar el inicio generalizado de cambios de base, que hagan resistencia a las imposiciones ideológicas reflejadas en los currículos y legalidades administrativas. La relación puede invertirse, esto es en sí un proyecto pedagógico de liberación que ha de comenzar con la inmediatez de la escuela.

\subsection{La ideología desde una mirada marxiana y sus implicaciones para la filosofía de la educación}

Detectada la importancia de abordar el tema de la educación desde la perspectiva marxiana, junto a esas extensiones socio-históricas que hacen pensar en la validez del legado de Marx más allá, del de un teórico cualquiera adscrito a disciplina específica, puede darse paso a otros aspectos más concretos. "Lo concreto es concreto, dice Marx, porque es la síntesis de varias determinaciones, y por tanto, unidad de lo múltiple ${ }^{48 \text { ", }}$ como cita Lukács (1970, p. 43). Se partió, en la segunda sección, hacia una corta exposición sobre lo epistemológico para tener en cuenta al instante de explorar lo marxiano desde una lectura crítica de la educación, cuyo interés no era otro que el de dar la relevancia merecida a tan importante componente relacionado con el conocimiento.

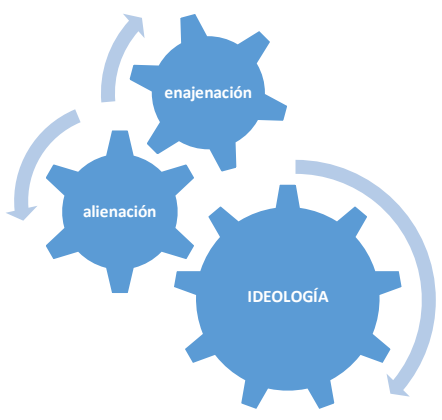

Gráfico No.5. Dinámica de la ideología e interdependencia. La ideología se produce y mantiene a través del movimiento generado por la fuerza de la alienación mental y la enajenación material.

Tocar ideología y praxis tendrá un doble rol: por un lado, porque son categorías presentes en el pensamiento marxiano cuya naturaleza es pedagógica; por otro lado, porque se manifiestan en la realidad material dentro

${ }^{47}$ ¿Nos reprocháis acaso que aspiremos a abolir la explotación de los hijos por sus padres? Sí, es cierto, a eso aspiramos. Pero es, decís, que pretendemos destruir la intimidad de la familia, suplantando la educación doméstica por la social. Trad. de The Marxists Archives.

${ }^{48}$ En Contribución a la crítica de la economía política, p. 289 
del acontecimiento educativo. Esto es válido sobre todo para la comprensión dialéctica de la educación en América Latina que despliega problemas, pero al tiempo una riqueza teórica que se transforma, propone e innova tal como se puede evidenciar en pensadores de renombre.

Los conceptos, o mejor, las concepciones sobre ideología y praxis que están ligadas desde este análisis de la educación con la lente marxiana, sirve como fenómeno u objeto de estudio, son plataformas para la reflexión transformadora en educación vista como acontecimiento político que oculta relaciones pero que a la vez puede ser oportunidad de develación de cambios.

Una filosofía de la educación que transite por la senda marxiana, ha de comprenderse desde su interés social, por esa lectura de la realidad para establecer posibilidades de conciencia transformadora, comprometida; en caso contrario, solo será un periplo teórico más, cosa que tampoco debe despreciarse pero que deja un sin sabor si no existiera el compromiso difusor.

Ahora bien, en este aparte se tomarán algunas categorías trabajadas desde Marx entretejiendo alusiones elaboradas posteriormente; aunque la meta no es exponer teóricamente en que consiste cada una, no podrá evadirse la oportunidad de resaltarlas. La intención es establecer en estas categorías los puntos que sirven para establecer un análisis crítico de la educación a partir de los aportes marxianos.

La lectura del común es creer que la ideología, o mejor la cuestión ideológica está agotada o es anacrónica. ¿Para qué seguir apostando a un término que está directamente ligado a experiencias histórico-políticas fracasadas? ¿Ya no ha hecho su trabajo la sociología y otras miradas de las ciencias sociales e incluso la filosofía sociocrítica?

No es cierto que este tema es agotable, decirlo podría tener dos sentidos: uno que permite encontrar la razón a que es agotable, pues no quiere seguir tratándose a la ideología a pesar de estar presente; esto favorecerá al sistema de cosas que pretende seguir adormeciendo a las mentes; esta razón da sentido a pensar que no se quiere rescatar este fenómeno, o sea, es mejor ocultarlo o negarlo para no provocar alejamientos de posturas debido a los discursos cercanos al radicalismo, ello puede "espantar" cualquier acercamiento con posturas que pretenden ser críticas pero que desechan los aportes marxianos. Otro sentido es, que precisamente es muy finito, ya que en su propia limitación necesita seguir desarrollándose teóricamente; por lo tanto, no merece siquiera pasar del mero anecdotario de pensamiento. La aseveración sintética de Ricoeur (1989), de que las clases dominantes se justifican desde y con la ideología, es acertada, llegando a superar el campo del puro debate de esta misma concepción ya que puede evidenciarse en el cotidiano tal opinión.

En otras palabras, retomar la ideología y la praxis con Marx para invitar a una lectura crítica desde la filosofía de la educación haciendo hincapié en la dimensión política faltante en la educación, para una Latinoamérica convulsionada y aún no definida, cosa a lo cual lo marxiano todavía nos puede dar razón. Eso sí, no olvidando lo que nos dice N. Kohan (Sf.) sobre

La teoría de la ideología no constituye una creación de Marx, quien tampoco inventó la lucha de clases, la teoría del plusvalor, ni muchas otras nociones, conceptos o teorías que habitualmente se le atribuyen por error o desinformación. Él mismo lo deja en claro en su correspondencia con Engels. Los antecedentes de la teoría marxista de la ideología son variados y lejanos. Podría mencionarse como precursor al pensador empirista Francis Bacon, con su teoría de los "ídolos" que obstaculizan el conocimiento de la ciencia. Podría agregarse, quizás, a Nicolás Maquiavelo y sus observaciones descriptivas sobre la manipulación de la verdad en El príncipe. (Sf., p. 60) 
Sin descuidar la referencia, de lo que se trata es de valorar la vigencia del legado marxiano para seguir construyendo la posibilidad de unas formas distintas de educación, como la formación política no ideologizada al estilo hegemónico, una educación que demande praxis. Que muestre a un Marx preocupado por la educación "inmediata", y cuyos trabajos, recomendaciones aún están vigentes y por tanto deben ser dinámicas, transformadas dentro de ellas mismas.

Por lo tanto, la propuesta se encaminará por la vía de la comprensión sobre lo que la concepción de ideología y de praxis pueden otorgar a la investigación en filosofía de la educación desde una perspectiva marxiana para Latinoamérica de manera generalizada. O sea, la retoma de elementos clave que aplican al análisis, crítica y propuesta sobre el fenómeno que toca a la formación del hombre y la mujer.

Acercar a la lectura marxiana de la realidad escolar, de aquellos sujetos del proceso educativo, libre de cualquier macartismo, es un deber de las formas pensadas desde y para América Latina, no para creer que es preponderante, solo por tener elementos teóricos efectivos para repensar todo lo relacionado con la educación. Para esto hay que decir que la teoría de la sociedad en Marx ha de tomarse en cuenta, he ahí la extensión holística cuando se toca lo marxiano; en él puede decirse que, la teoría de la sociedad es una teoría del conflicto (Campbell, 1999). En la sociedad es donde se manifiesta la ideología y a través de ella las caracterizaciones de la escuela en sus diferentes niveles.

Para el caso de la ideología, se expondrá el criterio de Marx, la visión marxista y, entre líneas, la propuesta idónea de latinoamericanos entre los que se cuentan Ludovico Silva. Tomando referencias de terminologías esenciales como alienación-enajenación, Estado y las conexas, me aproximaré a su concreta relación con la educación, sus influencias, negatividades y dialéctica sin olvidar el carácter denunciante de lo marxiano en su apreciación sobre la ideología.

Luego pasará algo similar con la praxis. Solo se tomarán aquellos aspectos que puedan vincularese con una filosfía de la educación. ¿Cómo se piensa desde un filosfía de la educación la praxis? ¿Qué ofrece? Serán interrogantes asumidas al interior del viaje con Marx y lo marxiano. La categoría de trabajo tendrá un sitio especial.

Al final, se dará la relación entre estos dos grandes conceptos-situaciones en el ámbito de la filosofía de la educación. Se propondrá una lectura alternativa que recomiende el apoderamiento de estos conceptos a la hora de pensar y hablar del sentido que debe tener la educación con ingredientes marxianos para proyectarse como una de las bases teórico-metodológicas para reflexionar sobre la escuela inmediata y su papel político.

\subsection{El asunto de la ideología}

Falsa conciencia es para Marx, eso que llaman: ideología; así la presenta en sus escritos. Nos recuerda Silva (1985) que: "ni Marx ni Engels emitieron nunca una definición expresa de la ideología, pero ello no nos impide extraer una caracterización precisa a partir de los numerosos textos que ambos consagraron al tema" (P. 15). Esta acotación puede servir para, precisamente, y siguiendo al espíritu marxiano, justificar la apertura del tema de la ideología al acontecimiento de la formación humana.

La ideología en Marx no es tomada como un concepto solamente, se convierte en una denuncia de su misma existencia. La versión marxiana de ideología parte del mismo Marx. "Se sabe que la expresión "ideología" fue forjada por Cabanis, Desttut deTracy y sus amigos, los cuales asignaron como objeto la teoría (genética) de las ideas" (Althusser, 1989, p. 195). Marx lo utilizará solo cincuenta años después con un sentido distinto, con una aplicación a situaciones concretas de las que pocos habían teorizado. Marx hace una 
epistemología, o mejor, una socioepistemología muy comprometida con la alternativa filosófica -en el sentido reflexivo- para examinar lo ideológico.
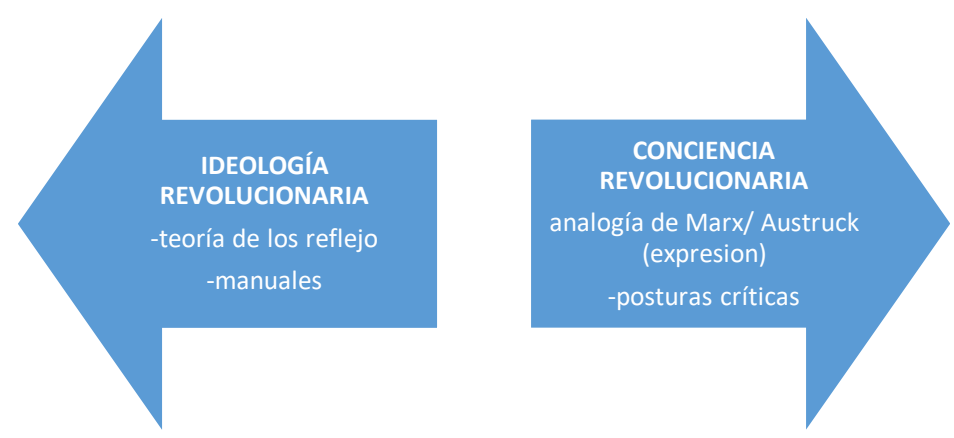

Gráfico No. 6. Ideología Vs. Conciencia. La ideología solo es un compendio de ideas que pueden llegar a ser estáticas, que pueden partir de la doxa y sosotenerse ahí. En cambio, se necesita es la conciencia, la conciencia revolucionaria debe sustituir a la ideología revolucionaria. Así lo manifestó Ludovico Silva.

En Silva (1971), hay una historia accidentada del término ideología. No obstante, dicho accidente es inducido por la misma forma de pensarla ya que obedece a los requerimientos de los poderes materiales de la época y la sociedad. Del Valle, por nombrar un ejemplo dilucidado, aporta a finales de la tercera década de los años treinta del siglo XIX: "todos los poderes tienen influencia muy activa en la educación intelectual y moral. Los representantes de los pueblos, los reyes o jefes, los magistrados y jueces son institutores primeros de las naciones" (1982, p. 98); esto lo muestra desde su percepción experiencial; puede decirse que se adelantó en América Latina, se aproximó a la teoría de influencia de poderes en el acontecimiento educativo.

Para lo marxiano, la ideología podrá leerse en dos sentidos no distanciados: uno, en el sentido conceptual del término que luego empieza a descubrirse a partir de otras terminologías; por ejemplo, con el planteamiento de socio categorías. Marx no soslaya el término ni lo mira como simple peyorativo pues sabe que es algo serio que necesita teorizarse, hasta sus manifestaciones. El otro sentido se da, para hacer pedagogía del término-fenómeno que es la ideología. Broccoli, reconoce que: "nosotros conocemos una sola teoría que se plantee como critica de las ideologías: la marxista. Por eso proponemos una teoría de la educación que se inspire en la misma" (1980, p. 28). Aquí la teoría a lo que aspira es a volverse práctica, y comenzará a ser, será en la medida en que vislumbre las relaciones ideológicas intrínsecas en el fenómeno educativo institucionalizado.

Marx propone que la ideología no es una condición innata, sino que es una consecuencia lógica de un sistema de cosas, por esto, la ideología en su negatividad es superable. Claro es que, en Marx la palabra ideología solo tiene un sentido nocivo. La ideología será retomada como apariencia, como ilusión. Marx no necesita acudir a la ideología (Broccoli, 1980) al momento de recomendar abrir los ojos a la realidad objetiva que de todos modos es construcción subjetiva.

Así Marx defiende, en La cuestión judía y en otras obras, la idea de Feuerbach sobre que los hombres construyen su representación alienada (=imaginario) de sus condiciones de existencia, porque estas condiciones de existencia son en sí mismas alienantes (en los Manuscritos del 44: porque el trabajo alienado, esencia de la sociedad alienada, domina estas condiciones). (Althusser, 1989, p. 198) 
Marx no da un concepto específico de ideología de carácter abstracto, no es su interés seguir viendo metafísicamente este tipo de representaciones sino también demostara su materialidad; lo que si elabora es un diagnóstico, una concepción alternativa y bien cimentada de lo que significa para la vida individual y social del hombre y la mujer, estar bajo la influencia ideológica, que va desde los preceptos religiosos hasta las formas culturales y de consumo. Su interés es la concreción reconocida de la ideología como instrumento de dominación.

Comienza a hablar Marx de ideología en sus obras de etapa juvenil cuando menciona la enajenación (Del Noce y Riestra, 1975), aunque a sus 17 años ya se encontraba en sus cartas esa resistencia hacia modelos idealizados como se puede constatar en Carta al padre (Marx, 1982). No abandona esta categoría en todo su trasegar. Es parte de su proyecto definir que es ideología, alienación - enajenación, haciéndola presentar en las diferentes esferas de la vida cotidiana. Pero Marx no salió de la nada a decir que era lo que significaba la ideología; su teoría es resultado de otras perspectivas, leídas dialécticamente. Desafortunadamente, también se dio el enfoque ideologizado y no la cientificidad a la hora de poner a la obra de Marx al servicio de las situaciones en el siglo venidero (Guadarrama, 2013).

Marx ve su entorno, lo interpreta y transforma la forma de pensarlo. Para ello acude a distintas herramientas filosóficas, pero les da su propia pulida, les retira el óxido, las cauteriza para reelaborar caminos de comprensión. En Los Manuscritos del 44 y La ideología alemana, se encuentra la clave que puede distinguirse la postura marxiana, esa que comienza a alejarse del idealismo de Hegel, lo mismo que complementar la limitada crítica de Feuerbach. Poner el dedo en la llaga de la producción material, convulsionó a crédulos e incrédulos de los dogmas economicistas y sociales que imperaban incólumes de cualquier observación científica.

En 1859, ya observados los fenómenos inmediatos, en su prólogo a La contribución a la crítica de la economía, Marx (2012c), devela en tal contexto, las contradicciones en el seno de la nueva sociedad burguesa, en los distintos ámbitos, sirve para crear sus tesis sobre estas contradicciones y las crisis derivadas, así también para tratar de evidenciar la revolución necesaria para superar la situación generalizada de ideologización, en otras palabras, de alienación. Esa condición tendrá sus orígenes en las relaciones económicas; para él no habrá duda. Por cuanto,

El plusvalor sacó al hombre de la sociedad idílica para convertirlo en una mercancía, el sujeto humano empezó a trabajar para el capitalista, a afianzar la propiedad privada en vez de impulsar una vida de igualdad, de equidad, de libertad. Desde allí comienzan a sostenerse los fundamentos de desigualdad. (Guzmán, 2017, p. 175)

$\mathrm{Al}$ atacar la abstracción manipulada, presentada en las razones económicas dándole importancia al tema del trabajo, dialécticamente, se elabora un abordaje crítico. Así, paradójicamente, la abstracción conducida por un interés intrínseco en descubrir las relaciones ocultas y, al tiempo, evidentes, permitieron planificar el rumbo hacia la ciencia económica para, precisamente, voltear su función como ciencia alienada al servicio de las clases dominantes con su sistema de cosas. Aislar, unir y relacionar elementos, volverlos a reencontrar para construir ese todo social, es clave y allí está el acontecimiento educativo.

La complicidad de las ciencias, fue develada en el mismo actuar científico crítico marxiano, como lo recuerda Gramsci (1970). La economía política comienza a ser social. Y es social porque busca desmontar lo señalado por Marx; estudiar el sistema, generando propuestas, no de gobierno o sistemas, sino de 
comprensión. Las categorías hegelianas y que expresó en obras anteriores Marx, fueron herramientas de aplicación. Esto es revolución conceptual para aplicar en su futuro esfuerzo teórico. Hay entonces, una integridad entre lo estrictamente filosófico y lo político económico que también es filosófico en tanto se hace la reflexión con investigación, con aplicación categorial en búsqueda de la claridad.

El tratamiento de la economía política, le abrió las puertas en su labor para enfrentarse a la realidad hecha de ilusión, de falsa ilusión. En este terreno, luego de dedicación a un contexto definido, difícilmente sus observaciones fueron replegadas. La ideología no está desligada de la producción, esa ingenuidad de que la economía era objetiva y que las leyes de la misma eran eternas inmutables, encuentran en el desmonte de lo ideológico, su principal némesis. El sistema se sustenta en idealizaciones, que a su vez son construcciones humanas. Desafortunadamente, la misma "ley" ideológica no ha permitido -excepto en lapsos de crisis coyunturales- un repunte del análisis desde lo marxiano de la ciencia económica.

Concretament, la enajenación-alienación serán las situaciones que mostrarán la existencia influyente de lo ideológico que mantiene, precisamente, estas situaciones. Existe más allá de las simples relaciones sociales evidentes. Están en función de lo ideológico. "Digamos que la ideología es el instrumento con que la clase social dominante manipula la conciencia de las clases sociales dominadas, para hacer aceptable (natural, justo, bello) el orden social en que se asienta su dominación” (Núñez Tenorio, 2015, p. 31).

La contraposición ideología-ciencia que se destaca, da un especial carisma a la obra marxiana. Pues, se extiende a una de las concepciones más destacadas del momento histórico. Esto da una visión interesante de la propuesta de Marx, quien quiere realizar ciencia y no ideología porque precisamente quiere demostrar que hacer ideología no es hacer ciencia y viceversa como pretendían hacer ver los poderes de facto que influían en la cotidianidad, entre ellos el poder del pensamiento racional encarnado formalmente en la filosofía.

Descubrir la ideología y sus consecuencias exigía abstraerse. Allí estaba presente, convirtiéndose en elemento característico pero negativo, profundamente enajenadora. En el caso de la filosofía, llegó a sospechar que ella misma estaba al servicio de la ideología, que era en sí resultado ideológico cuya pretensión no era otra que mantener los cimientos teóricos del sistema de producción.

La ideología es más que una palabra o un objeto de estudio al que se está acostumbrada a tratar desde la sociología o las ciencias políticas. La ideología para algunos es algo abstracto solamente, eterno e indefinible como lo repasa Althusser (1989), algunas posturas intentan separarla de las relaciones de poder. Para el común cuando se habla de ideología de inmediato se relaciona con las prácticas políticas, programas y formas de ver al Estado por parte de algún grupo humano declarado. El descuido en tratar en este tipo de conceptos crea percepciones equivocas, en esto la escuela y todo el aparato educativo tienen gran responsabilidad, pues es de esperarse que los partidos políticos -francos y declarados entes ideológicos- no superan sus propios intereses de justificación de contenido. Más, aquella de la delimitación partidista, es limitarse peligrosamente en vez de sumergirse en las aguas de la explicación filosófica con intenciones en educación, pero en educación como praxis, como ejercicio político.

La alienación producto de la acción ideológica, a su vez secreta razones para conservar y hasta reproducir ideología. Es un fenómeno cíclico. Por esto pensadores marxianos como Silva establecían tesis tan sencillas 
pero profundas como la existencia de la alienación no es solamente algo propio de la sociedad capitalista (Guzmán, 2017).

En función de lo anterior, la ideología en el transcurso de la materialidad social humana ha hecho presencia, es histórica y si bien se puede afirmar su existencia en abstracto lo que la hace evidente y lógicamente útil, es la manifestación que llega a hacer en las individualidades que conforman colectivos. Es más, la relación entre ideología y trabajo aún es incomprensible e incluso irreconocible como se puede avistar en la todavía valiosa obra de Fernández Enguita (1985); donde la crítica de Marx se presenta para dar importancia al develamiento de este tipo de fenómenos en América Latina.

Dentro del sentir marxista-marxiano de los últimos tiempos, quiero resaltar tres grandes vertientes que han elaborado una teorización sobre el tema que nos toma. Gramsci (2005) (2007a), Althusser (1989) y Silva (1979), han dedicado esfuerzos por destacar la importancia de tratar la ideología, -independiente de sus marcadas diferencias y contextos- como aporte científico de Marx y no como un simple fenómeno cubierto de imaginarios o espontaneidades de un grupo de individuos.

La ideología se ideologiza, con ello se fortalece. Sin la ideologización no habría ideología, y sin des ideologización no habría espacio para nuevos tipos de conciencias. La ideología por antonomasia es conflictiva y antagónica. Entonces, según esto último, encontramos los choques entre formas de ver el mundo; famosas fueron las Cruzadas medievales, el mal llamado descubrimiento de lo que llamarán América, las revoluciones burguesas, las guerras civiles colombianas, la Segunda Guerra Mundial, el bipolarismo, etc. Todo con una evidente carga ideológica la cual, junto al factor económico, han desatado los distintos males representados en guerras, por lo menos así puede leerse sintéticamente desde una visión salida de Marx.

Es difícil, siguiendo a Silva (2009), tratar a la ideología sin que la sombra de Marx esté allí, sin partir de él por lo menos si se quiere abordarla más allá, precisamente de la ideologización académica o infértil cuando se quiere limitarla a un término técnico o extremadamente vulgarizado.

El tema de lo ideológico como instrumento de dominación es clave para medir el grado de ausencia de la conciencia en una propuesta determinada (Varas, 2015). Paradójica y trágicamente, las extensiones de una lectura de Marx, terminaron convirtiéndose en ideologías en el sentido más reprobado por el mismo Marx. Esto provocó los ideologizados señalamientos contra todo lo marxiano, pues si bien no puede negarse una necesidad de conciencia crítica frente a las experiencias que se declararon socialistas, cabe decir que gran parte de los reproches no eran fruto de una conciencia denunciativa sino precisamente todo un arsenal ideológico, a esto le dio correspondencia el mundo socialista, se preocupó más por la contención que el autoexamen.

Sánchez Vásquez (1977), tendrá que decir desde su rescate de la filosofía de la praxis como práctica filosófica, que sabiendo que la ideología dominante ha moldeado las circunstancias, la realidad y por esto hay que desmontarla ya que obedece a una clase dominante; la inversión ideológica deberá darse. Deberá darse la transformación que de todas maneras obedecerá a una clase específica, en este caso la obrera, entonces siguiendo cierta lógica de Marx, deberá montarse la ideología de los trabajadores. En fin. Aquí es donde la postura de Silva (1974), en cuanto al término ideología, destaca de la del pensador mexicano. 
No puede negarse que el proponerse semejante práctica de la filosofía, representa una opción ideológica, claramente expresada en la segunda parte de la Tesis XI sobre Feuerbach. Se opta por la filosofía de la praxis, como nueva práctica de la filosofía, justamente porque "de lo que se trata es de transformarlo" (el mundo). Ahora bien, el optar ideológicamente no es exclusivo de esa filosofía. Se han registrado y se registran otras opciones ideológicas que determinan otras prácticas filosóficas cuando "de lo que se trata" es de conservar el mundo, o de transformarlo limitadamente de acuerdo con los intereses particulares de una clase social. Marx tenía presente una opción ideológica semejante al calificar la filosofía idealista alemana de teoría de la Revolución Francesa. Pero la transformación a la que se vincula la "filosofía de la praxis" es una transformación radical del mundo social, humano, que responde a los intereses de una clase - el proletariado - interesada en una transformación total.

Así, pues, la "filosofía de la praxis" supone una opción ideológica, un punto de vista de clase. Y de acuerdo con esta opción, tiene que dejar de limitarse a contemplar o interpretar el mundo y contribuir a su transformación. La teoría (la filosofía) arranca de esta opción, de la praxis misma y cumple una función práctica, y por esta inserción consciente, buscada, su práctica como filosofía cambia radicalmente. (Sánchez Vásquez, 1977, p. 67)

El manejo del término ideología en el campo marxista es discutido. Por un lado, se quiere mostrar a la ideología como ese medio de presión que impone un sistema de cosas. Pero, al tiempo se utiliza el término ideología para referirse a sus propuestas, a sus ideas políticas. En Casas (1989), se consignaba refiriéndose al socialismo científico, no obstante, la caída del Muro de Berlín que, "la ideología va a ser con mayor razón el arma indispensable, esencial para el análisis teórico y la práctica de la lucha que prosigue contra los restos del capital mundial" (P. 125). En el marxismo, la ideología como tal es asumida. "En la práctica el marxismo se convirtió en ideología para legitimar un sistema como en la URSS (Marcuse, 1971, p. 157), se convirtió en algo que Marx precisamente atacó. La sobre carga ideológica sobre pasó a la acentuación de conciencia de clase.

Con la sovietización del marxismo de finales del siglo XIX europeo, evidentemente los aportes del Marx "filtrados" por la oficialidad se convirtieron en ideología. Se llegó a la ortodoxia de algo que a todas luces proponía heterogeneidad. A ello se sumó el leninismo, luego el maoísmo, y así con otras versiones que, en algunos casos, más que una retroalimentación de lo marxiano fueron manifestaciones de sellos personales como el estalinismo que tuvo émulos a lo largo y ancho del globo (Dussel, 1990).

Por eso, cuando se trata de dividir también temáticamente a Marx, puede intuirse, aunque no se haya caído o enfatizado en corregir el yerro, que se juega a lo que dijo Silva (2009) sobre aburguesar a Marx cuando se le tildaba solo de una etapa filosófica y luego otra etapa científica dedicada a la ciencia económica. No. La intención puede notarse en toda su obra, es algo difícilmente negable. Veamos lo afirmado por él en su Vorwart de la Zur Kritik der Politischen Ökonomie:

(...) Das allgemeine Resultat, das sich mir ergab und, einmal gewonnen, meinen Studien zum Leitfaden diente, kann kurz so formuliert werden:

In der gesellschaftlichen Produktion ihres Lebens gehen die Menschen bestimmte, notwendige, von ihrem Willen unabhängige Verhältnisse ein, Produktionsverhältnisse, die einer bestimmten Entwicklungsstufe ihrer materiellen Produktivkräfte entsprechen. Die Gesamtheit dieser Produktionsverhältnisse bildet die ökonomische Struktur der Gesellschaft, die reale Basis, worauf sich ein juristischer und politischer Überbau erhebt und welcher bestimmte gesellschaftliche Bewußtseinsformen entsprechen.

Die Produktionsweise des materiellen Lebens bedingt den <9> sozialen, politischen und geistigen Lebensprozeß überhaupt. Es ist nicht das Bewußtsein der Menschen, das ihr Sein, sondern umgekehrt ihr gesellschaftliches Sein, das ihr Bewußtsein bestimmt. Auf einer gewissen Stufe ihrer Entwicklung geraten die materiellen Produktivkräfte der Gesellschaft in Widerspruch mit den vorhandenen 
Produktionsverhältnissen oder, was nur ein juristischer Ausdruck dafür ist, mit den Eigentumsverhältnissen, innerhalb deren sie sich bisher bewegt hatten. Aus Entwicklungsformen der Produktivkräfte schlagen diese Verhältnisse in Fesseln derselben um. Es tritt dann eine Epoche sozialer Revolution ein. ${ }^{49}$ (Marx, 1971, Pp. 8-9)

De ese apunte de su Contribución a la crítica de la economía política (Marx 2102c), puede extraerse, la idea general de la conciencia como construcción social. No debe olvidarse que en estos términos la palabra conciencia solo podría utilizarse en la medida en que se presente como esa actitud que procure y defina su postura contrapuesta a la ideología. Entonces, puede concluirse que, desde una lectura marxiana, siguiendo a Silva (1974), no es otra que aquella que contraponga la concepción y práctica de la conciencia no confundiéndola con la ideológica como se pretendió desde algunas posturas que utilizaron el apelativo de ideología para justificar su aversión al sistema capitalista.

Con la implantación del materialismo histórico y el materialismo dialéctico sin una reflexión profunda, sabiendo que ni siquiera fueron términos estrictamente usados por Marx, pasaron a convertirse en fundamentación inflexible del contenido socialista de la oficialidad. Se convirtieron en piezas de la ideología de izquierda olvidando el real sentido de la importancia de distinguir lo teórico-terminológicos con lo marxiano. Sin embargo, aparece quienes como Mariátegui (1959), Guevara (2011), Ponce (1981), Sánchez Vázquez (1988) o Dussel (2014b) además de denunciarlo, se apresuraron a establecer maneras críticas y proponentes y hasta prácticas para el caso América Latina. Mc Laren (2001), destaca la obra teórica de Guevara y Freire con la perspectiva de lo bancario en relectura de la ideología como está propuesto en Varas (2015), son ellos modelos de pedagogía revolucionaria cada uno en su estilo y circunstancias, pero siempre con el mismo fin general.

El tema de la ideología ha tomado distintos matices dentro de las mismas corrientes salidas de la obra de Marx. Sociólogos, antropólogos, historiadores y economistas han manoseado con y sin pinzas, el asunto. La teoría de las estructuras ha sido una de las más apetecidas al tratar de explicar la presencia de la ideología en la vivencia macro social.

Lo cierto es que la ideología está presente. No puede negarse. Lo que hay que hacer es seguimiento, diagnosticarla y prevenirla. Veamos a continuación una comparación entre lo establecido por la visión europea y la de un latinoamericano sobre el asunto de la ideología en el "edificio" mundano.

Es de suma importancia, independiente de las polémicas teoréticas, retomar un poco el asunto de las estructuras y sus subdivisiones. Pues a pesar de todo, este tema ayudará a comprender la onda en la que se ha movido la alusión a la ideología, de su nicho histórico. La sociología, y con ella la sociología de la

\footnotetext{
${ }^{49}$ (...) El resultado general a que llegué y que, una vez obtenido, sirvió de guía a mis estudios puede formularse brevemente como sigue: En la producción social de su vida, los hombres entran en determinadas relaciones necesarias e independientes de su voluntad, relaciones de producción, que corresponden a un determinado grado de desarrollo de sus fuerzas productivas materiales. Estas relaciones de producción en su conjunto constituyen la estructura económica de la sociedad, la base real sobre la cual se erige la superestructura jurídica y política y a la que corresponden determinadas formas de conciencia social.

El modo de producción de la vida material condiciona el proceso de vida política, social espiritual en general. No es la conciencia de los hombres la que determina su ser, sino, por el contrario, el ser social es lo que determina su conciencia. En cierta fase de su desarrollo, las fuerzas productivas materiales de la sociedad entran en contradicción con las relaciones de producción existentes, o bien, lo que no es más que la expresión jurídica de esto, con las relaciones de propiedad en el seno de las cuales se han desenvuelto hasta entonces. (trad. según Marx, 1989, p. 7)

${ }^{50}$ Vorwort. Seitenzahlen verweisen auf: Karl Marx/Friedrich Engels - Werke, (Karl) Dietz Verlag, Berlin. Band 13, 7. Auflage 1971, unveränderter Nachdruck der 1. Auflage 1961, Berlin/DDR. S. 7-11
} 
educación (Fernández Enguita, 1986a), ha tenido en estos conceptos una mina sobreexplotada que ofrece excelentes análisis sobre los marcos ideológicos y su influencia-relación con el acontecimiento educativo en las últimas décadas.

En Aparatos ideológicos del Estado, Althusser (1989) hace toda una exposición sobre la ideología. El sistema se mantiene en la medida en que permite que las circunstancias se mantengan, o sea, se reproduzcan las condiciones, ese es su primer objetivo. En carta a Kugelman, Marx (1976b-9) dice que hasta un niño sabe que una sociedad no se sostiene si no garantiza las condiciones de reproducción de las condiciones para que la sostengan. "Las mismas ideas de Marx ocurren en un plano distinto del material, y ocurren por tanto en la superestructura social, pero no constituyen ideología sino ciencia. ¡Creo que Althusser estará de acuerdo en esto!" diría Silva (2009, p. 109), así dos visiones, una europea y otra latinoamericana se encuentran.

\section{Ideología, moral, política}

superestructura

2 niveles

\section{Iuríidirn-nolítica}

\section{Infraestructura o base económica}

En Ludovico Silva (2009), quien habla del rescate de la conceptualización sobre las apariencias, la relación gráfica puede representarse de la siguiente forma:

Lo aparente:

Edificio social

Ideología

Lo real:

\section{Ideología}

Estructura socio-económica

Mostrándose, en términos generales, un sostenimiento de la superestructura a la estructura.

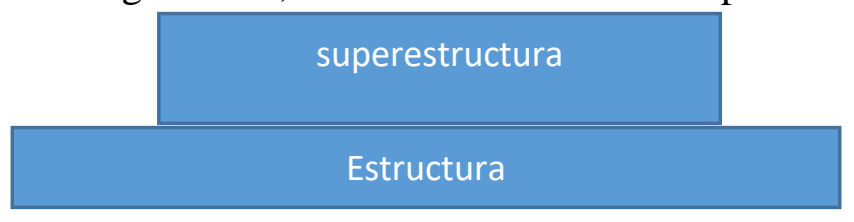

Gráfico No. 7. Sobre estructuras de la sociedad tomadas a la manera clásica de la sociología marxista.

El significado del conocimiento de las posturas teóricas sobre las estructuras sociales, da un avistamiento sobre la relación de sumisión en la que se encuentra un sistema educativo en relación a los poderes reales que ejercen el mandato socio-político y hasta las pautas culturales. Estos conceptos no salidos de forma exacta por Marx, de todas maneras, pueden servir para entender la dinámica socio-política. 
Ocurre lo mismo que con la alienación, que comenzó siendo una metáfora ética y se convirtió, progresivamente, en explicación socioeconómica. Decir el trabajador está "alienado de sí mismo" es, por de pronto, una metáfora; pero pasa a ser una explicación científica cuando descubrimos, guiados por Marx, que la fuerza de trabajo del obrero, al convertirse en mercancía (a lo que lo obliga el régimen social de producción), se convierte en el enemigo número uno del propio trabajador. (Silva, 2011, p. 71)

Así mismo, en la medida en que a través del análisis científico que acude a la historia y a la crítica, descubre los flujos de las estructuras. La imposición se realiza verticalmente de arriba hacia abajo obedeciendo a la visión económica y que sobre el trabajo se tenga en el seno de la dirigencia que controla al Estado. Por tanto, la escuela es un instrumento necesario e importante para la reproducción de las circunstancias alienantes o enajenadoras, para mantener la apariencia social. Aunque difícilmente un sistema político acepte directamente su influencia ideológica basta con la revisión de las leyes, organización y currículos de los diferentes niveles de formación para encontrar los fundamentos ideológicos a los que se circunscribe la escuela, que va desde las visiones epistemológicas hasta las recomendaciones prácticas inmediatas.

Si en tiempos de Marx surgió un interés que llevaría a una toma de posición por parte del proletariado, décadas después, cuyo desmantelamiento peticionado eran formales, vindicación de derechos que señalaban lo siniestro de la acumulación de capital en pocas manos, no se limita aquí la denuncia, no se limita la advertencia marxiana sobre el grave daño que hace la ideología en las mentalidades. Por ello, si bien es cierto que es esencial hacer ver el carácter explotador del sistema en tanto produce ganancia no socialmente distribuida según aporte a la producción (Marx, 1977); lo más destacable es que también existe una producción, una reproducción de conformidad con el sistema de cosas auspiciado con una deformada visión sobre el trabajo ${ }^{51}$ que ya Weber (2008) observaba, esa visión que desplazó la cosmovisión católica romana del trabajo.

Finalmente, hoy no solo sigue la exagerada producción de ganancia a pocas manos, también la implantación de una anticultura del consumismo. La promulgación de libertades y otras falacias, han hecho que este fenómeno sea legitimado a través de los discursos cargados de una doble intención sobre derechos y deberes. La contracultura de la que nos habla Silva (2013) sigue haciendo eco, remarcando las brechas sociales, así como degenerar en el conformismo universal. Entonces, a la par del aumento de capital privatizado está la "ganancia" ideológica que sí está muy bien distribuida entre la población inmensamente mayoritaria alrededor del globo.

\subsection{La denuncia contra la alienación}

Pero, ¿qué es lo importante de abordar el tema de la ideología? ¿Cuál es la relación no tan evidente? Pues bien, el ocultamiento intencional de toda ideología, que además es histórica, se lleva a cabo a través del contacto social y de la influencia de los actores y aparatos ideológicos que martillan de una manera u otras a las mentes, a las conciencias. Es decir, los efectos de una abundancia de ideología se encuentran en la alienación-enajenación que pueda encontrarse en los individuos y en la comunidad. Entonces, lo marxiano es un esfuerzo por mostrar teóricamente a la ideología en esos términos, pero sobre todo denunciarlos, mostrarlos a los sentidos y a la razón, para así generar las condiciones de desmonte de la misma.

\footnotetext{
${ }^{51}$ Visión protestante sobre el trabajo y el señalamiento pecaminosos del ocio, la confusión entre libertad y decisión de labor con
} la vagancia, etc. 
Tratar los términos castellanizados de enajenación y alienación, ya es problémico; no obstante, se debe ser tácito. José Aricó en su presentación de El capital, libro I- capítulo VI inédito de Marx (1984), en la sección sobre enajenación (XV), se refiere al atolladero lingüístico entre los términos claves que: "Lo más habitual es traducir Entfremdung por alienación (influencia sin duda de la palabra francesa aliénation). Más castellana y sobre todo más expresiva (relación transparente con ajeno) es enajenación: puede sostenerse que la preferencia por alienación constituye un claro caso de enajenación lingüística" (P. XV).

Mészáros (2008) muestra cómo Marx, se lamenta del grado de alienación de los trabajadores. Por esto, acude a una forma contra filosófica a la vez que científica para encontrarse con los fenómenos inmediatos, ahora con el robustecimiento que podía ofrecerle otras disciplinas leídas de manera dialéctica. La ciencia garantiza una aproximación a la conciencia. Al ser consciente de la necesidad de alejarse de lo ideológico. Por ello, el análisis marxiano del ámbito económico dio las respuestas que Marx venía buscando sobre algo que parecía solo metafísico.

La alienación en Marx puede ser considerada como un concepto filosófico, pero no al estilo hegeliano, no al estilo especulativo. Es filosófico porque es un concepto de la máxima generalidad, aplicable al entero sistema de pensamiento de Marx y aplicable a toda la historia conocida; por sus raíces, sus basamentos están en toda la teoría económica social de Marx. La alienación es el paso universal del valor de uso al valor de cambio. Esta, y no otra, es la que se desprende de las grandes obras económicas. (Silva, 1983, p. 11).

Ya se ha dicho: la conciencia no influye en las circunstancias, es lo contrario; como primera medida. La anterior es la paráfrasis de Marx socializada en su texto La Ideología alemana (Marx-Engels, 1994). La idea más acentuada en las mentalidades ha sido la que pone a la conciencia como inicio de todo, y no hablo solo de las posturas académicas e intelectuales que históricamente han podido verse, como los casos de la historia o la política. Hablo del cotidiano que es lo importante de toda esta exploración filosófica de la educación como lo apunta también García (2005). Para las mentalidades comunes parece que únicamente se les ha formado en la importancia de la "fuerza" mística de la conciencia, olvidando la influencia de los acontecimientos que rodea materialmente a esa misma conciencia.

Hablar de alienación es tan válido como la explotación, como capitalismo y como hablar de capital. El problema en este sentido, es también un problema de identidad. El rescate marxiano de la alienación, encuentra en este término un gran aliciente a seguir proponiendo una manera distinta de abordaje. Al pasar de un aspecto económico-social a un aspecto antropológico dentro de la comprensión de la sociedad industrial decimonónica, logra extenderse a pleno siglo XXI. Fromm en 1989, comparte:

Parte del discurso revolucionario de Karl Marx consistió en señalar que el hombre se ha alienado en el curso de su proceso de realización personal. Ahora, cuando ha transcurrido más de un siglo desde que Marx expuso este principio, la alienación no ha perdido nada de su candente actualidad; en realidad se ha convertido en un fenómeno global. (P. 343)

La alienación arranca del ser humano su dignidad; en todos los sentidos, el material es el que más se denota afectado directamente, lo que no implica que esta situación no tenga consecuencias en los comportamientos sociales, todo lo contrario, uno de los síntomas más graves: la pasividad y la resignación al sistema de cosas al que "correspondió" vivir.

Cuando el fruto del trabajo no es recuperado por un pueblo, por el trabajador; por la mujer, por el hijo, su ser queda alienado. Cuando el fruto del trabajo del otro dominado, totalizado, se lo apropia sistemáticamente el dominador; cuando dicha apropiación deviene habitual, institucional, histórica, en ese momento la alienación es real, cierta, efectiva: es un modo de producción injusto. (Dussel, 2014, p. 96) 
Por asunto metodológico y de comprensión para esta sección, es pertinente diferenciar entre alienación y enajenación sin entrar a profundidad pues lo importante es tener claridad para hacer con estas categorías una lectura crítica del acontecimiento educativo. Aquí no se evita el tema del trabajo, pues de esa actividad humana es que se puede ver la materialidad del esfuerzo marxiano por descubrir la realidad e invitar a transformarla. La idea no es entablar discusión terminológica, sino asumir lo fundamental.

La enajenación aparece, en su manifestación moderna, con la propiedad privada. Al convertirse en una situación generalizada, generada, la cual busca conservar el sistema de cosas desviando la lectura de la realidad, se convierte en alienación, esta última se va a relacionar más con el tema de la ideología. Pero, valga recalcar, es para interpretación de esta exploración teórica. Así para el fenómeno educativo, ha de hablarse de alienación cuyo desmonte es en sí una praxis.

Silva (2011), al referirse del estilo literario de Marx, recomienda tener en cuenta los juegos intencionales del pensador social, al decir que alienación es la realidad a la que se refiere Marx. Merece ser esta la palabra, sin desconocer que Marx usó también el término der Entfremdung (masc.) que fue traducida como alienación, y die Entäusserung (fem.) como la palabra enajenación; la que puede primar al tocar directamente los temas sobre ideología. Aclara también que no son tanto conceptuales sino verbales los usos de dichos términos. Y cita los Manuscritos de 1844 las alusiones:

Wie würde der Arbeiter dem Produkt seiner Tätigkeit fremd gegenübertreten können, wenn er im Akt der produktin selbst sich nicht selbst entfremdete: Das Produkt ist a ja nur das Resümee der Tätigkeit, der Produktion. Wenn also das Prosukt der Arbeit dei Entäusserung ist, so muss die Produktion selbst die tätige Entaüsserung, die Entäusserung der Tätigkeit der Entäusserung sein. In der Entfremdung des Gegenstandes der Arbeit resümiert sich nur die Entfremdung, die Entäusserung in der Tätigkeit der Arbeit selbst. ${ }^{52}$ (Marx en Silva, 2011, pp. 58-59)

Con lo anterior, queda claro que puede apreciarse una sutil diferenciación entre alienación y enajenación en el campo de la realidad material, que sin lugar a dudas, parte de la relación trabajo-producción-objetivo. En los escritos llamados de madurez se destaca la palabra der Entfremdung (alienación), mientras die Entäusserung (enajenación) es igual de utilizada. Musto (2014), citando a D’Abbiero (1970) ${ }^{53}$, afirma que Marx utilizó los dos términos como si fueran sinónimos; mientras en Hegel eran de distinto significado.

Clásicamente se sabe que la situación alienante se desprende de la situación que pone al hombre como mercancía, sobre todo en su enajenación de su propia intervención en la producción material de bienes y servicios, es decir de la venta de su fuerza mortal de trabajo. Entonces, puede definirse como enajenación esa situación material en la que la persona trabajadora no es independiente de los poderes que determinan al mercado laboral.

Ahora bien, el trabajo es una relación económica o económico-social. Y el joven Marx va a abordar su explicación desde un marco teórico filosófico: la teoría de la alienación feuerbachiana. Y la situación concreta de trabajo, de miseria, de opresión ... será explicada bajo el concepto de "trabajo enajenado". (Bermudo, 1975, p. 107)

\footnotetext{
${ }^{52}$ ¿Cómo podría el trabajador enfrentarse como un extraño al producto de su actividad, si en el acto mismo de la producción no se alienase de si mismo? El producto no es otra cosa que el resumen de la actividad, de la producción. Si, por tanto, el producto del trabajo es la enajenación, la producción misma es la enajenación activa, la enajenación de la actividad, la actividad de la enajenación. En la alienación del objeto-producto del trabajo no hace sino resumirse la alienación, la enajenación de la actividad del trabajo mismo. En, Karl Marx, Ökonomisch-philosophische Manuskripte aus dem Jahre 1844, en Marx-Engels Werke. Pp. 154 (trad. en Silva, 2011).

${ }^{53}$ Ver Marcella D’Abbiero, Alienazione in Hegel. Usi e significati de Entäusserung, Entfremdung, Verüsserung, Roma: Edizioni Dell'Ateneo, 1970, pp. 25-7
} 
Mientras, lo alienante es esa afectación ideológica que busca justificar el sistema de cosas, legitimarlo y legalizarlo. Dar razones válidas a la enajenación es una misión fundamental de la ideología alienante. Aun así, la alienación es una especie de "espíritu" influyente que hace nicho en la cultura y las tradiciones a través de las instituciones y los discursos, más allá de las estructuras que se nombran en el ambiente intelectual que han tratado sabiamente el tema.

En Manuscritos económicos y filosóficos, Marx (Sánchez Vásquez, 2003) discute en sentido crítico las posturas de Hegel:

Marx reprocha a Hegel que no haya tomado bastante en serio a la alienación verdadera; que sea culpable de un "idealismo acrítico" que pueda transformarse fácilmente en "positivismo acrítico", listo para vindicar la verdadera vida alienada en el preciso instante en que cree haberla sometido intelectualmente. (Fromm, 1989, p. 353)

En Hegel (2010), la alienación se retoma al ámbito humano; es tratada como esa separación a la vez como alteración. Si bien en Hegel se realiza todo un sistema del cual se alimenta mucho el Marx preocupado por el análisis filosófico, como buen practicante de la filosofía, no se encasilló; extendió a la realidad inmediata lo elaborado por el idealista alemán. Categorías como extrañamiento (que será la enajenación), darán forma al legado crítico marxiano. Marx transforma la objetivación de Hegel, recrea la realidad con la mirilla de la alienación como interpretación. Con razón Broccoli (1980) destaca a la Fenomenología como un aporte para la comprensión de una filosofía de la educación marxista, pues esta obra en sí era una novela pedagógica.

La dilucidación social de la dialéctica del amo y el esclavo se puede aplicar a la realidad escolar, a la que no escapa esa realidad que es la alienación. El abordaje hegeliano del trabajo que sería revolucionario para ser señalado en un pensador tan estudiado como Hegel, ha de encontrarse en lo elaborado por Marx. Además, el concepto de totalidad, donde el "todo social" del que habla Marx, lo aleja del todo hegeliano (Athusser, 1989) al enfocarlo a las apariencias que dominan el mundo social humano. La importancia de lo social en las categorías es lo que hace especial lo marxiano.

Hegel es el primero en enfocar el problema de la enajenación como problema fundamental de la posición del hombre en el mundo y con respecto a él. Pero la enajenación es para él, al propio tiempo, con el término de alienación (Entäusserung) la posición de cualquier objetividad. Si se la concibe coherentemente, la enajenación se identifica así con la objetividad. En la medida en que supera la enajenación, el sujeto-objeto idéntico debe superar al propio tiempo la objetividad. Pero puesto que el objeto, la cosa, existe para Hegel solo como alienación de la autoconciencia, su reasunción en el sujeto representaría el fin de la realidad objetiva y, por ende, de Ia realidad en general. Ahora bien, Historia y conciencia de clase se alinea con Hegel en el sentido de que también en este libro la enajenación está situada en el mismo plano que la objetivación (para usar la terminología de los Manuscritos económico-filosóficos de Marx). Este fundamental y burdo error contribuyó ciertamente al éxito de Historia y conciencia de clase. Como ya dijimos, desenmascarar la enajenación era un problema que se estaba discutiendo y que poco después se convirtió en una cuestión central de la crítica de la civilización, que estudiaba la condición del hombre en el capitalismo del presente. Para la crítica filosófico-burguesa - baste pensar en Heidegger - era absolutamente obvio sublimar la crítica social en una crítica puramente filosófica, hacer de la enajenación en su esencia social una eterna "condición humana", para usar un término que se puso de moda más tarde. (Lukács, 1970, p. 20)

La anterior síntesis correlativa alrededor de la enajenación desde Lukács, es un claro caso del abordaje de este tema filosófico que no puede dejar de ser tocado desde una filosofía de la educación que propenda por la aplicación de la praxis. Para Lukács, la conciencia de clase está estrechamente ligada a la historia que ha de superarse, naturalmente, so pena de arrebatar el sometimiento ideológico impuesto por el sistema de cosas. La objetivación pasa a ser interpretada para conducir a la toma de actitud, o sea, de conciencia. De 
ahí la denuncia sobre la misma manipulación de categorías en pro de un desconocimiento real y superable de una situación concreta como lo es la alienación.

Hay que comenzar por advertir que cuando Marx habló de «formas de la conciencia social» no empleaba
la palabra «conciencia» en el sentido que hoy le damos nosotros y que la separa radicalmente de la
«inconciencia». Marx empleaba la palabra «conciencia» en sentido hegeliano. Así, la ideología era una
«conciencia falsa», que es algo que nosotros no llamaríamos propiamente «conciencia», sino más bien
todo lo contrario. (Ludovico, 2009, p. 107)

En consecuencia, plantear la cuestión de la formación humana en los términos de conciencia se proyecta en responsabilidad social, lo cual desde Marx va más allá de un derecho promulgado por el pensamiento liberal proclamado por la clase burguesa de su época y el cual se ha prolongado hasta nuestros días. "Una de las primeras preocupaciones de Marx fue de hecho la alienación del proletariado. El proletariado vive enajenado, dedica su vida a hacer cosas que no son para él, que él no consume y cuyo destino desconoce" (Barylko, 2005, p.191).

Claramente, el desmonte de la idea instrumental de la educación como medio de "superarse" exige una acción teórica que puede encontrar respaldo en la situación de inversión que se hace de la misma educación tradicional. Es decir, el superarse está supeditado a las circunstancias materiales que pueda propiciar el núcleo familiar, la fuente de trabajo o el Estado financiador.

Al hablar de filosofía con Marx, se trata sobre del examen crítico al que debe exponerse toda la realidad para así conseguir una conciencia de transformación de esa realidad si es negativa, si es nociva para la convivencia social, si interrumpe el desarrollo libre y responsable del ser humano visto ya no, este último, como mera máquina o individuo inerte dentro de un espacio.

"En Marx existen las alienaciones fundamentales, estas son: la religiosa, la filosófica, la política, la social y la económica" (Del Noce - Riestra, 1975, p. 28). Contra ellas existen caminos para ser contenidas o por lo menos identificadas para poder, dialécticamente, superarlas a la forma que recuerda la propuesta hegeliana. Interés marxiano es formar en la emancipación, y para ello de suma importancia es la caracterización que presentan los tipos de alienación. Únicamente, conociéndolas se pueden desmontar a través de la praxis denunciante y transformadora.

Sin olvidar lo mencionado arriba, está la perspectiva marxiana que desarrolla la postura de alienaciónenajenación correlacionada con su origen en el trabajo humano y su saqueo. Esto evidenciará la transversalidad de la idea de estas categorías en los intereses socio denunciantes de lo marxiano.

Marx (2012a) en 1844 destacará los conceptos que salen de su ropaje abstracto para manifestarse, en la cotidianidad. Podrá verse que su esfuerzo de comprensión tocará a futuro toda la concepción del mundo del trabajo en su relación con las dinámicas sociales y el juego real de la vida material. Los cuatro aspectos de los que tratará Marx serán: "la alienación del trabajador con su producto, la alienación de la actividad del trabajador, la alienación del trabajador con la especie o consigo mismo, y la alienación del trabajador con las demás personas" como lo apunta Martínez (Sf.)

Para tener en cuenta, el primer término, esto es el fenómeno que se presenta en la alienación del obreropersona con su producto material -en el que invierte su vida física, emocional y mental-, la cosa que se produce es inmediatamente propiedad de quien paga por el proceso al que se somete la cosa. La producción es enajenada. Así mismo, funciona la cadena donde el obrero se convierte en consumidor y gasta el salario, 
se une a la cadena básica de la economía y, por tanto, de la sociedad. El sometimiento llega a su máxima expresión y difícilmente es detectada; en esto último el protagonismo de la ideología es notable.

El segundo término es aquel que reconoce a la actividad alienadora que puede llegar a ser el trabajo que ya de por sí, desde la producción material centrada en otros intereses cerrados, ya es enajenador. El tiempo, la salud y su mente, ya pertenece a quien ofrece dinero a cambio de su fuerza de mediar la naturaleza, de forzarla, es decir, de su fuerza de trabajo. Cuerpo y espíritu ya no pertenecen totalmente al hombre. He aquí la contradicción lógica: mientras se produce ganancia para una persona o agrupación, se genera miseria, dependencia y pobreza de todo tipo en la masa trabajadora que renuncia además a su capacidad creadora.

Tercer término esn el relacionado con el trabajo que ya está enajenado; hay así una relación de alienación en el propio sujeto trabajador con la idea general de hombre, consecuentemente consigo mismo. Por lo menos así se consigna en Marx (2001).

En cuarto término, está la situación enajenado con relación a los demás sujetos, con los otros hombres (Marx, 1982c). Ésta se encontrará en las esferas sociales. La escuela será reproductora de esta situación para la crítica marxiana. Por muchas razones, y de distintas maneras que, van desde la postura familiar hasta la formación más intelectual, los efectos de la alienación se harán notar además que siendo su fin encumbrarse y auto justificarse para no ofrecer ninguna actitud de cambio de cosas, si acaso asomos de reformas, eso sí, según las posibilidades y sin perjuicio del stablishment.

Ahora bien, en cuanto a la alienación y la enajenación, ha de aclararse que se tomará a la alienación desde su concepción inmaterial reflejada en la ideología o mejor en la influencia que los fetichismos ejercen sobre las mentalidades. Y la enajenación será esa extensión material del desposeimiento de lo que en principio es propio, es una condición económico-social de arrebatamiento en muchos casos reconocida como ocurre con el trabajo cuando se vuelve ganancia para otro ajeno al esfuerzo directo. Ya en los Grundrisse (Marx, 2006), hará reclamos y ofensivas hacia los economistas de corte burgués. Desde allí, les denunció "por cometer un error garrafal semejante al que él reprochaba a Proudhon en 1847: el error de confundir objetivación (Vergegens tándlichung) con alienación (Entfremdung)” como lo acota Silva (2009, p. 76).

Por ello, Marx pone a la economía política como alienación, es un ejemplo ilustrativo al reconocer que toda esa teoría del sistema económico solo busca defender un sistema de cosas que sobrevive gracias a la negación de las facultades humanas para beneficio de un sector supremamente reducido. "Esa es una de las características de la estructura económica de la sociedad contemporánea (...) El fetichismo no sólo es un fenómeno de la conciencia social, sino del ser social" (Rubin, 1974, p. 108).

El fetiche de la mercancía y la propiedad, nada en los mares de la conceptualización, para aprehenderlos en su negación, hay que aprender a pescarles. Por esto se trae a colación el siguiente aparte:

A diferencia de Hegel, Marx distingue la objetivación de la alienación: aunque para Marx toda la alienación es objetivación, no toda objetivación es alienación, sino sólo cuando a la objetivación se añade la propiedad ajena. De ahí que para Marx toda alienación del hombre parece ser, en el fondo, alienación del hombre respecto a otro hombre (es una relación humana), como dice ya en los Manuscritos, o respecto de una totalidad en devenir (Del Noce - Riestra, 1975, p. 92).

Para Marx, según Abaggnano (1964), "la sociedad capitalista, que ha dividido netamente capital y trabajo, arrebatando a los trabajadores la disponibilidad de lo que producen, ha determinado una laceración interior, una escisión o alienación en la personalidad humana misma” (P. 502); esto quiere decir que esta categoría nace explícitamente de las relaciones materiales. 
Sobre las apariencias y el intento de explicación de otras cosas, los estructuralistas del siglo XX y los ortodoxos hicieron cada uno por su parte, toda una teorización para explicar lo que ellos consideraban clave: las estructuras y el resto de subyacentes. En fin, muy a pesar de no desarrollar el asunto por parte de Marx, esto se prestó para intentos interpretativos que poco tuvieron que ver con una posible aplicación neta de lo marxiano. Por un lado, se llegó al estado líquido y por otro al solido sostenimiento de lo dogmático.

La medida en la cual la conciencia no se hace consciente de la situación alienante, o en aquella situación donde la consciencia es consciente de esa alienación pero no comprende que es tal, ni su profundidad y muchos menos el impacto social de esa consciencia de alienación, o sea de una conciencia conscientemente alienada que en ultimas define una actitud reaccionaria pero sujeta por esa misma naturaleza a la sumisión y al miedo al cambio; determina fácilmente la acción de los factores ideológicos impregnados en el ambiente. Uno de esos factores es el modelo de enseñanza-aprendizaje impartido por la educación dentro de un sistema de cosas.

Marx ejemplifica la situación desde su país, echando la culpa a la alienación. Pone especial atención en esa situación negativa dentro de la filosofía. Al hacer observaciones sobre la situación de Alemania o Prusia, de las revoluciones no producidas, todo se debe a "una situación alienante, y su causa está en la filosofía. Por eso, antes de criticar la alienación política hay que suprimir la alienación en la filosofía" (Del Noce 1975, p. 19).

En palabras tradicionalmente pedagógicas, un tipo de ignorancia consciente - pero no solo aquella que está relacionada con la ausencia de conocimientos- frente a las situaciones sociales es resultado de los procesos de aprehensión, pero yendo a la raíz se encuentran serios indicios en los modelos educativos. Esto pasaba en tiempos de Marx y sigue pasando todavía.

Una ignorancia consciente que no despierta interés por reivindicar el sentido más adecuado de la realidad, de crear crítica, determinará la permanencia en un estado no solo de minoría de edad como dirá y buscará decir Kant desde la pedagogía (1986), sino que además se reflejará en el resto de los individuos, la transmisión de esa actitud no permitirá fácilmente el desligue alienante. Así las cosas, solo quedará dejarle a las supraestructuras, cuya atención será la más mínima, evacuar este tipo de fenómenos, pues cuanto más se esté en condición alienante menos cerca se estará del fin de un Statu quo.

Paradójicamente, la alienación puede tener un sentido pedagógico, una pedagogía de la negación podría erigirse desde este estado subjetivo. La alienación no es innata no se nace con ella, es provocada, intencionalmente en su fuente, pero transmitida de manera inconsciente en las relaciones cercanas de los individuos que pueden ser, por ejemplo, las relaciones familiares. La observación histórica y el examen de los imaginarios pueden hacer de la alienación una justificación para girar hacia el cambio de mentalidad.

La cuestión es si estos cambios deben partir de la materialidad o de las ideas o, al contrario. Desde lo marxiano puede leerse a partir de la dialéctica. El verdadero problema es hasta dónde los sujetos conscientes que crean o derrumban instituciones, serán capaces de orientar los caminos de una comprensión del estado de alienación, así como la necesidad de su superación.

La alienación ha de ser descubierta para contrarrestarla. Ese descubrimiento puede ser liderado por la educación liberadora que caracterice la importancia de conocer los procesos socio-históricos para entender la urgencia de la transformación pues en tanto situación socio mental, la alienación es el combustible para que el motor de una aparente situación normal siga siendo entendida y racalcada, como algo normal. 
Lo marxiano no se conforma con elaborar una teoría sobre la alienación que partía de Hegel. En los términos marxianos la alienación tiene una relación estrecha con la producción material basada en el adueñamiento del otro, sobre todo de sus capacidades físico-mentales; apegada a la historia, por esto es asunto material que debe tomarse en cuenta a la hora de pasar a la praxis. Los modelos imperantes son proclives a establecer idearios para sostenerse. La historia de las resistencias es una historia contra alienación. Precisamente esa alienación impide la felicidad del ser humano, limitándolo en su creatividad (Barylko, 2005).

Combatir la alienación debe alejarse de los métodos que precisamente utilizan las formas de alienación. No obstante, sin contar con los espacios que se han prestado para dicho fin. En otras palabras, la educación ha de revolucionarse, esto se logrará en la medida en que se emancipe ella misma del sistema imperativo; liberarse de la mercantilización a la que ha sido sometida es una necesidad básica para lograr emprender la senda de la emancipación humana y de la proyección de la educación como herramienta para consolidar los derechos y deberes universales, no alienables.

La visión sovietizada borró las metas de emancipación formativa. El socialismo real olvidó el mensaje marxiano. Esta experiencia política lo que hizo fue burocratizar al extremo el aparato estatal, olvidó muchos principios para lograr a través de la formación una aproximación al hombre y la mujer de carácter revolucionario. El enfoque puramente economicista de planificación centralizada no tuvo en cuenta el impulso de una producción de la industria liviana y de bienes y servicios; además, olvidó algunas pautas conceptuales desprendidas del pensamiento de Marx, esto facilitó una reacción negativa al exterior y una inconformidad interna en las masas.

"El socialismo real redujo la explotación económica mas no la dominación sociopolítica ni la alienación" (Dietrich, en Guerra, 2007, p. 66). Se dio un fenómeno cuestionable desde todo punto de vista, el cual no será dejado de echar en cara por las reacciones y que tiene que ver con esa alienación dada en el seno de quienes se amparaban en una forma revolucionaria que se suponía debía transformar lo negativo: "el fetichismo de la mercancía fue reemplazado por el culto a la personalidad, la deificación del líder, quien solía ser primer secretario del Partido Comunista, jefe del Buró político y primer ministro, simultáneamente" (Guerra, 2007, p. 70).

Otro terreno es el de la religión (el cual no debe confundirse con la espiritualidad). Marx retoma el tema de las creencias religiosas, ellas son precisamente, ejemplos muy cercanos y bien camuflados de la alienación. A lo sumo, la escuela apenas puede ser un lugar que puede darse como espacio de políticas seculares pero que difícilmente no está inmersa en la influencia de las religiones, eso sí, hablo de la escuela financiada directamente por los Estados u organizaciones religiosas

\subsubsection{El caso de la religión}

El caso de la religión como forma alienante ha de leerse con mucho cuidado. Si bien la religión en su manifestación institucionalizada dice garantizar el contacto con lo divino, dice ofrecer la vida eterna en otra dimensión, esto hace que la conciencia humana se repliegue de sus intereses terrenales. Las lecturas marxianas sobre la religión son muy críticas; el lema de Marx sobre el "opio" de los pueblos sigue causando resquemor entre las personas creyentes de todo el mundo. Más la propuesta marxiana es precisamente despojar al hombre de todo manto divino y entenderse como parte del mundo, de ese mundo que vive y sufre, de ese mundo que ha sido fruto de la intervención humana. Si se acerca a la visión marxiana, su 
pretensión no es más que llegar a un estado de conciencia que separe lo terrenal de lo mítico, siendo entendido aquello, el ser humano puede hacerse más espiritual que religioso. La alienación aliena al mismo espíritu.

La religión es creación humana, no hay duda de eso. Es más, gran parte de la hisotria de las religiones está ligada a formas de cver al mundo, de someterse a predicamente que parecen invariables, o a poderes terrenales que se declaran ungidos por las divinidades, por un ser supremo. Detrás de esto existe toda una gama de intereses económicos y políticos. No puede desconocerse el gran legado de muchas religiones, y lo que pueden aportar, pero siempre delimitando, midiendo los grados de ideología que pueden tener.

Si bien la religión en su expresión más recalcitrante e intolerante aliena, cabe ser muy prudente para llegar a una dialéctica abierta a la tolerancia de credos. Hoy la espiritualidad es un derecho individual y es deber humano respetarla, pero también respetar la no injerencia de la religión en asuntos del Estado o en las vidas, tradiciones y formas de ver el mundo de otras formas de pensar o creer.

La teología de la liberación, para el caso de algunos lugares del mundo, supo dirimir este posible antagonismo entre lo marxiano y la religión. Pues se tomó una lectura consecuente de la obra marxiana y la realidad de los lugares que padecían las inclemencias del sistema de segregación social cuya base de sostenimiento eran precisamente esos lugares de la periferia.

El reconocimiento de la alienación implica una labor pedagógica en sí. Marx en sus obras trata el asunto de manera recurrente. Su propia vida fue una resistencia al sistema de cosas que incluía la relgión. Con todo lo que pueda decirse contra su posible descuido de otros asuntos - hasta los familiares que se utilizan de manera falaz-, la fuerza vital que reposa en cada ser humano puede hacerlo constructor o destructor de su propio destino y el de los demás. Entonces, la alienación se convierte en un asunto que traspasa lo personal al hacerse sentir en el campo espiritual.

En en acto práctico de la educación, lo marxiano plantado en nuestra realidad inmediata no pretende negar la existencia y el derecho a la espiritualidad; todo lo contrario. Es adquirir una conciencia de reconecerse como ser libre y espritual, profese la creencia que quiera profesar. En lo que debe orientarse el papel de una propuesta filosófica marxiana es, en contener las osturas dogmáticas que proceden de la ideologización de las religiones, cosa extremadamente difícil por la misma esencia del tema y por su rezago histórico.

No se trata ni de seguir imponiendo las creencias religiosas por encima de la vida académica, ni de academizar la religión, se trata más bien de apertura y de reséto por los espacios. Hacer de espacios como la iglesia o las congregaciones, escenarios más de reflexión social y política, es un desafio que debe sobrepasar las murallas físicas de las instituciones educativas. No se trata de inmiscuirse en discusiones religiosas, pero sí de generar un diálogo cosntructivo con un fenómeno social en crecimiento como lo es la eclosión de credos de fe.

\subsection{Filosofía de la eduación y alienación}

Si las condiciones no cambian será difícil que el cambio de mentalidad, el cual ha de ser autónomo y responsable, se dé. Así mismo, si no existe un acercamiento a la crítica, las individualidades no podrán exigir los cambios. Esta relación dialéctica deja una paradoja, pues la consecución de un desmonte siquiera gradual de la alienación, está sometida a un flujo de arriba hacia abajo y de abajo hacia arriba. De todos 
modos, parece que las cosas no superarán la acción de la voluntad de las dos grandes esferas en las que se mantienen las sociedades: el espacio supraestatal y las masas que reciben toda la influencia.

De todas maneras, podemos rescatar de Marx, al respecto la idea de poner a la teoría como un arma. Las armas de la crítica a las que Marx (2012c, en Fromm, 2002) adujo en su Introducción a la Crítica a la filosofía del derecho de $\mathrm{Hegel}^{54}$, ayudarán a interpretar el conjunto de fenómenos que generan a la alienación y que también ésta produce, aunque en él está la esperanza del derrocamiento del sistema.

Por decir, de otra manera la alienación suele pensarse como ese estado en el que la persona no es, para el caso de la relación obrero-trabajo, dueña de su propia labor, no es dueña de su esfuerzo físico o mental, además de no superable. La persona vende su fuerza de trabajo, invierte su tiempo y salud en la mercancía, el propietario vende y recoge la ganancia que no le es por naturaleza inmediata. Solo a través de la institucionalidad política de la propiedad logra adueñarse jurídicamente de la ganancia. El propietario compra la fuerza de trabajo a un costo que no implique perdidas a sus ganancias y que logre dejar consciente al obrero de la "justicia" de su salario u otro tipo de pago.

A pesar de existir una relación aparentemente justa, lo que hay es una relación de explotado y explotador; relación que se profundiza en la alienación del sujeto. El sujeto es tratado como cosa que impulsa un proceso, que lo facilita, pero nada más. Psicológicamente el trabajador ya se siente una pieza más del engranaje más no se da el lugar que debería darse. El individuo alienado no tiene la capacidad de objetar, pues no tiene un contacto la formación antialienante.

La relación con la naturaleza no es independiente, las necesidades pueden cubrirse con la naturaleza de manera primaria, entrando en contacto directo con ella pueden encontrarse los elementos básicos. Más cuando surgieron otras necesidades surge entonces la industria que se especializa en la producción de elementos que cubran esas necesidades extendidas. La industria recluta seres humanos, estos producen riqueza con su trabajo a través de la creación de mercancías que a su vez deben ser consumidas por los individuos. El trabajo físico e intelectual ya le pertenece al sistema de cosas por medio de los propietarios y la legislación que ha enajenado. Esta enajenación es material, tiene sus efectos inmediatos en la baja capacidad de adquisición de bienes y servicios precisamente por parte de quienes protagonizan los procesos de trabajo.

El hombre y la mujer ceden su libertad sin darse cuenta, o por lo menos dándose cuenta, pero sin pasar del estoicismo práctico del cotidiano sin dejar de encontrarse incluso, un pensamiento de resignación cercano a un tipo de predestinación que no puede desafiarse. Solo aumentar el tiempo de trabajo podría garantizar otro ingreso extra para sostener un modus vivendi mínimo. Esto último lo vivió y viven las clases trabajadoras. Sacrifican el tiempo de sus vidas, el tiempo que pudieran compartir con su prole, el acompañamiento familiar tiende a desaparecer y con esto la serie de problemas derivados de esta situación de otorgamiento de plustrabajo en beneficio de terceros. Todo esto lo establece teóricamente lo marxiano, y no se equivoca en dichas observaciones al observarse la reacción en el "laboratorio" de la sociedad que es el cotidiano.

${ }^{54}$ De la Introducción a la Crítica de la filosofía del derecho de Hegel. critica de la religión 1Tomada de La sagrada familia, Editorial Grijalbo, México, pp. 9, 10 y 11. Trad. de W. Roces. 
La pérdida de tiempo es la peor forma de enajenación, esto puede demostrarse en los Grundrisse (GonzálezGonzález, 2008). Recordando que el ser humano es un ser finito, no longevo, muy susceptible con la exposición al ambiente, proclive a hospedar enfermedades de todo tipo; el constante tiempo, se convierte en variable que solo podrá, en su gasto subjetivo-no inversión- acrecentar las relaciones de dominación. Su vida se dedica a satisfacer las necesidades de terceros. Además, esto tiene una problemática social que se desarrolla en las personas que o bien no quieren ser insertados en el sistema de trabajo y conseguir recursos con acciones delictivas o aquellas que simplemente se dedican a la mendicidad. Otros sectores, se dedicarán a las labores informales del comercio.

La alienación no permite darse cuenta de eso que sucende de manera inmediata, sino de forma distorsionada. Los distractores sobreabundan en la sociedad del consumo, en la sociedad que pone los valores creados a partir del trabajo enajenado por encima de los valores humanos. Moralmente está bien visto que un individuo dedique gran cantidad de su tiempo al trabajo, el asunto que se oculta es que ese trabajo será, en la mayoría de los casos, enajenado. De todas maneras, la enajenación es impuesta pues hace parte esencial del modelo de producción capitalista, su negación es la negación de la realidad real, obedece a una racionalidad y por ende es real, existe y causa mutaciones sociales acompañadas de efectos negativos.

En el campo de la educación, los rastros de la alienación educativa se manifiestan en las prácticas inmediatas de la escuela perfeccionándose cada vez en regiones como América Latina (González, 2015). Hay que decir que existen dos grandes fuentes de ésta. Por un lado, aquella alienación que hace parte de la postura ideológica oficial de un sistema y que se enquista en los llamados currículos ocultos; hacen parte de la política gubernamental, en muchos casos está soterrada, propende por un doble discurso; crea prototipos y eleva ejemplificaciones fácticas pero la inversión en el ramo de la formación pertinente se limita los criterios que dicte la tecnocracia economicista. Se ve a la educación como gasto y no como inversión, se tiende a favorecer al sector privado sobre el sector oficial.

La alienación penetra a los actores educativos, extendiéndose a los núcleos familiares, ofreciendo la idea de la superación sobre las dificultades, generando poquísimas posibilidades de superación y sobre todo de conciencia. También se nota en la institución educativa de la mayoría de los países la utilización a ultranza del ideario de "patria" que defienden las clases dominantes. Aquello sirve para limitar las mentes a una versión de la historia y la política que conviene al Statu quo, una versión que no merezca críticas, cuya oficialidad sea el mejor argumento para no pensar en un cambio de cosas.

La otra fuente que permea a la escuela y que de alguna manera está ligada a la gran fuente oficial, es aquella que desarrolla todo un fetichismo alrededor de la individualidad extrema. La mentalidad alienada en el actor pedagógico-académico encarnado en el docente que ha sido expuesto y por conciencia no asume su papel protagónico y transformador, de compromiso social, es la otra fuente directa. Cabe aclarar que la desesperanza es uno de los alicientes para renunciar o para no acercarse a la visión crítica que ha de tener la educación. Así mismo, el desconocimiento de las relaciones que hay detrás de los sistemas macro y microestructurales agravan la situación.

La alienación educativa se manifiesta cuando la educación demuestra que ha perdido su horizonte, sus metas humanistas y sociales. Los procesos se convierten en vez de un goce colectivo y de crecimiento individual, en unas exigencias de tipo instrumental, de requerimientos estandarizados y cifras a cumplir.

Por ejemplo, las políticas de masificación de la educación sin detenerse a repensarla son contradictorias como lo vio Guevara (1965) desde su vivencia, pues si bien desde lo marxiano se defiende la inclusión, así 
como la educación-formación de masas han de especificarse los medios materiales para que esto no se confunda con el hacinamiento y la uniformidad absoluta en detrimento de los intereses de una comunidad, de una sociedad que se mueva por el bien común. Entonces, cuando se encuentra un número exagerado de individuos, obligados a recibir durante periodos de tiempo unos contenidos, ya se atenta contra la calidad humana que debe reinar en los espacios académico-formativos. Aquí se presenta también una enajenación directa del docente cuyo esfuerzo vital debe aumentarse y con éste su afectación física y económica de la que Althusser (1983) trató en su momento a pesar de sus reconocimientos hacia la resistencia docente.

Marx entre 1850 y 1860 cambia su ampliación de la alienación a la idea de fetichismo. La visión material que pondrá a la mercancía como objeto de estudio, será clave para la abstracción de la misma y su regreso a la vida material representada, o mejor, manifestada en las relaciones humanas desprendidas, producidas por esas interacciones entre sujetos y mercancías, y sujetos y sujetos con mercancía. Aquí se madura la concepción no ontológica de la alienación; eso sí, sin dejar de verse de una manera particular, mucho menos neutral de la mano, con lo marxiano.

Con esa herramienta teórica se puede también definir la conversión de la educación en un fetiche en la medida en que se promueve sin darle su papel protagónico en la transformación social reemplazándolo por la idea unidimensional de ser solo un medio para acceder a mejoras materiales en el marco de una economía de mercado, esto conlleva a que sea vista a la educación como una mercancía y a su vez esta idea fetichizada produce cíclicamente la impresión de ser acertada dicha idea.

Para algunos autores, es la teoría del fetichismo de la mercancía -que estará ligada a la alienación- es la base del pensamiento económico de Marx; así lo pensó Rubin ${ }^{55}$ (en Musto, 2015). Mientras, el mismo Marx en su Tercer Manuscrito (Crítica de la dialéctica hegeliana y de la filosofía de Hegel en general), expone, reconoce y objeta la reflexión de Hegel. Habló que en Hegel estuvo presente la importancia de la alienaciónenajenación en su Fenomenología, que ésta debía ser "ojeada" pues se mostraba como verdadera fuente y el secreto de la filosofía hegeliana (Marx, 2001). Marx puso esa alienación o fetichismo a la mercancía sin perder su extensión antropológica, y con ella en los diferentes ámbitos de la vida humana en sus nefastas, y en ocasiones, disfrazadas consecuencias. Así también lo ha sido en el ejercicio de la educación como se puede evidenciar teóricamente en Mészáros (2008).

No puede dejarse de hacer justicia a Lukács (1970), pues gracias a su retoma, a partir de algunas "pocas" alusiones en las obras de Marx, de la teoría de alienación, logra revivir una lectura que reivindicaría la opacidad a la que fue sometida tan destacada concepción. Y es que en la sección de El capital (Marx, 1976a) sobre Der Fetsichcharakter der Ware ${ }^{56}$, según Musto (2015), es donde Marx, "elaboró el concepto de reificación (Verdinglichung, Versachlichung) para describir el fenómeno por el que la actividad laboral se contrapone al hombre como algo objetivo e independiente, y lo domina mediante leyes autónomas y ajenas a él"' (p. 173).

El estado de alienación que se desprende del cuestionamiento filosófico en varios autores revolucionarios (Dunayevskaya, 1989), en lo marxiano pasa de allí al ámbito económico cuando observa los comportamientos productivos y los idearios alrededor de éste. Desde este punto de vista la postura marxiana

${ }^{55}$ Ensayos sobre la teoría marxista del valor (1928)

56 "Fetichismo de la mercancía" 
no pierde el carácter antropológico y ético práctico para establecer el análisis; las armas de la filosofía se manifiestan para denunciar estos fenómenos que han enajenado y alienado a la educación en forma general.

Por ser histórica, la alienación es superable. Para Silva (2009) son tres factores materiales que hacen que la alienación sea histórica. La creencia de que la ideología no tiene historia es otra versión más de corte, precisamente, ideológico.

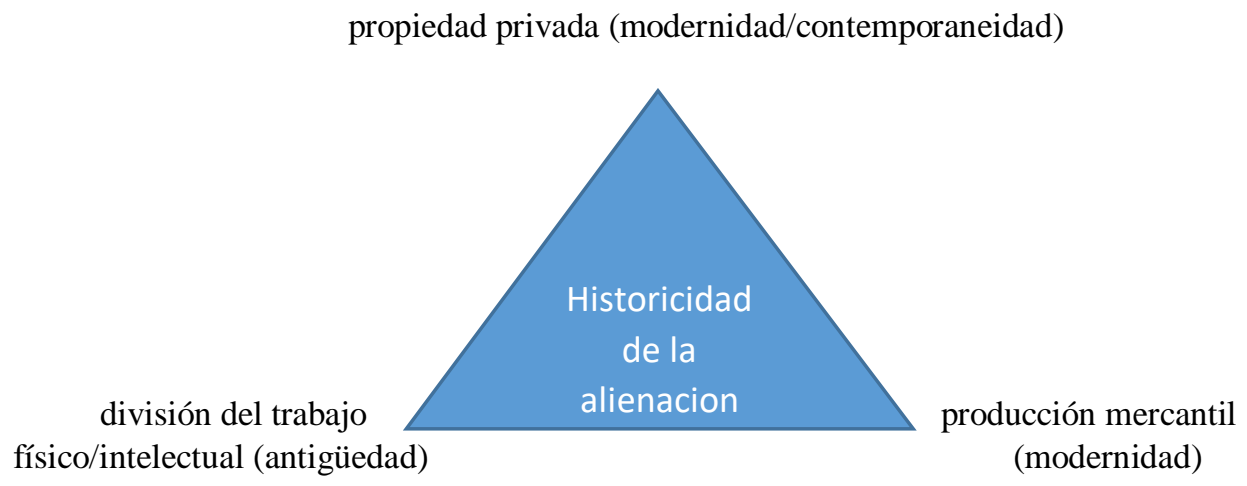

Gráfico No. 8. Alienación y producción que se expresa materialmente en la enajenación, ella es consecuencia de la histora humana.

Las herramientas marxianas no dan la solución, no pretenden ser la panacea, pero sí mostrar las relaciones que desatan un modo peculiarmente hegemónico. Lo marxiano por su naturaleza crítica no puede pretender imponerse. Marx ya sabía lo difícil que era luchar contra el sistema de cosas y a más de ciento cincuenta años del Manifiesto, la situación se ha vuelto monolítica, el capital en pocas manos se sigue reproduciendo, la alienación y la enajenación se camuflan fácilmente siendo consentidas en algunas mentalidades que ni siquiera se benefician de ellas, etc. Empero, las problemáticas se acrecientan y parecen no ser suficiente aliciente para despertar del letargo en gran parte de la humanidad ahora globalizada.

La invitación marxiana es, tener consciencia del grado de alienación al que estamos sometidos por distintos medios y prácticas (Silva, 1974). En la medida en que haya una exigencia por un cambio tangible de cosas, se podrá tener esperanza en la única arma que todavía se tiene para transformar el medio: la educación.

\subsection{Estado y poder: crítica desde la filosofía de la educación liberadora}

Una filosofía de la educación que pretenda tomar la mano de lo marxiano no evade el tema del poder representado en la idea y realización de Estado. Si desligarse de la ideología es realmente difícil hasta para los teóricos de la educación pensada de manera alternativa como lo dice Broccoli (1980); la acción del Estado como forma material, ha de ser revisada por la lupa crítica de lo marxiano, identificándolo en tanto actor decisivo dentro del acontecimiento educativo.

Existe una diferencia entre Estado y gobierno. Si bien en Marx, el Estado debe ser el garante de la educación en tanto derecho, esto significa que el Estado debe garantizar la purga de elementos ideológicos y aquellos factores que faciliten que el sistema de cosas imperante domine los hilos de la formación humana institucionalizada. Pero, se encuentra una férrea oposición con la participación del gobierno en los asuntos 
educativos, pues sabe que un gobierno es más inmediato, no así sus efectos. Además, a la hora definitiva, Estado y gobierno son dos formas que difícilmente podrían subsistir en el sistema político que Marx criticó y aún permanece en esencia y hasta en forma. Lo único que media -hasta ciertos puntos- es la democracia; aunque esta tampoco convence mucho a Marx en su versión burguesa.

Hablando sobre "la fundamentación de la democracia", Gimeno Sacristán, citando el Libro V de La República ${ }^{57}$, dice que, "desde que Platón planteó que el buen gobierno del Estado debía quedar en manos de los filósofos, la educación aparece como una condición de la existencia de formas de organización social justas y armoniosas" (2000, p. 22).

Históricamente hablando, ha sido el Estado, como ente y forma de organización política, el que ha determinado la institucionalización de la escuela como manera de presencia efectiva en los últimos siglos. Más, el fin es evidente: sostener una manera de ver al mundo guiada por la versión que de un modo u otro respalda el Estado; esto lo pone en evidencia muy bien la teoría marxista en su tratamiento sobre la ideología (Laclau, 1978). La conformación y consolidación del Estado, en los diferentes países, ha sido liderada -en la mayoría de los casos- por las clases dominantes con unas estructuras ideológicas definidas y un modelo económico definido por la ganancia en pocas manos en detrimento del bienestar social para el grueso de la población.

La crítica al Estado es también la crítica a la ideología. El Estado se mantiene con ella, y ella es producida por aquel. Lo marxiano establece unas pautas generales para tomar en cuenta la hora de hacer cualquier abordaje sobre el Estado. Y es que el tema del Estado es clave para entender, interpretar y proponer la transformación en los procesos educativos por lo menos en la sociedad globalizada actual.

Cuando el Estado está movido por intereses ajenos a su función de garante social, y por el contrario se sostienen amañamientos de clases dominantes, el resultado será gobernar para esos sectores poderosos o a quienes representen poder. Así mismo, si un sistema es consciente de su papel transformador, no estaría en lo correcto si elevando banderas de emancipación, tomara acciones negativas reflejadas en la educación. Por ello el asunto de la ideología vista como vector dogmático se aleja de la liberación material e intelectual, aquí el justo medio podría rescatarse, concretamente sobraría, desde lo marxiano, se hace la acertada puntuación sobre el tema de la ideología, incluso desde el ámbito epistemológico.

Entre esas pautas están las que obedecen al rastreo histórico, su origen, su relación con los sectores que acoge, sus formas de financiamiento junto a su contenido ideológico. El análisis de las políticas públicas en los distintos campos ha de tomarse en consideración al momento de buscar la relación ideológica entre el Estado y las políticas educativas.

Desde la concreción del pensamiento liberal y la promulgación de los derechos universales, la educación hace parte de ese compendio de prerrogativas, convirtiéndose la forma estatal en la veedora del cumplimiento de este derecho universal desde finales del siglo XVIII. Según los requerimientos tradicionales de la modernidad, el Estado debe regular la práctica educativa, proteger los derechos

${ }^{57}$ Como los filósofos no gobiernan los Estados, o como los que hoy se llaman reyes y soberanos no sean verdadera y seriamente filósofos, de suerte que la autoridad pública y la filosofía se encuentran juntas en el mismo sujeto, y como no se excluyan absolutamente del gobierno tantas personas que aspiran hoy a uno de estos dos términos con exclusión del otro; como todo esto no se verifique, mi querido Glaucón, no hay remedio posible para los males que arruinan los Estados ni para los del género humano [Platón, La República, Libro V, pág. 185] en Gimeno Sacristán, 2000, p. 22) 
individuales y colectivos de la educación, ha de formalizar la institucionalización de la educación pública y privada diferenciándolas a la vez que delinear los puntos comunes. Muchos han sido los pensadores dedicados a las reflexiones filosóficas sobre el Estado como ilustra Gantiva (2005). A la par, sobre la hegemonía de la que habló Gramsci (Broccoli, 1977) y sus efectos negativos en las sociedades inmediatas.

La caracterización moderna del poder y sus manifestaciones se ha extendido hasta nuestros días del siglo XXI, con sus acercamientos, con sus mitos y con sus problemas clásicos. El Estado como realización de la razón existe en Hegel (Trann Duc Taho, 1965). Ni hablar de su idea sobre el culmen de dicha noción cuando se refiere a la revolución burguesa que estalló tras la toma de la Bastilla (Marcuse, 1993b). Esto marcó los rumbos de las políticas modernas de esas formas de organización propuestas por occidente y que conocemos hoy como Estado.

Como antecedente próximo a la visión marxiana, que establece líneas directas de la relación entre poderes y sistema educativo, sobre todo el poder hegemónico estatal; ya "Hegel insiste en la liberación y en la autonomía de los individuos como meta de la educación. Pero en definitiva el individuo queda demasiado <<integrado>> en el estado y en última instancia, en la férrea lógica de la totalidad" (Ginzo, en prólogo de Hegel, 1991, p. 49). Pero se queda corto. El interés del pensador idealista, no será desentrañar las tramas del poder en su afección a la formación, pero sí su posicionamiento teórico que de manera dialéctica fue leído, interpretado, criticado y lo mejor: transformado.

El Estado no es un ente per se, es acción, o sea, gobernabilidad. Como sea manejado éste, se deduce el rumbo de sus subordinados. "Se pueden considerar como los dos descubrimientos más difíciles para la humanidad: el del arte de gobernar a los hombres, y el del arte de educarlos; todavía hoy se discute acerca de estas ideas" polemizaba Kant (1986, p. 6). Así se puede juzgar los conceptos de formación que se dan en el seno del Estado que no siempre son el sentir de la población y peor aún de sus necesidades más básicas.

El Estado es histórico como históricas sus consecuencias. Las circunstancias sociohistóricas demarcadas en el paso de cada momento y de sus peculiaridades han sido a su vez causa, también efecto del devenir humano. En ocasiones existe la tendencia de establecer visiones mecanicistas muy en boga con la modernidad. La tendencia mecanicista tuvo gran acogida para interpretar y hasta justificar la trama política en la que se mueven las relaciones de poder. La visión epistémica del mecanicismo, si bien justificada a primera vista, no logra evidenciar filosóficamente, por lo menos desde la postura que sostiene una intencionalidad de ocultamiento de la verdad, de la sospecha; el conocimiento de esa realidad fundante, de esa supuesta fuerza que en la realidad marxiana no desventura en las decisiones humanas.

La preponderancia moderna en sostener la necesidad de una forma de organización política que centralice, que sea garante, que unifique y delinee pautas o simplemente logre dirimir conflictos entre las comunidades que lo conforman como ente nacional (idea de Homo hominis lopus), esa preponderancia vino a calar en la materialidad. La idea de Estado, como idea, se consolidó en abstracción, de una abstracción tangible representado en instituciones garantes.

Respecto a lo anterior, se establece una posición ideológica por sostener la obligatoriedad, la "necesidad necesaria" sin más del Estado, de esta especie de gendarme, principio y fin de toda la civilización moderna. $\mathrm{Y}$ es que el Estado suele legitimarse en su autopostura de haber nacido del consenso, emanado como benéfico ideal. He ahí el mito originario. El Estado satisface al hombre total de una manera imaginaria (Del Noce y Riestra, 1975). Más, la reconstrucción del Estado, es menester ideológico. 
El problema está en el manejo intencionado que se le ha dado a esta idea. Por ejemplo, en materia de educación, si bien es cierto que el Estado debe tener la obligación de estar presente, su papel debe ser el de garante, el de defender la accesibilidad pública al conocimiento, a la formación y orientador de políticas solidarias que no se comprometan con la visión mercantilista.

Claro, pensar esto sería una ingenuidad más que una utopía o una positividad teórica pues en la medida en que esté ideologizado su rol, será contenedor de cualquier cambio, aquí se cumple una manifestación del antagonismo marxiano. De aquí que, la idea de la educación obligatoria de la que habla Gimeno Sacristán (1994), tenga cierta validez al hablar de las responsabilidades oficiales de la entidad política que encarna el Estado.

El Estado aparece justificado por versiones hasta naturalistas y, además como actor objetivo, aparentemente neutral. Por ser un animal social y político se necesita de un poder supremo que evite salvajismo. Desde una lectura marxiana, aprovechando los fundamentos del darwinismo que magistralmente utilizan Marx y Engels, se genera una lectura novedosa sobre las relaciones de poder y su valida relación con la naturaleza, con aquellos dictámenes que han de encontrarse en el mundo natural. Naturaleza "natural" y naturaleza social, son revestidas de la interpretación dialéctica marxiana. En esto último, tanto Hobbes como Darwin (Engels en Marx \& Engels, 1975) han de encontrarse, ponerse y contraponerse.

El Estado pierde objetividad cuando refleja los intereses de las clases dominantes; cuando los legaliza y los legitima. La filosofía no se encargaba sino de interpretar o también de ser parte del edificio ideológico. Pero la propuesta marxiana rompió con el paradigma, vendría a ser radical. Será una denuncia contra el Estado como vector ideológico a través de sus aparatos, de sus extensiones. De ahí las críticas de Marx a la realidad instruccional de su época.

Marx acude a varias fuentes por más que sean fuente de la época burguesa. Ejemplo, las lecturas de Spinoza por parte de Marx (2012) complementaron su formación materialista y de otros aspectos, entre ellos, la visión sobre el poder y la democracia o el mismo dinero ${ }^{58}$. Se abre el rescate a las concepciones alternativas -por más peligrosas que ellas fueran-, a temas como el de la participación o de la idea misma de democracia, pero apuesta por una idea que parta de la importancia por vindicar los nuevos sectores de la sociedad, en su tiempo del proletariado quines debían formarse en una democracia real, efectiva e incluyente que pusiera por encima los intereses de la clase trabajadora.

De cualquier modo, ello ratifica el carácter pedagógico que hay en los esfuerzos marxianos de interpretación y transformación, cosa que deberá tomarse en cuenta cuando de alternativas formativas se trata. No cabe duda, hablar de democracia es más que hablar de un simple sistema político que irónicamente defenderá la clase burguesa en su tiempo y de la cual todos, absolutamente todos los tipos de poder no excluyen de sus discursos pero que en la práctica se aleja.

La producción de ideas, y con ellas las del Estado, junto a las respectivas relaciones de poder, no aparecen de la nada, ni siquiera de una supuesta existencia del absolutismo ideal, son lo contrario; se emanan de las circunstancias materiales. Lo absoluto en tanto tal, en tanto fundamento de las ideas son en realidad

\footnotetext{
58 ...Entre Baruch, el "hebreo virtuoso", y Marx pueden encontrarse semejanzas, analogías, líneas generales que cruzan ambos pensamientos. Un ejemplo se encuentra en la Ética, su libro más respetable desde el punto de vista académico: allí Spinoza define al dinero como "compendio de todas las cosas" (IV, capítulo XXVIII), en el cual se desarrolla la servidumbre humana: "Pero el dinero ha llegado a ser un compendio de todas las cosas, de donde resulta que su imagen suele ocupar el alma del vulgo con la mayor intensidad", expresión que tomada a la ligera, literalmente y sin más recuerda la definición del dinero del Marx maduro en Das Kapital como "equivalente general" en el proceso de intercambio de mercancías. Varela Gonzalez, Nicolás (2014). Marx y el enigma Spinoza. Recuperado de: http://www.rebelion.org/docs/191262.pdf
} 
materialidades, pedazos de ese todo material, ya que la constatación de su extensión en la vida social real, cuyo impacto suele ser trágico o contradictorio, en su tangibilidad dejan ver su esencia o mejor, dejan sentir su verdadera acción; su extensión práctica.

Una filosofía de la educación encargada de pensar la educación desde un enfoque marxiano ha de desligarse la creencia en la intromisión absoluta del Estado ideologizado, sobre todo cuando se trata de la construcción académica, con ello no se quiere decir que el Estado deje de verificar procesos, todo lo contrario, en tanto ente público es quien precisamente debe asegurar la armonía del sistema educativo. Claro está, el dilema se daría en el tipo de sistema político que se encarna en ese Estado. No hay duda, en un sistema de cosas que hace venia y vive del fetichismo hacia la mercancía, el lucro, los modelos foráneos y la exclusión, las garantías de transformación no se darán.

La idea burguesa de Estado no ofrece posibilidades a la formación libertaria humana, todo lo contrario. Si esto es así desde la visión burguesa, se agrava con la confluencia de la oligarquía como conductora de un Estado. Si bien el Estado surge, desde diversas versiones aburguesadas de la historia, como necesidad, a esto se le ha dado un manto sagrado para que pueda protegerse de la crítica consecuente. Althusser (1989), destaca la "teoría marxista" del Estado, allí denuncia a la represión del Estado, por ser en sí un aparato ideológico y por reproducir, a su vez, más aparatos represivos e ideológicos que le permitan mantenerse, monopolizar el medio.

El mismo Marx, como sujeto de su época, vivió una coyuntura histórica determinada por la supremacía ideológica, hasta metafísica del Estado (Riazánov, 1966). El despotismo pululaba, ahora bajo otra forma, pero la esencia, o mejor, los objetivos y su naturaleza poco había variado. Y no es por la figura de Marx, es por lo que significó su contexto.

Las hégiras a las que se sometió fueron las mismas vividas por cientos de miles en sus tiempos ayer y ahora, consecuencias de la capacidad para develar la realidad, por luchar para establecer pautas que pudieran conllevar a las transformaciones sociales que subvirtieran a la oficialidad gubernamental.

Con todo, la educación no debe tratarse como instrumento de dominación, esto lo denuncia de manera explícita los contenidos marxianos y de algunos marxistas como Gramsci (2007a). Para Marx, el Estado debe promover la formación pública, gratuita y que corresponda a las necesidades del hombre y la mujer y los niños (Engels, 1847); por lo menos, en cualquier caso, ha de establecerse un espacio de formación patrocinado por el Estado, pero sin inmiscuirse ideológicamente en la escuela al respecto en su Kritik des Gothaer Programms, puede leerse:

[Die demokratischen Programmforderungen sind reformistisch und vom „Untertanenglauben ... an den Staat verpestet"]

B. Die deutsche Arbeiterpartei verlangt als geistige und sittliche Grundlage des Staats: 1. Allgemeine und gleiche Volkserziehung durch den Staat. Allgemeine Schulpflicht. Unentgeltlichen Unterricht." Gleiche Volkserziehung? Was bildet man sich unter diesen Worten ein? Glaubt man, dass in der heutigen Gesellschaft (und man hat nur mit der zu tun) die Erziehung für alle Klassen gleich sein kann? Oder verlangt man, dass auch die höheren Klassen zwangsweise auf das Modikum Erziehung - der Volksschule - reduziert werden sollen, das allein mit den ökonomischen Verhältnissen nicht nur der Lohnarbeiter, sondern auch der Bauern verträglich ist? „Allgemeine Schulpflicht. Unentgeltlicher Unterricht.“ Die erste existiert selbst in Deutschland, das zweite in der Schweiz und den Vereinigten Staaten für Volksschulen. Wenn in einigen Staaten der letzteren auch 
„höhere“ Unterrichtsanstalten „unentgeltlich“ sind, so heißt das faktisch nur, den hö- heren Klassen ihre Erziehungskosten aus dem allgemeinen Steuersäckel bestreiten. (...)

Der Paragraph über die Schulen hätte wenigstens technische Schulen (theoretische und praktische) in Verbindung mit der Volksschule verlangen sollen. Ganz verwerflich ist eine „Volkserziehung durch den Staat". Durch ein allgemeines Gesetz die Mittel der Volksschulen bestimmen, die Qualifizierung des Lehrerpersonals, die Unterrichtszweige etc., und, wie es in den Vereinigten Staaten geschieht, durch Staatsinspektoren die Erfüllung dieser gesetzlichen Vorschriften überwachen, ist etwas ganz andres, als den Staat zum Volkserzieher zu ernennen! Vielmehr sind Regierung und Kirche gleichmäßig von jedem Einfluss auf die Schule auszuschließen. Im preußischdeutschen Reich nun gar (und man helfe sich nicht mit der faulen Ausflucht, dass man von einem „Zukunftsstaat“" spricht; wir haben gesehn, welche Bewandtnis es damit hat) bedarf umgekehrt der Staat einer sehr rauen Erziehung durch das Volk. Doch das ganze Programm, trotz alles demokratischen Geklingels, ist durch und durch vom Untertanenglauben der Lassalleschen Sekte an den Staat verpestet oder, was nicht besser, vom demokratischen Wunderglauben, oder vielmehr ist es ein Kompromiss zwischen diesen zwei Sorten, dem Sozialismus gleich fernen, Wunderglauben ${ }^{59}$. (Marx, 2012d, p. 17)

He ahí un precedente, aunque ya en América, Rodríguez había tocado muy particular y originalmente el tema de la educación a la población como proyecto para la naciente República de Colombia (Rodríguez, 2007b). La educación debe ser popular, incluyente como dice Freire (1974) y liberadora. Para el caso de América Latina, la educación ha de ser inventiva siguiendo al poco referenciado por los círculos academicistas eurocéntricos: al maestro Simón Rodríguez, cuya utopía se presenta como oportunidad en la medida en que se asuma la conciencia histórica (Ramírez Fierro, 1994), es por esto que la educación ha de ser una opción para establecer cambios conscientes en las mentes, sembrar dudas y errar para mejorar.

${ }^{59}$ B. "El Partido Obrero Alemán exige, como base espiritual y moral del Estado: 1. Educación popular general e igual a cargo del Estado. Asistencia escolar obligatoria general. Instrucción gratuita". ¿Educación popular igual? ¿Qué se entiende por esto? ¿Se cree que en la sociedad actual (que es de la única de que puede tratarse), la educación puede ser igual para todas las clases? ¿O lo que se exige es que también las clases altas sean obligadas por la fuerza a conformarse con la modesta educación que da la escuela pública, la única compatible con la situación económica, no sólo del obrero asalariado, sino también del campesino?

"Asistencia escolar obligatoria para todos. Instrucción gratuita". La primera existe ya, incluso en Alemania; la segunda, en Suiza y en los Estados Unidos, en lo que a las escuelas públicas se refiere. El que en algunos estados de este último país sean "gratuitos" también centros de instrucción superior, sólo significa, en realidad, que allí a las clases altas se les pagan sus gastos de educación a costa del fondo de los impuestos generales.

El párrafo sobre las escuelas debería exigir, por lo menos, escuelas técnicas (teóricas y prácticas), combinadas con las escuelas públicas.

Eso de "educación popular a cargo del Estado" es absolutamente inadmisible. ¡Una cosa es determinar, por medio de una ley general, los recursos de las escuelas públicas, las condiciones de capacidad del personal docente, las materias de enseñanza, etc., y, como se hace en los Estados Unidos, velar por el cumplimiento de estas prescripciones legales mediante inspectores del Estado, y otra cosa completamente distinta es nombrar al Estado educador del pueblo! Lo que hay que hacer es más bien substraer la escuela a toda influencia por parte del gobierno y de la Iglesia. Sobre todo en el imperio prusiano-alemán (y no vale salirse con el torpe subterfugio de que se habla de un "Estado futuro"; ya hemos visto lo que es éste), donde es, por el contrario, el Estado el que necesita recibir del pueblo una educación muy severa.

Pese a todo su cascabeleo democrático, el programa está todo él infestado hasta el tuétano de la fe servil de la secta lassalleana en el Estado; o -- lo que no es nada mejor -- de la superstición democrática; o es más bien un compromiso entre estas dos supersticiones igualmente lejanas del socialismo. Trad. Critica al programa de Gotha. Traducción en, https://www.marxists.org/espanol/m-e/1870s/gotha/gotha.htm 
Otro factor se relaciona con el poder del Estado. La doctrina religiosa calaba en el fenómeno educativo, era una especie de contenedor social. La religiosidad combinaba acertadamente su doctrina confesional con algunas necesidades humanas del ámbito espiritual. Otorgaba, en su doctrina educativa, la posibilidad de retraerse de lo mundano y regresar a lo espiritual; a un cambio de vida que alejara al hombre de unas "ambiciones" que rayaban con los mismos planes divinos; la rebeldía era, además de un delito, un acicate para ser condenado en la eternidad como está en Weber (2008).

Estado e Iglesia seguían su idílica relación muy a pesar de la experiencia francesa. Otro asunto abordado por Marx, fue la intromisión lógica de la Iglesia en los asuntos educativos con el beneplácito del Estado. La escuela se estaba masificando, y con ella la sujeción a las normas de la moral de las diferentes congregaciones protestantes cristianas que competían con el catolicismo oficial. El mercado de la educación se ofrecía al mejor postor. Los dividendos que obtenían las iglesias, en muchos casos, no eran tan materiales, pero si ideológicos, de aceptación por sus exigencias y rigidez. No cabe duda que las órdenes religiosas eran organizadas y se trazaban sus horizontes.

Lo anterior garantizaba al Estado una preocupación menos, pues los administradores de la educación, ya fueran laicos o religiosos cubrían, de alguna manera, las peticiones de los sectores menos favorecidos. No obstante, la educación seguía siendo excluyente en gran parte de la Europa decimonónica, modelo que se extendería al resto del globo, especialmente en los espacios de la periferia.

El monopolio del conocimiento seguía en manos de los sectores reaccionarios y con ello las materialidades y los asuntos inmediatos como los contenidos, currículos y demás elementos que rodeaban a la escuela. La aglomeración de masas favorecía el sostenimiento del statu quo. Esto fue juiciosamente denunciado y recopilado por Marx y Engels a sus maneras (Marx-Engels, 1977).

Ya en Hegel se manifestaba la simpatía hacia un sistema estatal fuerte, pero que en definitiva descuidaba, por inercia, los asuntos prioritarios como la educación popular; Hegel no iba más allá o simplemente no era de su interés, pero esto no es lo reprochable, lo reprochable es su disposición para justificar un sin número de situaciones que se materializaban desde su mundo de las idealista-romático, desde ese absoluto (Marx, 2001). Quizás, porque, como dice del Noce \& Riestra: "Hegel es un filósofo, y como tal un ser alienado que concibe las alienaciones de modo abstracto" (1975, p. 110).

El sistema educativo ha sido visto también por parte del Estado como espacio de formación en el trabajo, pero no en el trabajo liberador sino en el encaje del individuo en un engranaje social. La jerarquización de oficios, -ya planteada desde tiempos platónicos- abre el paso a la modernidad. Ahora el asunto es ser "productivo" para un sistema de relaciones que giran en torno a conceptos que parecen inamovibles. Marx apuntaba, criticando esta lógica, que

El obrero comercial no produce directamente plusvalía. [...] En segundo lugar, la formación previa, los conocimientos comerciales y de lenguas, etc. se reproducen cada vez más rápidamente, más fácilmente, de un modo más general y más barato a medida que progresan la ciencia y la educación popular, cuanto más se orientan en un sentido práctico los métodos de enseñanza, etc. del régimen de producción capitalista. La generalización de la enseñanza pública permite reclutar esta categoría de obreros entre clases que antes se hallaban al margen de ella y que están habituadas a vivir peor. (Marx, 1976, p. 293) ${ }^{60}$

Lo magistral de lo marxiano está en la capacidad de ver como un todo a sus partes y a sus partes, luego, como un todo; descomponer mediante la abstracción para recomponer partes, dista de la tendencia tradicional meramente contemplativa. Nada se desliga. La teoría económica de Marx, así existan posturas

${ }^{60}$ El capital, Vol. 3 trad. de Wenceslao Roces 
de una cierta validez que sostienen una ruptura tajante entre el Marx filosófico y el Marx científico, fue puente para que aún se pueda entender el grado de influencia de las condiciones materiales y de producción en las relaciones que estarían presentes en la escuela, extendiéndose a la misma población infantil. La alienación tomaría la forma masificada e institucional en el seno de las ya precarias aulas de clase.

La educación en tanto proceso ha de ser, no únicamente no alienante sino también, no alienable, pero aún más antialienante. El monopolio, la hegemonía debe borrarse, para dar paso a un sistema de cosas alternativo. Hay que tener cuidado, pues Marx y su obra, en general son tildadas, incluso desde posturas cercanas, de contenerse dentro de los límites del eurocentrismo (de Soussa, 2011). Si bien es cierto que es fruto de esos resultados racionalistas occidentalizantes, no cabe duda, que independiente de ello es una forma muy desafiante al sistema de cosas establecido por la manera de pensar europea.

Entonces, la educación ha de sostenerse como espacio integrador. El valor del trabajo y su complementariedad con la vida social, solo se puede reconocer en la medida en que se libera y se es consciente del compromiso de cambio. La educación ha de ser transformadora, motor de crítica que desarrolle términos acordes a las necesidades vitales de la sociedad. "Marx dijo que el hombre, al actuar sobre la naturaleza y transformarla para su satisfacción de sus necesidades, primero forma y luego transforma su propia naturaleza" (Novack, 1977, p 35).

Si el Estado es proclive, y naturalmente, alineado al establecimiento indiscutible del monopolio, el cual ejerce mediante extensiones ideologizantes como la educación (instrucción), entonces no existirá libertad del ser para desarrollarse plenamente sino una centralidad de contenidos, de elementos sesgados en la medida en que obedecen a los requerimientos de las clases dominantes, quienes mantienen las riendas del sistema. Con la masificación de la educación, también aparecen las influencias nefastas de la ideologización estatal, de esa ideologización inyectada por la proyección mercantilista de las dimensiones humanas. Así las cosas, la alienación y la enajenación se oficializan; esto ha venido ocurriendo durante casi dos siglos de oficialización de lo que se llamaría sistema educativo.

Ayer como hoy, los sistemas educativos o de instrucción giran en torno a los afanes de ganancia del sistema predominante. La misma idea de competencias, sin una reflexión filosófica y pedagógica seria (pues obedece a la visión mercantilizada), ha abierto las sendas a una serie de situaciones concretas carentes de sentido formador. En tanto invención del sistema de mercado, la estandarización ha olvidado su lado social, obedeciendo a la lógica cuyo cimiento y fin, es la obediencia al sistema de cosas imperante.

En esta medida, vamos viendo aparecer en América Latina, con creciente rapidez, aquella contradicción entre "oferta" de la Escuela y "demanda" del mercado de trabajo, que es típica de todas las sociedades capitalistas. Pero esta contradicción se halla envuelta en condiciones y contradicciones secundarias, que agravan la situación. (Vasconi, Sf. sp.)

Paradójicamente, la mayoría de las experiencias del socialismo real hicieron de su sistema estatal un poderoso y cuestionable ente. Si bien era necesaria la creación de Estados, estos se desviaron del ideal socialista y del verdadero significado de la figura marxiana de "dictadura del proletariado" y la democracia popular. El Estado policíaco, por ejemplo, fue la imagen que más imperó en occidente y no por motivos ajenos a las voluntades de los politburós. De esta experiencia hasta el noble García Márquez (1965) escribió una excelente crónica.

El mismo Marx propendió por la formación autodidacta. Aplicó esto último entre sus hijas (Marx, E., en Fromm, 2012). Ello puede demostrar el alto grado de sospecha que tenía Marx por la educación de masas llevadas a cabo por los sistemas estatales y aquellos cercanos a las doctrinas religiosas, a la adjudicación 
de dicha responsabilidad social y científica de manera indiscriminada o mejor, la repartida entre el capital privado que veía a la educación como negocio, como enajenación; y la que era proclive a la alienación, o sea, a la confesional la cual no distaba de los intereses económicos y no únicamente de conveniencias político-temporales.

En la superficie, los procesos tienen la particularidad no sólo de "esconder" la dinámica interna, sino también de distorsionarla. Es conocida la tesis de la fetichización planteada por Marx, en donde las relaciones entre los hombres se les presentan a éstos como relaciones entre cosas. (Osorio, 2004, p. 19)

El Estado está conformado por personas de carne y hueso con intereses, en la mayoría de los casos, distintos a los que puede dictar el mismo sentido común, esos intereses y metas que deben concentrar a una comunidad humana. Las formas estatales obedecen a una ideología determinada por las relaciones sociales e inclusive sus costumbres e historia o versión de la historia, así lo comparten Silva (1971) y Althusser (1989). La crítica al Estado no ha de soslayarse, Marx ya lo recomendaba frente al despotismo monárquico y también contra el liberalismo que soterraba los beneficios de las clases dominantes bajo el disfraz de una democracia ejercida por la burguesía en detrimento de la clase trabajadora y el resto de la población.

El ejemplo de la ley de enseñanza dada en la Francia de agitaciones políticas dejó ver la alianza de sectores para conservar sus privilegios doctrinarios, ya fueran extremadamente conservadores y religiosos, o autoproclamados liberales radicales y anticlericales (Marx, 1979); es un caso de entente para enfrentar a una propuesta distinta que pudiera dar oportunidad de formación a otros sectores que se estaban sublevando, es decir al sector trabajador y popular. De todas maneras, las clases dominantes a la verdad no discrepan a la hora de unirse contra alternativas que amenacen su estabilidad. La historia está llena de ejemplo; la joven América Latina, ya está curtida, tristemente curtida en esto, es continuidad todavía desde los años de las guerras de independencia.

El Estado por ser más que un ente, en verdad es una materialidad, una representación del acuerdo general, se ha descarrilado de su deber ser sobre todo en los países de la periferia. Por un lado, marcha el Estado y por otro los intereses de la población. Por un lado, el Estado establece sus criterios y formas de coerción, por el otro la población se agobia a causa de las negativas acciones del Estado. Lo paradójico del asunto es que el Estado como cosa pública se ha venido desmontando gradualmente, pues los sectores económicos han suplido las funciones del Estado, entre ellas la de garantizar la educación democrática, autónoma, constructiva, de calidad y gratuita.

Si bien desde lo marxiano se hace una proyección de la abolición del aparato estatal, antes de esa etapa remota para la realidad de hoy, la acción del Estado es clave para impulsar los cambios en el sistema, el Estado es necesario hoy para generar políticas claras de formación educativa que equilibren las circunstancias favorables. Las vías democráticas podrían abrir las puertas para la transformación del Estado, pero volviendo al asunto esencial, todo retorna a la educación misma. Un Estado alienado es fruto de la alienación intencional en los sujetos que lo componen, y este siempre defenderá la enajenación en sus distintas manifestaciones como lo fue en tiempos de Marx, en otro contexto, como lo es ahora en múltiples contextos.

Núñez Tenorio retomando a Althusser, nos recuerda que "la concepción científica de ideología comienza por su definición objetiva como práctica: no hay sociedad sin un sistema de nociones, visiones, ideas, etc., mediante la cual las clases, los grupos y las personas reproducen esa sociedad y su lugar en ella" (Núñez Tenorio, 2015, p. 31). 
Para el caso latinoamericano, la realidad se establece en la hegemonía del Estado sobre la educación. Los efectos alienantes y de descuido intencional de la formación humana se materializan en las políticas sobre el ramo. Por ser sistemas totalmente oligárquicos, en su inmensa mayoría, y por estar a merced de una dependencia del centro, la emancipación individual, así como la colectiva, por razones evidentes de temor a los cambios - ni siquiera digamos marxista-, no solo no es tema de interés, sino que ha sido vetado. No obstante, algunos avances se han presentado a lo largo y ancho, pero no son suficientes. La escuela sigue reproduciendo las situaciones que mantienen al sistema de cosas, a la alienación. Solo algunos acercamientos se han dado, más siguen estando a la decisión del aparato estatal, donde ha primado lo ideológico y no la conciencia, no hay atención a las reales necesidades de liberación humana por parte de los que dirigen las riendas del Estado.

Cardona Castro afirma en 2002 que "la alienación finalizará cuando la clase ínfima, es decir, el proletariado, derrote a la burguesía" (P. 110); lo complicado de este avistamiento es que en América Latina más que burguesías lo que existen son oligarquías dependientes y entreguistas. Sin embargo, puede decirse que en el caso de la escuela será dada la emancipación, el ánimo anti alienación cuando los actores de la educación se formen en conciencia y ese papel, hay pocas dudas, está encarnado en el sector docente que logre llegar a los poderes estatales para iniciar un rumbo equilibrado, una política propia que no copie modelos y que mucho menos se guie por los dictámenes economicistas y de la ganancia monetaria para las clases dominantes.

\subsection{Crítica de la filosofía de la educación contra la ideologización de la ciencia}

Al tratar una crítica filosófica a la educación y sus procesos, no ha de olvidarse que esto se relaciona con la ciencia, pues es uno de los medios actuales por medio de la cual esta se difunde y se recrea. La versión marxiana de la ciencia que acá nos interesa es, la particularmente denunciativa. Aquella preocupada por mirarla más allá de las apariencias o de los decretos cientificistas que tratan de olvidar que la ciencia como dimensión humana es producto de la materialidad y no algo independiente de las relaciones de poder. Por tanto, la ciencia es susceptible a la influencia ideológica y así puede manifestarse o no en el acontecer educativo.

Lo marxiano recalca que, la ciencia burguesa tiene una diferencia abismal con los planteamientos críticos de Marx y del marxismo elaborado con posterioridad. Si así no fuera, no habría nada de especial. Hay que decir, algunas posiciones catalogan al punto de vista de la totalidad desde el marxismo es la verdadera brecha entre la visión burguesa de ciencia y no la que solía pensarse, esto es: la preponderancia de lo económico en la idea de historia, así también lo compartió Lukács (1970).

La inmediatez aplicada a lo científico o a lo que se cataloga ciencia, surtirá los efectos negativos si es tratada ideológicamente con marcos extremistas o de simple utilitarismo. La escuela inmediata, no permite ver de cerca el fenómeno científico en tanto acontecimiento social plagado de contradicciones; lo inmediato de la ciencia suele limitarse a los sustentos demostrables, a la última palabra y, por supuesto a la relación directa de productividad. Aunque, en la actualidad la visión de ciencia varía según clases sociales y fines de las mismas instituciones.

La escuela es campo de batalla de lo ideologico y lo epistemológico. Cerrando sus apuntes sobre la escuela en tanto espacio de contradicciones entre los perfiles epistémicos e ideológicos junto a los intereses globales y locales como lo apuntala Vasconi (Sf.) en su tendencia plasmada en Contra la escuela. Igual, hoy sigue chocando la tendencia humanista contra la cientificista, aunque, el tratamiento de la misma ciencia como 
ocurría en la escuela tradicional ha sido desplazado por el interés hacia el consumo y no hacia la más mínima explicación centifica. Sin embargo, la ciencia y la tecnología siguen produciendo más que artefactos, modas y tendencias; la ciencia como medio liberador sigue siendo ajena a la periferia.

Dussel (1980), acota: "la ciencia es el más sutil instrumento de dominación, sobre todo cuando se pretende "universal". No hay en su sentido real, humano, histórico, una ciencia "universal". Las opciones precientíficas son esenciales para la ciencia y éstas son políticas, sociales, cultural" (P. 129). Después, consecuencia de toda la hegemonía epistémica occidentalizadora, saldrá al debate las epistemologías del sur. No puede negarse, paradójica y felizmente, que una postura tan occidental como el marxismo, tendría mucho que ver. Ellas con un compromiso epistémico y sobre todo político, de denuncia, también de propuesta.

Otro elemento indiscutible entrelazado con una filosofía de la educación al estilo marxiano es la ciencia y sus perspectivas ya que lo marxiano ve a la ciencia desideologizada desafiadora a los dogmas. Entre los intereses de Marx, está la ciencia como creación humana que ha de estar al servicio de cubrir las necesidades; en ella se debe formar, pero ha de estar libre de toda manipulación, alejada de toda concepción que no contribuya a la emancipación humana.

Modelo educativo y ciencia en la sociedad capitalista parecen inseparables; lo marxiano descubre las relaciones reciprocas entre estas dos cosas. Intenta desconocerse ese interés en el planteamiento de Marx, imponiéndose la idea de que solo el sistema capitalista es el llamado a crear las condiciones necesarias para el desarrollo de la ciencia de punta, aunque no fue interés de Marx este asunto. No obstante, Schmidt aclara que, "Marx piensa en las escuelas politécnicas que proporcionan conocimientos científicos-naturales" (Schmidt, 1977, p. 171).

Las ciencias naturales y las ciencias de los fenómenos sociales, tendrán como punto de análisis sus orígenes, contribuciones, carga ideológica, avances - caso de la evolución darwiniana o de la química-, e inclusive, las políticas estatales de desarrollo de ellas mismas. Con las armas de la crítica serán incursionadas por la mente inquisitiva de lo marxiano (Marx - Engels, 1975).

La ciencia y su aplicación, el pensarla y repensarla es una actitud más que pedagógica o instrumental, política. Ya sea como producto de las condiciones estructurales o coyunturales; ya sea por su misma fuerza creativa. Ningún aparato político ha menospreciado a la ciencia o por lo menos a la técnica, ni aun el modo feudal, dentro del cual se cree que hubo desinterés por la actividad científica, dejó de ser un campo de interés.

Lo marxiano reconoce en la ciencia un valor material como impulsora de cambios y a la vez, producida por cambios. La ciencia en la sociedad moderna es determinante para facilitar la comprensión de la naturaleza, dominar sus fuerzas, entender la importancia de su difusión y, por supuesto, alimentar la complejidad del sistema de producción. La ciencia se ha puesto al servicio de la actividad económica en función de los monopolios y la acumulación. La ciencia ideológica es, aquella que está al servicio del capital y sus necesidades de explotación (Silva, 2011).

En People's Paper, 19 de abril de 1856 se lee:

Las victorias de la ciencia parecen tener por precio la perdida de carácter. Al mismo tiempo que la humanidad domina a la naturaleza, el hombre parece volverse esclavo de otros hombres o de su propia infamia. Incluso la vida pura de la ciencia parece incapaz de brillar si no es sobre el oscuro fondo de la ignorancia. Todas nuestras invenciones y progresos parecen tener como resultado dotar a las fuerzas 
naturales de vida intelectual y estupidizar la vida humana convirtiéndola en una fuerza material.

(Marx-Engels, 1972, p. 84)

No obstante, lo anterior, para Marx también hay que hacer ciencia de los fenómenos sociales, ella podrá acercar a los sujetos a la realidad; la concepción marxiana es cuestionadora del trato con el que venía circulando la idea de ciencia (Marx, 1982) donde el materialismo histórico hará su aportación (Harnecker, 1971). Existió un afán por teorizar sobre los sufrimientos humanos; lidera entonces, lo marxiano, a la investigación social. La ciencia con su apreciado método científico encuentra en Marx una forma social.

Si bien existen críticas por parte de quienes consideran que lo que propone Marx se distancia de lo que es ciencia, sobre todo por el terreno tan relativo -que es el humano en lo cual se enfatiza-, el interés por desmontar un mero utilitarismo y extender los estudios a las relaciones sociales, lo hace precisamente por detectar elementos no muy conciliadores en la ciencia a través de representantes materializados de corrientes centradas en la sola interpretación objetiva de un mundo que no toma en cuenta -según los científicos- lo subjetivo. Algo similar pasará con la filosofía, con la postura tradicional de filosofía.

Lukács (1970) destaca el tema de la ciencia desde la visión marxista, al retomar el tema de la dialéctica y del método; pero, no logró consolidar el tema de la alienación ${ }^{61}$ que pudo nombrarse en el fenómeno del conocimiento y la ciencia. Entonces, la ciencia con Marx es crítica; no la ciencia -por supuesto- en el sentido positivista, sino de una manera revolucionaria. Esto no caerá ni sigue cayendo bien en algunos círculos.

No es la preponderancia de los motivos económicos en la explicación de la historia lo que distingue de manera decisiva al marxismo de la ciencia burguesa; es el punto de vista de la totalidad. La categoría de la totalidad, la dominación, determinante y en todos los dominios, del todo sobre las partes, constituye la esencia que el método de Marx ha tomado de Hegel y que él trasformó de manera original para convertirlo en fundamento de una ciencia totalmente nueva. (P. 59)

A propósito de la brecha entre filosofía y ciencia, producida por distintas causas histórico-culturales, el esfuerzo marxiano no se ahorra al comprender que una reflexión ha de darse en el seno de las ciencias. La propuesta teórica marxiana, empieza a abrirse paso para encontrar una conexión y un rescate por la integración entre pensamiento y método científico, sobre todo para que al final, la concepción de ciencia estuviera más cercana al facilitamiento de la vida del ser humano y no para pocos sectores.

La forma materialista de ver al mundo y a sus relaciones, recrea la crítica; a futuro se verán esfuerzos por destacarlo como método. Broccoli nos comenta: "el materialismo histórico, además, elimina viejas antinomias entre filosofía y ciencia, ya que supera en la realidad las características tradicionales de estas disciplinas, innovando profundamente sus contenidos y metodologías” (Broccoli, 1980, p. 23).

Sacristán (1977) por su parte relaciona tres aspectos que sobresalen de lo marxiano a partir de lo que para Marx significaba la ciencia. No es acumulación de información dativa, ique sería la ciencia con esa limitación!, tampoco meros procesos, meros métodos independientes de las voluntades humanas; la ciencia

\footnotetext{
${ }^{61}$ Georg Lukács, en el año de 1922, publica un libro titulado Historia y conciencia de clase, en donde aborda en extenso la teoría de la alienación, a partir del análisis exhaustivo de las obras hasta entonces conocidas de Marx. En esta obra, Lukács trata el problema de la alienación como si tuviera a la mano Los manuscritos económico - filosóficos de Marx, que sin embargo no serían dados a conocer sino diez años más tarde.1 A pesar de los novedosos hallazgos de Luckács, la teoría de la alienación no ocupó un lugar importante en los teóricos de inicio del siglo XX. En, ¿Es la alienación una problemática marxista? Un desafío para repensar el marxismo en el nuevo milenio. Martínez, Rigoberto (Sf.). México, párr. 1
} 
no es tan autónoma como se pretende establecer, la estancia del interés ideológico se evidencia hasta en el interés que afirma lo contrario. Es más, Marx resignifica a la ciencia en teoría, sobre todo en el develamiento de su intención.

Por ello, el autor español, en su empresa Materiales de los años setenta del siglo XX, especifica que: primero, Marx es un tipo de Galileo de las ciencias humanas y sociales, en la medida en que realiza aportes en materia moral, pero sin desligar la práctica.

La segunda matriz teórica obedece a la derivación que de su idea de ciencia está en el pensamiento alemán de su época, aquella desprendida de Hegel con su concepto de totalidad, pero vista con la dialéctica, una ciencia de la totalidad pero a su vez con elementos conformativos que ocupan un lugar, una funcionalidad dentro de la totalidad; anecdóticamente aplica a la misma vida de Marx, ya que "Marx no es un sociólogo puro ni un filósofo puro ni un economista puro, lo que él hace es componer una totalidad encajando todos esos elementos" (Martínez, 2002, p. 2) de ahí que para nosotros se pueda entender como un sociopedagogo.

El tercer matiz de ciencia, según Sacristán (1977), es la concreción de la inyección de crítica con el enfoque transformador. En conclusión, dice Sacristán que: "Science, Kritik y Wissenschaft son los nombres de las tres tradiciones que alimentan la filosofía de la ciencia implícita en el trabajo científico de Marx" (López Arnal, 2015, p. 11).

La noción de ciencia en Marx, en el culmen de lo más epistemológico, "piensa que si el empirismo más radical tuviera razón solamente con contemplar veríamos las esencias y no haría falta la ciencia” (Martínez, 2002, p.2). Así las cosas, la ciencia es necesaria pues los fenómenos esconden tras de sí su verdadera esencia. Esto sería magistralmente aplicado a las relaciones concretas derivadas del sistema productivo. He ahí el valor epistemológico de lo marxiano, y es que "la labor científica de Marx y Engels estuvo siempre determinada por las exigencias de la lucha revolucionaria” (Glasser, 1941, p. 17).

La criticidad marxiana no tiene límites a la hora de esgrimir argumentos, muchas veces con algo de sarcasmo e ironía, llegando a utilizar elementos susceptibles para el individuo promedio, con esto se ganó no pocos comentarios, ataques, efectos negativos sobre todo de los sectores religiosos del cristianismo y después, los provenientes de los distintos credos; hasta nuestros días siguen esos señalamientos hacia todo lo que huela a Marx. Esto, en el apoyo marxiano a la teoría darwiniana de la evolución.

De todos modos, Marx (1975), explica la evolución del trabajo manufacturero al fabril, donde el capitalista invoca la unidad y su papel protagónico en la aparición de una nueva sociedad. Sin embargo, lo que se ve es la total sumisión, hasta de los conocimientos del individuo, al capital.

Los conocimientos, la inteligencia y la voluntad que desarrollan el campesino o el artesano independientes, aunque más no sea en pequeña escala al igual que el salvaje que ejerce todo el arte de la guerra bajo la forma de astucia personal, ahora son necesarios únicamente para el taller en su conjunto. Si las potencias intelectuales de la producción amplían su escala en un lado, ello ocurre porque en otros muchos lados se desvanecen. Lo que pierden los obreros parciales se concentra, enfrentado a ellos, en el capital. Es un producto de la división manufacturera del trabajo el que las potencias intelectuales del proceso material de la producción se les contrapongan como propiedad ajena y poder que los domina. Este proceso de escisión comienza en la cooperación simple, en la que el capitalista, frente a los obreros individuales, representa la unidad y la voluntad del cuerpo social de trabajo. Se desarrolla en la manufactura, la cual mutila al trabajador haciendo de él un obrero parcial. Se consuma en la gran industria, que separa del trabajo a la ciencia, como potencia productiva autónoma, y la compele a servir al capital. (Marx, 1975, pp. 439-440) 
Detrás del quehacer científico hay unas relaciones; a su manera la presencia de la división del trabajo de la cual ya Marx no deja de tratar. No obstante, independiente del sentir individual de Marx, no había otro propósito sino el de hacer caer en la cuenta lo alienado que se podía llegar a ser, lo enajenado que podía llegarse a ser cuando no se conocen las realidades que nos rodean, esas realidades disfrazadas. En Grüner (2004), se puede rescatar a propósito:

Lo que Marx viene a hacer -esa es su "genialidad"- es sencillamente a mostrar que ese es el movimiento de la realidad, y a denunciar que cierto pensamiento hegemónico (la "ideología dominante", si se quiere simplificar) tiende a ocultar esa unidad profunda, a mantener separados los "momentos", promoviendo una "división del trabajo social" ("manual" versus "intelectual", para decirlo rápido), con el objetivo de legitimar el universo teórico de la pura "interpretación" como patrimonio del Amo, y el universo práctico de la pura "acción" como patrimonio del Esclavo, ya que la clase dominante sabe perfectamente -aunque quizá no siempre lo sepa conscientemente- que ni la pura abstracción de la teoría, ni el puro "activismo" de la práctica, tienen realmente consecuencias materiales sobre el estado de cosas del mundo. $\mathrm{O}$, en otras palabras, que no producen verdadero conocimiento de la realidad, en el sentido de Marx. Nunca mejor ilustrada esta tesis que en la famosa alegoría que construyen Adorno y Horkheimer, en su Dialéctica de la Ilustración, a propósito del episodio de las Sirenas en la Odisea de Homero: el astuto y racionalizador capitán Ulises -el Burgués, atado al mástil de su barco, puede escuchar ("interpretar") el canto de las sirenas, pero no puede actuar; los afanosos marineros -el Proletariado-, con sus oídos tapados por la cera que Ulises les ha administrado, pueden actuar, remar el barco, pero no pueden escuchar. Ninguno de los dos puede realmente conocer esa fascinante música: Ulises no quiere hacerlo -quiere simplemente recibirla, gozar pasivamente de ella-, los marineros no pueden hacerlo -ocupados, "alienados" en su tarea práctica, ni siquiera se enteran de su existencia-. (Sp.)

El fenómeno científico se muestra como realización del sistema de cosas. El capitalismo se adjudica el papel de partera de la ciencia moderna y la muestra como objetiva, decreta que es menester separarla de cualquier pretensión de acercarla a otras formas de ver al mundo, pues solo ella puede acercarnos a la verdad. Solo la ciencia puede garantizar el progreso, por esto no puede siquiera pensar en su freno si las consecuencias no son muy afortunadas. La idea de incompatibilidad con prácticas como la ética o lo social, si acaso se tocaban de manera superficial o por algún tipo de conveniencia. Con Marx, creyente en la ciencia, con unas posturas polémicas sobre esta cuestión, de todos modos, se abre otro horizonte; la ciencia al servicio de los hombres.

Hoy entendemos con Markovic que:

Los valores humanos universales que expresan los intereses necesidades de la humanidad en general de ninguna manera son incompatibles con la verdad y el método científico. Sin ellos la ciencia quedaría reducida a mero conocimiento positivo y estaría desprovista de auténtico espíritu crítico. (1978, p.198)

Asertivo ha sido el tratamiento hecho a la economía y a la política, tratadas con interés científico hacía lo social. Entre otras, Marx se acerca a los clásicos. Se interesa en la técnica, observa de primera mano el acto mecánico, ve en todo esto algo que muchos no ven; descubre las relaciones intrínsecas, por eso la antesala de los Manuscritos del 44 que serán el fruto del encuentro de Marx con la economía política (Althusser, 1974). Su obra crítica se extenderá hasta El capital. La práctica política de la lucha de clases ha demostrado la inversión hecha por Marx; parece así alejarse de algunos contenidos hegelianos, dedicándose al hecho científico. Con El capital se compacta la teoría crítica a la ideología misma y no como se cree, que es una obra ideológica; todo lo contrario. Nace la criticidad científica al estilo social marxiano. 
En un tercer momento (mediados del siglo XIX), Marx asumió radicalmente el punto de vista de la sociedad civil como "sociedad regulada", como "hogar de la historia". Esta fue la apuesta fundamental del marxismo crítico. (Gantiva, 2005, p. 70)

Entonces, si “el carácter crítico y trascendental de las categorías económicas, expresado hasta entonces por conceptos filosóficos, es demostrado más tarde, en El Capital, mediante las categorías económicas en sí mismas" (Marcuse, 1993, p. 271); esto da como conclusión la consecuente apropiación de las realidades materiales del individuo a la ciencia económica, una verdadera revolución teórica, la cual, desafortunadamente, va ser muy tomada en cuenta subrepticiamente por los economistas de tendencias neoliberales a futuro, y bueno, ya el pensador de Tréveris, tenía claro el rol de los "expertos" en la producción, pero a la par daba su fórmula: "así como los economistas son los representantes científicos de la clase burguesa, los socialistas y los comunistas son los teóricos de la clase proletaria” (Marx, 1999, p. 141). Pero esto no se queda en esta cancha, ya se advertía en la década de los 70 del siglo XX:

La misma situación escandalosa existe en filosofía ¿Quién ha comprendido la prodigiosa revolución filosófica provocada por el descubrimiento de Marx? Sólo los militantes y los dirigentes proletarios. La mayor parte de los filósofos de profesión ni siquiera la ha sospechado. Cuando hablan de Marx es siempre, salvo excepciones rarísimas, para combatirlo, condenarlo, "digerirlo", explotarlo o revisarlo. (Althusser \& Balibar, 1974, p. 8)

El pensamiento económico fundamentado en el liberalismo tratará poco el asunto del sufrimiento humano, mucho menos la ideología como negación de la conciencia social. Fenómenos que parecen tan simples como el sufrimiento, pasarán, si acaso, al plano de las consecuencias inevitables del progreso, cuando no aun invocando la gracia o la voluntad divina. No obstante, teóricamente se levantan los cimientos de las nuevas directrices que gobernarán las economías modernas. Desde allí puede decirse que "la teoría pura caracteriza al agente independientemente de su ambiente" (Hahn \& Hollis 2004, p. 12); por lo menos así fue entre los reproductores de esa visión clásica que aún a inicios del siglo XXI, persisten exegéticamente.

Todo intento por estudiar al pensamiento marxiano o al marxista, no puede ni debe estar desligado de la comprensión, en dos sentidos, del fenómeno económico, de esa producción material; de un lado, el análisis propio que hace Marx y Engels con el método dialéctico; del otro la propuesta frente al modelo imperante del capital dictatorial en busca de una real transformación donde la economía y el capital estén al servicio del hombre y no al revés como hegemónicamente se venía dando.

Sus obras contienen asuntos tan humanos y tan filosóficos, abren los caminos polémicos para encontrarse con el rol del individuo en la construcción de su sendero material en busca de su emancipación. Vivir de verdad sin ser esclavo de un sistema de cosas es la meta, o mejor una de las metas. Difícilmente puede encontrarse con sus trabajos y dejar de cuestionarse, ya con ese simple hecho, en términos concretos personales, se avanza a una comprensión que de hecho está ya transformando las perspectivas de quien se acerca a los fenómenos. A la sazón,

Leer El capital como filósofo es exactamente preguntarse acerca del objeto especifico de un discurso científico y la relación especifica entre este discurso y su objeto; es pues plantear la unidad discursoobjeto el problema de los títulos epistemológicos que distinguen esa unidad precisa de otras formas de unidad discurso-objeto. (Althusser \& Balibar, 1974, p. 20)

La propuesta de Marx no es solamente una revolución social. Es una revolución epistemológica. Puede definirse desde sus pensamientos, desde sus proyectos y que, a la vez propugnan por generar otros cambios en las conciencias que materialicen la vía alterna de bienestar donde el hombre pueda ser libre, donde se 
emancipe de ataduras. Esto sobrepasa la dicotomía entre idealismo-materialismo de la que habló Rosental (Sf.). La propuesta marxiana toma a la praxis con una pauta distinta. Bermudo Ávila comenta:

En mi exposición de la teoría marxista del conocimiento la tesis principal -la cual considero el centro teórico de la teoría marxista de la praxis- es el concepto de práctico social consciente. Si nos planteamos el problema del conocimiento a nivel individual, a nivel psicológico, nos es imposible ver la teoría y la práctica como dos aspectos de un mismo proceso real, teórico- práctico, del proceso de la praxis. Planteado individualmente, o de modo abstracto, el pensamiento y la realidad, la conciencia y la existencia, aparecen como dos realidades, como dos niveles cuya única relación puede ser la de concordancia, adecuación, etc. En cambio, situada en el plano social, es decir, como práctica social, nos es posible entender y explicar la conciencia como un producto de la práctica real de los hombres y como una característica de esta práctica, es decir, como un aspecto de esta. (1975, p. 112)

Un cambio de visión de la práctica dentro de un modelo científico sustentado por un sistema económico es aporte significativo para tomar un camino social de todo aquello que el hombre produce. La sociabilidad de la actividad humana se asocia a los fines que deben plantearse para el acercamiento a la emancipación del sujeto. La superación del antagonismo teoría/práctica, aporta a la construcción de la misión, para el caso, de la formación humana en términos de la educación.

La tradición occidental de la que Marx bebe y a la que pertenece, tiene un fuertísimo resorte en la historia de la filosofía. El propio "conocimiento conceptual de Hegel, en tanto teoría, Marx lo utilizará; "la wesentliche Bestimmung ${ }^{62}$ de la ciencia filosófica, organizándola en torno a principios epistemológicosontológicos, lógica subyacente en el mismo Das Kapital" (González Varela, en Marx, 2012, p. 42), y con esto gran parte de los enfoques que vendrán a darse en áreas como la educación en las diferentes latitudes.

Habermas (1986) destaca el papel de la ideología en la técnica y la ciencia desde una perspectiva que reconoce el valor investigativo de Marx; la destrucción de la aparente libertad para develar la verdadera situación, traspasa los intereses de un panorama meramente epistemológico.

La abstracción que hace Marx de la realidad para descubrir las verdaderas relaciones y los intereses que hay detrás de ellos, más allá de la especulación, son rezadas por la teoría, por la investigación. En Inglaterra, logra retomar este ejercicio para desenmascarar relaciones verdaderas (Osorio, 2004). Marx hace de la abstracción un ejercicio práctico, con ella logra mostrar la existencia y efectos de la plusvalía, junto a otras interpretaciones de la sociedad de su tiempo. La abstracción hegeliana, tiene otro rumbo y es filosóficamente válido. No obstante, a propósito de esto último, de La ciencia de la lógica ya Lenin (1909) advertía la presencia de claves para la lectura comprensiva y la interrelación idealismo-materialismo.

La teoría del valor, solo por citar un ejemplo, convierte a Marx en un pensador del cual todavía hay mucho por definir. La utilización dialéctica de sus críticas, establecen avances en la apertura del pensamiento para ponerlo al servicio de las causas sociales. Es el caso de la inmediatez, que fuera tratada con la óptica de la economía, pero que, a la vez, tendrá repercusiones en el instante de repensar los aportes epistémicos marxianos conducentes a develar situaciones ocultas.

En él encontramos un primer principio, consistente en la discrepancia crítica al señalar las formas como los clásicos han tomado el problema de las supuestas leyes del valor que produce efectos más que negativos al ser humano de carne y hueso. Así también, tratando ese mismo problema,

\footnotetext{
${ }^{62}$ provisión de material
} 
...el segundo principio en el que Marx apoya su solución consiste en introducir una clara distinción entre el nivel de lo concreto y el nivel de lo abstracto. Ello resultará fundamental en la posibilidad de afirmar que la ley del valor es plenamente valida. Para Marx lo concreto constituye la realidad inmediata, el nivel de las apariencias y de los fenómenos, y todo aquello que forma la consciencia espontánea de los agentes que participan de una práctica determinada. Marx señala que no es posible explicar la realidad, si uno se mantiene en el plano de lo inmediato. La compresión científica de la realidad exige trascender la apariencia para alcanzar la esencia de las cosas, la cual no se manifiesta directamente. La abstracción representa para Marx el recurso que permite trascender lo inmediato y que conduce a la esencia oculta de la realidad. (Echeverria, Sf., Sp.)

Es de aclarar que "la misión crítica de la escuela también ha de tener como tarea cuestionar la sociedad en que está inserta, mostrando posibilidades alternativas frente a la misma. Esta última dimensión parece insuficiente asumida en la exposición hegeliana" (en Hegel, 1991, p 57), he aquí la separación de las perspectivas de los dos pensadores decimonónicos.

Marx es fruto del pensamiento occidental. Las construcciones filosóficas no llenaban a Marx quien miraba más allá de las abstracciones; su vida se movió entre los cambios de paradigma en el ámbito de la ciencia y los juzgaba (Riazánov, 1962). Su preocupación por la ciencia y los asuntos del conocimiento atravesaron límites de la criticidad.

La teoría del conocimiento ideada por el famoso filósofo alemán Kant está estrechamente relacionada con esa posición. Sostenía que las "cosas en sí” existen como realidades objetivas. En esto estaba de acuerdo con el materialismo. Pero luego afirmaba que el hombre podrá conocerlas: sólo podemos conocer fenómenos, es decir, "las cosas tal como se nos aparecen". Con esta conclusión Kant retrocedía al idealismo. (Novack, 1977, pp. 21-22)

Tomando a Cartesius, a los británicos y luego a Kant, muy a pesar de sus análisis, no se preocuparon, como representantes de un sistema de pensamiento de origen material, por la extensión social del conocimiento y de la ciencia; estos dos referentes del pensamiento occidental se convertirán en occidentalizadores como muchos otros, serán -independiente de sus valiosos aportes- baluartes del ser europeo centralizado. Del tema del mecanicismo o la autonomía no pasaban a la crítica social de un sistema que ya generaba contradicciones. La visión mecanicista del conocimiento de la anterior filosofía será no solo descartada sino también denunciada (Guzmán, 2017).

Entonces, en lo marxiano, a pesar de que es válida la tesis de que: "la conclusión a la que llega es que la economía capitalista, en todos sus aspectos y por su propia constitución, implica siempre la explotación del obrero" (Del Noce y Riestra, 1975, p. 68); no se limita a esto. Ya que si bien se señala en la descomunal obra de Marx - Engels, en su mayoría el contexto europeo y huelga decir, son propuestas salidas de esa evolución occidental de la filosofía, solo las orientaciones marxianas logran calar en el análisis, en la propuesta política de cambio para aquellas sociedades que sufren los efectos nefastos del sistema basado en la extrema mercantilización de todas las dimensiones humanas y de la naturaleza.

El carácter científico del saber y del conocimiento sofisticado, no superaba el interés por encontrar explicaciones desde el ámbito de la metafísica o el criticismo clásico. Hay que "aterrizar" a los fenómenos reales, a los fenómenos sociales, las herramientas del pensamiento; para ello hay que negar a la filosofía, o mejor, a la filosofía que se venía haciendo. Como anotación relativa Ceballos M. (2015) contextualiza que:

Esto significa que, en la reconstrucción del proceder de las ciencias, Descartes antepone un ideal metafísico de búsqueda de certezas definitivas al cual subordina el método científico. Este proyecto de edificación de una ciencia y una filosofía fundadas en certezas y evidencias absolutas ha fracasado sin ningún asomo de duda. 
Kant (1982), por su parte, ejecuta una maniobra distinta: invierte la relación e intenta someter la metafísica a las exigencias de la cientificidad, dando por descontado que las ciencias siguen el camino certero de adquisición del saber más confiable. (Ceballos M., 2015, p. 34)

Otro rumbo toma lo marxiano. Cuando Marx descubre que las relaciones sociales determinadas son productos de las relaciones sociales de los hombres, o sea, "los mismos hombres que establecen las relaciones sociales conforme a su productividad material producen también los principios, las ideas y las categorías conforme a sus relaciones sociales" (Marx, 1999, p. 126); se descubre toda una nueva construcción teórica comprometida en amalgamar diferentes campos del conocimiento en aras de reivindicar la dignificación del hombre como centro de interés más allá del antropocentrismo moderno.

Los asuntos sobre el saber deben ser revisados, pues hacen parte de la trama que puede llegar a justificar la injusticia, la expoliación o la misma acumulación exagerada de riqueza en pocas manos. La sospecha estaba sobre los nuevos paradigmas. En Introducción a la filosofía de la praxis, Antonio Gramsci comenta sobre la verdad dentro de la actitud científica, esa verdad encaminada a los temas más concretos.

En la discusión científica se supone que el interés radica en la búsqueda de la verdad y en el progreso de la ciencia y por esto demuestra ser más 'avanzado' el que adopta el punto de vista de que el adversario puede expresar una exigencia que debe incorporarse, aunque sea como momento subordinado, a la propia construcción. (Gramsci, 1970, p. 39)

De nuevo, en el caso de Marx, quizás no las descubrió porque siempre estuvieron allí, solo que estaban ocultas, camufladas. Marx destaca el papel primordial de la ciencia aplicada dentro del sistema de explotación, la tecnifica y mejora, logra desplazar al hombre. Entonces se crean otras actividades y relaciones, casi siempre muy dependientes.

Ejemplo es hoy la anticultura del consumo, es decir, se está formando al ser para el consumo, o para las "labores" no mecanizadas al estilo clásicamente industrial, formas de trabajo en apariencia sutiles pero que en verdad son formas de explotación nuevas. Se consume el tiempo mortal, los Grudrisse (Marx, 2006 vol.2) siguen vigentes en el tema del tiempo como productor de riqueza, otra forma cosificada de producción de capital, ahora suscitada de la tecnología de punta.

Hace de la ciencia un reclamo. Acude a la historia para teorizar desde la terrenalidad. Qué más muestra de la sujeción del factor humano -pero sobre todo su "dolencia"- en Marx, que la preponderancia, en sus análisis, los cuales no desfallecen de sustentos desde las diferentes disciplinas, que la denuncia al sistema más allá de las diatribas por cuanto dicho sistema de cosas atenta contra el hombre, la mujer, la infancia y su bienestar.

El caso irlandés de 1846 (Marx, 1998) donde quizás hiperbólico, recrimina él, la desaparición física de "más de un millón de seres humanos" (P. 881), situación funesta donde la vida humana valía poco, era el sacrificio que se debía pagar por el progreso, "lo pobres diablos" (P. 881) muertos por inanición no eran dignos de disfrutar de las mieles del sistema. La revolución epistemológica es una revolución social, su revolución teórico-social es una revolución epistemológica. Qué mejor muestra de complementariedad dialéctica aplicada, ya que el impacto sobre la comprensión de la ciencia y de la técnica, así como de sus efectos (De Soussa, 2011), recaen directamente sobre una sociedad de carne y hueso.

Acá, la ligazón con las necesidades de formación de las masas pone por encima los factores humanizadores sobre los afanes cientificistas o tecnicistas que se promueven como valores en el telón del sistema de relaciones esgrimido por el mercado capitalista. 
Una praxis que quiera actuar en la educación debe volver la cara a la ciencia como realidad transformable. Ha de retomarla como medio al servicio de la humanidad y no de un sistema imperante; con la ciencia entendida como tal, aplicada a lo cotidiano y a los mismos contenidos, podrá llegarse al reencuentro con la esencia de la ciencia pensada desde la eticidad. La ciencia en tanto herramienta de la revolución, va más allá de una aplicación a procesos medidos por el método científico. A pesar de la realidad ideológica de la ciencia y la tecnología (Habemas, 2015) cosa que hipotéticamente no cambiará si no cambia el modelo macro, la crítica debe seguirse generando y creando ambientes educativos y de comunicación para lograr disminuir los efectos negativos, conservar la esperanza en el cambio de paradigmas ideológicos será una meta a alcanzar.

La ciencia no puede seguir siendo arma de la ideología, máxime de una ideología del consumo como ahora puede verse; ella misma en directa proporción con sus objetivos, ayudará al desmonte ideológico de ella misma (Núñez Tenorio, 2015). El discurso científico no debe confundirse con el cientificismo constituido por las formas cerradas de hacer ciencia que se recargan de exclusión.

\subsection{Filosofía de la educación y currículo: entre ideología y conciencia}

Vale el esfuerzo pensar en que la idea de currículo puede llegar a ser confusa, así haya grandes teóricos y teorías. Más, quiero exponer que hay dos grandes concepciones que podemos ya definir. La primera, esa concepción generalizada de currículo que se limita a pensarlo objetivamente, o por lo menos a hacerlo desde algunos discursos, pues un tema tan destacado no está fuera del interés político como se ha afirmado anteriormente. La segunda, esa que lo pone en la mesa de la criticidad; aquí tenemos dos visiones, una más moderada y otra radical.

Nos interesará la segunda. Por un lado, esa visión moderada parte de elementos valiosos de análisis y en su mayoría depende de la evolución de la teoría general de la crítica, no deja de asociarse a lo social. No obstante, carece de una caracterización en la praxis propiamente como la entiende lo marxiano; quizás no es su interés en algunos frentes. Esto, podría encajarla de reformismo simple, pero también podría ser una manera paulatina de infiltrarse en el sistema.

La otra, la "radical", está compuesta por varias perspectivas también. Pero, en común está la necesidad formal de actuar frente a la situación; esto es a través de inserciones significativas. Suele proponerse también, una postura macro, incluso como proyecto político que pueda adscribirse como programa que llegare a ser oficializado en conjunción con algún vector partidista o sector social, etc.

Cuando se afirmaba que, "Revolutionäres Bewusstsein ist das Produkt von gemeinsamer Aktion und Diskussion" 63 (Engels, 1892, p. 563), se está siendo radical en la medida en que quiere hacerse distinción de aquello que hace especial al enfoque marxiano, para este caso, también la educación como acontecimiento social ligado a la materialidad y a sus extensiones concretas como lo es la escuela inmediata.

La radicalidad también se convierte en algo que contradice esta misma palabra. Me explico, si se tiene como objetivo hacer de la educación, a través de un currículo ideologizado por la perspectiva marxista para el caso-, se convierte en ideología, o sea, en una apariencia, en otras palabras, en una falsa conciencia;

${ }^{63}$ La conciencia revolucionaria es el producto de la acción conjunta y la discusión. 
la distinción entre conciencia revolucionaria e ideología revolucionaria no deja de ser clave (Silva, 2011b). La meta no es ideologizar, es si "politizar" al currículo con la criticidad, con acuerdos mínimos como la búsqueda de métodos y contenidos y una visión de administración social de la educación. Por ejemplo, la apreciación por la vida en todas sus manifestaciones estaría dentro del radar de un currículo críticamente radical, pues la misma vida es y debe ser una radicalidad. $\mathrm{O}$ sea, no es politizar a la manera clásica que la misma filosofía política burguesa definió y divulgó. Es hacer del currículo un instrumento político.

Es la aplicación en el terreno de la educación, de la disensión entre lo que llamaron ideología revolucionaria frente a la conciencia revolucionaria. Definida la conciencia, cuyo fundamento estará en la praxis, de lo que se trata es, precisamente, de unificar posturas y objetivos. Pero, antes no podrá perderse de vista cual es la visión de mujer y hombre, de individuo y comunidad que se tiene y se quiere construir, orientar. Así mismo, la realidad del contexto que se vive como lo avizoró Rodríguez -para el caso hispanoamericano de las nacientes repúblicas- en su momento y el cual no deja de ser precedente (Ocampo López, 2007).

Reconociendo la susceptibilidad del currículo, de esa realidad que está más allá de la teoría sobre el currículo oculto, y las demás derivaciones; podrá retomarse este elemento como herramienta adecuada a las necesidades que busca un rescate del valor de la educación para liberar al individuo y con él, a la comunidad. Si Zuleta (1975) apuntaba sobre la importancia de tocar a las carreras y a las facultades para que existiera una conciencia frente a los efectos neutralizadores del proeder capitalista, con más acentuación esta situación ha de recalacarse en la escuela, la base de todo proceso socio-revolucionario.

El punto de vista crítico del currículum revela las diferentes situaciones incoherentes dentro de la sociedad y por consiguiente del sistema y proceso educativo. Para Torres (1996), las prácticas tecnocráticas encuentran su mejor expresión en la escuela a través del currículo; pero eso, a mi juicio no es lo peor, es la difusión de la concepción del ideario de "superación" al modo del capitalismo, que confunde conscientemente, un proyecto de vida válido que ha de girar en torno a la solidaridad con los demás y su entorno, con el arribismo y el canibalismo que podrá encontrarse alrededor de una escuela inmediata, de una vida común.

Ese ángulo analiza de forma precisa como los currículos contienen un alto grado de ideología y en ciertas ocasiones se muestran dogmáticos e invariables. Es por eso que Giroux (2004) defiende la puesta en marcha de una concepción activista del currículo para lograr acercarse a propuestas que aporten a los cambios que no están negados.

Una de las demandas contra la idea e instrumentalización del currículo, surge precisamente de esa razón instrumental que denuncia la escuela de Frankfurt (Wiggershaus, 2011), en particular de pensadores como Adorno, Marcusse y Horkheimer. La criticidad sale de este ambiente marxista europeo occidental que ha de sobrevivir a los ataques fascistas, por un lado; y a los desprecios de la oficialidad estalinista, por el otro.

Históricamente la idea de currículo y su concreción ha sido pensada y activada por los intereses de clase. Ahora, el currículo en países como Colombia, Ecuador o Venezuela fue por décadas dictado desde una visión conservadora y reaccionaria. A esto se aunaba la incomunicación entre los diferentes niveles de formación, los horizontes no eran claros y es difícil definir si esto era por incompetencia administrativa de los entes encargados o era una intencionalidad real pero oculta. La mirilla del desmonte ideológico nos dirá la segunda opción anterior. 
Aquello implica el develamiento de nuestros sistemas educativos todavía funcionando de forma distorsionada la cual sólo se supera estudiando propositivamente, profundamente el currículo, lo mismo las estrategias pedagógicas con una reflexión activa. Siempre sin dejar de lado la sospecha del origen de las pautas que puedan regirlo.

Freire con su defensa de lo latinoamericano (McLaren, 2001), de esa perspectiva crítica, pero "desde acá", es el principal referente cuando de posturas de defensa de lo latinoamericano se refiere en materia de educación, incluyendo la conceptualización integral de currículo. Vale decir que, muchas veces este autor ha sido mal interpretado o señalado de estar bajo el ánimo puramente ideologizante.

La teoría de currículo se le define como una suma de exigencias académicas como base de experiencias (Sacristán, 1994). Desde otra visión, se reconoce la influencia del legado tecnológico y eficientista dentro de los currículos. Este aspecto refleja la faceta economicista, mostrando el afán del sistema y de la superestructura dominante, los cuales contextualizan a una escuela y una sociedad determinada. Sacristán (1994) a finales del siglo XX, hacía la denuncia de la copia de la visión de EE.UU para el caso español y como efecto dominó sobre las sociedades dependientes como las hispanoamericanas. Al leer los apartes de Baudelot y Establet (1976), pueden encontrarse los rasgos trasplantados a sistemas educativos.

De un modo, la teoría curricular como ideología es la que más se aproxima a la realidad. Sin darse cuenta los actores educativos reciben lineamientos políticos y culturales (característica de la aplicación y creación del currículo); obedeciendo a intereses de los grupos dominados y al orden impuesto. Por ello, el hecho curricular debe ser objeto de preocupación en cuanto es el motor de las actividades y experiencias educativas.

De otro modo, toda la teoría crítica, según Kemmis -en su momento- hace "en las escuelas, el saber se contempla frecuentemente de forma cientificista: revela una fe en la ciencia en los campos particulares que se acerca peligrosamente a la justificación del poder mediante el solo recurso de la autoridad" (Kemmis, 1993, p.125).

Ello no quiere que en las escuelas se trasmita de forma uniforme una ideología dominante, pues la misma escuela sirva de escenario y debe ser así para abrir una discusión seria y fundamentada donde surjan alternativas ideológicas. Desde la teorización curricular se puede partir a construir el factor que trate de armonizar y presentar de forma correcta los intereses de la educación; que conlleve al ligamiento de las verdaderas necesidades del individuo y la comunidad, haciendo de la práctica docente una función social. La respuesta contrahegemónica podrá darse en el mismo campo como afirma Torres (1996).

He aquí la clave para garantizar las dinámicas curriculares más allá de la centralidad de los aún impajaritables contenidos, de sus respondientes principales y su compromiso tangible: el rol de los docentes. En resumen, formación y currículo van de la mano. La autora argentina Inés Dussel (2006) rescata las pautas de análisis para el caso al traer de su experiencia, la inagotable importancia de pensar los currículos en concordancia con la recuperación democrática del conocimiento y los saberes; la tenencia de la situación contextual, con una clara correspondencia de pensar y poner en acto al ser político, democrático no sin antes darle la dignidad correspondiente a la labor educativa.

Claro, para poner en práctica una visión crítica del currículum y de la elaboración teórica sobre el mismo, es preciso estar al tanto de que, en cuanto teóricos y en cuanto profesores, somos productos de las ideologías; no obstante, exige que nos organizamos con otros para hacer muestras propias críticas, históricas 
y políticamente sensibles, de muestras de valores e ideas educativas sobre currículum, sobre nuestras propias prácticas educativas, y sobre nuestras propias situaciones de trabajo. Entonces es, cuando abordamos el proceso cooperativo de crítica de la ideología, "cartografiando" la realidad.

Al cartografiar nuestras ideas, prácticas, anhelos, planificaciones y situaciones en términos de su historia, de las relaciones sociales que activan, de las consecuencias que producen, la elaboración de la teoría crítica del currículum requiere que colaboremos en la lucha política para superar la irracionalidad, la injusticia y la coerción en nuestro propio trabajo y, a través de nuestro trabajo, en la sociedad en su conjunto (Kemmis, 1993); en otras palabras, la educación implícita y explicita en una propuesta curricular debe ser desafiante del statu quo, debe ser una apuesta de voluntad política estamental e individual; la propuesta se erige como acción como compromiso político.

Kemmis (1993), resumió, primero que un currículo alternativo crítico, debía tomar en cuenta en las dimensiones del lenguaje-discurso una proyección dialéctica. Segundo, en el campo activo de las relaciones sociales-organizativas una proyección hacia la construcción de sujetos con aspiraciones participativas, democráticas y perfiles comunitarios. Para cerrar en tercer lugar, en términos de acción-práctica, una preparación para la emancipación.

Para el caso de América Latina con sus particularidades la institucionalidad, para bien o para no tan bien, se ha trazado una serie de metas y otras cosas en los últimos lustros. Ya en 2008 la UNESCO junto a otras oficinas gubernamentales de países de la región y de otras instituciones, delinearon algunas políticas para actuar en conjunto. Los contextos de conflicto, por ejemplo, de algunas zonas buscaban ser comprendidas en esa etapa de postconflicto y a través, precisamente, de la educación. Evitar repetición era apostar por modelos de educación incluyentes, abiertos, democráticos, veraces, autónomos, críticos y autocríticos.

El pensar la educación integral e integradora no se limita a los debates académicos. Para citar un dato que muestra los esfuerzos de voluntad política, el seminario de la UNESCO a finales de la primera década del 2000 sobre asuntos educativos para Latinoamérica y El Caribe, enfatizó dos grandes temas:

Los dos temas-claves de este seminario fueron: (i) los más recientes procesos de reforma curricular de los países que han sufrido conflictos armados y (ii) el desarrollo de la cohesión social. Ambos tienen especial relevancia en el contexto centroamericano. Nuevos currículos y nuevos sistemas educativos han sido propuestos en los seis países en la última década, y los procesos de desarrollo e implementación de estos nuevos documentos involucran cuestiones muy diversas, de ámbito local, regional y global. (UNESCO, 2004, p. 1)

La crítica social es un medio (sociométodo) efectivo para descubrir los verdaderos intereses que se esconden detrás de la cuestión curricular, y claro está, del mismo proceso y sistema educativo. Por ello, el primer objetivo de la educación tiene que ser la orientación dirigida hacia el estudio para que logre desarrollar las investigaciones críticas que permitan comprender el proceso al cual responde la sociedad y cómo han llegado a tener estructuras actuales, estructuras ya sean históricas, sociales, económicas, políticas o culturales. Conforme a ello, él estudiante podrá desarrollar formas de acción y de reflexión que les facilite ser activos partícipes en la discusión abierta y democrática sobre los diferentes aspectos de su vida como actor de una sociedad, de una comunidad determinada.

Considerados así sumariamente, después de esa corta pero temeraria posición, de lo que se trata es primero de generar los espacios, en otras palabras, de ser agentes generadores de espacios de discusión sobre 
currículo comprendido desde la realidad inmediata que no es otra que la realidad de nuestra América, de pensar a nuestra América desde acá; desde los chiquillos de la primera infancia, pasando por los mozalbetes, llegando a los cursos postgraduales y de experticia. Integrar el currículo con los asuntos de la región en todos sus aspectos bajo el lente de la crítica y la propuesta, es apostar por un fin pertinente para estos momentos de cambios donde la democracia y el debate franco y pacífico de las ideas no deben tener reversa sino que están en el compromiso histórico de ir consolidándose de ir expandiéndose, en esto el currículo juega un papel importantísimo, de no ser así se quedará en un concepto o "campo" para falaces predicadores del discurso teoricista que solo alardearían de sus tecnicismos.

\subsection{El caso más universal: la cuestión del imaginario infundado y polemizado sobre Marx}

Para una filosofía de la educación con lo marxiano, es central hacer de los acontecimientos un motivo para analizar y abstraerse, para luego reestructurar. Cómo no tocar, al final de este tema, una ejemplificación muy relacionada con lo que puede hacer la influencia ideológica sobre los imaginarios. Es el caso de la visión generalizada sobre Marx a partir de los hechos históricos, el declive y los desaciertos de las experiencias, la propaganda, la unívoca versión y los ataques de formas ideológicas como la religión y la manipulación geopolítica.

Marcuse, en su momento demandó más compromiso sobre los asuntos inmediatos. No fue proclive a lo hermético de la teoría, a su aridez que se aproximaba más a doxa que a otra cosa significativa. Resalta la importancia de no sustituir las esencias del mensaje actualizado de lo marxiano y su compromiso geopolítico, o mejor socio-geopolítico. Al respecto decía:

En mi presentación, yo no hago la distinción que hacen algunos de mis colegas, entre Marx y Engels por un lado y la teoría marxista posterior, por el otro. Más bien considero, por ejemplo, a la teoría del imperialismo de Rosa Luxemburgo, Hilferding y Lenin como desarrollos auténticos de la teoría marxista original. (Marcuse, 1979, p. 37)

La reacción contra el marxismo y lo marxiano se dio en la forma de ideología, de esa idea de ideología que puede verse en Silva (2009). Para entender la correlación de pensamiento y praxis en términos de la educación desde Marx es necesario hacer justicia, eso sí de forma somera, de las actuaciones en algunos escenarios que tocaron el desarrollo de la humanidad sobre todo en el siglo XX y principios del XXI. Esto es preciso acercarlo a la luz de la comprensión dialéctica para entender la propuesta del rescate de categorías que están vigentes para el análisis y crítica a la educación desde la filosofía marxiana.

El apelativo de "marxista" produce todavía, en países cuyas sociedades han recibido una formación apegada a visiones teo-conservaduristas, en el mejor de los casos, desconocimiento y rechazo cuando no desprecio El mismo Marx tuvo que lidiar con el resquemor hacia lo denominado socialismo.

Los imaginarios reaccionarios fueron construidos mucho antes de la fundación de la URSS en 1922; ya en muchos países estaba la idea del marxismo como ideología antidemocrática, violenta, atea y apatriada, entre otras rotulaciones. Esto impactó de manera negativa. La educación de corte liberal y religiosa, hicieron un buen trabajo a lo largo y ancho del mundo. Las cúpulas religiosas de las diferentes creencias pudieron sufragar en las familias, desde sus discursos y textos catequéticos, un ideario escatológico contra cualquier 
simpatía hacia la nueva ideología infernal. En los países latinoamericanos llegó a afirmarse que los comunistas comían niños y tenían pacto con el demonio; la excomunión fue un arma ideológica cuando no la invitación a cometer crímenes contra estos rojos (como el diablo) pues era orden divina aniquilarlos, era un acto de fe como lo fueron las infames Cruzadas; se desata la nueva cacería de brujas. Con esto puede "entenderse" la actitud reaccionaria de ciertos sectores comunistas.

Para comprender porque cierta repulsión en el imaginario universal a la hora de tratar temas desde la lente marxiana o marxista, hace falta establecer un reconocimiento sintético al contexto en el que se tratará de implantar a nombre Marx, todo un sistema de cosas. Este contexto se desarrollará por casi ocho décadas con experiencias duraderas otras fugaces, otras "algo" exitosas, trágicas o que han sobrevivido jugando a las condiciones en apariencia contrarias. Basta reseñar Le Livre noir du communisme: Crimes, terreur, répression (El libro negro del comunismo) para quedar aturdido, traumatizado y convertirse en un furibundo anticomunista, ante todo: anti Marx, ni siquiera antimarxista.

Así como el comunismo científico fue elaborado en occidente, así también la reacción partió de allí. A propósito, en una entrevista a Hinkelammert (2001) le preguntaban: "La derecha defiende a capa y espada el sistema occidental capitalista, y, por lo tanto, rechaza el socialismo. ¿Los motivos de ese rechazo son que el marxismo es materialista, ateo y totalitario o son otros los motivos encubiertos?" A lo cual este responde:

FH.: Hablar de los motivos, es algo difícil. Se trata de la pregunta por la razón del anticomunismo en nuestra sociedad. Se sigue tratando del fantasma del comunismo que recorre Europa y el mundo. La razón no puede ser que el comunismo sea materialismo, o ateísmo o totalitarismo, pues los que reprochan todo eso al marxismo son muchas veces ateos (y si no son ateos son idólatras), casi siempre son totalitarios y encubren intereses muy materiales.

Según se dice, Thomas Mann sostenía que la mayor imbecilidad del siglo XX es el anticomunismo. El anticomunismo transforma todos aquellos valores que Max Weber había denunciado como "ética de convicción" que amenaza a la responsabilidad, en valores del comunismo. En nombre de la lucha en contra del comunismo los destierra de nuestra sociedad. De este modo se hace imposible su reivindicación. Efectivamente, el anticomunismo nos ha hecho perder la libertad.

La escena central del drama de Bertolt Brecht: Galileo Galilei, consiste en el interrogatorio en el cual los inquisidores enfrentan a Galileo. Lo enfrentan en nombre de Aristóteles, que es su fuente de verdad. Concluyen, por supuesto, que Galileo está equivocado. Éste les pide que vean por el telescopio para conocer lo que ocurría con las lunas del planeta Júpiter. Los inquisidores se niegan a mirar, aduciendo que jamás podría verse nada que no estuviera ya dicho en la física de Aristóteles. De esta manera desautorizaron la realidad en nombre de una verdad preconcebida.

El anticomunismo crea una situación como ésta, pero la crea de una manera invertida. Por eso, no tiene una sola máxima autoridad de la verdad. En vez de eso, tiene una máxima autoridad de la falsedad. Esta autoridad máxima del anticomunismo no es Aristóteles, sino Marx. Para comprobar que alguna tesis es falsa, es suficiente comprobar que Marx la compartió. (Pp. 87-88)

El Muro de Berlín, los gulags, la Revolución Cultural de Mao, el Régimen de Pol Pot, los métodos del Sendero Luminoso en Perú y otros temas tristemente célebres han sido relacionados con la figura de Marx. Todo ha sido sostenido - hay que decirlo- con una aparente razón de denuncia cuando en el trasfondo es solo parte de la lógica lucha antagónica entre visiones del mundo. Sin negar los crímenes donde deben existir responsabilidades individuales, también se han generado mitos alrededor de esto (Durán-Cousin, 1997) que exageran las consecuencias sin contar la acción de la parte reaccionaria. 
Pero, luego de leer el Livre noir du capitalisme (Libro negro del capitalismo) de 1998, se equilibra la balanza, no sin antes lamentar toda la muerte y destrucción que dejó esta confrontación bajo el pretexto de ser ideológica, pues infinitos intereses se movían alrededor de este eufemismo.

La repulsión también se dio en los escenarios del debate filosófico. Los calificativos que buscaban ridiculizar a Marx, al catalogarlo de profeta -como el caso de Popper (Slavin, 2008)-; daban razón de una intencionalidad por desacreditar más que encender un franco debate sobre las ideas. Las filosofías neo positivistas, las neoliberales y, aquellas cuyo basamento eran los criterios dogmáticos de la religión, no ahorraban esfuerzos contradictores. Cabe decir, mucho de lo elaborado por aquellas sirvieron para blindar aspectos teóricos al interior del pensamiento marxiano y marxista, así como ejercicio propio del debate de ideas.

Lo importante es comprender que, a pesar de la materialización de ciertos elementos marxianos, lo que prevaleció fueron aplicaciones marxistas entremezcladas con personalismos o complejas adaptaciones a las circunstancias, a las indicaciones ideológicas locales. Por esto las herramientas ofrecidas por la filosofía, dan la oportunidad de despejar las confusiones, adquirir un sentido crítico, que conduzca a la comprensión de la trama histórica en la que pueden llegar a desenvolverse ideas que han de producir efectos materiales concretos o imaginarios como ocurrió con la falsa o verdadera aplicación de algún tipo de cosas relacionadas con Marx.

La postura antiimperialista que se desprende de la lectura entrelineas de Marx, de ese pensador que se preocupa en sus años tardíos por los problemas geopolíticos, junto a sus quejas por la utilización de los obreros para las guerras enfrentándolos en campos de batalla o produciendo para la industria bélica, le ganará no poco enemigos. Sostiene Scaron que Marx en una carta a Engels del 14 de junio de 1853, demuestra su crítica a la dominación imperial: “...Por lo demás, la administración británica en la India, en su conjunto, era cochina y sigue siéndolo hasta la presente" (en Prólogo de, Marx- Engels, 1972, p. 6). Ya él mismo veía lo que se vendría para los inicios del siglo $\mathrm{XX}$, las dos grandes conflagraciones que en el fondo tenían intereses económicos más que políticos estrictamente hablando. El mensaje de unidad internacional de obreros, de abolición de la propiedad privada sobre los medios de producción y la emancipación de las formas de alienación, serán intencionalmente disociadas hasta en la misma educación impartida en muchos países del mundo a lo largo y ancho del siglo XX e inclusive todavía en pleno siglo XXI.

En el campo socialista, Lenin se convertirá en un referente que encarnará, de todas maneras, una postura marxista. En Lenin, se darán algunos ingredientes fuertemente contraculturales; la educación fue vista como la mejor vía para enfrentar a los hostigamientos e iniciar una lectura diferente y novedosa del sistema, no sin contratiempos, pero sobre todo negatividades a posteriori como se registra en Hobsbawm (2003). Entonces desde Lenin,

...el abordaje educacional que defendía debía adoptar la totalidad de las prácticas políticas, educativas y culturales, dentro de una concepción amplia de lo que es una transformación emancipadora. De esta forma una contraconciencia, estratégicamente concebida como alternativa necesaria a la internalización dominada colonialmente, podría realizar su gran misión educativa. (Mészáros, 2008, p. 53) 
Después del triunfo bolchevique de 1917, el mundo no será el mismo. El sistema que venía consolidándose tendría un contrincante más que ideológico. Esperanzas se plantaron a partir de allí por parte de movimientos obreros alrededor del mundo, pasó lo impensable: por lo menos teóricamente hablando había llegado al poder de un país atrasado, pero históricamente influyente, una fracción de izquierda que se autoproclamaba seguidor de la visión marxista. Tiempo después, tampoco el mundo mirará con los mismos ojos a Marx y a su legado después de los hechos de 1989-1991.

Otra concepción rechaza, bajo el argumento de fracaso del socialismo, establecer cualquier diálogo a partir de los aportes marxianos. Esto deja ver un desconocimiento de lo que es el pensamiento de Marx, pues este no puede limitarse a una experiencia histórica distinta a las metas propuestas desde la criticidad marxiana. Rooke (2003), dice que "la rápida desintegración del stalinismo después de 1989 no significó la muerte del marxismo sino más bien el <rechazo al trabajo> bajo un <comunismo> de cuartel" (P. 136). Es decir, no es la concepción socialista sino primeramente la aportación categórica la esencial para reconstruir la criticidad de una propuesta filosófica en educación.

Para Feinmann (2006), aunque la caída del Muro de Berlín no será más el pretexto del fin de la historia, la desaparición de los dos bloques totalitarios (fascismo institucional y comunismo de Estado) no serán más de utilidad para construir teorías de conflicto; Fukuyama ya no sirve. Ahora los poderes armamentistas de occidente necesitan otra teoría del conflicto; Hungtington, entonces, crea el llamado choque de civilizaciones, el cual va impactar más negativamente en nuestros días (Feinmann, 2006). Sin embargo, seguirá siendo un fantasma el contenido y sobre todo el significado de lo marxiano, máxime cuando intenta darse una interpretación desde lo vigente en Marx en campos tan sociales como la educación.

Una última idea cercana a la estigmatización de lo referente a Marx, fue la que se impuso en las mentalidades al pensarse que en socialismo se abolía la propiedad, que se tenía un desprecio por el trabajo como esfuerzo, esto en los países de regímenes liberales en vías de desarrollo. Se veía a cualquier asociación sindical como líderes de un tipo de "vagancia"; pues el simple hecho de exigir en huelgas era anti natura, no era posible tolerar esta visión del trabajo, pues el trabajo era para generar riqueza que al final daba progreso y ocupar a otros para evitar vicios. El trabajo marxiano no tenía cabida pues era un tipo de alcahueta. No podía desafiarse la predestinación de la división del trabajo, mucho menos si se incentivaba la crítica.

Un sistema de cosas pensado desde el socialismo relacionado con Marx, significaba el establecimiento de una limitación de libertades, de escasez, de militarización de la sociedad, y de una burocracia que se enquistaría al perpetuarse en el poder. Sobre esto último, la experiencia histórica dará su veredicto insistiendo en el desvío de lo propiamente marxiano. Broccoli en 1980 señalaba al respecto que:

Es indudable, sin embargo, que también en las sociedades socialistas cuando se detuvo la praxis de transformación, antes de la realización del comunismo, y se instauró "comunicación" entre los detentores del poder, que sabían, y todos los demás, que no sabían exactamente como era patrimonio de los primeros, el socialismo se acabó y se instauró, más bien, una burocracia. (P.31)

Los imaginarios siguen estando presentes. Por ejemplo, cuando se habla de educación desde el marxismo, se tienen prevenciones, en la mayoría de los casos, porque precisamente algunas formaciones individuales no han superado la etapa del macartismo académico, consecuencia del macartismo político y cultural. Aun cuando lo marxiano es definido como el abordaje de categorías objetivas dentro de las relaciones presentes 
en la trama educativa, no puede negarse que por su espíritu crítico obtenga no pocos enemigos más que contradictores.

La visión marxista y marxiana de la educación perdurará mientras perdure el sistema capitalista de cosas. Mientras haya fetichismo, habrá crítica al mismo. "Siendo el marxismo una teoría critica del capitalismo, persistirá mientras éste exista" (Núñez Tenorio, 1998, p. 153). La crisis a la que se apela, no tiene sentido, excepto el de ser otra etapa más de los procesos, de los cuales se retroalimenta convirtiéndose las etapas de crisis, en fortalezas. De esto ejemplo es el mismo Sánchez Vásquez, quien, a pesar de la crisis del socialismo real, respondió diciendo que en América Latina el asunto de la praxis marxista -marxiana diría yo- tendrá cabida mientras el sistema capitalista no cese (Arriarán Cuéllar, 2014).

La única crisis evidente, y que no afecta en grandes proporciones a las sociedades desarrolladas capitalistas por motivos de la verticalidad dependiente ${ }^{64}$, es la del sistema capitalista por sus propias contradicciones; Marx en Capital y crisis (1986), expone las muy conocidas predicciones que sobre economía hubiera podido dar, no sin ese espíritu crítico que traspasó toda su obra, pues en el campo económico, sus aportes han sido escondidos o adjudicados a otros por razones lógicamente ideológicas. Recordando siempre que, sus tratados de economía tienen una intención totalmente social, humana y de reconocimiento de la teoría para entender las relaciones inmediatas que obedecen a un establecimiento basado en la producción y acumulación.

${ }^{64}$ Línea de explotación de recursos y dependencia económica de la periferia; toda crisis que se desata en el mundo capitalista desarrollado encuentra alivio en la intervención financiera, el consumismo y la guerra por recursos disfrazada de otros motivos. 


\title{
TERCER MOMENTO FILOSOFÍA DE LA EDUCACIÓN y PRAXIS
}

\begin{abstract}
Seguimos pensando que el marxismo es ante todo y originariamente una filosofía de la praxis, no sólo porque brinda la reflexión filosófica de un nuevo objeto, sino especialmente por "cuando de lo que se trata es de transformar el mundo" forma parte como teoría, del proceso mismo de transformación de lo real. (Sánchez Vázquez, 1980)
\end{abstract}

La ideología no es solo un fenómeno propio de la abstracción o del juego proselitista, esta es apenas un asomo de lo que puede desatarse en espacios tan sensibles como la educación. Logrando exponer la visión crítica de la ideología de la mano de Marx y de otros teóricos, vemos que, a pesar de su dañino efecto, sobre todo en la educación, existen maneras de repelerla. Una de estas formas es la aproximación a la conciencia social que puede darnos la educación crítico-proponente; pero ésta podrá darse en la medida en que se avance de la práctica a la praxis. La praxis se traduce en transformación, esta tiene que dar mucho en al acontecimiento educativo mismo, desenvolverse allí; ojalá convertirse en una actitud a niveles micro y macro sin perder de vista que es un tema político e alto compromiso histórico debido a las consecuencias negativas que el sistema de cosas ha desatado.

Ahora miremos el segundo gran socioconcepto, la segunda socio categoría que nos servirá para ir tejiendo la comprensión crítica de la escuela inmediata ya no como amenaza planteada con la ideología, sino como oportunidad si se empieza a integrar con la praxis.

En esta sección invitaremos al pensador Adolfo Sánchez Vásquez para que nos sirva de resorte a la hora de retomar el sentido de la praxis como vía hacia la transformación educativa en los entornos inmediatos que propician la inmediatez.

\subsection{Aproximación a lo que es praxis}

En Marx hay carácter práctico, este carácter es revolucionario, y así lo pone intencionalmente. La praxis tendrá, en últimas, un carácter denunciante. Ya sabemos la posición que tuvo Marx con la filosofía, posición que debe leerse desde la dialéctica y sin resentimientos ideológicos. La filosofía debía actuar, comprometerse con aquellos hombres, mujeres y niños relegados por el nuevo sistema de cosas; él nunca maquillo su postura de pensador al respecto; por esto será perseguido político e intelectualmente discriminado; la capacidad de filosofar no podía ser más como venía siendo, como venía haciéndose.

Sánchez Vásquez (1980) afirma que: "el marxismo es, ante todo -seguimos pensando-, una filosofía de la praxis y no una nueva praxis" (P. 15), esto lo hace resaltando el carácter histórico de la praxis en tanto conciencia filosófica que con Marx adquiere un sentido más concreto, denunciante y social. Este autor sabe de la importancia en reconocer los aportes de Hegel y Feuerbach sobre el particular, lo cual llevará a Marx a hacer de la praxis parte íntegra de su concepción para transformación del mundo más que para su teorización al sentido absoluto de abstracción idealista. La postura de Sánchez Vásquez entorno a la praxis es vigente, pues hace rescate del asunto (Uc Sánchez, 2016), además de basarse en Gramsci para dicha visión en América Latina, toca las relaciones entre educación y praxis desde la perspectiva de Marx como dice Arriarán Cuéllar (2014), así como de la conciencia y la vida cotidiana (Gandler, 2006). 
Gramsci (1970), propuso en su postura sobre la filosofía de la praxis la conciencia que debe existir al resaltar los problemas para el estudio de esta, entre las que están la definición de las obras y los programas de Marx, lo metodológico, la relación con aspectos del ámbito político y epistemológico (ciencia-sentido común).

En la realidad del mundo, la filosofía de la praxis de la que habla Sánchez Vásquez (1977), determinará, más que una nueva práctica filosófica, un rescate de lo marxiano de Marx. Se comparte, entonces, su aporte conceptual a propósito de mostrarse preocupado por la confusión de conceptos aparentemente parecidos, a saber, entre práctica y praxis.

Praxis: en el sentido de la Tesis I sobre Feuerbach (de Marx): "Actividad humana como actividad objetiva", es decir, real; "actividad revolucionaria... crítico-práctica". Actividad, pues, orientada a la transformación de un objeto (naturaleza o sociedad), como fin acorde a la subjetividad consciente y actuante de los hombres y, por consiguiente, actividad —en unidad indisoluble — objetiva y subjetiva a la vez. Lo determinante en este proceso práctico no es la transformación objetiva (separada de la subjetividad) ni la actividad subjetiva (separada de la objetividad) sino la unidad de ambos momentos. Este concepto de praxis se da cumplidamente en la forma ejemplar de ella que es el trabajo humano, tal como lo define Marx en El Capital, y no puede identificarse con el althusseriano de "práctica" que ve lo determinante en el proceso de transformación mismo haciendo abstracción del momento subjetivo. (Sánchez Vásquez, 1977, p. 64)

Originalmente, en su primera tesis de los apuntes sobre Feuerbach, Marx define la praxis como "crítica revolucionaria". Reclamando su conocimiento, escribe al final del mencionado fragmento ${ }^{65}:$ “(...) Er betrachtet daher im Wesen des Christenthum nur das theoretische Verhalten als das echt menschliche, während die Praxis nur in ihrer schmutzig jüdischen Erscheinungsform gefaßt und fixiert wird. Er begreift daher nicht die Bedeutung der „revolutionären“, der, praktisch-kritischen“ Tätigkeit”"66 (Marx, 1845, párr. 1). La pasividad, el exceso contemplativo inquietaba al joven Marx y con esto llegará hasta sus últimos días, bregando por dar a la praxis su lugar histórico.

Precisamente, esa pasividad, esa primacía de la contemplación fue la que no encajó en el joven Marx desde sus años de destacado estudiante de filosofía por allá en la década de los treinta decimonónicos. Sobre el concepto de praxis en la juventud de Karl Marx, logra decirse por estudio de Bermudo (1975), que:

Respecto a la teoría de la praxis, no aparece el menor paso hacia su elaboración. Al contrario, la escisión teórico-práctica, característica de toda la filosofía burguesa, está como elemento determinante en el pensamiento del joven Marx. Por un lado, la práctica aparece como actividad crítica (tal como ya formuló en su Tesis doctoral: la filosofía ha de ser práctica, pero la práctica de la filosofía es la crítica). La práctica es, pues, para el Marx de la Gaceta una fuerza política que sigue a la teoría. Es la materialización de la idea (...)

\footnotetext{
${ }^{65}$ Geschrieben im Frühjahr 1845. Nach der Veröffentlichung des Marx-Engels-Lenin-Instituts, Moskau 1932. Diese Version aus Karl Marx u. Friedrich Engels, Werke, Bd.3, Berlin 1978, S.5-7. Transkription u. HTML-Markierung: Einde O’Callaghan für das Marxists' Internet Archive.

66 "Por eso, en La esencia del cristianismo sólo considera la actitud teórica como la auténticamente humana, mientras que concibe y fija la práctica sólo en su forma suciamente judaica de manifestarse. Por tanto, no comprende la importancia de la actuación "revolucionaria", "práctico-crítica".
} 
Y va a ser precisamente esta posición burguesa utópica una condición de la ruptura política del joven

Marx con la burguesía. Marx, como teórico, intelectual burgués, identifica filosofía y política. (P. 102)

Es sano conocer la conceptualización, pero sobre todo la contextualización de praxis de uno de los primeros pensadores de esta dimensión categorial como lo es Marx. Pues, siguiendo lo marxiano, se deja incompleto cualquier asunto si no analizamos lo contextual y las fuerzas que están presentes. Él mismo se dio cuenta del problema que genera la separación de teoría y práctica en el seno del Estado, esa fue una separación intencional, pues el ideal era progreso, a costa de sometimiento de la explotación de otros sectores; de un discurso liberal-democrático más la reacción feroz del aparato coercitivo los cuales frenaban e intimidaban, y así los hizo saber en su Gaceta. Esta coyuntura no fue esquiva al sentir del joven Marx, la cual se reflejará en sus futuros aportes sociocientíficos. Rózhin (1966) decía en contestación a su pregunta sobre el concepto de práctica que, "práctica es la actividad social, material y adecuada a las gentes, orientada a la transformación de la naturaleza y la sociedad" (Rózhin, 1966, p. 249).

Algo podría ser susceptible de interpretación, de contradicción y, es el hecho de que sí la praxis es práctica -en su sentido lato-, en su origen griego $(\pi \rho \bar{\alpha} \xi l \varsigma)$, so pena de caer en simplismo terminológico; desde lo marxiano adquiere otro sentido. Y es que la dificultad podría residir en la afirmación sobre la no dejación de un método específico por parte de Marx. Pues bien, Marx no deja recetas, ni obligatoriedades, lo que no quiere decir que no haya una metodología general marxiana que pueda construirse a partir de la realidad concreta, eso sí, sin renunciar a su compromiso social e histórico en los diferentes ámbitos del cotidiano. Todo aquello que denuncie la explotación en todas sus manifestaciones, que busque emancipar y que busque transformar materialidades, está cercano a la praxis siempre y cuando no abandone su sustento formal.

Sostiene Silva (1974), que en Marx teoría y práctica son complementarios; no son esquivos entre sí. Así mismo, hay un solo Marx que integra teoría y práctica, que se preocupa por tal asunto en todo su compendio filosófico. Él mismo es teoría y práctica, caso bastante difícil de encontrar en un pensador, máxime hoy cuando hablamos es de profesores de filosofía más que filósofos, tal cual dictó Henry David Thoreau en Walden $^{67}$, en su momento. Gran parte de la vida y obra de Marx fue praxis viva (González, 2015). Por eso, al encontrarse con la vida diaria y su valor social, se hará acercamiento a una de las intenciones marxianas poco discutidas en su aporte: rebelarse contra el imperante sistema de cosas.

La obra marxiana es una obra praxiológica. Es decir, por contenido, forma y mensaje, es transformadora. Hasta en sus cartas más íntimas o sobre temas misceláneos (Marx-Engels, 1973a) está el reflejo de su interés por la transformación. La transformación liberadora y para la liberación es lo que hace especial, contradicho y a la vez polémico al Marx práctico. Debe decirse que no puede confundirse, como se ha hecho, a la praxis marxiana con una especie de pragmatismo, pues este último es mecánico, tiende a la superposición sobre lo otro en aras de un beneficio; la praxis en cambio, es reflexiva, transformadora, revolucionaria y no busca sino aquello que trate de garantizar: un cambio consciente en la materialidad sin ir en detrimento.

67 "There are nowadays professors of philosophy, but not philosophers. Yet it is admirable to profess because it was once admirable to live. To be a philosopher is not merely to have subtle thoughts, nor even to found a school, but so to love wisdom as to live according to its dictates, a life of simplicity, independence, magnanimity, and trust. It is to solve some of the problems of life, not only theoretically, but practically". 
La noción de praxis, sin embargo, es una noción compleja. Es decir, es una noción unitaria y diversa. Praxis no es ni "practicismo" ni "criticismo", ni cientificismo", sino que es, unitariamente, la actividad humana -practico-sensible - en la que se articulan un determinado conocimiento de la realidad social, una crítica radical a dicha realidad y un proyecto para su transformación. (González, 2015, p. 196)

Para Lenin (2010), sin teoría no hay práctica ${ }^{68}$. La praxis desde lo marxiano exige una revolución íntegra entre epistemología y política. A la par de la intención por el desmonte de la ideología están las necesidades de un desmonte epistemológico y por supuesto de una propuesta política en tanto exige transformación de las situaciones, para este caso, de las relaciones intrínsecas en la escuela.

Pues bien, desde el punto de vista de Marx, la transformación de la realidad es la tarea de todas las ciencias, y no específicamente de una sola de ellas; la filosofía tiene la tarea de transformar, al igual que las otras ciencias de la naturaleza. (Broccoli, 1980, p. 40)

Toda la propuesta filosófica marxiana se reconoce en filosofía de la transformación. El gran aporte de Marx, a diferencia de los anteriores pensadores, ha sido el carácter denunciante de su filosofía, la crítica y la invitación a transformar para la totalidad social a través del replanteamiento de la filosofía de la praxis (Sánchez Vásquez, 1980). Sus cimientos se levantan del análisis de las situaciones inmediatas que, siendo abstraídas, vuelven al escenario mortal, escudriña las relaciones y fenómenos entre las personas y sociedades, rechaza las banalidades de las formas aburguesadas de pensar, busca respuestas en la actitud científica en la producción económica; llegando a la conclusión de que no hay leyes innatas o eternas en ningún campo de la vida, todo es hecho, desatado por la voluntad de las personas y sus sociedades.

Hacer praxis exige autocrítica; en esto falló la experiencia soviética. Cuando el joven Marx comprobó con los hechos que, la acción de las clases dominantes no eran lo que aparentaban, supo que estas clases elitistas no darían tregua al momento de sentirse amenazadas (Silva, 1983); entonces recogió sus apuntes sobre política liberal burguesa a la que admiraba hasta cierto sentido; remitió a la consciencia el contenido filosófico de esta clase, y viró con razones hacia una apuesta por algo distinto, alternativo que incluyera a los excluidos que ahora eran motor de toda la sociedad. Descubrió que esa clase revolucionaria que en su momento prometía, ya no era tal; luego él, se convirtió en autocrítico y con ello en un ejemplo de su misma propuesta de praxis. La práctica llevada a cabo por los burgueses, negaba cualquier progreso real, él mismo vivió persecución. La praxis no podía traicionar su esencia transformadora, mucho menos si las propuestas de transformación son inmediatas o parciales.

En Tesis sobre Feuerbach rescatadas por Engels (1986) y que consignará al final de su libro: Ludwig Feuerbach y el fin de la filosofía clásica alemana ${ }^{69}$; se encuentran sin rodeos los presupuestos marxianos sobre la práctica entendida como praxis. Hay que decir, bajo el espíritu de esta exploración que, dichas tesis no fueron descuidadas por Marx en toda su obra, con ellas se demuestra una transversalidad praxiológica que puede verse, entre otras, en el interés por dar a conocer su punto de vista sobre la realidad. Sin duda su monumental obra encarna dichas tesis, no podría surtir efecto lo marxiano desde una filosofía de la educación sin la lectura fáctica de aquellas puntualidades.

Para efectos de una visión de la filosofía de la educación que vaya de la mano de lo marxiano, la tesis once es de vital observación, pero más lo es, en primera instancia, la octava y luego la tercera, pues ellas nos

${ }^{68}$ Aclarando que se habla de teoría revolucionaria y práctica revolucionaria, textualmente en el líder soviético.

${ }^{69}$ Ludwig Feuerbach und der Ausgang der klassischen deutschen Philosophie (1886) 
permiten tener la aproximación e invitación a la praxis como realización que se hace en la más conocida, que es la onceava. Esto sea dicho de paso, porque ha de destacarse la dinámica del cotidiano, de eso inmediato en el análisis circunstancial donde se presenta el acto educativo, y la escuela inmediata como acontecimiento histórico y de compromiso.

La labor pedagógica marxiana se encaró en sus diferentes obras; esa labor fue retomar la teoría como práctica, su obra fue precisamente esto. Como dice Silva (1974), existió en sus escritos tempranos el interés por no disociar teoría de práctica. No fue sino en sus Thesen über Feuerbach donde estaría esa concepción global del mundo como algo transformable.

Si bien las tesis aparecen en tanto observaciones del materialismo anterior y a la postura de Feuerbach, la tendencia de este pensador alemán, se sabe, calará en la invención marxiana. Marx pasará de las contradicciones terrenales a las contradicciones sociales, "las contradicciones de la práctica humana" (P. 185). Lo que busca Marx es reconocer en la práctica teórica un camino para contra atacar a todas las formas de alienación. Caso puntual es aquel que parte del ejemplo de la que tiene que ver con esta actitud negadora cuya fuente se da en la órbita religiosa (Opium des Volkes). Establece así, un caso muy del cotidiano que encierra elementos teóricos y muy evidentes en la práctica que en definitiva solo serán superables con una retoma de la praxis en los ambientes sociales que se debían gestar en el seno de las clases trabajadoras.

Cada tesis es especial, y guarda una rica invitación a ser escudriñadas, a ser dinamizadas para que retomen vigencia. La tesis más relacionada con el asunto de la praxis es la numero once, ha sido la más difundida. Empero, la octava tesis guarda el mensaje directo sobre la práctica que se refleja en lo cotidiano. Esto es para destacar, pues para esta exploración investigativa y propositiva, lo cotidiano de la mano de una lectura marxiana es lo principal dentro del acontecimiento educativo. La octava tesis reza: "Alles gesellschaftliche Leben ist wesentlich praktisch. Alle Mysterien, welche die Theorie zum Mystizism[us] veranlassen, finden ihre rationelle Lösung in der menschlichen Praxis und in dem Begreifen dieser Praxis "70 (Marx, párr. 11, $1845)^{71}$.

Por su versión al castellano, dice: “[VIII] La vida social es, en esencia, práctica. Todos los misterios que descarrían la teoría hacia el misticismo encuentran su solución racional en la práctica humana y en la comprensión de esa práctica"72 (Marx, 1845, párr.,12). Empieza a asomarse el motivo teórico por lo cotidiano, por esa fugacidad que es la vida humana, pero que, al tiempo, prolonga las relaciones de explotación mediante imaginarios socioculturales.

\footnotetext{
${ }^{70}$ Toda vida social es esencialmente práctica. Todos los misterios que impulsan la teoría del misticismo [nosotros] encuentran su solución racional en la práctica humana y en la comprensión de esta Praxis (práctica). [VIII] La vida social es, en esencia, práctica. Todos los misterios que descarrían la teoría hacia el misticismo, encuentran su solución racional en la práctica humana y en la comprensión de esa práctica, en Marxists archives.

${ }^{71}$ En versión de: Geschrieben im Frühjahr 1845.Nach der Veröffentlichung des Marx-Engels-Lenin-Instituts, Moskau 1932. Diese Version aus Karl Marx u. Friedrich Engels, Werke, Bd.3, Berlin 1978, S.5-7. Transkription u. HTML-Markierung: Einde O’Callaghan für das Marxists' Internet Archive.

${ }^{72}$ Escrito en alemán por Karl Marx en la primavera de 1845. Fue publicado por primera vez por Friedrich Engels en 1888 como apéndice a la edición aparte de su Ludwig Feuerbach y el fin de la filosofía clásica alemana.
} 
La reflexión sobre el trabajo le permite a Marx explicar la conciencia como producto social e históricamente determinado. De las vagas formulaciones de los Manuscritos pasa, en las Tesis sobre Feuerbach, a una formulación esquemática de una nueva teoría del conocimiento basada en el nuevo concepto de praxis. (Bermudo, 1975, pp. 98-99)

Ahora bien, la idea de praxis en Marx surge de su visión del valor que lo lleva al origen del trabajo enajenado (Marx, 1982a). Cuando el sujeto aplica todo su ser y mortalidad en la creación más allá de la simple poiesis a la cual está atado por la circunstancia mercantil de su fuerza de trabajo, crea, innova, pero sobre todo se siente libre, emancipado. La idea del trabajo libre y emancipado, pero con una conciencia individual y social del mismo, no como el que se ve en algunas especies de la naturaleza que a la sazón cita Marx en $E l$ capital (2013).

La socio-investigación filosófica marxiana se convierte en praxis en el momento en que se dan los resultados teóricos evidenciables en la realidad historial del individuo y de la sociedad. Se habla de praxis en dos sentidos: uno, en el esfuerzo por evidenciar las contradictoras situaciones de explotación y sus consecuencias; y dos en el instante en que se pide transformar la realidad como lo hace Marx en su tesis número once (Marx, 1845).

No podemos abandonar este ingreso sin tocar el término de práctica. El apunte sobre la praxis desarrollado en el primer item (1) guardado en las Tesis sobre Feuerbach es referente del mexicano Sánchez Vásquez para iniciar la teorización sobre la Filosofía de la praxis como nueva práctica de la filosofía, vertiente que puede aportar bastante a la filosofía de la educación marxiana con ingrediente latinoamericano. Tal como se hizo anteriormente con el concepto de praxis, ahora será el de práctica, pues no está de más comprender su especificidad, por esto Sánchez Vásquez acota:

Práctica: si su significado se amplía, hasta incluir todo proceso de transformación, cualquiera que sea el material, los instrumentos de transformación y el producto, cabe hablar entonces de "práctica teórica" o también de "práctica onírica" o "alucinatoria", pero en este caso el concepto de práctica desborda (o más bien falsifica) el sentido originario de "praxis" (en la Tesis de Marx antes citada). La teoría pierde su especificidad al convertirse en una forma de praxis y se borra la distinción entre teoría y praxis. $(1977$, p. 65)

Según este autor, dentro de la retoma filosófica de la praxis, no puede descuidarse la diferenciación de estos dos términos, los cuales podrán encontrarse para integrarse en pos de una labor filosófica de carácter transformador y no como simple contenido. El autor sigue diciendo que:

Práctica" tiene el sentido de actividad o ejercicio y de acuerdo con él hablamos de < práctica filosófica> (como forma de la "práctica teórica") con el significado de modo de hacer, cultivar o ejercer la filosofía. Pero se trata de una práctica que de por sí no es praxis”. (P. 65)

La diferencia o aclaración entre práctica y praxis, ha de establecerse para seguir una orientación conceptual la cual pueda ofrecer herramientas de comprensión para leer la educación desde una lectura filosófica con lo marxiano.

Quiero invitar a Antonio González (2012), cuyo tratamiento de la praxis aparece a la manera de un "surgimiento", o como él mismo llama en toda su obra: "radical". Acudiendo a una visión poco aceptada entre círculos marxistas, más no por esto menos apreciable, precisamente, por su rescate de lo "esencial" y 
por tratarse de una ventana distinta de análisis que de todos modos no pierde ese horizonte, aquellos objetivos que se planea la actitud práxica. Para él este momento teórico y de comprensión, dice:

La praxis, de entrada, no es algo visible, objetivado ante nosotros. La praxis, más bien, es transparente, y el esfuerzo filosófico consiste justamente en mostrar lo que de entrada no se ve, no porque esté oculto "más allá de las apariencias sensibles", como pensaron los clásicos, sino más bien porque está más acá de todas las cosas, como la luz que no se ve pero sin la cual es imposible la visión. Al mostrarnos la praxis, la filosofía nos sitúa ante un campo de trabajo inesperado, y enormemente rico en contenidos. Allí están todos nuestros actos, con su enorme multiplicidad. (González, Sf., párr. 20)

En concordancia con lo anterior, Pérez Villamarín (2015), retoma la importancia de la "novedad de los actos" como filosofía primera, encausados en las indicaciones que al respecto hiciera un pensador alejado de lo marxiano como lo fue Zubiri. Pero, no por ello deja de ser interesante esta concepción que rescata el tema de la praxis en la historia del pensamiento.

Entre los griegos, la idea de poiesis no superó su relación con la producción concreta. La idea de praxis en la modernidad racional se encajona en la "práctica" que consolide el modelo económico y político desprendido del mercantilismo. Así, por ejemplo, la eclosión de la ciencia como validez universal para aplicar sin ninguna o poca reflexión, siguiendo una serie de pasos de ensayo y error, es de vital importancia para el sostenimiento de un sistema de cosas determinadas por las relaciones hiladas del mercado.

Los caminos de la aplicación práctica de los conocimientos fueron tema de debate a inicios de la modernidad; la instrucción se dio en la aplicación de pautas tanto en la escuela como en la fábrica. El empirismo inglés dará una idea muy original de práctica en la medida en que se ajusta a la realidad de un país que busca establecerse como potencia mundial. Por ello la necesidad productiva y de conocimiento del mundo, exige la reestructuración del pensamiento y la instrucción tangible en lo que se necesita para imponer la hegemonía. Lo instrumental toma el lugar privilegiado, requisito es ahuyentar cualquier acción que ponga en riesgo la idea aflorada de práctica. El pragmatismo y la automatización se convertirán necesariamente en una forma de participar en el modelo de producción capitalista, y con esto una visión aplicada a la educación.

Epistemológicamente hablando, el concepto marxiano de praxis es un logro que puede verse más que una simple postura crítica; es "unidad entre ética y ciencia" (González, 2015, p. 195). Sánchez Vásquez (2003), aprecia que la praxis es en sí una actividad humana que tiene fines que a su vez exigen una determinada actividad cognoscitiva. En ese orden, la fundamentación teórica no está desligada, solo exigiéndose la acción teórica puede garantizarse la conciencia de praxis y su efectividad. Para redondear puede notarse que,

La filosofía moderna - a partir de Kant- había planteado la oposición entre acción y cognición. En la acción se enfrentan un sujeto activo y un objeto pasivo. La relación produce un cambio efectivo en el objeto que, como la cera, asume la forma impuesta por la acción del sujeto. Este, al menos aparentemente, permanece inalterable. En cambio, en la cognición se opone un sujeto cognoscente y un objeto de conocimiento. El proceso de conocimiento consiste en el registro de una imagen del objeto en la conciencia del sujeto tal como el espejo refleja cuando nos vemos en él. La transformación no se opera en el objeto, sino en el sujeto, cuya conciencia es enriquecida con la imagen. La oposición entre acción y cognición, en los términos de idealismo gnoseológico, es sustituida en la filosofía contemporánea por la contradicción entre la teoría y la praxis. Estas categorías ya no se mueven como 
sujetos individuales y/o abstractos y objetos empíricos y/o inertes, sino con prácticas y teorías colectivas, sociales, históricas. (Núñez Tenorio, 2015, p. 22)

A la final, teoría y práctica se integran en el concepto marxiano de praxis. Así debe leerse al surcar los caminos del acontecimiento educativo con las categorías marxianas. La praxis es compromiso sociocrítico con la realidad. Es histórica y dinamizadora. Está es una acción revolucionaria cuando inicia la resistencia a las imposiciones ideológicas, a las alienaciones de todo tipo que llegan a la escuela e influyen en ella y en las mentalidades de todos los miembros de la comunidad educativa. Destruir los ídolos del panteón sistémico, cuyo credo final gira en torno al capital y al consumo en este siglo XXI, es una de las principales realizaciones que puede brindar la praxis como proyecto político.

\subsection{La formación praxiada, menester de una filosofía marxiana de la educación}

Hacer praxis filosófica en educación está dentro de la criticidad del sistema de cosas imperante, sobre todo en las sociedades alienadas por éste. En otras palabras, con la perspectiva de Sánchez Vásquez (1999), el edificio teórico de lo marxiano desde América Latina para el acontecimiento de la educación adquiere sentido autóctono y de compromiso por la emancipación desde la educación.

Llegando al punto de saber que en Marx el planteamiento clásico sobre la praxis separada de la teoría no solo no aplica, sino que han de ser inseparables; controvierte, a la par de una subordinación o relegamiento de la primera respecto de la segunda o de la segunda a la primera. En lo marxiano se invierte la contraposición que se había dado en la tradición del pensamiento o el descuido por comprender el impacto social de conjugar teoría con práctica praxica.

Con Marx, es negada la supremacía de la "teoría" estéril, pero esta negación es justificada, es equilibrada, para precisamente dar más valor a lo teórico en tanto revalida la visión crítica del entorno. No es un rechazo a la teoría, sino al teoricismo porque tiene elementos alienantes fruto del sistema de cosas que critica Marx. De hecho, el cliché de que sin teoría no hay práctica, es consecuente con una propuesta social en cualquier ámbito.

Si algunas posturas entienden la praxis como creación, consciente de su objetivo transformador, podemos decir con seguridad que, "la obra más grande entre todas es la de crear; y la educación es una especie de creación" (Del Valle, 1982, p. 90). Sin perder de vista que es una creación humana y, por lo tanto, es susceptible de humanización. Praxis es creación consciente encaminada a la transformación, de ahí su importancia para establecer criterios en una filosofía de la educación marxiana que aun sea válida.

A. Sánchez Vásquez, nos seguirá ayudando a encontrar una base teórica para acercarnos a la adecuada concepción de praxis. La filosofía de la praxis desde esta perspectiva va a ser el pilar fundamental de la educación. La filosofía marxista es la filosofía de la praxis (Sánchez Vásquez, 2011). Además, presenta cinco funciones tangibles y aportantes: crítica, política, gnoseológica, conciencia misma de la praxis y de autocrítica. Pero advierte de ésta que:

La filosofía de la praxis por sí sola no transforma nada; no es acción real, práctica, pero puede contribuir a la praxis. Ciertamente, como hemos venido sosteniendo, no reducida a la versión teoricista de ella: a simple filosofía acerca del objeto praxis, sino como elemento de la praxis misma. En suma, no hay que dejar que sea acorralada en el dilema en que se pretende acorralarla: o bien es teoría y en 
este caso no transforma; o es transformación, pero entonces queda fuera de la teoría. Falso dilema, pues no se trata de tener que decidir entre interpretación y transformación, o entre teoría y praxis, sino de optar por la teoría adecuada "cuando de lo que se trata es de transformar el mundo". En este caso: la que sirve a esta transformación. La transformación del mundo, de la realidad humana y social se presenta, pues, como un fin u objetivo último al que han de ajustarse tanto el pensamiento como la acción. (Sánchez Vásquez, 1977, p. 67).

Lo mismo pasa con una educación que esté en busca de la emancipación, con ese corte crítico que desea desarrollarse de manera práctica. Los discursos no hay que abandonarlos, más es hora de enfatizar en las acciones replanteadas por el sociólogo y pensador Fals Borda (2003) con su propuesta de la acción participación, por traer un ejemplo praxico de la interacción que puede lograrse entre ciencia y pueblo.

Sánchez Vásquez (1978), al replantear el concepto de praxis en Marx, considera que, además de ser revolucionario el concepto pide por su naturaleza dialéctica, actualización. La concepción marxiana de praxis encuentra un excelente lugar en el campo de la educación. Siendo lo marxiano una fuente de criticidad, de aporte teórico, llegándose a establecer varias vías metodológicas de comprensión y actuación, esto permite al acontecimiento educativo pasar de una inmediatez pragmática, a un desenvolvimiento praxico. Lo praxico exige actualización, pero no con el afán de un modo de ver al mundo centralizado en el interés económico, sino el interés por el sujeto, por su comunidad.

La visión marxiana de la educación parte, como se ha dicho, de las alusiones generales que se hacen sobre el particular a lo largo y ancho de la obra de Marx, combinado con las posturas teórico-metodológicas, o las recomendaciones que logran identificarse de las mismas situaciones que él planteó. Para esto, es clave comprender la dialéctica con la que Marx critica la educación y a la escuela. La escuela como institución de interés burgués, debe ser replanteada, así también la que se da en la familia y, por supuesto, en la fábrica; todas han de ser praxiadas y solo a través de la concreción de caminos podrá llegarse a la toma de conciencia de clase, estos caminos son los de la formación integral del individuo.

Huelga decir que, no es una crítica que ha de tildarse de anacrónica -la que Marx pensó para su épocapues, no ha cesado la actuación esencial de la escuela como institución y mucho menos perdido protagonismo en la orientación ideológica que pretende un sistema de cosas.

En términos macropolíticos, la praxis no ha sido tomada en su sentido siquiera social por obvias razones en las entidades que administran la educación desde sus alejados y clientelistas despachos. La praxis no importa, no genera cifras ni índices, al contrario es peligrosa.

Sánchez Vásquez, cuyo concepto de praxis educativa deriva de Marx según Arriarán Cuéllar (2014), retoma el planteamiento de que "la praxis educativa, para ser coherente, tiene que plantearse primero la transformación del Estado" (P. 146). Con esto, sabe que, el empoderamiento de los aparatos del Estado podrían facilitar los cambios, pero para llegar a esta instancia hace falta el trabajo pedagógico político, activista de base que ha de incluir no solo al sector obrero organizado sino a los movimientos sociales, en esto difiere del condicionamiento que Marx dio al limitar el papel a la clase proletaria; he aquí el valor de la actualización para regiones como América Latina donde los sectores sociales sobrepasan, lógicamente, los apuntes textuales del propio Marx. 
La relación dinámica que debe darse de la base a cabeza y de la cabeza a la base, podrá darse cuando o bien se estructure un Estado -u otra forma de organización- garante y promotor de lo social con una base poblacional consciente de su papel transformador. O sea, un Estado que se proyecte a sus bases humanas. Mientras no ocurra esto, la situación será complicada, las tensiones sociales ocultas o no, serán síntoma de una solidificación del interés de la clase dominante y el sistema político-jurídico que lo representa.

La unidad social entre teoría y práctica ha de sobrepasar los discursos a los que está acostumbrada la población del común. Esto presupone una toma de actitud que ha de realizarse en la persona viva. Los entes solo serían garantes de que se lleve a cabo un ambiente donde pueda desenvolverse esta fusión, en este caso la institucionalidad escolar a partir de un modelo de Estado distinto al que obedece a la mercantilización de la misma vida. Ahora, un ambiente que garantice dicha fusión, en diálogo con el entorno, es un espacio histórico en busca del desmonte de las apariencias, en procura del rescate de la emancipación y de ver, entre otras, al trabajo, como algo que merece ser reivindicado fuera de los marcos del sistema de cosas que enajena.

\subsubsection{La praxis frente a la ideología}

Objetivo de la praxis desde una filosofía de la educación con herramientas marxianas, es el análisis de la ideología y sus efectos alienantes, son objetivos de la praxis desde una filosofía de la educación con matiz marxiano. El desmantelamiento de la enajenación y de las alenaciones que rodean a la humanidad impidiéndole su realización individual y colectiva. Si bien la praxis se erige como algo activo que exige un tipo de apersonamiento para llegar a la transformación consciente. Puede decirse, entonces:

La conciencia no aparece simplemente como producto de la práctica, sino como aspecto de un proceso real específicamente humano: el proceso de la praxis. El concepto de praxis expresa, pues, el proceso de la práctica social, que por ser práctica del hombre es práctica consciente. (Bermudo, 1975, p. 97)

Hay un interés de conciencia por retomar el camino de la praxis para liderar el proceso de la emancipación humana. Sin transformación, sin praxis no habría nada especial sino una simple exposición teorética, exegeta y monolítica que servirá simplemente para realizar parafraseos, volver a esa forma de pensar aburguesada la cual bajo el manto de la objetividad ocultar las intenciones de someterse al sistema de cosas. Vuelve la enajenación a presidir la preocupación por la formación, con ello la confusión, la búsqueda de legitimación del sistema de cosas mercantilista y de consumo imperante.

Dice Bermudo (1975): el nivel de conciencia es el que puede llevar a definir el nivel de práctica; yo agrego que a su vez la relación se invierte, o sea, al generarse esa cadena, el nivel de práctica seguirá elevando el nivel de conciencia que ha de solventarse en lo teórico sin dejar de lado las razones específicas.

La cuestión se dificulta cuando se intenta definir la teoría y la práctica. La génesis de estas concepciones se encuentra en la división capitalista del trabajo, donde el trabajo manual y el trabajo intelectual manifestado en la ciencia, se presentan a servicio del capital como lo concibió Marx (2012). Parece no existir integración; no obstante, están en función irrestricta del sistema. Ahora de lo que se trata es de ver esa dialéctica aportante para comprender la función de cada una y su interrelación: o sea lucha de contrarios y unidad. La visión crítica, ofrece la oportunidad de mirar teoría y práctica como unidad necesaria para 
establecer a la praxis en un campo social de acción donde los actores se interrelacionen proponiéndose metas concretas sin intermediarios.

Es por la teorización de la indignación y su difusión, para lo que dedica toda su mortalidad, Karl Marx. Él sabe que no es fácil hacer de la realidad una oportunidad para la transformación ya que el daño ideológico es profundo y pareciera congénito. Pero, por ser histórica, la alienación no es inherente al hombre (Silva, 1983), sino que es superable; cualquier afirmación de lo contrario es verbigracia, comprobación de alienación. "Si Marx hubiese pensado que la alienación, en lugar de ser un producto histórico, fuera un fenómeno inherente a la naturaleza humana, ¿para qué propondría la revolución comunista y la desalienación?” (Silva, 2009, p. 55). La praxis repele a la alienación en todos los campos.

Volvamos a lo que Silva (1974) reseña sobre la alienación y su relegación mediante la praxis: "la palabra <alienación> significa siempre, de un modo u otro, la idea de separación, disociación, desgarramiento de algo que no esté ya más en su sitio, expropiación de algo que no está ya más en su región propia" (P. 50). La alienación es un síntoma de alejamiento entre teoría y práctica. La práctica separada de la teoría es puro activismo, practicismo, proselitismo ciego; a su vez, la teoría sin práctica, disociada de ella, se queda sin activación empírica, solucionadora, "tiende a convertirse es especulación ideológica" (P. 51).

Hablando del trabajo, este y la praxis están íntimamente relacionados. El trabajo consciente, en primera instancia, esa autoidentificación, será un paso para la liberación real del sujeto. La praxis se remonta al grado de influencia del trabajo sobre un orden social.

La educación ha de combinarse con la formación socializada en el trabajo, pero con el matiz de trabajo liberador. Él no niega el valor de la formación escolar, solo hace ver las apariencias. De hecho, defiende que la educación debe estar financiada por el Estado, ha de ser un derecho universal no exclusivo a clases, edades o sexos, pero enfocada al interés del individuo y de la comunidad. La educación debe ser práctica liberadora, que emancipe mentes y cuerpos, por esto el apersonamiento de la noción social del trabajo como fuerza que no debe ser enajenada mediante acciones u opiniones alienables debe ser centro de interés de una sociedad que piense y actúe en pro de la dignificación humana. Los niños en su formación deben ser incluidos en la vivencia de la unidad entre teoría y práctica, claro con sus niveles de apropiación, capacidades, esfuerzos y responsabilidades

En El capital se encuentran algunas observaciones pedagógicas muy interesantes al respecto. A la unidad entre proceso cognoscitivo y proceso de transformación de la naturaleza, producida por la industria, debe corresponder a la unidad de la enseñanza teórica y práctica de los niños. (Schmidt, 1977, p. 170)

En términos materiales, para afrontar la enajenación Marx y Engels (1976 a2) ${ }^{73}$ plantean una unión de factores, dentro de los cuales está la educación aunada al apersonamiento de un sentido consciente de la importancia del desarrollo de las fuerzas productivas alrededor del trabajo praxiado:

[18] Con esta «enajenación»,...sólo puede acabarse partiendo de dos premisas prácticas. Para que se convierta en un poder «insoportable», es decir, en un poder contra el que hay que hacer la revolución,

${ }^{73}$ En, Feuerbach. Oposición entre las concepciones materialista e idealista (Primer Capítulo de La Ideología Alemana). 
es necesario que engendre a una masa de la humanidad como absolutamente «desposeída» y, a la par con ello, en contradicción con un mundo de riquezas y de educación, lo que presupone, en ambos casos, un gran incremento de la fuerza productiva, un alto grado de su desarrollo; y, de otra parte, este desarrollo de las fuerzas productivas (que entraña ya, al misma tiempo, una existencia empírica dada en un plano histórico-universal, y no en la existencia...(P. 34)

Con la división entre trabajo intelectual y trabajo físico, se da una ruptura entre teoría y práctica que, proyectará un aparente grado de importancia según su determinado rol en la sociedad, roles que también son impuestos por la visión hegemónica de las clases en la cúspide. Es aquí donde puede encontrarse una definición temporal, así como conceptual sobre la separación entre teoría y práctica. La división del trabajo, propia del modelo capitalista, es el origen del olvido intencionado pero oculto de la praxis (Grüner, 2004).

Lo social, su sentido, sus efectos, determinará si existe praxis en la medida en que se haya transformado la realidad negativa. Así, la praxis significa retoma de la unidad indviduo-comunidad desde lo marxiano, en consonancia con la apuesta a desmontar eso que precisamente difundió la idea de separación que, luego se reflejaría en las divisiones sociales y señalamientos hacia los sectores marginados. Ahora la praxis debe ser social, emancipadora, con un profundo compromiso político que va a fortalecerse gracias al acercamiento de las mentes a la formación consciente, a la transformación revolucionaria cosa que garantice un alejamiento de lo ideológico que enajena y aliena.

Althusser (1974), toma como punto de partida también al trabajo, aunque con su tinte afanado de respaldo cientificista. Allí la materia prima y su transformación no es lo importante, lo que se rescta es la práctica en la medida en que es transformadora. $\mathrm{O}$ sea, no es la postura que oculta el capitalismo al intentar mostrar que hay una actividad inerte. Desde apreciaciones marxistas aparecen tres grandes tipos de praxis: la política, la economía y la ideológica cada una con una propuesta para la transformación de éstas cuando la acción social sea dada. Gramsci (Gantiva, 2008) a su vez, acentúa en el tema político y el papel del intelectual orgánico.

En la pauta de Marx existía una necesidad que era la consecución de la revolución de los proletarios para iniciar la ruta al modelo socialista. "Lo más importante en la enseñanza de Marx - escribía Lenin- es la aclaración del papel histórico universal del proletariado como creador de la sociedad socialista" (Suchodolski, 1977, p. 133). Y es que la comprensión de la praxis en Lenin (1909), retomando a Hegel en la conversión de su lógica para ser transformada por los aportes de Marx, por ejemplo, en El capital, conforma tanto un aporte teórico, pero aún más práctico por el significado de la revolución rusa independiente de la retrospección histórica (Budgen, et. Al, 2010).

Alcanzar las metas científicamente propuestas, demandaría la previa organización de los obreros alrededor de una teoría argumentada que blindará la acción; él comprendió la necesidad de la formación praxiológica para avistar las metas. Además, no podía conformarse con el patrón clásico burgués de la actividad educativa, de lo que se trata es de, como dice Suchodolski: una enseñanza de la educación del proletariado (1977). Podemos decir, a nuestro interés reflexivo: una enseñanza colectiva de la educación-formación de los diferentes actores de la escuela ${ }^{74}$.

74 Esto porque en la escuela latinoamericana de vertiente tradicional, suele solo adoctrinarse en teorías pedagógicas, etc., exclusivamente para el sector profesoral, pero no se contempla la socialización de dichos patrones teórico-metodológicos con 
Por eso entender la filosofía de la praxis como oportunidad y sobre todo, en tanto propuesta, la convierte en la opción filosófica viable para tratar a la educación latinoamericana. Al verse como una muestra de inconformidad, de anhelo de terminación de algo pospuesto, merece ser escudriñada, explorada por el componente docente y administrativo que comience su camino hacia la liberación del yugo enajenador del sistema. Observemos un poco la perspectiva que tenía Sánchez Vásquez y de la cual se alimenta este rescate de la praxis para llegar a una filosofía de la educación que sea praxica. En suma:

Puesto que estos rasgos configuran una forma de hacer filosofía que es diferente a las que responden a alguna preocupación metafísica, epistemológica, existencial o antropológica, en sus textos de los años sesentas y setentas, Sánchez Vázquez se refería a ella como una innovación radical en la filosofía y como una nueva práctica de la filosofía. La diferencia fundamental consiste en que el contenido de esta forma de filosofar es la praxis y en que la práctica filosófica se construye a partir de tres momentos: el conocimiento de la realidad por transformar, la crítica de lo existente y el proyecto de emancipación. (Yurén, 2009, pp. 247-248)

Hay una urgencia por atender -como sucede con ideología- y es llevar a la educación por el camino que conduzca a los sentidos más esenciales y materiales de la formación humana. Muchas posturas salidas del pensamiento crítico contemporáneo, se han dedicado a esta empresa. Para lograr la construcción solidaria del conocimiento con un sentido humano, ecológico y social de la formación humana, se necesita comprender a la educación como un compartir dinámico, abierto y profundamente democrático -no desde la cosmovisión liberal clásica-, donde la praxis sea parte del edificio teórico-práctico, lo cual a su vez, se puedan crear las condiciones para facilitar el asentamiento consciente de la praxis en el sujeto para que se comparta en lo colectivo.

Con Ponce (1985), la comprensión dialéctica del fenómeno alienante y la necesidad de la praxis es totalmente aceptada, pues debe darse el conocimiento del antagonismo para que la toma de conciencia surta efectos reflexivos, en esto la historia crítica ofrece oportunidades, horizontes de comprensión que también encontramos en versiones como la de Valenzuela y Raimundo (2008). La escuela latinoamericana, producto de ese devenir histórico poco socializado entre las clases relegadas, alienada para los sectores medios y, por supuesto, negada por la mayoría de los sistemas oficiales de los Estados oligarquícos, puede encontrar en el rescate de la praxis la oportunidad histórica que consiga una verdadera independencia mental, pensada como emancipación mental que conllevará a la liberación material del sistema dependiente y contrarrestar el grado de consumismo al que nos ha llevado el modelo globalizado de mercado (Mészáros, 2008).

El acontecimiento educativo es susceptible de ser "praxiado". Para ello, debe ser pensado a partir de la realidad tangible no limitada a la percepción inmediata, sin perder de vista las mismas fuerzas que rodean dicha realidad. La necesidad de transformación crítica de la educación - para el caso de la escuela inmediataen estos momentos de crisis exige una teoría consecuente que colabore con la misma comprensión, pero no una ciencia que enrede más los asuntos, la cual pretensiosamente esté solo preñada de buenas intenciones sin tomar posición política pues no puede perderse la idea de que la educación es un fenómeno político y como tal ha de asumirse; si así se concibe desde el sistema hegemónico de cosas, más debe asumirse como

los estudiantes y acudientes, cosa que sería interesante pues podría integrar propuestas de estos entes y acercarlos a las metas que proponen los modelos pedagógicos y hasta las políticas educativas. 
campo de formación política sin que lleve a extremismos ideológicos, sino todo lo contrario como campo de diálogo, de praxis.

Preparar al individuo como sujeto político a que tome las riendas primero de su propia existencia y luego como parte fundamental del mundo, se desliga de la visión egoísta del sistema que propone el capitalismo. Hacer al hombre y la mujer -e incluso a las demás expresiones sexuales- protagonistas de su propia emancipación es objetivar la praxis a favor de los objetivos verdaderos de la educación, dialécticamente a la subjetivación. "La educación es, pues, una praxis de la sociedad, una actividad continua del hombre que crescit y concrescit; educa educándose y acreciendo paso a paso la propia energía educadora” (Mondolfo, 1936, p. 74).

Una filosofía de la educación que pueda aportar en este siglo XXI de la mano de Marx, que siga luchando por la dignificación social de la formación crítica y propositiva, es por antonomasia praxis. Teniendo en cuenta este término, no cabe la confusión de desviarse hacia otros intereses no relacionados con la finalidad transformadora del acto educativo sociocrítico y proponente, lo cual, debe presentarse por medio de acciones planificadas, concretas, logrando tocar al individuo y a su comunidad para darse un lugar dinámico en la historia.

En el campo de la educación no se trata de dar un debate sobre la pertinencia o no del ideario marxista o marxiano. De lo que se trata es precisamente de rescatar la esencia de la praxis en tanto concepción central del compendio marxiano para una filosofía de la educación relacionada con los cambios estructurales en todas las esferas. La versión clásica nos dice que, "la revolución no es para Marx algo del futuro, sino que constituye la última etapa del revolucionario actuar de la actualidad (...). Solo en la "práctica revolucionaria" se educan los hombres del mañana" (Suchodolski, 1977, p. 137). Sin embargo, hoy no podemos hablar de revolución como se hablaba hace un par de décadas atrás, lo que tampoco significa que no pueda darse un estado de conciencia.

Educar a los trabajadores en la filosofía de la praxis llevaría a concientizar su rol transformador. Hoy, entonces se trata de educar y contener en las prácticas educativas, una perspectiva basada en la filosofía de la praxis para los actores y elementos de la escuela inmediata. Para el caso de los actores educativos, han de estar dispuestos a concientizarse sobre su rol. Abandonar la percepción de su acción como algo árido, será la oportunidad para recuperar el sentido social y crítico que ha de caracterizar a la escuela, sus prácticas, sus currículos, sus objetivos y demás elementos vivos. La unidad dialéctica entre teoría y práctica praxiada a partir de las vivencias inmediatas, pueden ser la oportunidad para la consecución de un desmonte de la alienación al identificar los elementos y acciones concretas que generan tal negación.

En el sistema de cosas imperante, la praxis deja de ser praxis para convertirse en convencionalismos dirigidos por la elite política, económica y la científica al servicio de los poderes dominantes. La praxis no es praxis dentro del sistema capitalista, puesto que la concepción se desliga de su carácter social y solo se acerca a un vago reconocimiento de práctica; esto es una contradicción no superable sino por la vía del desmonte de la misma ideología que no toma en cuenta la transformación socioeconómica como algo necesario para superar contradicciones tangibles en la sociedad. 
La praxis se constituye entonces en instrumento de denuncia, pues parte de la realidad material y no de ideas abstractas o especulaciones sobre temas invisibles. El sufrimiento humano tiene mucho que ver, así como la observación del bajo apersonamiento de las condiciones contrarias al bienestar, las cuales son justificadas por la ideología hegemónica que actualiza sus estrategias de inoculación a conscientes y subconscientes. Las herramientas de la praxis coadyuvan a la identificación de las negatividades. Sánchez Vásquez (2007b) rescata, con su visión marxiana, la mayor relevancia de la dimensión ética en la praxis educativa para, acertadamente vincularla en la lucha contra la injusticia, la explotación y la guerra; he aquí una ética tomada de la praxis con intenciones políticas al rescate del ejercicio educativo.

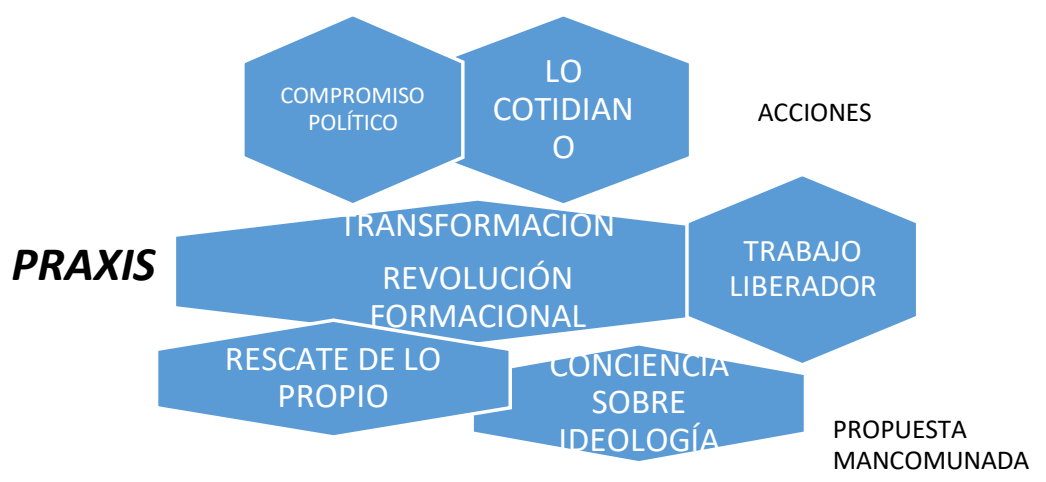

Gráfico No. 9. La praxis, aporte indiscutible de la forma marxiana de hacer filosofía para una filosofia de la educación. La praxis es superación de la inmediatez y se puede aplicar a los distintos mabitos de la vida escolar.

\subsection{La filosofía de la educación y el planteamiento de la educación como acontecimiento político}

El proceso de formación del ser humano en términos de educación, en el campo marxiano es, por un lado, un espacio sensible y que es utilizado por las conveniencias ideológicas del sistema hegemónico dictado por el capital privado. Por lo cual hace parte de una interpretación filosófica de la educación. De otra parte, hay que decir que también es oportunidad, pues a través de la educación, pueden iniciarse los cambios de conciencia acompañados en relación dialéctica con los cambios materiales.

Gramsci (1970), tocará desde su postura sobre la filosofía de la praxis, la cuestión de la enseñanza en política, el doble sentido, donde recrea el caso entre jesuitas y Maquiavelo para develar el interés que puede hacerse de los asuntos de poder entre teoría y práctica, así decía:

La filosofía de la praxis tenía que realizar dos tareas: combatir las ideologías modernas en su forma más refinada, para poder constituir su propio grupo de intelectuales independientes, y, educar las masas populares, cuya cultura era medieval. Esta segunda tarea, que era fundamental dado el carácter de la nueva filosofía, absorbió todas las fuerzas, no sólo cuantitativa sino también cualitativamente; por razones "didácticas" la nueva filosofía se combinó con una forma de cultura algo superior a la media popular (muy baja) pero que era absolutamente inadecuada para combatir las ideologías de las clases cultas, cuando la nueva filosofía había nacido precisamente para superar la más alta manifestación cultural de la época, la filosofía clásica alemana, y para suscitar un grupo de intelectuales propios del nuevo grupo social. Por otro lado, la cultura moderna, especialmente idealista, no consigue elaborar una cultura popular, no llega a dar un contenido moral y científico a sus programas escolares, los cuales siguen siendo esquemas abstractos y teóricos; por esto pasa de ser la cultura de una limitada aristocracia intelectual, que sólo llega a prender en la juventud cuando se transforma en política inmediata y ocasional. (P. 57) 
En este sentido, vale la pena traer de nuevo la postura de Sánchez Vásquez, quien haciendo alusión a la filosofía de la praxis, trata de exponer con ejemplo histórico una lectura de lo ideológico-político cuando desataca la opción ideológica que puede representar para una determinada clase social la praxis. En el caso de la clase obrera -que en Marx es la única que podía liderar la transformación-, la filosofía será el arma de la clase trabajadora; pero quedaría por aclarar si el factor de clase, ahora dominante podría llevarla a sostener y promulgar una ideologización como ocurrió en la Revolución francesa del siglo XVIII o en las revoluciones llamadas comunistas del siglo XX (Sánchez Vásquez, 1977).

De todos modos, no hay que enfrascarse en el asunto de los términos, pero si saber que con el ánimo de evacuar problemáticas de comprensión y sana utilización de los conceptos; no sobra recordar que no puede ni debe hablarse de una ideología revolucionaria para cambiar la educación. La educación debe estar desideologizada, debe estar en el despertar de la conciencia, centrándose, eso sí en la denuncia de la ideología y sus efectos nefastos.

La ideología es un sistema de valores, creencias, representaciones que auto generan las sociedades en cuya estructura haya relaciones de explotación a fin de justificar idealmente su propia estructura material de explotación, consagrándola en la mente de los hombres como un orden natural e inevitable o filosóficamente hablando como una nota esencial al ser humano. Por esto es absurdo hablar de ideología revolucionaria, dado que una revolución no puede genuinamente ser impulsada por prejuicios, fetiches o catecismos sino contra ellos. (Morán B. y León, 2008, párr. 21)

Lo político, independiente de un juicio moral o ético, se caracteriza por estar presente en la vida del ser humano. Lo político, como acontecimiento histórico y cultural, se manifiesta tanto en las esferas organizativas del Estado o los sistemas jurídicos, así en las relaciones diarias de los individuos. Lo político acontece, se actualiza en la educación y su extensión: la escuela, no está fuera de este marco.

La escuela es una institución estructurada por la modernidad burguesa, no hay duda (Fernández Enguita, 1985). Sin embargo, esto no significa que le pertenezca por Cuius regio, eius religio ${ }^{75}$. La escuela, también se nos presenta como campo social, es un espacio donde se manifiesta muy bien la lucha de clases y el choque de visiones no solo académicas sino políticas. La escuela es una institución más que social, es una institución política, como tal debe ser pensada para poder replantearse, rebelándose contra las indicaciones poco ajustadas a una reivindicación. Pero, la escuela con todo y sus relaciones, que se quieren hacer ver armónicas cuando no lo son. Es antagónica de hecho, es el síntoma para diagnosticar el grado de injerencia de la ideología. Entonces, si hay relaciones intrínsecas de carácter ideológico, será política por este motivo.

La escuela pensada y materializada en América Latina (con la excepción de Cuba después de la revolución) en el siglo XX, fue además de excluyente y descuidada, heredera directa de los resabios decimonónicos los cuales provenían del vasallaje colonial, además de imbuida por el conservatismo latinoamericano. El sistema no sistémico educativo ha sido un Frankenstein teórico, receptor de ideas y políticas extranjeras y con ellas de una visión de mundo, una total alienación. A consecuencia, la escuela de este inicio del siglo XXI apenas si se ha dejado pensarse así misma.

${ }^{75}$ Especie de mirada de derecho divino, que reza: "según sea la del rey, así será la religión (o del reino)" 
Para Gutiérrez (2005), "la política es una práctica totalizadora y diaria que impregna y matiza todo cuanto hacemos" (P. 25); así la educación se conforma en práctica política, en doble sentido: primero, el que nos indica que la institución educativa como espíritu totalizador proyectado por la materialidad de clase o de Estado. Trastoca a los actores y define su idea de escuela, de hombre y sociedad, de trabajo, etc. El segundo sentido, es política la educacion, pues políticas son las relaciones; el poder detrás de las apariencias, de las abstracciones inducidas, aquellas alejadas de la objetividad. Así mismo, política debe ser la respuesta que nos ofrece la praxis, pero esa praxis revolucionaria compartida por lo marxiano. Entonces, no ha de escaparse la doble lectura contradictoria de lo político dentro del acontecimiento educativo. Desafortunadamente, la despolitización del sector magisterial aleja cualquier posibilidad de toma de posición crítica frente a las trágicas realidades sociales.

La escuela debe ser un espacio político, no proselitista. Creer que la escuela no ha de politizarse es un punto de vista bastante discutible, precisamente por los imaginarios que sobre "lo político" se tiene. A propósito, Gutiérrez (2005) dice: “este afán por despolitizar la acción educativa no es sino una manifestación más de fuerte carga política y de la imposición ideológica de las clases dominantes a través del aparato escolar" (P. 25). Ello sustenta la intención de alejar, como ha pasado desde tiempos remotos - ejemplo, en nuestra América-, el irónico alejamiento inducido de la escuela a los problemas políticos y sociales.

Resistir al sistema de cosas y generar trasformaciones, para este caso, al interior de la escuela, puede resultar un camino que conlleva a metas micro políticas precisas en contornos del cotidiano cercano. Sin embargo, siglos de enquistamiento de formas de ver el mundo sumado a los amañamientos característicos de los últimos tiempos que se centran en lo pragmático, hacen que las conciencias estén arrulladas al son del facilismo material o de la desesperanza.

La escuela es un acontecimiento político, en tanto tal ha de aprovecharse si se desea ser cnstuctores de nuestra propia historia. Entonces, una vida educativa dedicada a establecer y difundir los criterios acordes a la participación en los espacios inmediatos, debe ponerse como meta superar la inmediatez política para encaminarse hacia la toma del poder decisorio, por lo menos en la vida escolar con las orientaciones de una visión alternativa de carácter social y reivindicativo. Esto es imposible sin una concreción de lo que es democracia y participación en tanto rescate del asunto político centrado en las necesidades oportunas de las comunidades.

Por supuesto, la democracia, términó alejada de su sentido práctico más cercano a lo que debería ser -para el caso latinoamericano- es irrefutablemente otra de las dimensiones de acción en las que debe preocuparse la praxis. En tanto compromiso político, la praxis educativa pensada desde una filosofía marxiana de la educación debe abrir el paso hacía la conformación de un modelo democrático que se presente en las esferas microsociales encontradas en la escuela. Es necesario el desplazamiento de la concepción oligárquica de lo que es democracia porque sigue siendo un pretexto ideológico que encuentra en la escuela alienada su nicho reproductivo.

Hoy la participación debe extenderse a los diferentes sectores sociales, culturales e incluso de diversidad sexual. La democracia no puede seguirse pensando desde la única acción o responsabilidad de los sectores que los una solo el factor trabajo, o el sindicalismo; esto sería un gran yerro, así también lo pensó Gramsci (1970) con relación a la praxis, en su momento. Si bien ha existido desde la originalidad de Marx un 
protagonismo del sector proletario, las dinámicas cambian y no con ello se borra el mensaje marxiano, todo lo contrario, no hay más teoría cercana a la reivindicación que aquella que surge del pensamiento de Marx, es uno de los pensamientos sociales y políticos que se ha sostenido en el tiempo a pesar de los ataques.

El dominio de la clase obrera que se espera debe entenderse de otra manera, una manera dialéctica pues la idea no es mutar en aquello que precisamente se desprecia. "La prioridad del dominio de clase hace que en el pensamiento de Marx se desdibuje la existencia de otras formas de dominación nacional, racial, sexual, étnica- que cobran gran importancia en nuestra época” (Sánchez Vázquez, 1999, p. 189).

Tradicionalmente se ha relacionado al pensamiento político de Marx con comunismo, partidismo izquierdista y dictadura, entre otras cosas que únicamente fueron llevadas a cabo en los países del llamado socialismo real del siglo XX; esto dista de la propuesta política marxiana que se inició como lucha acérrima contra los despotismos monárquicos y teocráticos que estaban por un lado y, contra los Estados capitalistas que se levantaban con la explotación pero que recubiertos por el liberalismo, mostraban una cara amable cuando en realidad lo único que reconocían era el predominio de los intereses de la clase dominante, de la clase propietaria. La democracia para Marx era otra cosa.

Veamos un poco qué opinaba Marx de la democracia. La clase obrera era la destinada a gobernar, organizarse en comunas (Marx, 1976 b-8), establecer una dictadura del proletariado -que ha sido ideológicamente mal entendida-, eliminar la cosmovisión burguesa, generar las condiciones para pasar del socialismo al comunismo, transformar a la economía y llegar a la abolición del Estado, son, entre otras generalidades, las proclamas macro políticas elaboradas. En carta a Wedydemeyer (Marx, 1852) expone el término más no deja directriz como forma de gobierno.

La participación en Marx debía darse desde las bases, la organización comunal era su apuesta. La democracia popular constituía, como puede leerse en varios textos, su determinación formal por un sistema político. Aunque a Marx se le ha reprochado no dejar una "receta" de propuesta tangible de Estado o sistema político, ésta evidentemente no era su intención; en cambio, había que evacuar la cuestión socioeconómica.

Puede decirse, siguiendo a Marx, que el obstáculo material más notable para el desarrollo de una democracia concreta y real es la propiedad privada, origen de todo mal político. Así las cosas, para encontrarse con la democracia, se debe abolir la propiedad privada -aclararse que es la propiedad sobre los medios de producción y las fuerzas productivas- sin este acontecimiento no puede pensarse en una democracia plena. Aunque no queda completa si no se socializan los recursos, donde la sociedad organizada -yo añadiría en comunidades-, más que el Estado, entre a administrar a la política oficial y los medios de producción como lo sugiere Sánchez Vásquez (1985).

Veamos que dicía Engels sobre el asunto, rescatando las alusiones conjuntas ante la organización de obreros, sobre algunas indicaciones recopiladas en Principios del comunismo:

La democracia sería absolutamente inútil para el proletariado si no la utilizara inmediatamente como medio para llevar a cabo amplias medidas que atentasen directamente contra la propiedad privada y asegurasen la existencia del proletariado. (Engels, 1847, sf. p. 11)

Continuaba proponiendo doce medidas, que debían tomarse para activar un plan de acción frente a las condiciones de su entorno, aprovechando la efervescencia del sector obrero y dialécticamente la misma 
represión, que tenían que ver con la democracia para la clase trabajadora como protagonista llamada a cambiar la historia a ocupar ese lugar, y así repeler a la propiedad privada.

Aquí hay una estrecha relación con la formación escolar a la que debía accederse, pues educarse podía generar las condiciones del sostenimiento de la propuesta del proletariado. Y se lee en el punto ocho, de los doce, lo siguiente: "8) Educación de todos los niños en establecimientos estatales y a cargo del Estado, desde el momento en que puedan prescindir del cuidado de la madre. Conjugar la educación con el trabajo fabril" (P. 11).

Los actores sociales que hoy se encuentran en la escuela; en el campo el sector campesino y en la ciudad los sectores trabajadores, están llamados a participar activamente dentro del fenómeno educativo que toca a sus hijos para el caso del sistema escolar primario y secundario. La apatía hacia el acontecimiento político es producto razonable del sistema de cosas. Hoy no puede hablarse netamente de proletariado, pero mejor aun se puede hablar de actores y sectores productivos de base, cuya organización ha de ser un objetivo social. Establecer la conciencia de una praxis educativa y de formación en academia, artes y oficios en razón del establecimeinto social de cosas no puede seguir demorándose. El actuar político de estudiantes, profesionales, obreros, campesinos y demás actores sociales ha de ser comprendido como compromiso histórico.

¿Cómo pensarse la praxis desde la preocupación por el rescate de lo político sin aludir a la democracia? Simplemente no sería praxis. Desde la perspectiva de la educación, el tema de la democracia es un tema de praxis. Y es praxis porque deben ejecutarse las acciones para que haya garantía de participación, pero antes también hay que purgarla de las lecturas que ponen a esta actitud llamada democracia, al estrecho determinismo de representatividad, de derechos y deberes salidos del dictamen del actual sistema de cosas.

La praxis debe ser democrática y así la democracia será praxis. Una escuela que pretenda enfrentarse a lo hegemónico debe estar formada científica y políticamente, ser abierta, participativa, proponente y administradora de las acciones socio pedagógicas que llevará a cabo. La praxis explayada en la participación constructiva de los miembros de la escuela, comprendiendo filosóficamente la actividad educadora como emancipación en aras de la transformación material, mental y espiritual no puede ni debe repetir las prácticas clientelistas y de representatividad al estilo de los partidismos, pues "una sociedad que ha reducido su democracia a la mera representatividad, está políticamente enferma" (Gutiérrez, 2005, p. 12).

Política y educación a partir del carisma marxiano, puede tener una doble relación horizontal: una de la educación como interés político, otra, de interés político por la educación. Esto va más allá de un juego de palabras. De todas maneras, teniendo en cuenta el enfoque marxiano, la relación en cualquiera de las dos, hay que comprenderlas en su ración de ideología imbuida que debe ser desmantelada, estableciendo la propuesta de una educación popular pertinente sin abandonar la rigurosidad científica y sociocrítica.

Lo pedagógico ha de superar a lo ideológico. Por esto, la educación a través de la praxis e interesada en seguir cosechando praxis, no puede dejar de ser radical en el abordaje de los asuntos político-educativos a todos los niveles (González, Sf.).

La disciplina consciente se convierte en un camino para amalgamar los intereses de las clases subyugadas -que ideológicamente son todas de una u otra manera-, haciéndose conscientes de sus falencias y errores podrán identificarse, participar e iniciar su paso al ruedo político-participativo. 
“La acción política en relación con los oprimidos tiene que ser, en el fondo, una acción pedagógica en el sentido auténtico de la palabra, por lo mismo, una acción con ellos" (Freire, 1971, p. 53). No se trata de generar falsas expectativas, ni mucho menos de poner a la pobreza como algo totalmente dignificante ni como motor o centro del mundo; no. Ni siquiera revictimizar; de lo que se trata es de elevar al oprimido al rango de protagonista político sin resentimientos, en tanto realizador, creador de los destinos de su propio trasegar por el mundo compartiendo los valores peculiares de la fraternidad.

Reconociéndose como sectores afectados por el sistema económico, los sectores populares han de ser liberados en doble sentido: uno, liberarse del imaginario que echa la culpa de sus afectaciones materiales a ellas mismas (por ejmplo, lo que llamaban vagancia) tomando hasta razones de predestinación divina, que no obedecen sino a la aplicación de la ideología domiannte a una falsacion de la realidad; en un sentido.

El otro sentido, es el que se refiere a las individualidades. Acá es cierto que un individuo no puede ser conformista o empedernido quejoso; en otras palabras, si bien es cierto lo de la inversión que hace Marx (1999) al papel de la conciencia, no es una opinión absoluta o peor aún, conferirlo de infalibilidad; para una filosofía de la educación con Marx, es importante la toma de conciencia, de autoformación en ésta y el desenvolvimiento como ser activo que no espera que otros definan sus pasos; en honor a la verdad también las personalidades, fruto de su formación familiar, académica con los pares, suelen no ser asumidas dentro de la personalidad, de la psiquis.

El acontecimiento político es oportunidad para las clases populares, las más victimizadas por el bombardeo ideológico y las consecuencias del modelo económico. Bien diría Freire hace más de cuatro décadas: "la acción política en relación con los oprimidos tiene que ser, en el fondo, una acción pedagógica en el sentido auténtico de la palabra, por lo mismo, una acción con ellos” (Freire, 1971, p. 53).

\subsection{La educación como ejercicio político}

Marx sabía el sentido político que tenía la educación como institución de corte burgués. Junto a la religión y al mismo sistema jurídico, era uno de los mejores y más efectivos espacios para ejercer el monopolio, la hegemonía (Gramsci, 2007b). La obra de Marx es una obra con atisbos políticos, fuertemente ligada a la búsqueda del poder por parte de una clase social en pleno surgimiento, es una propuesta revolucionaria, anti Estado y que defiende la participación y la organización directa de la población. Esto quiere decir que, la misma educación es ejercicio político, así la formación del obrero otorgará herramientas de lucha.

El marco crítico en educación, lo que se deriva de la pedagogía llamada crítica se considera como tal si tiene por lo menos los siguientes supuestos: "la participación social, la comunicación horizontal entre los diferentes actores que integran los estamentos, la significación de los imaginarios simbólicos, la humanización de los procesos educativos, la contextualización del proceso educativo y la transformación de la realidad social” (Ramírez B., 2008, p.109).

Así mismo, podemos decir con Gutiérrez (2005), que la educación es una praxis política que ha de liderar el sector educativo, principalmente con la orientación de docentes comprometidos en generar condiciones de pensamiento propicias de criticidad sin llegar a los lindes ideológicos. La lucha por presentar un modelo pedagógico propio e incluyente, no es solo una condición para la academia o los actores directamente implicados; la lucha por una pedagogía respondiente es una lucha política. 
El socio praxiólogo Marx, es radical: "la revolución en general -el derrocamiento del poder existente y la disolución de las viejas relaciones es un acto político. Y sin revolución no puede realizarse el socialismo" (Marx, 1982, p. 520). He aquí una postura definida. Como acto transformador, lo político en lo marxiano, debe ser pensado, teorizado y ajustado a las realidades sociales

Desde lo micro, con la voluntad política de individuos formados no exclusivamente en socialismo -en el sentido tradicional acuñado- sino en conciencia social, hasta lo macro de la mano de un modelo estatal de inclusión social, el poner resistencia a modelos que solo obedecen a la visión mercantilizante de la formación humana, para el caso de la educacion, pasa a convertirse en una lucha de poder. Más esta debe darse en el marco de la democracia, aprovechando cada espacio sin apego a personalismos o intereses particulares.

Educar sin hacer política, claro, bajo la connotación y la implicación social de la misma, no garantiza ninguna extensión social de la educación. La educación es un ejercicio político, quiérase o no. Desde cualquier óptica, es manifestación de política cualquier discurso por apolítico que se pretenda ser, éste será siempre todo lo contrario, o sea, político, tenga o no un fuerte ingrediente ideológico; de hecho, la misma supuesta actitud de neutralidad es una expresión política muy clara. Paradójicamente la política debe ser un ejercicio pedagógico de reivindicación sociopolítica (Freire, 1994). Otra cosa, en concreto, es aislarse o intentar separar educación de las reflexiones sobre el asunto.

Nada está sin relación, es vital comprenderlo. En efecto, siguiendo a Marx (2012), "nos encontramos, pues, con el hecho de que determinados individuos que, como productores, actúan de un determinado modo, contraen entre sí estas relaciones sociales y políticas determinadas" (P. 205b). La acción liberadora es una acción política, si bien la conciencia es una forma de referirse a la actitud crítica y transformadora que ha de ser revisada, mejorada y compartida constantemente, de poco o nada serviría solo abonar el campo de las ideas y no avanzar a su materialización, pues se insiste en un desmonte ideológico.

"La alienación debe ser superada en la práctica y no, como cree Hegel, en la conciencia" (Rooke, 2003, p. 112), esto porque, la praxis revolucionaria determinará el desmonte alienador de la ideología y ayudará a formar la conciencia en el sentido social del término; tampoco sería desconocer lo contrario, pues si la conciencia no se supera, la praxis será otra cosa y se convertirá en precisamente lo que quiere desmontar, lo que denuncia, esto es: apariencias, ocultamiento.

Una de las perspectivas más recientes en el debate de la filosofía de la educación y que, además, es coherente con la construcción de una perspectiva práctica, con enfoque marxista, del campo educativo, es la que sirve a los propósitos de una escuela crítica, propositiva a la vez que, transformadora en el contexto latinoamericano. Ésta reconoce el ejercicio y los objetivos de la educación más allá de una simple reproducción de saberes y teorías científicas que se dinamizan a través de diversas formas de relación entre los sujetos del conocimiento poniendo en evidencia su condición inherentemente política (Torres, 1996).

Dicha perspectiva de análisis, no puede acuñarse fácilmente como escuela estrictamente hablando, más bien puede entenderse como un conjunto de múltiples formas de pensamiento que confluyen en aspectos y preocupaciones comunes, y que se enriquece de los aportes de pensadores apersonados del devenir inmediato de sus contextos para poner en evidencia el marco de la praxis que se desprende del análisis filosófico de la educación. 
En este campo, cabe mencionar la postura de Adorno (1998), quien, desde su llamado a no olvidar, convence del papel transformador del poder de la educación,

La educación política en su conjunto debería, en fin, centrarse en hacer imposible la repetición de Auschwitz. Tal cosa sólo será posible si aborda además este problema, el más importante de todos, abiertamente, sin miedo de chocar con poderes establecidos del tipo que sea. (P. 91)

Este escenario retorna al problema básico relativo a los fines de la educación, es decir, que se pregunta ¿para qué la educación?, ¿qué tipo o idea de hombre se busca desarrollar? Cuestiones aquellas que han sido tratadas desde tiempos remotos en diferentes rincones donde hubo grupos humanos, desde los sofistas, dirigentes y filósofos del mundo mediterráneo hasta las culturas originarias.

La respuesta política al asunto supone una condición inherentemente transformadora de la educación, supuesto heredado de la influencia del pensamiento rousseauniano, y posteriormente, el kantiano, entre otros, que permite identificar la escuela como escenario de construcción de un tipo particular de sujetos, coherente con un modelo de sociedad dominante. La crítica política de la educación pone en evidencia a la escuela como un mecanismo de consolidación de los factores sociales necesarios para legitimar y perpetuar el orden social establecido, por tanto, como mecanismo ideológico de las clases dominantes. Gutiérrez (1988) se refiere a la educación como acción política explícita y consciente, llegando a afirmar que

La escuela es la institución social que, por su naturaleza, sus funciones y estructura, cumple como ninguna otra con objetivos políticos. El sistema escolar, de cualquier sociedad, es reflejo fiel de la política e ideología de los grupos gobernantes o de los partidos políticos en el poder. (P. 17)

De tal modo, logra convertirse incluso en un mecanismo ideológico del Estado, en los términos construidos por Althusser (2003). Así, continúa Gutiérrez (1998), “se cumple inexorablemente, tal como lo señaló Marx, que la clase que en la sociedad detenta el poder, detenta también el control cultural y los aparatos educativos" (P. 18). Adorno (1998) hará lo propio desde su denuncia y petición sobre la cual la educación debe "intencionarse", sobre todo en los asuntos competentes a la memoria, al no olvido.

Hay que decir que algunos reformismos de izquierda como decía Gutiérrez (2005) en los ochenta, han y siguen ignorando "que la hegemonía implica subordinación de la pedagogía a la política y no viceversa" (P. 19); allí citaba los ejemplos de Cuba, Nicaragua y Perú ${ }^{76}$ que aprovecharon la coyuntura para politizar sus respectivos sistemas educativos.

Más, lo anterior lleva a plantear el reconocimiento consciente de la realidad, de esa objetividad subjetiva que se representa en lo ideológico, la cual hace parte de esa naturaleza antagónica que puede llegar a convertirse en algo dialéctico; debe dejarse a Broccoli (1982), quien alimentándose de Gramsci, define:

Tener la pretensión de liberarse de la ideología - en una sociedad que vive de ella- sin ajustar cuentas con las ciencias del hombre, y, por lo tanto, con esa ideología, es un absurdo y quien lo sostiene, tarde o temprano termina por pagar las consecuencias. Pretender que Piaget, Bachelard, Foucault, Althusser, Monod y muchos otros no pagan sus tributos a la ideología de que son portadores es un auténtico absurdo. Porque entonces se supone que estos científicos sean inmunes a la ideología que en cambio, asumida en significado marxista, los domina tanto como al último hombre de la calle. Más bien, es en su significado marxista, y sobre todo su acción sobre los hombres y la ciencia. (P. 28).

\footnotetext{
${ }^{76}$ La Cuba socialista, la Nicaragua sandinista y el Perú del general izquierdista declarado Velasco Maldonado introdujeron unas reformas estructurales y de contenido donde, entre otras, primaba el rescate de la historia crítica, el ataque a la visión capitalista del trabajo y el consumo, así como el rescate del tradicionalismo local. El tema de lo latinoamericano no quedó por fuera como interés que debía ser insertado en la educación de los diferentes niveles.
} 
Por lo mismo, se hace énfasis, entonces, en la naturaleza evidentemente política de la escuela, como lo señaló en su momento el mismo Freire (1994) pese a que muchos de los discursos que la soportan hablan de la educación como escenario neutral, desprendido precisamente de la política, situación imposible de identificar en la praxis, si se tiene en cuenta que "la educación es la manifestación institucionalizada del fenómeno de la socialización” (Gutiérrez, 1998, p. 18), como lo ha expresado la perspectiva sociológica, y este proceso, a su vez, implica un ejercicio de dominación y control social. Así, la educación "de lo que se trata, en primera instancia, es de inculcar funciones, conductas, creencias y valores. En síntesis, de dotar a cada hombre de una ideología de modo que su inserción en la sociedad no signifique una contradicción o un conflicto" (Gutiérrez, 1998, p. 22), operando entonces como una forma eficaz y privilegiada de inculcación ideológica.

En el mismo sentido Carnoy (1977) caracteriza la educación como una forma de imperialismo cultural, poniendo en evidencia los fines de la educación que pueden representar un ejercicio de dominación, o bien, de liberación. En este sentido se muestran las prácticas características de la escuela como argumentos de tono político, de legitimidad ideológica, no neutral, no objetiva, sino con intenciones prácticas bien específicas. Y este ejercicio ideológico no ocurre solo de manera explícita, sino que mecanismos "ocultos" facilitan la legitimación de los supuestos que están en la base de la formación de los individuos.

Diversas formas de reproducción del saber, del sentido de lo ético y de lo estético, e incluso de las formas de dominación social, además de las mismas prácticas tecnocráticas de la escuela, evidencian las dimensiones del poder existentes en el contexto social educativo (Torres, 1996). La naturalización de todas estas dimensiones hace de la escuela un mecanismo para legitimar el orden social. Chomsky (2007) incluso remite a una forma de adoctrinamiento tendencioso en la escuela, la cual, lejos de favorecer el pensamiento independiente, "no ha dejado de interpretar un papel institucional dentro de un sistema de control y coerción” (P. 24).

América Latina se constituye en el suelo fértil de las distintas corrientes aparecidas en los contextos sociohistóricos; en ese suelo crecen y se alimentan, se desarrollan, buscan contribuir a la transformación dinámica, claro sin no pocos obstáculos, pero con un gran impulso hoy a comienzos del siglo XXI con algunos gobiernos que han girado a otros horizontes alternativos donde la fundamentación ortodoxa del sistema hegemónico no tiene cabida. En lo latinoamericano confluyen ideas, concepciones que siguen construyéndose y las cuales necesitan ser revisadas en la práctica del cotidiano negando de este modo la monotonía teorética y la praxis que no avanza del discurso.

Particularmente, la integración entre filosofía de la liberación como proyecto latinoamericano, ha desarrollado toda una propuesta interesante, merecedora de ser rescatada y cada vez alimentada. Es una forma de pensar de nuestras raíces. No cabe duda del gran compromiso madurado en esta postura no eurocéntrica que ha sabido teorizar lo marxiano para una realidad inmediata. Del compromiso político, Dussel establece toda una propuesta en su Pedagógica, de allí puede leerse:

Políticamente la pedagógica latinoamericana comienza por acoger la revelación del "ser latinoamericano", la voz nuestra. Allí comienza también la filosofía si en verdad es la "pedagógica analéctica de la liberación histórica". Se trata del ser latinoamericano del ser nacional, de la cultura, proyecto y ser de los grupos marginados, de la juventud, del niño latinoamericano (como el gamín bogotano)... La simbólica al comienzo de los cuatro últimos capítulos de esta Ética quieren expresar la voluntad del dejar hablar a nuestra América latina, voz en verdad apagada, ronca por el sufrimiento, pero llena de esperanzas... (Dussel, 1982, p. 54) 
No sobra poner en este aparte, el asunto de la no inclusión de temas latinoamericanos, o en términos de la época del siglo XIX, de Hispanoamérica o a un Nuevo Mundo, en las reflexiones profundas de Marx como lo dijera Aguirre (1985). Pero, hay que ver que el interés principal de Marx está en el fenómeno presentado precisamente en Europa y hasta en los Estados Unidos, no por ello deja de ver la interconexión mundial que gira en torno al capital y sus relaciones, todo por razones obvias. China, India, África y la América meridional no escapan a algunas alusiones, unas regiones más que otras. Sin embargo, lo marxiano tiene una fuerte presencia en los contenidos autóctonos.

En efecto, la propuesta marxiana de ver al mundo, de ver la realidad en búsqueda de la transformación, hace que sea más que un método, método que se extenderá en las décadas; hace que sea una lupa incisiva para estudiar cualquier contexto en esencia, claro con las peculiaridades que él mismo reconoce. Además, podría interpretarse de un modo no tan simplista o fatalista, la ausencia de tiempo para tocar fenómenos más allá del Mar del Norte. Cosa similar pasa con la educación como fenómeno de estudio dentro de las categorías marxianas y marxistas. Si bien Marx se quedó corto en unas cosas, no quiere decir que tampoco las haya pensado o estén intrínsecas en su sistema no sistemático. Scaron en prólogo a Marx (1972), define al respecto,

América Latina rara vez fue objeto de atención preferente, o siquiera sostenida, por parte de Marx y Engels. Para la conciencia europea del siglo XIX esta región del mundo era casi una terra incognita, y sólo grandes acontecimientos (la lucha por la independencia hispanoamericana, la guerra de México, la intervención anglo-franco-española contra ese mismo país) obligaban a no pocos estudiosos y políticos del Viejo Mundo a recordar que el término "América" no siempre era un sinónimo exactamente intercambiable por la denominación "Estados Unidos". (P.6)

Se reafirma la condición política de la escuela en los análisis constructivistas de enfoque social -porque existe un constructivismo más cercano al positivismo y hasta a los tecnicismos mercaderistas o intelectualistas-.

En general, la praxis ha de ser pensada y actuada. Pero, pensada teóricamente sin llegar a los áridos academicismos o tecnicismos que pueden desviar los objetivos sociales tangibles; ni actuada como apariencia sino como vivencia, dinámica, cambiante y propositiva. Sin olvidar que hacer praxis es integrar teoría y práctica, en este caso en el acontecimiento educativo, tampoco olvidar el carácter político de la misma, carácter que solo puede manifestarse en los que lideran en el entorno inmediato el quehacer educacional pues mientras no se den las condiciones a nivel macro (sistema estatal), la escuela debe ser ese campo de batalla donde cada vez se derroten las formas ideológicas del sistema de cosas dominante que como va, no ofrece sino un panorama aciago a nuestro planeta, a las esperanzas que guarda la humanidad.

Enfatizar en una visión emancipadora y crítica de la educación, alejarse de la postura mercantilista de la misma, es obligación de la escuela; desafortunada o afortunadamente, no existe otro compendio más original y autotransformador que el ofrecido por Karl Marx, -quien también es fruto de la historia- y desde el cual salen ideas, ejemplos y cosas no terminadas para ser transformadas. Qué mejor espacio que la escuela en todos sus niveles para debatir y rebatir, reforzarlo con la experiencia cotidiana, democrática y participativamente.

No se trata de seguir las prerrogativas eurocéntricas o anacrónicas como podría darse el caso de creer ciegamente en Marx; de lo que se trata es de tomar herramientas y transformarlas. Tampoco se puede dejar de observar la vigencia del mensaje del Marx sociopedagogo que sobre todo martilla mentes en América Latina. 
Tener presente a Marx en materia de transformación, no es simple moda o mesianismo como se dice por ahí en boca de muchos intelectuales que se hacen llamar marxistas, quienes obedecen a las lógicas más cuestionables del sistema de mercado - vender libros a precios exorbitantes y permitir esto a las editoriales con contenidos críticos, etc.- donde ni siquiera versiones libres comparten, en fin. Si es moda, será moda social, dialécticamente clásica; si es mesianismo, será como factor de rescate de la dignidad, el derecho a emanciparse y la incansable resistencia por un mundo posible, por unos sujetos posibles.

La escuela como espacio para desatar la competencia furtiva, la producción de mentes maleables, de modelación de personas sin identidad ni actitud crítica, listas para el consumo, que denigre del real sentido del trabajo y de la rebeldía ha de reemplazarse por la escuela praxiológica no ideologizada, si política.

Lo mínimo es, iniciar el develamiento de las formas actuales de alienación, llevar el tema a la escuela y reconocer en los actores de la comunidad educativa seres humanos constructores de su propia historia y de la de los demás. Generar práctica social más allá de la producción material.

La práctica social del hombre no se reduce a su actividad en la producción, sino que tiene muchas otras formas: la lucha de clases, la vida política, las actividades científicas y artísticas; en resumen, el hombre, como ser social, participa en todos los dominios de la vida práctica de la sociedad. (Mao Tse Tung, 1968, p. 318)

La praxis es la práctica teórica y la teoría práctica que, evoluciona y puede dar muchas herramientas para enfrentarse al sistema educativo monopolizador que ha llevado a la confusión y la seducción por encasillarse entre las propuestas dictatoriales autómatas extremas, de un lado, y los permisivismos "anárquicos", volátiles, por otro.

Pensar con el marxismo en estos inicios del siglo XXI, a doscientos años de la aparición física de Karl Heinrich Marx, es un verdadero desafío y, por grata providencia, un tema de profunda o no tan profunda polémica; igual, cualquier intento de transformación real, no podrá nunca negar cualquier pizca de lo marxiano.

\subsection{El tema del trabajo praxiado}

Eje central del pensamiento emanado de Marx, es el trabajo. Si el acontecimiento educativo es visto con esta perspectiva, este ámbito no podrá quedar por fuera. Así, no habría transformación educacional sin la transformación de esta capacidad humana llmada trabajo, pero para esto se debe explorarlo con la propuesta marxiana.

Cabe decir, la llamada reproducción social subordinada, tratada por Morales Zuñiga (2009), está ligada en esencia a esa mortalidad natural del ser humano; en materia será la que garantice la prolongación en tiempo y espacio del trabajo humano, más que nada, de su alienación, sin esta última no habrá garantía de sostenimiento del sistema de cosas de corte capitalista. Esta reproducción, que es automática, está estrechamente relacionada con las exigencias del mercado que a su vez sustenta políticamente las directrices educacionales en los Estados contemporáneos.

El tema del trabajo es merecedor, de una revisión más extensa y profunda, pues las formas han variado, no así su carácter histórico, su, digamos, esencia en el término alusivo. Tocar lo marxiano por antonomasia es 
tocar al trabajo. Veamos el concepto que determina Marx en su etapa de propuesta concreta, en el Programa de Gotha:

1. "El trabajo es la fuente de toda riqueza y de toda cultura, y como el trabajo útil sólo es posible dentro de la sociedad y a través de ella, el fruto íntegro del trabajo pertenece por igual derecho a todos los miembros de la sociedad".

Primera parte del párrafo: "El trabajo es la fuente de toda riqueza y de toda cultura".

El trabajo no es la fuente de toda riqueza. La naturaleza es la fuente de los valores de uso (ique son los que verdaderamente integran la riqueza material!), ni más ni menos que el trabajo, que no es más que la manifestación de una fuerza natural, de la fuerza de trabajo del hombre. Esa frase se encuentra en todos los silabarios y sólo es cierta si se sobreentiende que el trabajo se efectúa con los correspondientes objetos e instrumentos. Pero un programa socialista no debe permitir que tales tópicos burgueses silencien aquellas condiciones sin las cuales no tienen ningún sentido. En la medida en que el hombre se sitúa de antemano como propietario frente a la naturaleza, primera fuente de todos los medios y objetos de trabajo, y la trata como posesión suya, su trabajo se convierte en fuente de valores de uso, y, por tanto, en fuente de riqueza. Los burgueses tienen razones muy fundadas para atribuir al trabajo una fuerza creadora sobrenatural; precisamente del hecho de que el trabajo está condicionado por la naturaleza se deduce que el hombre que no dispone de más propiedad que su fuerza de trabajo, tiene que ser, necesariamente, en todo estado social y de civilización, esclavo de otros hombres, de aquellos que se han adueñado de las condiciones materiales del trabajo. Y no podrá trabajar, ni, por consiguiente, vivir, más que con su permiso.

Pero dejemos la tesis tal como está o, mejor dicho, tal como viene renqueando. ¿Qué conclusión habría debido sacarse de ella? Evidentemente, esta:

"Como el trabajo es la fuente de toda riqueza, nadie en la sociedad puede adquirir riqueza que no sea producto del trabajo. Si, por tanto, no trabaja él mismo, es que vive del trabajo ajeno y adquiere también su cultura a costa del trabajo de otro". (Marx, 2000, p. 8-9)

El gran socio teórico de este aspecto presente por milenios entre los humanos, no deja de preocuparse por su afectación originada por las condiciones del modelo económico y todo su bagaje. No se conformó con definirlo socialmente, también lo despejó de las dudas, de la ideologización a la que era sometido como concepto, como práctica.

De una manera figurativa, Marx explica sencillamente su concepción de trabajo siempre en concordancia con el lado crítico, siempre en clave dialéctica. Su postura no es inmóvil, mucho menos acrítica o neutral. Entonces, él afirma:

Concebimos el trabajo bajo una forma en la cual pertenece exclusivamente al hombre. Una araña ejecuta operaciones que recuerdan las de un tejedor, y una abeja avergonzaría, por la construcción de las celdillas de su panal, a más de un maestro albañil. Pero lo que distingue ventajosamente al peor maestro albañil de la mejor abeja es que el primero ha modelado la celdilla en su cabeza antes de construirla en la cera. Al consumarse el proceso de trabajo surge un resultado que antes del comienzo de aquél ya existía en la imaginación del obrero, o sea idealmente. (Marx, 2013, p. 216)

He ahí el alto aprecio a la función social e individual que tiene el trabajo. De ahí también sus vehementes apuntes, sus mordaces e incomprendidas diatribas. No era para menos, el sistema de mercado laboral arrebataba la libertad bajo la apariencia de una finalidad universal de progreso y bienestar. La idea era superar un sistema que saqueaba la fuerza del obrero y lo llevaba a la indigencia (Guzmán, 2017, p. 176).

Las categorías tendrán un lugar privilegiado para el Marx teórico, que pasará de ese teórico a un socioteórico en el sentido estricto del término. La observación terminológica no reposará en meros conceptos, pues el objetivo es ayudar a comprender la infamia a la que se sometía a la humanidad cercana 
de su entorno en pro de un reducido sector. De la siguiente forma decía en sus Manuscritos económicofilosóficos de 1844:

... la enajenación [Entäusserung] del trabajador en su producto significa no solo que el trabajo de aquel se convierte en un objeto, en una existencia externa, sino que también el trabajo existe fuera de él, como algo independiente, ajeno a él; se convierte en una fuerza autónoma de él: significa que aquella vida que el trabajador ha concedido al objeto se le enfrenta como algo hostil y ajeno. (Marx, 2004, p. 175)

De lo anterior, puede definirse la diferencia entre una actitud autómata y una actitud libre, la cual no solo se encuentra en las relaciones laborales asalariadas sino también que invitan a reflexionar en la vida escolar que concierne a todos los actores inmersos en la educación. Una educación que equilibre las relaciones de poder, que no otorgue libertades aparentes ni dependencias sino autonomía e importancia de conciencia, será un principio conducente a la realización humana de manera solidaria, constructiva y transformadora.

Frente a la ciencia, la denuncia contra ésta consiste en que la ciencia es utilizada como medio de justificación de la explotación. A pesar de ser admirador de la ciencia y de los avances teóricos de la economía clásica, así mismo, al facilitarse su estudio directo, eleva sus críticas trasversales contra esta vía de ciencia reproductora de la infamia. He aquí su crítica contra esta en el trato que da a lo más preciado de un ser humano en términos de desenvolverse en el medio social, el trabajo:

Según Marx, la economía política había descubierto que la esencia del hombre es efectivamente el trabajo. Pero después, en sus desarrollos y aplicaciones, aliena al hombre y no pone los medios para conservar ese carácter humano del trabajo que había descubierto. Es una economía cínica, dirá. El trabajo ha sido abstraído -y con él, el hombre- y se convierte en puro medio para ganar dinero. (De Noce y Riestra, 1975, p. 69)

Tomando en cuenta que la integración de política con práctica tiene sentido con la idea de praxis, como dice González (2015), produciéndose así en acto político e histórico, se asume entonces, una postura antropológica. La praxis definiría al hombre en tanto hombre, precursor el mismo de su encuentro con la historia propia y encontrarse con la de los demás; el trabajo es acto político también. Afirma González (2015), cuando requiriendo a Petrovic ${ }^{77}$ que, el hombre es un ser de la praxis. Yo añadiría: sobre todo para reconocerse en la praxis y realizarla en principio mediante su trabajo, su dedicación, su compartir social. Este compartir ha de revisarse, difundiéndose en la escuela emancipadora.

La dimensión humana transformadora que conocemos como trabajo (Arbeit /Werke) para Marx, se convierte en el factor de más preocupación humana, precisamente por ser histórico y estar sometido a las inclemencias de los dictámenes de los modos de producción que, a través de la historia han existido.

La relación existente entre trabajo y alienación, será un arma denunciante de lo marxiano para corroborar el adecuado acompañamiento teórico de categorías que parecen abstractas pero que tiene una materialización más que evidente. Esto hace ver la imperiosa necesidad de rescatar al ser humano de los estados catastróficos de enajenación (física-productiva) y alienación (mental-política). Así:

... la enajenación [Entäusserung] del trabajador en su producto significa no solo que el trabajo de aquel se convierte en un objeto, en una existencia externa, sino que también el trabajo existe fuera de él, como algo independiente, ajeno a él; se convierte en una fuerza autónoma de él: significa que

${ }^{77}$ Gajo Petrovic, pensador humanista yugoslavo (1927-1993). Se destacó por sus trabajos sobre praxis. 
aquella vida que el trabajador ha concedido al objeto se le enfrenta como algo hostil y ajeno. (Marx, 2001, 106-107)

El trabajo como fuerza integradora y propia del ser humano se enajenó. Se convirtió en mercancía, entró al juego de la oferta y la demanda. El ser humano empezará a ser teorizado desde un conjunto de ciencias que escasamente podrían ser refutadas, pues ellas mismas serán producto del devenir.

Sostener la idea en que "el valor de una mercancía no se determina solamente por la cantidad de trabajo que le confiere su forma definitiva, sino también por la masa de trabajo contenida en sus medios de producción" (Marx, 1984, p. 383) ${ }^{78}$, era sostener una perspectiva la cual tocaba directamente al ser humano como creador de procesos de los cuales no era ya dueño, y por ende, no poder aspirar a una emancipación a menos que fuera consciente de dicho fenómeno, más, procesos que generaban riqueza en unas pocas manos -cómo ocurre aún en pleno inicio del siglo XXI-, la invitación es a ilustrarse de dichos asuntos y con esto hacer de la situación una oportunidad dialéctica para superar estas etapas.

La forma suprema de praxis era la theoria como se dijo al inicio de esta gran sección; ella misma era considerada suprema manifestación de teoría misma, no había otro fin distinto a la contemplación. Esto tuvo efectos contradictorios si se mira desde la historia económica y mucho más desde la acomodación ideológica. González, en su trabajo sobre la praxis, nos comparte:

¿Qué es la praxis? Para Aristóteles, la prâxis designa aquellas actividades cuyo fin está en ellas mismas, a diferencia de otras actividades "productivas" (poíesis), que tendrían su fin en aquello que ellas crean. Praxis es escuchar la música por el sencillo deseo de escucharla, mientras que la construcción de un barco con el fin de navegar no sería para Aristóteles praxis, sino mera producción. (Sf., párr. 1)

Independiente de las perspectivas (ya sea aristotélica, marxista, etc.), hay algo en común: que depende siempre de los actos humanos, ya sea contemplación o disfrute de las cosas, ya sea para producir cosas en cubrimiento de necesidades (González, Sf.). Hay que decir que el mismo Marx no da soluciones puntuales, no era su intención -por eso se cae cualquier señalamiento de mesianismo-. Recuérdese que paradójicamente se dedicó más al funcionamiento del sistema capitalista, cuya gran categoría viva -para él- era el trabajo, que a las soluciones (Feinmann, 2012); sólo daba las pautas, entre ellas la importancia de organizarse y formarse como clase. Esto conduce a comprender porque debía autoformarse y así comenzar el tránsito por la liberación autónoma, independiente sin esperar otros actores.

Hegel tuvo algunos avances significativos que serán tomados por Marx (Guzmán, 2017). Un alma alienada, encontramos en la terminología hegeliana. Es la conciencia de sí, pero en conflicto pues sabe y no sabe al tiempo sobre su naturaleza dividida, esto inquieta y le puede hacer infeliz (Hegel, 2010). La ilustración gráfica del amo y el esclavo, arroja la comprensión de esa preocupación de Hegel por el trabajo; es por sí misma pedagógica. La negación del esclavo será en Marx la negación del asalariado; el trabajador será ahora el llamado a construir la historia así las circunstancias les sean contrarias.

En la economía clásica el trabajo es abordado de una manera apenas obvia para la versión mercantilista. Se establecen categorías, jerarquizaciones, relaciones superficiales y legislación; pero, de todas maneras, se

${ }^{78}$ El capital, crítica de la economía política. Libro primero, el proceso de reproducción de capital. Libro I, vol. 2. Trad. de Pedro Scaron. 
demuestra la importancia por no brindar protagonismo al trabajo humano sino al capital. No obstante, no ha de desconocerse el factor de fuerza laboral ni tampoco la importancia del trabajo libre para facilitar las relaciones de producción, distribución y consumo.

La misma idea de libertad física -recuérdese la infamia de la esclavitud moderna llevada al extremo por las potencias "civilitorias"- del hombre esclavizado, poseía una intencionalidad para nada filantrópica, solo obedecía a la dinámica, a las exigencias del sistema de mercado. Había que liberar la mano de obra para que pudiera consumir; Marx notó esto último en los ejemplos de EE.UU de la segunda mitad de su siglo y así puede verse en sus observaciones (Marx, 1976b-4).

Nada está desligado en lo marxiano. Para el caso de la expoliación de América en su papel dentro del concierto mundial del desarrollo capitalista, como hito, apuntó que el descubrimiento de América -él hablaba de descubrimiento- consolidó el sistema global mercantilista, gracias también al abuso y el sometimiento de individuos y su fuerza de trabajo que se sumaba al saqueo de minerales y otros productos (Marx-Engels, 1972); el coloniaje dotó de metal precioso a las potencias como aparece en el muy pictórico capítulo XXIV de El capital (Marx, 1976a) y no la mitología idílica que promovía el ideario oficial, apropiado a su vez por la población como todavía se nota hoy.

Si en alguna dimensión humana puede demostrarse los efectos del sistema de mercado y la enajenación acompañada con la presencia fáctica de la alienación -que acá logra verse distinta, a la par-, es el trabajo. Es muy común ver a un estudiante no contento con su entorno sin razones específicas; así es más común ver a personas ejerciendo oficios, labores y artes sin espíritu de libertad o siquiera de agrado. A esto se suma el empobrecimiento de la mano de obra debido a los bajos salarios y los altos costos de la canasta básica; sin mencionar las limitaciones que hay a los accesos de servicios mínimos. No hay aportes al crecimiento personal, mucho menos al material en palabras de Guzmán (2017).

Todo se aglomera en males tangibles, volcándose contra la clase trabajadora. La persona sin conciencia en palabras de Marx, de clase- busca y encuentra a través del trabajo, o mejor del ocuparse en "algo" la sobrevivencia terminando por dar más robustecimiento a la cadena de sometimiento, de enajenación (García, 2005).

La educación y sus instituciones han elaborado estrategias como la orientación o exploración vocacional además de las políticas de la diversificación y etc. Sin embargo, no ha sido suficiente en muchas ocasiones. Falta la visión del trabajo como algo emancipador, falta el ejercicio político del mismo. La educación en el trabajo debe distinguirse de la automatización, pero esto se hace cada vez más difícil pues los Estados apuestan por seguir generando ejércitos de mano de obra barata bajo el manto de las oportunidades de formación ${ }^{79}$; esto se hace sin mirar las necesidades de la población, sino con el interés de tecnócratas defensores del sistema de consumo y mercado.

Luego, se aborda con lo marxiano varias perspectivas. Acá intentamos establecer la importancia del tema del trabajo con la visión marxiana de la educación, pero para ello, como arriba exhortamos, la historicidad

\footnotetext{
${ }^{79}$ Ejemplo es el SENA en Colombia. La mayoría de la oferta formativa se centra en preparar a los estudiantes de colegios en convenios, en áreas de mercadeo o logística. Fenómeno digno de estudio crítico.
} 
de esta dimensión social, descuidada adrede por los poderes gobernantes y los intentos por sepáralo del acontecimiento educativo, desechan lo que conduzca a la criticidad; así también el trabajo entendido como dignidad y algo no enajenable, se convierte en oportunidad para la toma de conciencia que tanto hace falta en el sector obrero, campesino y estudiantil.

En educación para el trabajo en los niños, Freinet (1971) tiene muchos aportes significativos desde su propia experiencia. Desde su postura, la educación con el trabajo logra acercar a los individuos tempranamente a esa diension humana, eso sí, generando conciencia de su valor social y no como simple mercancía al servicio lucrativo de otros. No obstante, el sistema de cosas, este pedagogo francés propone resistencia.

El trabajo con todo es social por naturaleza, es transformación directa del medio para suplir aquellos requerimientos básicos; el exceso produce otros efectos. La exigencia de explotar la naturaleza más de lo que se necesita conduce al establecimiento de una clase que determina las pautas de producción, y otra que se ofrece para ser utilizada, además de ser consumidora. Es todo un ciclo donde el trabajador es el menos favorecido.

"No puede haber una solución efectiva para la autoalienación del trabajo sin que se promueva, conscientemente, la universalización conjunta del trabajo y de la educación" (Mészáros, 2008, p. 62). La educación está en deuda por el descuido ofrecido al trabajo en tanto fuerza activa para generar cambios profundos, pues poco se ve al trabajo como dignidad social y más como una mercancía que no tiene otra opción que someterse a la oferta y la demanda, al éxito o al fracaso inducidos.

La escuela se ha limitado a producir individuos, más no conciencias. La historia de la escuela, de esa escuela capitalista, parafraseando lo que nos teorizaron Baudelot y Establet (1976), nada más ha dado razón de los intereses del mercado laboral autómata en el mejor de los casos o ha aportado de alguna manera $\mathrm{u}$ otra al aislamiento del individuo entregándolo a los extremos de la delincuencia o la mendicidad; esto es una realidad, realidad en la que se regocija el sistema de cosas representado a su vez por el Estado, el cual con el doble discurso, solo sigue ofreciendo su intervención a favor del capital, o sea al trabajo enajenado.

En L'ecole capitaliste en France, texto clásico, se estudia la escuela de ese país entre 1965-1975 (Baudelot y Establet, 1976), puede servir de antecedente, pues en su trabajo de campo se habla del poder de la ideología de clase en ella, so pena de las peticiones de la postguerra por parte de las alas progresistas; no obstante, seguía la imposición más que reformista, acomodada de las clases dominantes, las cuales traicionaron los acuerdos de socialización y medidas emancipadoras que el sector partisano, que hizo frente al nazismo-fascismo, propuso; esto se puede deducir de manera fácil mirando los objetivos de la escuela. La formación de mano de obra calificada para la acumulación de riqueza y, sobre todo la idea de supremacía de lo galo, también destaca como aspecto negativo.

Desde esta orilla latinoamericana, una de las tesis de Vasconi (Sf.) con las cuales cierra su perfil sobre la escuela, sigue esculcando el tema docente, su rol, como defensor de las retóricas sobre el utilitarismo de la educación. Leamos:

En la Escuela Capitalista, los cuadros docentes -más allá de sus propósitos individuales- operan como agentes ideológicos de la burguesía. Pero a nivel de conciencia -o, subjetivamente, si se prefiere a expresión-reproducen ("viven") las contradicciones objetivas de la Escuela capitalista. (Sp.)

Volviendo a Marx (Marx-Engels, 1977), de él surgió el interés por proponer la educación politécnica, con características socialistas de tipo científico para separarla de la idea de los utópicos o de la educación del 
trabajo benefactorista, monástica, autárquica, aislada, al estilo Owen o Fourier. Ésta fue entendida de otra manera en América Latina, más “civilitorias”, nunca fue leída en clave marxiana. De hecho, se recreó un modelo más ligado a la producción de mano de obra barata y escalafonada. Algunas instituciones eran del carácter confesional otras dependían de entes gubernamentales; eran la alternativa, la solución impuesta al déficit universitario que los mismos gobiernos intencionalmente hicieron. Se pensaba que instruir en artes $\mathrm{u}$ oficios era la panacea, hubo descuido del sentido dignificante y sobre todo voluntario de las políticas sobre educación y trabajo.

La situación se sigue agravando, pues ahora se trata es de producir consumistas y personal para el sector servicios y mercadeo y afines. Esto se presenta en el sistema educativo -si se le puede llamar asíglobalizado. El desmonte es urgente.

Dicha tarea requiere la superación de la alienación del trabajo y la negación del orden capitalista. La educación aparece como locus fundamental en esa lucha, puesto que es donde gran parte de las disposiciones de la ideología capitalista se reproducen (a través de la internalización). (Leher en prefacio, Mészáros, 2008, p. 16)

La acción trabajadora no puede ser individual, y por inercia tampoco la praxis desvinculada con los otros, con la comunidad. El trabajo entendido desde la praxis liberadora es encuentro consigo mismo y con los demás. El trabajo ha de liberar al hombre, y no ser elemento mercantilizado para generar ganancia a terceros. Es necesario en esto el desencadenamiento de una visión de trabajo como dignificación humana que aprecie el tiempo libre que podría utilizarse para el disfrute pleno del individuo con sus congéneres y sociedad filial cercana.

El ocio entendido como espacio inalienable para el desarrollo de la libertad individual para el disfrute del mismo sentido social, es de necesaria revisión política. Quitar el "pecado" del sudor que se profesa a partir de ese maniqueísmo bíblico, cuyo real mensaje providencial es someterse a los mandatos de los poderosos, debe insertarse en la acción liberadora de la escuela.

En una sociedad socialista, para estudiosos del fenómeno marxiano, no habrá separación entre teoría y praxis, alejamiento que en un sistema de cosas regido por la ganancia que al final lleva a la enajenación; el ocio debe estar presente para que el individuo se realice, que sea dueño de su tiempo libre (Morán B. y León, 2008). "Así como el tiempo determina la medida de libertad más allá de la praxis material necesaria, también, inversamente, determina el grado de humanización que se puede alcanzar dentro de esa praxis" (Schmidt, 1977, p. 171).

Marcuse, décadas atrás apuntalaba: "el tiempo libre transforma al que disfruta de él en un sujeto diferente, y como sujeto diferente entra en el proceso de producción inmediata" ${ }^{\text {" }}$ (1993a, p. 269). Cabe decir, esa visión de la productividad en el máximo esfuerzo solo degenera en plusvalía que nunca retornará al ser humano pues el tiempo y las condiciones físicas o mentales gastados en ella, no darán ningún beneficio, todo lo contrario, tal como lo demuestra la historia del cotidiano al ocaso de las vidas de los sujetos.

Charles Chaplin en Modern Times (1936) nos invita a reflexionar sobre todos los efectos que en el cotidiano tiene el sistema laboral enajenado y el contexto de una sociedad segmentada, de un Estado represor en todo sentido. De la persona común y corriente se espera su máximo esfuerzo, los adelantos de la ciencia se materializan, pero con miras a optimizar y ahorrar tiempo productivo en las cosas que se producen, mientras

${ }^{80}$ [en, Marx. Grundrisse der Kritik der politischen Oekonomié. loc. cit., pág. 559] 
el obrero se desgasta. La cosificación ${ }^{81}$ toma la cúspide del proceso (Marx, 1984), es razón en sí. La enajenación llega a su máxima expresión cuando las condiciones mentales, físicas y espirituales llegan a un punto crítico (Marx, 2013). Total, al aparato no le interesa, pues si una ficha falla, tendrá el repuesto, si un hombre, mujer o niño se muestra "ineficiente” habrá como reemplazarlo.

Quizás el momento más infame del sistema de trabajo capitalista es cuando las fuerzas, la ciencia, la tecnología, todo el recurso está destinado a la guerra. Las dos grandes guerras y sus consecuentes conflagraciones regionales, reflejaron la degeneración más aberrante del sistema explotador. Los obreros de un bando produciendo armas, con el lema ideológico de patria o etc., contra el otro bando cuyas armas y equipamientos y provisiones salían de las manos obreras, de gentes pobres salidas del pueblo llano. Todo para seguir enriqueciendo a los empresarios de la muerte que seguían a los orates estadistas en sus empresas de muerte y destrucción. La apariencia se devela. Las cosas en el final de esta segunda década del siglo XXI se han agudizado.

Los obreros sentían prurito, eran conscientes de su situación enajenada y alienada. La acción ideológica era más fuerte como feroz el odio inoculado. Otros quedaban en los campos de batalla. De todas maneras, esto puede tomarse como un fracaso de esa idea de internacionalismo solidario al que tanto apeló Marx y que los movimientos obreros proclamaron. Con razón Marx denuncia al "nacionalismo", la historia reciente se lo había demostrado con los ejemplos de Francia y Prusia. Si bien el sistema de opresión político estatal era poderoso, faltó la praxis del individuo conformado en colectivo para haber impedido tanto crimen, tanto desprecio por la vida. La dialéctica amo y esclavo fue evidente una vez más al unísono; la sumisión no ha sido superada.

De estos ejemplos globales, la escuela emancipadora podría tomar la postura crítica de cada ámbito inmerso en los acontecimientos históricos para mostrar las nefastas consecuencias de las confrontaciones desatadas por las posiciones egoístas y la sed de poder que solo tiene un trasfondo económico. En palabras de Freire; "nadie libera a nadie, nadie se libera solo: los hombres se liberan en comunión" (1971, p. 52).

En esta perspectiva, debe abanderarse la causa del trabajo como algo que una a los pueblos, les haga recapacitar sobre las intenciones que tienen los poderes tras las confrontaciones provocadas por los poderes económicos. A la verdad, en el mundo de hoy donde con un solo botón podría liberarse la más brutal fuerza manipulada de la naturaleza, las cosas se ponen más difíciles, más las acciones de contención no están de más y menos para la escuela esperanzadora que se realiza en la praxis.

No puede limitarse a la comprensión de que la alienación capitalista solo aliena al trabajo (García, 2005). No. También aliena a todo el cotidiano, toda la vida individual y social del ser humano. Los pueblos están llamados a ser actores imprescindibles para, a través de ejercicios democráticos y rebeldía, empoderarse de

\footnotetext{
81 "Sucede con la categoría "cosificación” lo mismo que con la categoría “objetivación”, es un concepto incompleto, le han cortado una parte. La expresión conceptual completa es la siguiente: cosificación de las relaciones económicas capitalistas. No sabemos si hay otras clases de relaciones que experimenten la cosificación, pero no debemos generalizar en exceso, llevar los conceptos más allá de sus límites originarios hace que pierdan concreción y precisión. Este error puede observase en Wikipedia, se define la cosificación como la transformación de los seres humanos en cosas. En este error también incurren muchos marxistas. En El Capital de Karl Marx de lo que se habla es de la cosificación de las relaciones sociales no de las personas. Y de momento debemos ser rigurosos con este contenido conceptual”. Objetivación, cosificación y alienación. Francisco Umpiérrez, en Rebelión
} 
su historia, de su destino material. La exigencia de un modelo de trabajo distinto al modelo expoliador, es un derecho-deber más que social para las sociedades dependientes de la periferia.

En palabras de Adorno (1998) una emancipación, un no olvidar y un no repetir prácticas alienantes, infames y aniquiladoras del aprecio por la vida misma. Encontrar una manera armónica entre ciencia y trabajo en pro del progreso humano, es menester de un nuevo sistema no sistema que apunte a la formación integral y crítica del ser humano desde sus primeros años hasta el mismo ocaso.

La obra de P. Blonskij (1884-1941), destacado pedagogo soviético, cuya centralidad fue la preocupación por el tema del trabajo en la sociedad socialista, merece ser nombrada. Tras la revolución de octubre, defensor de la educación politécnica, de la polivalencia, destaca entre los pensadores de la pedagogía socialista; Palacios (1984) sobresale su aporte a la teoría del trabajo en la inmediatez de la escuela. Tras la revolución, él "propuso una estrecha combinación entre trabajo productivo e intelectual que implicaba su desaparición, ya que su protagonismo educativo pasaría a ser ocupado por la comuna y la fábrica” (Dietrich, 1976, cf. Hernández Salamanca, 2013, p. 57, sf.).

Las teorías sociales dicen que el trabajo debe ser productivo en bienes, materiales, espirituales, más para ser socializados y no individualizados al extremo, no enajenación; para eso se necesita un buen equipo teórico y una organización adecuada para que el estudio sea más que agradable, socialmente comprometido. Esto en la pedagogía no puede estar ausente. A propósito Freinet resalta:

El trabajo sea el gran principio, motor y filosofía de la pedagogía popular, actividad de la cual se desprenden todas las adquisiciones. En la sociedad de trabajo, la escuela así regenerada y reconstruida quedará encuadrada en el proceso de la vida y del ambiente, y se convertirá en una rueda de mecanismos sociales, del que en la actividad, se encuentra demasiado arbitrariamente apartada. (1980, p.41)

Este enfoque social de trabajo como eje de toda actividad escolar, de lo cual la pedagogía y sus diversas corrientes se han encargado, parten del supuesto de que la escuela debe oponerse a la tradicional forma de educación pasiva y formal, también que se plantee el problema de la formación humana unido al problema de la adquisición conceptual y de habilidades para desenvolverse a contextos determinados, pero además centrarse en la sociabilidad, en el bienestar común micro y macro. De esa manera también lo entendió Freinet (1971). El aspecto fundamental de orientar la actividad escolar en función del trabajo colectivo, que tiene que ver con el nuevo orden debe ser cuidadoso para no caer en la acriticidad o el automatismo de cualquier corte ideológico. Por lo tanto, es menester concretar la organización de todas las actividades, incluido el trabajo en función de una racionalización humana de la vida escolar, buscando con ello la formación armoniosa de los individuos dentro de un ambiente social en perspectiva futura.

Para dar paso a nuestro próximo capítulo, recaudemos lo hasta aquí alcanzando y resumamos lo dicho sobre la praxis retomada con la visión marxiana para una puesta en marcha del valor que tiene la educación, su fenómeno educativo en cuanto es social, y por eso susceptible de las fuerzas que dialécticamente confluyen en la realidad. Entonces, la praxis sobrepasa lo pragmático, al convertirse en oportunidad dentro de la escuela inmediata regida por la inmedatez que le ha impuesto el sistema de cosas hegemónico. Ideología e imaginarios infundados versus conciencia revolucionaria, utilitarismo y cosificación frente a praxis; ese es el asunto próximo al destacar el desenvolvimiento y el reconocimiento de ideología y praxis en el espacio histórico y social que denominaremos "escuela inmediata". 


\title{
CUARTO MOMENTO \\ LA ESCUELA INMEDIATA COMO MATERIALIDAD DE LO IDEOLÓGICO y DE LA PRAXIS
}

\author{
La vida social es, en esencia, práctica. \\ Todos los misterios que descarrían la teoría hacia el misticismo, \\ encuentran su solución racional en la práctica humana y \\ en la comprensión de esa práctica \\ Octava tesis sobre Feuerbach, en Marx 1845
}

Cuanto más completo es el mundo en tanto apariencia, tanto menos superable es su aparición como ideología.

T. Adorno

El propósito de la educación es mostrar a la gente como aprender por sí mismo.

El otro concepto de la educación es adoctrinamiento.

N. Chomsky

Establecidos los modos de la interpretación marxiana sobre la ideología y sobre la praxis para efectos de una filosofía de la educación comprometida con la transformación de base, podrá avanzarse a la siguiente fase de extensión. En esta fase de extensión se observará cómo los elementos desprendidos de la ideología (alienación-enajenación) se presentan en los espacios concretos del acontecer educativo. Al tiempo, la praxis, será aprovechada al momento de devolverle el compromiso sociohistórico al acontecer educativo a niveles macro y micro, sin perder de vista que todo parte del contradictor sistema socioeconómico imperante, o sea, el capitalismo con sus nuevas fases.

El interés sobre lo inmediato y la inmediatez en la escuela, ha de tener desde la filosofía de la educación vista con la lente marxiana-, el punto clave que demuestra la insistencia de la ruptura social por parte de la visión proclive a la consolidación obediente al capital. Como dirá Mészáros: "solamente la más amplia de las concepciones de educación nos puede ayudar a alcanzar el objetivo de un cambio verdaderamente radical proporcionándonos instrumentos de presión que rompan la lógica desmitificadora del capital" (2008, p. 44).

Aquella, es la concepción que trata de mostrar las formas, las categorías para desmantelar a las apariencias del modelo educacional imperante que, hoy obedecen a las orientaciones hacia una sociedad consumista y conformista. No se trata de un afán teórico, se trata de una percepción y un sentir de algo en lo que están inmersos los seres humanos en formación.

En definitiva, este aparte versará sobre la escuela inmediata como espacio material donde se desenvuelve la ideología en sus diferentes manifestaciones pero que, a la vez, puede ser oportunidad para el rescate del sentido marxiano de praxis. Para ello, hay que tomar en cuenta unos conceptos claves como lo inmediato, la inmediatez, lo concreto y lo cotidiano. Además de la extensión propositiva a los actores -el principal de ellos: el docente- y otros factores como lo es el currículo y el accionar político. 


\subsection{Referentes cercanos a la escuela inmediata}

En este apartado trataremos algunos autores - quienes son también actores- ya que desarrollaron y vivieron sus experiencias en sus contornos inmediatos, convirtiéndose en referentes para el abordaje de perspectivas alternativas de formación alejados del dictamen del capital; sede la lógica de lo marxiano que aquí planteo: develaron la ideología y aplicaron praxis. Ellos pueden ilustrar con sus aportaciones, actitudes frente a situaciones problémicas de sus respectivos contornos. Así mismo, nos acercaremos a los conceptos principales para adentrarse en la propuesta marxiana de la lectura de la escuela inmediata con las herramientas de una filosofía de la educación que invite a reflexionar sobre la práctica y la escuela como manifestaciones del orden económico, social y político imperante, las cuales transmiten sus negativas dictamenes al grueso de la población.

\subsubsection{Autores-actores}

Un autor-actor es, aquella persona que dedicó su pensamiento a reflexionar sobre la educación, quién además, produjo aportes al mejoramiento de su contorno educativo como orientador de procesos y sujeto político activo. Desde el punto de vista de algunos autores-actores, la escuela pensada desde sus relaciones, las cuales son mediadas por la situación contextual, y más allá de las apariencias discursivas que brinda la oficialidad; contiene una carga extensa de criticidad y propuesta. Freinet (1975b) y Freire (Palacios, 1984), son ejemplos de intervención de sus espacios inmediatos; son de todos los modos, antisistémicos, pues aplican su propia creación a la realidad, hacen de las dificultades oportunidades, sin abandonar la crítica, todo está ligado a la emancipación mediante la educación, reconociendo la situación material de despojo, opresión y exclusión; aparece la denuncia del sistema económico-social. Sus aportes se esfuerzan por la superación de desigualdades y la formación de la población excluida.

Freinet es clave para una lectura de la escuela inmediata, por las circunstancias en las que se desenvolvió. Esa historicidad que vivió, esa realidad que transformó. Su alusión a la escuela y sus investigaciones propositivas partieron de su contacto con las condiciones sociales del cotidiano más allá de lo escolar (1975a). El planteamiento que busca integrar a los estudiantes de base a la solución de situaciones se aleja de los preceptos tradicionalistas de la escuela aburguesada.

Otra perspectiva la presentan Trilla Bernet (2007) basados en Makarenko. Ellos muestran interés común en la triada: trabajo, formación integral y formación comunal. En los dos se denota la importancia dada a la praxis en su relación con la capacidad de producción material e intelectual de los niños y jóvenes ligados a la importancia política por emancipar conciencias que contradigan la enajenación impuesta por el sistema económico de mercado.

A. Makarenko por su parte ${ }^{82}$, inspirado en las necesidades de su tiempo, -paradójicamente- de su entorno ideológico, desarrolla una aplicación de la educación con carácter colectivista en su práctica. Su combinación equilibrada de trabajo como riqueza individual y colectiva, conjugado con la conciencia de la disciplina como forma nacionalista, fueron puntos esenciales en su propuesta educativa, la cual había que

\footnotetext{
${ }^{82} \mathrm{Su}$ trabajo fue reconocido por algunos sectores de la oficialidad del politburó, ganando la confianza para que su modelo fuera tomado en cuenta en algunas experiencias escolares de la URSS.
} 
aprovechar al nuevo sistema en general, o mejor generar un nuevo ambiente basado en los principios de la vida en comunidad junto a la participación activa de los padres en la cotidianidad escolar. Para este pedagogo soviético, el respeto y el cuidado de las buenas relaciones interpersonales no podían perderse en el cotidiano de la colonia educativa para que de allí se extienda a la vida externa, a su entorno familiar y a la sociedad; para el caso a la sociedad soviética (Palacios, 1984).

El filósofo marxista Ranciére (2010) se destaca por la idea sobre el maestro ignorante. Este autor trata en su reconocida obra sobre el valor de rescatar algunos antecedentes que han trabajado el tema de la escuela de manera crítica utilizando el entorno inmediato. Él destaca la importancia de establecer "lazos horizontales" entre educadores y estudiantes en procura del crecimiento colectivo hacia una emancipación también colectiva, integrada y solidaria. Su alusión a Joseph Jacotot, será una de las figuras a retraer para los tiempos difíciles que busquen profundizar y concienzar transformaciones retadoras del sistema establecido.

Importante es enfatizar que, desde Hispanoamérica Simón Rodríguez (2015), pensador y maestro fruto de sus tiempos, se preocupaba por la identidad de un sistema de educación distinto, el cual debía ser construido, apropiado en las tierras liberadas del poder militar y político del imperio español. A pesar de la exigencia que conllevara a una justificación de inmediatez del contexto, no se quedó en esta inmediatez; más bien, creyó en las necesidades de formar ciudadanos integrales, en oficios y academia, removedores de los cimientos del colonialismo, quinees estarían preparados para afrontar al neocolonialismo venidero, advenedizo. La educación liberadora como algo prolongado en el tiempo, no inmediato, sino de extensión, será un aporte concreto de este latinoamericano. Puede decirse que sus aportaciones, se orientan al rescate de las realidades cercanas, no se van a limitar al tradicionalismo de corte europeo que ya de por sí criticó.

En autores latinoamericanos, encontramos serios indicios de actitud denunciante ante las situaciones de alienación y enajenación en distintos lugares en estos dos últimos siglos. La resistencia de las ideas emancipatorias de la mano de la formación integral que responde a las exigencias de desmonte ideológico, chocan contra aquellas foráneas. Dichas materializaciones "desde acá" nos acercan al estudio de contextos negativos, donde un Martí educador y luchador antiimperialista -quien escribe su Edad de oro- está pensando en algo más que la instrucción académica de sus alumnos; formar seres políticos para su región in extenso, no únicamente para su isla. Lo inmediato en tanto limitante no era objetivo de las formas de pensar la educación es nuestros representantes, ellos entendían la urgencia, pero sabían que la inmediatez no era solución a las dificultades sociales, económicas, políticas y culturales dentro de sus contextos.

Para pensar la escuela inmediata en América Latina, y lograr transformarla, no puede apartarse a la historia intrínseca de la educación formalizada y de las otras formas de educación no formales como la idiosincrasia o la familia.

A pesar de los distintos autores, la reflexión sobre la escuela en tanto materialidad concreta y espacio de contradicción, de lucha de posturas, etc. tiene todavía mucho por explorarse. Este apenas será un inicio inmediato, más sin inmediatez. 


\subsubsection{Lo inmediato y la inmediatez}

Lo inmediato (die unmittelbare ${ }^{83}$ ) parte de la concepción filosófica proyectada a través de Marx, en cosas y fenómenos relacionados con la realidad material, con el sentir y trasegar del género humano. Si uno se mantiene en el campo aparente, se quedará en lo inmediato, y si se queda en lo inmediato no se podrá explicar la realidad tal como refuerza Echeverria (Sf.), y si no se interpreta, el camino hacia la transformación no se dará, esto invita a mirar todos los planos en los que se desarrolla el devenir humano y social.

Lo inmediato está relacionado con las limitaciones espacio temporales, pero esa justificación de hacer de lo inmediato algo central, puede ocultar otras realidades e intentar resolver de manera parcial algo que puede resolverse procesualmente para concretar objetivos, esto suele pasar mucho en los temas sociales y, la escuela no está fuera de ellos. Lo inmediato no se zafa del modo de producción de una determinada sociedad.

Marx de hecho, se acerca a lo económico como hecho social de hombres de carne y hueso; "Marx se aproxima a la economía a partir de sus investigaciones y estudios en filosofía e historia" (SantancárgeloBorroni, 2012, p. 1). El tema de lo inmediato se sustrae del pensamiento económico, pero es una de las categorías más ligadas al tema de las vivencias concretas, del cotidiano y de los efectos que sobre estos recae cuando el sistema de cosas impone su voluntad so pretexto de ser efectos absolutos que nada o poco tienen que ver con la acción humana de unos pocos en el poder.

Por su parte, la inmediatez la señaló Marx (1976) en los términos de los movimientos en la economía relacionada con la transformación inmediata de fuerzas laborales en mercancía y con ello en ganancia usufructuada. Más de allí dejó huella relacionada con la denuncia hacia un sistema de cosas, cuyo único interés es la ganancia económica y la plusvalía económica e ideológica como dirá Silva (2011b).

El sistema de mercado sabe cómo sostener y vigilar la inmediatez a niveles macro y micro, a individuos y a Estados; solo controlar la inmediatez garantizará sostener el porvenir de la misma inmediatez que se repetirá de manera automatizada; aparentemente no podrá tener otro fin que no sea el que el propio sistema produzca para que evolucione, así se mantiene el mito de que no hay fuerzas humanas que puedan superar las eternas leyes del sistema de mercado y su implantación socio-política.

Lo paradójico del asunto es que, la producción no se queda en lo temporal inmediato, pues debe extenderse para garantizar la consolidación de la ganancia y asegurar su propia existencia. La reposición periódica es mecanismo para sostener este tipo de mecanizaciones productivas. A su vez, en términos más mundanos, la inmediatez se va con la mortalidad humana (tiempo en el mundo material) que fue utilizada para la producción, en otras palabras, el aparato reproductor que parecería esfumarse no se esfuma pues existen otras vidas mortales (sujetos) con todo su tiempo para ser aprovechado en el sistema productivo.

En la escuela, que yo llamo, inmediata donde impera el inmediatismo, trata de vivirse el día a día sin o con muy poca reflexión, sobre las cosas a mediano o largo plazo. El afán administrativo de la escuela inmediata es "producir" resultados satisfactorios que se concretan en los índices áridos que tiene que ver con

${ }^{83}$ Lo inmediato 
resultados maquillados de pruebas, promociones automáticas de manera indiscriminada, y otras proyecciones estadísticas. La exigencia inmediata de la oficialidad central del Estado mediante sus entes administrativos, extremadamente burocráticos, raya con la esencia y materialidad de la educación. El cotidiano escolar se rige por la normatividad confusa, antes que de las realidades cercanas a las comunidades y a los individuos de carne y hueso.

Si bien se ha descrito al inmediatismo desde un vértice sociológico, político y filosófico, pensadores como Hakim Bey ${ }^{84}$ lo han cuestionado. La confrontación entre capitalismo e inmediatismo es punta de lanza para abogar por la visión inmediatista del mundo; lenguaje, tecnología, redes, etc. median en las relaciones y, por ello deben ser entendidas con sospecha dice Bey (1994); así mismo ha de ser observado en el acontecer educativo.

La inmediatez es característica negativa cuando se apodera de las mentes como solución limitada en tiempo y espacio, al querer dar razón de una situación o tarea a manera de automatización o simplemente en tanto requerimiento que no llega ni a lo pragmático. Acá, hasta los afanes -exigencia tiránica del sistema capitalista-, sustituyen de manera consciente la toma de tiempo para medir circunstancias, efectos y alternativas a las situaciones concretas.

Si la mediación es la existencia o definición de un concepto tomando en cuenta su relación con otro concepto; consecuentemente, las propiedades de conceptos como alienación, enajenación o praxis serán reveladas en su accionar con otros objetos - para el caso- con otras circunstancias y actores. "La categoría de la mediación, en unión de la categoría de lo inmediato, expresa el hecho de la concatenación universal de los fenómenos, de la universalidad del desarrollo de las cosas multiformes y de los conceptos que las reflejan", esta concepción se presenta en el lenguaje de materialismo propuesto en el Diccionario filosófico sobre materialismo. Su relación con los contenidos, por ejemplo, dentro de un currículo, podrá arrojar datos interesantes. La interacción en una realidad permitirá reconocer la cosa concreta dada, para el caso, la problemática de alienación en la escuela cuando se toma como inmediatez, siendo a la vez fruto de la inmediatez.

Volviendo al contexto regional, es importante ver como en América Latina y El Caribe, nuestra escuela se manifiesta ligada a la materialidad histórica, se establece como espacio dialéctico del cotidiano. Lo inmediato puede resultar atractivo cuando se toma como acción para resolver problemas. Esto lo han aplicado muy bien los sectores que dominan la economía y la política desde hace más de dos siglos en nuestros países, los cuales se conforman en Estado. A esta situación materializada de manera negativa, la filosofía de la educación cuya meta sea transformar realidades, debe enfatizar desde el conocimiento tangible; untarse de comunidad será el lema praxico.

La inmediatez es consecuencia directa de la influencia ideológica, ella define el diagnostico social de la escuela inmediata. Esta inmediatez podría convertirse en oportunidad sí, dialécticamente, profundiza los problemas en la escuela inmediata permitiendo por su grado de presentación material, ser percibida por actores que busquen transformar la realidad y científica y pedagógicamente, combatir esta situación. Esto ha de darse al abordarse lo cotidiano.

\footnotetext{
${ }^{84}$ Ha teorizado sobre la anarquía ontológica. Es poeta y ensayista de nacionalidad estadounidense. Nació en 1945. Se identifica con las formas de resistencia a la mediación, su concepción no se acerca ni a las caracterizaciones de la propuesta de la sociedad de la representatividad de corte capitalista, ni a la planificación al estilo socialista unilateral.
} 
Lo cotidiano será leído en la clave de lo inmediato, y lo inmediato en clave del cotidiano. La escuela inmediata es concreta, como concretas son sus relaciones y los resultados sociales; pero hay que abstraerse un poco para percibir más allá de esa propiedad.

\subsubsection{Lo cotidiano y lo concreto}

Para tratar lo inmediato y comprender su relación como algo presente en la materialidad escolar, es menester tener en cuenta dos cosas: primero, la temática del cotidiano como vivencia. Segundo, la noción de lo concreto del mundo social tangible. Estos dos aspectos hacen presencia, ayudando a comprender las dinámicas y los resultados en el proceso educativo a los que están inmersas las individualidades junto a sus respectivas comunidades. Beuchot y Primera (2004, en Rodríguez Vásquez), nos recuerdan que la vida cotidiana puede ser un fin en sí misma si se busca la humanización que aleje la visión del capital.

Primero, lo cotidiano en su versión ortodoxa significa todo aquello que está en la frecuencia, que se hace con habitualidad, etc. Desde lo social, puede decirse que es ese espacio -tiempo del individuo, pero que se hace valioso cuando se traduce en relaciones dentro de una comunidad y de la interacción con los espacios del entorno y la exterioridad. Hoy, las exigencias del cotidiano, promueven su inclusión a cualquier intento de educación, de los mismos procesos de enseñanza-aprendizaje.

Lo cotidiano tiene un gran valor en la versión marxiana de la vida. No solo de la vida material concreta, sino la inclusión de aquellas prácticas e influencias que, se podrían decir espirituales, pues ellas también parten de materialidades que se presentan y representan en la mortalidad cotidiana de la humanidad. El acontecer educativo hace parte de ese conjunto de cosas y situaciones del cotidiano; hoy más que nunca en otra etapa de la historia, la escuela es más universal y con ella universales también sus posibilidades, problemas y consecuencias. Los exponentes más destacados de la crítica hacia el sistema capitalista, según Buenfil (1991) lo tenían claro:

La educación extendida a múltiples prácticas sociales y en múltiples espacios parece ser más rica y compleja. Para Marx, la vida cotidiana; para Lenin las luchas diarias y prácticas; para Gramsci todas las prácticas hegemónicas ${ }^{21}$ y para Althusser todos los aparatos ideológicos del Estado, son espacios de la educación. (P. 186)

Lo inmediato se presenta en lo cotidiano. Sin embargo, trata de camuflarse en aquello, ponderándose ideológicamente, en tanto, fin último por parte de los intereses predominantes. Lo cotidiano contiene a lo inmediato, y no al revés, pues pensar que lo inmediato contiene a lo cotidiano impide las reflexiones sobre los problemas y soluciones de fondo que deban darse en un determinado contexto. Lo inmediato se da en el cotidiano, es subjetivo; mientras el cotidiano está ahí, es objetividad temporal pero producida por las fuerzas materiales que predominan en la sociedad, las cuales eligen una entrega casi irrestricta de toda la capacidad humana (ejemplo, el tiempo gastado en el trabajo que produce ganancia, en sacrificio de otras potencialidades y capacidades o derechos del sujeto-comunidad).

${ }^{21}$ Cabe señalar que existen ciertas diferencias entre la noción gramsciana de hegemonía y la que se sustenta en esta charla, es decir, la noción de Laclau y Mouffe (supra nota 16). 
Zucconi (2014) con su concepción de inmediatez, se refiere a que el patrón de comportamiento propio de la cotidianeidad, es la relación directa entre pensamiento y acción. Por eso según sea el grado de sometimiento a un estilo de vida, así también será la caracterización de la forma de pensar y actuar o su adormecimiento. "La conducta específica de la vida cotidiana es la conducta inmediata" (P. 302). Cabe decir que esta autora hace alusión a lo inmediato, desde un área integrada a los temas de la escuela como lo es el trabajo social (Netto, 2012).

Si bien lo cotidiano está relacionado con lo inmediato; frente a la inmediatez su relación ha de ser la de observación. Lo cotidiano ha de ser convertido en praxis, ello puede desmontar la impuesta idea sobre la pertinencia mítica de establecer a la inmediatez como algo justificable y que pasa desapercibida, como algo inevitable, como algo a lo que debe llegarse para concretar soluciones. Ahora se trata de la superación de la inmediatez, la cual puede representarse en la visión de mundo acrítica de los sujetos ${ }^{85}$.

Segundo, en cuanto a lo concreto quiero referirme a la materialización tangible de algún fenómeno o fuerza, no es susceptible de taxonomía moral. Por ejemplo, la concreción de la inmediatez en los comportamientos de los distintos actores que confluyen en la escuela inmediata, se dan en los marcos de las relaciones sociales, esto se hace tangible en las repercusiones que encontramos y podemos percibir en el contexto inmediato. Más lo concreto no se limita a lo obtenido a través de los sentidos, va más allá.

Marx (2008) en su Contribución a la crítica a la economía política, nos puede ayudar a entender una concepción adecuada de lo concreto, cuando señala que:

Lo concreto es concreto, porque es la síntesis de numerosas determinaciones, por tanto, unidad de lo diverso. Aparece en el pensamiento como proceso de síntesis, como resultado, no como punto de partida, aunque sea el efectivo punto de partida, de la intuición y de la representación. (2008, p. 301).

Como unidad de lo diverso, la búsqueda de lo concreto, extendido al acontecer educativo, será no un afán, sino una oportunidad en sí misma, una vía de la reflexión-acción sobre la necesidad de formarse dentro de la escuela inmediata para hacer frente a los factores macro y micro que interfieren en las prácticas; a esa totalidad diversa que conforma al acto educativo y la misma escuela. Lo concreto determinará el diagnóstico, el estado de alienación o la ausencia de la misma- del cotidiano vivido que, de todas maneras, no será ajena la escuela inmediata.

Volvemos a Kosik (1963), en su visión de lo concreto, decía que la cotidianidad era fenoménica, la cual se manifestaba y ocultaba al tiempo. Desde esta perspectiva, y sabiendo el fuerte instinto humano hacia lo utilitario, la escuela inmediata con su dosis alta de inmediatez no tendrá sino un carácter más que denunciativo en su actuar dialéctico ya que, paradójicamente han de ser más concretas las afecciones al tejido social.

\footnotetext{
${ }^{85} \mathrm{Si}$ la esencia es el ser superado en su inmediatez como puede verse en Hegel (Ciencia de la lógica), entonces, la esencia de la escuela inmediata se manifiesta en su extensión sensible, en este caso, la percepción de las dinámicas y contradicciones en ella explicitas, las cuales rebosan las murallas de las mismas instituciones escolares víctimas de las consecuencias sociales del sistema sociopolítico predominante.
} 
Lo concreto se define en su presentación histórica; los hechos determinan la presencia de lo concreto. Entonces, lo concreto en la escuela inmediata es el compendio de aquellos hechos, aquellas prácticas desarrolladas al interior del acontecer educacional o administrativo. Los efectos de los hechos determinarán el sentido que se otorgue a lo concreto como resultado, a su vez, histórico. El valor se otorgará según el efecto de los hechos, incluyendo el sentido político.

Si concreta es la realidad -por más adversa que sea-, concreta ha de ser la propuesta que contrarreste a la permisividad de la escuela inmediata y su fundamento ideológico. La verdadera revolución educativa no es ideológica sino conscientemente política, en cuanto el poder para convertir a la educación en vía de liberación y bienestar es algo que atañe la misma convivencia humana y hasta con su entorno. La política concreta del compromiso es la salida que puede construirse para devolverle la idoneidad a la educación; en definitiva, "sin compromiso no hay posibilidad de transformación alguna" (Gutiérrez, 2005, p.155).

En cuanto a la escuela inmediata, encontramos a los seres humanos inmediatos, más son inmediatos cuando su cotidiano los sustraen de la posibilidad de leer su realidad concreta; realidad distante de los objetivos materiales que puedan garantizar situaciones favorables. Los actores escolares son convertidos, a su vez en sujetos inmediatistas en la medida en que reproducen su visión alienada de mundo. Cabe decir, el ser inmediato, es aquel que corresponde a la sensibilidad directa y limitada que busca suplir una necesidad de manera limitada en tiempo y espacio.

Finalmente, si lo cotidiano exige transformación social; lo inmediato cargado de inmediatez no podrá lograr sino lo contrario pues es de su resorte mantener el estado de cosas alienado. Por su parte, lo concreto, rebosa cualquier enfoque físico o metafísico para plantarse como un tipo de actitud política para lograr objetivos desde una educación centrada en el interés por recuperar la dignidad humana y la justicia social que tanto reclama la historia.

\subsubsection{La superación de la inmediatez}

Para tratar una postura que intente explorar o definir a la escuela inmediata, tendrá que tratarse a la inmediatez y concretar su superación. Es en el acontecer educativo donde, mediante el apersonamiento de herramientas de crítica y propuesta por parte de los actores - especialmente el factor docente-, ha de darse la transformación en ideas y prácticas.

Miremos lo siguiente para pisar un poco el terreno de la sustentación teórica. Si bien Hegel tocó el tema de lo inmediato en obras como Ciencia de la lógica, de la que Marx toma sustentos (GPM, 2000), la inmediatez de la escuela inmediata se supera en la medida en que se planteen los objetivos materiales, ésta tendrá una dialéctica por las mismas características.

La superación dialéctica de la inmediatez, se ha de manifestar mediante la negación de esa inmediatez como único camino de la educación para resolver situaciones que podrían comenzar a solucionarse si se plantean como algo social de dimensiones macro, extendidas en tiempo y espacio. El sentido del acontecimiento educativo desde la óptica marxiana, plantea un sentido complementario.

Es decir, no la resolución para únicamente el individuo sino para la comunidad conformada por seres humanos que han de ser emancipados por sí mismos al lograr reencontrarse con el sentido adecuado de la 
formación humana en dignidad reconocedora de potencialidades para iniciar la conciencia de la construcción de un estado de cosas distinto al que ofrece el mundo determinado por el consumismo y la explotación en todas sus manifestaciones

Recordemos, la inmediatez (die Unmittelbarkeit ${ }^{86}$ ) tendrá dos sentidos. Como aquello que busca resolver situaciones que se presentan en un determinado tiempo-espacio; llegando a clasificarse como intervención concreta. Esta inmediatez, puede estar más cercana al pragmatismo, cosa que de todas maneras fue y sigue siendo uno de los elementos fundacionales del tradicionalismo educativo de corte oligarco-burgués.

En otro sentido, como limitación inoculada en el imaginario de las personas. Es decir, como acción delimitada por la forma de ver el mundo. Pensar y actuar con inmediatez equivale a no tener pretensiones de reivindicación, a no hacer resistencia. He aquí un claro ejemplo de la efectividad de la instrucción en el sistema de cosas por parte del accionar del Estado; una generalización de un tipo de estoicismo social.

En general, este aspecto se ha transformado en estrategia para esquivar los verdaderos problemas. Lo inmediato aparece como problema y se dan transitorias soluciones, ocultando con ello las relaciones materiales que se mueven tras las situaciones concretas. Lo inmediato desde el punto de vista de la producción capitalista es positivo. Con lo inmediato se obtiene ganancia, bajan las perdidas y se satisface al consumidor. Para necesidades inmediatas, soluciones inmediatas; para demanda inmediata, oferta inmediata; para formar a los ciudadanos, escuela inmediata. Así se toma en la escuela la visión mercantilista de la educación, pero no solo con efectos económicos, sino con el binomio alienación/enajenación.

Cabe destacar de nuevo que, lo inmediato no es exclusivamente asunto de tiempo o cumplimiento efectivo e intervención; no. Lo inmediato en este análisis próximo a lo marxiano, consiste en la limitación de ver más allá de las apariencias; y en el acontecer educativo, sí que hay mucho de estos reflejos. Tampoco quiere decir que debemos ir al extremismo de rechazar cualquier solución de facto a las situaciones negativas, tomar esta actitud sería nocivo. De hecho, de lo que se trata es de transformar la realidad en favor de la comunidad, para el caso de la educación, de los sujetos para invitarlos a ser activos sujetos de transformación social.

Por tanto, surge una cuestión: ¿para qué es la educación si no para resolver situaciones inmediatas? Pues, podría decirse que, si bien se necesitan cubrir necesidades emergentes, no puede limitarse la educación a dicho precepto, ya que resolver problemas o situaciones atadas a lo inmediato (factor tiempo), desde una visión marxiana se rechaza creer que este es el fin de los procesos educativos.

En el cotidiano proselitista vemos los afanes que hacen las clases politiqueras por responder a necesidades, prometiendo el cielo y la tierra, ofreciendo dadivas, sobre todo en épocas de elecciones. Esto es un buen caso de aplicar la crítica a lo inmediato que, en el mejor de los casos, da soluciones a corto plazo sin medir las consecuencias, dejando que el problema sea tapado momentáneamente, luego saldrá a la luz la verdadera realidad.

En ese orden, ¿acaso una educación con criterios sociocríticos, y más con un contenido de elementos de análisis marxianos, no busca resolver problemas pendientes provocados por el sistema capitalista de cosas? Pues bien, la respuesta es sí, pero con la gran salvedad de que, no se trata de una inmediatez árida; se trata

\footnotetext{
${ }^{86}$ Inmediatez, en Marx
} 
de aprovechar las amenazas para convertirlas en oportunidades como sucede con la ideología y el entorno material. Ahora, debe ir en contravía de cualquier conformismo inmediato.

Madriz (2012) acota: un hecho que cambia la vida es un "acontecimiento"; por tanto la educación para la filosofía de la educación con el enfoque marxiano es un acontecimiento realizado y susceptible de ser realizado por el ser humano que a su vez es producto de su contorno material. Ahora, si la escuela cambia la vida o pretende cambiar condiciones solo en el campo de lo pragmático individual, el sentido social comenzará a ser cuestionado, abandonará su razón histórica de ser.

Entonces, si cambia o pretende cambiar, lo consecuente es que ese cambio conduzca a una transformación entendida en clave marxiana que es uno de los enfoques más acordes a la denuncia del sistema, proponiendo un verdadero cambio individual y social, pensado a niveles macro y micro, en las extensiones materialesinstitucionales creadas por la cultura humana. Esto es superación.

\section{2. ¿Qué es la escuela inmediata?}

La escuela inmediata no es una propuesta en sí, es solo el escenario donde se reflejan las nuevas, pero a la vez poco cambiantes relaciones ideológicas y materiales determinadas por la hegemonía del sistema de cosas imperante, así como por la resistencia que presentan algunos actores dentro de esa misma escuela inmediata que no se dejan cautivar por el inmediatismo de apariencia resolutoria.

Ahora bien, escuela inmediata es más que una unión de dos palabras que en sí mismas encierran un concepto teórico-práctico diverso y específico a la vez. La escuela inmediata es aquella que se presenta en el cotidiano del acontecimiento educativo, pero que tiene unas características y dinámicas amarradas a las condiciones materiales desencadenadas por el sistema de cosas imperante. No es espontánea, aunque se presenta en la materialidad diaria escolar.

Escuela inmediata es la forma en que se lee la actividad teórico-práctica al interior de la vida educacional en la institución escolar de escuelas y colegios, con la lupa marxiana sobre la inmediatez y lo inmediato. Dicha escuela inmediata surte efectos sociales ya que se sostendrá en los espacios posteriores de la educación, para el caso, los de la universidad o para la misma cotidianidad de su formación como ciudadano o en su desenvolvimiento socio-familiar. La escuela inmediata en su lectura marxiana no se limita a la institución formal. Por ser un fenómeno material donde conciencia y materialización de la misma, donde circunstancias y niveles macro y micro se encuentran o desencuentran.

La escuela inmediata es la que se centra en el afán del inmediatismo. No mira más allá de las radicalidades pues se conforma con el repaso de corrientes teóricas y directrices político-administrativas de Estados tercerizados y neoliberales. La escuela inmediata, en su papel consciente, no tiene interés en mediar entre los sujetos y su realidad, solo es intermediaria que busca plusvalía ideológica

La escuela inmediata, por ejemplo, es la escuela de los resultados cuantitativos sin sentido, pero que al no encontrar los resultados cuantitativos esperados, empieza a desesperarse y -mediante las directrices administrativas- decide efectuar cambios en detrimento de lo correcto. La escuela en su inmediatez, es de las apariencias; como aquella que sostiene que la toga y el birrete, asegura la felicidad de un sujeto que está siendo engañado por el sistema de consumo haciéndole pensar que al graduarse -a pesar de no haber superado o manejar los mínimos- es competente para ser arrojado a la realidad que el mismo sistema voraz establecido por la dictadura del capital; aunque lo peor es no haber sido formado en sentido social e 
histórico. O de aquellos sujetos que por su excelencia esperan algo más significativo por parte del Estado, y se frustran al ver que las oportunidades se cierran ante su cara. Es reproductora de los vicios del sistema de cosas, como la injusticia, permisividad y sobre todo del estado de alienación/enajenación.

La lógica de la escuela inmediata está en concordancia con el sistema de cosas establecido. Esta funciona a niveles macro y micro; es la lógica socioeconómica y sociopolítica de la mercantilización, del fetichismo inmediato desprendido de la visión de consumo y de limitación socio-crítica, -los cuales pretenden ser negados pero que existen-, cumpliendo una función social, ya no de única reproducción sino de sostenimiento, alimentación y consolidación del sistema. Aun así, existe la esperanza material de revertir el asunto, pues ella misma puede ser oportunidad, de lo contrario no tendría sentido tratarla y superarla.

La escuela inmediata misma parece objetiva, pero en el trasfondo es subjetiva pues es fruto de la materialidad de sus actores y los entes que la rigen. La escuela inmediata es histórica por antonomasia. La escuela inmediata tiene una espacialidad, se presenta en la materialidad del acontecimiento educativo, en cuya materialidad se afecta por las condicionantes del sistema económico imperante que se justifica con sus raíces, entre ellas la más sostenedora: la ideología.

...la escuela es la institución social que, por su naturaleza, sus funciones y estructura, cumple como ninguna otra con objetivos políticos. El sistema escolar, de cualquier sociedad, es reflejo fiel de la política e ideología de los grupos gobernantes o de los partidos políticos en el poder. (Gutiérrez, 1988, p. 17)

Si el pensar cotidiano es una forma ideológica de la práctica humana de cada día como indica también Kosik (1963), lo que se piensa y lleva a cabo en la educación, difícilmente sería libre. Aunque hay que decir, es la misma influencia del sistema de cosas el que ha castrado cualquier alternativa, cualquier concreción de formas distintas, así también en la escuela, en los procesos formacionales. Es complicado entender las formas retrogradas de pensar y actuar si no se entiende las dinámicas cíclicas del sistema que genera y es establecido por esa misma dinámica material.

La filosofía de la educación pensada en clave marxiana, permite definir a la escuela inmediata como lugar de contradicciones, pero también de oportunidades. La praxis pensada con lo marxiano para nuestra escuela inmediata, ojalá con ingredientes latinoamericanos, históricos y políticos, aporta herramientas de análisis para la comprensión de los procesos formativos, así como para el direccionamiento de los mismos.

Para acercarse a la escuela inmediata hay que adentrarse en ella, conocer sus actores y abrir todos los sentidos. Sin reconocer las dinámicas socioeconómicas afectantes a los individuos, no puede llegarse a la meta filosófica idónea, la cual dará paso a la develación de las apariencias. No puede percibirse la escuela inmediata desde fuera, si se hace hay que decir que solo se miraría desde la tribuna de la especulación que podría estar viciada por otras percepciones de contenidos ideológicos también. Hay que explorarla, vivirla, sufrirla y confrontarla, de ahí el importantísimo rol del docente no inmediato.

Como docente de base, hice alusión a la escuela inmediata relacionándola con la experiencia cercana, es decir, el cotidiano escolar, el cual deja ver todas las relaciones con las que carga la escuela (Ramírez Angarita, 2017). Lo característico de ese espacio consiste en su impacto -también inmediato- hacia los actores que confluyen en él. Lo inmediato no se queda en la mera percepción, pues la materialización ha de manifestarse al momento de vivir esa escuela inmediata que se prolonga y frente a la cual se ha de tomar posición tanto crítica como propositiva.

En términos comunes, la escuela inmediata, es repetitiva, es la escuela acrítica, la escuela que se declara apolítica, es monótona en sus cuatro paredes, cuantitativa, confusa y poco comprometida con la realidad 
cercana. Sin embargo, por su propia naturaleza, esa escuela inmediata, con todo y su inmediatez, no deja de ser campo de encuentro y confrontación; eso también lo hace que sea escuela inmediata.

Sobre los fundamentos teóricos presentes en la escuela inmediata, a pesar de verse discursos de teóricos, las alusiones de aportes realmente críticos brillan por su ausencia. Broccoli (1980) percibe la dificultad en pretender desligarse de la ideología, por esto dice: "pretender que Piaget, Bachelard, Foucault, Althusser, Monod y muchos otros no pagan sus tributos a la ideología de que son portadores es un auténtico absurdo" (P. 28). Los autores son convertidos en ideología y no en consciencia. Toda teorización o tecnicismo que resuelva desconocer las fuerzas que se enfrentan detrás de la educación, son sin duda posturas que consciente o inconscientemente tratan de tapar la realidad oculta, llevándola solo a la importancia de la inmediatez o de sustentos ad baculum.

Las nuevas corrientes pedagógicas y psicopedagógicas han llegado a la escuela inmediata, reconformándola, dándole sus particulares toques; muchas veces se trata de ajustar el contexto escolar a los veredictos teoricistas, funcionales. La escuela inmediata se debate entre el extremo permisivo que intenta ser neutral, colaborando de manera cómplice al sistema de cosas imperante sin darse cuenta, incluso se diatriba contra el tema de la rigurosidad como algo banal o el señalamiento de la necesaria disciplina consciente como algo estrictamente represor; y las del molde tradicionalista de carácter autoritario o memorístico propio de la escuela burguesa. Para superar hay que equilibrar sin abandonar la tendencia a la dimensión socio-crítica, a la formación socio-histórica del individuo y las comunidades.

Si bien Marx trata lo inmediato como un obstáculo a la hora de detenerse en él porque no permite ver la realidad (Echeverría, Sf.), su postura infiere un uso de la concepción de inmediatez. No es solamente la inmediatez de la que habla Marx (2009) en su postura sobre el valor, donde a partir de su contenido a todas luces hegeliano, distingue lo abstracto de lo concreto. La cuestión es rescatar eso concreto, pero siendo consciente de que no puede quedarse allí; así la escuela inmediata ha de ser pensada con cierto grado de abstracción o simplemente no sería pensada -en el sentido robusto del significado-. Aunque llegar a un tipo de "esencia", y no leerla en clave dialéctica, sería volver a discusiones bizantinas que aportarían poco a la urgencia con las que se merece ser tratado el acontecer educativo.

Pensar con la inmediatez como única vía, implica un riesgo de quedarse en esa inmediatez, más no pensarla y mucho menos vivirla, sería pasar desapercibido, cosa que demostraría el descuido de desarrollar nuestras capacidades sensibles; si bien hay unas relaciones ocultas que se perciben, en el escenario escolar dichas ocultaciones difícilmente dejan de manifestarse, de ser evidentes a los sentidos orgánicos. Lo concreto se manifiesta en el acontecer diario, cuyos principales protagonistas serán las personas de carne y hueso junto a los dictámenes de sus extensiones institucionales e ideológicas.

El acontecer cotidiano es central en la escuela inmediata. El cotidiano hace presencia y, al tiempo, se hace cotidiano. Pero, no es el cotidiano pensado per se; es un cotidiano que trae la postura de cotidianidad que ya se había denotado en lo marxiano, en las experiencias sociocríticas de Marx.

La escuela inmediata es propuesta para repensar la labor docente, colaborando en el rescate del compromiso político de los diferentes actores, quienes están en la responsabilidad histórica de redefinir el rumbo de la educación en una época de monopolio del ideario consumista acompañado de una obnubilación ideológica. Para el caso del ente docente, es instrumento de acción política de un lado (Gutiérrez, 2005), que se convierte en agente de la ideología si no se forma en ciencia y praxis, vector de reacción ideológica (Silva, 1979). Esto respalda la idea no extinta, de la escuela como aparato ideológico. 
Mirando lo regional, la escuela inmediata, tomando en cuenta lo latinoamericano, tiende a la falencia de dos cosas. Esto es a un rescate de los aportes latinoamericanos para repensar la educación desde acá, desde América latina sin excluir aportes importantes foráneos. Y dos, carencia de aprovechamiento de las realidades cercanas para reactivar el sentido crítico-propositivo para hacer del acontecimiento educativo un proceso socio político, soportado en la formación integral y académica, donde la misma idea-acción de ciencia sea soporte del inicio del desmonte de las negatividades en la comunidad y, desde allí, a la totalidad social. La inmediatez hace perder de vista el aprovechamiento que puede darse al establecer un dialogo de saberes y experiencias que tome lo latinoamericano en sentido formacional.

La escuela inmediata es la prueba más concreta de la existencia de un interés - que se oculta en desinterésdescuido- por parte de las clases dominantes que llevan todavía las riendas de los ministerios de educación y filtran sus mandatos hasta las bases, hasta el acontecimiento mismo de cada aula. La exploración de la escuela inmediata es un asunto central para una filosofía de la educación marxiana pues en ella se materializan la ideología y la misma praxis.

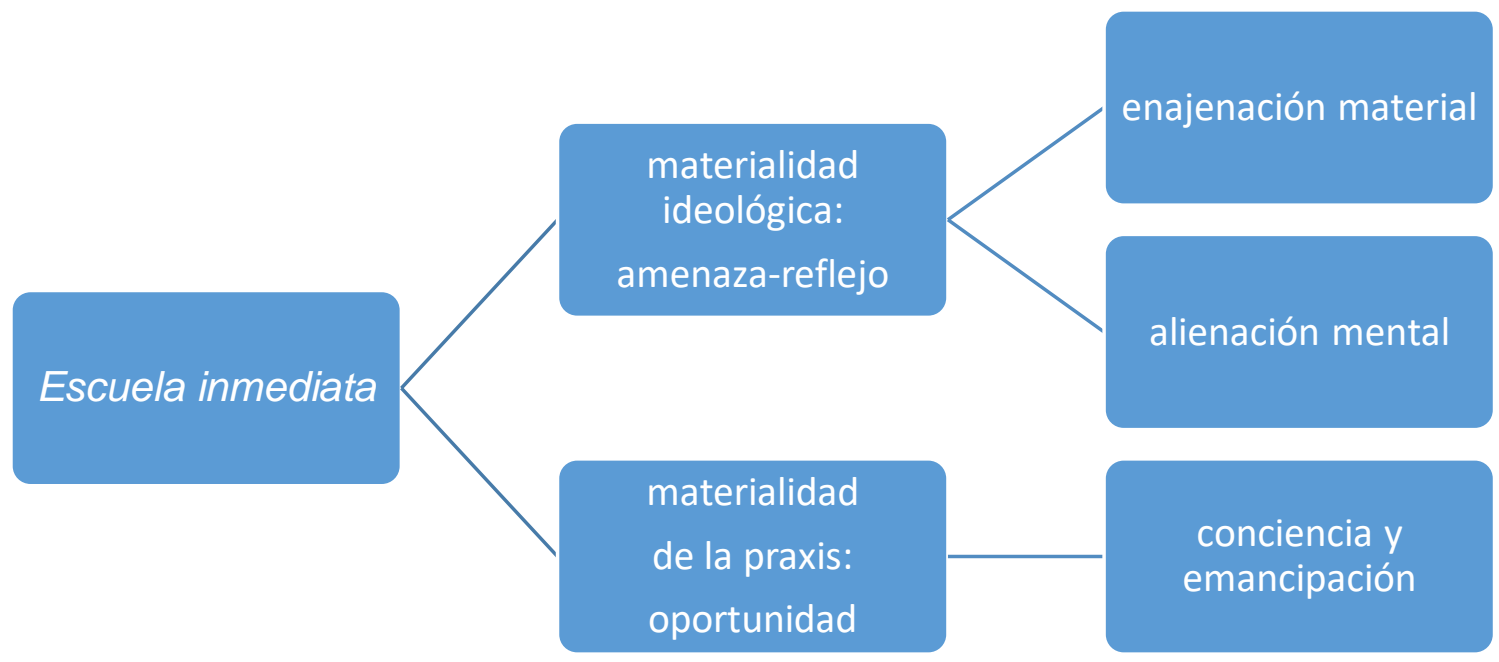

Gráfico No.10. La escuela inmediata es lugar de contradicciones. Sus materializaciones permiten que se manifieste. Se materializa con la ideología en tanto amenaza presente por ser alienadora y justificar la enajenación. Sin embargo, es oportunidad si se actúa en praxis por ser superación consciente y conducir a la emancipación.

\subsubsection{Su presencia dialéctica}

La escuela inmediata se presenta como fenómeno social, su presencia es dialéctica. Desarrollar la lectura teórica de la escuela inmediata como aporte final, integradora de la visión crítica de la educación, como acontecimiento social ligado a unas coyunturas particulares, provenientes de contextos macro y micro, será la extensión material de su propia concepción. En tanto acontecimiento, en este caso material, la escuela inmediata es clave para entender las dinámicas sociales más allá de la comprensión sociológica que ya tienen mucho que ofrecer, pero que desde el pensar la educación, todavía tendrá relaciones ocultas por desarrollarse a medida que se presente el sistema de cosas imperante.

El asunto es que no podría cambiarse el estado de cosas si no se hace examen de esas cosas y circunstancias -en este caso relaciones- que, precisamente, hacen particular ese estado de cosas que pretende cambiarse. Y es así porque para el caso de la escuela inmediata, ésta no acontece desligada a las negatividades, de 
hecho, lo inmediato se toma de la manera más indiscriminada, confundiéndose con la evacuación de necesidades que, aunque muy válidas, tienden a dejar por fuera la extensión en tiempo y espacio de los fines de una formación social y política. A su vez, la escuela del acontecer pide oportunidades.

Los aportes de análisis entre elementos marxianos idóneos como ideología y praxis invitan a repensar las relaciones al interior de la escuela, pues a pesar de un desconocimiento que quiera darse desde posturas "neutrales", la vigencia de una filosofía de la educación a partir de criterios marxianos seguirá vigente mientras exista el modelo capitalista y, sobre todo, su manifestación en la escuela. Con Zucconi (2014), ha de afirmarse que, al movimiento de lo real para llegar a entenderlo, la dialéctica es un buen comienzo.

El imaginario plantea que, las personas pasan y las instituciones permanecen; esta máxima se equivoca, pues las instituciones son creadas por personas con intereses, entre esos intereses puede estar el sostener a las instituciones y su institucionalidad. Las instituciones son extensiones materiales de intereses, no son entes independientes en sí; existen porque son sostenidas sus existencias bajo intereses humanos. Baste ver la vida diaria, por eso ese tipo de "alienación de la vida diaria del hombre contemporáneo constituye la base y la fuente de todas las otras formas de su condición alienada” (Fromm, 1989, p. 330).

La escuela inmediata no es un ente, es todo un conjunto de relaciones sociales desatadas en la práctica escolar. Es una totalidad. Por su inmediatez, muchas veces carece de ser reflexionada, se fragmenta y con esto se pierde la valoración dialéctica de la misma. Los afanes por resolver cuestiones colaterales le quitan el valor real de la inmediatez a la escuela inmediata, valor real en el sentido en que podría aprovecharse para saber cómo opera.

La escuela inmediata tiende a verse como institución, se presenta, lógicamente, en la institución escolar. Como aparato ideológico - cosa que se puede demostrar al interior de la escuela-, la institución escolar impone sus pautas, las cuales la mayoría de las veces no se notan explicitas, así la escuela inmediata es mediada por las fuerzas intrínsecas del aparato escolar instituido y que se instituye en la práctica cotidiana. Es más, las mismas circunstancias caóticas que se presentan, aparentan un sin sentido cuando en realidad obedecen a una lógica con demasiado sentido. Por citar un caso, las exigencias desde las políticas de calidad y a la vez las permisividades que hasta encuentran sustento jurídico para los casos concretos de promoción, sin cumplir los mínimos por parte de los educandos; en palabras del cotidiano, la exigencia de calidad solo con cifras, independiente de los procesos, fuera del sentido sociopolitico de la educación, le restan credibilidad como factor de transformación y emancipación.

Cabe recalcar que, la propuesta de escuela inmediata tiene dos sentidos tal cual se apuntó anteriormente. Uno como ese espacio material en el que se presentan las relaciones provenientes del sistema de cosas dictaminadas por la ideología, en este caso la lectura de esa presentación objetiva dentro de la escuela; el descubrimiento de la escuela como campo de acción ideológico facilitará la identificación de lógicas subyacentes afectantes.

La otra, es aquella que propone a la misma escuela inmediata como oportunidad de praxis transformadora. Es decir, la escuela inmediata como producto ya no de objetividad sino de subjetividades evidentes en la materialidad de los individuos y sus comunidades; la superación de esa visión objetiva para convertirse en una proyección de acciones concretas, que partan de una toma de lo cotidiano de manera crítica y proponente, para establecer puntos de partida a la hora de pensar y actuar frente al acontecimiento educativo. Así, la escuela inmediata es una escuela de naturaleza dialéctica, la cual podrá pensarse como tal. La praxis como vivencia en la actividad educativa, buscará superar a la inmediatez en su negatividad

La manifestación de una doble materialidad permite entender la dinámica propia de los elementos encontrados en la escuela inmediata estrechamente vinculados a lo marxiano. En la escuela inmediata se 
evidencia en la actuación de la ideología y sus componentes; que llegan a tocar y es, inclusive en doble relación, trastocada por los mismos actores internos (educadores, padres, estudiantes) y externos (Estado, sociedad, mercado) concretos. La praxis también logra manifestarse, ya sea desde las posturas teóricoprácticas, ya sea desde acciones concretas de un cambio de cosas o con la aparición de resistencias pedagógicas maduradas en proyectos, currículos y otros elementos-espacios que brinda el devenir escolar.

\subsection{1. La escuela inmediata como materialidad de lo ideológico}

La inmediatez es la suprema evidencia del carácter ideológico pues ella se alimenta y alimenta de manera dinámica a la alienación y a la enajenación, las cuales se materializan en el acontecer escolar de distintas maneras evidenciándose en el interior de la escuela inmediata y proyectándose al exterior extraescolar. Alienación y enajenación son parte fundamental para sostener el carácter ideológico de la educación ya que son fuerzas que se intensifican en los sujetos y con ellos la sujeción a condiciones asimiladas donde lo crítico-propositivo tiende a desaparecer por los mismos efectos contraproducentes de la inoculación ideológica que traspasan práctica, pensamiento, currículo y formas de actuar. El reto socio-histórico consistirá en darle la vuelta a la situación y, pasar de lo ideológico a la consciencia social, es un estado superable.

En general, lo ideológico convive en la escuela inmediata. Todos los actores educativos son vectores potenciales de ideología. Si retomamos la propuesta y denuncia de Marx sobre ideología como lo hace Silva (1983), nos encontraremos en la realidad oculta, precisamente, por esa ideología. La simple apariencia deja de ser apariencia cuando se manifiesta en la problemáticas materiales e intelectuales de las que es productora la escuela inmediata con su gran motor que es la inmediatez y la despreocupación social.

Por un lado, la alienación es una situación innegable en la escuela y está directamente relacionada, proporcional al modelo educativo y al sistema que lo sostiene. Lo alineador hace presencia y se materializa en la escuela, entre los individuos, es viral. Por ejemplo, hoy existen formas de alienación que convierten en fetiche distintas cosas del cotidiano, hechas para el consumo que van desde posturas sobre la vida, pasando por modas y hasta eventos deportivos con figuras multimillonarias, ídolos que representan la mercantilización.

La alienación como estado socio mental, surge y siempre busca sostenerse tras bambalinas de apariencias de armonía o simples convencionalismos que tienden a normalizar situaciones a todas luces dudosas de converger en los verdaderos fines de la educación.

Por el otro, la enajenación se toma para nuestra escuela inmediata como algo más cercano a los sentidos estrictamente hablando, pero en relación con la producción material y el trabajo. Es decir, la enajenación se presenta en la misma finalidad que se da en la escuela frente a las metas a futuro (profesionales o no) que se quieren con los educandos. Formarse ya no tanto para el trabajo como si para el consumo, es cumplir con los mínimos requeridos en una sociedad proclive a la enajenación absoluta del individuo.

En el cuerpo docente, la enajenación se presenta en su adscripción como trabajador de un sistema educativo que no brinda muchas garantías, por tanto puede volverse algo monótono y lo convierte en un "operario" del sistema educativo que solo puede estar ahí porque no tiene otras posibilidades de empleo; al depender de un salario que a su vez depende de comportamientos y conocimientos delineados, los enajena.

La enajenación es evidente no sólo en el hecho de que mis medios de vida pertenezcan a otro, sino en que todo es distinto de sí mismo, mi actividad es otra y, por último (y éste es también el caso del capitalista) que un poder inhumano lo domina todo. (Marx, 2012, p. 159) 
La enajenación es la más difícil de las situaciones; ella misma es teorizada por Marx en la relación social del trabajo (2012). De ésta solo se puede resistir -en la mayoría de sociedades- quizás de manera mental, pues el tema de los medios para sobrevivir materialmente implica la misma existencia terrenal humana. Mientras exista el modelo económico de mercantilización habrá enajenación.

En la escuela inmediata, el tema del tiempo, lo más preciado para los seres humanos debido a su finitud, es uno de los factores menos observados. La enajenación del tiempo a merced de la tiranía de la ganancia para terceros es tema de urgencia por su presencia nociva en la sociedad como lo avizoró Marx (2016a) y posteriormente el mismo Marcuse (1993a). La libertad en el tiempo y el goce de esta en función individual, con el otro cercano y social, no debe sustraerse a simples señalamientos de disfrute desde la visión cerrada del consumismo. La plenitud del tiempo como factor social no podrá soslayarse al momento de intentar transformar las visiones de mundo en los actores educativos.

Hay que arrebatar, mediante la educación consciente, el mito de la pertenencia del tiempo a la producción, máxime cuando ésta solo atrofia al ser humano en requerimientos de la ganancia para terceros ajenos -más aún- a sus intereses de vida. El afán y la satisfacción hacia el sistema deteriora nuestra humanidad, nos limita, nos hace socialmente infelices así no se reconozca.

La filosofía de la educación con la lente marxiana establece aproximaciones para detectar las acciones que representan un ambiente ideológico según lo expuesto en la sección sobre ideología tratada en el segundo momento. Para el caso docente, la práctica escolar de ellos mismos, junto a sus posturas sobre temas de contexto cercano y exógeno, denotan las posturas ideológicas de los sujetos más que aptitudes realmente políticas. Puede presentarse, como afirmé en algún momento:

La escuela misma, por resquemores, por no comprometerse, por abandonar la causa justa de los oprimidos que mencionaba Martí o Freire, pero que en seminarios y cursos de formación se dice leer y evocar por parte de alguna parte de la masa del magisterio, ha negado el rescate de la realidad, ha negado la difusión mínima de alternativas epistémicas, de prácticas consecuentes. La escuela inmediata que nos ha tocado, y contra la que se resiste y se seguirá resistiendo, a la sazón dista de generar debate. Es más, con los temas actuales se ha mostrado algo obtusa, tiende a no ver más allá de su arrogante postura «objetiva». (Ramírez Angarita, 2017, p. 310

En cuanto a la transversalidad, la carga ideológica y de imaginarios hace fuerte presencia en los currículos de la escuela inmediata; a veces no se puede definir que es más nocivo, un desconocimiento de las sugerencias centrales sobre el tema o la implementación al libre albedrio. En fin, su propio descuido, representa algo más que simple descuido o ausencia de liderazgos. Las pautas curriculares manifiestan una postura que, para el caso de la escuela inmediata, reportan el seguimiento a políticas centrales, cuyo desobedecimiento podría implicar desacato a la norma. Aunque existe lo explícito en materia de autonomía, en ocasiones la inmediatez de los imaginarios e ideas de un colectivo o individualidad, terminan por alimentar las propuestas curriculares. En ocasiones las disertaciones no son epistemológicas sino ideológicas. Eso es un escenario común de la escuela inmediata.

Otra materialización en la escuela inmediata es el antagonismo de clase. La caracterización que se impone a la educación en las clases populares, son consecuencia directa de la relegación estatal que estratifica a su población. La negación de este aspecto es un reconocimiento mismo, pues el afán por desplazar este tipo de situaciones evidentes de la escuela, o el no darle el debido tratamiento, es prueba fehaciente de las tensiones que permanecen en la escuela. No se trata de una lucha física, se trata ahora de la imposición de un modelo pensado por las "cumbres" de la dirigencia que en su totalidad - en tanto totalidad hasta epistémica- imponen formas clasistas de ver al mundo, de interpretarlo y de acondicionarlo (no 
transformarlo) a los acomodos del régimen de cosas. Bajo el manto de una inclusión -que a todas luces es incompleta- se oculta.

Lo clasista logra con éxito ocultarse tras las mediaciones discursivas de la "superación" individual, la financiación escuálida (que alimenta con recursos al sector privado) ${ }^{87}$ bajo el manto de inclusión social y discriminada, y una que otra reforma intencionalmente paliativa. El escalamiento social, del capital social, tal como lo ilustró Bourdieu, da muestra del pulso de la plusvalía ideológica vertida en la cotidianidad (Silva, 2000).

La penetración de estándares desaplicados a la realidad contextual, e infinidad de indicadores derivados de la visión mercantilizada de la educación, muestran la ausencia de consenso, cuando paradójicamente, para el caso del sector público, la masa dependiente del sistema económico es a la que está dirigida la política educativa. En América Latina ha prevalecido -con poquísimas excepciones-, la falta de mecanismos que parten de la misma falta lógica de voluntad idónea para integrar los intereses de esas mismas masas que sostienen al sistema.

La más evidente materialización de lo ideológico es el silencio de la escuela y sus actores frente a los problemas de la realidad social y hasta ambiental local, nacional y global. Se ha creído que participar es un acto de política y, por lo tanto, la escuela debe ser apolítica; craso error, de hecho el simple silencio ya es un acto político permisivo. La escuela debe ser política no proselitista. Alejarse del escenario de decisión, es sumergirse aún más a las profundidades de las intenciones retrogradas del sistema ideológico imperante.

Una acción educativa revolucionaria que avance hacia la puesta en praxis de propuestas alternas emanadas de las referencias sociocríticas podrían ser el inicio con rumbo al desmonte de la ideología al interior de las vivencias de la escuela y con ella al resto de la vida humana, de los contextos donde se desenvuelven los actores de carne y hueso.

\subsubsection{La escuela inmediata como manifestación material de la praxis}

Dialécticamente hablando, la misma escuela inmediata puede ser manifestación material de la praxis. Si la praxis desde la perspectiva marxiana es transformación, en el campo de la educación tiene sentido también de oportunidad. En la escuela inmediata, la praxis es la máxima de las materializaciones; sin embargo, es procesual. En la consecución de asaltar a la escuela con sus relaciones, buscará desmontar lo ideológico con acciones concretas de tipo político tocando los ámbitos epistemológico, pedagógico y administrativo. Una filosofía de la educación sociocrítica ha de estar en alianza con la filosofía de la praxis tal como se concibe siguiendo las categorías marxianas.

Si la educación es una praxis, entonces resulta más adecuado trabajar desde la perspectiva de la filosofía de la praxis que desarrollar una filosofía de la educación de signo prescriptivo que se funde en fines abstractos desligados de las necesidades sociales. Conviene, sin embargo, tener presente que, si bien es cierto que hacer filosofía de la praxis es desarrollar una práctica, se trata de una actividad "que de por sí no es praxis". Esto es así porque la filosofía es una actividad que no transforma objetivamente el mundo, sino que para influir en la transformación necesita insertarse en una praxis. (Yurén, 2009, p. 248)

${ }^{87}$ El caso colombiano del programa oficial del MEN denominado "Ser pilo paga" (2013-2015), donde si bien hubo apertura a financiación a la educación superior, la mayor oferta era del sector privado. Hubo muchos casos donde los estudiantes fueron avocados a endeudarse para responder con las obligaciones económicas frente a los entes bancarios o establecimientos educativos. 
Si la escuela inmediata se nos presenta como realidad social y política es porque detrás de ella hay unas relaciones socioeconómicas y un enfoque epistémico interesado. Ese todo social afecta a la humanidad de los individuos traspasándose a las comunidades que a su vez conforman un todo social. Por ello, hay que tratarla con la delicadeza teórica y metodológica del caso siempre con miras a darle la otra lectura: la de posibilidad.

La materialización de la praxis en la escuela inmediata se da en los resultados concretos que brinde la misma posibilidad en tanto tal. Resultados pensados y accionados de la mano de la no-inmediatez. Ahora, sin la crítica y la observación del comportamiento de la escuela inmediata, no habría oportunidad. Esta praxis deberá presentarse en la institucionalidad pública pero también -aunque más difícil por su naturaleza- en el privado.

El sector público, el de más cobertura en países como Colombia, pero aun obediente al establecimiento ideológico, está llamado a liderar los procesos de transformación praxiológica. No siendo así, surgen varios interrogantes: “¿de qué sirve el sistema educativo, más aún el público, si no es para luchar contra la alienación? ¿Para contribuir a descifrar los enigmas del mundo, especialmente, el extrañamiento respecto de un mundo producido por los propios hombres?” (en, Prefacio de Roberto Leher, en Mészáros, 2008, p. 11).

Ahora bien, para la escuela inmediata los componentes humanos y sus relaciones son centro de interés, pues a partir de ellos se filtra todo el contenido externo que impacta en ella. Es así que docente, currículo y alumno mirados en su materialidad histórica, podrían ser el comienzo del desmonte ideológico al que ha estado sometida la educación de base, lo cual permita asumir los retos de a educación a nivel local para sumar al nacional como recomienda Vasco en 2006.

Por el lado del ente docente y administrativo, la praxis se materializa cuando estos se convierten conscientemente en sujetos de cambio dentro de la escuela inmediata. Han de pasar a ser instrumento de acción política de un lado (Gutiérrez, 2005), dejando de ser agente de la ideología; si no se forma en ciencia y praxis, seguirán siendo transmisores útiles de reacción ideológica como lo acota Silva (1979). El educador no como ideólogo sino como actor, como científico social, es otro de los asuntos centrales para, a través de la praxis, desde la escuela inmediata, combatir las avasallantes acciones contradictoras de la ideología.

Con razón Marx (1845) en su tercera tesis, invita a la formación del educador; formándose en teoría y práctica, el docente avanzará a las materializaciones de la praxis, pero como ente solidario y con acciones conjuntas. Por ello, el mismo Freire (1982) con su pedagogía de la esperanza se hace partícipe de la máxima junto a Gramsci (2007a, 2007b), sobre el papel de transformación mediante el estudio propio y la formación constante. Si bien el docente está llamado a ser líder, su posición no debe ser autocrática, no deberá abandonar su posibilidad de relación cercana con sus educandos, pues conociendo sus necesidades de todo tipo, logrará internarse en las contradicciones del sistema de cosas que atropella a los sujetos de la educación. En otros términos, el educador tiene mucho que compartir y aprender de sus estudiantes; si esta relación no se da, no podemos hablar de praxis desde la perspectiva marxiana. Dar importancia a "una práctica educativa en la cual el educador es a su vez educado por "el educando" y viceversa" tal cual lo expresa Buenfil Burgos (1991, p. 191), mostrará el sentido praxiado dentro de la escuela inmediata.

Retomando lo concerniente a la filosofía de la praxis, fuente teórica para el desmonte ideológico, Sánchez Vásquez (1977), nos recomienda tener al día que:

Reducir la filosofía de la praxis a una filosofía del objeto (sobre la praxis); es seguir encerrándola en el marco de una filosofía de la interpretación del mundo. En ambos casos se olvida lo que define, en última instancia, su novedad como nueva práctica de la filosofía: su relación necesaria y racional con 
la praxis al insertarse en ella y cumplir la función práctica que hace de la filosofía de la praxis la filosofía de la revolución. (P. 68)

Y si la filosofía de la praxis está comprometida con la revolución mental, así también vista para la educación podría acompañar los procesos de una revolución académica y administrativa aún en mora en esta parte del mundo.

Cuando se toca el término de revolución, es de la conciencia, pero no de una consciencia abstracta, objetiva y menos acrítica. La revolución, acá no está relacionada -desde una apuesta filosófica- con las armas, excepto las armas de la crítica que ya reseñaba dialécticamente el propio Marx $(2012 \mathrm{c})^{88}$. Esta aseveración, aunque pareciera insistente, nunca estará de más, es una puntuación más que defensiva pues, la realidad histórica ha enseñado que los sectores reaccionarios en todos sus niveles no dejan de difamar las posturas contrarias a sus intereses. La revolución ha de ser una revolución de conciencias, pero acá han de estar comprometidas las voluntades de los sujetos inmersos en el acontecer de la escuela inmediata.

La revolución educativa no es únicamente una revolución de conciencias en el sentido romántico o discursivo, debe ser una revolución de conciencia material, de acciones al interior de la escuela. En Freire es a través de la práctica y no con cursos ni discursos como se debe desenvolver la escuela (Gutiérrez, 2002). "Para Marx en quien la práctica era el criterio último del conocimiento, resultaba indispensable comunicarse prácticamente con el público, ser entendido hasta la raíz a fin de poder influir prácticamente en la tarea de Veränderung o transformación subversiva del mundo” (Silva, 2011, p. 33).

La praxis -en su concepción integral- deberá salir de la escuela inmediata hacia la población, hacia la comunidad, para ello en necesaria la aplicación de prácticas que integren lo cotidiano como construcción de las fuerzas y de ahí, la denuncia a las inconsistencias, a las contradicciones del sistema socioeconómico imperante. De lo que se trata es de relacionar en las aulas la conciencia y vida cotidiana (Gandler, 2010). Así la praxis no será otra cosa que la combinación de elementos teóricos y prácticos para interpretar y transformar realidades; entre estos estarán la búsqueda de la historia crítica desde todas las áreas y los temas de actualidad local, nacional, regional y mundial.

Que las bases transiten por una educación pertinente, abierta y bajo condiciones favorables, no es saludable para los Estados alienadores. Por ello, mientras lo cotidiano sea más distractor, así serán los beneficios de plusvalía ideológica para el sistema. Cuanto más se deprede entre sí el pueblo, cuanto más se haga daño entre sí, se robe y asesine entre sí -por ejemplo-, más habrá pretextos para hacer de los modelos educativos que defienden la competencia y la "escalera social", una excelente fórmula de sometimiento. De aquí que pueda apostarse a la conciencia colectiva como iniciadora de transformación, esa es la esperanza material de la que habla Freire (1982).

La escuela inmediata, leída dialécticamente, respetando la postura que tuvo Suchodolski (1977) sobre la "educación marxista" y de su preparación para un futuro socialista ${ }^{89}$ en su momento histórico; se manifiesta

88 "Es cierto que el arma de la crítica no puede sustituir a la crítica de las armas, que el poder material tiene que derrocarse por medio del poder material, pero también la teoría se convierte en poder material tan pronto como se apodera de las masas." (Marx, 2012c, en Fromm, 2002, p. 230)

${ }^{89}$ En la pedagogía burguesa la educación tiene un carácter apologético respecto del orden existente y no prepara a la juventud para un nuevo futuro. Según las concepciones de los utópicos la educación para el futuro impide cualquier vínculo con las condiciones actuales. La concepción marxista, por el contrario, expresa cómo se debe organizar el conjunto de la enseñanza que prepara ya en la actualidad capitalista el futuro socialista. (Suchodolski, 1977, p. 137) 
de otra manera en el presente, para ese porvenir que no puede pedirse sea socialista en sentido estricto, pero si más social. De todas maneras, la versión marxiana de la praxis brinda herramientas que no deben ser ideologizadas.

El válido comentario del mexicano Sánchez Vásquez (1997) quien brinda una perspectiva holística muy acertada sobre la diferencia y cercanía entre práctica y praxis, coadyuva a definir a la práctica como cercana a la visión inmediata sin necesariamente ser inmediatez. No así la praxis, cuya radicalidad no reposa en asuntos inmediatos, sino que es ambiciosa en el sentido de divisar el horizonte de la educación, se prolonga porque sabe que los problemas son consecuencias de la prolongación de situaciones de negación social y política que encubren lo económico, lo de base.

Si la praxis es histórica, es por ende dinámica. Si es dinámica cada vez que se replantea se convierte en oportunidad para que en la escuela inmediata sea conocida la frontera entre práctica y praxis. Entre la mecanización y la conciencia se debaten los actores de la escuela inmediata; pareciera que no fuera suficiente con la crisis por la que atraviesan los modelos impuestos que parten de la confusión entre los extremos del tradicionalismo y la versión educativa de un "laissez-faire" educacional cuya intencionalidad ideológica raya con las pretensiones de ser libertarias. Las versiones que se autoproclaman "alternativas" son de cuidado, podría ser un lote más de producción del sistema de cosas como lo fue en su tiempo la filosofía aparentada que enfrentó Marx.

Entonces, sabiendo cómo se presenta en la materialidad escolar la praxis, en esa escuela inmediata que está a merced de la inmediatez producida por la ideología y sometida a las fuerzas concretas del sistema de cosas. Pasemos a mirar como en el actor docente y el factor currículo, en tanto son dos grandes pilares del acontecer educativo -que al fin y al cabo perfilan a la escuela inmediata-, se manifiestan de manera dialéctica la inmediatez al tiempo que materialidades como oportunidades de transformaciones reales.

Definitivamente, la escuela praxiada, es contraria a la escuela regida por los dictámenes del capital que le ordena el desplazamiento del ser humano como fin último y constructor propio de su felicidad y de su disfrute en este mundo material. La praxiada se construye para alcanzar los caminos de transformación socio-históricos en la formación integral; es emancipadora. La otra, sigue siendo ideologizada, monopolizadora y altamente ideologizada. 


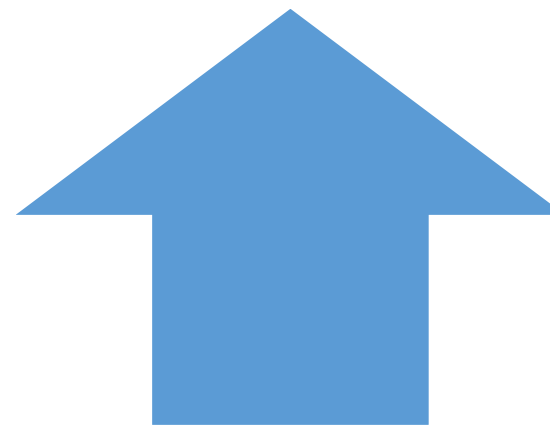

\section{ESCUELA EMANCIPADORA: PRAXIADA}

-crítica y alternativa

-de base-necesidades no solo inmediatas

-desmonte de la alienación

-reconocimiento de la enajenación para propuesta

-docente líder, estudiantes transformadores y currículos emancipadores

-lo comunitario - participativo

-mediación-no mediación

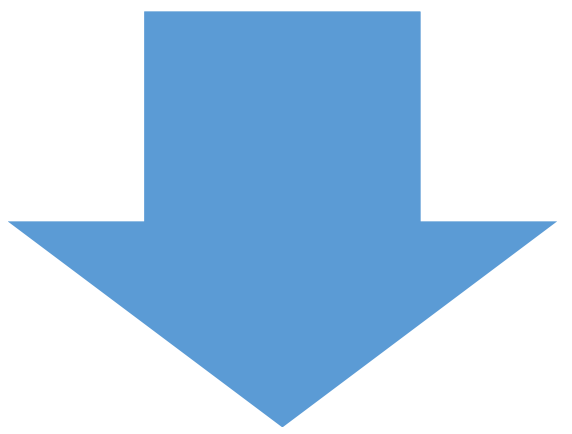

\section{ESCUELA CAPITALISTA ACTUAL: IDEOLOGIZADA}

-retazos de traidcionalismos y apariencias de nuevas perspectivas

-economicista-mercancía

-relación de cúpula tecno-burocrática

-confusión de liderazgos

-posturas teóricas impositivas y reduccionistas

-lo individualista-representativo

-permisividad

Gráfico No. 11. Comparación entre las dos concepciones generales de escuela. Una tradicional capitalista, que ahora se ha enfocado al consumismo extremo y al desentendimiento sobre los reales problemas individuales y colectivos; es vertical, con orientaciones de cúpulas. La otra, la alternativa, de carácter socio-histórico, rigurosa y con una visión socil del conocimiento; es horizontal, emanada de la voluntad comunal.

\subsection{Dos materialidades: el actor docente y el factor currículo}

Como se ha insistido, una filosofía de la educación con la aportación marxiana sobre ideología y praxis, conseguirá constituir una visión distinta al acercarse a las materialidades concretas que actúan en la escuela inmediata como amenazas presentes, también como oportunidades sociales.

Para seguir la secuencia teórica, ahora aplicada a dos materialidades concretas de la escuela inmediata, tendremos en cuanta dos: la del cuerpo docente por cuanto es materialidad humana ceñida a su contexto, a las características que derivan de su voluntad y de su historicidad, de sus intereses y de sus grados compromiso social. A la par, estará la visión de currículo que materializa -en teoría- las prácticas inmediatas y prolongadas; el currículo como resultado humano y de intereses internos y externos es susceptible de manipulación, en contraste de oportunidad.

De un lado, el análisis y la crítica a la escuela inmediata, tienen al cuerpo docente como principal materialidad humana, no es el centro de los procesos de enseñanza-aprendizaje, sino el centro de interés por cuanto en su humanidad social, se descarga la responsabilidad civil de prestar la labor de formar, de educar o de instruir. En la visión capitalista de la educación, el docente es relegado a terceros planos, pues sabe que un cuerpo docente formado podría ser un gran bache en la armonía del sistema de cosas.

El sector docente es el principal actor que puede comenzar una actitud praxiológica en el seno de la escuela, en sus diferentes niveles, el cual podría aportar positivamente cuando se apersona de su papel histórico. 
Pero para ellos, debe existir una formación en ciencia y en crítica social, que puedan ofrecer la capacidad de desarrollar herramientas críticas y proponentes. Un docente pasivo o cuya actitud haya sido permeada profundamente por el sistema de cosas, es un actor que debe revisarse así mismo en su conciencia de protagonismo. Existe un aporte marxiano específico, que puede coadyuvar teórica y muy sencillamente al sector docente a identificarse en fuerza de cambio, en desmonte de lo ideológico, relacionando práctica y cotidianidad.

De otro lado, "el currículo es un concepto de uso relativamente reciente entre nosotros con la acepción que tiene en otros contextos culturales y pedagógicos en los que cuenta con una mayoría tradicional" decía Sacristán en 1994 (P. 13). A pesar de esta visión, de un experto, en habla hispana -en su momento-, los estudios del currículo y las relaciones de éste con su alrededor, fue muy trabajado por la sociología de la educación. La filosofía de la educación avanza en las reflexiones de este componente en el sentido de la educación, en su impacto individual y social, con lo marxiano el horizonte de comprensión se abre mucho más, se mira holísticamente cosa que lo hace escurridizo a la hora de especificar.

El currículo como también los programas de estudio, en su nicho inmediatista, se erigen en elementos de transposición ideológica al interior de los sistemas educativos (Morales Zuñiga, 2009). En consecuencia, al ser elemento estructural de la educación material, el currículo es de lo más contradictor que puede haber. El ejercicio dialéctico ayudará a explorar generalidades que, desde la criticidad lograrán distinguir los efectos de la ideología, al tiempo que aquellas propuestas delineadoras de oportunidades para que la educación señale la vereda del cambio concreto de relaciones.

\subsubsection{El docente entre lo inmediato y lo práxico}

Existen variadas críticas a la profesión docente, que van desde aquellas sobre su rol académico-pedagógico hasta su nueva idea de "cuidador" de niños y adolescentes, de jóvenes y hasta adultos. El docente quien nada en el mar de las dificultades y los contextos, que se relaciona con lo inmediato y en ocasiones se llena de inmediatez, puede también liberarse cuando adquiere un sentido comprometido asumiendo su rol de orientador, de liberador para que las personas a su cargo puedan transitar con herramientas en la mortalidad del mundo, llegando a las conclusiones que verifiquen si es necesaria o no una transformación social de su entorno.

Un docente inmediato que se encierra en su visión de inmediatez será un docente característico de la escuela inmediata institucionalizada. Hay que decir, la formación docente presenta muchas falencias, se reservan las realidades para dar paso a la teorización sobre corrientes de la pedagogía muchas veces foráneos. La delicada situación de distancia entre formación docente y criticidad rigurosa, sumada a la presión del sistema de cosas sobre la mentalidad de estos, aumentan el riesgo de ser sostenedores del sistema sin darse cuenta de ello.

Por el contrario, en la escuela inmediata también se podrá presentar el docente no inmediatista, aquel que tomará su sentido social como un asunto de política, resistiendo en práctica, sustentado en teoría, contra las acciones influyentes del sistema; su labor podrá demostrar que en ocasiones la conciencia de lo social puede transformar lo micro, las realidades. De todas maneras, el antagonismo no se hará esperar pues, cuando los intereses chocan al interior de la escuela, no lo hacen individuos sino construcciones culturales con arraigos que podrán develar la ideología o la conciencia. 
Aquello trastoca al cuerpo docente, como lo señala Morales Zuñiga (2009), cuando se refiere a la impregnación ideológica consciente o no consciente que convierte en una clase de "vector" a quien debería tomar la senda del reconocimiento del papel propositivo y político en la educación en vez de seguir consolidando el satu quo.

En las últimas décadas se ha desplazado al docente a un segundo plano sobre todo en visiones pedagógicas que buscan innovarse, a veces tratando de imponerse como modas de "avanzada". Se olvida que el docente es esencial en los procesos. Si bien el final es hacer de los educandos unos sujetos libres, solidarios y proponentes desde una postura marxiana; para esto el papel del educador es vital más que central para una educación crítica de alto compromiso político.

Además, recuérdese que el docente es un actor más del sistema de mercado hoy. Él ofrece su fuerza, su capacidad, total. Su trabajo, ya sea en el sector público estatal, ya sea en el sector privado en cualquier nivel. Es tratado como mercancía bajo el sistema de mercado, así también es visto como administrador de clases. En el terreno de lo ideológico, es visto como sostenedor o como crítico del estado de cosas imperante. En fin, el cuerpo docente es un actor más del engranaje de producción. Por tanto, es un sujeto sometido a los dictámenes de la enajenación y la alienación. El cuerpo docente conoce, mejor que el educando, lo que es el cotidiano; lo que no puede conocer o quiera desconocer, es toda la trama social detrás del acontecimiento educativo.

El docente no puede negar la existencia de las brechas de clase dentro de los contextos donde ejerce su labor. Él ha de reconocer las variaciones a nivel cercano de la división de clases y aquellas que se dan a nivel nacional. La filosofía de la educación con ingrediente materialista que parta de lo marxiano habrá de ser entendida en su función social sin perjuicio de una comprensión histórica de la formación de las clases, sin generar tampoco odios infundados sino de despertar conciencias para identificarse y comprometer a los educandos en su papel histórico-social. Suchodolsky por allá en 1977, compartió algo interesante que todavía puede tenerse en cuenta:

La teoría materialista dirige la atención del educador a los problemas de la situación material de clases de los hombres en la práctica y en la teoría, a los problemas de su trabajo productivo y a los procesos de la formación de sus representaciones y concepciones de la vida diaria real. (P. 185)

El docente praxiado debe ser más que práctico en el sentido tradicional (utilitarista) del término. La práctica desde lo marxiano, cuando Marx la toca en esos términos, es una relación con la vida social del hombre con otros semejantes a través, por ejemplo, del trabajo. Marx quita el carácter moralista e individualista de lo que se denomina práctica. La práctica tendrá un sentido filosófico y dialéctico en la obra de Marx. Para Marx, la humanidad tendrá que pasar al estado de conciencia de la praxis y ésta, a su vez, generará conciencia, pero para eso habrá de aprovecharse los contextos y construir los nuevos rumbos de liberación.

No debe confundirse, la propuesta no es que el docente sea marxista, eso sería ideología (siguiendo a Silva), se trata es de acercarse a lo marxiano como a todo lo que francamente aporte hacia la transformación de la escuela inmediata que él mismo vive y sufre, que enfrenta y buscará superar.

Toda praxis pedagógica requiere un método concreto, dialógico y comprometedor. Concreto, es decir, que debe partir de la realidad y no puede darse en el vacío. Cada aquí y ahora, cada situación concreta, cada acción vivida, tienen que ser el arranque y el sostén del "momento reflexivo" de la praxis. (Gutiérrez, 2005, p. 154) 
El aquí y el ahora, es una emergencia, pero no espontánea per se, es una emergencia histórica, pues las situaciones que ocurren alrededor no son espontáneas, son productos de toda una serie de fuerzas materiales, las cuales han de ser observadas en la escuela del cotidiano. Con esto se confirma que devienen de las influencias materiales del orden económico y social. Por ello, todavía es vigente decir que:

Los educadores no deben imaginarse que pueden establecer arbitrariamente los ideales educativos. Deben comprender que su actividad depende, principalmente en las etapas de desarrollo social determinadas, de las relaciones materiales predominantes. No se encuentran nunca con un "niño en sí", sino con un niño de una clase determinada, con un niño que crece bajos determinadas relaciones sociales. (Suchodolsky, 1977, p. 36)

En consecuencia, tratemos el depender económicamente de un salario, para el caso docente. La alienación también llega al magisterio, pues cuando esta profesión se convierte en un medio para su existencia -la del sujeto mismo-, y se es consciente de esto y solo de esto, ya se está convirtiendo en una esencia dicha posición sobre la vocación, esto lo podemos ver desde los Manuscritos marxianos (Marx, 2012a). Entonces, se hace parte del grupo que sufre la enajenación; la cosa empeora cuando asumida dicha condición no se busca superarla o por lo menos contrarrestarla en lo cotidiano, asumiendo una postura sumisa y autómata.

Esto último lo ubica en la clase trabajadora. Como parte de una comunidad, de una actividad social de alto impacto, este componente se desenvuelve en el cotidiano de la escuela, aunque a veces olvida la importancia que debe darle a ese mismo cotidiano relacionándolo con la totalidad social. Sin embargo, muy a parte de entrar en una discusión sobre una supuesta revisión de la división del trabajo, el sector magisterial tiene una gran responsabilidad, pues no transforma materia inerte, sino que comparte su tiempo, sus fuerzas vitales, literalmente su salud y su vida con otros seres humanos que están en formación, sobre todo en los niveles de educación básica; está sometido a todo tipo de presiones, alegrías, decepciones, tramas personales y de colegaje, persecuciones y hasta riesgos a su integridad física y el de sus propios seres queridos, etc. esto los hace especiales, merecedores por antonomasia de toda atención pero también ser más reflexivos de su protagonismo así no quieran las individualidades reconocerlo. El no reconocimiento sostiene la negatividad.

Marx acude a una situación de la escuela para explicar el tema de la ganancia, de la enajenación laboral; nos da una ilustración de su época que no varía en pleno siglo XXI:

Si se nos permite ofrecer un ejemplo al margen de la esfera de la producción material, digamos que un maestro de escuela, por ejemplo, es un trabajador productivo cuando, además de cultivar las cabezas infantiles, se mata trabajando para enriquecer al empresario. Que este último haya invertido su capital en una fábrica de enseñanza en vez de hacerlo en una fábrica de embutidos, no altera en nada la relación. (Marx, 1975, p. 616)

A la verdad, esa situación en el sector del magisterio poco o nada ha variado en los países de América Latina dominados por las oligarquías y las directrices del mercado. El caso si bien puede verse expresamente en el sector privado, también aplica a los maestros adscritos al régimen público, pues allí no es al empresario directamente hablando al que se le da el plusvalor; es al Estado el cual de todas maneras opera bajo las órdenes de los sectores políticos y económicos que han gobernado durante más de doscientos años la vida de estos países; exiguas son las excepciones. La ganancia también se da en el campo ideológico, la plusvalía ideológica de la que habla Silva (2011b), hace presencia activa y reactiva en el teatro escolar. 
Consecuente para un docente que tenga voluntad de construir la transformación, es el Marx (1978) de la tercera tesis, quien se opone a los sistemas alienados de formación. Además del señalamiento -que puede leerse en clave dialéctica- sobre que el educador debe ser educado. Así plasma esta tercera postura:

3. Die materialistische Lehre von der Veränderung der Umstände und der Erziehung vergißt, daß die Umstände von den Menschen verändert und der Erzieher selbst erzogen werden muß. Sie muß daher die Gesellschaft in zwei Teile - von denen der eine über ihr erhaben ist - sondieren.

Das Zusammenfallen des Ändern[s] der Umstände und der menschlichen Tätigkeit oder Selbstveränderung kann nur als revolutionäre Praxis gefaßt und rationell verstanden werden. ${ }^{90}$ (Párr. 3-4)

El educador no solo "debe ser educado" en el sentido actual de hacerlo más eficiente o competitivo sino en el apersonamiento de auto identificarse como orientador de consciencia social. Si bien lo académico es importante, lo urgente consiste en combinar teoría y práctica en los espacios y saber que se está tratando con seres humanos históricos, únicos y potencialmente activos. Mostrar las herramientas de la crítica debe ser un compromiso social, eso sí, equilibrando dicha acción, pues las intenciones de ideologizar de un lado o del otro, no aportan a la generación praxiológica que tanto necesitan nuestros pueblos. El docente debe ser científico y no ideólogo aplicando el criterio de Silva (2009) al afirmar que, a través de la actitud científica y el enfoque social de no encubrimiento del sistema de cosas podrá darse un cambio material.

Podría entonces pensarse que el solitario hecho de establecer un discurso crítico garantizará la realización de una praxis. No. Deben existir criterios que pongan en la mesa del debate las circunstancias económicas y políticas, que surtan efectos de discusión en las áreas del conocimiento. Descubrir los factores económicos que influyen en los contextos, así como aquellas ideas que impulsan una justificación de un sistema determinado de cosas cuyo basamento es la acumulación material limitada a sectores dominantes, acudiendo a conceptos desmitificados; todo aquello es menester de una actitud comprometida de altísima voluntad de quienes por interés social llegan al estrado de la docencia y no por "escampar" y acomodarse en una cierta posición socio-económica.

Un docente proclive al sentimiento social de emancipación antes que de inyección de conocimientos -los cuales tampoco pueden obviarse- deberá formarse en lo autóctono también. La historia de las propuestas pedagógicas y las políticas educativas realizadas para las divididas sociedades de América Latina, son historias llenas de hegemonía anglofrancesa o germanófila. Las ideas prácticas identificadas como propias han brillado por el descuido, el ocultamiento y el menosprecio de los Estados. Son los casos de Eugenio de Santa Cruz y Espejo con su obra educativa ${ }^{91}$; un Simón Rodríguez de la educación popular y anti propuestas lancasterianas (Rojas, 1990); de un Martí (Ledesma R., 1997) dedicado a los niños, antiimperialista y a la emancipación concreta; de un Ponce (Arpini, 2006), teórico de los efectos de la dominación en la escuela;

\footnotetext{
90 [III] La teoría materialista de que los hombres son producto de las circunstancias y de la educación, y de que por tanto, los hombres modificados son producto de circunstancias distintas y de una educación modificada, olvida que son los hombres, precisamente, los que hacen que cambien las circunstancias y que el propio educador necesita ser educado. Conduce, pues, forzosamente, a la sociedad en dos partes, una de las cuales está por encima de la sociedad (así, por ej., en Robert Owen). La coincidencia de la modificación de las circunstancias y de la actividad humana sólo puede concebirse y entenderse racionalmente como práctica revolucionaria.

91 Véase: Espejo, Eugenio de Santacruz (1982). Obra educativa. Caracas: Biblioteca Ayacucho.
} 
de un Fals Borda (Ocampo López, 2009) con un método salido de las entrañas del sentipensar del pueblo llano; los aportes sobre la liberación de Dussel (2014) o de un Freire (2005) defensor en teoría y práctica del oprimido; todos ellos -y otros anónimos- individuos vivientes, con una actitud crítica pero sobre todo creadora, entre otros, quienes sin duda, llevan en sus recomendaciones elementos tan profundos como los elaborados por el mundo ajenamente desarrollado ${ }^{92}$.

El docente con sentido socio-histórico siempre estará dispuesto en respadar la organización de base, su aporte intelectual, academcio y político es de gran valor. Lo comunal, dentro de la escuela ofrece un espectro positivo, pues trabajar sobre el entorno cercano, permite más cercanía entre las dinámicas escolares, el conocimiento con sentido social como herramienta de liberación y los sujetos políticos transformadores. En contraste con la ideología del subdesarrollo de la que habló Silva (2011 c), está el aprovechamiento de la vida en comunidad. La acción mancomunada de los grupos comunitarios reconocidos en el acontecimiento educativo; es la extensión visible de la praxis.

En los sistemas educativo actuales, un índice de evaluación docente es su impacto con la comunidad; cosa dificial en los paisajes urbanos. Se dice que el docente debe inmiscuirse en la comunidad donde labora, incluirla como suya. También es cierto que han de generarse las circunstancias, las facilidades, -hasta el Estado lo pone dentro de sus criterios como obligación- pero, en la realidad no se facilita dicho acercamiento inmediato.

La praxis será en el educador o no será. Es decir, siendo claro con ese compromiso político que implica la praxis, la formación de los educadores debe darse en una toma de conciencia que parta del análisis de la situación material y de la abstracción práctica de dicha situación. Si el educador no se identifica como sujeto histórico de transformación será un individuo más al servicio del sistema de cosas en cuyas manos será útil.

Al identificarse en sujeto de cambio, en otro actor con poder de orientación dentro del proceso educativo, sin reparos, de mente abierta hacia su propia formación, hacia el reconocimiento del dinamismo; el docente será líder de una etapa de emancipación real dentro de la escuela-comunidad. Para ello, ha de reinventarse un rescate por la dignidad docente y una mejora del escenario inmediato que conlleve a la adecuación de espacios facilitadores para acercar a los actores estudiantiles o educandos a la vivencia de un desmonte de la alienación desde la práctica educativa que, siendo así, ya se convierte en praxis.

Al proponerse el desmonte de la ideología, junto a todo lo que implica su influencia o condiciones generadoras de la misma, ya se asume el papel político (no proselitista) del educador. Dicho desmonte puede darse mediante la lectura crítica de la realidad sin importar el área de conocimiento que se imparte o para la cual se está preparado académica e intelectualmente. Dándose una praxis política en educación y desde la educación, puede generarse la concreción de posturas muy propias del cotidiano que, sin dejar de lado el trabajo de otros tratados sobre educación, reivindicativos, auténticos, dignos de ser explorados y difundidos para que sean dinamizados. Así podría darse lo que Carucí (2009) resume cuando trata de la educación como praxis política, cuando trata de socializar su transformación constante, su resurgir como pedagogía crítica.

${ }^{92}$ Pues su desarrollo ha dependido de la explotación de los recursos y de otros pueblos. 
Obsérvese un apunte que integra varios elementos, pero que tocan en definitiva al docente. Por ejemplo, el estudioso de la praxis, el mexicano Sánchez Vásquez (1999) estudia con el marxismo, la importancia de dinamizar las categorías y ajustarlas a las coyunturas y no lo contrario. Para él, "los maestros, investigadores y estudiantes constituyen un grupo ligado a la intelectualidad orgánica, es decir, al bloque ideológico opuesto al bloque hegemónico capitalista” (Arriarán Cuéllar, 2014, p. 145).

El cuerpo docente praxiado ha de avanzar de la interpretación de su escuela inmediata a la transformación de la misma. Volviendo al tratado de las tesis marxianas, la onceava es el culmen general marxiano sobre la praxis. La práctica crítica, la cual es práctica revolucionaria, deja ver desde tiempos tempranos la intención investigadora de Karl Marx (Engels, 1986). Diciendo: "Die Philosophen haben die Welt nur verschieden interpretiert, es kömmt drauf an, sie zu verändern" ${ }^{93}$ (Marx, 1854; 1978), Marx invita a retraer el marco teórico sobre la importancia de la práctica, a establecer en toda su obra este faro, para que las embarcaciones que transportan la propuesta práctica lleguen a puerto seguro e internarse tierra adentro.

A propósito, Sánchez Vásquez en su pedagogía de la praxis advertía que, Kemmis lo mismo Carr, critican la formación teoricista de los docentes, más no llegan a comprometerse mucho con la transformación política y social (Fernández Enguita, 1985). En cambio, los docentes praxiados, estarán apersonados de su papel protagónico, histórico, proponente y comprometido, en teoría y práctica social.

¿Y la formación de educadores? Las escuelas de formación de docentes, por obvias razones, prefieren estudiar posturas más líquidas sobre la educación y la práctica, ayer como hoy, o sobre índices y mercadeo, que sobre transformación ya que esta última es vista como algo lejano, utópico y en ocasiones hasta subversiva y, en el mejor de los casos: anacrónica. La proyección social se limita a requerimientos formales que no sobrepasan los formatos de evidencia automatizada.

El docente inmediato pierde su identidad cuando no propone estrategias, cuando no asume su papel político, alejándose de la realidad inmediata; sólo vive en la queja, pero a la hora de resolver no lo contempla siquiera. El docente inmediatista no se prepara para resistir los embates del sistema, cree que sí se muestra complaciente en las situaciones comprometedoras de la escuela inmediata, está cumpliendo lo mínimos; confunde laxitud con permisividad, y así sostiene esas lógicas.

El docente inmediato será alienado y enajenado laboralmente; estará a merced de la ideología. Por su parte, el docente gestor de cambios concretos, el praxiado, al reconocerse a sí mismo como sujeto histórico desmontará la alienación y, aunque le será difícil no estar enajenado por el sistema económico -en países extremadamente dependientes de la visión mercantil de la vida- ya que subsiste de un salario -sea en lo privado, sea en lo público- no bajará la cabeza para insistir en un cambio de cosas que favorezca una justicia social que podrá iniciarse en la misma escuela inmediata.

93 [XI] Los filósofos no han hecho más que interpretar de diversos modos el mundo, pero de lo que se trata es de transformarlo. Trad. Progreso, 1969. 


\subsubsection{Las manifestaciones ideológicas del currículo: entre lo evidente y lo oculto}

Para el caso del currículo, si se toma en cuenta la manera de ver a la educación como un vehículo de la ideología, hay que advertir que también es objeto de estudio de la propuesta crítica. De hecho, es una de las temáticas más tardías en desarrollarse por las mismas dinámicas de aparición. Esto puede dar fe de la inmarcesible vigencia de las armas de la crítica que ofrece lo marxiano para el abordaje de cualquier fenómeno o cosa que influya de alguna manera en los procesos educativos o de formación humana

Históricamente, es el elemento más manipulado a niveles macro y micro; Magendzo y Donoso (1992) reconocieron los grados ideológicos de los diferentes autores de renombre a la hora de meterse en la teorización curricular. Sobre currículo existe todo un océano de indicaciones teóricas y metodológicas, expertos y críticos, en algunos momentos se pone de moda, más no se trata de modas, solo que es tan constante mientras existan las formas de formar o educar o incluso de instruir, pues lo curricular es columna vertebral para cualquier organización que quiera dársele a un proceso institucionalizado.

Desde las funcionalistas hasta las sociocríticas de Mc Laren o Giroux pasando por las más recalcitrantes de corte religioso-conservador que apuntan a la mística de familia, propiedad y tradición. Es de conocimiento que, el currículo se manipula conforme a necesidades ideológicas, que, en últimas, obedece a los dictámenes económicos, por tanto la enajenación del currículo garantiza su prolongación alienante.

El currículo tampoco es una idea abstracta. No debe ser visto como un absoluto; el mismo es producto de la materialidad humana. No es una providencia la que lo produce. El problema es cuando éste no es pensado desde los mínimos de las necesidades. La postura neutral clásica, nos dice que:

Cuando definimos el currículum, estamos descubriendo la concreción de las funciones de la propia escuela y la forma particular de enfocarlas en un momento histórico y social determinado. Con ello se enfatiza la idea de currículo como desarrollo centrado en la educación que busca entender la problemática del conocimiento y la actividad educativa en relación directa con las necesidades de los contextos sociales y los momentos históricos específicos. (Sacristán, 1994, p. 16)

Lo inmediato se apodera del currículo mediante la inmediatez ya sea institucionalizada o individual. Materialmente se manifiesta cuando hay "ajustes" o en el caso de la aparición de nuevas tecnologías, surgen con ello replanteamientos en todos los elementos que se relacionan con el acontecimiento educativo. Para los países de la periferia, las pautas que llegan del exterior son tomadas como receta, en muchas ocasiones sin ser siquiera revisadas a profundidad. No obstante, estar actualizado no significa renunciar a la criticidad hacia el orden establecido y las fuentes que originan dicho orden. Lo primordial, parece es incentivar el consumo de tecnología, mas no su producción material, mucho menos la humanización del fenómeno tecnológico.

El currículo es el principal elemento que, por su naturaleza y definición, se le inyectan las indicaciones de una forma de poder determinada. Los expertos, operan como "elegidos" - esto recuerda la intencionalidad de la división clásica del trabajo marxiano que no desecha la versión hegeliana-, delinean toda una arquitectura oficial no sin introducir algunos retoques distintos pero que no se acentúen mucho; este último proceder es apenas lógico desde una concepción marxiana. Aparecen los ideólogos del currículo quienes se encubren tras la argumentación de ser los especialistas que necesitan los nuevos tiempos.

Aunque existe la idea objetiva de currículo, esta no se materializa, pues, la escuela como aparato ideológico de un Estado (Althusser, 2003), necesita legitimarse a través del currículo, que siempre llevará el mensaje de la visión del Estado. Universalmente el concepto de currículo es aceptado de manera objetiva, cuando 
en verdad se quiere tomar desde una neutralidad enmascarada a la hora de observar la práctica inmediata. Enciclopédicamente puede decirse que:

El currículo es uno de los más importantes instrumentos de construcción y difusión pública del sentido de la educación escolar pues en él se expresa qué se espera que aprendan los niños y jóvenes en las escuelas y los medios y condiciones que deben garantizarse para el logro de esos aprendizajes. (UNESCO, 2004, p.7)

De la anterior definición neutral, muy congruente con lo que significa tajantemente qué es currículo, quedan las cuestiones sobre que es lo que prima en cada sociedad dominada por formas de gobiernos que -en su mayoría para los países periféricos- se sustentan en su modelo económico y mismamente, obedecen a ciegas a intereses de las potencias con su sistema de consumismo acelerado.

Desde la investigación-acción sobre el curriculum, Kemmis en 1993, dilucidó que "desde esta perspectiva, gran parte del trabajo de la teoría crítica sobre currículum consiste en analizar los procesos mediante los que nuestra sociedad y nuestros puntos de vista sobre ella se han formado" (P. 113).

Generalmente, la oficialidad estatal mediante sus ministerios, determinan que el currículo es declarado autónomo e invita a la autonomía, pero la intención es otra, lo mismo sus efectos. Ésa es la intención de una idea real de currículo. Hay un fenómeno que a primera vista parecería una contradicción y es, la declaración de autonomía que, en ocasiones se plantea en las indicaciones reglamentarias de la educación, pero no queda clara. Dicha autonomía, mal entendida, podría ser esa estratagema para disfrazar el descuido del sistema gubernamental, pero no es así; un Estado de corte neoliberal-dependiente no actúa con inconciencia de sus políticas.

Sobre la perspectiva social del currículo, puede observarse lo que comenta Bernstein (1993) sobre la negatividad de la transmisión cultural, o en la invitación hecha por Gimeno Sacristán (1994) cuando dice que:

Las formas a través de las cuales la sociedad seleccionada, clasifica, distribuye, transmite y evalúa el conocimiento educativo considerado público refleja la distribución del poder y de los principales de control social. El currículum define los que se considera el conocimiento valido, las normas pedagógicas, lo que se pondera como la transmisión válida del mismo y la evaluación define lo que se toma como realización válida del mismo conocimiento. (P. 21)

Y es que la existencia de un doble discurso sobre currículo, ya genera por si solo desconfianza cuando hay acercamiento al fundamento en el que se basan. No se sabría definir si es una ventaja o lo contrario, puesto que cuando se encuentra en la práctica un desconocimiento social de este elemento.

Si se toman literalmente los fines expuestos por la clásica teoría tecnicista que nos define Kemmis (1993) en lo referente al currículo, tal exposición tiene sentido, parte de una realidad que se supone conocida pero que no es así pues es solo la apariencia. La apariencia sale a flote por la simple búsqueda de aplicación de metodologías y hasta contenidos fuera del orbe regional propio, pues el único fin es obedecer a las tendencias económicas globales. Antes era la instrucción en artes y oficios, luego la industrialización parcial, que fuera pausada por la especialización en explotación de materia prima todo con la concepción de la mano de obra tecnificada. Ahora, prepara individuos para el consumo y una manipulada ciudadanía mundial de otro tipo con intereses.

Otro punto es el currículo oculto y su doble lectura. En el campo de la preocupación por la ideología y su carga en la educación, está la teoría del currículo oculto. Esta realidad contiene cosas interesantes que han 
de ser leídas en clave dialéctica. Esta teoría también ha sido susceptible de interpretación contradictoria en la medida en que propone la observación en un solo sentido.

De nuevo está el tema del currículo oculto, cuyas dificultades de estudio son evidentes por su misma naturaleza (Torres, 1996). Sin embargo, como fenómeno humano es social, y por ende existente, manifestándose en los hechos. Quizás no haya algo más dialéctico que el mismo curriculum oculto. No es secreto que esta acepción carece de identificación como problema (ya sea de ventaja o no para una propuesta crítica) dentro de la cotidianidad escolar. Algunas veces parecería que es algo innato, algo que debería verse desde el psicologismo y hasta desde la filosofía primera. Con esto solo se logra seguir ocultando al currículo oculto.

La sacralización de los contenidos, la de la autoridad que los imparte, la negación de la libertad y de la singularidad del sujeto que aprende, la carencia de democracia escolar, han conformado con excesiva frecuencia una pedagogía autoritaria que ha producido efectos de currículum oculto claramente negativos. La apuesta utópica ilustrada tiene que ser compatible con los valores de democracia, de libertad y de respeto a los derechos de quienes aprenden y a las condiciones para que esos aprendizajes ocurran de la mejor forma posible. (Gimeno Sacristán, 2000, p. 119)

Algunas experiencias educativas concretas no tuvieron otra forma de resistencia que la aplicación de un currículo oculto en las instituciones de todos los niveles para hacer frente a los dictámenes oficialistas. Son los casos de docentes en El Salvador, Guatemala, los países del Cono Sur y con toda seguridad en varias dosis en países bajo el control de las oligarquías.

Fernández Enguita (1985) tocaba el tema del currículum oculto con las herramientas de la sociología. Allí, citando a Marx, dice: “el ser consciente es la expresión consciente del ser real: Marx (P. 237); esto aplica para los casos que dejaron al descubierto su currículo oculto, no sin las consecuencias de represión administrativa, disciplinaria, judicial y hasta extrajudicial. Esta es la forma más manifiesta de lo que hay alrededor de los intentos de hacer de la educación un proceso crítico, de lectura de la realidad y de propuesta; en varios casos hubo martirio. Miremos brevemente un panorama.

El caso colombiano cuenta con la infame particularidad, por ejemplo, de ser perseguida la profesión docente $^{94}$. Si se era crítico o luchador social, pues no solo el Estado estaba ahí "fiscalizando", también los actores armados (paramilitarismo y guerrillas), multinacionales y las mafias del narcotráfico, o las formas de delincuencia común y del microtráfico que veían y siguen viendo al sector docente un enemigo que les arrebata sus "botines" de sus garras. De esta realidad poco se trata.

Volviendo al asunto de abordaje, mirándolo como forma de resistencia contra una propuesta oficial, otorga maneras interesantes de cómo se hace dicha resistencia y cuáles sus fines. Por ejemplo, un currículo oculto puede obedecer a intereses individuales de un docente y no a un interés académico o social. Si un docente es consciente de su alienación y resiste, puede deducirse que su proyección será, precisamente, entre otras, valorar dicha resistencia como lo consigna Giroux (2004).

El fenómeno del currículo oculto, por sus características es el fenómeno más práctico que dilucida los idearios de las individualidades que son a su vez, producto del entorno inmediato. Es la práctica más

\footnotetext{
${ }^{94}$ Según cifras de FECODE, el sindicato colombiano que agrupa a nivel nacional a los docentes públicos, en los últimos 20 años han sido asesinados más de mil profesionales de la educación en circunstancias relacionadas con su labor. El $90 \%$ de estos crímenes permanecen en la impunidad. Se responsabiliza a los actores armados, en su mayoría de fuerzas de utra derecha. Véase: http://hsbnoticias.com/noticias/nacional/999-maestros-asesinados-durante-los-\%C3\%BAltimos-20-a\%C3\%B1os-en-colombia106811
} 
ideologizada que puede darse, o también la existencia de los más destacados recursos de resistencia contra políticas educativas que desprecian el reconocimiento de una realidad material que pudiera ser transformada.

Las reflexiones alrededor del currículo en los espacios escolares de hoy, debe llevarnos al planteamiento de una necesidad de un currículo liberador como también lo comparte Giroux y Penna (1971) pero que sea en aula, desde el aula y para el aula. El punto de quiebre será la formación crítica susceptible en el docente y su conciencia de educarse como recomendaba Marx en su tercera tesis (Marx, 1974). Un currículo que vaya más allá de las indicaciones recetarias. El rescate de una opción alterna que promueva la importancia de tocar las realidades mundiales, regionales, nacionales, locales y comunales, problematizarlas, proponer discusión integral y generar conciencia, es obligación académica y humanista.

Una concepción de currículo liberador mostrará su compromiso sociopolítico con miras al cambio de paradigmas para las prácticas inmediatas pensadas allende de la inmediatez. Pero, cabe decir que mientras la educación siga pensándose desde la burocracia y la tecnocracia especializadas, desconocedoras -en su mayoría- de la realidad escolar, no habrá otra opción que rebelarse a nivel inmediato de la implantación arbitraria de indicaciones que solo obedecen a llevar a la escuela a un campo meramente, o paradójicamente, en el mejor de los casos instrumental o estadístico

El currículo podría ser el lugar de encuentro entre praxis y realización material de una propuesta crítica reforzada con la mirada marxiana, sin detenerse a hacer caso a los señalamientos ideológicos que quieran acudir a diatribas contra esas orientaciones adecuadas de identificar lo ideológico y proponer su desmonte, así como el trabajo basado en los principios de solidaridad, realización y emancipación, ya sea en el quehacer escolar, ya sea en su extensión tangible en la comunidad.

Repensar lo que significa y puede brindar el currículo, depurado de intereses ajenos a los actores escolares, es actuar ya, es el primer paso para liberarlo, poniéndolo al servicio de la labor docente consciente. Ya esto es una acción política donde la filosofía de la educación marxiana deberá, según la realidad y sus necesidades, construirse en la misma comunidad sin dejar de lado los elementos generales, los innegociables éticos, así como epistemológicos.

\subsubsection{El currículum praxiado como oportunidad emancipadora}

El currículo inmediato imbuido en el inmediatismo, no transforma realidades, puesto que no es su interés. Él mismo es producto del sistema de cosas y como su producto no tiene otra razón que no sea la de seguir dando forma a ese sistema que lo engendró y mantiene en un tipo de simbiosis.

Para ser un factor liberador, el currículo ha de ser prolongado en su visión educacional, sin perder su actualización epistemológica y extensión social. Es decir, no mediado por la intromisión ideológica o los intereses foráneos a la realidad del entorno; también de estar mediado con las herramientas de la crítica, la reflexión conceptual y la propuesta de acción social praxiológica. La propuesta no es establecer un tipo de currículo marxiano, mucho menos marxista, solo un currículo equilibrado, histórico y formador de carácter de ser humano, de ciudadano social del mundo que le rodea.

La praxis al ser tomada en la construcción curricular por parte de los diseñadores que sean comprometidos con su papel histórico y social, podrán llegar a proponer un currículo emancipador garante del inicio de una 
transformación a nivel micro del significado social de educación. Para seguir la secuencia de la revisión de la escuela inmediata y su componente curricular, tres cosas deberán enfatizarse una propuesta de currículo con aportes marxianos en educación:

Primero, interés por mostrar y develar la influencia de lo ideológico en la cotidianidad escolar, para esto se ha de solventar la visión de la actitud científica, la cual atravesará toda intención académico-formativa; a la par la del sentido socio-político de la educación. Segundo, la aplicación de una política curricular centrada en el rescate material del tema de trabajo, el cual ha de renunciar a la visión consumista de la actualidad. Un currículo que propenda a la liberación del ser humano, en estos tiempos confusos, no puede dejar atrás el tema de esta fuerza potencial que poseen hombres y mujeres. En tercer aspecto, plantearse el contexto cercano y regional, para el caso más cercano, lo local y latinoamericano. Una propuesta curricular de avanzada social, no debe dejar fuera toda la riqueza histórico-cultural de su contexto macro y micro. Ello se madura en la aplicación transversal de elementos que puedan tratarse en el devenir escolar. Ya la pedagogía, los estilos y la didáctica harán lo suyo.

Primero, para liberar a la educación de esa postura que la pone como mercancía, que la fetichiza en tanto escalera de ubicación estratificada, que la utiliza como tren de la ideología de un sistema cerrado y excluyente, se ha de liberar también al currículo. Con Dussel, podemos decir: "es necesario una nueva escuela, una nueva medicina, nuevos servicios para un hombre oprimido. Para ello es necesario primero desmitificar la pedagógica imperante, mostrar sus desproporcionados costos e indicar un camino liberador" (1982, p. 70).

Ahora, para que el currículo sea liberador, en primera instancia ha de liberarse al mismo currículo. Por ello, es pertinente que los sujetos de planeación curriculares sean sujetos comprometidos con lo social e histórico, que reconozcan en la escuela inmediata las relaciones dialécticas; que se enfoquen en problemas y soluciones, en metodologías alternativas sin dejar de ser exigentes, sobre todo, a una articulación de teoría y praxis.

Sin olvidar lo que Fromm decía sobre Marx que: "el fin de Marx era la emancipación espiritual del hombre, su liberación de las cadenas del determinismo económico, su restitución a su totalidad humana, el encuentro de una unidad y armonía con sus semejantes y con la naturaleza" (2012, p.15). No es volver al determinismo económico como base única de referencia. No obstante, no puede quedar fuera tan destacado aspecto del devenir social. No puede olvidarse que el fundamento de la alienación es la base económica.

Pensar y materializar un currículo emancipador implica reprobar toda intromisión del sistema capitalista de cosas, en todas sus manifestaciones; ello no quiere decir que no reconozca las realidades y problemas que ese mismo sistema ha desatado. El estudio de la base económica y social, ha de demarcar el sendero para la aplicación crítica y propositiva a una idea liberadora de currículo. La educación solo es una consecuencia más del sistema de cosas.

Desde esta perspectiva, queda bastante claro que la educación formal no es la fuerza ideológica primaria que consolida el sistema capitalista; tampoco, por si sola, es capaz de proveer una alternativa radicalmente emancipadora. Una de las principales funciones de la educación formal en nuestras sociedades es producir tanta conformidad o "consenso" como le sea posible, partiendo desde adentro y por medio de sus propios límites institucionalizados y sancionados legalmente. (Mészáros, 2008, p. 41)

Imaginar la posibilidad de rescatar al currículo como camino emancipador, partiría de la misma idea del desenmascaramiento ideológico del currículo, tomando en cuenta las apreciaciones que sobre ideología la 
presentan como un vector de imposición a la educación. No puede olvidarse: si hay algo material, práctico, identificable, ese algo es el currículo. Si se quiere recordemos al Marx (1976a-6) preocupado por el tema de la consciencia, con su martillante -y también mal interpretada- advertencia sobre esta, la relaciónimportancia con la vida y la realidad social. Esa conciencia parte del sistema económico catalizador de las relaciones materiales y hasta espirituales de los sujetos y las comunidades.

En cuanto a la formación socio-política, un currículo liberador contendrá una serie de abordaje sobre los temas de formación política de conciencia; es decir, de formación política del individuo y las comunidades desde sus propias áreas de estudio. En la historia política de América Latina sigue predominando un gran desconocimiento del poder político de las bases, es por ello que las comunidades y los individuos no pueden dejar de formarse en una cultura democrática de apertura, pero sobre todo de conocimiento de su propia historia política. Un currículo liberador no puede prescindir de la formación ciudadana activa; ha de repuntar la importancia sobre la participación antes que de la representación. Esto se da cuando un sujeto se apropia de lo importante que es participar de los procesos electorales de sus entornos.

En definitiva, emancipar al currículo del sistema de cosas cuya base es lo económico, significa en términos generales, tener presente esto mismo y tocarlo en toda la dimensión que la idea de currículo encierra, pues el factor ideológico nace en esa lógica temporal y productiva capitalista.

En segundo término, el tema de la potencial mortal humana capaz de transformar materia, es decir, al trabajo. En proyección al asunto del trabajo, un currículo pensado en las raíces de las necesidades sociales de la población es un currículo que apela por la transformación de la idea de trabajo, la cual se contrapone de aquella que rodea desde tiempos remotos la determinación religiosa que en conjunto con la maduración burguesa-oligarca, ha alienado el concepto real de trabajo, al colmo de desdibujar sus metas emancipadoras.

Un currículo liberador ha de retomar el tema del trabajo como factor liberador. De la consolidación de la complementariedad de la triada: estudio-trabajo-sentido social, dependerá el sentido social de la formación del trabajo no enajenado. Correcto se hace al tener en cuenta que, "el capital comienza por subordinar al trabajo bajo las condiciones técnicas en que, históricamente, lo encuentra” (Marx, 2013, p. 376).

No se trata de volver a los currículos politécnicos -al estilo apaciguador de los años sesenta y setenta-, por ejemplo, pensados con una mentalidad de competencia laboral paridos por la concepción occidental e impuestos en la periferia. Se trata es de rescatar la formación integral cuya base no sean las simples competencias laborales - tan de moda- sino la complementariedad social de la fuerza transformadora del trabajo sin despojar a los otros de esta fuerza so pretexto del mito del esfuerzo y la "predestinación" económica. Indicador de transformación es, educar en la mentalidad del trabajo libre y solidario, complementario, libre del consumismo de mano de obra barata fruto de la visión tercerizada, a lo cual el currículo liberador deberá apostar.

El trabajo no puede quedarse en la capacidad de transformar a la naturaleza o al medio. Mucho menos como esa actividad para "ganarse la vida"; ese ideario debe ser sepultado, pues su significado ha de buscarse en las indicaciones elaboradas desde lo marxiano. Una escuela que piense el trabajo como fuerza propia que no debe ser enajenada, será una escuela emancipadora. La resistencia debe darse en la medida en que el ser humano se apropie de aquello que le ha sido arrebatado y de lo cual terceros se aprovechan de la manera 
más ignominiosa con, inclusive, la protección del Estado y su extensión institucional, entre ellas la escuela tradicionalista-conservadora.

Hoy, los riesgos desatados por las problemáticas sociales (drogadicción, pandillismo, abuso, etc.) se está tragando las esperanzas de la juventud, y lo inmediato no ha surtido efecto. Nada de estos flagelos está fuera del sistema de cosas imperante. Una política educacional global sin el rescate debido de un currículo transformador, equilibrado y proponente, el cual reivindique, además, a las artes y los oficios en conjunción con la academia y la formación sociopolítica de individuos y comunidades, se aparta de cualquier interés transformador.

Tercero, en lo tocante a lo que puede dar un ingrediente auténtico para concretar un currículo emancipador, está el tema de la regionalidad extensa, para este caso, la América Latina como espacio a emancipar a través de la educación crítica, rigurosa pero social y humana al tiempo. Cabe recordar que, lo marxiano exige una postura geopolítica contundente donde prime el concepto de pueblo.

Emancipación de currículo, aplica por efecto, a lo geopolítico. No solo es un asunto micro. Si se habla de un currículum emancipador, hay que volver a nuestra historia regional, para concretar una identidad regional mediante el estudio de pensadores autóctonos como lo recomiendan Ramírez Angarita -Patiño (2013) en la combinación entre filosofía e historia, para contribuir a la transformación.

Para la educación latinoamericana-caribeña, que busque cumplir más allá de las simplezas de un sistema contradictor, con metas concretas de llegar a seres humanos potenciales de aportación, la emancipación es ingrediente de suma importancia. Emancipación pensada con un sustento histórico, que busque sacudir cimientos socio-económicos y reconocer el aspecto cultural e idiosincrático de la región. Los modelos impuestos están en apuros, se encuentran en una etapa de crisis, gracias a la fetichización de la educación como mercancía.

Del discurso decolonial debe pasarse a la acción descolonizadora de los currículos, en todos los campos del conocimiento, siempre pensando en el equilibrio. La propuesta antiimperialista e integracionista de los pueblos, bajo la batuta de los aportes locales, darán luces para nutrir la puesta en marcha de una conciencia material sobre la necesidad de unificar esfuerzos en la región, que no solo vengan de gobiernos centrales, sino de los pueblos mediante la escuela.

El estigma de estar condenados al atraso es otra forma ideológica que quiere seguir consolidándose; a esto se debe responder de manera directa acudiendo a nuevas propuestas críticas de formación integral. Mucho discurso al estilo de queja se pregona en la escuela inmediata, de ahí la necesidad de aportar antes de quejarse, y el currículo construido en conjunto puede dar luces positivas para iniciar factores de cambio en la práctica.

En el campo epistemológico, catapultar el rescate de las epistemologías del sur como dice De Soussa (2001), será otra pieza del conjunto que estará en función del reconocimiento de lo autóctono en tanto oportunidad de virar la relación de dominación epistémica que tanto despojo ha degenerado. El ocultamiento de aquello que pueden aportar desde los pueblos originarios hasta la cultura popular, no podrá quedar fuera del grueso de un currículo emancipado y que busque emancipar.

El socio curriculum equilibra la balanza que por mucho tiempo ha estado hacia un solo sentido. Este socio currículo ha de transformarse, adaptarse a las realidades y no al contrario. Estar al servicio de la población estudiantil, alimentarse con los asuntos de actualidad en función social de la educación de base. 
Ejercitar el intelecto hace parte de esas propuestas puntuales que no deben exigirse solo por coyunturas o para un determinado tema. Hay que volver a la filosofía, a la teoría y a la praxis y por supuesto a otras áreas del conocimiento; combinar clásicos con contemporáneos, pero sobre todo no descuidar el cotidiano de nuestra escuela inmediata. (Ramírez Angarita, 2017, p. 308)

Los currículos actuales parecen olvidar esta dimensión real, la dejan a la deriva, abandonada a la dictadura del mercado, a la simpleza de formación en áreas de "moda" que alienan y sigue enajenando a las nuevas generaciones. No cabe duda, la desesperanza y la crisis inmediata de la escuela es debida, también, a la acción inactiva de una concepción de currículo que se preocupe por la esencia social del individuo y de la comunidad se centraliza en las inmediateces administrativas, de apariencias para cumplir con la legislación.

Definitivamente, repensar el currículo implica con una óptica filosófica marxiana de la educación, el abandono de todo intento por ideologizar el currículum, de lo que se trata es de retomarlo como opción política de transformación, primero al interior de la escuela, luego que se vea reflejado por lo menos, en las realidades cercanas. Un currículo inmediato obedecería a necesidades inmediatas; esto sería aceptable si las inmediateces partieran de los contextos cercanos; sin embargo, lo mejor a seguir es la adecuación proyectada de curriculum, su replanteamiento donde haya que ajustar cosas, pero sobre todo que sea de construcción colectiva donde prime la formación integral y el apersonamiento de la realidad a intervenir a transformar.

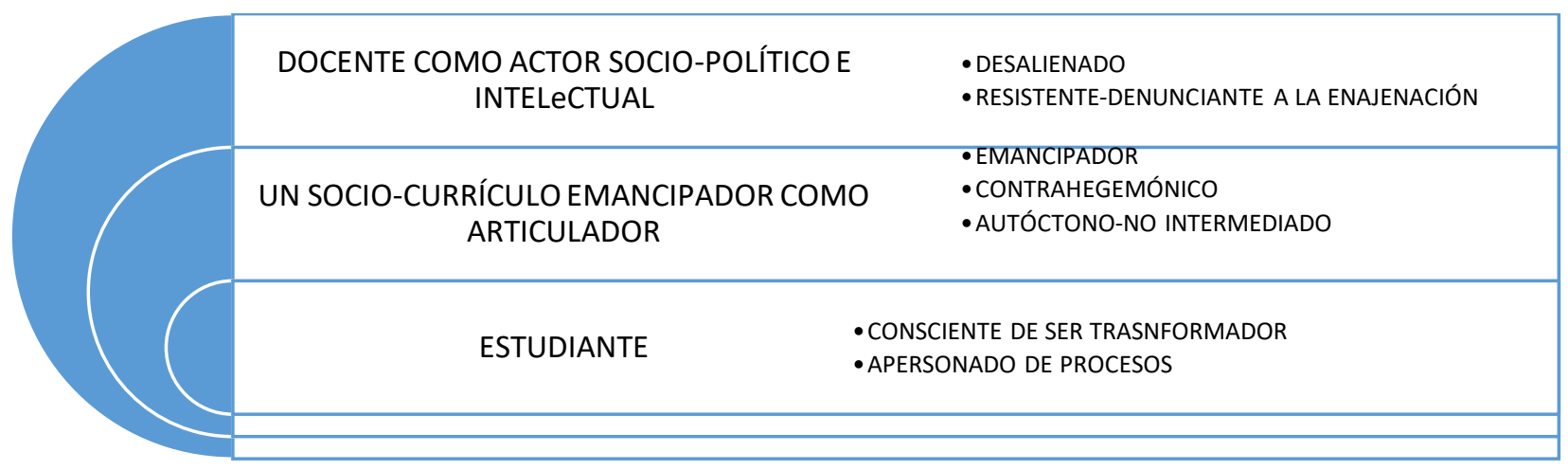

Gráfico No. 12. Conjunción de actores y elementos. Tres son los componentes básicos para ser analizados en la escuela inmediata. Dos, son sujetos, protagonistas conscientes susceptibles del ambiente socio-histórico. El otro (curriculum) es instrumento que puede estar a merced o puede liberarse para emancipar los procesos.

\subsection{El doble movimiento de la oportunidad sociopolítica}

Cuando establezco el doble movimiento, me quiero referir a la dinámica de lo macro hacia lo micro y aquella que deviene de lo micro buscando llegar a lo macro. Siendo lo macro la institucionalidad del sistema jurídico y el Estado; siendo lo micro el espacio concreto dado en las bases. Tradicionalmente se ha dado la filtración hegemónica vertical desde la tradicional política institucional hacia las bases, mientras desde lo micro, los efectos hacía arriba no han sido muchas.

Así las cosas, la propuesta política concreta podría darse de una manera vertical en principio, pero una vez funcionando, todas las relaciones deberán ser horizontales. O sea, si lo macro se convierte en un Estado social constituyente, su impresión sobre las bases será horizontal. La relación con la escuela abandonará 
toda influencia ideológica para plantarse en el real compromiso de la educación como formación sociohistórica con el enfoque crítico-propositivo que lo distancie de las convencionales formas de instrucción.

Para superar en términos materiales la situación que se presenta en la escuela, de la cual salen muchas situaciones problemáticas que pueden notarse y sentirse en el cotidiano, ha de pensarse en una reorientación de tipo macro. Esta apuesta a lo macro se da, en general, teniendo en cuenta la incapacidad lógica del Estado que solo ve a la educación como un sustento de su visión de país, de sociedad. Lo marxiano argumenta la necesidad de vencer los estigmas, a no quedarse en las predestinaciones que quieren hacer valer los imaginarios infundados. La otra es aquella que ha de partir de las bases hacia arriba. Pero, antes miremos brevemente una contextualización.

En la región, las mismas cifras de inversión en educación e investigación de alto impacto en la mayoría de países de América Latina son irrisorias comparadas con los gastos en otros sectores como el militar o el aparato bucrocrático (UNESCO, 2014), esto sin contar los recursos y bienes que se escapan en manos de las dirigencias y empresarios corruptos. El PIB global no alcanza a sobrepasar los mínimos en países con una preponderancia del modelo de dependencia capitalista, ejemplos claros son Chile, Colombia, México y Brasil. El BID (La República, 2017) estima que en total se invierte un 5,1\% en la región, incluyendo El caribe en educación, siendo Colombia uno de los Estados que poco invierte en este sector.

Para reforzar el anterior aspecto, Pérez Villamarín (2016) comparte su particular visión sobre la exclusión y la relación de esta con los márgenes de pobreza, los cuales, en definitiva, llevan a un panorama negativo en tanto se convierte en una amenaza global a la misma supervivencia humana. Dando así crédito a la clásica postura crítica sobre el tema de la educación, la exclusión y la marginalidad.

La relación vertical de este gran modelo se rige por la visión mercantilista de la educación. El Estado sigue siendo gendarme, pero no protagonista en el impulso que garantice reales transformaciones políticosadministrativas conducentes a la apuesta por un cambio profundo que venga desde arriba. Esto último, por las características socio-históricas de dichas naciones, por estar manejadas desde la época de la independencia por familias oligárquicas de clases dominantes, cuyo contacto con la realidad no les es familiar. Esto demuestra la funcionalidad del mito de sostener que las elites son las más aptas para gobernar y por ello las indicadas para delinear las políticas educativas mismas.

En cambio, en otras naciones con tendencias al progresismo, la inversión pública en educación ha crecido, a pesar de las dificultades económicas y políticas, tal cual puede ratificar la CEPAL; esto presume la intención de un sistema político por poner los más altos esfuerzos para concretar cambios. Aquí puede notarse una relación aun vertical, donde los Estados con una visión distinta de lo social tratan de transmitir cambios conscientes para que su población pueda adquirir por lo menos grados de conciencia.

En Venezuela, Ecuador, Nicaragua o Bolivia la actuación de los sectores populares, se manifiestan en las organizaciones de base; la relación encuentra proyección desde la base hacia el Estado. No obstante, la situación de décadas de alienación aún persiste en gran parte de la población tanto de estos países como del resto en América Latina y El Caribe. En otras palabras, a pesar del trabajo de base, algunos sectores populares todavía se muestran renuentes a la invitación a un cambio de cosas, en lo que desde Fromm 
podría decirse: es un miedo a la libertad. Aquí es notable el tema de la voluntad política de los Estados, y la voluntad simple de los individuos en aras de la liberación mental y material.

Para ilustrar, el caso cubano es el más notable desde los años sesenta. Según el Banco Mundial (WB, 2014), la inversión de este país en educación es sui generis tomando en cuenta el bloqueo al que ha sido sometida y a los escasos ingresos de su economía nacional y a su PIB. Puede notarse el alto grado de conciencia y contundencia del papel de la formación humana que tradicionalmente se conoce de esta isla caribeña de corte socialista con elementos auténticos. Su política educacional no es inmediata en la medida en que no se ha pensado con inmediatez política, sino con conciencia de formación distinta a los modelos copiados tal cual suele verse en otros países.

A pesar de las negaciones que quieren darse desde las tribunas que jalan a un neutralismo, existe una clara relación entre perspectiva económica de un Estado y modelo educativo más allá de la simple observación presupuestal. Si un Estado apuesta por cambios profundos que centren su interés en la inversión para mejorar condiciones de estudio en todos los niveles, los resultados se verán en los siguientes años. Así, si la comunidad participa directamente y reconoce su protagonismo en la formación humana más allá de un simple medio para "escalar" socialmente, será una comunidad en verdad pertinente más que competente. La relación Estado-comunidad ha de ser directa y horizontal, aunque en principio podría ser vertical.

ESTADO (socializante)

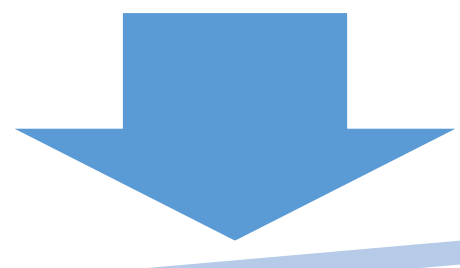

macro politicas sociales y de impulso participativo y emancipador

integrador latinoamericano

COMUNIDAD (bases)

formacion de base

cociencia de clase

integrante

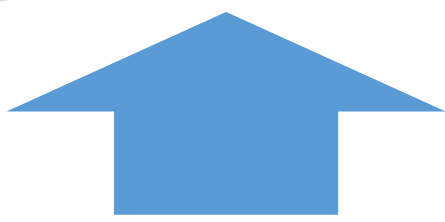

Gráfico No 13. Coincidencia del modelo político que complemente la doble relación entre lo macro y lo micro/ lo micro y lo macro. Se presentan los movimientos verticales que obedecen a las influencias políticas, dando primacía a la acción comunitaria sobre las decisiones centralizadas. La relación debe ser doble, de equilibrio entre base y Estado.

Para llegar a la toma de decisiones sobre el asunto educativo, hay que llegar a la cúspide del Estado, esto tiene dos vías, la del sufragio y la de las armas. La primera, es la más consecuente para no causar traumas, aunque no deja de generar desconfianza entre sectores alternativos electoralmente excluidos; pues la segunda ha dejado experiencias de doble efecto más que negativo para cualquier propuesta de cambio, el caso de la subversión ha sido más que dramático. Entonces, la vía democrática hoy, es la más atractiva. Aunque ha de reconocerse que sin formación política de los individuos y de la comunidad, no habrá esfuerzos que maduren en decisiones políticas a nivel macro; volvemos al problema de la formación, del abandono que ha hecho la escuela de este tipo de asuntos relevantes.

Tampoco puede negarse que las clases dominantes y los poderes extranjeros han hecho una clara campaña para deslegitimizar cualquier intento de cambio social a lo largo y ancho del continente. El conjunto social 
dominante ha utilizado todo el aparato ideológico y recursos propios y públicos para contrarrestar cualquier influencia que no esté con sus intereses de clase. La reacción de todo tipo no ha cesado, aun en pleno inicio del siglo XXI. Desde el uso irresponsable y amañado de los medios de comunicación, hasta los bloqueos y utilización de la fuerza pública, ningún medio se escatima; por ello mantener al sistema educativo a su merced, es garantí de permanencia y adormecimiento. La inmediatez es una de las mejores armas reaccionarias.

Ahora bien, un acercamiento a una propuesta de desmonte de la inmediatez en la escuela, dado en todas las esferas de la educación, para este caso puntual, en la escuela inmediata en su sentido dialéctico, es una apuesta política o mejor: sociopolítica. En esto lo marxiano tendrá mucho que aportar, sobre todo la relectura de fenómenos como la alienación, la enajenación y la praxis, esos deben estar intrínsecos en cualquier apuesta concreta que quiera pensarse para transformar la realidad.

La organización de trabajadores, estudiantes y campesinos será prioridad para una apuesta de Estado social incluyente y solidario. Como poder constituido (sistema jurídico-Estado) por la voluntad de un poder constituyente (pueblo), la educación liberadora, más que de calidad de rigurosidad, de realidades concretas, propenderá por la inclusión y la equidad; por la educación gratuita en los tres primeros niveles y precios solidarios en los siguientes. Los individuos formados harán parte de esa formación

Para impulsar las transformaciones de arriba hacia abajo, desafiar al modelo económico imperante no podría quedar en las diatribas. Este es el gran reto para generar situación de cambio transformador. Este punto es neurálgico, ya que existen intereses económicos enquistados que no estarán dispuestos a negociar siquiera algunos mínimos. De aquello podrá sacarse algunas razones de la eclosión de movimientos insurgentes, de sectores radicalizados en la clase oprimida o clases medias también. Tocar el modelo, es tocar la base del problema social. Difícilmente habrá cambio positivo sin tocar de fondo el tema económico macro, según las lógicas actuales, es proponer un Estado social distinto, el cual equilibre y no sea representante de los sectores económicamente poderosos.

Existe la posibilidad de hacer del Estado un ente que impulse las transformaciones, esto no tendrá pocos enemigos porque es tocar toda la estructura de poder caracterizada por la tenencia del mismo por parte de clases dominantes. Más, no puede ni debe renunciarse a esta meta histórica atada a las transformaciones de raíz que no le son "propiedad" exclusiva de una visión marxista. La idea es que sean los sectores que más han sido invisibilizados los que lleguen a las instancias de los poderes públicos. Sobre esto existe diversas interpretaciones del ámbito de la política con un tinte marxista. Esto facilitaría la relación de intervención de las grandes estancias a la vida cotidiana de los individuos y las comunidades a través de la educación liberadora, socialmente incluyente, con reconocimiento en formación política y de conciencia.

A su vez, las comunidades organizadas, en este caso, comunidades educativas democráticamente constituidas en sus aspectos administrativos ( políticas a nivel micro que hagan retomar el camino de una educación que dignifique la profesión docente, el trabajo académico, el trabajo social, la participación de la familia, la autonomía, y el auto reconocimiento también del estudiante como estudiante sujeto de derechos y deberes. La escuela del retazo, de modelos foráneos y sobre todo del afán inmediato de "producir" bachilleres o profesionales, habrá de desaparecer para dar paso a una forma reivindicativa realmente incluyente, justa y capaza de estar acompañando a la comunidad. 
La construcción de una manera política de dirigir la educación en el ámbito nacional, sin el lastre de la vieja estructura representativa, habrá de darse si en vez de intereses partidistas o personales, se hace énfasis en las metas sociales, por ende, humanas, con un carácter vinculante pero siempre participativo. Esta relación en principio vertical, se irá transformando en horizontal. Aunque el poder comunal deberá unificarse y prevalecer sobre el poder supraestatal.

Otra circunstancia, podría ser, reconociendo la realidad ideológica de nuestra región, el fortalecimiento de las bases para rescatar la dignidad y la rigurosidad social en la educación, aunar esfuerzos con una cultura de formación familiar cercana a lo crítico-propositivo que abandone toda postura reaccionaria de herencia hasta colonial. Es decir, la organización comunitaria que pueda gestionar sus cambios en materias como la educación según sus propias necesidades sin quedarse en los inmediatos afanes.

Al fin y al cabo, la escuela inmediata solo podrá superarse en su visión de inmediatez con la toma de conciencia social sin quedarse en la identidad de clase, sino avanzando en la identificación como seres humanos dignos que han sido víctimas de un sistema de cosas, el cual ha utilizado al aparato sistémico de la educación como vehículo alienador, conformista o simplemente dadivoso.

La organización autónoma al interior de las comunidades educativas, se establece como pilar fundamental si esta parte del principio de participación y no de sola representatividad. Las propuestas concertadas, enfocadas a precisas resoluciones no mediadas que, contrarresten la manipulación, determinen rumbos claros y atiendan las necesidades no inmediatistas, al tiempo que reconozcan la necesidad de cambios a nivel macro y micro para saldar la deuda histórica con la dignificación material y hasta espiritual del ser humano. Esta es una forma de resistencia que nos recuerda el gran legado de Marx, de ese Marx interesado por la formación del individuo y de la comunidad.

La oportunidad política debe generarse en la base que conforma a la escuela. La educación deberá fortalecer la participación comunal pues ella podría conducir a identificarse como sujetos de su contexto. El modelo masificador va en fracaso, el de representatividad ha sido el gran culpable de los problemas y la concentración del poder en unos pocos, los cuales se caracterizan por su perpetuación en el poder y con ello, su visión de mundo. En general en la escuela inmediata los esfuerzos por iniciar una cultura de la democracia popular y participativa, de la valoración de la ecuanimidad, la justicia social y la real inclusión.

Para lograr la meta política cercana, el cuerpo docente, independiente de la intromisión estatal, debe emprender esta causa social e histórica, que sea un agente más de propensión al cambio. Currículo y filosofía de las instituciones deben ir de la mano con la formación democrática y ciudadana que, deberá empezar en la escuela y al tiempo volver a la escuela como construcción constante que apunte hacia una forma de vida adecuada a las necesidades con integralidad social, un modelo sostenible, justo.

La praxis que es política -a su vez- en la escuela inmediata, al identificarse como espacio de cambio concienzudo mental y material, en su propia desalienación, habrá de liderar la contraofensiva contra la ausencia de conciencia ambiental; combatir la xenofobia y el racismo; el rechazo radical a la discriminación de todo tipo; ofrecer la importancia de recrear la capacidad de distinguir entre religión y espiritualidad; reconocer lo cultural de cada grupo humano; ofrecer las herramientas para discernir entre las versiones de democracia que ocultan intereses oligárquicos o de las tradicionales versiones de tiranía y aquellas que se disfrazan de libertad; así también el valor de la soberanía y la consecución de la paz con justicia social.

En conclusión, puede darse los cambios desde el Estado y su ordenamiento jurídico hacia las bases; lo que implicaría la llegada al poder de las visiones de las bases, pues deducirá que las mismas bases se han superado para llegar a la toma de decisiones en lo macro. Es imposible que las dirigencias tradicionales 
busquen el bienestar para la población de base, si no lo han hecho en más de doscientos años, menos en estas coyunturas. Y, si los cambios se presentan en el seno de las comunidades, estos deben aspirar a traspasar las dificultades coyunturales, si bien es un buen síntoma de organización comunal, ha de avanzarse para que sea conocida a niveles macro y no quedarse en lo micro -volveríamos al asunto de la llegada al poder- ; esta relación de expansión podrá ser horizontal. Formación comunal y educación no se desligan son del mismo origen.

\subsection{La escuela inmediata como acontecimiento para una filosofía de la educación marxiana}

Muchas visiones de educación hoy, son producto de modas y de abordajes poco comprometidos con la transformación concreta que lleve a un sostenimiento en teoría y práctica de un mundo posible. Es más, algunas posturas se muestran críticas, pero en verdad no van al fondo de la problemática; aún desconocen y tratan de anacrónica el rescate por demostrar que el poder de las súpraestructuras siguen dictaminando los rumbos de la educación en las sociedades. La negación de la alienación y de la enajenación o de los efectos positivos que puede tener la praxis desde le sentido marxiano, es clara muestra de esa misma teorización marxiana sobre la contradicción del pensamiento que no se compromete con la transformación política de la vida cotidiana.

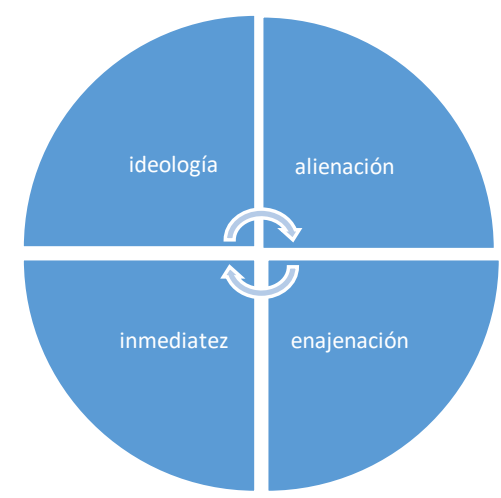

Gráfico No. 14. Dinámica presentada en la escuela inmediata. La ideología es producida y sostenida por el sistema de cosas; esta a su vez produce y es sostenida por su producto: la alienación. La enajenación se presenta en el ámbito material y es consecuencia del sistema económico. Todo, en la escuela se rige en la inmediatez que es producto del sistema y se mueve en las otras tres dimensiones. Funciona como un todo y se interrelaciona.

Morales Zuñiga en 2009, decía en su aproximación latinoamericana a una lectura del fenómeno de la educación desde la perspectiva marxista, que desde esta forma de ver y transformar al mundo: "es fundamentalmente necesario preguntarse cuáles son las condiciones materiales e histórico-culturales en las que se desarrollan los sistemas educativos modernos, así como su devenir, con el fin de comprender la orientación a la que corresponde la dinámica educativa" (P. 2). Por ello, la escuela inmediata cumple con estos requisitos para ser abrazada por la lente socio crítica del Marx interesado por la formación humana.

Para denominarse "inmediata" es porque se desprende de esa inmediatez tratada por Marx. La escuela ideologizada siempre ha existido, es un resultado social humano; pero la diferencia es que ahora ha llegado al extremo por su universalización, al tiempo de su alta tendencia al consumismo y la carencia del abordaje de los temas cercanos, de la pobreza para criticar a la cotidianidad y del bajo compromiso histórico en los sujetos y en las comunidades. 
La escuela inmediata si es un fenómeno digno para ser explorado con lo marxiano, distinguirla en teoría, caracterizarla en práctica y, por supuesto, superada en praxis. Las herramientas en pensamiento económico, en filosofía de la historia, en postura sociológica y en filosofía de la educación de la mano de Marx, son imprescindibles como ninguna otra postura filosófica para entender y descubrir la realidad tras este fenómeno material.

La escuela inmediata acontece. Ella es producto del sistema de cosas desprendido del capitalismo "pirata", del sistema periférico de dependencia enquistado en los países de América Latina. Sí, ella existe como amenaza más que ideológica. Empero, es oportunidad para develar, para denunciar la cultura del inmediatismo. Por ser un fenómeno social concreto, con consecuencias igual de tangibles, latentes, se convierte en interés desde la lupa marxiana.

Lo que sí puede llegar a ser, es ser superada y aprovechada para constituirse en alternativa de conciencia más que terminar generando más posturas ideológicas o pragmáticas del otro extremo. Al tenerse como posible superación del reflejo y al comprenderse como explicación del porqué emerge y se consolida como espacio inmediato, ligero y limitante, se dará paso a la conciencia de ser superada en individua y colectivo, en relación macro-micro y viceversa.

No se pretende hacer una "resurrección" de la propuesta marxista concebida en el siglo XX, hacer eso sería contramarxiano en toda su expresión. Lo ideológico lo dejamos a otros campos. Se trata de repensar a la educación como un asunto social comunitario-popular e incluyente, de repensarla y creer que en ella todavía existe la esperanza material de poner los intereses de la mujer y el hombre y otros géneros sin el dictamen del capital; es más, los mismos intereses de preservación planetaria y como especie.

Pasar de la masa a la comunidad, de la masificación a lo comunitario, es refrescar los aportes marxianos. La organización popular de base organizada desde las comunidades permite a lo marxiano intervenir en propuesta para que el individuo se realice como ser social al interior de su comunidad, entenderse como sujeto histórico y con esto, su activación participativa en el ámbito político. La exigencia de una educación comunal, es algo novedoso que puede ser tratado en la escuela inmediata para superarse en praxis. La conciencia revolucionaria ha de ser comunitaria, armada con la crítica y la acción propositiva. Para esto es básico explorar las versiones sobre la historia, haciendo también, de la actitud científica -en todas sus manifestaciones y áreas del conocimiento- un camino de lucha hacia la democratización que remueva las viejas estructuras de sometimiento.

En este análisis marxiano, la conciencia no es tomada como algo únicamente abstracto, tampoco pragmático, lo marxiano da a la conciencia un sentido social, de carácter transformador, pero acompañada de la materialidad. Y esto puede verse en el marxismo, en la idea de lo en sí y lo para sí, de la fuerza revolucionaria de la conciencia (Guzmán, 2017). Cabe retraer que, se habla de conciencia revolucionaria y no de ideología, así será aplicada a la dinámica educacional, aunque la concentración de esta característica, para esta propuesta marxiana, ha de darse en la formación docente. Un docente con consciencia social y voluntad de utilizar, de transformar su inmediato con rigurosidad, será un debelador de las amenazas que se presentan en la escuela.

No es secreto que lo marxiano para este siglo XXI, que encuentra alojamiento en el llamado socialismo del siglo XXI, tiene mucho que aportar cuando se arroja fuera lo ideológico en el sentido denunciado por Silva, enfocándose con el carácter de herramienta liberadora de base. Muy a pesar de su satanización mediática, lo marxiano encuentra eco, para este caso, en una propuesta de pensar filosóficamente a la educación. 
El rol del docente es supremamente rescatado desde el sentido marxiano. Es polémico, con tanto bombardeo de posturas, las cuales ponen al estudiante como centro del proceso, decir que es el docente quien debe ser el centro de atención. Y esto es consecuente si se toma en cuenta que, el mismo docente está a cargo no solo de procesos o contenidos, sino de lo más importante: las personas; al darles su centralidad histórica como sujetos, dichos estudiantes serán sujetos resistentes a la alienación y críticos de la enajenación.

Otro asunto álgido, es pensar que la escuela y por efecto, la educación son medios para llegar a fines inmediatos. Claro, dichos fines están enmarcados en la visión neoliberal, para el caso de América Latina y la periferia en general; otra forma de dominación y predominio de lo aparente. En este aspecto, la teoría de la apariencia, del reflejo hace su mejor aparición. Se tiene un imaginario y varios discursos -hasta consuetudinarios- sobre la igualdad de derechos en términos de acceso a la educación, cuando se sabe que la mayoría de Estados solo se preocupan por obedecer a estándares y cifras, se olvidan de lo que significa educar y formar a la ciudadanía, pero esto no inconsciente tal cual suele creerse, esto hace parte de las lógicas del sistema periférico.

Más los fines para las clases sociales siguen siendo distintas, ayer como hoy. No hay duda, en todos los niveles se percibe diferencias tajantes, hasta en los propios niveles sociales. La división del trabajo se ve reflejada en la escuela, lo que ha cambiado es, en gran medida, el adiestramiento de la máquina para pasar al mundo del consumo y de lo virtual. Sin embargo, las formas de explotación siguen estando presentes, la resistencia es persuadida por las versiones defensoras del estilo de vida basado en la competencia y el individualismo cuando no de resignación.

En el tema del trabajo, se cree que, la escuela debe garantizar futuros empleos. Según el rango social, el esfuerzo, las capacidades o los ingresos, se podrá aspirar a una ocupación según el relato resumido en la escuela inmediata. Desde lo marxiano, el tema del trabajo es amplio, en él se soporta toda la extensión social de la potencialidad humana sin más criterios que la libertad y la no producción de ganancias monetarias a terceros que solo se benefician del esfuerzo mortal de otros. El trabajo debe liberar y significar complementariedad humana tal cual acompaña Marcuse (1969). La denuncia de querer convertir al trabajo en un instrumento de dominación y sometimiento, es otro de los asuntos centrales del abordaje marxiano al interior de la escuela inmediata.

Mientras haya inmediatez como forma unilateral de ver la realidad, de la manera más negativa, existirá la escuela inmediata, al tiempo, ésta seguirá siendo oportunidad para no perder de vista, para explorarla con la compañía de lo marxiano y del propio Marx, el Marx aún vigente a doscientos años de su natalicio. Las fuerzas sociales, políticas y económicas se manifiestan de manera contradictoria en la cotidianidad y con ella, en el acontecer diario de la escuela.

La filosofía de perspectiva marxiana, encuentra una plataforma en el fenómeno educativo, encarna todo lo que puede verse en el ser humano, desde sus miedos hasta sus esperanzas. La actitud filosófica en praxis debe acercarse y generarse en y es con y para el ser humano, mundanizarse la acercará al sentido que le da el joven Marx en sus tesis. Las respetables, pero en ocasiones descontextualizadas observaciones filointelectualistas de querer separar la reflexión filosófica de la acción o de la toma de posición, son tan objetables como alienadoras. La vida está ahí, la realidad está allí, y a ella hay que acercarse. Hay que ponerse las botas, quitarse la franela y ponerse el yugo para aminar paso a paso con el sentir y el percibir del otro y de los otros. Sin esto, la filosofía se quedará como veía Marx, en la crítica roedora en el mejor de los casos. 
La escuela inmediata es un caso general que contiene miles de casos, de materialidades cotidianas. En ese orden: ¿acaso el estudio de caso debe ser adjudicado a un campo del saber exclusivamente? Los casos sociales no solo pueden ser tomados muy en cuenta por la filosofía de la educación, sino que es imperativo, deber filosófico explorarlos. O es que las mentes, por muy abstractas que pretendan serlo, no se mueven en una realidad, ¿no dependen la materialidad para poder abstraerse, para existir en el mundo? En términos del común, y para ser radical: viven, se mantienen de los mismos elementos mínimos que les permiten cumplir funciones vitales $\mathrm{y}$, a partir de ellas, funciones intelectuales. A su vez, hoy la dependencia del sistema de producción que origina al sistema de cosas, está presente en aspectos que antes eran inimaginables.

Al fin y al cabo, sigue existiendo una soberbia, una tozudez frente a la aceptación de lo social como problema filosófico que, recuerda más los señalamientos macartistas que al ejercicio serio y comprometido del filosofar "con" y "para" seres humanos. Esto sigue notándose en los escenarios educativos. Las limitaciones se han venido dando en el seno de las mismas academias, aquellas que conservan visiones aún persistentes en el divorcio vida cotidiana-filosofía, aquellas que Marx demandó. El filósofo puede acudir a las herramientas de la comprensión marxiana, alejándose por un momento de los preceptos "ultra lunares". Por esto es consecuente decir que:

El filósofo, él mismo una forma abstracta del hombre enajenado, se considera la medida del mundo enajenado. Toda la historia de la enajenación y de la revocación de esta enajenación es, por tanto, sólo la historia de la producción del pensamiento abstracto, es decir, del pensamiento absoluto, lógico, especulativo. (Marx, 2102, en Fromm, p. 181)

Que no siga sucediendo -como en los tiempos de Marx-: el olvido por los sensibles temas sociales que a la final son todos aquellos que afectan al cotidiano por parte de una actitud neutral de la filosofía que, de todas maneras, es hecha por personas de carne y hueso; esto dejará incompleto su compromiso con la humanidad. De cualquier modo, esas mismas actitudes ya sean "neutrales" no serán tales; pues serán producto del contexto que a su vez es consecuencia del sistema de cosas.

Pareciera que lo inmediato en tanto, inmediatez producida, ha sido instrumento efectivo para consolidar los efectos sociales de la alienación y la enajenación en y desde la escuela; esto merece ser pensado para trazar la superación material, reconocer las fuentes de estas negatividades y transformar realidades.

Si hay algo que componga a la totalidad real del individuo frente a su otro y frente a su comunidad, es el cotidiano. El cotidiano puede tomarse en cuenta en el campo de los estudios de casos por otras disciplinas, pero con la filosofía de la educación se verá como una totalidad, pero una totalidad social no pasiva que espera mediante una política macro y micro servir integralmente a la humanidad sin la mediación del capital, del sistema de cosas imperante que se rige por la visión mercantilizada del mundo. 


\section{CONCLUSIONES}

Esta exploración investigativa se resume en el reencuentro con Karl Marx más allá de la interpretación tradicional que lo ha relacionado solo desde otras perspectivas más políticas o económicas. Se centró en la búsqueda de un Marx interesado por la educación como formación individual y colectiva, como acontecimiento social de alto impacto, como un fenómeno que pude leerse de manera dialéctica. El Marx interesado por los temas educacionales, por tratarse de algo que toca a lo individual y a lo social, despertó interés de la filosofía de la educación.

Por ello giró en torno a dos cosas: una, el sustento teórico visto desde una dialéctica con enfoque marxiano sobre ideología y praxis; segundo, estos mismos elementos en un espacio histórico social que llamo escuela inmediata. La ideología como amenaza, la praxis como oportunidad. No sin antes redimensionar la misma vida material e intelectual de Karl Marx y su significado para las formas alternativas de pensar.

Definitivamente, la vida de Karl Marx (1818-1883), sus vivencias, encuentros y desencuentros con su realidad inmediata, se proyecta en toda su propuesta de pensamiento socio crítico; por lo tanto, la educación como acontecimiento social y de lucha de poderes no le fue ajena. Él mismo tomó todo aquello, lo cual se convirtió en insumo para repensar la realidad y así desmontar las justificaciones del sistema capitalista que se dio también en el sistema educativo como forma de dominación y alienación.

Con la mirada marxiana, muy apegada a la crítica de la realidad, con la búsqueda de las condiciones materiales como centro, sale a flote el ocultamiento, se descubre la negatividad de la inmediatez, cuando esto tiene objetivos adscritos al sistema de cosas imperante y no a un tipo de concreciones prolongadas y radicales que conlleven a las transformaciones que tanto urgen y que han de comenzar en la formación educativa de sujetos y comunidades; no sin antes fortalecer la conciencia socio-histórica de los actores que viven, sufren y proponen al interior del acontecer escolar de base.

En el campo al que no dedicó ninguna obra Marx, lo marxiano será reivindicado. Quizás Marx no quiso escribir sobre la educación para que no fuera tomado como teórico de algo tan importante, no quiso ideologizarla. En sus obras es concienzudo a la hora de tocar los temas relacionados con la formación humana, tal vez quiso que desde ellas se hiciera la lectura acorde a las realidades.

No obstante, no cabe duda sobre lo pedagógico de la obra de Marx. Él más que ningún otro pensador vivió en carne propia lo positivo y negativo del acontecer educativo. Su favor en pro de una transformación radical de lo formativo que lleva al sostenimiento del sistema capitalista de cosas imperante, nunca deja de verse en su propuesta. La lucha contra los males del sistema, contra la explotación y en búsqueda de la concreción de la liberación para disfrutar de nuestra mortalidad, en una lucha educativa que ha darse en todos los frentes.

Acertado es Tarcus (2015), en su introducción a algunos escritos compilados de Marx, al momento de reconocer la suma importancia de leerlo en el siglo XXI; su labor fue y es pedagógica por donde se le mire, su interés fue la formación en cuerpo y alma de quienes podía tomar las riendas de sus destinos históricos, combatir sus penurias y hasta vicios.

Así las cosas, he dividio tres grandes grupos de consclusiones. El primero el de carácter heurístico sobre el papel de la filosofía y con ella el de la filosofía de la educación. El segundo, sobre los hallazgos de ideología y práxis; y por ultimo, la escuela inmediata como espacio de dialéctica cotidiana de orígenes intencionales. 


\section{La retoma filosófica marxiana}

Importante es, notar que, al abordar el tema de la educación y la consecuente preocupación marxiana, se descubre en que no existen ni "dos" ni "varios" Marx a la manera en que ilustrativamente lo han querido dividir magistralmente a través de la historia del pensamiento contemporáneo. En el tema de la educación como vía de transformación, la obra y el interés marxiano se unifica. Marx es uno, sus obras son un solo bloque, el hilo conductor es la formación humana individual y colectiva para inciciar el camino de emancipación de los modelos represivos, incluidos el escolar que deviene del dictamen del capital.

Si es con Marx, puede darse la condición de bajar a la filosofía -en este caso el de la educación- a la tierra, tal cual lo hizo con la filosofía de Hegel (Arndt, 2008). La filosofía debe llegar a las mentes, a darse lo que llama Feinmann ${ }^{95}$, sacar la filosofía a la calle; para el caso, la filosofía de a pie, esa que proponga transformación sin ideologización pero si con compromiso social.

La propuesta de abordar el acontecimiento educativo con Marx, implica no solo un asunto metodológico sino, un valioso rescate de esa construcción filosófica que se encuentra en Marx y en sus sucesivas extensiones de pensamiento, para los temas de filosofía de la educación. Podemos decir con suma seguridad que Marx es un "sociopedagogo".

Una filosofia de la educación es una filosofía de la denuncia del sistema de cosas que afecta idearios en individuos y grupos, así como una constante aparición de lucha de clases que quiere ser ocultada en los escenarios educativos logra atisbarse con la lente marxiana hoy en pleno comienzo del siglo XXI. El hombre sigue estando en el interés marxiano, máxime en educación, pero ahora lo comparte con el medio esa es una de las mejores actualizaciones de lo marxiano, así debe comprenderse en una educación emancipadora que también entienda que lo económico fundamenta la visión universal de vida, de educación y mundo.

El tema de Marx siempre será un tema geopolítico, y si es pensar la educación de manera global, lo será aún más; el final de la Guerra Fría no fue el final de las contradicciones del sistema de cosas capitalista, es paradójicamente la retoma de ideas y acciones en búsqueda de un mundo mejor que muchos aun sueñan y que es posible si se juntan las voluntades materializar proyectos educacionales. Y no hay duda, una educación de conciencia siempre será un peligro global en contra del poder global. La búsqueda de un mundo multipolar es la búsqueda de respuestas a grandes desafíos que implican la misma supervivencia. La educación como acontecimiento transformador radical seguirá siendo la única forma consecuente que podrá entablar el diálogo mundial y el desmonte de un sistema que solo ha traído la profundización de las crisis emanadas de su lógica, de su naturaleza contradictoria y, lo peor: su ocultamiento.

\section{Materialización y superación de ideología y praxis}

Otro de los hallazgos más destacados, es el estrecho contraste entre ideología y praxis que se presenta en los escenarios educativos. Mientras la ideología hace fuerte presencia y a la vez consolida su poder con la alienación mental y la enajenación material; convirtiéndose en amenaza oculta, de manera exponencial y reproductora hasta de estados de ánimos frente al sistema de cosas de manera evidente. Por su parte, la praxis al ser reconocida en su base marxiana, se presenta como estrategia pertinente para iniciar el desmonte de aquellas dos situaciones.

95 En, Filosofia aqui $y$ ahora -
https://www.youtube.com/watch? $\mathbf{v}=$ hcAMtbWhNuI 
Esto no es nuevo, lo auténtico es aclarar la presencia dialéctica de estos elementos en la temporalidadespacio desarrollándose de manera material en la escuela del acontecer cotidiano que se comporta como una inmediatez requisitiva que cumple su función sociopolítica y económica tal cual la dictamina el sistema de cosas basado en la mercantilización y la plusvalía en todas sus formas.

En el campo concerniente a la ideología, la transformación educativa no es ideológica. Esta debe ser de conciencia. Una conciencia social de connotaciones materiales. Si la praxis no es solo la tradicional versión de práctica, así también la conciencia revolucionaria no es ideológica, debe ser de transformación. Conciencia y praxis deben ir de la mano para reconducir a las metas de la formación humana.

En aquel orden aportante del orbe sociopistémico también, vale destacar los importantes aportes de Ludovico Silva y Adolfo Sánchez Vásquez, entre otros acompañantes de esta exploración temática. Uno, en el tema de la peculiar mirada sobre el sentido original de ideología y de alienación; el otro en la ilustración filosófica sobre la praxis, su diferencia de la práctica y rescate. Los dos con un toque latinoamericano basado en sus realidades, frutos de la construcción teórica, y muy cercanos a la educación pues fueron también docentes y, por supuesto, conocedores de Marx; pueden abrir horizontes de comprensión al tema educativo.

En lo correspondiente a los actores y elementos fundamentales conjugados en el acto educativo, estos tienen el compromiso histórico, desde la perspectiva marxiana, de afrontar los desafíos, a asumir sus roles transformadores. El currículo no deja de ser intrumento susceptible de influencias ideológicas, pero puede convertirse en camino para el inicio de una puesta en común para el rescate de la formación sociointegral.

Evidentemente, el papel crítico y de liderazgo del ente docente en los procesos sociales de transformación son pilares de inigualable importancia. El docente ha perdido centralidad en el sistema capitalista pues es solo una pieza laboral más; una propuesta marxiana equilibra el rol del educador más allá que un simple instructor o un vector de un sistema de cosas. Se denota una paulatina manera de opresión a la profesión docente cuando esta se acerca a las rutas de propuesta autónoma y social.

Evidentemente, si se toma a la práctica educativa con el sentido meramente instrumental, mecánico y en obediencia al sistema de cosas basado en la mercantilización de las cosas y al sumisión (por ejemplo, instruir en el consumismo, ya que formar no sería la palabra adecuada), no se podrá hablar de praxis en el sentido que busca reivindicar a la educación como camino de liberación. Por ello la urgencia de que sujetos tan protagonistas como el cuerpo docente, comience a concienzarse de su rol para no ser vector de alienación-enajenación. Si la práctica se hace consciente y comprometida, dinámica y constructiva, está avanzará hacia la praxis, la cual en sí misma lleva el mensaje de transformación. Las prácticas deberán orientarse hacia fines explícitos del significado social e histórico de elementos como currículo, contenidos, proyectos, sentidos de vida, etc.

Una perspectiva filosófica en educacion con enfoque marxiano, tendrá en cuenta el rescate de la concepción marxiana de trabajo. El trabajo no debe ser mercancía, ni tampoco ha de limitarse a estar en función de la producción para el consumo de los acumuladores de capital-beneficio. Recriminar e identificar lo negativo de formar en el consumo perse, es un deber. Recordando con Fromm que: "homo consumens, el consumidor total, cuya única finalidad es tener más y usar más. Esta sociedad produce muchas cosas inútiles y, en igual proporción, mucha gente inútil”' (Fromm, 2008, p. 47).

El rescate de la praxis demuestra que el factor irrecuperable de tiempo y de la mortalidad humana dan un sentido sublime e integrador del trabajo, por ello no podrá apartarse de la esencia emancipatoria. Una escuela que no oriente en la materialización de la idea de trabajo como una potencialidad social humana para transformar entornos de manera positiva, como liberación y como esa fuerza complementaria 
individual y colectiva, es una escuela sometida a los trágicos, pero muy ocultos dictámenes de la opresión social.

Puede decirse con suma franqueza que, si bien sigue presentándose la idea de ver a la escuela como aparato ideológico del Estado y de reproducción del sistema, lo cual varios autores e investigadores definieron, la cuestión es que hoy más que esto, es un medio de experimentación y difusión del consumismo extremo en todos sus sentidos. Por ejemplo, el evacuar como "salchichas" a estudiantes graduándolos sin mirar consecuencias sociales, es responder a las demandas laborales del subcontrato o de simples consumidores de cosas. Las necesidades son de todos tipos no únicamente materiales, las hay psicológicas o espirituales, etc. La escuela tiende a consolidar las nuevas formas de explotación, ahora, en consumidores junto a la clásica afección social de la alienacion y la enajenación.

Se hace necesario incentivar el tema del trabajo entre los niños, adolescentes y jóvenes, en la formación en este ámbito ya que, el sistema educativo se ha centralizado solo en los temas académicos sin mirar los intereses de cada individuo en el tema laboral. El regreso de las artes, oficios y orientaciones profesionales con sentido social, deben volver a la escuela inmediata. Muchos individuos se gradúan -para el caso colombiano- sin ni siquiera tener los mínimos cognitivos, procedimentales ni comportamentalesciudadanía; siendo presa fácil de las amenazas de todo tipo que pululan en sociedades atrasadas. Lo académico no está siendo tomado en serio, pero tampoco la formación laboral independiente; esta confusión impide el desarrollo de la creatividad y el reconocimiento de la potencialidad para el trabajo. La formación en la cultura marxiana del trabajo, será un reto que difícilmente afrontará este sistema imperante que siempre verá consumidores y personal que venda su mano de obra para generar acumulación de capital privado.

\section{La presencia dialéctica de la escuela inmediata}

La escuela inmediata en la cual se presentan las características denunciadas por lo marxiano, no es una propuesta utópica en el sentido común del término. No es tampoco una metodología, es una materialización socio-historica que se muestra o intenta mostarse objetivamente pero que en realidad es subjetiva. Así, pensar las categorías como alienación, enajenación y praxis, allí materializadas por sus efectos sociales, se convierte en algo de interés desde una posición filosófica de la educación, permitiendo identificar lo inmediato lleno de inmediatez, lo cual impide desarrollar las pautas emancipatorias de la formación humana; pero que a la vez al ser identificada puede convertirse en oportunidad insoslayable.

La pedagogía del oprimido como aporte latinoamericano es fruto del constructo de necesidades de liberación socioeconómica y, por supuesto se convierte en propuesta política, e incluso geopolítica; es oportunidad. La escuela inmediata, a diferencia de la corriente de Freire, es un espacio histórico donde se dan las relaciones de poder a nivel micro y, con ellas, las amenazas latentes que se manifiestan a futuro, las cuales apenas serán percibidas o atendidas con inmediatez. Sin embrago, existe una relación teórica con la concepción de oprimido esgrimida magistralmente y cuyo basamento epistemológico es clave para sustentar la propuesta política de transformación en el seno de las prácticas lo cual complementa la postura de examinar el dialéctico sentido de la escuela inmediata. Sin embargo, en la escuela inmediata, es el docente quien debe reivindicarse como sujeto comprometido.

Esta socioexploración concluye con la propuesta de escuela inmediata como acontecimiento material, dialéctico y la cual pide ser abordada de la misma forma para superarla. Siendo el micro lugar donde se 
manifiestan las relaciones sociales y de conflictos de fuerzas poderes. La escuela inmediata es aquella que solo actúa en la premura del tiempo, la cual obedece a la inmediatez que impone el sistema social, político y económico imperante del subsistema capitalista dependiente que domina a la mayoría de los países de América Latina; por esto se presume la existencia de la escuela inmediata, no así su reconocimiento para afrontarla.

La escuela inmediata la componen las personas de carne y hueso que conllevan a su vez toda su voluntad y toda su vivencia, que puede ser ideológica o de conciencia. Sin embargo, las fuerzas externas -que también parten no de leyes sino de decisiones mortales- hacen presencia en la escuela inmediata para vigilarla, para moldearla, para seguir poniéndola a las órdenes del sistema imperante.

La escuela inmediata raya con lo oportuno. Lo oportuno tiene que ser radical para no quedarse en inmediatismos. Así, las acciones inmediatas no dejan lugar a la radicalidad (ir a la raíz) que debe darse, accionarse oportunamente y prolongarse como política acorde a las necesidades individuales y colectivas.

La escuela inmediata no es el simple reflejo -al estilo tratado en el tema de ideología- del sistema de cosas, sino manifestación-explicación de los efectos del sistema de cosas que a nivel macro afecta a lo micro en el acontecimiento escolar, tocando a todos los actores y fuerzas. La escuela inmediata deja ver que el aparente sin sentido que superficialmente parece verse con la incompetencia de un Estado y sus extensiones, no es otra cosa que una aplicación lógica que busca precisamente camuflarse; en otras palabras, la situación de crisis generada es una política generadora de una anti filosofía, del régimen que impere.

La educación de enfoque mercantilista y neoliberal apuntala a la reproducción de individuos inmediatos (alienados y enajenados), que sean garantes de la multiplicación material de idearios equivocados. A esto juegan los dos grandes sectores que administraran la educación en América Latina: el público y el privado. El sector público, donde reina la confusión y la cual sus apuestas por los retazos y la pusilaminidad encajonada a la burocracia estatal no dan luz de interesarse por orientar al sujeto como ser de transformación. Por su parte, el privado si bien en muchos casos pareciera riguroso, no lo es, pues su visión es la de mercancía hacia el sujeto; al regirse por la oferta y la demanda, se hace sospechosa de querer cambiar el sistema de cosas por obvias razones.

No es secreto, la escuela inmediata poco se preocupa por los contextos y las problemáticas dejadas por el sistema de cosas. El trato inmediatista sobre flagelos como lo son el alto consumo de sustancias alucinógenas y de alcohol entre los niños y adolescentes de los establecimientos públicos y privados, entre otros males; acrecienta la crisis socio-histórica en los países Latinoamericanos, ya que las políticas se limitan a tartar a la escuela como un mercado de contratos y de plusvalía ideológica.

La inmediatez tiene una aplicación muy actual en lo que es la obediencia a entes externos. Es el caso de la concepción de cobertura y calidad. Cumplir índices y cantidades se ve aplicado a la acumulación de personas en espacios físicos tangibles. Existe una particularidad que afecta muchísimo a las dinámicas educativas en todos los niveles, en especial en la educación básico y media; esto es: el número de educandos por aulas; hay que "ahorrar", es la máxima del Banco Mundial y el FMI. Esta situación se convierte en macro problema, bajo el pretexto de ser apertura, de no tener recursos para limitar el número de almas al interior de los cursos, etc. con esto se atenta contra el derecho a disfrutar de ambientes sanos y académicamente abiertos, que pudieran concomitar al desarrollo pleno de procesos para una formación adecuada y liberadora. Así mismo, la calidad se limita a las directrices de los índices de origen foráneo.

El riesgo es la absoluta implantación de la mentalidad inmediata de estilo inmediatista que ya predomina en las individualidades y colectividades. Esto determinaría una total alienación que caería muy bien al modo de producción que invalida cualquier intento de autonomía o rescate de la dignidad humana. La escuela 
inmediata, en su carácter negativo se prolonga en la sociedad, más allá de sus muros físicos en las diferentes esferas del mundo social y cotidiano. La escuela inmediata en su grado de oportunidad, será ejemplificación de superación de esa inmediatez asocial. Y es aquí donde el docente tendrá protagonismo.

El docente como miembro de un sector social y económico, puede llegar a ser actor principal en la búsqueda de superación siempre y cuando retome su valor como factor de transformación. Al reconocerse como profesional de la educación, orientador de la formación integral, podrá liderar procesos adecuados hacia la liberación del estudiante dentro de su entorno escolar y social. El factor docente será centralidad con perspectiva horizontal al interior de los procesos educativos.

La intervención política de esencia social en la escuela podrá dar razón de un interés efectivo, de una praxis comprometida con las transformaciones materiales. De lo contrario, la inmediatez será la "socio pandemia" anunciada en el siglo XXI para los países de la periferia. Ello se contrarrestará siempre y cuando la relación macro-micro/micro-macro se empiece a concretar en formas alternativas de gobierno micro y organización socio comunal; para esto la educación seguirá siendo a la manera marxiana, la única senda amable a trasegar en este mundo mortal. 


\section{BIBLIOGRAFÍA}

Abaggnano, Nicolás (1964). Historia de la pedagogía. México: Fondo de Cultura Económica.

Abaggnano, Nicolás (1994 a). Historia de la filosofía, Vol. I. Trad. de Juan Esterlich y J. Pérez B. Barcelona: Hora S.A

Abaggnano, Nicolás (1994 b). Historia de la filosofía, Vol. III; la filosofía del Romanticismo, La filosofía entre los siglos XIX y XX. Trad. de Juan Esterlich y J. Pérez B. Barcelona: Hora S.A

Abaggnano, Nicolás. Fornero, Giovanni (1994 c). Historia de la filosofía. Vol. IV, tomo I. Traducción de carlos Brriga y Manuela Pinottic. Barcelona: Hora S.A.

Abaggnano, Nicolás (1994 d). Historia de la filosofía. Vol. IV, tomo II. Barcelona: Hora S.A

Acha, Omar. D'antonio, Débora (Sf). Cartografía y perspectivas del "marxismo latinoamericano". Universidad de Buenos Aires. Recuperado de: http://www.ncsu.edu/acontracorriente/winter_10/articles/Acha_DAntonio.pdf

Aguirre, Manuel Agustín (1985). Marx ante América latina. Homenaje a Carlos Marx por el centenario de su muerte. Universidad Central: Quito.

Adorno, Theodor (1998). Educación para la emancipación. Madrid: Morata.

Afanasiev, Víctor (2000). Fundamentos de filosofía. México: Editores mexicanos unidos, S.A.

Agamben, Giorgio. (2001). Infancia e historia: destrucción de la experiencia y origen de la historia. Trad. de Silvio Mattoni. Buenos Aires: Adriana Hidalgo Editores S.A.

Alegre, J.P. (2014, marzo 4). Comunismo "Historia de una ilusión" Documental Completo (archivo de vídeo). Recuperado de, https://www.youtube.com/watch?v=JfGtfO9YvkE, en 3-11-2016

Alfaro, Héctor G. et al (1993). Filosofía de la educación hacia una pedagogía para América Latina. México: UNAM.

Aricó, José M. (2010). Marx y América Latina. Buenos Aires: Fondo de Cultura Económica.

Aricó, José M. (2011). Nueve lecciones sobre marxismo en política y economía. México: El Colegio de México.

Arndt, Andreas (2008). Actividad objetiva. El concepto de acción de Marx en su controversia con Hegel. En, Filosofía de la acción (Gustavo Leyva, editor). Madrid: Síntesis. Pp. 437-448

Arpini, Adriana (2006). Anibal Ponce: El trabajo de pensamiento. En, Araucaria, Revista Iberoamericana de Filosofía, Política y Humadidades. No. 16. Pp. 226-247

Arriarán Cuellar, Samuel (2014). Filosofía y praxis educativa según Adolfo Sánchez Vázquez. En, Revista Iberoamericana de Educación Superior. Volumen 5, Issue 13. Pp 143-156

Althusser, Louis (1971). La filosofía como arma de la revolución. Trad. de Oscar del Barco y Enrique Román. Córdoba: Pasado y Presente.

Althusser, Louis (1974). La revolución teórica de Marx. Trad. de Marta Harnecker. México: Siglo XXI. 
Althusser, Louis. Balibar, Etienne (1974). Para leer el capital. Trad. de Marta Harnecker. México: Siglo XXI.

Althusser, Louis (1989). Los aparatos ideológicos del Estado. Trad. México: Siglo XXI. Pp. 102-151. En pp.

Althusser, L. (2003). Ideología y aparatos ideológicos del estado. Buenos Aires: Nueva Visión.

Arndt, Andreas (2008). Actividad objetiva. El concepto de acción de Marx en su controversia con Hegel. En, Filosofía de la acción (Gustavo Leyva, editor). Pp. 437-448. Madrid: Síntesis.

Arrow, Kenneth J. (2004). Los valores y la toma de decisiones colectivas. En, Introducción, en Filosofía y teoría económica. Hahn, Frank. HOLLIS, Martin; compiladores. México: FCE. Pp. 218-250

Astarita, Rolando (Sf). Método dialéctico y Hegel I. disponible en https://rolandoastarita.wordpress.com/2012/01/02/metodo-dialectico-y-hegel-1/

Attali, J. (2007). Karl Marx o el espíritu del mundo. Trad. de Victor Goldstein. Buenos Aires: Fondo de Cultura Económica.

Azócar Añez, Ramón Eduardo (11/05/2015). La visión epistemológica de la educación. Aporrea. Disponible en, https://www.aporrea.org/educacion/a207491.html

\section{$\underline{\mathbf{B}}$}

Bachelard, Gaston (1973). Epistemología. Madrid: Anagrama.

Balibar, Etienne (2000). La filosofía de Marx. Trad. por Horacio Pons. Aires: Nueva Visión.

Baranger, D. (2004). Epistemología y metodología en la obra de Pierre Bourdieu. Buenos Aires: Prometeo.

Barylko, Jaime (2005). Marx y la importancia de la sociedad. En, La filosofía: una invitación a pensar. Buenos Aires: Booket. Pp. 189-202

Baudelot, Ch., Establet, Roger (1976). La escuela capitalista en Francia. México: Siglo XXI.

Bauman, Zygmunt (2002). La hermenéutica y las ciencias sociales. Trad. de Víctor M. Boyé. Buenos Aires: Nueva Visión.

Bello, Andrés (1951). Filosofía del entendimiento y otros escritos filosóficos. Caracas: MEN.

Berger, P. \& Luckmann, T. (1968). La construcción social de la realidad. Buenos Aires: Amorrortu Editores.

Bermudo, José Manuel (1975). El concepto de praxis en el joven Marx. Barcelona: Península.

Bernardini, A. \& Soto, J. (1984). La educación actual en sus fuentes filosóficas. San José: EUNED.

Bernstein, Basil (1993). Sociología de la Transmisión Cultural. Poder, Educación y Conciencia. Santiago: CIDE (reproducción realizada para funcionarios del SNP-ICFES V/97).

Betancourt, Mabel.; Puche, María Eugenia (1997). El proyecto pedagógico, facilitador de un aprendizaje significativo. Bogotá: Ministerio de Educación Nacional.

Bey, Hakim (1994). Inmediatism. San Francisco: AK.

Biblioteca Socialista Digital. Recuperado de: http://www.formacion.psuv.org.ve/categoria/biblioteca/ 
Blanco, C., Cabrera, A., Gaete, T. \& Pinilla, J.P. (2010). La evolución del constructivismo (desde una perspectiva constructivista). Revista Mad, 23: 43-54.

Bloch, Ernst (1983). El estudiante Marx. En, Karl Marx sin marxismo. Bogotá: Cuadernos de Iniciativas Obreras. Pp. 73-82

Bloch, Ernst (2004). El principio esperanza, Vol. 1. (Informe). Pequeños sueños diurnos. -

Trad. Felipe Gonzáles. Edición al cuidado de Francisco Serra. Madrid: Trotta.

Bloch, Ernst (2004). El principio esperanza, Vol. 2. (Construcción). Proyecciones de un mundo mejor (arte médico, sistemas sociales, técnica, arquitectura, geografía, perspectiva en el arte y la sabiduría) -Trad. Felipe Gonzáles. Edición al cuidado de Francisco Serra. Madrid: Trotta.

Bloch, Ernst (2004). El principio esperanza, Vol. 3. (Identidad). Imágenes desiderativas en el instante colmado (moral, música, imágenes de la muerte, religión, naturaleza oriental, sumo bien. Trad. Felipe Gonzáles. Edición al cuidado de Francisco Serra. Madrid: Trotta.

Bobbio, Norberto (2001). Ni con Marx ni contra Marx. Recuperado de: http://es.scribd.com/doc/154088860/Bobbio-Norberto-Ni-Con-Marx-Ni-Contra-Marx-Buenos-Aires-FCE

Bolívar, Simón (2007). La instrucción pública. En, Pensamiento pedagógico emancipador latinoamericano. Luis Damiani. Omaria Bolívar [Comp.]. Caracas: UBV. Pp. 38-43

Bonilla, Heraclio compilador (1991). Los Andes en la encrucijada. Quito: Libri-Mundi- FLACSO.

Bourdieu, Pierre (1979). Los tres estados del capital cultural. Recuperado de: http://sociologiac.net/biblio/Bourdieu-LosTresEstadosdelCapitalCultural.pdf

Bourdieu, Pierre. (2003). Capital cultura, escuela y espacio social. Buenos Aires: Siglo XXI.

Bourdieu. Pierre (1986). La escuela como fuerza conservadora: desigualdades escolares y culturales. La Nueva Sociología de la Educación. México: El Caballito.

Bowen, J. \& Hobson, P. (1979). Teorías de la educación: Innovaciones importantes en el pensamiento educativo occidental. México: Limusa.

Braudel, F. (1970). La historia y las ciencias sociales. Madrid: Alianza.

Broccoli, Angelo (1977). Antonio Gramsci y la educación como hegemonía. México: Patria S.A.

Broccoli, Angelo (1980). Marxismo y educación. Trad. de Silvia Tabachnik. México: Nueva Imagen.

Broccoli, Angelo (1977). Ideología y educación. Trad. de Silvia Tabachnik. México: Nueva Imagen.

Bruner, Jerome S. (1995). Desarrollo cognitivo y educación. Madrid: Morata.

Budgen, Sebastián. Kouvelakis, Stathis. Zizek, Slavoj (2010). Praxis. Lenin reactivado: Hacia una política de la verdad. Trad. José María Amoroto. Madrid: Akal. Pp. 189-193

Buenfil Burgos, Rosa Nidia (1991). Análisis de discurso y educación. México: DIE-CINVESTAV-IPN

$\underline{\mathbf{C}}$

Calvo, Tomás (1992). De los sofistas a Platón. Bogotá: Cincel. 
Canales Valenzuela, Iván Raimundo (2008). FILOSOFÍA DESDE EL HORIZONTE DE LA PRAXIS Desde la Inteligencia Sentiente (X. Zubiri) a las Estructuras de la praxis (A. González). pp. 1-25. Recuperado de: https://webcache.googleusercontent.com/search?q=cache:_qOtjCLStAEJ:https://ircav.files.wordpress.co $\mathrm{m} / 2008 / 08 /$ filosofia-desde-el-horizonte-de-la-praxis1.doc+\&cd=1\&hl=es\&ct=clnk\&gl=ve

Canfield, Martha (2009). Literatura hispanoamericana: historia y antología. Tomo I. Milán: Hoepli Editores.

Cantón Navarro, José (2008). Una Revolución martiana y marxista. La Habana: Centro de Estudios Martianos.

Cappelletti, Ángel J. (1987). Mitología y filosofía: los presocráticos. Bogotá: Cincel.

Cardona C., Francisco Luis (2002). Karl Marx. Madrid: Edilmat.

Carnoy, M. (1977). La educación como imperialismo cultural. Madrid: Siglo XXI.

Carnoy, M. (2010). La ventaja académica de Cuba. México: FCE.

Carucí, Nerliny (2009). La educación como praxis política y la pedagogía crítica que la rehace. Rescatado de, https://www.aporrea.org/educacion/a91192.html. En 20-04-2017

Casas, Ulises (1989). El socialismo en América, Capítulo IV, en El socialismo científico: vigencia histórica y futuro. Bogotá: Crear Arte. Pp. 144-174

Ceballos, Adalberto (2013). Los desafíos del marxismo contemporáneo. Veracruz: Universidad Veracruziana.

Ceballos Melguizo, Ramiro (2015). La razón rebelde. Pequeño tratado de la virtud crítica. Medellín:

Universidad de Antioquia.

CEDETRABAJO-IDEP (1997). Lecturas de filosofía. Bogotá: IDEP.

CEDIAL (1972). Los cristianos latinoamericanos y socialismo. Bogotá: CEDIAL.

Cerutti, Horacio (2006). Filosofía de la liberación latinoamericana. FCE.

Chateau, Jean, compilador (2013). Los grandes pedagogos. Trad. de Ernestina Champourcin México: FCE.

Chorurio Muñoz, Josá Alín. Meleán, Ramón Segundo (2008). Pensamiento e ideas pedagógicas de Célestine Freinet. En, REDHECS, edición 4. No. 3. Pp. 48-55

Chávez Frías, Hugo R. (2006). La unidad latinoamericana. Bogotá: Ocean Sur.

Chávez Frías, Hugo (2007). Moral y luces, la educación con valores socialistas. En, Pensamiento pedagógico emancipador latinoamericano. Luis Damiani. Omaria Bolívar [Comp.]. Caracas: UBV. Pp. 520- 536

Chavolla, Arturo (2005). La imagen de América en el marxismo. Guadalajara: Prometeo.

Chomsky, Noham (2002). La estructura emergente del orden mundial. Trad. por Norma i. Ojeda. Bogotá: UNAL.

Chomsky, Noham (2007). La (des)educación. Barcelona: Crítica.

CNN. (2008). Entrevista con Lipovetsky [Video]. Recuperadohttp://www2.milenio.com/node/20135

Cohan, Walter (1996). Filosofía de la educación. Algunas perspectivas actuales. Revista Aula, 8: 141-151.

Recuperado de: http://dialnet.unirioja.es/servlet/articulo?codigo=122535

Collingwood, R.G. (2006). Idea de la Naturaleza. México: Fondo de Cultura Económica. 
Comenius, Juan Amós (1986). Didáctica magna. Trad. de Saturnino López P. Madrid: Akal.

Comninel, George (2012). El concepto de emancipación en la obra temprana de Marx en Revista Internacional Marx Ahora, No. 33 de 2012. La Habana. Pp. 42-59.

Corsi, G., Esposito, E. \& Baraldi, C. (1996). Glosario sobre la teoría social de Niklas Luhmann. Mexico: Universidad Iberoamerican.

\section{$\underline{\mathbf{D}}$}

De Arismendi, Alcira Legaspi (1965). Pedagogía y marxismo. Montevideo: Pueblos Unidos.

De Lacroix, Luis Perú (2007). Diario de Bucaramanga. Caracas: El perro y la rana.

De Soussa Santos, Boaventura (2011). Las epistemologías del sur. México: FCE.

Del Noce, Augusto; Riestra, José A. (1975). Karl Marx, escritos juveniles. Madrid: Magisterio Español.

Del Valle, José Cecilio (1982). El educador. En, Obras escogidas. Caracas: Biblioteca Ayacucho. Pp. 87-136

Dietrich, Heinz (Sf.) El socialismo del siglo XXI. Recuperado de: https://www.rebelion.org/docs/121968.pdf

Dietrich, Thierich. (1976). Pedagogía socialista. Salamanca: Sígueme.

Dognin, P.D. (1975). Introducción a Karl Marx. Trad. de Joaquin Lepeley L. Bogotá: Génesis.

Dunayevskaya, Raya (1989). Filosofía y Revolución: De Hegel a Sartre y de Marx a Mao. Trad. México: Siglo XXI.

Durán -Cousin, Eduardo (1997). Comunismo, principio y fin de un sueño. Quito: Ediciones Abya-Yala.

Dussel, Enrique (1980). La Pedagógica Latinoamericana. Bogotá: Nueva América.

Dussel, Enrique (1985). La producción teórica de Marx, un comentario a los Grundrisse. México: Siglo XXI.

Dussel, Enrique (1995). Filosofía de la liberación. Mérida: Universidad de Los Andes.

Dussel, Enrique (1998). Hacia un Marx desconocido: Un comentario de los manuscritos del 61-63. México: Siglo XXI.

Dussel, Inés (2006a). Anales de la educación común. En, Tercer siglo, año 2, número 4. Filosofía política del currículum / agosto. Publicación de la Dirección General de Cultura y Educación de la Provincia de Buenos Aires, Dirección Provincial de Planeamiento. Pp. 95 a 105

Dussel, Enrique (2006). 20 tesis de política. Buenos Aires: CLACSO.

Dussel, Enrique (2010 a). El último Marx (1863-1882) y la liberación latinoamericana. Buenos Aires: CLACSO.

Dussel, Enrique (2010 c). La producción teórica de Marx: Un comentario a los Grundrisse. Buenos Aires: CLACSO.

Dussel, Enrique. Mendieta, Eduardo. Bohórquez, Carmen (2009). El pensamiento filosófico latinoamericano, del Caribe y "latino" (1300-2000). México: Siglo XXI.

DusselL, Enrique (2014a). 16 tesis de política. México: Siglo XXI 
Dussel, Enrique (2014b). Filosofía de la liberación. México: FCE.

$\underline{\mathbf{E}}$

Echeverría, Bolívar (2011). Crítica de la modernidad capitalista. La Paz: Vicepresidencia del Estado Plurinacional de Bolivia.

Echeverría, Rafael (Sf.). La ciencia presunta de Marx. Recuperado de:

https://books.google.com.co/books?id=mxOWBwAAQBAJ\&printsec=frontcover\&hl=es\&source=gbs ge _summary_r\&cad $=0 \# \mathrm{v}=$ onepage $\& \mathrm{q} \& \mathrm{f}=$ false

Einstein, Albert (2009). ¿Por qué el socialismo? Caracas: Ministerio para el Poder Popular para la Comunicación y la Información.

El Universal. "Por primera vez asumo el marxismo". Caracas, sábado 16 de enero de 2010. Disponible en, http://www.eluniversal.com/2010/01/16/pol art por-primera-vez-asu 1726209

Engels, F. (1892). Brief an Sorge. Berlín: MEW 38. P. 563

Engels, F. (1996). El origen de la familia, la propiedad privada y el Estado. Trad. ACL. Caracas: Fundamentos.

Engels, Federico. (1974). Carta a Werner Sombart. En, C. Marx \& F. Engels, Obras Escogidas, en tres tomos, Editorial Progreso, Moscú, 1974, págs. 532-534, 569. Recuperado de:

https://www.marxists.org/espanol/m-e/cartas/e11-3-95.htm

Engels, Friedrich (Sf.). Del socialismo utópico al socialismo científico. Bogotá: Los Comuneros.

Engels, Friedrich (1961). Dialéctica de la Naturaleza. México: Grijalbo.

Engels, Friedrich (1973). Anti Düring. En, La moral comunista. México: Ediciones de Cultura Popular.

Engels, Friedrich (1974). Carta a Konrad Schmidt en Berlín. Recuperado de, https://www.marxists.org/espanol/m-e/cartas/e27-x-90.htm

Engels, Federico (2006). Introducción a 'Dialéctica de la naturaleza' y Otros escritos Sobre Dialéctica. Madrid: Fundación Federico Engels.

Engels, F. (1976 a5). Principios del comunismo. En, Marx, C. Engels, F., Obras escogidas. Tomo I. Moscú: Progreso. Pp. 82- 98.

Engels, Frederich (1976b-1). Prefacio a La guerra campesina en Alemania. Prefacio a la segunda edición de 1870, en Marx C. \& Engels, F. Obras escogidas, Tomo II. Moscú: Progreso. Pp.167-18

Engels, Frederich (1976b-2). Contribución al problema de la vivienda. Segunda parte: como resuelve la burguesía el problema de la vivienda, en Marx C. \& Engels, F. Obras escogidas, Tomo II. Moscú: Progreso. Pp. 344-356

Engels, Frederich (1976c-1). Introducción a la "dialéctica de la naturaleza", en Marx C. \& Engels, F. Obras escogidas, Tomo III. Moscú: Progreso. Pp. 5-13

Engels, Frederich (1976c-2). Viejo prólogo para el [anti]-Dühring. Sobre la dialéctica, en Marx C. \& Engels, F. Obras escogidas, Tomo III. Moscú: Progreso. Pp.57-65. 
Engels, Frederich (1976c-3). El papel del trabajo en la transformación del mono en hombre, en Marx C. \& Engels, F. Obras escogidas, Tomo III. Moscú: Progreso. Pp. 66-79

Engels, Frederich (1976c-4). Del socialismo utópico al socialismo científico. Prólogo a la edición inglesa de 1892, en Marx C. \& Engels, F. Obras escogidas, Tomo III. Moscú: Progreso. Pp. 98-160.

Engels, Frederich (1976c-5). Discurso ante la tumba de Marx, en Marx C. \& Engels, F. Obras escogidas, Tomo III. Moscú: Progreso. Pp.171-173

Engels, Frederich (1976c-6). Ludwig Feuerbach y el fin de la filosofía clásica alemana, I., en Marx, C. \& Engels, F. Obras escogidas, Tomo III. Moscú: Progreso. Pp. 353-395

Engels, Frederich (1976c-7). Cartas Engels a W. Borgius, en Marx C. \& Engels, F. Obras escogidas, Tomo III. Moscú: Progreso. Pp. 530-532

Engels, Friedrich (1979). El origen de la familia, la propiedad privada y el Estado. Bogotá: Colombia Nueva.

Engels, Friedrich (1882). Lettre à E. Bernstein, 2-3 novembre, en l'Archive Iternet des Marxistes. Recuperado de: https://www.marxists.org/francais/engels/works/1882/11/fe18821102.htm\#toppage

Engels, F. (1984). Carta de Engels a Sombart, marzo de 1895, en Marx-Engels, Obras escogidas, tomo III. Moscú: Editorial Progreso. Pp. 534

Engels, Friedrich (1986). Ludwig Feuerbach y el fin de la filosofía clásica alemana. Moscú: Progreso.

Engels, Friedrich (1993). Frederick Engels' Speech at the Grave of Karl Marx (Highgate Cemetery, London. March 17, 1883). Recuperado de: https://www.marxists.org/archive/marx/works/1883/death/burial.htm Rescatado el 24-02-2017

Engels, Friedrich (1999). Karl Marx. (Seitenzahlen verweisen auf: Karl Marx/Friedrich Engels - Werke. (Karl) Dietz Verlag, Berlin. Band 19, 4. Auflage 1973, unveränderter Nachdruck der 1. Auflage 1962, Berlin/DDR. S. 96-106.) Recuperado de, http://www.mlwerke.de/me/me19/me19_096.htm , En 28-022017

Engels, Friedrich (2002). Dialéctica de la Naturaleza. La Habana: Pueblo y Educación.

Engels, Friedrich (2002). La situación de la clase obrera en Inglaterra. Recuperado de: https://www.marxists.org/espanol/m-e/1840s/situacion/

Engels, Friedrich (2003). La revolución de la ciencia por el señor Eugen Dühring, Anti - Dühring. Moscú: Instituto del Marxismo-Leninismo \& Editorial Progreso. Recuperado de, https://www.marxists.org/espanol/m-e/1870s/anti-duhring/ad-seccion1.htm\#xii, el 2-06-2016

Engels, Friedrich (2009). El papel del trabajo en la transformación del mono en hombre. Moscú: Progreso.

Engels, Friedrich (2014). La revolución de la ciencia por el señor Eugen Dühring, Anti - Dühring. Trad. Grupo de traductores de FFE. Madrid: Fundación Federico Engels.

Escalona, Julio (2016). Geopolítica de la liberación. Caracas: EL perro y la rana. 
Fallas, Luis A. (1994). Aspectos dialécticos en los primeros filósofos, en Revista de Filosofía. San José: Universidad de Costa Rica. Volumen XXXII - Número 77. Pp. 81-92

Fals Borda, Orlando (2003). La ciencia y el pueblo: nuevas reflexiones. En, Investigación acción participativa. inicios y desarrollos. Lima: Tarea. Pp. 65-84

Fazio Vengoa, Hugo (1994). Después del comunismo. La transición en Europa Central y Oriental. Santa fe de Bogotá: Tercer mundo-IEPRI.

Feinmann, José P. (2008). Qué es la filosofía. Buenos Aires: Prometeo.

Feinmann, José Pablo [Sociologandoabc] (2011-dic.-30). Filosofía y praxis: la dialéctica en el pensamiento de Marx. Recuperado de: https://www.youtube.com/watch?v=FcleCYVuilQ

Fernández Enguita, Mariano (1985). Trabajo, escuela e ideología: Marx y la crítica de la educación. Madrid: Akal.

Fernández Enguita, Mariano (1986 a). Marxismo y sociología de la educación.

Fernández Enguita, Mariano. Edit. (1986 b). Marxismo y educación. Madrid: Akal.

Fernández Fernández, José Antonio (2007). Paulo Freire y la educación liberadora. En, El legado pedagógico del siglo XX para la escuela del siglo XXI. Pp. 313-339

Ferreira Dos Santos, Laura (2003). Deseo y educación. En Educación y filosofía (Jean Houssaye, compilador). Buenos Aires: Eudeba. Pp.13-46.

Flórez, Rafael; (1986). Acevedo, Jairo; Bedoya, José, et. Al. Cuatro ensayos sobre pedagogía y saber. Medellín: Universidad de Antioquia.

Freinet, Celestine (1971). Educación por el trabajo. Trad. Margarita Michelena. México: FCE

Freinet, Celestine (1975a). Por una escuela del pueblo. México: Laia.

Freinet, Celestine (1975b). Técnicas Freinet de la escuela moderna. Trad. Julieta Campos. México: Siglo XXI.

Freinet, Celestine (1980). Hacia una pedagogía popular. Bogotá. Quimel.

Freire, Paulo (1971). Pedagogía del oprimido. Trad. no definida. Bogotá: Ediciones Camilo.

Freire, Paulo (1974). La educación como práctica de la libertad. Buenos Aires: Siglo XXI.

Freire, Paulo (1982). Pedagogía de la esperanza, un reencuentro con la pedagogía del oprimido. México. Siglo XXI.

Freire, Paulo (1994). La naturaleza política de la educación. Barcelona: Planeta.

Freire, Paulo (2005). Pedagogía del oprimido. México: Siglo XXI.

Freire, Paulo (2007). La antilogicidad y dialogicidad con matrices de teorías acción cultural antagónicas. En, Pensamiento pedagógico emancipador latinoamericano. Luis Damiani. Omaria Bolívar [Comp.]. Caracas: UBV. Pp. 260-312

Fromm, Erich (1989). Humanismo socialista. Traducción de Eduardo Goligorsky. México: Paidós. 
Fromm E. La revolución de la esperanza (2008) Ediciones Fondo de Cultura Económica, México D.F.

Fromm, Erich (2012). Marx y su concepto de hombre. México: FCE.

Foucault, M. (1992). Microfísica del poder. Madrid: Ediciones de la Piqueta.

\section{$\underline{\mathbf{G}}$}

Galeano Corredor, Janneth (2004). La concepción marxista de la educación (capt. 2). En, Experiencia como docente en un colegio privado de convenio de Ciudad Bolívar, Bogotá. Reflexiones sobre políticas educativas y la realidad académica de los jóvenes populares dentro del contexto de la globalización. Bogotá, UNAL. pp. 42-73

Galeano, Eduardo (2003). Las venas abiertas de América Latina. México: Siglo XXI.

Galeano, Eduardo (2007a). La contraescuela: traición y promesa del fin del milenio. En, Pensamiento pedagógico emancipador latinoamericano. Luis Damiani. Omaria Bolívar [Comp.]. Caracas: UBV. Pp. $393-401$

Galeano, Eduardo (2007b). Pedagogía de la soledad: lecciones de consumo. En, Pensamiento pedagógico emancipador latinoamericano. Luis Damiani. Omaria Bolívar [Comp.]. Caracas: UBV. Pp.369-392

Gandler, Stefan (2010). Conciencia y vida cotidiana en la filosofía de la praxis de Adolfo Sánchez Vásquez. En revista, Utopía y Praxis Latinoamericana Año 15. No 48 (enero-marzo. Pp. 11 - 23. Recuperado de: https://www.researchgate.net/publication/50285274_Conciencia_y_vida_cotidiana_en_la_Filosofia_de_la _praxis_de_Adolfo_Sanchez_Vasquez [accessed Jul 17, 2017].

Gantiva, Jorge (2005). Un ensayo sobre Gramsci. Bogotá: Magisterio.

Gantiva, Jorge (2008). Un ensayo sobre Gramsci. El sentido de la filosofía, de la política y la tarea del pensar. Caracas: Centro Internacional Miranda

Garabito, Indira Sol. Hernández, Geidy Morfa (2011). Telesur, en defensa de lo latinoamericano. La cultura de resistencia y liberación en los medios de comunicación masiva en Contribuciones a las Ciencias Sociales Abril, 2011. Recuperado de: http://www.eumed.net/rev/cccss/12/sgmh.htm

García, Camilo. Shakespeare, Marx y poder del dinero. El Espectador, Cultura, 6 e marzo, de 2015. Recuperado de, www.elespectador.com/noticias/cultura/shakespeare-marx-y-el-poder-del-dinero-articulo-547727, el 23 de abril de 2016

García, George I. (2005). Marx y Engels: la vida cotidiana como praxis. En, La producción de la vida diaria. Temas y teorías de lo cotidiano en Marx y Husserl. San José: Perro Azul. Pp. 23-55. Recuperado de, http://www.pensamientocritico.info/index.php/articulos-1/otros-autores2/marx-y-engels-la-vidacotidiana-como-praxis, en 10-06-2017

García Canclini, Néstor (2002). Culturas populares en el capitalismo. México: Grijalbo.

García Junceda, J.A. (1984) Uno y múltiple: La dialéctica de los contarios en Heráclito. Recuperado de: http://webcache.googleusercontent.com/searchq=cache:duepm4tjjQYJ:revistas.ucm.es/index.php/ASHF/a rticle/download/ASHF8484110029A/5147+\&cd=6\&hl=es\&ct=clnk\&gl=co 
García Márquez, Gabriel (1965). De viaje por los países socialistas. 90 días en la "Cortina de hierro". En, Revista Cromos [Pdf.]. Bogotá

García Morente, Manuel. (1994). Lecciones preliminares de filosofía. México: Porrúa.

García Morente, Manuel (1992). Análisis de la cultura europea, en Estudios y ensayos. México: Porrúa. Pp. 41 55.

García, M. \& García, J. (2012). Filosofía de la educación. Cuestiones de hoy y de siempre. Madrid: Narcea.

García Solana, Oscar (Sf.) Las pedagogías olvidadas. Los pedagogos rusos. Cuyo. Recuperado de: http://ww2.educarchile.cl/UserFiles/P0001/File/Pedagogos\%20rusos.pdf

Gemkow, Henrich (2010). Carlos Marx biografía completa. Buenos Aires: Omega-Alfa. Recuperado de: https://www.marxists.org/espanol/m-e/bio/carlos-marx-biografia-completa.pdf, en 23-02-2017

Giddens, Anthony (1994). Los escritos del joven Marx. En: El capitalismo y la moderna teoría

social, Primera parte: Marx, capítulo I. Barcelona: Labor. Pp. 31-55. Recuperado de: http://www.academia.edu/12114167/Los_Escritos_del_Joven_Marx.

Gil, F. (1997). Teoría sociológica de la educación. Bogotá: Editorial Nueva América.

Gimeno Sacristán, José (1994). El curriculum, una reflexión sobre la práctica. Madrid: Morata.

Gimeno Sacristán, José (2000). La educación obligatoria: su sentido educativo y social. Madrid: Morata.

Giroux, Henry y PENNA Anthony. (1971), "Social education in the classroom: The dynamics of the hidden curriculum", Theory and Research in Social Education, 7. Minneapolis. University of Minnesota

Giroux, Henry (2004). Teoría y resistencia en educación. Una pedagogía para la oposición. Trad. México: Siglo XXI.

Glasser, M. (1941). Cómo estudiaban Marx-Engels y sus discípulos. Montevideo: América.

Godelier, Maurice. Marx, Karl. Engels, Friedrich (1972). El modo de producción asiático. Barcelona: Martínez Roca.

Gómez, Margarita V. (2011). Levinas y Freire: la ética de la responsabilidad para la interacción cara-a-cara en la educación virtual. En Innovación Educativa, Vol.11, no. 57. Pp. 157-168. Recuperado de:

http://www.desarrolloweb.ipn.mx/sites/inovacion/Revistas/Documents/Revistas\%202011/Revista\%2057/ 15Levinas_y_Freire57.pdf

González, Antonio (Sf.) ¿Qué es la praxis? Disponible en, http://www.praxeologia.org/praxis.html Rescatado el 10-07-2017

González, Antonio (2012). Resurgimiento. Una ontología de la praxis.

González, Luis Armando (2015). El concepto de praxis en Marx: la unidad de ética y ciencia.[Pdf]. pp. 195226. Recuperado de,

http://www.uca.edu.sv/revistarealidad/archivo/4e737ae510d91elconceptodepraxis.pdf. En 10-06-2017

González, Mike (20-03-2012). Marx y la Comuna de París de 1871. Recuperado de:

http://2014.kaosenlared.net/kaos-tv/12016-marx-y-la-comuna-de-par\%C3\%ADs-de-1871 el 25-02-2016 
González Casanova, Pablo (1988). Sobre el marxismo en América Latina. Revista Dialéctica. Año XII, diciembre. No. 20. Pp. 7-17

González, Pedro. González, José Antonio (2007). Ludovico Silva: la alienación del tiempo libre en los Grundrisse de Karl Marx. (Tesis). Caracas: UCV.

Gould, Carol (1983). Ontología social de Marx. Individual y comunidad en la teoría marxista de la realidad.

GPM (2000). Hegel, Marx y la dialéctica. Madrid. (pdf). Recuperado de, http://www.nodo50.org/gpm/dialectica/todo\%20.pdf

Granese, Alberto (2003). Pensamiento crítico y educación. En Educación y filosofía (Jean

Gramsci, Antonio (1970). Introducción a la filosofía de la praxis. Trad. de Selección y traducción de J. SoléTura. Barcelona: Península.

Gramsci, Antonio (2001). La revolución contra El Capital. Recuperado de, https://www.marxists.org/espanol/gramsci/nov1917.htm en 20-12-2016

Gramsci, Antonio (2005). Antología. Trad. Manuel Sacristán. México: Siglo XXI.

Gramsci, Antonio (2007a). Material ideológico. En, Pensamiento pedagógico emancipador latinoamericano. Luis Damiani. Omaria Bolívar [Comp.]. Caracas: UBV. P. 453

Gramsci, Antonio (2007b). Pedagogía y política. En, Pensamiento pedagógico emancipador latinoamericano. Luis Damiani. Omaria Bolívar [Comp.]. Caracas: UBV. P. 464

Grevillot, Jean Marie. (1990). Las grandes corrientes del pensamiento contemporáneo. Madrid: Zig-zag.

Grüner, Eduardo (2004). Marx(ismo) y la praxis del conocimiento. Grupo Pensamiento crítico. Recuperado de: http://www.pensamientocritico.info/index.php/articulos-1/otros-autores2/marx-ismo-y-la-praxis-delconocimiento, Recuperado el 30-06-2017

Guadarrama, Pablo (1999). Bosquejo histórico del marxismo en América Latina en Despojado de todo fetiche. Autenticidad del pensamiento marxista en América Latina, Capítulo I. Pág 1-72. Bogotá: UNINCCA UCLV. Recuperado de:

http://www.archivochile.com/Ideas_Autores/guadarramapg/guadarramapg00001.pdf

Guadarrama, Pablo (2004). El pensamiento de la integración latinoamericana ante la globalización en Cuadernos Americanos. N. 103. Enero-febrero 2004. V. 1. p. 34-59; ISSN. 0185-156X. El cuervo. Universidad de Puerto Rico. No. 31, año 16 enero-junio 2004. Universidad Nacional Autónoma de México: México. P., 19-32.

Guadarrama, Pablo (2008). Pensamiento filosófico latinoamericano. Caracas: El perro y la rana.

Guadarrama, Pablo (2011). Dirección y asesoría de la investigación científica. Bogotá: Magisterio.

Guadarrama, Pablo (2013). Pensamiento filosófico latinoamericano. Humanismo, método e historia Tomo III. Bogotá: Planeta.

Guerra Borges, Alfredo (1991). La integración de América Latina y el Caribe: la práctica de la teoría. México: Instituto de Investigaciones Económicas, UNAM.

Guerra, José (2007). ¿Qué es el socialismo del siglo XXI? Caracas: Librorum. 
Guevara, Ernesto Che (1965a). Discurso de Argel. Recuperado de:

http://www.archivochile.com/America_latina/Doc_paises_al/Cuba/Escritos_del_Che/escritosdelche0077. pdf

Guevara, Ernesto (1965). El socialismo y el hombre en Cuba. Recuperado de, https://www.marxists.org/espanol/guevara/65-socyh.htm, 20-11-2016

Guevara De La Serna, Ernesto (2006). Síntesis biográfica de Marx y Engels, en Apuntes críticos a la Economía Política. México: Ocean Sur. Pp. 35-60

Guevara, Ernesto “Che” (2007a). Discurso en el Aditorium de la Universidad Central de Las Villas. En, Pensamiento pedagógico emancipador latinoamericano. Luis Damiani. Omaria Bolívar [Comp.]. Caracas: UBV Pp. 224-227.

Guevara, Ernesto "Che” (2007b). El Socialismo y el Hombre en Cuba. En, Pensamiento pedagógico emancipador latinoamericano. Luis Damiani. Omaria Bolívar [Comp.]. Caracas: UBV Pp.200-214

Guevara, Ernesto (2011a). "Notas para el estudio de la ideología de la Revolución Cubana, (diciembre de 1960) En Cuadernillo no. 1 de presentación Cátedra Che Guevara. Buenos Aires: Colectivo Amauta.

Guevara, Ernesto (2011b). "Sobre la teoría marxista y la necesidad de la formación política" [Fragmento de la reunión bimestral en el Ministerio de Industrias del 22/2/1964]. En Cuadernillo no. 1 de presentación Cátedra Che Guevara. Buenos Aires: Colectivo Amauta.

Guevara, Ernesto (2013). Apuntes filosóficos. Compilado por María del Carmen Ariet García. La Habana: Ciencias Sociales.

Gutiérrez, Francisco (2005). Educación como praxis política. México: Siglo XXI. Recuperado de: https://books.google.co.ve/books?id=3Cgefz2BthwC\&pg=PA38\&lpg=PA38\&dq=baudelot+y+establet+y +las+razones+del+aparato+escolar\&source=bl\&ots=PffDNdZKgu\&sig=Q6zJ1iOrJ14IocgXNc9YhzWt_ $9 \mathrm{w} \& \mathrm{hl}=\mathrm{es} \& \mathrm{sa}=\mathrm{X} \& \mathrm{ved}=0 \mathrm{ahUKEwiXwJC0iMDUAhXGO5oKHTRfBncQ6AEITDAF \# v=onepage \& q=ba}$ udelot $\% 20 \mathrm{y} \% 20$ establet $\% 20 \mathrm{y} \% 201 \mathrm{as} \% 20$ razones $\% 20 \mathrm{del} \% 20$ aparato\%20escolar \&f=false

Gutiérrez, Francisco (1988). Educación como praxis política. México: Siglo XXI.

Gutiérrez, Francisco (2005). Educar en la praxis. En, Educación como praxis política. México: Siglo XXI. Pp. 151-156

Guzmán, Nelson (31-05-2009). Ludovico Silva: Marxismo, ideología y revolución. Recuperado de:

Gramscimanía. Disponible en, http://www.gramscimania.info.ve/2009/05/ludovico-silva-marxismoideologia-y.html

Guzmán, Nelson (2017). El marxismo como teoría de la revolución. En, Tiempos de incertidumbre. Caracas. Fundarte. pp. 167-177

$\underline{\mathbf{H}}$

Habermas, Jürgen (1986). Ciencia y técnica como ideología. Trad. por Manuel Jiménez R. Madrid: Tecnos. Hadot, Pierre (1998). ¿Qué es filosofía antigua? México: Fondo de Cultura Económica. 
Hahn, Frank. HOLLIS, Martin; compiladores (2004). Introducción, en Filosofía y teoría económica. Trad.

Eduardo L. Suárez. México: FCE. Pp. 7-40

Halperín Donhi, Tulio (1981). Historia contemporánea de América Latina. Alianza Editorial.

Hamburgeur Fernández, Álvaro Andrés (2014). El socialismo del siglo XXI en América Latina: características, desarrollos y desafíos. En, Revista de Relaciones Internacionales, Estrategia y Seguridad. Universidad Militar Nueva Granada. Pp. 131-154

Harnecker, Marta (1971). Los conceptos elementales del materialismo histórico. Bogotá: Siglo XXI.

Harvey, David (Sf). Historia del neoliberalismo. Disponible en

http://www.extension.edu.uy/sites/extension.edu.uy/files/breve_historia_del_neoliberalismo._harvey.pdf o Akal. 2007

Hegel, George W. (1991). Escritos pedagógicos. Trad. e introducción de Arsenio Ginzo. Madrid: FCE.

Hegel, G.W. F. (2010). Fenomenología del espíritu. Versión bilingüe deutsch-castellano, trad. Antonio Gómez Ramos. Madrid: Abada-UNAM.

Hegel, George (1980). Lecciones sobre la filosofía de la historia universal. Madrid: Alianza Editorial.

Heinrich, Michael (2011). ¿Cómo leer el Capital de Marx? Madrid: Escolar y Mayo editores.

Heinrich, Michael (06-09-2016). Je ne suis pas marxiste. En, Marxismo crítico. Recuperado de, https://marxismocritico.com/2016/09/06/je-ne-suis-pas-marxiste-mh/. Rescatado en 25-04-2017

Heller, Claude (1980). El ejército como agente de cambio. México: FCE.

Heller, Agnes (1992). Historia y Vida Cotidiana. México: Grijalbo.

Hernández Salamanca, Oscar Gilberto (2013). La pedagogía socialista en la URSS: fundamentos para la configuración del individuo plenamente desarrollado. En, Rollos nacionales- nodos y nudo. volumen 4 N. 34 , enero - junio. Pp. 49-60

Herrera, W. (2005). Una defensa de la interpretación constructivista de la teoría moral kantiana. En: Herrera, W. \& Gamboa, C. (Editores). Kant: Defensa y Límites de la Razón. Bogotá: Universidad del Rosario, 99116.

Hinkelammert, Franz (1989). Teología del mercado total. La Paz: Hisbol.

Hinkelammert, Franz (2001). ¿Qué queda de Marx? Entrevista hecha por Benjamín Forcano y Manuel García Guerra pp. 84-94 . En Conversaciones y entrevistas con Franz J. Hinkelammert (hasta 2001) Editores José Duque/ Germán Guttiérrez DEI, San José Costa Rica, 2001. Recuperado de: http://webcache.googleusercontent.com/search?q=cache:jmu8ejJm6Y4J:www.pensamientocritico.info/in dex.php/libros/libros-de-franz-

hinkelammert/espanol\%3Fdownload\%3D10:Entrevistas\%2520y\%2520conversaciones\%2520con\%2520F ranz $\% 2520$ Hinkelammert+\&cd=1\&hl=es\&ct=clnk\&gl=co, 20-11-2015

Hinkelammert, Franz (2005). Hacia una economía para la vida. Ciudad: Editorial Departamento Ecuménico de Investigaciones (DEI).

Hobsbawm, Eric (2003). Historia del siglo XX. Barcelona: Crítica. 
Ho Chi Mihn (1930). Programa del Partido Comunista de Indochina. Recuperado de, https://www.marxists.org/espanol/ho/1930.htm en, 24-01-2017

Höffe, Otfried (2003). Breve historia ilustrada de la filosofía. Barcelona: Altaya.

Houssaye, compilador). Buenos Aires: Eudeba. Pp. 143-172

Hoyos V., Guillermo (2008). Filosofía de la educación. Trotta.

Huberman, Leo (1983). Los bienes terrenales del hombre (Historia de la riqueza de las naciones). Trad. Gerardo Dávila. México: Nuestro Tiempo.

\section{$\underline{\mathbf{I}}$}

Ibañez, José A. (2013). Para leer a Luhmann. México: Universidad Iberoamericana.

Imbernon, Francesc., Carretero R., Mario et al. (2007). El legado pedagógico del siglo xx para la escuela del siglo XXI. Jaume Trilla Bernet, coord. Barcelona: Graó.

Iliénkov, Evlad V. (2012). La lógica económica del socialismo. Quito: ER edithor.

Irenée, Henri (2004). Historia de la educación en la antigüedad. Madrid: Akal.

Izazaga, Luis Mauro (2011). Reflexiones sobre la filosofía de la educación. Filosofía y Educación. Perspectivas y propuestas. México: Universidad Autónoma de Puebla.

\section{J}

Jaeger, Werner (1944 a). Paideia. Los ideales de la cultura griega, Tomo I. México: Fondo de Cultura Económica.

Jaeger, Werner (1994 b). Paideia. Los ideales de la cultura griega, Tomo II. México: Fondo de Cultura Económica.

Jaeger, Werner (1994 c). Paideia. Los ideales de la cultura griega, Tomo III. México: Fondo de Cultura Económica.

$\underline{\mathbf{K}}$

Kagelmacher, Mónica. (2010). Los valores educativos en la posmodernidad: una propuesta desde la filosofía de la educación de Octavi Fullat. Tesis Doctoral. Barcelona: Universitat Ramón Lull. Recuperado de: http://www.tdx.cat/bitstream/handle/10803/32194/TESIS\%20FINAL.pdf;jsessionid=8666030319D2B63 CD76B2B46C1A2178A.tdx2? sequence $=1$

Kant, Emmanuel (1985). Tratado de pedagogía. Bogotá: Ediciones Rosaristas.

Kautsky, Carlos (1946). La doctrina económica de Marx. Trad. Anny Dell, Erba. Buenos Aires: Lautaro.

Kemmis, Stephen (1993). El curriculum: más allá de la teoría de la reproducción. Madrid: Morata.

Keneth, John (1976). Economía y subversión. Barcelona: Plaza y Janes. 
Kim Il Sung (1971). Obras escogidas III. Pyongyang: Ediciones en Lenguas Extranjeras.

Kinnen, Eduardo (1969). El humanismo social de Marx. Andrés Bello. Recuperado de:

https://books.google.com.co/books?id=pKvE2e6feskC\&pg=PA39\&dq=la+incomprensi\%C3\%B3n+de+m arX\&hl=es\&sa=X\&ved=0ahUKEwj14JeL_tXSAhXC5SYKHXpRCRgQ6wEIRjAI\#v=onepage\&q=la\%2 0incomprensi\%C3\%B3n\%20de\%20marx\&f=false

Kohan, Néstor (Sf.). Nuestro Marx. Recuperado de, http://www.cronicon.net/paginas/Documentos/No.44.pdf

Kohan, Néstor (1998). Marx en su (tercer) mundo: hacia un socialismo no colonizado. Buenos Aires: Biblos.

Kohan, Néstor (2011). "El Che Guevara y la filosofía de la praxis" (Capítulo del libro Ernesto Che Guevara: El sujeto y el poder. Buenos Aires, Nuestra América, 2005. páginas 20-51). En Cuadernillo no. 1 de presentación Cátedra Che Guevara. Buenos Aires: Colectivo Amauta.

Kohan, W. (1996). Filosofía de la Educación. Algunas perspectivas actuales. Aula, 8: 141-151. Recuperado de: http://www.researchgate.net/publication/41555756_Filosofa_de_la_Educacin_Algunas_perspectivas_actu ales

Kohan, Walter. O. (1998). Filosofía de la educación: a la busca de nuevos sentidos. Educacao e Filosofía, 12 (24) 91-121, jul./dez. Recuperado de: http://es.scribd.com/doc/58994684/articulo-kohan-fa-educacion

Kopnin, P.V. (1966). Lógica dialéctica. Versión al español de Lydia Kuper de Velasco. México: Grijalbo. Recuperado de: https://es.scribd.com/doc/232288814/122870253-Kopnin-Dialectica-de-La-Logica

Korschc, Karl (1978). Marxismo y filosofía. México: Ariel.

Kosik, Karel (1963). Dialéctica de lo concreto. México: Siglo XXI.

Kuhn, Thomas S. (1996). La estructura de las revoluciones científicas. Trad. Agustín Contini. México: FCE.

Kuusinen, Otto v. et al (1965). Manual de marxismo-leninismo. México: Grijalbo.

$\underline{\mathbf{L}}$

Labraña, Julio (2012). La educación como garantía de igualdad o desigualdad en la sociedad moderna:

Observación desde la teoría de sistemas sociales. En, Revista Mad, No. 26. Universidad de Chile, pp. 17 33. Recuperado de: file:///C:/Users/Claudinovic/Downloads/18894-57132-2-PB.pdf

Laclau, E. (1978). Política e ideología en la teoría marxista. Siglo XXI, México.

(1985). “Tesis acerca de la Forma Hegemónica de la Política”, en Hegemonía y alternativas políticas en América Latina. J. Labastida Martín Del Campo (comp.). Siglo XXI, México.

(1986). "Discurso, hegemonía y política: Consideraciones sobre la crisis del marxismo", en Los nuevos procesos sociales y la política contemporánea. J. Labastida Martín Del Campo. Siglo XXI, México.

Laclau, Ernesto. Chantal, Mouffe (2004). Hegemonía y estrategia socialista. Buenos Aires: FCE

Lafargue, Paul (1890-1891). Recuerdos de Marx. En, Fromm E. (2012). Pp. 233-252

Lander, Edgardo (2000). La colonialidad del saber: eurocentrismo y ciencias sociales. Perspectivas Latinoamericanas. Buenos Aires: CLACSO. 
Laqueur, Walter (1994). La Europa de nuestro tiempo. Desde el final de la Segunda Guerra Mundial hasta la década de los 90. Buenos Aires: Vergara.

La República (16-11-2017). Según el BID, América Latina y el Caribe destina 5,1\% del PIB en gasto a educación.Recuperado de, https://www.larepublica.co/globoeconomia/segun-el-bid-america-latina-y-elcaribe-destina-51-del-pib-en-gasto-a-educacion-2544622

Ledesma Reyes, M. (1997). Simón Rodríguez, Martí y Hostos. Una pedagogía para la independencia de los pueblos latinoamericanos. En, Ensayo y error, año VI, vol. 12 -13. UNESR. Pp. 21-36

Lefebvre, Henri (1956). Para conocer el pensamiento de Karl Marx. París: Nouvelle édition.

Lefebvre, Henri (1961). Introducción al marxismo. Buenos Aires: Eudeba.

Lenin, V. I. (1909). Materialismo y empiro- criticismo. Recuperado de, https://www.marxists.org/espanol/lenin/obras/1908/mye/index.htm

Lenin, V.I. (1968). El Estado y la revolución. Pekin: Ediciones en lenguas extranjeras.

Lenin, Vladimir (1973). La lucha de los pueblos de las colonias de los países dependientes contra el capitalismo. Moscú: Progreso.

Lenin, Vladimir (1980). Tres fuentes y tres partes integrantes del marxismo. En, Colección VI. Lenin, Marx, Engels y marxismo. Pekin: Ediciones en lenguas extranjeras. Pp. 73-80

Lenin, Vladimir (1997). La doctrina de Marx. En, Lecturas de filosofía. Bogotá: IDEP-Cedetrabajo. Pp. 54-59

Lenin, V.I. (2000). Carlos Marx (Breve esbozo biográfico, con una exposición del marxismo). Recuperado de: https://www.marxists.org/espanol/lenin/obras/1910s/carlos_marx/carlosmarx.htm el 20-02-2016

Lenin V. I. (2010). ¿Qué hacer? Caracas: Ministerio del Poder Popular para la Comunicación y la Información.

León Pesántez, Catalina (2013). El color de la razón: Pensamiento crítico en las américas. Quito: Corporación Editora Nacional.

Levitas, Maurice (1978). El Marxismo y la sociología de la educación. México: Siglo XXI.

Lewis, John (1989). El marxismo de Marx. México: Nuestro Tiempo.

Lichtensztejn, S. (2009). Nuevas políticas económicas de la izquierda en América Latina. Veracruz:

Universidad Veracruzana. Recuperado de:

http://www.uv.mx/iieses/files/2013/05/13_Nuevas_politicas_economicas_de_izquierda_en_america_latin a2.pdf

Lipovetsky, G. (2000). La era del vacío. Barcelona: Anagrama.

Llopis, Carmen; Carral, Clemente (1984). Las ciencias sociales en el aula. Madrid: Narcea.

López Arnal (Ed.) (2015). En las cercanías del 5 Mayo. Una antología de Manuel Sacristán sobre Karl Marx.

Recuperado de: http://www.rebelion.org/docs/198543.pdf , el 5-05-2016

Lowy, Michael et al. (1975). Sobre el método marxista. México: Grijalbo.

Löwy, Michael (1982). El marxismo en América Latina. Antología desde 1909 hasta nuestros días. México: Era. 
Lowy, Michael (2003). Progreso destructivo: Marx, Engels y la ecología. Recuperado de, https://marxismocritico.files.wordpress.com/2012/01/progreso-destructivo-marx-engels-y-laecologc3ada.pdf

Löwy, Michael (2011). "La filosofía del Che", Primera parte del libro El pensamiento del Che Guevara, pp. 7 36. En Cuadernillo no. 1 de presentación Cátedra Che Guevara. Buenos Aires: Colectivo Amauta.

Luhmann, N. \& Eberhard, G. (1993). El sistema educativo: problemas de reflexión. México: Universidad de Guadalajara.

Luhmann, N. (1996). La educación como sistemas. Buenos Aires: Paidós.

Luhmann, Niklas (2010). La sociedad de la sociedad. México: Herder.

Lukács, Georg (1970). Historia y conciencia de clase. La Habana: Ciencias Sociales.

Lukacs, Gyorgy (1970a). El joven Hegel y los problemas de la sociedad capitalista. México: Grijalbo.

\section{$\underline{\mathbf{M}}$}

Madriz, Gladys (2012). Vivencia, acontecimiento y alteridad en el acontecimiento de aula. En, Amor, violencia y formación. Hermenéuticas de escrituras y lecturas. Caracas: Fundarte. Pp. 179-196

Magallón, Mario (2005). Filosofía de la educación para la liberación en la América Latina del siglo XXI: entender la realidad del siglo XX y su proyección hacia el siglo XXI a través del lenguaje. En, Revista de Estudios Latinoamericanos, No. 40. Pp. 55-72. Recuperado de: http://www.redalyc.org/articulo.oa?id=64004003

Magendzo, A. Donoso, P. (1992). Teorías del currículo y concepciones curriculares. En, Diseño Curricular Problematizador: Una opción para la elaboración del currículo en Derechos Humanos desde la pedagogía crítica. Santiago: Sed.

Manacorda, Mario Alighiero (1979). Marx y la pedagogía moderna. Trad. Prudencia Comes. Barcelona: Oikos.

Manacorda, Mario Alighiero (1987). Historia de la educación, Vol. 1. De la antigüedad al 1500. Trad. Miguel Martí. México: Siglo XXI.

Manacorda, Mario Alighiero (1987). Historia de la educación, Vol. 2. Del 1500 a nuestros días. Trad. Miguel Martí. México: Siglo XXI.

Makarenko, Antono (Sf.) Poema pedagógico. Recuperado de: file://C:/Users/User/Downloads/poemapedagogico.pdf

Makcovic, Milhailo (1968). Dialéctica de la praxis. Buenos Aires: Amorrortu.

Mao Tse Tung (1968). Cinco tesis filosóficas en Obras Escogidas, Ediciones en Lenguas Extranjeras, Tomo I. Pekín: Editorial del Pueblo. Pp. 317-32.

Marcuse, Herbert (1969). Marx y el trabajo alienado. Trad. Marcelo Pérez Rivas. Buenos Aires: Carlos Pérez.

Marcuse, Herbert (1971). El marxismo soviético. Trad. Juan M. De la Vega. Madrid: Alianza Editorial. Pp. 157-158. 
Marcuse, Herbert (1979). La sociedad industrial y el marxismo. Trad. Alberto José Massolo. Buenos Aires: Quintaria.

Marcuse, Herbert (1993a). El hombre unidimensional. Ensayo sobre la ideología de la sociedad industrial avanzada. Trad. Antonio Elorza. México: Planeta-Agostini.

Marcuse, Herbert (1993b). Razón y Revolución. Trad. Julieta Fombona de Sucre y Francisco Rubio Ll. Madrid: Alianza Editorial.

Mariategui, José C. (1959). Defensa del marxismo. Lima: Amauta.

Mariátegui, José Carlos (2007a). El proceso de instrucción pública. En, Pensamiento pedagógico emancipador latinoamericano. Luis Damiani. Omaria Bolívar [Comp.]. Caracas: UBV. Pp. 146- 157

Mariátegui, José Carlos (2007b). Ética y socialismo. En, Pensamiento pedagógico emancipador latinoamericano. Luis Damiani. Omaria Bolívar [Comp.]. Caracas: UBV. Pp. 134-139

Marín, José (2003). Globalización, diversidad cultural y práctica educativa. En, Revista Diálogo Educacional, Vol. 4, No. 8. Pp. 1-22. Recuperado de: http://www.redalyc.org/pdf/1891/189118046002.pdf

Markovic, Mihailo (1978). El Marx contemporáneo. México: FCE.

Martí, José (1939). Nuestra América. Buenos Aires: Losada S.A.

Martí, José (2009). Obras completas Edición crítica, Tomo I 1862-1876, Cuba, España y México. La Habana: Centro de Estudios Martianos.

Martí, José (2007). Con todos y para el bien de todos. En, Pensamiento pedagógico emancipador latinoamericano. Luis Damiani. Omaria Bolívar [Comp.]. Caracas: UBV. P. 99

Martí, José (2007). Educación popular. En, Pensamiento pedagógico emancipador latinoamericano. Luis Damiani. Omaria Bolívar [Comp.]. Caracas: UBV. P. 108

Martí, José (sf.). Nuestra América. Recuperado de http://biblioteca.clacso.edu.ar/ar/libros/osal/osal27/14Marti.pdf

Martínez, Francisco José (2002). Epistemología marxista. Trascripción realizada por Igor Sádaba. Madrid: Universidad Complutense. Recuperado de: http://pendientedemigracion.ucm.es/info/eurotheo/materiales/hismat/fjmar. En 30-011-2015,

Martínez, Rigoberto (Sf.). ¿Es la alienación una problemática marxista? Un desafío para repensar el marxismo en el nuevo milenio. México: PDF

Martínez, Sergio (2005). Constructivismo y filosofía de la educación. En, Martínez, S. \& Guillaumin, G. Historia, filosofía y enseñanza de la ciencia. México: UNAM. Recuperado de, http://www.cad.unam.mx/programas/actuales/cursos_diplo/diplomados/uaem/00_cont/09_material/materi al/04_qui/12_y_17_Historia.pdf

Martínez Boom, Carlos Alberto (2012). Verdades y mentiras sobre la escuela. Bogotá: IDEP.

Marx, Carlos (1849). Trabajo asalariado y capital. Bogotá: Marat. 
Marx, Carlos (1852). Carta a Joseph Weydemeyer. Recuperado de: https://www.marxists.org/espanol/me/cartas/m5-3-52.htm

Marx, Carlos (1976 a). El Capital, critica a la economía Política, tomo I. Traducción de Wenceslao Roces. México: Fondo de Cultura Económica.

Marx, Carlos (1976 a1). Discurso pronunciado en la fiesta del aniversario del People's Paper. En, Marx, C. Engels, F., Obras escogidas. Tomo I. Moscú: Progreso. Pp. 513- 515.

Marx, Carlos (1976 a3). Futuros resultados de la dominación británica en la India. En, Marx, C. Engels, F., Obras escogidas. Tomo I. Moscú: Progreso. Pp. 506- 512

Marx, Carlos. (1976 a6). Prólogo a la Contribución a la Crítica de la Economía Política. En, Marx, C. Engels, F., Obras escogidas. Tomo I. Moscú: Progreso. Pp. 516- 520

Marx, Carlos (1976 b). El Capital, crítica a la economía Política, tomo II. Traducción de Wenceslao Roces. México: Fondo de Cultura Económica.

Marx, Carlos (1976 b-3). Manifiesto Inaugural de la Asociación Internacional de los Trabajadores, en Marx C. \& Engels, F. Obras escogidas, Tomo II. Moscú: Progreso. Pp. 5-13

Marx, Carlos (1976 b-4). Carta a Lincoln, en Marx C. \& Engels, F. Obras escogidas, Tomo II. Moscú: Progreso. Pp. 18-19

Marx, Carlos (1976 b-5). Sobre Proudhon (Carta a J. B. Schweitzer) en, Marx C. \& Engels, F. Obras escogidas, Tomo II. Moscú: Progreso. Pp. 20-27

Marx, Carlos (1976 b-6). Salario, precio y ganancia, en Marx C. \& Engels, F. Obras escogidas, Tomo II. Moscú: Progreso. Pp. 28-76

Marx, Carlos (1976 b-7). Instrucción sobre diversos problemas a los delegados. Del Consejo Central Provisional, en Marx C. \& Engels, F. Obras escogidas, Tomo II. Moscú: Progreso. Pp. 77-86

Marx, Carlos (1976 b-8), La Guerra Civil en Francia, en Marx C. \& Engels, F. Obras escogidas, Tomo II. Moscú: Progreso. Pp. 214-259

Marx, Carlos (1976 b-9). Carta a Ludwig Kugelmann, en Marx C. \& Engels, F. Obras escogidas, Tomo II. Moscú: Progreso. Pp. 442-443

Marx, Carlos (1976 c). El Capital, crítica a la economía Política, tomo III. Traducción de Wenceslao Roces. México: Fondo de Cultura Económica

Marx, Carlos (1982a). Escritos de juventud, tomo I. Trad. de Wenceslao Roces. México: Fondo de Cultura Económica.

Marx, Carlos (1982b). Escritos de juventud, tomo II. Trad. de Wenceslao Roces. México: Fondo de Cultura Económica.

Marx, Carlos (1982b-1). Crítica del derecho del Estado de Hegel. En, Escritos de juventud, tomo II. Trad. de Wenceslao Roces. México: Fondo de Cultura Económica. Pp. 319-438

Marx, Carlos (1982b-4). Crítica de la filosofía del derecho de Hegel. En, Escritos de juventud, tomo II. Trad. de Wenceslao Roces. México: Fondo de Cultura Económica. Pp. 491-502 
Marx, Carlos (1982c). Manuscritos económico - filosóficos de 1844. En, Obras fundamentales tomo I. México: FCE

Marx, Eleanor (2014). Karl Marx. notas dispersas. En Como era Carlos Marx, Visto por quienes lo conocieron (Selección de textos). Recuperado de, https://www.marxists.org/espanol/marx-eleanor/sf/nota.htm en 2402-2017 Editorial Progreso:

Marx, Carlos. Engels, Federico (1972). Correspondencia. Buenos Aires: Cartago.

Marx, Carlos. Engels, Federico (1976 a). Obras escogidas. Tomo I. Moscú: Progreso. Pp. 513- 515

Marx, Carlos. Engels, Federico (1976 a2). Feuerbach. Oposición entre las concepciones materialista e idealista (Primer Capítulo de La Ideología Alemana). En, MARX, C. ENGELS, F., Obras escogidas. Tomo I. Moscú: Progreso. Pp. 11-81.

Marx, Carlos. Engels, Federico (1976 a4). Manifiesto de Partido comunista. Marx, C. Engels, F., Obras escogidas. Tomo I. Moscú: Progreso. Pp. 99- 140.

Marx-Engels (Sf.) Articles by Marx and Engels in New York Daily Tribune. Marxists Internet Archive Encyclopedia. Recuperado de; https://www.marxists.org/archive/marx/works/subject/newspapers/newyork-tribune.htm en 20-02-2017

Marx, Carlos. Engels, Federico. (1976 a). Obras escogidas. Tomo II. Moscú: Progreso.

Marx, Carlos. Engels, Federico. (1976 b). Obras escogidas. Tomo III. Moscú: Progreso.

Marx, Carlos. Engels, Federico (1972). Sobre arte y literatura. Bogotá: sin editorial.

Marx, Carlos. Engels, Federico (2006). Las revoluciones de 1848. Trad. de Wenceslao Roces. Selección de artículos de la Gaceta Renana. Prólogo de Alberto Cue. México: FCE.

Marx, Karl (1845). Thesen uber Feuerbach [ed. 1978]. Recuperado de, https://www.marxists.org/deutsch/archiv/marx-engels/1845/thesen/thesfeue.htm

Marx, Karl (1932) Introducción al materialismo dialéctico y al socialismo científico. Madrid: Aguilar.

Marx, Karl (1971a). El capital, crítica de la economía política. Libro I, Capítulo VI, inédito. Traducción de Pedro Scaron. México: Siglo XXI.

Marx, Karl (1971b). Teoría marxista del método. Medellín: Tiempo Crítico.

Marx, Karl (1972). Elementos fundamentales para la crítica de la economía política. Volumen 2. Trad. de Pedro Scaron. Buenos Aires: Siglo XXI.

Marx, Karl (1975). El capital, crítica de la economía política. Libro I, vol. I. Trad. de Pedro Scaron. México: Siglo XXI.

Marx, Karl (1976). Glosas marginales para del Tratado de A. Wagner. En, Estudios sobre el capital. Trad. de José Aricó, et. al. Madrid: Siglo XXI. Pp. 169-184

Marx, K. (1977). La génesis del capital. La llamada acumulación originaria en, el capital. Capítulo XXIV. Moscú: Progreso. Pp. 3-73

Marx, Karl (1979). Las luchas de clases en Francia de 1848 a 1850. Moscú: Progreso.

Marx. Karl (1980). Contribución a la crítica de la economía política. Buenos Aires: Siglo XXI. 
Marx, Karl (1984 a). El Capital, I. Barcelona: Orbis.

Marx, Karl (1984 b). El Capital, II y III. Barcelona: Orbis.

Marx, Karl (1984). El capital, crítica de la economía política. El proceso de producción de capital. Tomo I (libro), vol. II. Trad. de Pedro Scaron. México: Siglo XXI.

Marx, Karl (1986). Capital y crisis. Pedro López D., editor. México: Quinto Sol

Marx. Karl (1989). Contribución a la crítica de la economía política. Traducción al ruso por Marat Kuznetsov; al español por Editorial Progreso. Moscú: Progreso.

Marx, Karl (1997a). El capital, crítica de la economía política. Libro II, vol. 4. Trad. de Pedro Scaron. México: Siglo XXI.

Marx, Karl (1997b). El capital, crítica de la economía política. Libro II, vol. 5. Trad. de Pedro Scaron. México: Siglo XXI.

Marx, Karl (1997c). El capital, crítica de la economía política. Libro III, vol. 6. Trad. de Pedro Scaron. México: Siglo XXI.

Marx, Karl (1997d). El capital, crítica de la economía política. Libro III, vol.7. Trad. de Pedro Scaron. México: Siglo XXI.

Marx, Karl (1997e). El capital, crítica de la economía política. Libro III, vol. 8.Trad. de Pedro Scaron. México: Siglo XXI.

Marx, Karl (1999). Miseria de la filosofía. Contestación a la filosofía de la miseria de Proudhon. Trad. José mesa. Villatuerta: Folio.

Marx, Karl (1999a). Capital, trabajo y plusvalía. Madrid: Longseller.

Marx, Karl (2000a). Crítica del Programa de Gotha. Recuperado de: https://www.marxists.org/espanol/me/1870s/gotha/gothai.htm

Marx, K. (2000b). El dieciocho Brumario de Luis Bonaparte. Recuperado de: Marxists archive. Abril. Preparada por Juan R. Fajardo. MIA.

Marx, Karl (2001). Manuscritos económico-filosóficos de 1844.recuperado de: https://pensaryhacer.files.wordpress.com/2008/06/manu scritos-filosoficos-y-economicos-1844karlmarx.pdf

Marx, Karl (2004a). Diferencia entre la filosofía de la naturaleza de Demócrito y la de Epicuro. México: Sexto Piso.

Marx, Karl (2004b). Manuscritos económico-filosóficos de 1844. Buenos Aires: Colihue.

Marx, Karl (2006a). Elementos fundamentales para la crítica de la economía política (Grundrisse) 1857-1858, vol. 2. Trad. Pedro Scaron. México: Siglo XXI.

Marx, Karl (2006b). Elementos fundamentales para la crítica de la economía política. Borrador 1857-1858. Vol. III. Trad. Pedro Scaron. México. Siglo XXI. (Grundrisse) 
Marx, Karl (2007). Elementos fundamentales para la crítica de la economía política. Borrador 1857-1858. Vol. I. Trad. Pedro Scaron. México. Siglo XXI. (Grundrisse)

Marx, Karl (2007confirmar). Elementos fundamentales para la crítica de la economía política. Borrador 18571858. Vol. II. Trad. Pedro Scaron. México. Siglo XXI. (Grundrisse)

Marx, Karl (2008). Contribución a la crítica de la economía política. Biblioteca del pensamiento socialista. México: Siglo XXI.

Marx, Karl (2009). El Capital, Libro I-Capítulo VI, Inédito. Resultados del proceso inmediato de producción.Trad. Pedro Scaron. México: Siglo XXI editores.

Marx, Karl Heinrich (2012). Cuadernos de Spinoza. Trad. y estudio preliminar por Nicolás González V. España: Montesinos.

Marx, Karl (2012a). Manuscritos económicos y filosóficos. Trad. de Julieta Campos. En Marx y su concepto de hombre, de Erich Fromm (2012). Pp. 97-201. México: FCE.

Marx, Karl (2012b). La ideología alemana en Marx. Trad. de Julieta Campos. En Marx y su concepto de hombre, de Erich Fromm (2012). México: FCE. Pp. 205-226.

Marx, Karl (2012 c). De la Introducción a la Crítica de la filosofía del derecho de Hegel. Critica de la religión 1, tomada de La sagrada familia. México: Grijalbo. Pp. 9, 10 y 11. T Pp. 230

Marx, Karl (2012c). Prólogo De La Contribución A La Critica De La Economía Política, en Marx. Trad. de Julieta Campos. En Marx y su concepto de hombre, de Erich Fromm (2012). Pp. 227-229. México: FCE.

Marx, Karl (2012 d). Kritik des Gothaer Programms. Recuperado de, https://marxwirklichstudieren.files.wordpress.com/2012/11/kritik-gothaer-programm.pdf

Marx, Karl (2013a). El capital, crítica de la economía política. El proceso de producción de capital. Tomo I (libro), vol. 3. Trad. de Pedro Scaron. México: Siglo XXI.

Marx, Karl (2013b). El capital, crítica de la economía política. Tomo I (libro), vol. 3. Trad. de Pedro Scaron. México: Siglo XXI.

Marx-Engels (2007). Fundamentos teóricos del pensamiento crítico latinoamericano. Carlos Marx y Federico Engels: dialéctica, educación y práctica social. En, Damiani, Luis y Bolívar, Omaira [comps.]. Pensamiento pedagógico emancipador latinoamericano. Caracas: UBV. Pp. 405-438

Marx, Karl ( ). Manuscritos económicos y filosóficos en Marx. Moscú: Progreso. Pp. 95-201.

Marx, Karl. Engels, Friedrich (Sf.). Manifiesto del Partido comunista. Rescatado en: https://www.marxists.org/espanol/m-e/1840s/48-manif.htm

Marx, Karl. Engels, Friedrich (Sf). Marx-Engels: correspondance. L'Archive Internet des Marxistes. Disponible en, https://www.marxists.org/francais/marx/correspondance.htm

Marx, Karl. Engels, Friedrich (1932). El Manifiesto Comunista. Madrid: Cenit.

MARX, Karl. ENGELS, Friedrich (1971). Über Erziehung und Bildung. Berlin: Gebundene Ausgabe

Marx, Karl. Engels, Friedrich (1972). Materiales para la historia de América Latina. Traducción de Pedro Scaron. Córdoba: Pasado y Presente. 
Marx, Karl. Engels, Friedrich et al (1973). La moral comunista. México: Ediciones de Cultura Popular.

Marx, Karl. Engels, Friedrich (1973 a). Cartas sobre las ciencias de la naturaleza y las matemáticas. Trad. Joaquin Jordá. Barcelona: Anagrama.

Marx, Karl. Engels, Friederich (1974). Tesis sobre Feuerbach. Madrid: Grijalbo.

Marx, Karl, Engels, Friederich. (1977). Textos sobre educación y enseñanza. Editor, Alberto Corazón. Madrid: Alberto Corazón.

Marx, Karl. Engels, Friederich (1994). La ideología alemana. Valencia: Universitat de València.

Marx, Karl. Engels, Friedrich (2003). Escritos sobre literatura. Trad. por Fernanda Aren et. al. Buenos Aires: Calihue.

Marx, Karl. Engels, Friedrich (2008). Manifest der Kommunistischen Partei. Amsterdam: Metalibri.

Marx, Karl. F. Engels (2009). El Capital, Crítica a la economía política. Libro III. "El Proceso global de la producción, capitalista”, Vol. 6. Trad. León Names. México: Siglo XXI editores.

Marx, Karl. Engels, Friedrich (2011). El Manifiesto Comunista. México: Centro de Estudios Socialistas.

Marxists Internet Archive (Sf.). Obras completas de Marx y Engels. Versión poliglota. Recuperado de: https://www.marxists.org/espanol/index.htm

Massè, Carlos (2007). El sistema de la educación en Luhmann desde una perspectiva crítica. Cinta de Moebio. .En Revista de Epistemología en Ciencias Sociales, 30, pp. 296-308 recuperado de: http://www.facso.uchile.cl/publicaciones/moebio/30/masse.pdf

Mays Vallenilla, Ernesto (Sf.). El problema de América. México: UNAM.

Mc. Laren, Peter (Sf.). Pedagogía crítica, humanismo marxista y transformaciones en Latinoamérica. Recuperado de: http://www.herramienta.com.ar/herramienta-web-6/peter-mclaren-entrevistadopedagogia-critica-humanismo-marxista-y-transformaciones

Mc. Laren, Peter (2001). Che Guevara, Paulo Freire y la pedagogía de la revolución. Prólogo de Ana Maria Araújo Freire. Trad. María Guadalupe Benítez Toriello. México: Siglo XXI.

Mc. Laren, Peter. Farahmandpur, Ramin. (2006). La enseñanza contra el capitalismo global y el nuevo imperialismo: una pedagogía crítica. Madrid: Editorial Popular.

Mc. Laren, Peter. Jaramillo, Nathalia E. (2006). Pedagogía y práxis en la era del Imperio: hacia un nuevo humanismo. Madrid: Editorial Popular.

Mc Lellan (1984). Marx:su legado. Trad. Diorky traductores. Barcelona: Círculo de lectores.

Mchitarjan, Irina (2009). John Dewey y el Desarrollo de la Pedagogía Rusa antes de 1930 — Informe sobre una recepción olvidada. En, Encuentros sobre Educación Volumen 10, Otoño 2009. Pp. 163 - 186

Meek, Ronald (1975). La Fisiocracia. Barcelona: Ariel.

Mehring, Franz (1965). Carlos Marx, el fundador del Socialismo científico. Trad. Wenceslao Roces. Buenos Aires: Claridad.

Mèlich, J. (2008). Filosofía y educación en la posmodernidad. En: Hoyos, G. (Editor). Filosofía de la Educación. Madrid: Trotta. Pp. 35-44 
Mèlich, Joan C. (1995). La maldad del ser. La filosofía de la educación de Emmanuel Levinas. Enrahonar, 24, pp. $145-154$

Melotti, Umberto (1971). Revolución y sociedad. México: FEC.

Mendieta, E. (2008). Educación Liberadora. En: Hoyos, G. (Editor). Filosofía de la Educación. Madrid: Trotta. Pp. 341-356

Mészáros, István (2001). Más allá del capital: hacía una teoría de la transición, tomo I. La Paz: Pasado y presente XXI. Recuperado de: http://www.formacion.psuv.org.ve/wpcontent/uploads/2013/09/M\%C3\%A1s-all\%C3\%A1-del-capital-Hacia-una-teor\%C3\%ADa-de-latransici\%C3\%B3n-Tomo-I.pdf

Mészáros, István (2008). La educación más allá del capital. Presentación de Emir Sades. Buenos Aires: Siglo XXI.

Mignolo, Walter, compilador (2001). Capitalismo y geopolítica del conocimiento. Buenos Aires: Ediciones del Signo.

Monarca, H. (2009). Los fines de la educación. Sobre la necesidad de recuperar y revisar el debate teleológico. Madrid: Narcea.

Moncayo, Víctor Manuel (1983). Karl Marx sin marxismo. Bogotá: Cuadernos de Iniciativas Obreras. marzoabril.

Mondolfo, Rodolfo (1936). Feuerbach y Marx. La dialéctica y el concepto marxista de la historia. Trad. de M. Alberti. Buenos Aires: Claridad.

Montenegro, Walter (1995). Introducción a las doctrinas político económicas. Bogotá: Fondo de Cultura Económica.

Moore, T. (1999). Introducción a la filosofía de la educación. México: Editorial Trillas.

Morales Zúñiga, Luis C. (2009). Educación y sociedad: apuntes para una aproximación a la praxis educativa desde el marxismo. En Actualidades Investigativas en Educación, Revista Electrónica, Volumen 9, Número 2. pp. 1-13. San José: Instituto de Investigación en Educación da la Universidad de Costa Rica. Recuperado de: http://revista.inie.ucr.ac.cr/uploads/tx_magazine/marxismo.pdf

Morán Beltrán, Lino. León del Río, Yohamka (2008). Reflexiones en torno al pensamiento marxista de Ludovico Silva. En, Revista de filosofía, Vol. 26, No. 58.. Maracaibo.

Morin, Edgar (2000). La mente bien ordenada. Barcelona: Seix Barral.

Morin, Edgar (2001). Los siete saberes necesarios para la educación del futuro. Barcelona: Paidós.

Musto, Marcello (2015). Revisitando la concepción de la alienación en Marx. En, De regreso a Marx Nuevas lecturas y vigencia en el mundo actual. Buenos Aires: UMET. Pp. 171-208

$\underline{\mathbf{N}}$

Nicol, Eduardo (2007). La primera teoría de la praxis. México: UNAM. 
Nicolaus, Martin (2007). El Marx desconocido. En, Marx, Karl, 2007. Elementos fundamentales para la crítica de la economía política. Borrador 1857-1858. Vool. I. Pp. XI-XL

Nietzsche, Friedrich (2002). Sobre el porvenir de nuestras instituciones educativas. Trad. De Carlos Manzano. Barcelona: Tusquets.

Netto, Jose Paulo (2012). Trabajo Social: critica a la vida cotidiana y método en Marx. Colegio de Trabajadores Sociales Provincia de Bs. As. La Plata. Buenos Aires: Sin editorial.

Novack, George (1977). Los orígenes del materialismo. Trad. de Alba Naimán Bogotá: Pluma universitaria.

Núñez Tenorio, José Rafael (1998). Desviaciones y futuro del socialismo científico Capt. V, en La vigencia contemporánea del marxismo. Caracas: UCV. Pp. 75-201.

Núñez Tenorio, José Rafael (2015). Ciencia, praxis e ideología. En, Introducción a la ciencia. Caracas: La Trinchera. Pp. 14-43

$\underline{\mathbf{O}}$

Ocampo López, Javier (2007). Simón Rodríguez, el maestro del Libertador. Revista Historia de la Educación Latinoamericana, vol. 09. UPTC. pp.81-102

Ocampo López, Javier (2009). El Maestro Orlando Fals Borda Sus Ideas Educativas Y Sociales Para El Cambio En La Sociedad Colombiana. En, Revista Historia de la Educación Latinoamericana, vol. 12. UPTC. pp. $13-41$

Ordoñez, Jacinto (2004). Introducción a la pedagogía. San José: Universidad Estatal a Distancia.

Ordoñez, Jacinto (2010). La educación latinoamericana en ocasión del segundo centenario. En Signos de vida, 57, diciembre. Recuperado de: http://issuu.com/clai/docs/sv57_web.

Osorio, Jaime S. (2004). Crítica de la ciencia vulgar. Sobre epistemología y método en Marx. En, revista Herramienta No. 26, Julio-2004. Buenos Aires: Herramienta Ediciones. Pp. 11-31.

Ortega y Gasset, José (1998). Origen y epílogo de la filosofía. México: Fondo de Cultura Económica.

$\underline{\mathbf{P}}$

Palacios, Jesús (1984). La cuestión escolar. Críticas y alternativas. Barcelona: Laia.

Parra Escobar, Ernesto. Fals Borda, Orlando (1985). Reflexiones sobre investigación acción. Medellín: Universidad de Antioquia.

Peña, Paco (17-10-2011). El desencuentro de Marx y América Latina. En, Gramscimanía. Recuperado de, http://www.gramscimania.info.ve/2011/10/el-desencuentro-de-marx-y-america.html. En 2-02-2017

Pérez Villamarín, Diego G. (2015). Surgimiento: hacia una ontología de la praxis. En, Cuadernos de Filosofía latinoamericana.Vol. 36, no. 113. Pp. 227-24

Pérez Villamarín, Diego G. (2016). Educación en una cultura de la exclusión, la marginación y el riesgo global. Educación, Sociedad e Interculturalidad. En, Diálogos desde la Comprensión y Acción Educativa en América Latina. Bogotá: USTA. Pp. 183-197 
Surgimiento: hacia una ontología de la praxis. En, Cuadernos de Filosofía latinoamericana.Vol. 36, no. 113. Pp. 227-240

Peters, R. (1977). Filosofía de la Educación. México: Fondo de Cultura Económica.

Piaget, Jean (1972). Epistemología de las ciencias humanas. Buenos Aires: Proteo.

Piketti, Thomas (2014). El capital en el siglo XXI. Trad. De Eliane Cazenave y Tapie Izoard. México: FCE.

Pividal, Francisco (2006). Bolívar: Pensamiento precursor del antiimperialismo. La Habana: ALBA.

Platón (1872). Teages, en Obras completas tomo 11. Trad. y edición de Patricio Azcárate. Madrid. pp. 63-84

Platón (2009a) Diálogos I. México: Porrúa.

Platón (2009b). Diálogos II. México: Porrúa.

Platón (2008). La Leyes México: Porrúa.

Plejanov, J. (1946). Sobre la concepción materialista de la historia. Moscú: Ediciones en lenguas Extranjeras.

Plejanov, Jorge (1974). Las cuestiones fundamentales del marxismo. México: Roca.

Polanyi, Karl (1947). La gran transformación: los orígenes políticos y económicos de nuestro tiempo. Buenos Aires: Claridad.

Politzer, Georges (2002). Principios elementales y fundamentales de filosofía. Madrid: Alba.

Ponce, Aníbal (1981) Educación y lucha de clases. Madrid: Akal.

Ponce, Anibal (1984). Humanismo burgués y humanismo proletario. Cali: Marka.

Popper, Karl (1957). Sociedad abierta y sus enemigos. Trad. Por Eduardo Loedel. Edición de Norberto Rodríguez Bustamante. Buenos Aires: Paidós.

Popper, Karl (1971). The open society and its enemies, vol II. The high tide of prophecy: Hegel, Marx, and the aftermath. Princeton: Princeton University Press.

Q

Quintana, J.M. (1988). Teoría de la educación. Madrid: Dykinson.

$\underline{\mathrm{R}}$

Ramírez Angarita, Claudio. Patiño Trujillo, César Augusto (2013). Francisco de Miranda: precursor de la utopía colombiana. Bogotá: Imaginarios.

Ramírez Angarita, Claudio (2017). La lectura de los discursos sobre terrorismo. Una propuesta dialéctica. En, Filosofía de la política y el terrorismo [Comp.]. Caracas: Ediciones del Solar. Pp. 297-316

Ramírez Bravo, Roberto (2008). La pedagogía crítica Una manera ética de generar procesos educativos. En, Folios, Segunda época N.o 28, Segundo semestre, pp. 108-119

Ramírez Fierro, María del Rayo (1994). Simón Rodríguez y su utopía para América. México: UNAM. 
Ramonet, Ignacio (2002). Guerras del siglo XXI. Nuevos miedos, nuevas amenazas. Trad. José A. Soriano. Barcelona: Mondadori.

Ramonet, Hugo (2013). Hugo Chávez. Mi primera vida. Barcelona: Debate.

Rancière, Jacques (2010). El maestro ignorante cinco lecciones sobre la emancipación intelectual. Trad. Núria Estrach. Barcelona: Laertes.

Rancière, Jacques (2011). La educación pública y la domesticación de la democracia. [Comp.].Madrid: Miño y Dávila.

Reale, Giovanni., Antiseri, Darío (1998 a). Historia del pensamiento filosófico y científico. Vol.1 Antigüedad y edad media. Trad. de Juan Andrés Iglesias. Barcelona: Herder.

Reale, Giovanni., Antiseri, Darío (1998 b). Historia del pensamiento filosófico y científico. Vol.2 Del humanismo a Kant.Trad. de Juan Andrés Iglesias. Barcelona: Herder.

Reale, Giovanni., Antiseri, Darío (1998 c). Historia del pensamiento filosófico y científico. Vol.3 Del romanticismo hasta hoy. Trad. de Juan Andrés Iglesias. Barcelona: Herder.

Reiss, Edward (2000). Una guía para entender a Marx. Madrid: Siglo XXI.

Riazánov, D. (1962). Marx y Engels. Buenos Aires: Claridad.

Rice, P. (1997). Desarrollo humano: estudio del ciclo vital. México: Pearson.

Ricoeur, Paul (1989). Ideología y utopía. Barcelona: Gedisa.

Riestra, José A., Del Noce, Augusto (1975). Karl Marx, escritos juveniles. Madrid: Magisterio Español.

Ríos Beltrán, Rafael (2014). Pensar nuevas filosofías de la educación: un encuentro entre lo moderno y lo postmoderno. Revista de filosofía UIS, Vol. 13, No. 2 de 2014. Pp. 183-198

Rius (1972). Marx para principiantes. Ilustrado. México: Ediciones de cultura popular.

Rodríguez, Simón (2001). Obras completas, tomo I. Caracas: Presidencia de la República.

Rodríguez Vásquez, Hugo Hernán (2007). La antropología filosófica de la pedagogía de lo cotidiano: fundamentos para su sistematización. [tesis en lic. pedagogía]. México: UNUA.

Rodríguez, Simón (2007a). Carta de Simón Bolívar a su Maestro Don Simón Rodríguez. . En, Pensamiento pedagógico emancipador latinoamericano. Luis Damiani. Omaria Bolívar [Comp.]. Caracas: UBV. Pp. 47-48

Rodríguez, Simón (2007b). El libertador del mediodía de América y sus compañeros de armas defendidos por un amigo de la causa social. Sobre el proyecto de educación popular (1830). En, Pensamiento pedagógico emancipador latinoamericano. Luis Damiani. Omaria Bolívar [Comp.]. Caracas: UBV. Pp. 49-95

Rodríguez Acosta, Hugo (1986). Curso elemental de materialismo histórico. Bogotá: Los Comuneros.

Rojas, Armando (1999). Ideas educativas de Simón Bolívar. Prólogo de Augusto Mijares. Caracas: Monte Ávila.

Rojas Gómez, Miguel. Guadarrama, Pablo (2006). Los presupuestos histórico-teóricos de la Identidad latinoamericana que condicionan y promueven los proyectos integracionistas para el siglo XXI latinoamericano. Bogotá: Cátedras Andrés Bello- Convenio Andrés Bello. 
Rojas, Carlos (2010). Filosofía de la educación. De los griegos a la tardomodernidad. Medellín: Universidad de Antioquia.

Rojas Mix, Miguel (1991). Los cien nombres de América. Barcelona: Lumen.

Rooke, Mike (2003). La dialéctica del trabajo y la emancipación humana (trad. Marcela Zangaro. En, Bonefeld, Werner; Tischler, Sergio (Comp.). A cien años del ¿Qué hacer? Leninismo, crítica marxista y la cuestión de la revolución (pp. 109-140). Buenos Aires: Herramienta.

Rosental, Mark (Sf.) ¿Qué es la teoría marxista del conocimiento? México: Quinto Sol.

Rosental, Marc. M. (1962). Principios de la lógica dialéctica. Recuperado de: http://produccionesdigsoyuz.wordpress.com/2013/02/16/marc-moiseievich-rosental-principios-de-logicadialectica/

Rózhin, V.P, et al. (1966 a). Tratado de filosofía marxista, tomo I: el materialismo dialéctico. Trad. por Teodosio Varela. Bogotá: Suramericana.

Rózhin, V.P, et al. (1966 b). Tratado de filosofía marxista, tomo II: el materialismo histórico. Trad. por Teodosio Varela. Bogotá: Suramericana.

Rozitchner, León (2011). "La izquierda sin sujeto”. En Cuadernillo no. 1 de presentación Cátedra Che Guevara. Buenos Aires: Colectivo Amauta.

Rubin, Isaak Illich (1974). Ensayos sobre la teoría del valor de Marx. Buenos Aires: Pasado y Presente.

Rueda de Aranguren, Diana Milagros (2017). La Pedagógica Latinoamericana. Visión Dusseliana. Analéctica, año 20 No. 3,1 enero. Recuperado de, http://www.analectica.org/articulos/rueda-pedagogica/ Rescatado en 22-04-2017

Russell, Bertrand (2009). Karl Marx, en Historia de la filosofía. Trad. Por Julio Gómez de la Serna y Antonio Dorta. Madrid: Espasa.Pp. 837-846.

$\underline{\mathbf{S}}$

Sacristán, Manuel (1977). Materiales. Enero-febrero 1977, $\mathrm{n}^{\circ}$ 1. Barcelona: Materiales, S.A. de Estudios y Publicaciones.

Sacristán, Manuel (1977). Sobre las contribuciones filosóficas de Manuel Sacristán en Horitzons y Nous Horitzons. Recuperado de: http://fcim.cat/historiapsuc/pdfs/salvador\%20lopez\%20arnal.pdf. Rescatado el 20-04-2017

Sacristán, Manuel (1978). El trabajo científico de Marx y su noción de ciencia. La caja de herramientas. Extraído de la edición de los Jóvenes comunista. Madrid: Biblioteca virtual UJCE. Recuperado de: http://archivo.juventudes.org/manuel-sacrist\%C3\%A1n/el-trabajo-cient\%C3\%ADfico-de-marx-y-sunoci\%C3\%B3n-de-ciencia\#El_trabajo_cientifico_de_Marx_y_su_nocion_de_ciencia

Sacristán, Manuel (1983). Una conferencia de 1983, en el primer centenario del fallecimiento de Karl Marx. Los últimos años de Marx en su correspondencia [pdf]. Disponible en, http://www.rebelion.org/docs/119243.pdf 
Sacristán, Manuel (2004). Escritos sobre "El Capital" (y textos afines). España: El viejo Topo. Recuperado de: http://books.google.com.co/books?id=2waeBBGARLQC\&printsec=frontcover\&hl=es\&source=gbs_ge_s ummary_r\&cad $=0 \# \mathrm{v}=$ onepage $\& q \& \mathrm{f}=$ false

Sacristán Luzón, Manuel (2005). Seis conferencias sobre la tradición marxista y los nuevos problemas. Madrid: El viejo Topo.

Sánchez Vásquez, Adolfo (1977). La filosofía de la praxis como nueva práctica de la filosofía. En, Cuadernos Políticos, número 12, editorial Era, México, D.F., abril-junio, pp.64-68.

Sánchez Vázquez, Adolfo (1978). Ciencia y revolución. Madrid: Alianza Editorial.

Sánchez Vázquez, Adolfo (1980). Filosofía de praxis. México: Grijalbo.

Sánchez Vázquez, Adolfo (1982), Filosofía y economía en el joven Marx. México: Grijalbo.

Sánchez Vásquez, Adolfo (1985). Mi obra filosófica. En, Praxis y filosofía. Ensayos en homenaje a Adolfo Sánchez Vásquez. México: Grijalbo.

Sánchez Vázquez, Adolfo (1988). El marxismo en América Latina, en Revista Dialéctica. Año XIII, Julio No. 19. Pp. 11-28. Recuperado de http://148.206.53.230/revistasuam/dialectica/

Sánchez Vásquez, Adolfo (1997). Filosofía y praxis. En, Filosofía y circunstancia. México: Antropos. Pp. 113165

Sánchez Vázquez, Adolfo (1999). De Marx al marxismo en América Latina. México: Ítaca.

Sánchez Vázquez, Adolfo (2000). El valor del socialismo. México: Ítaca.

Sánchez Vásquez, Adolfo (2003). El joven Marx: Manuscritos de 1848. México: UNAM.

Sánchez Vázquez, Adolfo (2003). Filosofía de la praxis. México: Siglo XXI.

Sánchez Vázquez, Adolfo (2007). Ética y política. México: FCE.

Sánchez Vázquez, Adolfo (2011). Racionalidad y emancipación en Marx, en Revista Internacional Marx ahora, No. 32. La Habana: Ciencias Sociales. pp. 191-202.

Santancárgelo, juan Eduardo. Angela Borroni (2012). El concepto de excedente en la teoría marxista: debates, rupturas y perspectivas. En, Cuadernos de Economía de UNAL. Volumen 31, Número 56, pp. 1-20

Santos Gómez, Marcos (2014). Sujeto y educación en la filosofía de la educación de Bogdan Suchodolski, en Daimon. Revista Internacional de Filosofía, no 62, 2014, 87-100.

ISSN: 1130-0507. Murcia: Universidad de Murcia. Pp. 87-100. Recuperado de: http://dx.doi.org/10.6018/daimon/165551 . Rescatado 29-08-2014.

Santos Gutiérrez, Cristhian RIcardo (2017). Apuntes Para Una Articulación Crítica Entre Un Proyecto Ontológico De Liberación Y Un Programa Curricular En Construcción: Un análisis a la documentación legal vigente del programa de Lic en Filosofía e historia de la UGC a partir de la obra de Enrique Dussel Ética de la liberación en la edad de la globalización y la exclusión (1998). [Tesis de grado]. Bogotá: UGC.

Sanza Alonso, Sofia (2003). Indagando en los orígenes aristotélicos del pensamiento de Marx. Revista Nómadas de Ciencias Sociales. No. 8 , jul-dic. Recuperado de, http://pendientedemigracion.ucm.es/info/nomadas/8/sofis.htm el 24 de 08, 2016 
Sartre, Jean Paul (1963a). Crítica de la razón dialéctica. Tomo I, teoría de los conceptos prácticos. Libro I, de la "praxis" individual a lo práctico inerte.Trad. Manuel Lamana. Buenos Aires: Losada.

Schaff, Adam (1979). La alienación como fenómeno social. Barcelona: Círitca.

Schmidt, Alfred (1977). El concepto de Naturaleza en Marx. Madrid: Siglo XXI.

Schumpeter, Joseph Alois (1988). Capitalismo, socialismo y democracia. Barcelona: Orbis.

Schutz, Alfred (1974). El problema de la realidad social. Buenos Aires: Didot.

Selección de autores marxistas (Sf). recuperado de: http://www.marxists.org/espanol/marxistas.htm

Silva, Ludovico (1971). Teoría y práctica de la ideología. México: Nuestro Tiempo.

Silva, Ludovico (1974). Marx y la alienación: Ensayo. Caracas: Monte Ávila.

Silva, Ludovoci (1979). La alienación de la alienación. Mansucrito

Silva, Ludovico (1983). La alienación como sistema: la teoría de la alienación en la obra de Marx. Caracas: Alfadil.

Silva, Ludovico (2009). Anti manual para para uso de marxistas, marxólogos y marxianos. Caracas: Biblioteca de autores venezolanos-Monte Ávila.

Silva, Ludovico (2011). El estilo literario de Marx. Caracas: Fundarte.

Silva, Ludovico (2011b). La plusvalía ideológica. Caracas: Fundarte.

Silva, Ludovico (2011c). .Orígenes de la ideología del subdesarrollo: ucación y religión. Teoría de la ideología: textos para su estudio / Federico Engels, Carlos Marx. Contracultura. Selección y prefacio, Ludovico Silva. Caracas: El perro y la rana. pp. 155-164

Silva, Ludovico (2013). Contracultura. Caracas: Fundarte.

Silva, Ludovico (2013b). En busca del socialismo perdido. Caracas: Fundarte.

Silva, Ludovico (2017). Teoría del socialismo. Caracas: Fundarte

Slavin, Luis Pablo (2008). Las profecías de Marx: una refutación a Karl Popper. En Universitas, revista de Filosofía, Derecho y Política, no. 8, julio. Madrid: Universidad Carlos III, pp. 35-55.

Soetard, Michael (2003). Naturaleza y libertad en educación. En Educación y filosofía (Jean Houssaye, compilador). Buenos Aires: Eudeba. Pp. 125-142.

Sputnik (2016). El secreto de la popularidad del Partido comunista del Japón. Recuperado de, https://mundo.sputniknews.com/politica/201608261063070312-psj-indice-aceptacion-comunistas, en 209-2017

Steigerwald, Robert (2011). La nueva apropiación de Marx en Revista Internacional Marx ahora, No. 32. La Habana: Ciencias Sociales. pp. 153-162.

Strathern, Paul (2003). Marx en 90 mínutos. Madrid: Siglo XXI. 
Suárez, Carlos Abel (01-08-2010). Marx regresó y amenaza con quedarse. En, Sin permiso. Recuperado de: http://www.sinpermiso.info/printpdf/textos/marx-regres-y-amenaza-con-quedarse. Rescatado el 20-042017

Suchodolski, Bogdan (1977). Teoría marxista de la educación. Trad. María Rosa Porras. México: Grijalbo.

Suchodolski, Bogdan (1971). Tratado de pedagogía. Trad. Melitón Bustamante Ortiz. Barcelona: Saturno.

Sudárikov, A.A. (1969). ¿Qué es filosofía? Trad. Teodosio Varela. Bogotá: Ediciones Sudamérica.

$\underline{\mathbf{T}}$

Tablada Pérez, Ernesto (19812). El pensamiento económico de Ernesto Che Guevara. La Habana: Casa de las Américas.

Tarcus, Horacio (2015). Introducción. En, Karl Marx. Antología. Trad. por Pedro Scaron y otros. Buenos Aires: Siglo XXI. Pp. 7-57

TELESUR (2014). ¿Qué es chavismo? Recuperado de: http://www.telesurtv.net/articulos/2014/06/03/que-esel-chavismo-1105.html. Recuperado 5-06-2014

Thalheimer, August (1980). Introducción al materialismo dialéctico, concepción del mundo moderno. Madrid: Dédalo.

Therborn, Göran (2014). ¿Del marxismo al postmarxismo? Trad. Jaime Blasco Castyñera. Akal.

Torres, Jurjo (1996). El curriculum oculto. Madrid: Ediciones Morata.

Trann-Duc-Taho (1965). El materialismo de Hegel. Trad. José Sebreli. Buenos Aires: Siglo veinte.

Trilla Bernet, Jaume, coord. (2007). Antón Semionovich Makarenko y otras pedagogías marxistas. En, El legado pedagógico del siglo XX para la escuela del siglo XXI. pp. 123- 149. Recuperado de: http://dialnet.unirioja.es/servlet/libro?codigo=4983

$\underline{\mathbf{U}}$

Uc Sánchez, Manuel (2006). La praxis en el pensamiento de Adolfo Sánchez Vázquez. En, Enlace, vol.3, no. 3. dic. Recuperado de: http://www.scielo.org.ve/scielo.php?script=sci arttext\&pid=S169075152006000300006 rescatado el 20-06-2017

UNESCO (2004). Reforma curricular y cohesión social en América Latina: informe final del seminario internacional. San José- Geneve: UNESCO.

UNESCO (2014). Gasto público en la educación de América Latina ¿Puede servir a los propósitos de la Declaración de París sobre los Recursos Educativos Abiertos? Recuperado de, http://www.unesco.org/fileadmin/MULTIMEDIA/FIELD/Montevideo/pdf/CDCI1-Karisma-ES.pdf 
Valdez, César (2015, Mayo 6). Volver a Marx.Enrique Dussel. Sólo audio. [archivo de vídeo]. Recuperado de, https://www.youtube.com/watch?v=p4DeSZShqbY, el 20-02-2017

Valera Villegas, Gregorio (2014). Entrevista con Walter Kohan. Relaciones e implicaciones entre filosofía y educación. En, Ensayo y error, año XIII, No. 46-47. UNER. Pp. 173-194

Valera-Villegas, Gregorio (2016). Vida, formación y escritura. Una mirada otra del Che. Caracas: UCV.

Varas, Ibas (2015). Riesgos de la ideología. Caracas: Trinchera.

Vasco, Carlos E. (2006). Siete retos para la educción colombiana para el período 2006-2019. Medellín: EAFIT. Recuperado de: http://cmap.upb.edu.co/rid=1196125300531_825959605_1053/Vasco\%20Siete\%20retos\%20de\%20la\%20educaci\%C3\%B3n\%20colombiana\%202006-2019.pdf

Vasconi,Tomás A. (Sf.). Contra la escuela. ,

Vedda, Miguel (2003). Introducción, en Marx, Karl. Engels, Friedrich (2003). Escritos sobre literatura. Trad. por Fernanda Aren et. al. Buenos Aires: Calihue. Pp. 7-41

Vega Cantor, Renán (2013a). Capitalismo y despojo. Perspectiva histórica sobre la expropiación universal de bienes y saberes. Bogotá: Impresol.

Vega Cantor, Renán (2013). Contra la expropiación de los bienes y de la palabra En: Cartilla literaria: poemas de memoria histórica para liberar la palabra. Bogotá: Fundavivas Editores.

Velasco, Eloisa (1997). Maestros, alumnos, saberes, investigación y docencia en el aula. Bogotá: Magisterio.

Vila, I. (2007). Lev. S. Vigotsky: la psicología cultural y la construcción de la persona desde la educación.

Trilla, J. (Coord). El legado pedagógico del siglo XX para la escuela del siglo XXI. Barcelona: Editorial Graó. Pp. 297-228

Villarini, A. (2001). Teoría y práctica del pensamiento crítico. San Juan: Biblioteca del Pensamiento Crítico.

Villarini, A. (1998). La enseñanza orientada al desarrollo del pensamiento. San Juan: Proyecto Educación Liberal Liberadora.

Vitale, Luis (1983). Hacia una historia del ambiente en América Latina. México: Nueva Imagen. Recuperado de: http://www.estudiosecologistas.org/docs/reflexion/ecohistoria/a.pdf

Vygodski, V.S. (1978). Por qué no envejece el capital de Marx.

Vygotsky, Lev (2003). El desarrollo de los procesos psicológicos. Edición al cuidado de Michel Cole, et. al. Barcelona: Crítica.

Vygotsky, L., (2008). Pensamiento y lenguaje. México: Ediciones Quinto Soler.

Vygotsky L. (2009). El desarrollo de los procesos psicológicos superiores. Barcelona: Crítica.

\section{$\underline{\mathbf{w}}$}

Wallerstein, Immanuel (2007). Universalismo europeo. Madrid: Siglo XXI.

Weber, Max (2008). La ética protestante y el espíritu del capitalismo. Trad. Luis Legaz Lacamba. México: FCE. 
Wiggershaus, Rolf (2011). La Escuela de Fráncfort. Traducción de Marcos Romano. México: UNAM-FCE.

Woods, Alan. Sewell,Ros (2016). Introducción al materialismo dialéctico. Recuperado de: https://kmarx.wordpress.com/2016/09/17/introduccion-al-materialismo-dialectico/ rescatado en 17, 09, 2016

World Bank (2014). «Public Spending on Education, Total (\% of GDP)», 2014. Recuperado de, http://data.worldbank.org/indicator/S

Wright Milss, C. (1966). The Marxists. New York: Dell Plubishing.

Wyss, Dieter (1959). Marx y Freud. Su relación con la antropología moderna. Caracas: Nuevo Tiempo.

$\underline{\mathbf{Y}}$

Yurén, María Teresa (2009). La filosofía de la praxis educativa. Una construcción a partir de la obra de Adolfo Sánchez Vázquez. En, Homenaje a Adolfo Sánchez Vásquez. pp. 245-247. Recuperado de: de, http://ru.ffyl.unam.mx/bitstream/handle/10391/2015/23_ASV_Homenaje_2009_Yuren.pdf?sequence=1

\section{$\underline{\mathbf{Z}}$}

Zapata, Emiliano (1913). Manifiesto a la Nación de Emiliano Zapata, Campamento Revolucionario en Morelos, Octubre 20, 1913. Recuperado de: http://www.bibliotecas.tv/zapata/1913/z20oct13.html. Rescatado, 1504-2017

Zea, Leopoldo (1983). Visión de Marx sobre América Latina. En Nueva Sociedad, No. 66 mayo-junio 1983, pp. 59-66. Recuperado de: http://www.nuso.org/upload/articulos/1062_1.pdf

Zizek, Slavoj (2007). Recordando a Lenin. La Habana: Ciencias Sociales.

Zucconi, Micaela (2014). Vida cotidiana y trabajo social. El método desde Marx para superar la inmediaticidad. En, Plaza pública. Revista de trabajo social. Año 7 - No 11, Julio. Pp. 300-317

Zuleta, Estanislao (1975). El Marxismo y la Universidad. Conferencia dictada en la Universidad del Valle [Pdf]. Recuperado de, http://catedraestanislao.univalle.edu.co/Marxismo.pdf

Zuleta, Stanislao (2005). Elogio de la dificultad y otros ensayos. Medellín: Nuevo Hombre editores.

CRA-013-018 


\section{COLOFÓN}

\section{Más que la injusticia contra Marx, más que una reacción lógica}

Más que una reacción de contención, suele decirse muy poco de millones de vidas perdidas debido a la política de aniquilamiento del movimiento socialista mundial. Sin importar las visiones, las persecuciones estuvieron activas como todavía lo están en pleno siglo XXI. La propuesta salida de la mente de Marx, que no era otra cosa que poner todo en la lupa de las relaciones materiales que denigraban del hombre y de la mujer, el mensaje había de ser reprimido por cualquier medio; desde los más ideológicos y propagandísticos posibles hasta los programos más infames. Más que injusticia contra Marx, de lo que poco se habla es de las vilezas en nombre de la democracia que se llevaron a cabo en cada rincón del mundo y de lo cual Hobsbawm (2003) ilustra muy bien. Ojalá se hubiera dado crédito a los crímenes de occidente como los que recibieron las infames cárceles de los Estados declarados comunistas.

Volviendo al impacto contextual, no puede olvidarse, -como lo ha querido hacer la historiografía actual de raíces burguesas-, las ideas de origen marxista alentaron las luchas de descolonización en los cinco continentes. Sobre todo, después de la Segunda Guerra Mundial que reordenó el mapa global (Mc Lellan, 1984). Los procesos de la segunda mitad del siglo XX se cuentan por cientos. Nacionalismo y marxismo generaron más de un dolor de cabeza al stablishment. En varias ocasiones dichos movimientos tuvieron apoyo directo o indirecto del bloque oficialista o de China como en la Guerra de Corea o en Angola donde sorpresivamente el gigante asiático respaldó a los grupos contrarrevolucionarios; otros como el Congo de Lumumba o la Argelia del FLN no declararon ayuda directa del bloque oriental. "La lucha anticolonilista toma la forma de una guerra de liberación nacional de contenido marxista” (Casas, 198, p.129).

Las metrópolis perdían la hegemonía, con ella la visión de sociedad donde el poderoso, en este caso el europeo, se colocaba en el centro del mundo. Muy a pesar de los resultados de cada uno de los cientos de casos, la lucha no era solo por la liberación política, al acercarse a los contenidos de las figuras históricas se encuentran sus propuestas de país, de identidad, de valores, de esperanza, de la educación como centro de la emancipación humana y de inclusión, de rompimiento de las cadenas del imperialismo; entonces se llega a la conclusión de las analogías evidentes de lo presupuestado desde Marx y los programas de la gran mayoría de los movimientos de liberación nacional afroasiáticos y latinoamericanos, es decir, de esa forma de ver a la educación que tienen un sector progresista del llamado Tercer Mundo del tercer tercio del siglo XX hasta los inicios del siglo XXI.

De hecho, gracias a la promulgación de las obras de Marx, Engels y Lenin, en sus diferentes formatos e idiomas, pudieron los diferentes líderes prácticos formarse en marxismo y en tácticas de guerra popular. Un alto porcentaje de estos dirigentes se educaron en las metrópolis y fueron permeados por las enseñanzas regidas -en ocasiones subrepticias o censuradas- por la vertiente crítica de alto nivel marxista. Otros tantos, perfeccionaron sus posturas en los países del bloque soviético, ya fuera en teoría o tácticas de guerra de guerrillas, aunque no era comparable con el apoyo brindado por parte del bloque antagónico hacia las fuerzas de los países periféricos alineados con el sistema de dependencia capitalista. El elemento concreto del humanismo emanado del pensamiento de Marx parece haber pasado a un segundo plano, pero claro, las circunstancias de resistencia a las estrategias de occidente capitalista y sus aliados, permitía poco desarrollar 
tal ámbito. La urgencia era llegar al poder tras las sublevaciones proletarias violentas, el problema era que, no había chance evidente ni organización ajustada.

Pero, la reacción no se hizo esperar. A lo anterior también hubo respuesta del bloque unificado cuyas estructuras y superestructuras giraban en torno al capital. La cruzada empezaría por denunciar los posibles antivalores del comunismo y su origen socialista anticuado. Se llevó a cabo por todo el mundo la campaña de desprestigio contra todo lo que evocara proletariado, lucha de clases, ateísmo, propiedad común, etc. La postura crítica era tildada de subversiva, apátrida. El anticomunismo estaba de moda, la mayor imbecilidad que citaba Hinkelammert (2001), paradójicamente, se levantaba para defender la libre opinión y la libertad.

La ideología conservadora representada en las clases dominantes, en el imperialismo occidental y el gran capital, no cedieron ante la amenaza histórica que representaba el comunismo. Lógicamente, el principal motivo, el motivo material que estará siempre presente y financiando la lucha contra el socialismo y su expresión extendida que es el comunismo, será el motivo económico. El sistema capitalista no necesita de antagónicos, en el mundo social donde también se presenta la competencia por sobrevivir, este sistema no tolerará antagónicos. Para prevalecer, el sistema capitalista que fuera elaborado, implantado y defendido por hombres historiales, utilizará todos los recursos necesarios. "La lógica de la dominación está basada en la competencia. La conciencia debe hacer acceder a los hombres a la comprensión que todos sus productos son producidos por él con su esfuerzo" tal cual comparte Guzmán (2017, p. 174).

La periferia fue la más afectada. Hoy todavía se sienten las secuelas de la guerra antisocialista. Los recursos no faltaban para contrarrestar cualquier mínimo asomo o simpatía. Una de las mejores maneras era financiar a gobiernos derechistas sin importar si estos tenían los mínimos de una democracia real. La violación de los derechos humanos no importaba para las potencias occidentales, pues como peligro eminente, era

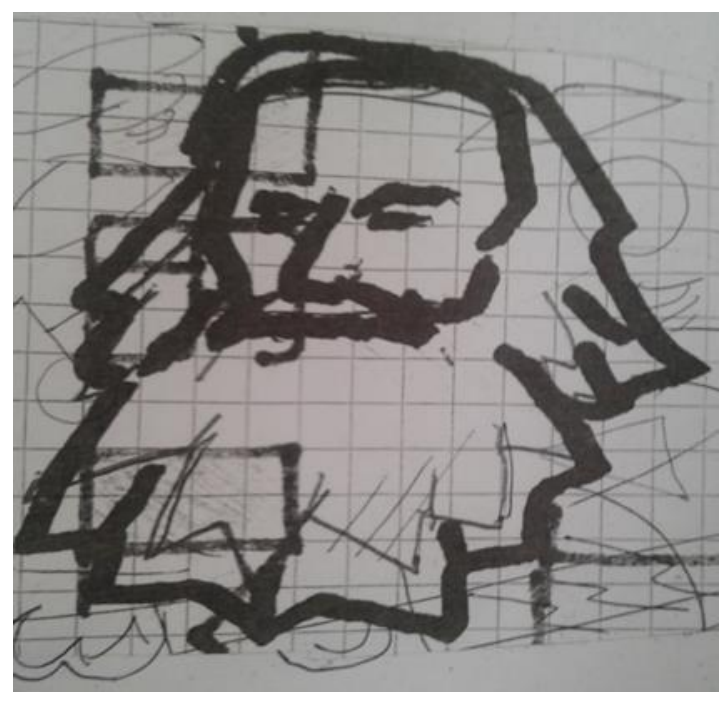
obligación "sagrada" detener las olas revolucionarias y ganar aliados para su visión de democracia.

Un nefasto fenómeno mundial fueron las financiaciones a gobiernos a todas vistas antidemocráticos tanto o más represores y sanguinarios que las mismas dictaduras de las democracias populares que occidente denunciaba. En el Tercer Mundo, las dictaduras militares, así, como las civiles de perfiles servilistas, se declaraban fieles a la democracia de tipo liberal e incluso ungidos por la divinidad de sus tradiciones para hacer frente al peligro rojo, a las huestes del infierno comunista. No tardaron los sabotajes, asesinatos, financiación indiscriminada de mercenarios, entre otros métodos, para que desalojaran de la población, de las instituciones gubernamentales, cualquier mínima categoría marxista.

En estos actos que no excluían otras formas de hacer política u oposición, jugaron un rol monstruosamente determinante los militares que representaban a las derechas, esos sectores armados catalogados desde las obras de Marx (2006), además "militares como zánganos" (P. 766). El caso del Plan Cóndor en varios países del Cono Sur de Sudamérica, mostró la cara feroz desatada por la intención perversa para frenar, incluso cualquier asomo democrático-participativo de sectores declarados de izquierda (Chomsky, 2002). 
El golpe de Estado contra el médico marxista Salvador Allende en 1973, democráticamente elegido, marcarían dos décadas de intolerancia política en Chile a manos de militares de ultra derecha.

En la academia latinoamericana Marx no podía tocarse pues era correr un riesgo de vida o muerte. De acuerdo con lo anterior el filósofo argentino J. P. Feinmann (Caballero, 2013) cuenta su propia experiencia resumiendo:

En una denominada lucha contra el marxismo internacional se mató a mucha gente. Marx y el antimarxismo y la lucha contra la subversión marxista fue ejercida con una brutalidad y una crueldad nunca antes vista entre 1976 y 1983 (...) de hecho durante esa época se quemaban los libros de Marx, porque si grupos de tarea entraban en la casa de alguien y encontraban libros de Marx, ya tenían suficiente motivo como para hacer desaparecer a esta persona... [vídeo]

Otros casos ilustrativos, llenos de tragedia fueron los de Guatemala, El Salvador y Colombia, o la contra nicaragüense, el Perú fujimorista, etc. donde actuaron fuerzas paramilitares que declaraban la guerra a muerte sin importar los más aberrantes métodos, ni contra quien se procediera (incluyendo ancianos y niños) para liberar a su noción alienada de nación, de la amenaza marxista.

En estos países el consentimiento y complicidad del Estado, la clase política, así como de los sectores económicos poderosos tuvieron gran parte de la responsabilidad. Los auxilios foráneos, ejemplo la CIA ${ }^{96}$, no cesaban de patrocinar las fuerzas terroristas que superaban con creces las mismas acciones de la insurgencia en estos países. Aunque los medios trataban de ocultar el horror y a los reales protagonistas y sus intereses, la ignominia no era fácil de ocultar.

La lucha anticomunista arrastró consigo a todo lo relacionado con Marx. Repeler cualquier interpretación de Marx por más moderada que fuera, era un fin patrio para la reacción en muchos países de la periferia. La contención de la crítica tuvo diversas manifestaciones, que iban desde la aniquilación y el desprecio por la vida, hasta la reivindicación de lecturas medievales de la educación.

Un actor entró en escena entre los años sesenta y ochenta. La teología de la liberación, para el caso educativo, tuvo gran influencia en la lucha contra la hegemonía occidentalizadora y sobre todo conservadora del sistema imperante. Como disidencia de la versión oficial soviética y en tanto renuente a los dictámenes del clero jerárquico, algunos religiosos y seculares lograron armonizar la postura de Marx y el sentido social del cristianismo. Junto a las versiones críticas de la educación con altos contenidos y reflexiones marxianas de orientaciones independientes, la educación liberadora rescata la idea de un hombre emancipado, que resista a la alienación y al consumismo; un tipo de "nuevo hombre" como lo llamó Ernesto Guevara retomando a Ponce.

La visión marxista de la educación era tenida como una visión subversiva y fue desterrada de cualquier discusión académica en la mayoría de los centros educativos de países de la periferia, especialmente en América Latina y países afroasiáticos donde, después de intervenciones neocoloniales, llegaron al poder

\footnotetext{
${ }^{96}$ La Escuela de las Américas que funcionaba en la zona ocupada del Canal de Panamá, tenía como fin dar instrucción en lucha contra cualquier ideal socialista. La instrucción en contrainsurgencia llevaba consigo también el desprecio infundado e intencional contra cualquier idea crítica. Allí se formaron militares y policías de diversos países de América por décadas, "aprendiendo" a reprimir y a ser fieles a los intereses de las clases oligárquicas dominantes de sus respectivos países.
} 
mediante la fuerza gobiernos pronorteamericanos, en el Congo o Uganda para mencionar únicamente dos ejemplos.

La reacción antimarxista fue una reacción, más que educativa -sería una contrariedad llamarla así- fue de instrucción, dogmática, pues no se podía poner el mínimo de duda o crítica hacía las bondades de los sistemas de mercado y su visión extendida de formación para el trabajo sometido, la técnica o la eminentemente académica por parte de la institucionalidad; irónicamente en la democracia, no tenían cabida ideas que hablaran de "reclamaciones" con tintes sociales comunistas o no.

\section{0}

Doscientos años después hay una realidad aparente a la que sigue sujeto Marx y su pensamiento bajo las órdenes de esos mismos poderes decimonónicos. En general, la otra realidad extendida materialmente, consiste en aquellas que se debate entre lo marxiano y lo marxista al analizar los efectos de la versión dogmática del marxismo imperante en gran parte del siglo XX. El marxismo de apariencia dado en varios Estados del mundo, principalmente los de Europa oriental, dejó huellas profundas ya fuera por sus actuares sobre todo relacionados con el trato a los derechos humanos, ya fuera por el exceso de propaganda que se dio. Hay que decir que hechos reprochables desataron toda una rotulación, toda incomprensión a las ideas que provinieran de Marx, sin hacer reflexión de hasta dónde eran marxianas, o por lo menos de un marxismo aproximado a sus indicaciones.

El imaginario general en el mundo relaciona dictaduras comunistas -e incluso aquellas que no lo son- con comunismo $^{97}$; y junto a éste último, a Marx; un Marx desdibujado, cuya esencia de pensamiento, sin haberlo abordado, es rechazado no sin intención de los sectores que precisamente él denunció, pero aún más paradójico: también de aquellos sectores vulnerados.

La contradicción revelará las aplicaciones del socialismo real, el juego geopolítico, las trágicas consecuencias y el alejamiento que al pensamiento marxiano como "filtro", no hubo para entender la realidad y transformarla. Casas en 1989, compartía: "los errores de los países socialistas actuales están en la formación de la conciencia social" (P. 12).

Todavía pulula una inmediatez global para tratar el tema de la validez actual del rescate del pensamiento de Marx, y menos en educación. En el plano geopolítico que bien ha calado en las mentalidades, la reputación de lo marxista que no tiene mucho a su favor; lo que no es tan obvio es el rechazo de las clases menos favorecidas del festín del capital, quienes precisamente han sido las más afectadas por el sistema de cosas imperante que se manifiesta en la injusta distribución de la riqueza que afecta a países sin distinción -unos más que a otros-, la actitud de repelencia puede estar relacionada al frágil mensaje que se ha dado en los mismo sistema educativos imperantes en la mayoría de países de la periferia.

Lo mínimos sociales no son garantizados, y las falsas realidades en todas las facetas de la vida humana -y hasta no humana- gobiernan con algo peor que la opresión y el despotismo. Todo lo que "huela" a alternativo tiene una pisquita de Marx; por ello hay que despreciarlo. El macartismo no ha desaparecido,

\footnotetext{
${ }^{97}$ En Colombia se registran confusiones entre grupos alzados en armas de inspiración marxista-leninista con el paramilitarismo
} de Estado y narcotráfico. 
todo lo contrario, ha mutado, pero paradójicamente esto da más respaldo a pensar y actuar con lo que Marx tiene para ofrecer en muchos campos y necesidades de la humanidad e incluso de su entorno ${ }^{98}$.

Todavía se echa la culpa, de modo ideológico, a Marx por los infames decesos y abusos llevados a cabo en nombre del comunismo. Lo curioso es que poco se mide con este racero, la situación de inequidad y riesgo planetario en todos los ámbitos que ha producido la codicia capitalista con su máxima aplicación geopolítica que es el imperialismo, muy autor de las políticas educativas complacientes con el sometimiento humano a los designios "irremediables" del sistema mundial basado en el consumo y la enajenación en todas sus expresiones.

En palabras de Silva (2011), quien en su texto El estilo literario de Marx, dirá que el pensador de Treveris es un ideoclasta, se sustenta la tesis del abandono ideológico que vivió, que le acompañó en su labor. Marx fue un rebelde, también reculó cuando lo consideró pertinente, fue emotivo, hombre de hogar, persona sintiente, al resurgimiento del que habla González (2012). En definitiva, un hombre de su mundo y de otros mundos, no los posibles, sino los realizables en los cuales puede aportar con demasía, pero no de la manera ideológica y extremista que desdibuja su proceder. No la falsa radicalización, pues ser radical es ir a la raíz, e ir a la raíz se aleja de toda posición que pueda crearse con el acompañamiento de la lupa marxiana.

Marx encarnó su propia teoría, su vida fue praxis. "El hombre es producto de un medio histórico determinado. Un genio que aporte una novedad lo hará sobre la base de lo existente. No puede surgir de la nada" (Riazánov, 1962, p. 2). Él mismo demostró que se puede ser revolucionario con la propia existencia, y autocrítico con su proyecto. No hay duda,

Se es persona, entre otras cosas, cuando se alcanza la conciencia de sí, del tiempo propio, y cuando se es capaz de responder de lo vivido en el mundo, es decir, en el lugar y las circunstancias en que se ha vivido. (Valera-Villegas, 2016, P. 19)

...podríamos decir: ¡sujetos que quieran transformar la realidad, de todos los países, uníos!

${ }^{98}$ El ecosocialismo y las denuncias de corte marxiano y marxista siguen generando conciencia ambiental a pesar del opacamiento que quieren darle los sectores conservadores del plano ambiental. 